UNIVERSIDADE DE SÃo PAULO

Programa InTERUNidAdes de PÓs-GraduAÇão EM BioInformática FaCUldade de Filosofia, CiÊnCIAS E Letras de Ribeirão PReto

Gabriela Der Agopian Guardia

\title{
Suporte ao desenvolvimento e à composição de serviços web semânticos para a análise de expressão gênica
}





\section{Gabriela Der Agopian Guardia}

\section{Suporte ao desenvolvimento e à composição de serviços web semânticos para a análise de expressão gênica}

Tese apresentada ao Programa Interunidades de Pós-Graduação em Bioinformática da Universidade de São Paulo para a obtenção do título de Doutor em Ciências.

Orientador: Prof. Dr. Cléver Ricardo Guareis de Farias

Durante a elaboração deste trabalho, a estudante recebeu apoio finaceiro da CAPES.

Ribeirão Preto - SP 
Ficha Catalográfica Elaborada pelo Serviço de Informação e Biblioteca

"Prof. Carlos Benjamin de Lyra do Instituto de Matemática e Estatística da Universidade de São Paulo"

\section{Guardia, Gabriela Der Agopian}

G914s Suporte ao desenvolvimento e à composição de serviços web semânticos para a análise de expressão gênica / Gabriela Der Agopian Guardia.

Ribeirão Preto : 2016. 429 p.

Tese (Doutorado) - Universidade de São Paulo

Orientador: Cléver Ricardo Guareis de Farias

Programa Interunidades de Pós-Graduação em Bioinformática

Área de concentração: Bioinformática

1. Desenvolvimento de Software 2. Expressão Gênica 3. Web Semântica. I. Farias, Cléver Ricardo Guareis de, orient. II. Universidade de São Paulo. III. Título

CDD - 572.8 
Foram muitas as pessoas que me incentivaram e apoiaram ao longo desta incrível jornada. Agradeço especialmente:

A todos os educadores que contribuíram para minha formação e me motivaram a seguir a carreira acadêmica;

Ao meu orientador, Prof. Cléver Ricardo Guareis de Farias, pela oportunidade, confiança, dedicação e valiosas sugestões durante o desenvolvimento deste trabalho;

Ao Prof. Luís Ferreira Pires pelas importantes contribuições ao trabalho e por todo o suporte durante minha estadia na Universidade de Twente;

Ao Prof. Ricardo Zorzetto Nicoliello Vêncio pelas sugestões ao longo do desenvolvimento deste trabalho;

À Patrícia Martorelli pelo auxílio nos aspectos burocráticos do programa de pós-graduação;

À minha mãe, Eliana, pelo amor incondicional, apoio e incentivo nos momentos mais difíceis, permitindo que tudo isso fosse possível;

Aos meus amigos, pelos longos anos de amizade, sempre compartilhando comigo os momentos de alegria e desespero, e compreendendo minha ausência;

Aos meus colegas de laboratório, pelas produtivas discussões e por tornarem a rotina de trabalho mais agradável. 
Estudos de expressão gênica geralmente envolvem a realização de processos de análise integrados para a obtenção de respostas biológicas de interesse. A realização destes processos frequentemente requer o uso combinado de uma série de ferramentas de software. No entanto, o processo de integração manual de ferramentas pode ser demorado e propenso a erros devido ao crescente número de ferramentas e formatos de dados disponíveis no domínio. De modo a automatizar o processo de integração, algumas abordagens têm sido propostas tanto para a adaptação das ferramentas de análise existentes como serviços web semânticos, quanto para o desenvolvimento de ambientes de suporte à integração (composição) de serviços web semânticos. Embora estas abordagens representem avanços, nenhuma solução adequada para o desenvolvimento e composição de serviços foi especificamente definida para o domínio de genômica funcional. Neste contexto, o principal objetivo deste projeto foi investigar uma solução completa para o desenvolvimento e composição de serviços web semânticos para a análise de expressão gênica. Como parte da solução proposta, definimos uma metodologia integrada para a implementação de serviços web semânticos criados a partir de ferramentas de software existentes e para a anotação semântica destes serviços. Nossa metodologia fornece diretrizes concretas para o desenvolvimento sistemático de serviços, considerando também os principais aspectos técnicos associados ao processo de desenvolvimento. Esta metodologia foi aplicada a um conjunto representativo de serviços que fornecem suporte às principais atividades de análise realizadas em diferentes tipos de dados de expressão gênica. De forma complementar, definimos uma solução completa para a composição semântica de serviços no domínio de análise de expressão gênica. A solução proposta foi implementada em uma plataforma de suporte semiautomático à composição de serviços web semânticos, chamada SemanticSCo. Esta plataforma fornece suporte flexível a todas as atividades envolvidas no processo de composição de serviços, incluindo a criação, publicação, requisição, descoberta, seleção, composição e execução de 
serviços. Além disto, a plataforma SemanticSCo foi projetada para prover suporte adequado a diferentes tipos de usuários, incluindo biologistas e bioinformatas. Neste sentido, a plataforma fornece aos usuários um alto nível de abstração para a definição de seus processos de análise, permitindo que os mesmos se concentrem mais nas questões de pesquisa biológicas do que nos aspectos subjacentes do processo de composição. Adicionalmente, a plataforma SemanticSCo suporta a definição e incorporação não apenas de serviços simples, definidos em termos de uma única operação, mas também de serviços complexos, definidos em termos de um conjunto de condições que restringem a ordem de invocação de suas operações. Finalmente, de modo a avaliar a plataforma de suporte desenvolvida, definimos diferentes cenários de composição para a análise (integrada) de dados de expressão gênica. O uso da plataforma SemanticSCo facilitou a definição destes cenários, permitindo assim a reprodução dos resultados obtidos a partir de diferentes estudos de expressão gênica previamente documentados na literatura.

Palavras-chave: análise de expressão gênica; serviços web semânticos; desenvolvimento de serviços; composição de serviços; plataforma de serviços. 
Gene expression studies usually involve the creation of integrated analysis processes for obtaining responses for a biological question. The creation of such processes often require the combined use of a number of software tools. However, the manual integration of tools can be cumbersome and error prone due to the increasing number of tools and data formats available in the domain. In order to automate the integration process, some approaches have been proposed for the adaptation of existing analysis tools as semantic web services as well as for the development of software environments to support the integration (composition) of semantic web services. Although these approaches present advances, to the best of our knowledge, no suitable solution has been proposed for the development and composition of web services in the functional genomics domain. In this context, this project aimed at investigating a complete solution for the development and composition of semantic web services to support gene expression analysis. As part of the proposed solution, we have defined an integrated methodology for the implementation of semantic web services created from existing software tools and the semantic annotation of such services. Our methodology provides concrete guidelines for the systematic development of services, also taking into account the main technical aspects associated with the development process. This methodology has been applied in the development of a representative set of services that support the main analysis activities performed on different types of gene expression data. Complementary to our methodology, we have defined a complete solution for the semantic composition of web services in the gene expression analysis domain. The proposed solution has been implemented in a software platform to support the semi-automatic composition of semantic web services, named SemanticSCo. This platform provides flexible support to all activities involved in the service composition process including service creation, publication, request, discovery, selection, composition and execution. Additionally, the SemanticSCo platform has been designed to support different types of users, including biologists and 
bioinformaticians. In this sense, the platform provides users with a high level of abstraction in the definition of their analysis processes, thus allowing them to focus more on biological research issues rather than on underlying details of the composition process. In addition, the SemanticSCo platform supports not only the definition and incorporation of (simple) services defined in terms of a single operation, but also (complex) services defined in terms of a set of conditions that constrain the order in which service operations should be invoked. Finally, in order to evaluate the developed support platform, we have defined a number of composition scenarios for the (integrated) analysis of gene expression data. The use of the SemanticSCo platform has facilitated the definition of these scenarios, thus allowing the reproduction of the results obtained from different gene expression studies previously documented in the literature.

Keywords: gene expression analysis; semantic web services; service development; service composition; service platform. 
Figura 1

Figura 2

Figura 3

Figura 4

Figura 5

Figura 6

Figura 7

Figura 8

Figura 9

Figura 10

Figura 11

Figura 12

Figura 13

Figura 14

Figura 15

Figura 16

Figura 17

Figura 18

Figura 19

Figura 20

Figura 21

Figura 22

Figura 23
Estrutura da tese. . . . . . . . . . . . . . . . . . 10

Processo de expressão gênica. . . . . . . . . . . . . . . . . . . . . . . 12

Experimento de microarray de DNA. . . . . . . . . . . . 15

Sequenciamento de RNA na plataforma Illumina. . . . . . . . . . 20

Etapas de processamento para a análise de microarray. . . . . . . . . . 23

Gráfico volcano plot. . . . . . . . . . . . . . . . . 30

Etapas de processamento para a análise de RNA-Seq. . . . . . . . . . 30

Análise de enriquecimento de grupos de genes. . . . . . . . . . . . 45

Representação gráfica de um grafo RDF. . . . . . . . . . . . . . 50

Representação gráfica de um fragmento OWL da ontologia Gene On-

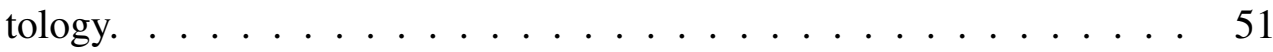

Modelo de interação da arquitetura orientada a serviços . . . . . . . . 54

Estruturas de armazenamento de um registro UDDI . . . . . . . . . . 61

Atributos de extensão da linguagem SAWSDL . . . . . . . . . . . 65

Composição automática de serviços. . . . . . . . . . . . . . 71

Integração semântica de serviços. . . . . . . . . . . . . . . . . . 73

Composição semântica de serviços . . . . . . . . . . . . . . 75

Equivalência semântica entre serviços . . . . . . . . . . . . . . 77

Metodologia proposta para a criação de serviços web semânticos. . . . 94 Arquitetura de um serviço web implementado como um adaptador. . . 96 Modelo para especificação detalhada de um caso de uso. . . . . . . . . 98 Anotações SAWSDL na metodologia proposta. . . . . . . . . . . . 105 Mapeamento de elementos WSDL para elementos BPMN. . . . . . . . 110 Interface gráfica de usuário da ferramenta Wsdl2 Creator. . . . . . . 113 
Figura 24

Figura 25

Figura 26

Figura 27

Figura 28

Figura 29

Figura 30

Figura 31

Figura 32

Figura 33

Figura 34

Figura 35

Figura 36

Figura 37

Figura 38

Figura 39

Figura 40

Figura 41

Figura 42

Figura 43

Figura 44

Figura 45

Figura 46

Figura 47
Interface gráfica de usuário da ferramenta Wsdl2Bpmn Mapper. . . . . 115

Descrição de serviço anotada com a abordagem SAWSDL. . . . . . . 118

Extensões propostas à metaclasse Class do metamodelo UML. . . . . 120

Extensões propostas às metaclasses Association e Dependency do metamodelo UML . . . . . . . . . . . . . . . . . . . . . . 122

Modelo para descrição de processos na ontologia GEXPO.

Modelo para descrição de processos e serviços na ontologia GEXPASO. 132

Caso de uso definido para o serviço EnrichmentAnalysis.

Diagrama de sequência UML definido para o serviço EnrichmentAnalysis. . . . . . . . . . . . . . . . 156

Descrição WSDL do serviço EnrichmentAnalysis. . . . . . . . . . . . 160

Fragmento da ontologia GEXPASO para a anotação semântica do serviço EnrichmentAnalysis. . . . . . . . . . . . . . . . . . . . . . 161

Anotação semântica da operação performEnrichmentAnalysis do serviço EnrichmentAnalysis.

Especificação BPMN do comportamento local do serviço EnrichmentAnalysis. . . . . . . . . . . . . . . . . 166 Etapas de um estudo de expressão gênica. . . . . . . . . . . . . . . . 172 Processo de composição de serviços para análise de expressão gênica. 174 Arquitetura de composição de serviços para análise de expressão gênica.178 Estratégia de composição para análise de expressão gênica. . . . . . . . 180 Módulos básicos da plataforma SemanticSCo. . . . . . . . . . . . . . 182 Estrutura do módulo Service Creation and Publication. Mapeamento de um serviço para a publicação no módulo Service Registry.

Interface gráfica para publicação de serviços na plataforma SemanticSCo.190 Estrutura de um serviço (processo) na plataforma SemanticSCo. . . . . 191 Estrutura do módulo Composite Service Enactment. . . . . . . . . . . 195 Interface gráfica de usuário na plataforma SemanticSCo. . . . . . . . . 198 Grafo de dependências da plataforma SemanticSCo. 199 
Figura 48

Figura 49

Figura 50

Figura 51

Figura 52

Figura 53

Figura 54

Figura 55

Figura 56

Figura 57

Figura 58

Figura 59

Figura 60

Figura 61

Figura 62

Figura 63

Figura 64

Figura 65

Fluxo de comandos codificado pela plataforma SemanticSCo. . . . . . 201

Estrutura do módulo Coordinator. . . . . . . . . . . . . . 203

Estrutura do módulo Service Composition. . . . . . . . . . . . . . . 206

Representação de uma matriz CLM. . . . . . . . . . . . . . . . . . . 212

Cenário para análise de dados de microarray na plataforma SemanticSCo.216

Criação do cenário de composição para a análise de dados de microar-

ray Agilent na plataforma SemanticSCo. . . . . . . . . . . . . . . . . 229

Cenário de composição para a análise de dados de microarray Agilent

na plataforma SemanticSCo.

Execução do cenário de análise de dados de microarray Agilent. . . . . 232

Proporção de genes reprimidos no grupo pré-TACTH identificados nas categorias da ontologia GO . . . . . . . . . . . . . 236

Proporção de genes induzidos no grupo pré-TACTH identificados nas categorias da ontologia GO e vias biológicas KEGG relevantes. . . . . 237 Genes mapeados para a via biológica KEGG neuroactive ligand-receptor interaction. . . . . . . . . . . . . . . . . 238

Proporção de genes induzidos no grupo pós-TACTH identificados nas categorias da ontologia GO e vias biológicas KEGG relevantes. . . . . 239 Criação do cenário de composição para a análise de dados de microarray Affymetrix na plataforma SemanticSCo.

Cenário de composição para a análise de dados de microarray Affymetrix na plataforma SemanticSCo. . . . . . . . . . . . . . 247 Execução do cenário de análise de dados de microarray Affymetrix. . 248 Genes diferencialmente expressos entre amostras dos grupos BIC, BANIC e BINIC.

Agrupamento hierárquico dos genes diferencialmente expressos nas amostras dos grupos ISOL, BIC, BANIC, BINIC.

Proporção de genes diferencialmente expressos no grupo BIC identificados nas categorias da ontologia GO e vias biológicas. . . . . . . . 254 
Figura 66

Figura 67

Figura 68

Figura 69

Figura 70

Figura 71

Figura 72

Figura 73

Figura 74

Figura 75

Figura 76

Figura 77

Figura 78

Figura 79

Figura 80

Figura 81

Figura 82

Figura 83
Proporção de genes diferencialmente expressos no grupo BANIC identificados nas categorias da ontologia GO e vias biológicas.

Proporção de genes diferencialmente expressos no grupo BINIC identificados nas categorias da ontologia GO e vias biológicas. . . . . . . . 256 Criação do cenário de composição para a análise de dados de RNA-Seq na plataforma SemanticSCo.

Cenário de composição para a análise de dados de RNA-Seq na plataforma SemanticSCo. . . . . . . . . . . . . . . . . . . . . 261

Execução do cenário de análise de dados de RNA-Seq. . . . . . . . . . 262

Genes diferencialmente expressos entre amostras de melanócitos tumorais. . . . . . . . . . . . . . . . . . . 264

Proporção de genes reprimidos nos melanócitos tumorais identificados

na categoria "processos biológicos" da ontologia GO.

Proporção de genes induzidos nos melanócitos tumorais identificados na categoria "processos biológicos" da ontologia GO.

Genes diferencialmente expressos entre amostras de melanócitos normais.

Proporção de genes reprimidos nos melanócitos normais identificados na categoria "processos biológicos" da ontologia GO.

Proporção de genes induzidos nos melanócitos normais identificados na categoria "processos biológicos" da ontologia GO. . . . . . . . . . 269 Estereótipo para a representação de conceitos de uma ontologia. . . . . 333 Estereótipos para a representação de componentes da linguagem WSDL

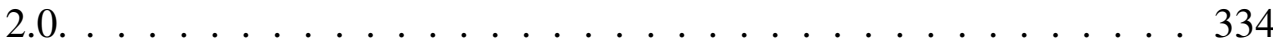

Estereótipos para a representação de componentes de esquemas XML. 335 Estereótipo para a representação do relacionamento faultReference. . . 335 Estereótipo para a representação do relacionamento references. . . . . . 336 Estereótipo para a representação do atributo de extensão modelReference da abordagem SAWSDL. . . . . . . . . . . . . . . 337 Regiões biológicas e biopolímeros. 
Figura 84

Figura 85

Figura 86

Figura 87

Figura 88

Figura 89

Figura 90

Figura 91

Figura 92

Figura 93

Figura 94

Figura 95

Figura 96

Figura 97

Figura 98

Figura 99

Figura 100

Figura 101

Figura 102

Figura 103

Figura 104

Figura 105
Processos biológicos envolvidos na expressão gênica e em sua medição. 342 Processo de medição de expressão gênica. . . . . . . . . . . . . . . 344 Experimento de microarray de DNA. . . . . . . . . . . . . . . 347 Experimento de sequenciamento de RNA. . . . . . . . . . . . . . . . 349 Dados de microarray. . . . . . . . . . . . . . . . . 352 Dados de RNA-Seq. . . . . . . . . . . . . . . . . . . . . . 354 Pré-processamento de dados Affymetrix no serviço MicroAffyNorm. 356 Pré-processamento de dados Agilent no serviço MicroAgilentNorm. . . 357 Pré-processamento de dados Genepix no serviço MicroGenepixNorm. 359 Análise diferencial de dados de microarray one-color no serviço $\mathrm{Mi}$ croOneDifferentialAnalysis. . . . . . . . . . . . . . . . . . . 360

Análise diferencial de dados de microarray two-color no serviço $\mathrm{Mi}$ croTwoDifferentialAnalysis. . . . . . . . . . . . . . . 362 Agrupamento hierárquico de dados de microarray no serviço MicroHCluster.

Agrupamento k-means de dados de microarray no serviço MicroK-

Cluster. 366

Geração de dendrogramas no serviço MicroHClusterViewer. . . . . . . 368 Análise diferencial de dados de RNA-Seq no serviço RnaSeqDifferentialAnalysis.

Análise de enriquecimento simples de dados de expressão gênica no serviço EnrichmentAnalysis.

Análise de enriquecimento simples de dados de expressão gênica no serviço DAVID-REST.

Análise de enriquecimento de grupos de genes no serviço GeneSetEnrichmentAnalysis.

Geração de grafos KEGG no serviço KeggPathwayViewer. . . . . . . . 376

Referências cruzadas entre as ontologias GEXPO e GEXPASO. . . . . 380

Definição XSD do comando DISCOVER_INPUT_SEMANTICS. . . . 404 Estratégia de suporte ao comando DISCOVER_INPUT_SEMANTICS. . 404 
Figura 106

Figura 107

Figura 108

Figura 109

Figura 110

Figura 111

Figura 112

Figura 113

Figura 114

Figura 115

Figura 116

Figura 117

Figura 118

Figura 119

Figura 120

Figura 121

Figura 122

Figura 123

Figura 124

Figura 125

Figura 126

Figura 127

Definição XSD do comando DISCOVER_FUNCTION_SEMANTICS. . 406 Estratégia de suporte ao comando DISCOVER_FUNCTION_SEMANTICS.406 Definição XSD do comando DISCOVER_SERVICES. . . . . . . . . . 407 Estratégia de suporte ao comando DISCOVER_SERVICES. . . . . . . 408 Definição XSD do comando INCLUDE_SERVICES. . . . . . . . . . . 409 Estratégia de suporte ao comando INCLUDE_SERVICES. . . . . . . . 410 Definição XSD do comando RESOLVE_SERVICES. . . . . . . . . . . 412 Estratégia de suporte ao comando RESOLVE_SERVICES. . . . . . . . 412 Definição XSD do comando VALIDATE_INPUTS. . . . . . . . . . . . 414 Estratégia de suporte ao comando VALIDATE_INPUTS . . . . . . . . . 414 Definição XSD do comando COMPOSE_SERVICES. . . . . . . . . . 416 Estratégia de suporte ao comando COMPOSE_SERVICES. . . . . . . 416 Definição XSD do comando GET_EXECUTABLE_SERVICES. . . . . 418 Estratégia de suporte ao comando GET_EXECUTABLE_SERVICES. . 418 Definição XSD do comando ADD_TO_CONTEXT. . . . . . . . . . 419 Estratégia de suporte ao comando ADD_TO_CONTEXT. . . . . . . . 420 Processamento de dados pelo serviço de adaptação ASl . . . . . . . . . . 422 Processamento de dados pelo serviço de adaptação AS2 . . . . . . . . . 423 Processamento de dados pelo serviço de adaptação AS3. . . . . . . . . . 424 Processamento de dados pelo serviço de adaptação AS4 . . . . . . . . . 426 Processamento de dados pelo serviço de adaptação AS5 . . . . . . . . . 427 Processamento de dados pelo serviço de adaptação AS6. . . . . . . . . . 429 
Tabela 1

Tabela 2

Tabela 3

Tabela 4

Tabela 5

Tabela 6

Tabela 7

Tabela 8

Tabela 9

Tabela 10

Tabela 11

Tabela 12

Tabela 13

Tabela 14

Tabela 15

Tabela 16

Tabela 17

Tabela 18

Tabela de contingência para análise funcional de expressão gênica . 43 Relacionamentos da ontologia GEXPO . . . . . . . . . . . . . . . 131 Relacionamentos da ontologia GEXPASO . . . . . . . . . . . . 133 Serviços para a análise de dados de microarray disponíveis no repositório GEAS． . . . . . . . . . . . . . . . . . . . . . 137 Métodos de pré-processamento do serviço MicroAffyNorm. . . . . . . 138 Métodos de pré-processamento do serviço MicroAgilentNorm. . . . . 139 Métodos de pré-processamento do serviço MicroGenepixNorm. . . . . 140 Métodos de correção de múltiplos testes do serviço MicroOneDifferentialAnalysis. . . . . . . . . . . . . . . . . 141 Métodos de agrupamento do serviço MicroHCluster. . . . . . . . . . . 143 Métricas de similaridade do serviço MicroHCluster. . . . . . . . . . . 143 Serviço para a análise de dados de RNA-Seq disponível no repositório GEAS. . . . . . . . . . . . . . . . . . 147 Serviços para a análise de dados de expressão gênica disponíveis no repositório GEAS． . . . . . . . . . . . . . . . . . . . . . . . . . . . 148 Métodos de correção de múltiplos testes do serviço EnrichmentAnalysis. 149 Organismos-modelo e classes de espécies Ensembl do serviço EnrichmentAnalysis. . . . . . . . . . . . . . . . 150 Tipos de categorias de anotação do serviço DAVID-REST . . . . . . . 151 Organismos-modelo do serviço KeggPathwayViewer. . . . . . . . . . 154 Operações do serviço EnrichmentAnalysis, tipos CRUD e métodos REST associados. . . . . . . . . . . . . . . . . . . . . 159 Estruturas de categorização definidas como extensões UDDI. . . . . . 186 
Tabela 19 Relacionamentos para o cálculo de similaridade semântica entre conceitos. . . . . . . . . . . . . . . . . . 209

Tabela 20 Classificação dos genes reprimidos/induzidos no grupo pré-TACTH. . 235

Tabela $21 \quad$ Principais recursos fornecidos pela plataforma SemanticSCo e outras plataformas de composição. . . . . . . . . . . . . . . . . . 284 


\begin{tabular}{ll} 
ADF & Array Design Format \\
A-DynamiCoS & Adaptable DynamiCoS \\
API & Application Programming Interface \\
BANIC & Bystanders Attentive to Non-Interacting Conspecifics \\
BIC & Bystanders to Interacting Conspecifics \\
BINIC & Bystanders Inattentive to Non-Interacting Conspecifcs \\
BPEL & Business Process Execution Language \\
BPMN & Business Process Model and Notation \\
BRG1 & Brahma-related gene-1 \\
CAGE & Cap Analysis of Gene Expression \\
CDNA & DNA complementar \\
CLM & Causal Link Matrix \\
CTM & Célula Estromal Mesenquimal Multipotente \\
DAVID & Database for Annotation, Visualization and Integrated Discovery \\
DNA & Ácido desoxirribonucleico \\
dNTP & Desoxirribonucleotideo trifosfato \\
FDR & False Discovery Rate \\
GAGE & Generally Applicable Gene-set Enrichment \\
GEAS & Gene Expression Analysis Services \\
GEO & Gene Expression Omnibus \\
GEXPASO & Gene Expression Analysis Services Ontology \\
GEXPO & Gene Expression Analysis Ontology \\
GO & Gene Ontology \\
HTML & HyperText Markup Language \\
\hline
\end{tabular}




\begin{tabular}{|c|c|}
\hline HTTP & HyperText Transfer Protocol \\
\hline IDF & Investigation Description Format \\
\hline ISOL & Isolated fish \\
\hline jABC & Java Application Building Center \\
\hline JAXB & Java Architecture for XML Binding \\
\hline JSON & JavaScript Object Notation \\
\hline KEGG & Kyoto Encyclopedia of Genes and Genomes \\
\hline MAGE-ML & MicroArray Gene Expression Markup Language \\
\hline MAGE-TAB & MicroArray Gene Expression Tabular \\
\hline MAPI & Modular API \\
\hline MIAME & Minimum Information About a Microarray Experiment \\
\hline MITF & microphthalmia-associated transcription factor \\
\hline MPSS & Massively Parallel Signature Sequencing \\
\hline mRNA & RNA mensageiro \\
\hline NCBI & National Center for Biotechnology Information \\
\hline ncRNA & RNA não-codificante \\
\hline ОВО & Open Biomedical Ontologies \\
\hline OBTS & Ontology for Bioinformatics Tools and Services \\
\hline OCL & Object Constraint Language \\
\hline OWL & Web Ontology Language \\
\hline OWL-S & Web Ontology Language for Services \\
\hline RDF & Resource Description Framework \\
\hline REST & Representational State Transfer \\
\hline RMA & Robust Multi-array Average \\
\hline RNA & Ácido ribonucleico \\
\hline RNA-Seq & Sequenciamento de RNA \\
\hline RPKM & Reads Per Kilobase per Million mapped reads \\
\hline RT-PCR & Real-Time Polymerase Chain Reaction \\
\hline SADI & Semantic Automated Discovery and Integration \\
\hline SAGE & Serial Analysis of Gene Expression \\
\hline
\end{tabular}


SA-REST

SASP

SAWSDL

SDRF

SemanticSCo

SIB

SLG

SLTL

SO

SOAP

TACTH

TMM

TRANSFAC

UDDI

UML

URI

URL

WADL

WAR

WSDL

WSML

WSMO

XHTML

XML

XSD

XSLT
Semantic Annotations for REST

Senescence-Associated Secretory Phenotype

Semantic Annotations for Web Services Description Language

Sample and Data Relationship Format

Semantic Services Composition

Service Independent Building Block

Service Logic Graph

Semantic Linear Time Logic

Sequence Ontology

Simple Object Access Protocol

Transplante Autólogo de Células-Tronco Hematopoiéticas

Trimmed Mean of M-Values

Transcription Factor Motifs

Universal Description, Discovery and Integration

Unified Modeling Language

Uniform Resource Identifier

Uniform Resource Locator

Web Application Description Language

Web application ARchive

Web Services Description Language

Web Service Modeling Language

Web Service Modeling Ontology

eXtensible Hypertext Markup Language

eXtensible Markup Language

XML Schema Definitions

Extensible Stylesheet Language Transformations 
1 INTRODUÇÃO 1

1.1 Contextualização . . . . . . . . . . . . . . . . . . 2

1.1.1 Integração de Ferramentas para Análise de Expressão Gênica . . . . . . 2

1.1.2 Desafios da Integração Automática de Recursos Computacionais . . . . 3

1.1.3 Integração Semântica de Serviços . . . . . . . . . . . . . . . . . 5

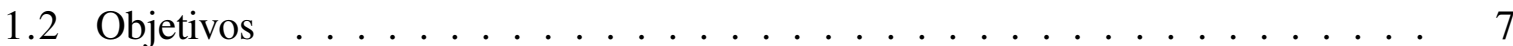

1.3 Escopo ........................... 8

1.4 Metodologia . . . . . . . . . . . . . . . . . . 8

1.5 Organização do Documento . . . . . . . . . . . . . . . . . . . . . . 10

2 EXPRESS ÃO GÊNICA 11

2.1 Obtenção de Dados de Expressão Gênica . . . . . . . . . . . . . . . . . . . 12

2.1 .1 Visão Geral . . . . . . . . . . . . . . . . . . . . . . . 12

2.1 .2 Microarrays de DNA . . . . . . . . . . . . . . . . . 15

2.1 .3 Sequenciamento de RNA (RNA-Seq) . . . . . . . . . . . . . 18

2.1 .4 Real-Time Polymerase Chain Reaction (RT-PCR) . . . . . . . . . . . 21

2.2 Análise de Expressão Gênica . . . . . . . . . . . . . . . . . . . . . . . 22

2.2 .1 Visão Geral . . . . . . . . . . . . . . . . . . . . . . 22

2.2.2 Análise de Dados de Microarray . . . . . . . . . . . . . . . . 23

2.2.3 Análise de Dados de RNA-Seq . . . . . . . . . . . . . . . . . . . . . . 29

2.2.4 Agrupamento de Dados de Expressão Gênica . . . . . . . . . . . . . . 39

2.2.5 Análise Funcional de Dados de Expressão Gênica . . . . . . . . . . . . 41

3 SERVIÇOS WEB SEMÂNTICOS 47

3.1 Web Semântica . . . . . . . . . . . . . . . . . . . . . . . . . . 48 
3.1 .1 Resource Description Framework (RDF) . . . . . . . . . . . . . . . . 49

3.1 .2 Web Ontology Language $(\mathrm{OWL}) \ldots \ldots . \ldots$. . . . . . . . 50

3.2 Serviços Web . . . . . . . . . . . . . . . . . . . 53

3.2.1 Desenvolvimento de Serviços Web . . . . . . . . . . . . . . 55

3.2 .2 Descrição de Serviços Web . . . . . . . . . . . . . . . . 58

3.2 .3 Publicação de Serviços Web . . . . . . . . . . . . . . . . . 60

3.3 Serviços Web Semânticos . . . . . . . . . . . . . . . . . . . . . . 62

3.3.1 Web Ontology Language for Services (OWL-S) . . . . . . . . . . . 63

3.3.2 Web Service Modeling Ontology (WSMO) . . . . . . . . . . . . 64

3.3.3 Semantic Annotations for WSDL (SAWSDL) . . . . . . . . . . . . 65

3.3.4 Semantic Annotations for REST (SA-REST) . . . . . . . . . . . . . 67

3.4 Composição de Serviços Web . . . . . . . . . . . . . . . . . . 68

3.4.1 Composição Automática de Serviços Web . . . . . . . . . . . . . 70

3.4.2 Composição Semântica de Serviços Web . . . . . . . . . . . . . . . 72

3.5 Abordagens para Desenvolvimento de Serviços Web Semânticos . . . . . . . . 77

3.6 Abordagens para Composição de Serviços Web Semânticos . . . . . . . . . . . 83

4 MEtodologia PARA DESENVOLVimento DE SERViÇOS WEB SEMÂN$\begin{array}{ll}\text { TICOS } & 93\end{array}$

4.1 Visão Geral . . . . . . . . . . . . . . . . . . . . . . . . . . . 93

4.2 Implementação do Serviço . . . . . . . . . . . . . . . . . 95

4.3 Geração da Descrição do Serviço . . . . . . . . . . . . . . . . . . . . . . . . 102

4.4 Definição das Ontologias . . . . . . . . . . . . . . . . . . . . . . . . . 102

4.5 Anotação Semântica da Descrição do Serviço . . . . . . . . . . . . . . . . . 104

4.6 Especificação do Comportamento Local do Serviço ～. . . . . . . . . . . . . 108

4.7 Ferramentas de Suporte à Metodologia . . . . . . . . . . . . . . . . . . . . 112

4.7.1 Ferramenta Wsdl2 Creator . . . . . . . . . . . . . . . . . 112

4.7 .2 Ferramenta Wsdl2Bpmn Mapper . . . . . . . . . . . . . . . . . . . 114

4.8 Perfil UML para a Abordagem SAWSDL $\ldots \ldots \ldots \ldots$

4.9 Conclusão . . . . . . . . . . . . . . . . . . . . . . . . . . . . 124 
5 DESENVOLVIMENTO DE SERVIÇOS WEB SEMÂNTICOS PARA A ANÁlise DE EXPRESS ÃO GÊNICA 127

5.1 Ontologias de Suporte . . . . . . . . . . . . . . . . . . . . 128

5.1 .1 Gene Expression Ontology (GEXPO) . . . . . . . . . . . . . . . 128

5.1.2 Gene Expression Analysis Service Ontology (GEXPASO) . . . . . . . 131

5.2 Repositório Gene Expression Analysis Services (GEAS) ～. . . . . . . . . . . 134

5.2.1 Serviços para Dados de Microarray . . . . . . . . . . . . . . 136

5.2.2 Serviço para Dados de RNA-Seq . . . . . . . . . . . . . . . . . . . 146

5.2.3 Serviços para Dados de Expressão Gênica . . . . . . . . . . . . . . . 148

5.3 Desenvolvimento do serviço EnrichmentAnalysis . . . . . . . . . . . . . . . 154

5.3.1 Implementação do Serviço . . . . . . . . . . . . . . . . . . . . . . . . 154

5.3.2 Geração da Descrição do Serviço . . . . . . . . . . . . . . . . . . . . . 159

5.3.3 Definição das Ontologias . . . . . . . . . . . . . . . . . . . 160

5.3.4 Anotação Semântica da Descrição do Serviço . . . . . . . . . . . . . . 162

5.3.5 Especificação do Comportamento Local do Serviço . . . . . . . . . . . 165

5.4 Conclusão . . . . . . . . . . . . . . . . . . . . . . . . . . 168

6 COMPOSIÇÃO DE SERVIÇOS WEB SEMÂNTICOS PARA ANÁLISE DE EXPRESS ÃO GÊNICA 171

6.1 Processo de Composição de Serviços . . . . . . . . . . . . . . . . . . . . . 172

6.1 .1 Estudo de Expressão Gênica . . . . . . . . . . . . . . . . . 172

6.1.2 Composição de Serviços para a Análise de Expressão Gênica . . . . . . 173

6.2 Arquitetura de Composição . . . . . . . . . . . . . . . . . . . . . . . . . 177

6.3 Estratégia de Composição . . . . . . . . . . . . . . . . . . . . . . . . . . . . 179

6.4 Visão Geral da Plataforma SemanticSCo . . . . . . . . . . . . . . . . . . . . . 181

6.5 Suporte à Criação e Publicação de Serviços ～. . . . . . . . . . . . . . . . . . . 184

6.5 .1 Módulo Service Registry . . . . . . . . . . . . . . . . . . . . . . 184

6.5.2 Módulo Service Creation and Publication . . . . . . . . . . . . 186

6.5.3 Representação de Serviços . . . . . . . . . . . . . . . . . . . . . . . . 189

6.6 Suporte à Composição e Execução de Serviços . . . . . . . . . . . . . . . . . . 192

6.6.1 Comandos Primitivos . . . . . . . . . . . . . . . . . 192 
6.6.2 Módulo Composite Service Enactment . . . . . . . . . . . . . . . . . 195

6.6.3 Módulo Coordinator . . . . . . . . . . . . . . . 203

6.6.4 Módulo Service Composition . . . . . . . . . . . . . . 205

6.6.5 Módulo Composition and Execution Context . . . . . . . . . . . . 214

6.7 Cenário de Análise . . . . . . . . . . . . . . . . . . . . 215

6.8 Conclusão . . . . . . . . . . . . . . . . . . . . . . . . . 219

7 ESTUDOS DE CASO 223

7.1 Estratégia para a Criação dos Cenários de Composição . . . . . . . . . . . . 224

7.2 Análise de Dados de Microarray Agilent . . . . . . . . . . . . . 225

7.2.1 Estudo Base . . . . . . . . . . . . . . . 226

7.2.2 Definição do Cenário na Plataforma SemanticSCo . . . . . . . . . . . . 228

7.2.3 Execução do Cenário de Análise . . . . . . . . . . . . . . . . . . 231

7.2.4 Análise Comparativa dos Grupos Pré-TACTH e Controle . . . . . . . 234

7.2.5 Análise Comparativa dos Grupos Pré-TACTH e Pós-TACTH . . . . . . 238

7.3 Análise de Dados de Microarray Affymetrix . . . . . . . . . . . . . . . . 240

7.3.1 Estudo Base . . . . . . . . . . . . . . . . . . . . . . . 240

7.3.2 Definição do Cenário na Plataforma SemanticSCo . . . . . . . . . . . . 243

7.3.3 Execução do Cenário de Análise . . . . . . . . . . . . . . . . . 246

7.3.4 Análise Comparativa dos Grupos BIC, BANIC e BINIC . . . . . . . . 250

7.4 Análise de Dados de RNA-Seq Illumina . . . . . . . . . . . . . . 257

7.4.1 Estudo Base . . . . . . . . . . . . . . . . . . 257

7.4.2 Definição do Cenário na Plataforma SemanticSCo . . . . . . . . . . . . 259

7.4.3 Execução do Cenário de Análise . . . . . . . . . . . . . . . . 262

7.4.4 Análise Comparativa de Melanócitos Tumorais . . . . . . . . . . . 263

7.4.5 Análise Comparativa de Melanócitos Normais . . . . . . . . . . . . . 266

7.5 Conclusão . . . . . . . . . . . . . . . . . . . . . . . 269

8 CONCLUSÃO 271

8.1 Principais Contribuições _ . . . . . . . . . . . . . . . 271

8.1.1 Metodologia para o Desenvolvimento de Serviços Web Semânticos . . 272 
8.1.2 Serviços para a Análise de Expressão Gênica . . . . . . . . . . . . . 272

8.1 .3 Ontologias de Suporte . . . . . . . . . . . . . 273

8.1.4 Abordagem para a Composição de Serviços Web Semânticos . . . . . . 273

8.1.5 Plataforma de Suporte à Composição . . . . . . . . . . . . . . . . . . . 274

8.2 Discussão . . . . . . . . . . . . . . . . . . . . . . 276

8.2.1 Desenvolvimento de Serviços Web Semânticos . . . . . . . . . . . . 276

8.2.2 Composição de Serviços Web Semânticos . . . . . . . . . . . . . . . 280

8.3 Trabalhos Futuros . . . . . . . . . . . . . . . . . . . . 287

PRODUÇÃO CIENTÍFICA

Referências $\quad 293$

Apêndice A PERFIL UML PARA SAWSDL 333

Apêndice B GENE EXPRESSION ONTOLOGY (GEXPO) 339

Apêndice C GENE EXPRESSION ANALYSis SERVICE ONTOLOGY (GEXPASO) 351

Apêndice D REFERENCIAS CRUZADAS ENTRE AS ONTOLOGIAS GEXPO E GEXPASO

Apêndice E ESTRUTURAS DE EXTENSÃo UdDi Do MÓDUlo SERVICE REGISTRY

Apêndice F PUBLICAÇÃO DE SERVIÇOS NO MÓDULO SERVICE REGISTRY

Apêndice G COMANDOS PRIMITIVOS E ESTRATÉGiAS DE SUPORTE DA PLATAFORMA SEMANTICSCO

Apêndice H SERVIÇOS DE ADAPTAÇÃO 


\section{NTRODU Ç ÃO}

No domínio biomédico, a integração manual de ferramentas de software tem se tornado um grande desafio devido ao número crescente de ferramentas e tipos de dados disponíveis. Neste sentido, suporte à integração (semi) automática de ferramentas e dados tem se tornado bastante desejável. De modo a facilitar a criação de processos de análise integrados, um número crescente de ferramentas tem sido disponibilizado como serviços web semânticos e o suporte automático à integração (composição) destes serviços tem sido investigado.

Esta tese aborda aspectos conceituais e tecnológicos do desenvolvimento e composição de serviços web semânticos, visando fornecer suporte à realização de estudos de análise expressão gênica. Neste sentido, este capítulo apresenta as principais motivações, os objetivos e as etapas seguidas para a realização do trabalho.

O restante deste capítulo está estruturado da seguinte forma: a Seção 1.1 contextualiza a nossa pesquisa e apresenta as nossas principais motivações; a Seção 1.2 apresenta os objetivos do trabalho; a Seção 1.3 delimita o escopo desta pesquisa; a Seção 1.4 elenca as etapas seguidas para atingir os objetivos especificados; finalmente, a Seção 1.5 apresenta a estrutura desta tese. 


\subsection{CONTEXTUALIZAÇÃO}

\subsubsection{Integração de Ferramentas para Análise de Expressão Gênica}

A área de pesquisa de genômica funcional possui como principal objetivo estudar a função de genes (e proteínas) por meio da medição de seus níveis de expressão para determinar os mecanismos envolvidos em diferentes processos biológicos [1]. O nível de expressão de um gene é usualmente obtido a partir da quantificação dos produtos gênicos, RNAs codificantes e não codificantes, sintetizados pelo gene em um determinado tecido ou tipo celular. Atualmente, dados de expressão gênica podem ser obtidos a partir de diferentes técnicas, tais como microarrays de DNA [2] e sequenciamento de RNA (RNA-Seq) [3]. Estas técnicas permitem a quantificação dos níveis de expressão de uma grande quantidade de genes simultaneamente.

Uma vez que dados de expressão gênica são obtidos, biologistas precisam frequentemente realizar vários processos de análise nestes dados para a obtenção de uma resposta biológica de interesse. Estas análises podem incluir várias atividades, tais como a normalização dos dados, a identificação de genes diferencialmente expressos, a construção de redes regulatórias de genes, o agrupamento de perfis de expressão e a anotação funcional de genes.

Diferentes ferramentas de software têm sido desenvolvidas de modo a permitir a realização de uma ou mais destas atividades. Em geral, estas ferramentas implementam funcionalidades específicas e são desenvolvidas de forma isolada. Inicialmente, estas ferramentas de análise eram disponibilizadas como aplicações independentes (standalone). As funcionalidades destas ferramentas podiam ser tipicamente acessadas por meio de uma interface linha de comando. Posteriormente, a popularização da web e o fácil acesso dos usuários a navegadores contribuíram para a disponibilização destas funcionalidades por meio de páginas web [4]. No entanto, as informações especificadas em páginas web não são estruturadas de maneira padronizada, dificultando assim, o acesso programático às funcionalidades fornecidas. Neste sentido, atualmente a disponibilização de ferramentas como serviços web tem representado uma tendência no domínio biomédico [5,6]. Serviços web fornecem interfaces de programação padronizadas, as quais facilitam o acesso programático às ferramentas, a interoperabilidade entre recursos computacionais e, consequentemente, a integração de dados/ferramentas no domínio [5]. Assim, 
um número crescente de ferramentas tem sido disponibilizado não apenas por meio de páginas web mas também como serviços web [7-11].

A análise de dados de expressão gênica frequentemente requer o uso combinado de uma série de ferramentas de software. O acesso a uma única ferramenta (ou serviço) é relativamente simples. No entanto, a integração manual destas ferramentas para a realização de um processo de análise requer que usuários transfiram dados entre as diferentes ferramentas e que, frequentemente, realizem conversões nos formatos dos dados devido a diferenças estruturais $[5,12,13]$. Este processo pode ser demorado e propenso a erros devido ao grande número de ferramentas de análise e formatos de dados disponíveis no domínio [14,15].

De modo a facilitar a criação de processos de análise integrados no domínio, biologistas frequentemente desenvolvem scripts que permitem a integração das diferentes ferramentas necessárias para suas atividades de análise [4]. Estes scripts recuperam dados armazenados em servidores com diferentes formatos de representação e métodos de acesso, e realizam conversões nos formatos dos dados de modo a adaptá-los para utilização em diferentes ferramentas de análise. No entanto, os tipos de dados associados às ferramentas não são especificados. Assim, a contínua atualização das ferramentas requer a adaptação constante dos scripts utilizados para integrá-las [4, 12]. Além disto, o desenvolvimento e adaptação de tais scripts normalmente requer que os biologistas estejam focados não apenas na obtenção de respostas biológicas, mas também nos detalhes tecnológicos subjacentes. Neste sentido, suporte à integração automática de ferramentas é bastante desejável no domínio [5, 6].

\subsubsection{Desafios da Integração Automática de Recursos Computacionais}

Ambientes de suporte têm sido propostos para a integração (semi) automática de recursos computacionais no domínio da bioinformática [16-20]. Estes ambientes permitem que as atividades de um determinado processo de análise sejam interconectadas de maneira adequada e executadas de forma automática. Em geral, estes ambientes auxiliam os usuários na execução do processo de análise por meio da execução individual de cada atividade e da transferência de dados entre as diferentes ferramentas, de modo a isentar os usuários dos detalhes subjacentes do processo de integração [13]. Desta forma, usuários com diferentes níveis de experiência 
podem acessar bases de dados e utilizar ferramentas de análise sobre os dados acessados de maneira integrada e transparente, permitindo assim, que eles estejam focados apenas na geração de conhecimentos biológicos [21]. No entanto, estes ambientes de integração atualmente representam apenas uma solução parcial para a integração automática de recursos computacionais, uma vez que lidam apenas com a heterogeneidade sintática dos dados compartilhados pelas diferentes ferramentas.

Uma solução completa para a integração automática de recursos computacionais heterogêneos deve considerar a integração do ponto de vista tanto sintático quanto semântico. A integração sintática permite que as ferramentas sejam capazes de trocar dados sintaticamente compatíveis. A integração semântica tem como princípios básicos a utilização explícita de semântica para a descrição dos significados dos dados compartilhados por diferentes ferramentas e o uso de modelos de referência que permitem o mapeamento de conceitos entre ferramentas distintas [6]. A realização de mapeamentos semânticos dos dados permite, por exemplo, que ferramentas distintas que compartilham dados com sintaxes diferentes, mas com a mesma semântica, sejam capazes de interoperar. Desta forma, a integração semântica permite a atribuição de significados não ambíguos aos dados compartilhados por diferentes ferramentas em um ambiente integrado, permitindo a troca de dados de forma semanticamente consistente.

O uso integrado de um conjunto de serviços web para a realização de uma tarefa complexa constitui uma composição de serviços. Um dos principais objetivos da comunidade de pesquisa em serviços web é fornecer suporte (semi) automático à composição de serviços [22]. Para que serviços web possam ser compostos de forma automática, os provedores de serviços devem publicar descrições de seus serviços na web e o software do consumidor dos serviços deve ser capaz de interpretá-las e de interagir com os serviços de forma automática.

De modo a facilitar o desenvolvimento e composição de serviços, os dados produzidos e consumidos pelos serviços são geralmente especificados por meio de linguagens computacionalmente interpretáveis, tais como HyperText Markup Language (HTML), eXtensible Markup Language (XML) e JavaScript Object Notation (JSON) [23]. O uso destas linguagens facilita a interconexão automática de serviços que compartilham dados sintaticamente compatíveis. Porém, diferentes linguagens podem ser utilizadas para especificar os dados produzidos/consumidos por serviços distintos. Além disto, os mesmos tipos de dados podem ser representados 
de maneira distinta em uma mesma linguagem. Neste contexto, a realização de mapeamentos entre diferentes representações de dados pode ser necessária para permitir a composição de serviços que compartilham dados sintaticamente incompatíveis, mas semanticamente equivalentes. De modo a facilitar a realização de tais mapeamentos, as descrições das interfaces de serviços devem possuir semântica processável por sistemas computacionais [24-26]. Uma vez que haja consenso sobre a semântica (significado) dos dados compartilhados entre serviços, os dados podem ser mais facilmente transformados de uma representação para outra, permitindo assim a composição automática de serviços e dados de forma consistente.

\subsubsection{Integração Semântica de Serviços}

A Web Semântica [27] representa uma extensão da web na qual a semântica das informações publicadas é especificada de forma explícita, permitindo seu processamento e interpretação por sistemas computacionais de maneira automática. As tecnologias da Web Semântica permitem a atribuição de significados bem definidos (semântica) às informações estruturadas publicadas na web por meio do uso de ontologias [28]. Uma ontologia é um recurso computacional utilizado para representar de forma explícita o conhecimento associado a um domínio, por meio da definição formal de um conjunto de conceitos e relacionamentos entre conceitos [29]. Ontologias permitem a interpretação de informações de forma automática, reduzindo o envolvimento humano na integração de dados e ferramentas [24,28].

Os serviços web semânticos baseiam-se nas tecnologias de serviços web e da web semântica. Por um lado, a tecnologia de serviços facilita a integração de ferramentas e dados do ponto de vista sintático. Por outro lado, as tecnologias da Web Semântica permitem o enriquecimento semântico das interfaces de serviços, facilitando a integração destes recursos de forma semanticamente consistente. Assim, os serviços web semânticos são serviços cujas interfaces são semanticamente anotadas com termos provenientes de ontologias [30]. A adição de semântica às interfaces de serviços permite a atribuição de significados não ambíguos às funcionalidades oferecidas pelos serviços e aos dados trocados entre diferentes serviços, facilitando a interpretação automática das interfaces de serviços por sistemas computacionais e permitindo a criação de mecanismos de suporte à composição automática de serviços [31,32]. 
Algumas abordagens têm sido definidas para o desenvolvimento de serviços web semânticos [33-37]. Em geral, estas abordagens fornecem um conjunto de práticas recomendadas para o desenvolvimento e descrição semântica de serviços. No entanto, as abordagens existentes não fornecem diretrizes concretas para o desenvolvimento sistemático de serviços web e para a anotação semântica dos serviços desenvolvidos. Adicionalmente, a maioria destas abordagens segue uma estratégia dirigida por modelos que, em geral, são definidos para domínios de aplicação específicos como por exemplo, epidemiologia, medicina diagnóstica e comércio eletrônico, entre outros. No entanto, as abordagens disponíveis não contemplam o domínio de genômica funcional. Finalmente, as abordagens para desenvolvimento e para anotação semântica de serviços são geralmente definidas de forma independente umas das outras. Embora estas abordagens possam ser utilizadas de forma integrada para o desenvolvimento de serviços web semânticos, algumas adaptações podem ser necessárias nos serviços quando estas abordagens são utilizadas em conjunto.

De forma complementar, diferentes abordagens têm sido propostas para a composição de serviços web semânticos no domínio da bioinformática [38-43]. Estas abordagens fornecem um conjunto de mecanismos e protocolos que permitem a composição semântica de serviços web em ambientes de suporte gráficos desenvolvidos para auxiliar os usuários na criação e execução de cenários de análise integrados. De modo geral, estes ambientes de suporte auxiliam o usuário na construção iterativa de uma composição de serviços (processo de análise), sugerindo os serviços mais apropriados a cada etapa do processo de criação da cadeia de composição. Estas sugestões baseiam-se na correspondência semântica entre os tipos de dados compartilhados entre serviços adjacentes na cadeia de composição. Uma vez que uma composição de serviços é completamente especificada, os ambientes de suporte auxiliam os usuários durante a execução do processo de análise, realizando a invocação automática de cada serviço definido na composição e transferindo dados entre os serviços.

Na maioria dos ambientes propostos, os usuários especificam uma composição de serviços de acordo com seus requisitos e preferências e, uma vez que a composição é completamente especificada, a mesma pode ser implantada e então executada. Após a execução, estes ambientes geralmente não fornecem suporte para o refinamento da composição de modo a acomodar possíveis mudanças nos requisitos dos usuários. Desta forma, essas abordagens assumem que 
os usuários são capazes de fornecer um conjunto completo de requisitos durante a fase inicial de definição de uma composição de serviços. Além disto, a definição de um processo de análise nestes ambientes é, em geral, realizada de forma concreta por meio da interligação de diferentes serviços web. Consequentemente, a definição de processos de análise nestes ambientes requer que os usuários possuam um conhecimento técnico computacional sobre os serviços disponíveis no domínio e sobre as funcionalidades oferecidas pelos mesmos, além dos tipos de dados produzidos/consumidos pelos serviços.

\subsection{OBJETIVOS}

O objetivo geral deste trabalho é investigar o desenvolvimento e composição de serviços web semânticos no domínio de análise de expressão gênica. Os objetivos específicos deste trabalho incluem:

1. Definição de uma metodologia para o desenvolvimento de serviços web semânticos que permita a implementação de serviços web a partir de ferramentas de software existentes e a anotação semântica dos serviços desenvolvidos, de maneira sistemática;

2. Aplicação da metodologia proposta no desenvolvimento de um conjunto representativo de serviços web semânticos que forneçam funcionalidades para a realização de diferentes atividades de análise em dados de expressão gênica;

3. Definição de uma abordagem para a composição de serviços web semânticos adequada aos requisitos do domínio de análise de expressão gênica que favoreça diferentes tipos de usuários;

4. Desenvolvimento de uma infraestrutura de suporte à criação e execução automática de composições de serviços web semânticos para a análise de expressão gênica. 


\subsection{ESCOPO}

Este trabalho possui como foco o desenvolvimento de um ambiente de suporte à criação e execução de composições (semânticas) de serviços de acordo com uma abordagem adequada aos requisitos do domínio de genômica funcional. No entanto, os seguintes tópicos estão fora do escopo deste trabalho:

1. Desenvolvimento de um conjunto abrangente de serviços para a análise de expressão gênica que forneça suporte a diferentes atividades de análise e tipos de dados. No contexto deste trabalho, desenvolvemos apenas um conjunto representativo de serviços, utilizado para propósitos de aplicabilidade da solução proposta. Este conjunto de serviços fornece suporte a diferentes atividades de análise em dados de microarray (one-color e two-color) e RNA-Seq. Estas atividades incluem normalização, identificação de genes diferencialmente expressos, agrupamento e análise funcional. No entanto, outros tipos de dados de expressão gênica e atividades de análise, tais como o processamento de redes gênicas, não são suportados;

2. Investigação aprofundada dos aspectos associados ao projeto e desenvolvimento de ontologias. No contexto deste trabalho, apenas investigamos os aspectos considerados necessários para a definição de ontologias de suporte à aplicação da solução proposta no domínio de genômica funcional. Neste sentido, estas ontologias não foram desenvolvidas com base em uma metodologia formal de desenvolvimento;

\subsection{METODOLOGIA}

De modo a atingir os objetivos especificados, as seguintes atividades foram realizadas neste trabalho:

A1. Estudo de diferentes abordagens para a obtenção de dados de expressão gênica, tais como microarrays de DNA, RNA-Seq e Real-Time Polymerase Chain Reaction (RT-PCR);

A2. Estudo de técnicas utilizadas para a análise de dados de expressão gênica. Durante esta atividade, foi realizado um estudo mais aprofundado das técnicas de análise, dos métodos 
estatísticos e das ferramentas disponíveis para a análise de dados de expressão obtidos a partir de microarrays de DNA e sequenciamento de RNA (RNA-Seq);

A3. Estudo das principais técnicas e linguagens para representação de conhecimento na web. Durante esta atividade, foi realizado um estudo aprofundado sobre o uso de ontologias para a representação de informações;

A4. Estudo dos fundamentos e das tecnologias associadas ao desenvolvimento, descrição e composição de serviços web (semânticos). Durante esta atividade, foi realizado um estudo sobre as principais abordagens para a descrição semântica de serviços web. Adicionalmente, foi realizado um levantamento sobre as abordagens existentes para o desenvolvimento e composição de serviços web semânticos;

A5. Definição de uma metodologia para o desenvolvimento de serviços web semânticos. Esta metodologia tem como objetivo fornecer uma abordagem sistemática para a implementação de serviços web e para a anotação semântica de suas interfaces com termos provenientes de ontologias;

A6. Aplicação da metodologia proposta no desenvolvimento de diferentes serviços web semânticos para a análise de expressão gênica. Nesta atividade, duas ontologias foram definidas de modo a possibilitar a aplicação da metodologia no domínio de análise de expressão gênica. Como parte desta atividade, diferentes serviços web também foram desenvolvidos e anotados semanticamente com conceitos provenientes das duas ontologias desenvolvidas;

A7. Definição de uma abordagem para a composição de serviços web semânticos adequada aos requisitos do domínio de análise de expressão gênica;

A8. Desenvolvimento de um ambiente centrado no usuário que dê suporte à criação e execução de composições de serviços web semânticos para a análise de expressão gênica;

A9. Avaliação do ambiente de suporte desenvolvido por meio da realização de diferentes estudos de análise de expressão gênica, utilizando os serviços web semânticos previamente desenvolvidos de acordo com a metodologia proposta. 


\subsection{ORGANIZAÇÃO DO DOCUMENTO}

A Figura 1 apresenta a estrutura desta tese, indicando como os capítulos estão relacionados com as etapas da metodologia. Os Capítulos 1, 2 e 3 apresentam a fundamentação teórica do trabalho. Os Capítulos 4, 5, 6 e 7 apresentam os resultados obtidos. Finalmente, o Capítulo 8 apresenta a análise dos resultados obtidos e as conclusões do trabalho.

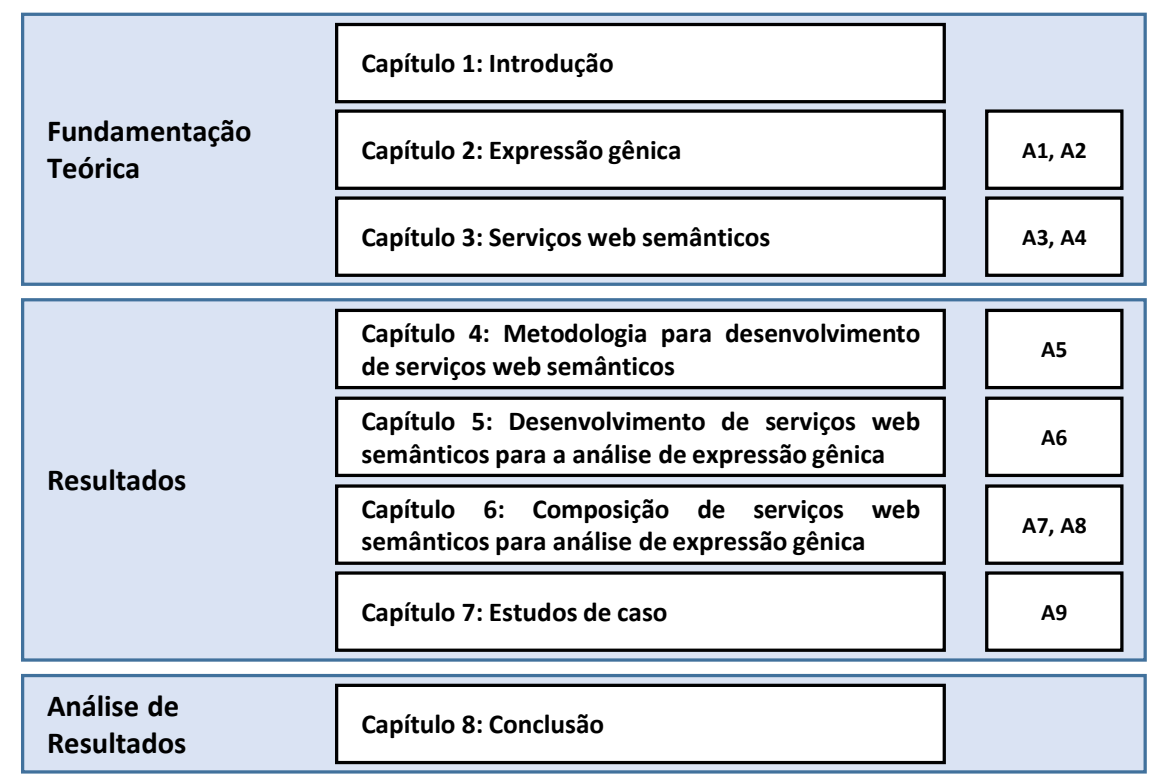

Figura 1: Estrutura da tese.

Os capítulos desta tese estão estruturados da seguinte forma: o Capítulo 2 apresenta uma revisão bibliográfica sobre o domínio de expressão gênica; o Capítulo 3 apresenta uma revisão bibliográfica sobre o desenvolvimento, descrição e composição de serviços web semânticos; o Capítulo 4 apresenta a metodologia proposta para o desenvolvimento de serviços web semânticos; o Capítulo 5 apresenta a aplicação da metodologia proposta no desenvolvimento de um conjunto representativo de serviços para a análise de expressão gênica; o Capítulo 6 apresenta a abordagem proposta para a composição de serviços web semânticos no domínio de genômica funcional e a infraestrutura de suporte desenvolvida; o Capítulo 7 apresenta os estudos de caso utilizados para a avaliação da infraestrutura de suporte desenvolvida para a composição de serviços web semânticos para a análise de expressão gênica; finalmente, o Capítulo 8 apresenta uma discussão sobre as contribuições deste trabalho e elenca direções para pesquisas futuras. 


\section{EXPRESS ÃO GÊNICA}

O Projeto Genoma $[44,45]$, considerado um marco da ciência, permitiu a montagem de um mapa dos genes humanos, abrindo caminho para diferentes áreas de estudo, tais como medicina personalizada e estudos populacionais. No entanto, grande parte da informação revelada por este projeto não podia ser efetivamente utilizada uma vez que as funções para a maioria dos genes descobertos eram desconhecidas. Neste contexto, a área de genômica funcional surgiu com o intuito de atribuir funções às informações genéticas armazenadas no genoma por meio da medição simultânea dos níveis de expressão de milhares de genes em resposta a diferentes perturbações ambientais. Quando o objetivo da genômica funcional é atingido, novos conhecimentos sobre os sistemas biológicos podem ser adquiridos e, no caso de doenças, por exemplo, novas terapias podem ser concebidas.

Expressão gênica refere-se ao processo biológico de síntese de produtos gênicos (RNAs codificantes ou não codificantes) a partir das informações codificadas em genes presentes no DNA. A Figura 2 apresenta uma visão geral do processo de expressão gênica. Neste processo, um transcrito primário é inicialmente produzido a partir das informações codificadas em um gene por meio do processo de transcrição. Este transcrito primário passa então por modificações durante diferentes etapas de processamento, que podem incluir poliadenilação e splicing (remoção de íntrons), entre outras. Após a etapa de processamento, um transcrito maduro é produzido. Este transcrito pode ser um RNA não codificante (ncRNA) ou um RNA mensageiro (mRNA). Caso um RNA mensageiro tenha sido produzido, o mesmo passa ainda por um processo de tradução, responsável pela produção de uma proteína. 


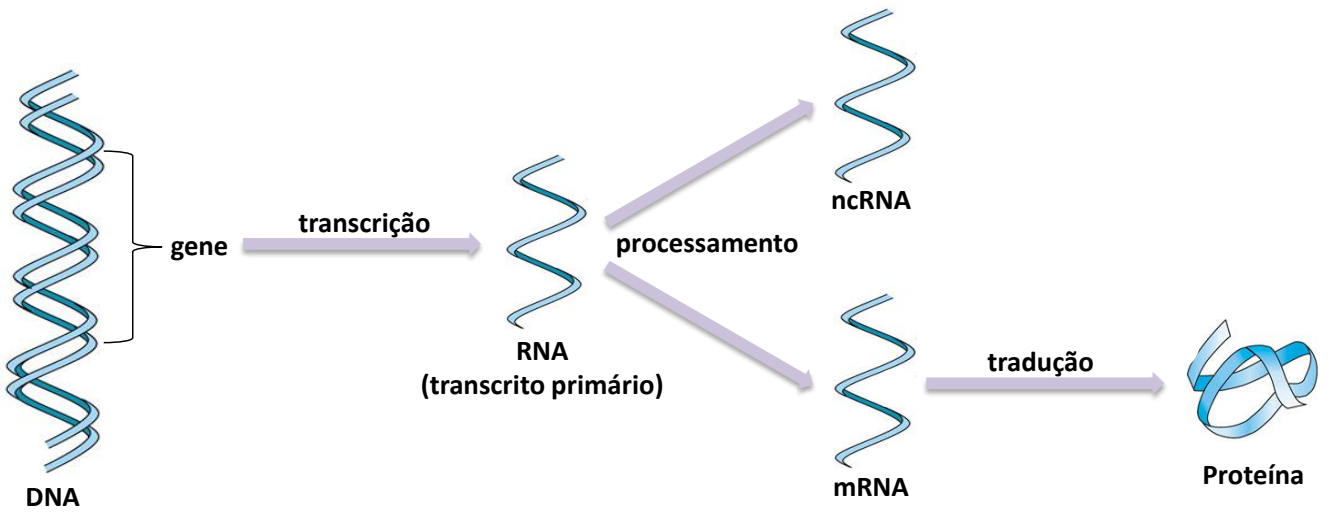

Figura 2: Processo de expressão gênica.

A medição da expressão gênica refere-se à quantificação do nível com que um determinado gene se expressa dentro de uma célula, tecido ou organismo, ou seja, a quantidade de RNAs codificantes e não codificantes produzidos pelo gene. A medição da expressão de genes em células ou tecidos distintos e a posterior análise comparativa dos dados gerados podem fornecer novas evidências biológicas. Atualmente, a medição dos níveis de expressão gênica pode ser realizada por meio de diferentes abordagens, tais como microarrays de DNA [1,2] e RNASeq [3]. Uma vez obtidos dados de expressão gênica, os biologistas frequentemente precisam realizar diferentes atividades de análise nos dados de modo a extrair conhecimentos associados aos fenômenos biológicos sendo estudados.

O restante deste capítulo está estruturado da seguinte forma: a Seção 2.1 apresenta as principais abordagens utilizadas para a obtenção de dados de expressão gênica; e a Seção 2.2 apresenta as diferentes atividades de análise que podem ser realizadas em dados de expressão gênica.

\subsection{OBTENÇÃO DE DADOS DE EXPRESS ÃO GÊNICA}

\subsubsection{Visão Geral}

Diferentes abordagens têm sido utilizadas para a obtenção de dados de expressão gênica. Estas abordagens podem ser classificadas de acordo com a técnica utilizada para a obtenção dos níveis de expressão gênica: abordagens baseadas em hibridização e abordagens baseadas em sequenciamento. As abordagens baseadas em hibridização permitem a quantificação de níveis 
de expressão gênica por meio da ligação não covalente (pareamento) de sequências nucleotídicas complementares. Os microarrays de DNA [1,2] e os tilling arrays [46] representam as abordagens baseadas em hibridização mais comumente utilizadas.

As abordagens baseadas em sequenciamento determinam os níveis de expressão gênica por meio da determinação direta das sequências nucleotídicas de interesse. Inicialmente, o sequenciamento de Sanger [47] de bibliotecas de expressed sequence tags (ESTs) era utilizado para a quantificação de níveis de expressão gênica. No entanto, esta abordagem permitia a medição dos níveis de expressão de poucos genes com um alto custo. Surgiram então abordagens baseadas em sequenciamento de tags, que são pequenos fragmentos de sequência utilizados para identificar transcritos de forma exclusiva. Estas abordagens permitem a medição de um maior número de genes a um custo mais baixo em relação à abordagem anterior. Exemplos de abordagens baseadas em sequenciamento de tags incluem Massively Parallel Signature Sequencing (MPSS) [48], Cap Analysis of Gene Expression (CAGE) [49] e Serial Analysis of Gene Expression (SAGE) [50].

O surgimento das tecnologias de sequenciamento de segunda geração [51] possibilitou o desenvolvimento de uma nova abordagem para a obtenção de dados de expressão gênica, o sequenciamento de RNA (RNA-Seq) [3]. Ao contrário das outras abordagens baseadas em sequenciamento, a abordagem RNA-Seq não requer a clonagem de DNA em vetores plasmídicos para a realização do sequenciamento, permitindo assim a medição de um número maior de genes a um baixo custo.

No entanto, esta abordagem também apresenta algumas limitações [52], incluindo a introdução de erros nas sequências durante o processo de amplificação das moléculas e a diminuição na precisão do sequenciamento com o aumento do tamanho dos fragmentos de sequências examinados. Neste sentido, as tecnologias de sequenciamento de terceira geração [53] têm surgido como uma alternativa para o sequenciamento de RNA. O sequenciamento de terceira geração não requer a amplificação das moléculas a serem sequenciadas e portanto, tem sido utilizado na análise de fragmentos de sequências maiores (entre 10.000 e 15.000 pares de bases). Contudo, esta abordagem de sequenciamento ainda possui um alto custo e assim, não tem sido amplamente utilizada. 
As abordagens baseadas em hibridização são relativamente baratas e permitem a medição da expressão de milhares de genes simultaneamente. No entanto, estas abordagens possuem algumas desvantagens em relação às abordagens baseadas em sequenciamento [3]. Em geral, as abordagens baseadas em hibridização limitam-se à detecção de transcritos que correspondem a sequências genômicas conhecidas. Por outro lado, as abordagens baseadas em sequenciamento permitem o estudo de organismos cuja genoma ainda não foi determinado.

Além disto, as abordagens baseadas em hibridização determinam o nível de expressão de um gene com base na intensidade de sinal obtida a partir da hibridização dos transcritos de interesse com sequências-alvo. No entanto, as sequências-alvo podem hibridizar perfeitamente com as moléculas de interesse ou apenas com segmentos destas moléculas (hibridização cruzada). Neste contexto, os sinais obtidos podem não corresponder exatamente aos níveis de expressão gênica. De forma contrária, nas abordagens baseadas em sequenciamento, o nível de expressão de um gene é determinado diretamente com base na contagem de fragmentos de sequências nucleotídicas. Assim, as abordagens baseadas em sequenciamento geralmente fornecem uma medição mais precisa dos níveis de expressão gênica.

Finalmente, as intensidades de sinal obtidas em abordagens baseadas em hibridização podem não corresponder diretamente aos níveis de expressão dos genes devido a fenômenos de saturação. No fenômeno de saturação, quando a intensidade de um sinal excede um valor limiar, este valor limiar é atribuído à mesma. Desta forma, os sinais obtidos para genes com níveis de expressão extremos podem não corresponder exatamente aos níveis de expressão reais. As abordagens baseadas em sequenciamento não estão sujeitas a fenômenos de saturação. Assim, em geral, estas abordagens são mais eficientes para a detecção de genes com níveis de expressão extremos (pouco ou muito expressos).

Apesar das limitações apresentadas, as abordagens de microarrays de DNA e RNA-Seq têm sido amplamente utilizadas. Outra técnica bastante utilizada para a obtenção de dados de expressão gênica que não se enquadra na classificação hibridização/sequenciamento é a Real-Time Polymerase Chain Reaction (RT-PCR) [54]. Embora esta técnica seja bastante precisa na detecção dos níveis de expressão gênica de uma amostra, a mesma não permite a análise de uma grande quantidade de genes simultaneamente. Desta forma, esta abordagem tem sido utilizada 
na validação de experimentos para a análise de um subconjunto de genes previamente identificado com o uso de outra abordagem.

\subsubsection{Microarrays de DNA}

A abordagem de microarray de DNA [1,2] baseia-se no processo biológico de hibridização, pelo qual sequências nucleotídicas complementares estabelecem ligações não covalentes, pareandose. Um microarray de DNA consiste em uma superfície sólida que possui um conjunto de spots de DNA contendo sequências específicas de DNA (sondas). Estas sondas são utilizadas para hibridizar com as amostras de DNA complementar (cDNA) que se deseja quantificar. Estas amostras são marcadas com alguma substância fluorescente. As sequências nucleotídicas marcadas que se pareiam com as sondas geram sinais que dependem da extensão das regiões pareadas e de condições experimentais, tais como temperatura. Os sinais obtidos determinam a abundância dos produtos gênicos sintetizados.

A Figura 3 apresenta uma visão geral de um experimento para medição de expressão gênica com a abordagem de microarray de DNA. Em um experimento de microarray, as amostras de cDNA de interesse inicialmente se pareiam com as sondas de DNA complementares presentes na superfície do microarray. Em seguida, as moléculas de cDNA não hibridizadas são removidas do microarray. Finalmente, uma imagem de microarray é produzida excitando-se as moléculas de cDNA previamente marcadas com um laser e escaneando-se o chip de microarray para medir a emissão de fluorescência destas moléculas.

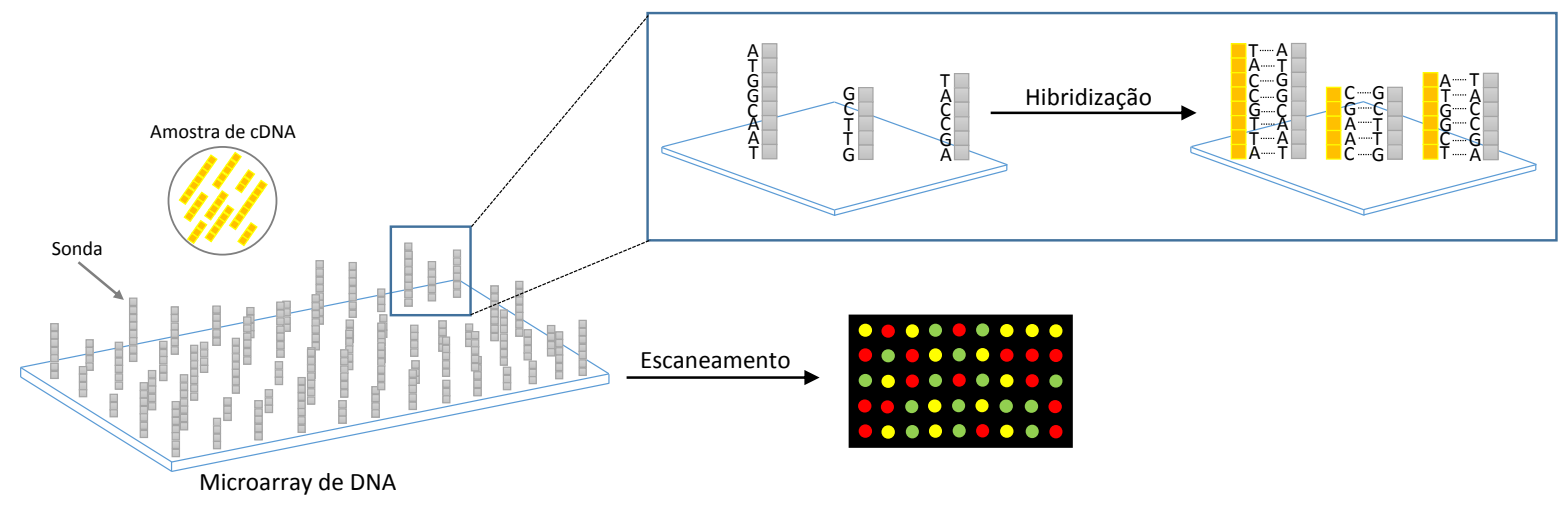

Figura 3: Experimento de microarray de DNA. 
A medição de níveis de expressão gênica usando microarrays de DNA pode ser realizada de acordo com duas abordagens distintas [55,56]: microarrays one-color/single-channel e microarrays two-color/ dual-channel. Os microarrays one-color representam uma abordagem mais recente, na qual todas as amostras biológicas de interesse são marcadas com a mesma substância fluorescente e hibridizadas em diferentes arrays. Esta abordagem permite a quantificação dos níveis de expressão absolutos de cada amostra. Na abordagem two-color, duas amostras biológicas de interesse são marcadas com diferentes substâncias fluorescentes e hibridizadas no mesmo array. Esta abordagem permite a quantificação dos níveis de expressão relativos entre as amostras.

Diferentes plataformas, tais como Affymetrix [57], Agilent [58] e Illumina [59], podem ser utilizadas para a realização de experimentos de microarray. Estas plataformas utilizam diferentes tecnologias e protocolos de hibridização. As plataformas Affymetrix e Illumina podem ser utilizadas apenas para a realização de experimentos de microarray one-color, ao passo que a plataforma Agilent pode ser utilizada para experimentos de microarray one-color e two-color. Além disto, os dados de expressão gerados a partir de um determinado experimento podem ser obtidos a partir de diferentes sistemas de escaneamento e processamento de imagens. Por exemplo, o sistema Genepix [60] permite o escaneamento e o processamento de imagens obtidas a partir de experimentos de microarray one-color e two-color. Os dados de expressão obtidos a partir de diferentes plataformas e sistemas de escaneamento de imagens apresentam diferentes formatos. Desta forma, a comparação de dados de expressão obtidos a partir de diferentes experimentos pode não ser trivial.

Adicionalmente, algumas variações da técnica de microarrays de DNA têm sido desenvolvidas para a realização de diferentes tipos de estudo. A variação mais comumente utilizada é a abordagem de tilling arrays [46]. Esta abordagem baseia-se no mesmo princípio dos microarrays de DNA, ou seja, sequências específicas de DNA (sondas) contidas em spots de um array são utilizadas para hibridizar com amostras de cDNA de interesse, de modo a quantificar o nível de expressão de diferentes genes simultaneamente. No entanto, ao contrário da abordagem tradicional de microarrays, as sondas contidas nos spots de um tilling array correspondem conjuntamente a sequências adjacentes ou parcialmente sobrepostas (contigs) de um genoma inteiro ou de uma parte de interesse do genoma. 
Assim como os microarrays de DNA, a abordagem de tilling arrays permite a medição simultânea dos níveis de expressão de uma grande quantidade de genes. No entanto, a abordagem de tilling arrays possui uma maior gama de aplicações. Os tilling arrays podem ser utilizados para a caracterização de regiões genômicas cujas funções não são previamente conhecidas, para a descoberta de sítios de interação DNA/proteína e de metilação, para a descoberta de regiões genômicas hipersensíveis a DNase, entre outras aplicações.

\section{Padronização de Dados de Microarray}

A troca de dados obtidos a partir de experimentos de microarray tem sido facilitada pelo desenvolvimento de diferentes padrões. A especificação Minimum Information About a Microarray Experiment (MIAME) [61] tem como objetivo estabelecer um modelo conceitual para a representação de experimentos de microarray, de modo a garantir que os dados gerados a partir destes experimentos possam ser interpretados de forma não ambígua e que as análises realizadas nos dados possam ser interpretadas e reproduzidas.

Além disto, o desenvolvimento de um formato comum para a representação dos dados de microarray, chamado MicroArray Gene Expression Markup Language (MAGE-ML) [62], tem permitido a troca de dados provenientes de diferentes estudos. No entanto, devido à sua complexidade, este formato não tem sido amplamente adotado. Por outro lado, o formato MicroArray Gene Expression Tabular (MAGE-TAB) [63] representa uma solução simplificada do formato MAGE-ML para a representação de dados de microarray, uma vez que os dados são representados em arquivos-texto tabulares.

De acordo com a especificação MAGE-TAB, um experimento de microarray pode ser completamente descrito por meio das informações contidas nos seguintes formatos:

i) Investigation Description Format (IDF), que fornece informações gerais sobre o experimento de microarray, tais como nome e descrição textual do experimento e dos protocolos utilizados;

ii) Array Design Format (ADF), que fornece informações sobre quais sequências estão localizadas em cada spot de um microarray; 
iii) Sample and Data Relationship Format (SDRF), que fornece uma descrição dos relacionamentos entre as amostras, os arrays, os dados e outros objetos utilizados ou produzidos durante o experimento;

iv) Raw and processed data files, que contêm os dados de expressão brutos e processados obtidos a partir do experimento, respectivamente. Estes arquivos estão codificados em American Standard Code for Information Interchange (ASCII) ou em binário e apresentamse em seus formatos nativos. Por exemplo, no formato CEL [64], no caso de dados gerados a partir da plataforma Affymetrix, e no formato GPR [65], no caso de dados escaneados a partir do sistema de escaneamento Genepix. Os dados de expressão também podem ser representados em matrizes de dados (arquivos texto tabulares).

De acordo com a especificação MAGE-TAB, as matrizes de dados e os arquivos IDF, SDRF e ADF devem ser apresentados em arquivos-texto tabulares.

Os dados obtidos a partir de experimentos de microarray são, em geral, disponibilizados publicamente em duas bases de dados principais: ArrayExpress [66] e Gene Expression Omnibus (GEO) [67]. Na base de dados GEO, os dados podem ser submetidos em diferentes formatos, tais como Simple Omnibus Format in Text (SOFT) [68] e MIAME Notation in Markup Language (MINiML) [69]. Na base de dados ArrayExpress, os dados são disponibilizados apenas no formato MAGE-TAB. Em ambas, os dados estão de acordo com o padrão MIAME.

\subsubsection{Sequenciamento de RNA (RNA-Seq)}

A abordagem de sequenciamento de RNA (RNA-Seq) [3] baseia-se no sequenciamento de moléculas de cDNA obtidas a partir de amostras de RNA de interesse. Esta abordagem permite não apenas a quantificação, mas também o mapeamento de transcritomas complexos.

Em um experimento de RNA-Seq, uma amostra de interesse contendo produtos gênicos (moléculas de RNA totais ou fracionadas) é inicialmente convertida para uma biblioteca de fragmentos de sequências de cDNA com adaptadores anexados a ambas as extremidades. Após a obtenção da biblioteca, cada molécula de cDNA é então amplificada e sequenciada com o uso de técnicas de sequenciamento de segunda geração. O sequenciamento das moléculas de cDNA 
gera pequenos fragmentos de sequências a partir de uma das extremidades da molécula (sequenciamento single-end) ou de ambas as extremidades (sequenciamento pair-end). Estes pequenos fragmentos de sequências são chamados de reads.

Ao contrário das abordagens SAGE, CAGE e MPSS, em que os fragmentos de sequências possuem um tamanho fixo, os reads gerados a partir de sequenciamento em um experimento de RNA-Seq podem possuir tamanhos variados. Em geral, os reads gerados possuem entre 30 e 400 pares de bases, dependendo da tecnologia de sequenciamento utilizada.

Diferentes plataformas de sequenciamento de segunda geração podem ser utilizadas para a obtenção de dados de RNA-Seq, tais como Illumina Genome Analyzer [70], Applied Biosystems SOLiD [71] e Roche 454 GS FLX [72]. Estas plataformas de sequenciamento adotam procedimentos e processos químicos diferentes. Por exemplo, na plataforma Illumina uma biblioteca de cDNA é primeiramente hibridizada à superfície de uma lâmina (flow-cell). Os fragmentos de cDNA hibridizados à superfície passam por uma etapa de amplificação, onde formam-se agrupamentos de fragmentos. Após esta etapa, a lâmina contendo os agrupamentos é colocada na máquina de sequenciamento. O processo de sequenciamento dos diferentes agrupamentos é realizado paralelamente e em ciclos. O número de ciclos determinará o tamanho dos reads produzidos e o número de agrupamentos determinará a quantidade de reads. Cada ciclo de sequenciamento envolve basicamente três etapas: incorporação de nucleotídeos, imageamento e clivagem de fluoróforos incorporados aos nucleotídeos.

A Figura 4 apresenta uma visão geral da abordagem de sequenciamento adotada na plataforma Illumina. Na primeira etapa do sequenciamento, os quatro tipos de nucleotídeos (A,T,C,G) rotulados com diferentes substâncias fluorescentes são adicionados. Com o auxílio da enzima DNA polimerase, apenas um destes nucleotídeos é incorporado a cada fragmento de sequência (complementar à base do template). Os nucleotídeos que não foram incorporados aos fragmentos de sequências são removidos. Na segunda etapa, o imageamento da lâmina é realizado de modo a determinar quais nucleotídeos foram incorporados aos fragmentos. Cada tipo de nucleotídeo é rotulado com uma fluorescência distinta e assim, emite um sinal diferente, permitindo sua identificação. Finalmente, a terceira etapa consiste na clivagem da substância fluorescente incorporada ao fragmento de sequência e na regeneração do seu grupo 3'-OH (remoção do 
grupo de terminação). Este procedimento é essencial para permitir a incorporação de um novo nucleotídeo no próximo ciclo de sequenciamento.

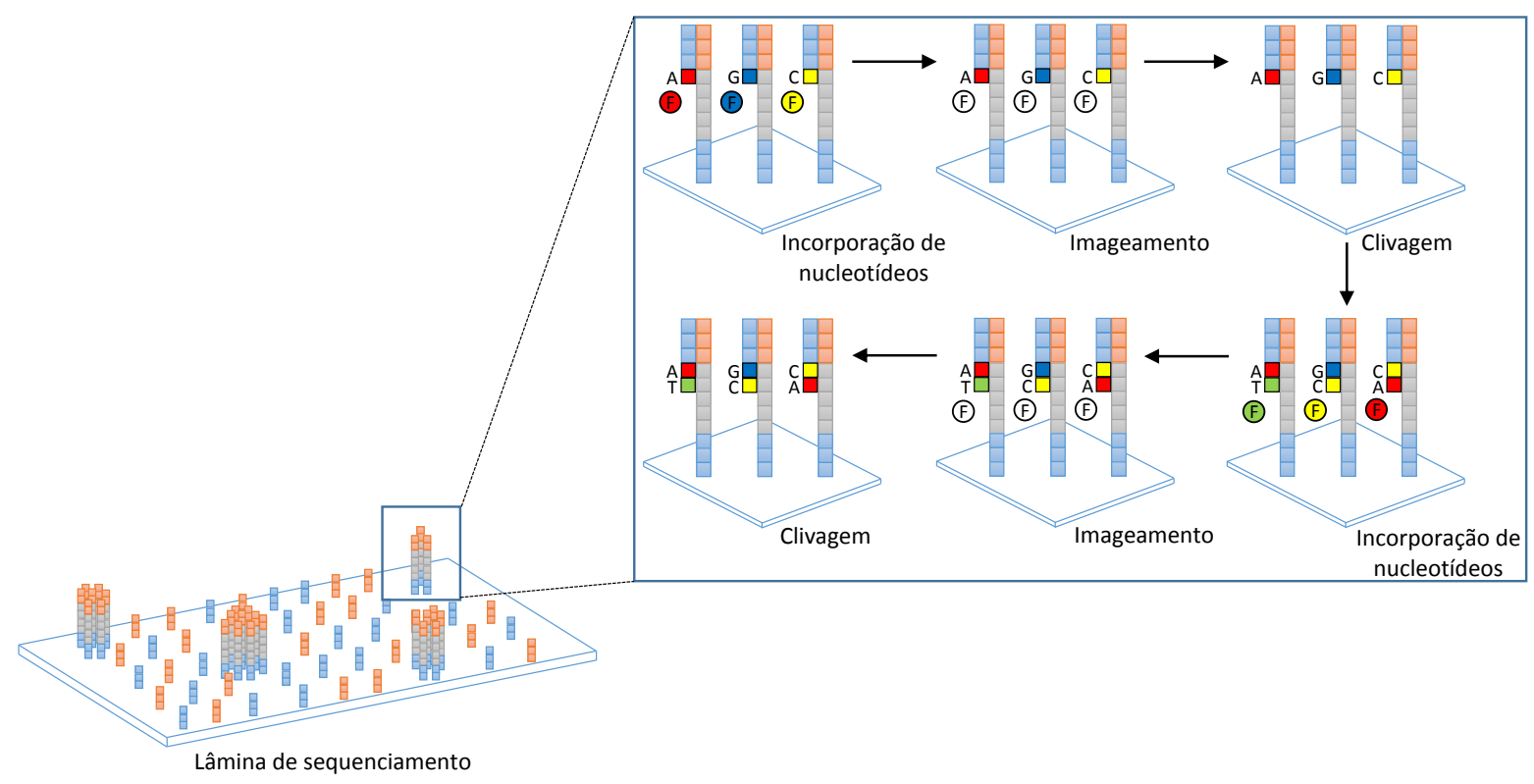

Figura 4: Sequenciamento de RNA na plataforma Illumina.

Independentemente da plataforma utilizada, os dados produzidos a partir de um sequenciamento consistem sempre em uma lista de fragmentos de sequências (reads) cujas bases estão associadas a scores de qualidade, no formato FASTA/QUAL ou FASTQ [73]. Um score de qualidade representa uma estimativa do nível de confiança com que uma base foi lida durante o sequenciamento. Após algumas etapas de processamento, o nível de expressão de cada gene pode ser determinado a partir da contagem dos reads correspondentes a cada gene. Como resultado, uma tabela de contagem de reads pode então ser produzida.

Dentre as abordagens baseadas em sequenciamento, RNA-Seq é a abordagem mais utilizada atualmente. Por um lado, esta abordagem fornece algumas vantagens, tais como a capacidade de detecção de novos transcritos e de splicing alternativo, e assim, tem substituído gradativamente o uso de microarrays de DNA em diferentes laboratórios. Por outro lado, o sequenciamento de RNA é uma abordagem relativamente recente. Consequentemente, o custo desta abordagem ainda pode ser limitante para a realização de alguns estudos e os métodos de análise associados a esta abordagem ainda têm sido amplamente estudados. Assim, os microarrays de DNA continuam a ser utilizados em diferentes cenários de análise de transcritoma. 


\subsubsection{Real-Time Polymerase Chain Reaction (RT-PCR)}

A técnica Real-Time Polymerase Chain Reaction (RT-PCR) [54] permite a medição dos níveis de expressão de genes-alvo específicos, não sendo, portanto, considerada uma abordagem global para a medição de expressão gênica. A técnica RT-PCR combina o procedimento de PCR convencional, que permite a amplificação (criação de cópias) de sequências nucleotídicas, com um mecanismo de detecção e quantificação por fluorescência.

No procedimento de PCR tradicional, uma solução tampão contendo as moléculas de DNA a serem amplificadas, desoxirribonucleotideos trifosfatos (dNTPs), primers e enzimas DNA polimerase, é colocada em um termociclador que permite alterações de temperatura em ciclos temporais pré-definidos. Cada ciclo da PCR consiste em três fases: desnaturação, anelamento e extensão. Na fase de desnaturação, as moléculas de DNA de fita dupla são desnaturadas (separadas) de modo a produzir moléculas de fita simples. Na fase de anelamento, os primers se ligam às extremidades 3' das fitas simples de DNA e a enzima DNA polimerase se liga aos primers para iniciar a construção de uma nova fita complementar. Finalmente, na fase de extensão, a enzima DNA polimerase realiza a síntese de uma fita de DNA complementar por meio da adição sucessiva de dNTPs complementares na direção 5' -3' da nova fita. No início do procedimento, cada ciclo de PCR gera o dobro de cópias de moléculas de DNA. Com o decorrer do tempo, a redução dos reagentes e da atividade da DNA polimerase causa uma redução da quantidade de cópias produzidas. O procedimento de PCR termina quando a atividade dos reagentes e a produção de cópias cessam. Em geral, 25 a 40 ciclos são realizados em um procedimento de PCR.

Na técnica RT-PCR, os produtos gênicos (moléculas de RNA) contidos em uma amostra de interesse são inicialmente convertidos para moléculas de cDNA por meio do processo de transcrição reversa. Estas moléculas são adicionadas a uma solução tampão contendo dNTPs, primers, enzimas DNA polimerase e sequências específicas de DNA (sondas) marcadas com substâncias fluorescentes. Esta solução é colocada em um termociclador que permite a medição do sinal gerado pela excitação das substâncias fluorescentes quando as sondas se ligam às moléculas de DNA (cópias) produzidas. As moléculas de cDNA são então amplificadas usando o procedimento tradicional de PCR. Durante o processo de amplificação, um sinal de intensidade 
é capturado ao final de cada ciclo. Quando a reação atinge a fase exponencial de amplificação (limiar de detecção), é possível determinar o número mínimo de ciclos necessários para a amplificação de cada molécula de cDNA. Quanto menor a quantidade de ciclos, maior a quantidade de uma determinada molécula de cDNA. Desta forma, é possível determinar os níveis de expressão gênica relativos das moléculas contidas na amostra de interesse.

\subsection{ANÁLISE DE EXPRESSÃO GÊNICA}

\subsubsection{Visão Geral}

Em geral, a análise de dados expressão gênica constitui um processo com diferentes etapas de processamento. Estas etapas podem incluir a normalização dos dados, a identificação de genes diferencialmente expressos, o agrupamento de genes de acordo com seus perfis de expressão, a construção de redes regulatórias de genes, a filtragem dos dados de acordo com algum critério pré-estabelecido, a anotação de genes com conceitos presentes em ontologias, a análise funcional dos dados, entre outras. Diferentes ferramentas de software permitem a realização de uma ou mais destas etapas individualmente. Assim, a análise de dados de expressão gênica frequentemente requer o uso de diferentes ferramentas de software.

Tipicamente, os dados de expressão gênica obtidos a partir de experimentos de medição podem conter erros relacionados a efeitos técnicos. Estes efeitos podem ser resultantes de diferenças nos procedimentos experimentais adotados e tecnologias utilizadas. A normalização de dados de expressão gênica tem como objetivo reduzir erros relacionados a estes efeitos técnicos, de modo a permitir a análise comparativa dos dados obtidos a partir de diferentes experimentos. Desta forma, a normalização dos dados é uma atividade fundamental no processo de análise de expressão gênica $[74,75]$.

Uma vez que os dados de expressão gênica tenham sido normalizados, duas atividades são usualmente realizadas: agrupamento e análise de expressão diferencial. O agrupamento de dados de expressão gênica tem como objetivo identificar grupos de genes com perfis de expressão similares em condições experimentais distintas. Esta atividade permite a identificação de genes coexpressos e, possivelmente, com funções relacionadas. A análise de expressão diferencial 
tem como objetivo identificar genes diferencialmente expressos entre duas ou mais condições experimentais distintas. Esta atividade permite a identificação dos genes direta ou indiretamente associados de forma relevante aos processos biológicos sendo estudados. Uma vez que um subconjunto de genes diferencialmente expressos é identificado, o mesmo pode ainda ser submetido a uma análise de agrupamento.

Finalmente, a análise funcional de dados de expressão gênica permite a identificação das vias e processos biológicos associados aos genes de interesse em um experimento. Em geral, esta atividade é realizada após a análise de expressão diferencial e/ou agrupamento dos dados de expressão. A identificação de vias/processos biológicos pode ser realizada por meio de um processo de análise de enriquecimento, que permite a identificação dos termos biológicos associados em maior proporção aos genes de interesse (anotações funcionais) em ontologias ou outras bases de dados de anotação funcional.

Algumas das atividades envolvidas na análise de expressão gênica, tais como a análise funcional dos dados, são independentes da abordagem utilizada para a obtenção dos dados. Outras atividades, tais como a normalização dos dados, são realizadas de forma específica dependendo da abordagem utilizada para a obtenção dos dados.

\subsubsection{Análise de Dados de Microarray}

Tipicamente, a análise de dados de microarray tem como objetivo a comparação dos níveis de expressão de genes presentes em diferentes tipos celulares ou em indivíduos com diferentes fenótipos. Em geral, este tipo de análise é constituído por diferentes etapas de processamento. A Figura 5 apresenta uma sequência de etapas de processamento tipicamente realizada para a análise de dados de microarray.

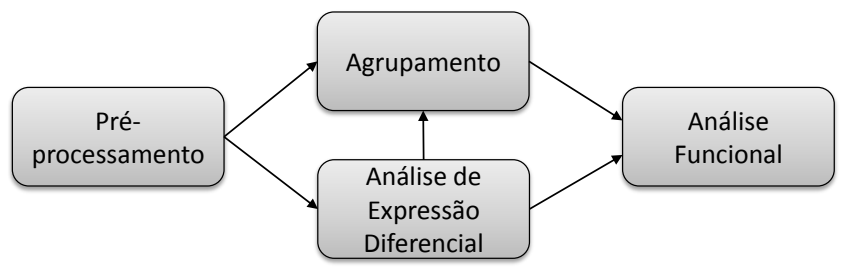

Figura 5: Etapas de processamento para a análise de microarray. 
O pré-processamento de dados de microarray tem como objetivo reduzir efeitos técnicos decorrentes das tecnologias utilizadas para a obtenção dos dados, de modo a permitir a análise comparativa de dados obtidos a partir de diferentes experimentos. Uma vez que os dados de microarray foram pré-processados, duas atividades frequentemente realizadas são a análise de expressão diferencial e/ou agrupamento dos dados. Estas atividades têm como objetivo principal a identificação de genes coexpressos em tipos celulares ou tecidos distintos. Finalmente, uma análise funcional dos genes identificados nas atividades anteriores é frequentemente realizada.

\section{Pré-processamento}

De forma geral, os dados de expressão obtidos a partir de experimentos de microarray podem conter erros relacionados a efeitos técnicos. Estes efeitos técnicos podem ser resultantes de diferenças na extração do mRNA, na preparação das amostras de interesse, nas condições experimentais da hibridização e nas tecnologias utilizadas tanto para a realização dos experimentos quanto para a obtenção dos dados de expressão [76,77]. Neste sentido, a atividade de préprocessamento de dados de microarray tem como objetivo reduzir erros relacionados a estes efeitos técnicos, de modo a possibilitar a posterior análise comparativa dos dados de expressão obtidos a partir de diferentes experimentos.

Em geral, o pré-processamento de dados de microarray one-color envolve quatro etapas [78]: correção de background, normalização entre arrays, correção de hibridização cruzada e sumarização. O pré-processamento de dados de microarray two-color envolve as mesmas etapas, exceto a de correção de hibridização cruzada, que é substituída pela etapa de normalização dentro de arrays. Diferentes métodos podem ser utilizados para a realização de cada uma destas etapas de pré-processamento. Wu [79] fornece uma revisão dos principais métodos estatísticos disponíveis para o pré-processamento de dados de microarray.

Muitas vezes o valor de intensidade obtido a partir de um spot de microarray one-color ou two-color não corresponde exatamente ao nível de expressão do gene de interesse, mas sim à soma dos valores das intensidades de background (viés) e de foreground (nível de expressão real). Este efeito de background é introduzido devido a fatores tais como irregularidades na superfície dos microarrays e efeitos do escaneamento das imagens de microarray. A etapa de 
correção de background refere-se à correção das intensidades de background de modo a obter-se a intensidade correspondente somente ao nível de expressão real do gene de interesse. Diferentes métodos podem ser utilizados para a realização desta etapa. Alguns métodos realizam a correção de background individualmente para cada amostra de microarray, ao passo que outros métodos permitem que diferentes amostras sejam corrigidas simultaneamente com base em um valor comum obtido a partir de todas as amostras.

A etapa de normalização entre arrays tem como objetivo normalizar os níveis de expressão de diferentes amostras de microarray one-color ou two-color, tornando-os comparáveis. Nesta etapa, uma distribuição de probabilidade é definida para um conjunto de amostras, e os dados de cada amostra são então transformados para a distribuição definida.

Em um experimento de microarray one-color, uma sonda pode hibridizar perfeitamente com um mRNA de interesse ou hibridizar apenas com um segmento deste mRNA. O valor de intensidade obtido para cada spot de microarray consiste na soma das intensidades obtidas a partir destes dois tipos de hibridização. A etapa de correção de hibridização cruzada consiste na correção das intensidades obtidas a partir de sondas que não pareiam perfeitamente com mRNAs de interesse.

Tipicamente, em um experimento de microarray one-color ou two-color, diferentes sondas ou spots são projetados para hibridizar com uma mesma sequência nucleotídica que pode representar, por exemplo, um determinado gene. A etapa de sumarização permite que os valores de intensidade obtidos em diferentes spots para uma mesma sequência nucleotídica de interesse sejam representados por meio de um único valor, o qual reflete a expressão daquela sequência. Em geral, este valor é representado em escala logarítmica, de modo a facilitar análises posteriores nos dados.

Em um experimento de microarray two-color, os valores de intensidade obtidos representam, a princípio, o nível de expressão relativo entre duas amostras (canais) hibridizadas no mesmo array. No entanto, efeitos técnicos provenientes, por exemplo, de diferenças na preparação das duas amostras ou no escaneamento dos dois canais, podem distorcer os valores obtidos. A etapa de normalização dentro de arrays tem como objetivo corrigir os valores de intensidade relativos entre os dois canais de um mesmo array. 


\section{Análise de Expressão Diferencial}

A análise de expressão diferencial de dados de microarray tem como objetivo principal a identificação de genes diferencialmente expressos entre condições experimentais ou tipos celulares distintos. Este tipo de análise pode ser realizado para a comparação de duas ou de múltiplas condições distintas, de acordo com diferentes métodos. Dudoit et al. [80] fornecem uma revisão dos principais métodos disponíveis para a análise de expressão diferencial em dados de microarray.

A análise de expressão diferencial de dados de microarray entre múltiplas condições permite, por exemplo, a identificação de genes com padrões de expressão mais diferenciados entre diferentes tipos de células tumorais. Este tipo de análise pode ser realizado por meio de diferentes métodos, tais como Analysis of Variance (ANOVA) [81] e Linear Models for Microarray Data (Limma) [82].

A análise de expressão diferencial de dados de microarray entre duas condições distintas, representadas por uma ou mais amostras de mRNA (réplicas), é mais comumente realizada e permite, por exemplo, a identificação de quais genes são sub ou superexpressos em células tumorais, em comparação a células saudáveis. Este tipo de análise pode ser realizado por meio de diferentes métodos. Os métodos mais simples e comumente utilizados incluem fold change [83-86] e teste t de Student [87-90]. Outros métodos incluem variações do teste t de Student, tais como o teste t regularizado [91], o teste S [92] e o teste B [93].

Embora os diferentes métodos de análise de expressão diferencial possam ser aplicados em dados de microarray não normalizados, os resultados obtidos podem não ser biologicamente significantes, devido a variações experimentais nos dados [94]. Desta forma, em geral, a análise de expressão diferencial deve ser realizada em dados de microarray já normalizados $[95,96]$.

O método mais simples para a análise de expressão diferencial de dados de microarray entre duas condições é o método não estatístico fold change. Na análise fold change de dados de microarray one-color, quando não há réplicas, o módulo da diferença entre os valores de expressão absolutos (em escala logarítmica) de cada gene em duas condições distintas é comparado a um valor limiar de corte pré-determinado. Se o módulo for maior do que o valor limiar pré-estabelecido, o gene é considerado diferencialmente expresso. Caso haja réplicas, o mó- 
dulo da diferença entre as médias dos valores de expressão absolutos (em escala logarítmica) de cada gene em duas condições é comparado ao valor limiar de corte e, se for maior, o gene é considerado diferencialmente expresso.

$\mathrm{Na}$ análise fold change de dados de microarray two-color, quando não há réplicas, o módulo do valor de expressão relativo (entre duas condições distintas) em escala logarítmica de cada gene é comparado a um valor limiar de corte pré-determinado. Se o módulo for maior do que o valor limiar pré-estabelecido, o gene é considerado diferencialmente expresso. Caso haja réplicas, o módulo da média dos valores de expressão (em escala logarítmica) de cada gene é comparado ao valor limiar de corte e, se for maior, o gene é considerado diferencialmente expresso.

O método estatístico mais simples utilizado para a análise de expressão diferencial de dados de microarray replicados entre duas condições é o teste de hipóteses t de Student. A aplicação deste tipo de teste em dados de microarray tem como objetivo verificar para cada gene do conjunto de dados se as médias dos seus níveis de expressão (para todas as réplicas) em duas condições experimentais distintas podem ou não ser consideradas diferentes de acordo com um valor limiar de corte pré-determinado. Este método estatístico deve ser aplicado, preferencialmente, quando os dados analisados possuem no mínimo seis réplicas (biológicas ou experimentais) por condição sendo estudada [95].

De modo geral, a primeira etapa de um teste de hipóteses t de Student conduzido em dados de microarray consiste no cálculo de uma estatística de teste t para cada gene do conjunto de dados. Cada estatística de teste t é então convertida para um valor-p, obtido a partir da distribuição $\mathrm{t}$ de Student. Finalmente, se o valor-p obtido para um determinado gene for menor do que um valor limiar (nível de significância) pré-determinado, então este gene pode ser considerado diferencialmente expresso nas duas condições.

Dadas as diferenças entre dados de microarray one-color e two-color normalizados, diferentes testes t de Student devem ser aplicados a estes diferentes tipos de dados. Dados de microarray two-color normalizados representam os níveis de expressão relativos (em escala logarítmica) de diferentes genes entre duas condições experimentais de interesse. A análise de expressão diferencial de dados de microarray two-color requer o uso do teste t de Student para uma amostra (one-sample Student's t test), uma vez que uma única amostra contém as duas condições expe- 
rimentais a serem comparadas. O teste de hipóteses t de Student para uma amostra tem como objetivo verificar se a média dos níveis de expressão relativos (entre duas condições) de um gene pode ou não ser considerada diferente de acordo com um valor limiar de corte pré-estabelecido para o valor de significância, ou seja, se o gene pode ser considerado diferencialmente expresso entre as duas condições distintas.

Por outro lado, dados de microarray one-color normalizados representam os níveis de expressão absolutos (em escala logarítmica) de diferentes genes em uma única condição experimental de interesse. Uma vez que duas amostras de dados referentes a condições experimentais distintas são necessárias para comparação, a análise de expressão diferencial de dados de microarray one-color requer o uso do teste t de Student para duas amostras (two-sample Student's t test). Além disto, em geral, assume-se que as variâncias dos níveis de expressão dos genes em duas condições experimentais distintas são diferentes. Sendo assim, o método de estimação de variâncias de Welch [97] é bastante utilizado. O teste de hipóteses t de Student para duas amostras tem como objetivo verificar se as médias dos níveis de expressão absolutos de um gene em duas condições distintas podem ou não ser consideradas diferentes de acordo com um valor limiar de corte pré-estabelecido para o valor de significância, ou seja, se o gene pode ser considerado diferencialmente expresso entre as duas condições distintas.

Em geral, quando um teste de hipóteses é conduzido para verificar se um gene é diferencialmente expresso em dados de microarray one-color ou two-color, dois tipos de erros podem ser cometidos: erros do tipo I e do tipo II. Erros do tipo I referem-se à obtenção de falsos-positivos, ou seja, considera-se que um gene é diferencialmente expresso em duas condições quando de fato não é. Por outro lado, erros do tipo II referem-se à obtenção de falsos-negativos, ou seja, considera-se que um gene não é diferencialmente expresso em duas condições quando de fato é. Normalmente, os testes estatísticos controlam a probabilidade de erros do tipo I. No entanto, na análise de expressão diferencial de dados de microarray, múltiplos testes estatísticos são conduzidos para uma grande quantidade de genes representada nos dados, levando a um acúmulo de erros do tipo I, chamado de "problema de múltiplos testes" [95, 98].

Diferentes métodos, tais como os métodos de correção propostos por Bonferroni [99], Holm [100], Hochberg [101], Hommel [102], Benjamini e Hochberg [103], e Benjamini e Yekutieli [104], podem ser utilizados para a correção dos valores-p obtidos quando múltiplos testes de 
hipóteses são conduzidos, gerando os chamados "valores-p ajustados". Com o uso destes métodos de correção, o valor-p ajustado obtido para cada gene é comparado ao valor limiar (nível de significância) escolhido para o teste t de Student e, se for menor, o gene pode ser considerado diferencialmente expresso nas duas condições.

Uma prática comum após a identificação de genes diferencialmente expressos em dados de microarray por meio de testes estatísticos é a geração de um volcano plot, de modo a facilitar a visualização dos resultados obtidos [95]. Um volcano plot é um gráfico gerado com valores de expressão gênica relativos (em escala logarítmica na base 2) no eixo x e com valores-p (negativados e transformados para uma escala logarítmica na base 10) no eixo y, para cada gene. Neste tipo de gráfico, os genes identificados como diferencialmente expressos com alto nível de significância no teste aparecem próximos à extremidade superior. Os genes com níveis de expressão extremos (muito baixos ou altos) aparecem nas extremidades direita e esquerda do gráfico. Desta forma, os genes de interesse, em geral, encontram-se nas extremidades superiores à direita e à esquerda do gráfico.

A Figura 6 apresenta um exemplo de um gráfico volcano plot para a representação de genes diferencialmente expressos. Cada ponto no gráfico representa um gene. Os pontos vermelhos e verdes indicam genes subexpressos e superexpressos, respectivamente. Os demais pontos indicam genes sem expressão diferencial entre as amostras de interesse.

\subsubsection{Análise de Dados de RNA-Seq}

Tipicamente, a análise de dados de RNA-Seq tem como objetivo a detecção de diferenças nos níveis de expressão de genes contidos em duas ou mais amostras. Este tipo de análise é realizado em estudos que visam à identificação de variações moleculares responsáveis por diferenças em fenótipos de interesse, tais como tipos celulares distintos. Em geral, este tipo de estudo é constituído por diferentes etapas de processamento. A Figura 7 apresenta uma sequência de etapas de processamento tipicamente realizada para a análise de dados de RNA-Seq.

O pré-processamento de dados de RNA-Seq tem como objetivo melhorar a qualidade global do conjunto de dados de sequenciamento. Uma vez que os dados foram pré-processados, as próximas atividades consistem no mapeamento e sumarização dos dados. Estas atividades têm 


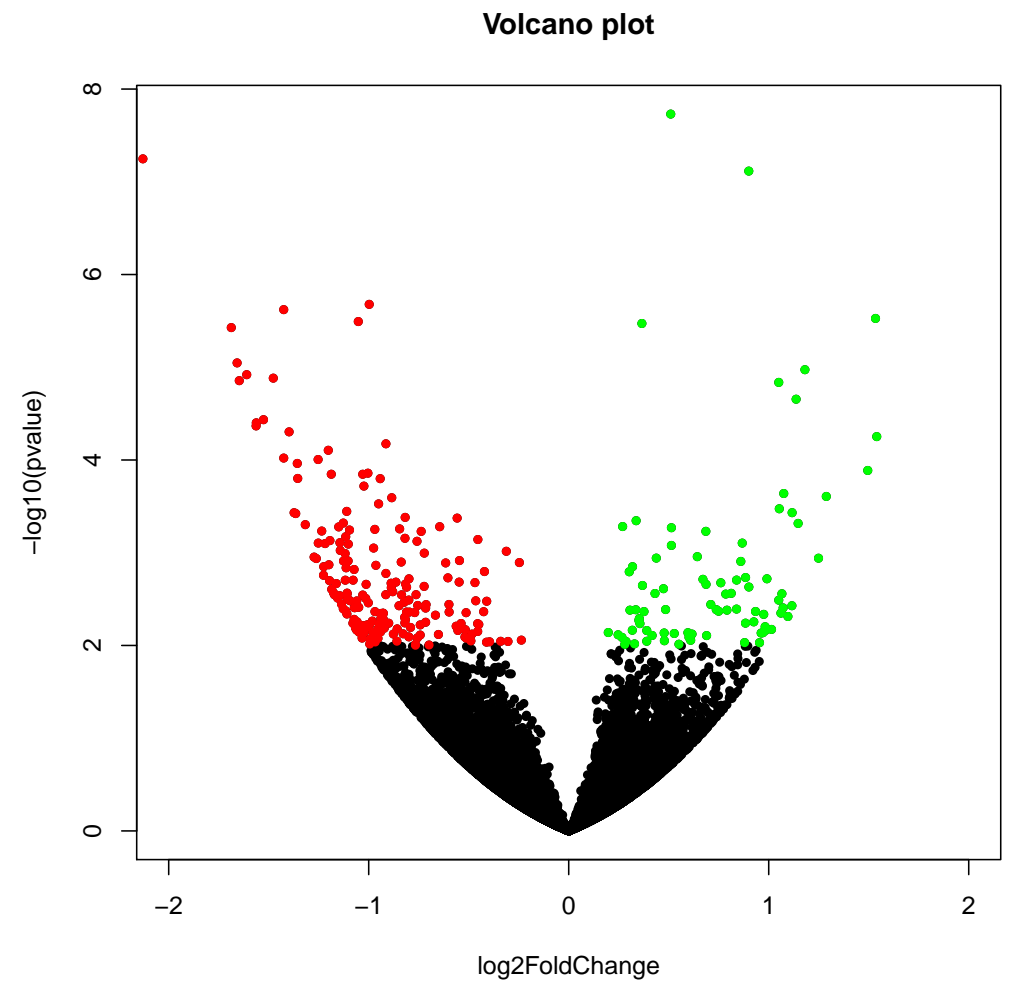

Figura 6: Gráfico volcano plot.

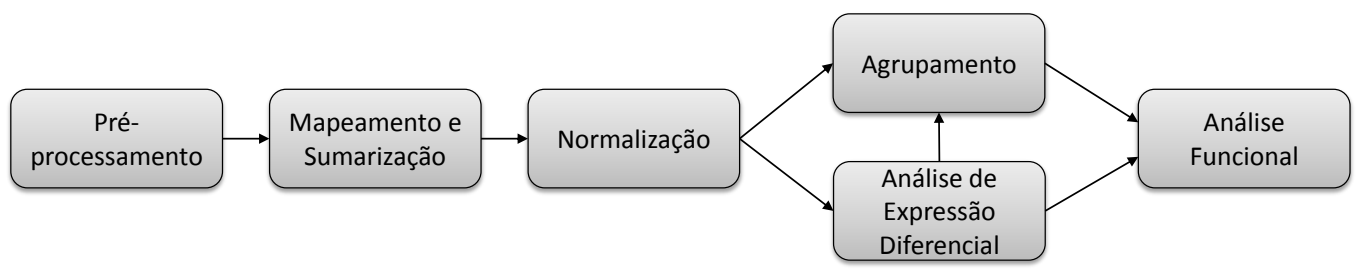

Figura 7: Etapas de processamento para a análise de RNA-Seq.

como objetivo a construção de tabelas de contagens de reads, que refletem, em princípio, os níveis de expressão gênica de diferentes amostras de interesse. Uma vez que estas tabelas são produzidas, a normalização dos dados de expressão pode ser realizada para reduzir os efeitos técnicos decorrentes dos protocolos e tecnologias de sequenciamento utilizados, tornando os dados provenientes de diferentes amostras comparáveis. Após a realização desta atividade, a análise comparativa dos níveis de expressão gênica de diferentes amostras pode ser realizada. Assim como em dados de microarray, este tipo de análise pode ser feito por meio de duas atividades: análise de expressão diferencial e/ou agrupamento. Após a análise comparativa dos dados, uma análise funcional dos genes é frequentemente realizada. 


\section{Verificação de Qualidade e Pré-processamento}

Uma vez que uma lista de fragmentos de sequências (reads) é produzida a partir do sequenciamento de RNA-Seq, a primeira atividade de análise dos dados consiste tipicamente na verificação da qualidade das sequências obtidas. Durante esta atividade, além da verificação da qualidade das sequências, também é possível identificar erros relacionados a efeitos técnicos nos dados. Estes efeitos técnicos podem estar associados, por exemplo, a erros no processo de preparação das amostras e/ou defeitos mecânicos durante o sequenciamento das amostras.

A verificação da qualidade das sequências obtidas a partir do sequenciamento de RNA constitui uma atividade de análise exploratória. De modo a facilitar esta atividade, algumas ferramentas de suporte [105-107] podem ser utilizadas para o cálculo de diferentes estatísticas que permitem descrever de forma resumida o grande volume de dados gerado a partir de um sequenciamento. Além disto, estas ferramentas fornecem representações gráficas que facilitam a interpretação dos dados. Diferentes estatísticas descritivas podem ser produzidas por estas ferramentas de suporte, tais como qualidade média dos reads por posição (base), frequência de bases nucleotídicas $(A, T, C, G)$ por posição, porcentagem de bases GC por sequência, porcentagem de sequências duplicadas, porcentagem de bases ambíguas (Ns) por posição, entre outras.

Após a verificação de qualidade das sequências, algumas etapas de pré-processamento podem ser consideradas necessárias, por exemplo, para a remoção de sequências de baixa qualidade e de artefatos de sequências identificados durante a atividade de verificação. De forma geral, o pré-processamento de dados de RNA-Seq tem como objetivo melhorar a qualidade global do conjunto de dados obtido a partir do sequenciamento para permitir um maior nível de precisão nas atividades de análise posteriores. O pré-processamento de dados de RNA-Seq pode envolver diferentes etapas [108]: clivagem de extremidades de reads, remoção de adaptadores/primers, filtragem de reads por qualidade, remoção de sequências duplicadas, clivagem de caudas poli$\mathrm{A} / \mathrm{T}$, entre outras.

As bases contidas na extremidade 3' de um read geralmente estão associadas a scores de qualidade mais baixos. Estes scores de qualidade baixos podem afetar a qualidade global de um read. Assim, uma etapa de pré-processamento frequentemente realizada em dados de RNASeq consiste na clivagem (trimming) das extremidades 3' dos reads, de modo a remover estes 
fragmentos de sequência de baixa qualidade. Após a remoção das extremidades de um read, se a sequência remanescente for menor do que um tamanho pré-definido (ex: 30 bases), o read é, normalmente, descartado.

Durante a etapa de preparação de uma amostra para sequenciamento, diferentes tipos de adaptadores são anexados às extremidades dos fragmentos de sequências. Estes adaptadores são utilizados no processo de amplificação das moléculas e podem conter sítios de ligação de primers. Durante o processo de sequenciamento, se um fragmento de cDNA for menor do que o tamanho dos reads (número de ciclos), a sequência adaptadora anexada ao fragmento também será parcialmente/totalmente sequenciada. Como resultado, o read produzido a partir deste fragmento de cDNA conterá não apenas a sequência do fragmento, mas também a sequência do adaptador. Além disto, uma outra situação possível é o sequenciamento de sequências adaptadoras não anexadas a fragmentos de interesse. Neste sentido, uma etapa de pré-processamento comum consiste na remoção de adaptadores/primers. Nesta etapa de pré-processamento, os adaptadores podem ser identificados por meio da comparação dos reads com uma biblioteca pré-definida de adaptadores e então removidos dos dados.

Uma etapa de pré-processamento frequentemente realizada em dados de RNA-Seq consiste na filtragem de reads com base em seus scores de qualidade. Nesta etapa, a filtragem é realizada com base em um valor de qualidade limiar pré-definido, que é utilizado para eliminar reads de baixa qualidade. Adicionalmente, outras etapas de filtragem podem ser realizadas, por exemplo, para a remoção de reads menores do que um tamanho pré-definido ou com uma determinada porcentagem de bases $\mathrm{N}$ (ambíguas).

Tipicamente, dados de RNA-Seq apresentam uma baixa proporção de reads idênticos (duplicados). Quando altas proporções são identificadas nos dados, os reads duplicados podem, possivelmente, estar associados a artefatos técnicos do processo de amplificação das moléculas. Assim, uma prática comum é a identificação e remoção de reads duplicados durante o pré-processamento de dados de RNA-Seq. No entanto, reads duplicados em altas proporções também podem estar associados a genes muito expressos. Nestes casos, a remoção dos reads pode criar um viés na estimação da expressão dos genes associados a estes reads. Assim, a distinção entre duplicações artificiais (técnicas) e biológicas, e a remoção de reads duplicados não são processos triviais. 
De modo geral, os efeitos das diferentes etapas de pré-processamento em dados de RNA-Seq não são amplamente conhecidos e assim, ainda não há um consenso sobre quais etapas devem ou não ser realizadas. Além disto, algumas etapas de pré-processamento podem ser computacionalmente custosas devido ao grande volume de dados produzido durante o processo de sequenciamento. Neste sentido, o estudo e desenvolvimento de métodos mais rápidos e eficientes para o pré-processamento de dados de RNA-Seq ainda representa uma área de pesquisa ativa [109].

\section{Mapeamento e Sumarização}

Após o pré-processamento de dados de RNA-Seq, a segunda atividade de análise dos dados consiste tipicamente no mapeamento (alinhamento) de reads de alta qualidade para um genoma de referência. Esta atividade tem como objetivo(s) a identificação de transcritos e/ou a estimação da abundância dos transcritos, refletindo seus níveis de expressão.

Em algumas situações, um genoma de referência pode não estar disponível para a espécie sendo estudada. Duas abordagens alternativas podem ser utilizadas nestas situações. A primeira abordagem consiste em interligar os reads obtidos no sequenciamento com o uso do método de novo [110], que não requer o conhecimento prévio do genoma do organismo que está sendo analisado. No entanto, o uso deste método é computacionalmente custoso e em geral requer reads paired-end e de tamanho maior para um maior nível de precisão [111]. A segunda abordagem consiste em alinhar os reads a um genoma de referência de uma espécie evolutivamente relacionada a espécie de interesse. Alguns estudos sugerem que esta segunda abordagem permite a obtenção de resultados melhores em relação ao uso do método de novo [109, 112].

De maneira ideal, o mapeamento de um read para um genoma de referência tem como objetivo encontrar a localização exata do genoma onde este read pode ser alinhado, ou seja, onde a sequência nucleotídica do read é idêntica à sequência de referência. No entanto, este processo de mapeamento pode não ser trivial, considerando-se que um read pode conter erros em sua sequência nucleotídica e que um read pode alinhar-se a múltiplas regiões de um genoma. Desta forma, o mapeamento geralmente tem como objetivo encontrar a localização do genoma onde um read pode ser melhor alinhado (maior similaridade), permitindo-se assim o alinhamento de reads com sequências nucleotídicas ligeiramente diferentes das sequências de referência. $\mathrm{O}$ 
mapeamento de reads para um genoma de referência pode ser realizado por meio de diferentes abordagens. Fonseca et al. [113] fornecem uma revisão das principais abordagens de mapeamento disponíveis.

Em geral, o processo de mapeamento de reads para um genoma de referência pode ser computacionalmente custoso [111]. Assim, a maioria das abordagens de mapeamento segue uma estratégia heurística inicial que permite a construção de uma lista reduzida de possíveis localizações de um read no genoma de referência. Em seguida, algoritmos de alinhamento local podem ser utilizados para identificar as regiões do genoma onde os reads podem ser melhor alinhados.

$\mathrm{O}$ alinhamento de um read a múltiplas regiões de um genoma representa um dos desafios associados ao processo de mapeamento. As abordagens de mapeamento utilizam diferentes estratégias para lidar com este tipo de situação. Algumas abordagens seguem a estratégia de simplesmente descartar múltiplos alinhamentos, enquanto outras consideram a alocação aleatória de reads ou o uso de estimativas de cobertura local para a alocação de reads. Um outro desafio consiste no fato de que os reads que correspondem a regiões limiares de exons (junções) não podem ser mapeados para o genoma de referência. Neste sentido, uma prática comum é a construção de bibliotecas de junções de exons utilizadas para permitir o alinhamento destes reads remanescentes [111].

Após o mapeamento de reads para um genoma de referência, uma atividade de análise exploratória dos dados obtidos pode ser realizada. Algumas ferramentas de suporte, por exemplo, a ferramenta Integrative Genomics Viewer [114], permitem a visualização gráfica de alinhamentos e fornecem diferentes métricas para a verificação da qualidade dos alinhamentos, tais como distribuição de regiões mapeadas e proporção de alinhamentos válidos, entre outras. Algumas etapas adicionais de filtragem dos dados podem então ser realizadas com base nestas métricas.

Após o mapeamento, a próxima atividade consiste na sumarização dos dados. A atividade de sumarização dos dados depende do objetivo do estudo e consiste em agregar os reads por unidades biológicas, tais como exons, transcritos ou genes, de modo a obter a contagem de reads alinhados a estas unidades.

Diferentes abordagens podem ser utilizadas para a sumarização de reads em dados de RNASeq [115-118]. A abordagem mais comum consiste na contagem dos reads alinhados aos exons de cada gene do genoma de referência. No entanto, uma proporção grande de reads pode estar 
alinhada a regiões exônicas não anotadas. De modo a capturar estes reads na contagem, uma abordagem alternativa frequentemente utilizada consiste na contagem de reads alinhados ao gene em toda sua extensão, incorporando também reads alinhados a íntrons.

Independentemente da abordagem utilizada, o resultado da sumarização dos dados consiste em uma tabela de contagem de reads para cada amostra sendo estudada. Cada célula da tabela consiste no número de reads mapeados para cada unidade biológica (ex: gene ou transcrito), refletindo assim os níveis de expressão gênica da amostra.

\section{Normalização}

Os dados obtidos a partir de experimentos de RNA-Seq podem conter variações relacionadas a diferentes efeitos técnicos. Por exemplo, variações técnicas entre amostras podem estar associadas a diferentes protocolos de preparação das amostras e a tamanhos distintos de bibliotecas de reads (cobertura de sequenciamento). Além disto, dentro de uma mesma amostra, variações técnicas podem surgir em decorrência de diferentes tamanhos de genes [119] e da proporção de bases GC [120], dentre outros. O objetivo da normalização de dados de RNA-Seq é eliminar estas variações decorrentes de efeitos técnicos, tornando os valores de expressão comparáveis tanto entre diferentes amostras quanto dentro de uma mesma amostra.

As estratégias de normalização de dados de RNA-Seq podem ser classificadas em dois tipos $[111,121]$ : dentro de amostras (within-sample) e entre amostras (between-sample). A estratégia de normalização dentro de amostras tem como objetivo corrigir variações técnicas nos níveis de expressão de genes contidos em uma mesma amostra de interesse, tornando-os comparáveis. Por sua vez, a estratégia de normalização entre amostras tem como objetivo eliminar variações técnicas nos níveis de expressão gênica de modo a permitir comparações entre dados provenientes de amostras distintas.

Diferentes métodos permitem a normalização de dados de RNA-Seq de acordo com a estratégia between-sample, tais como Upper Quartile [75], Trimmed Mean of M-Values (TMM) [122] e DESeq [123]. Além disto, alguns estudos têm mostrado a necessidade da estratégia de normalização within-sample, capaz de lidar com efeitos técnicos decorrentes de diferenças no tamanho e composição dos genes. Neste sentido, alguns métodos que implementam esta estratégia também têm sido desenvolvidos [124,125]. Finalmente, alguns métodos combinam as estraté- 
gias within- e between-sample, tais como os métodos Quantile [126] e Reads Per Kilobase per Million mapped reads (RPKM) [127]. Dillies et al. [121] e Bullard et al. [75] fornecem uma revisão dos principais métodos de normalização de dados de RNA-Seq e as principais vantagens e limitações associadas a cada método.

Reads Per Kilobase per Million mapped reads (RPKM) [127] é um método simples e amplamente utilizado para a normalização de dados de RNA-Seq [128-131]. Este método tem como objetivo corrigir artefatos técnicos decorrentes de variações dentro e entre amostras. Neste método, o número de reads mapeados para cada gene é corrigido de modo a eliminar variações decorrentes de diferenças nos tamanhos dos genes e das bibliotecas de reads. No entanto, um dos problemas apontados para este método está associado ao fato de que o valor de expressão obtido para cada gene é dependente dos níveis de expressão dos outros genes da amostra e que, frequentemente, um número grande de reads está associado a uma pequena porção de genes, criando um viés na contagem de reads associados a genes pouco expressos [119].

Adicionalmente, os métodos Trimmed Mean of M-Values (TMM) [122] e DESeq [123] têm sido crescentemente utilizados para a normalização de dados de RNA-Seq [132-135]. Estes métodos assumem que as variações técnicas entre amostras devem-se principalmente a diferenças nos tamanhos das bibliotecas de reads associadas às amostras: quanto maior a cobertura de sequenciamento de uma amostra, mais reads corresponderão aos genes daquela amostra, não refletindo necessariamente uma maior expressão destes genes em relação a outras amostras.

Nos métodos TMM e DESeq, o valor de expressão de cada gene contido em uma amostra é corrigido com base em um fator de normalização definido para a amostra, de modo a considerar o tamanho da biblioteca de reads da mesma. No entanto, os métodos TMM e DESeq diferem no cálculo dos fatores de normalização [121]. No método TMM, um fator de normalização é calculado para cada amostra com base no tamanho da sua biblioteca de reads e com base no tamanho da biblioteca de uma amostra global de controle. No método DESeq, um fator de normalização é calculado para cada amostra com base nos tamanhos das bibliotecas de reads de todas as amostras. 


\section{Análise de Expressão Diferencial}

A análise de expressão diferencial de dados de RNA-Seq permite a identificação de genes diferencialmente expressos entre condições experimentais distintas. O principal objetivo deste tipo de análise é permitir o estudo das variações moleculares responsáveis por mudanças fenotípicas de interesse [111].

O processo de análise de expressão diferencial em dados de RNA-Seq consiste em duas etapas [136]: modelagem estatística de expressão gênica e teste de expressão diferencial. Basicamente, a primeira etapa consiste em encontrar um modelo de distribuição estatístico capaz de descrever os dados de contagem de genes. A segunda etapa refere-se à aplicação de um teste estatístico nos dados modelados de acordo com uma determinada distribuição, visando à identificação de genes diferencialmente expressos. Estas duas etapas não são independentes, uma vez que a escolha de um teste estatístico depende do modelo de distribuição utilizado para representar os dados de expressão.

Na primeira etapa do processo de análise de expressão diferencial, um modelo de distribuição estatístico deve ser utilizado para representar os dados de contagem de genes. Alguns estudos sugerem que estes dados podem ser modelados de acordo com a distribuição de Poisson [137-139]. Esta distribuição assume que a variância de uma população é igual à sua média. Em dados de expressão contendo réplicas técnicas, ou seja, quando uma mesma amostra biológica é quantificada múltiplas vezes de forma independente, a variância de expressão gênica entre réplicas pode ser considerada, de fato, igual aos valores de expressão médios. Assim, a distribuição de Poisson é considerada adequada para a modelagem deste tipo de dado. No entanto, a variância de expressão gênica entre diferentes réplicas biológicas é maior do que os valores de expressão médios [137, 140]. Como consequência, o uso da distribuição de Poisson para a modelagem de dados com réplicas biológicas pode levar a um aumento na taxa de falsos positivos durante o processo de identificação de genes diferencialmente expressos nos dados. Neste sentido, algumas extensões ao modelo de Poisson têm sido propostas para capturar a variância biológica dos dados [141, 142].

De modo a lidar com a variância biológica dos dados, a distribuição binomial negativa tem sido utilizada como uma abordagem alternativa para a modelagem de dados de contagem de 
genes $[123,143,144]$. Nesta distribuição, a relação entre a variância $\sigma^{2}$ e a média $\mu$ é definida por $\sigma^{2}=\mu+f \mu^{2}$, onde $f$ representa um fator de dispersão. A distribuição binomial negativa permite a modelagem do relacionamento variância-média para os genes de forma mais flexível e assim, tem sido utilizada para a descrição de dados de RNA-Seq contendo réplicas biológicas.

A segunda etapa da análise de expressão diferencial de dados de RNA-Seq consiste na aplicação de um teste estatístico para determinar quais genes podem ser considerados diferencialmente expressos entre condições experimentais distintas. Diferentes métodos estatísticos podem ser utilizados para a comparação de duas condições experimentais em dados de RNA-Seq, tais como o teste exato de Fisher e suas variações, e o teste likelihood-ratio. Adicionalmente, testes estatísticos baseados no modelo linear generalizado têm sido amplamente utilizados para a análise de múltiplas condições experimentais [123,139, 143, 144]. Soneson e Delorenzi [145] fornecem uma revisão e um estudo comparativo dos principais métodos disponíveis para a análise de expressão diferencial em dados de RNA-Seq.

Os diferentes métodos propostos para a análise de expressão diferencial de RNA-Seq podem, em princípio, ser aplicados a dados de expressão não normalizados. No entanto, as variações decorrentes de efeitos técnicos nos dados podem levar a resultados que não são biologicamente significantes. Desta forma, a análise de expressão diferencial de RNA-Seq é frequentemente realizada em dados já normalizados. Adicionalmente, os métodos de normalização têm grande influência nos resultados obtidos durante a posterior análise de expressão diferencial dos dados [121]. Neste sentido, um número crescente de abordagens tem considerado o uso integrado de métodos de normalização e de análise de expressão diferencial $[143,146]$.

De forma similar à análise de expressão diferencial de dados de microarray de DNA, a aplicação de múltiplos testes estatísticos a uma grande quantidade de genes em dados de RNA-Seq leva ao acúmulo de erros do tipo I. Estes erros podem ser corrigidos por meio dos mesmos métodos de correção utilizados no contexto de microarrays de DNA, tais como Bonferroni [99] e False Discovery Rate (FDR) [103].

A análise de expressão diferencial de dados de RNA-Seq ainda apresenta alguns desafios. Neste sentido, o estudo e desenvolvimento de métodos para este tipo de análise também representa uma área de pesquisa bastante ativa [109]. Por exemplo, um dos desafios associados à análise de expressão diferencial consiste na dificuldade de detecção de genes associados a 
baixas contagens de reads [119]. Considere uma situação hipotética em que 10 e 20 reads tenham sido mapeadas para um gene $\mathrm{X}$ em duas amostras $\mathrm{A}$ e $\mathrm{B}$, respectivamente. Considere também que 100 e 200 reads tenham sido mapeadas para um outro gene Y nas mesmas amostras. Quando um teste estatístico é utilizado para analisar diferenças entre as amostras A e B, a probabilidade do teste identificar o gene Y como diferencialmente expresso é maior do que a probabilidade de identificar o gene $\mathrm{X}$, embora os dois genes estejam duas vezes mais expressos em B do que em A. Esta situação acontece porque testes estatísticos para a análise de dados de contagem de genes (discretos) tendem a perder o poder de detecção (rejeição da hipótese nula) com a redução do tamanho das amostras.

\subsubsection{Agrupamento de Dados de Expressão Gênica}

De modo geral, métodos para agrupamento de dados baseiam-se no cálculo de similaridades (distâncias) entre elementos com o intuito de agrupar os elementos mais similares. Diferentes métricas de similaridade podem ser utilizadas para estabelecer o grau de similaridade entre dois elementos [147], tais como distância Euclideana, distância Manhattan e coeficiente de correlação de Pearson.

Dados de expressão gênica podem ser agrupados de duas formas distintas [148, 149]: agrupamento de genes e agrupamento de amostras (condições experimentais). O agrupamento de genes consiste na identificação de grupos de genes com perfis de expressão similares em condições experimentais distintas. Este tipo de agrupamento permite a identificação de genes coexpressos e, possivelmente, com funções relacionadas. O agrupamento de amostras consiste na identificação de grupos de amostras similares. Este tipo de agrupamento permite a identificação de novas classes de amostras biológicas (e.g.: identificação de novas classes de tumores e de tipos celulares). Além disto, este tipo de agrupamento pode ser útil para a detecção de variações técnicas em dados de expressão gênica.

Embora métodos de agrupamento possam ser aplicados em dados de expressão gênica não normalizados, os grupos produzidos podem não ser de fato biologicamente relacionados [149]. Desta forma, em geral, o agrupamento de dados deve ser realizado em dados já normalizados. Além disto, uma atividade comum antes do agrupamento é a filtragem ou análise de expressão 
diferencial dos dados de expressão, com o objetivo de remover genes que apresentem pouca variação entre condições experimentais distintas.

Diferentes métodos têm sido utilizados para o agrupamento de dados de expressão gênica, tais como agrupamento hierárquico [150], agrupamento k-means [151], Self-Organizing Maps (SOMs) [152] e Principal Component Analysis (PCA) [153]. O uso de diferentes métodos permite a exploração de diferentes aspectos em dados de expressão gênica e, assim, não há um consenso sobre o melhor método a ser utilizado [154]. Jiang et al. [155] fornecem uma revisão sobre os principais métodos disponíveis para o agrupamento de dados de expressão gênica.

O método de agrupamento hierárquico tem sido amplamente utilizado para a análise de dados de expressão gênica [156-159]. Este método baseia-se em uma abordagem aglomerativa, segundo a qual diferentes perfis de expressão gênica são agrupados iterativamente, de modo a formar uma hierarquia de perfis de expressão.

No agrupamento hierárquico de genes/amostras, cada grupo contém inicialmente um único gene/amostra. O primeiro passo do agrupamento consiste na construção de uma matriz contendo as distâncias entre cada grupo. No segundo passo, os dois grupos mais similares (menor distância) são então fundidos para formar um novo grupo com os elementos (genes/amostras) contidos nos dois grupos anteriores. No terceiro passo, as distâncias entre este novo grupo formado e os outros grupos restantes são então calculadas e a matriz de distâncias é atualizada. Os passos 2-3 são repetidos até que todos os elementos estejam contidos em um único grupo.

As distâncias entre dois grupos podem ser determinadas de acordo com diferentes abordagens [147], tais como ligação simples, completa, média e de centroides. Na abordagem de ligação simples, a distância entre dois grupos é dada pela menor distância entre elementos contidos nos dois grupos. Na abordagem de ligação completa, a distância entre dois grupos é dada pela maior distância entre elementos contidos nos dois grupos. Na abordagem de ligação média, a distância entre dois grupos é dada pela média de todas as distâncias par-a-par (entre elementos contidos nos dois grupos). Os grupos com a menor distância média são então fundidos. Finalmente, na abordagem de ligação de centroides, a distância entre dois grupos é dada pela distância entre os centroides dos dois grupos.

Uma prática comum após a realização do agrupamento hierárquico em dados de expressão gênica é a geração de um dendrograma, de modo a facilitar a visualização dos dados agrupados. 
Um dendrograma é um diagrama hierárquico que ilustra a disposição dos grupos de genes/amostras estabelecidos por um processo de agrupamento hierárquico.

Um método de agrupamento não hierárquico bastante utilizado para a análise de dados de expressão gênica é o agrupamento k-means [160-163]. De acordo com este método, perfis de expressão gênica são particionados (de forma iterativa) em um número pré-determinado (k) de grupos, sem que haja o estabelecimento de relacionamentos hierárquicos entre os diferentes grupos. Em geral, o uso deste método é mais recomendado quando há um conhecimento prévio sobre a quantidade de grupos contida nos dados [154]. No entanto, uma abordagem alternativa é a execução do algoritmo múltiplas vezes para um mesmo conjunto de dados com diferentes números de grupos (k), de modo a tentar estabelecer um número ótimo de grupos [147].

No agrupamento k-means de elementos (genes ou amostras), inicialmente k elementos são selecionados de forma aleatória nos dados, de modo que cada elemento selecionado constitui o centroide de um grupo. No primeiro passo do agrupamento, as distâncias entre todos os elementos e os k centroides são calculadas. No segundo passo, cada elemento é atribuído ao grupo cujo centroide encontra-se mais próximo. No terceiro passo, os centroides dos k grupos são recalculados com base nos perfis de expressão de todos os elementos que constituem o novo grupo estabelecido. Os passos 1-3 são repetidos até que nenhum dos elementos seja movido (realocado) para um grupo distinto.

O algoritmo k-means tem como objetivo encontrar uma solução que minimize a soma das distâncias entre os elementos (genes/amostras) contidos dentro de cada um dos k grupos. Uma vez que a seleção inicial dos centroides é realizada de forma aleatória, diferentes resultados (possivelmente sub-ótimos) podem ser obtidos para um mesmo conjunto de dados a cada execução do algoritmo. Desta forma, em geral é aconselhável que o algoritmo seja executado múltiplas vezes para um mesmo conjunto de dados [147].

\subsubsection{Análise Funcional de Dados de Expressão Gênica}

A análise funcional de dados de expressão gênica tem como objetivo principal a identificação de vias ou processos biológicos associados aos genes de interesse em um experimento de medição de expressão gênica [164-166]. Este objetivo pode ser atingido por meio de uma análise 
de enriquecimento, que permite a identificação dos termos biológicos associados em maior proporção (mais relevantes) aos genes de interesse por meio de anotações funcionais. Estes termos podem representar processos biológicos, funções moleculares, vias biológicas, entre outros, e são provenientes de ontologias ou bases de dados de anotação funcional, tais como a ontologia Gene Ontology (GO) [167] e as bases de dados REACTOME [168], Kyoto Encyclopedia of Genes and Genomes (KEGG) [169] e Transcription Factor Motifs (TRANSFAC) [170].

$\mathrm{Na}$ análise de enriquecimento de dados de expressão gênica, a distribuição das anotações de cada termo biológico associadas aos genes de interesse é comparada à distribuição das anotações deste termo nos genes de um grupo de referência. Este processo é realizado por meio de um teste estatístico para determinar quais termos encontram-se enriquecidos no grupo de genes de interesse, ou seja, quais termos estão de fato associados em maior proporção a estes genes. Esta comparação é necessária porque, em alguns casos, o enriquecimento aparente de um termo biológico, ou seja, sua alta proporção no grupo de genes de interesse, pode estar refletindo apenas sua alta proporção no genoma de forma geral, e não especificamente no grupo.

Considere, por exemplo, um experimento de medição de expressão gênica no qual verificouse que $15 \%$ dos genes estão associados ao processo biológico de apoptose. Considere também que no genoma completo deste organismo (grupo de referência) apenas 3\% dos genes estejam relacionados a este processo. Neste caso, é possível verificar que, de fato, os genes sob estudo desempenham um papel importante no processo de apoptose. No entanto, se uma proporção muito alta dos genes do grupo de referência estivesse relacionada a este processo, não seria possível determinar a participação dos genes sob estudo no mesmo.

Diferentes grupos de referência podem ser definidos de acordo com o objetivo de um estudo $[164,171]$. O grupo de referência pode ser composto por todos os genes do genoma associado, por todos os genes do experimento, ou ainda, por todos os genes do genoma ou do experimento que se encontram funcionalmente anotados na base de dados sendo analisada.

De modo geral, o primeiro passo da análise de enriquecimento consiste na construção de tabelas de contingência 2 × 2 para cada termo biológico a ser analisado. A partir da construção destas tabelas, diferentes testes estatísticos podem então ser aplicados de modo a determinar o enriquecimento dos diferentes termos biológicos no conjunto de genes de interesse. Se os valores-p gerados a partir destes testes forem menores do que um valor limiar (nível de signifi- 
cância) escolhido para o teste, então os termos biológicos analisados podem ser considerados relevantes para o conjunto de genes de interesse.

Considere um organismo hipotético cujo genoma contenha $N$ genes (grupo de referência). Considere também que $K \leq N$ genes deste organismo tenham sido identificados como diferencialmente expressos em um experimento, e que $x \leq K$ destes genes estejam anotados com um termo biológico $T$ proveniente de uma ontologia ou base de dados de anotação. Finalmente, considere que $M \leq N$ genes do genoma deste organismo hipotético estejam anotados com o termo biológico T. A seguinte tabela de contingência pode ser construída:

\section{Tabela 1: Tabela de contingência para análise funcional de expressão gênica}

\begin{tabular}{c|c|c|c} 
& genes diferencialmente expressos & genes não diferencialmente expressos & total \\
\hline$T$ & $x$ & $M-x$ & $M$ \\
\hline$T^{c}$ & $K-x$ & $N-M-K+x$ & $N-M$ \\
\hline total & $K$ & $N-K$ & $N$
\end{tabular}

Onde $T$ representa o conjunto de genes anotados com o termo biológico $T$ e $T^{\mathcal{C}}$ representa o conjunto complementar.

Com base na tabela de contingência construída, a abordagem de enriquecimento fornece a probabilidade de se observar (de forma não casual) pelo menos $x$ genes do grupo de interesse anotados com o termo $T$. Esta probabilidade $p$ pode ser obtida, por exemplo, com base na distribuição hipergeométrica [97].

De forma análoga à análise de genes diferencialmente expressos, quando um teste estatístico é conduzido para verificar a relevância de um termo biológico em um conjunto de genes, erros do tipo I e do tipo II podem ser cometidos. Uma vez que múltiplos testes estatísticos são conduzidos para uma grande quantidade de termos biológicos, o acúmulo de erros do tipo I leva ao chamado "problema de múltiplos testes" [172].

Diferentes métodos de correção, tais como os métodos propostos por Bonferroni [99], Holm [100], e Benjamini e Hochberg [103], podem ser utilizados para a correção dos valores-p obtidos quando múltiplos testes estatísticos são conduzidos, gerando os chamados "valores-p ajustados". Com o uso destes métodos de correção, o valor-p ajustado obtido para cada termo biológico é 
comparado ao valor limiar (nível de significância) escolhido para o teste e, se for menor, o termo pode ser considerado relevante para o conjunto de genes sob estudo.

A análise funcional de dados de expressão gênica pode ser realizada por meio de três abordagens distintas [171]: análise de enriquecimento simples, análise de enriquecimento de grupos de genes e análise de enriquecimento modular. A análise de enriquecimento simples requer que os genes de interesse de um experimento sejam previamente selecionados com base em seus valores de expressão, por exemplo, por meio da análise de expressão diferencial dos dados ou por algum procedimento de agrupamento. Nesta abordagem, a distribuição de cada termo biológico associado a cada gene de interesse do grupo de genes pré-selecionado é comparada à distribuição deste termo nos genes do grupo de referência por meio de um teste estatístico. Diferentes testes estatísticos podem ser utilizados nesta abordagem [171]: teste exato de Fisher, teste hipergeométrico, teste Qui-quadrado, teste binomial, dentre outros. Em geral, os testes hipergeométrico, exato de Fisher e Qui-quadrado são recomendados quando o grupo de referência é pequeno [171], ao passo que o teste binomial é mais indicado para grupos de referência maiores.

A análise de enriquecimento de grupos de genes não requer a pré-seleção dos genes de interesse de um experimento. Todos os genes analisados no experimento são inicialmente ordenados de acordo com seus valores de expressão diferencial de modo que os genes subexpressos e superexpressos ficam situados nos extremos da ordenação. Os termos biológicos mais relevantes ao estudo estarão situados com maior probabilidade nos extremos da ordenação. Desta forma, ao contrário da análise de enriquecimento simples, que verifica o comportamento individual de cada gene, esta abordagem tem como objetivo testar o comportamento dos blocos de genes funcionalmente relacionados situados nos extremos da ordenação [166].

A análise de enriquecimento de grupos de genes pode ser realizada por meio de diferentes testes estatísticos [171]: teste exato de Fisher, teste t de Student, análise de permutações, teste de Kolmogorov-Smirnov, dentre outros. Na análise de enriquecimento de grupos de genes, os valores-p são calculados com base também nos valores de expressão experimentais obtidos para cada gene.

A Figura 8 apresenta um cenário hipotético de análise de enriquecimento de grupos de genes. Suponha que 20 genes tiveram seus valores de expressão medidos em um experimento de me- 
dição de expressão gênica. No lado esquerdo da figura, os genes apresentam-se ordenados de acordo com seus valores de expressão diferencial. No lado direito da figura, são apresentados três termos biológicos genéricos $A, B$ e $C$. Os pontos apresentados abaixo de cada termo biológico indicam os genes que estão anotados funcionalmente com cada um dos termos. Neste exemplo, pode-se observar que, predominantemente, apenas os genes subexpressos e superexpressos estão anotados com os termos $A$ e $B$, respectivamente. Desta forma, os termos $A$ e $B$ podem ser considerados biologicamente relevantes nas condições sob estudo. Por sua vez, genes subexpressos, superexpressos e também não diferencialmente expressos nas diferentes condições experimentais são anotados com o termo $C$. Assim, o termo $C$ não pode ser considerado biologicamente relacionado às condições sob estudo.

\begin{tabular}{|l|}
\hline gene 1 \\
gene 2 \\
gene 3 \\
gene 4 \\
gene 5 \\
gene 6 \\
gene 7 \\
gene 8 \\
gene 9 \\
gene 10 \\
gene 11 \\
gene 12 \\
gene 13 \\
gene 14 \\
gene 15 \\
gene 16 \\
gene 17 \\
gene 18 \\
gene 19 \\
gene 20 \\
\hline
\end{tabular}

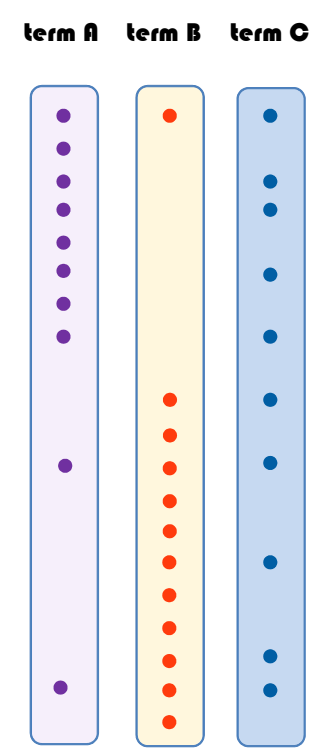

Figura 8: Análise de enriquecimento de grupos de genes. À esquerda apresenta-se uma lista de genes ordenados de forma crescente de acordo com seus valores de expressão diferencial. À direita apresenta-se três termos biológicos genéricos $A, B$ e $C$. Os termos $A$ e $B$ indicam termos biológicos relacionados ao experimento. $\mathrm{O}$ termo $C$ indica um termo biológico não relacionado ao experimento.

A análise de enriquecimento modular segue o mesmo princípio da análise de enriquecimento simples. No entanto, esta abordagem considera também os relacionamentos contidos entre os termos biológicos nas ontologias ou bases de dados de anotação sendo analisadas. Desta forma, o cálculo de enriquecimento é realizado para cada termo biológico individualmente associado a 
cada gene de interesse e também para grupos de termos biológicos conjuntamente associados a cada gene de interesse.

As abordagens de enriquecimento simples e modular podem ser utilizadas para a análise funcional de dados de expressão gênica que tenham sido previamente agrupados ou que tenham passado por um processo de análise de expressão diferencial. A abordagem de enriquecimento de grupos de genes é mais adequada quando o objetivo do estudo é a comparação de duas condições experimentais distintas e não inclui a realização de agrupamentos nos dados $[166,171]$. Diferentes métodos estatísticos podem ser utilizados para a análise de enriquecimento simples, modular e de grupos de genes em dados de expressão gênica. Huang et al. [171] fornecem uma revisão dos principais métodos disponíveis para cada tipo de abordagem de enriquecimento.

De modo geral, a análise de enriquecimento funcional em dados de expressão gênica é útil como um procedimento exploratório [171]. Os valores-p resultantes deste tipo de análise apenas sugerem termos biológicos possivelmente relacionados a um estudo e auxiliam o pesquisador a decidir, com base em seus conhecimentos biológicos se, de fato, os termos identificados são relevantes para o estudo em questão. Além disto, com base nos resultados obtidos, outros procedimentos experimentais podem ser realizados posteriormente para confirmar a participação dos genes de interesse nos processos biológicos identificados. 
A Web Semântica tem como objetivo atribuir significados precisos às informações estruturadas publicadas na web por meio do uso de ontologias, facilitando a interpretação automática de informações por sistemas computacionais. Serviços web são recursos computacionais com interfaces bem definidas que têm como objetivo facilitar a interoperabilidade sintática entre ferramentas. Os serviços web semânticos baseiam-se nas tecnologias de serviços e da web semântica, e representam serviços web cujas descrições de interfaces são anotadas semanticamente com conceitos provenientes de ontologias. Neste sentido, o desenvolvimento e uso de serviços web semânticos facilitam a interoperabilidade semântica entre ferramentas.

Este capítulo apresenta conceitos básicos associados ao desenvolvimento, descrição e composição de tais serviços. O restante deste capítulo está estruturado da seguinte forma: a Seção 3.1 apresenta uma revisão bibliográfica das principais técnicas e linguagens para a representação de conhecimento (semântica) na web; a Seção 3.2 apresenta uma revisão bibliográfica das principais tecnologias para o desenvolvimento, descrição e publicação de serviços web; a Seção 3.3 apresenta uma revisão bibliográfica das principais tecnologias para o desenvolvimento de serviços web semânticos; a Seção 3.4 apresenta uma revisão bibliográfica sobre os principais aspectos associados à composição de serviços web (semânticos); finalmente as Seções 3.5 e 3.6 apresentam algumas abordagens de suporte ao desenvolvimento e à composição de serviços web semânticos, respectivamente. 


\subsection{WEB SEMÂNTICA}

De modo geral, informações são publicadas na web com o uso de linguagens computacionalmente interpretáveis, tais como HTML e XML. Estas linguagens têm como objetivo estruturar os dados publicados, permitindo que sistemas computacionais (ex: navegadores) sejam capazes de extrair as informações necessárias e apresentar o conteúdo desejado aos usuários. No entanto, estas linguagens permitem a descrição do conteúdo publicado na web apenas do ponto de vista sintático. Assim, os sistemas computacionais são capazes de extrair informações publicadas na web, mas não de interpretá-las.

O objetivo da Web Semântica é estruturar o conteúdo publicado na web de modo que sistemas computacionais sejam capazes de processar os dados não apenas do ponto de vista sintático, mas também semântico. As tecnologias da Web Semântica [27,173] permitem a atribuição de significados precisos às informações estruturadas publicadas na web por meio do uso de ontologias [28]. Uma ontologia é uma especificação formal e explícita de uma conceitualização em um domínio de interesse [29]. Ontologias fornecem um conjunto de termos e de relacionamentos entre termos definidos de forma explícita por meio de uma lógica formal e restringem a interpretação e utilização desses termos e relacionamentos por meio de axiomas. Ontologias permitem a interpretação de dados por sistemas computacionais, reduzindo o envolvimento humano na integração de informações e ferramentas [24, 174].

A abordagem Linked Data $[175,176]$ consiste em um conjunto de práticas que podem ser adotadas para a publicação e interligação de dados estruturados na web. A ideia geral desta abordagem é permitir que os dados publicados na web sejam interpretáveis por sistemas computacionais, tenham seus significados (semântica) bem definidos por meio, por exemplo, do uso de ontologias, e sejam interligados por meio de diferentes recursos de dados.

De acordo com a abordagem Linked Data, todos os dados publicados na web devem ser exclusivamente identificados por meio de Uniform Resource Identifiers (URIs) [177] e passíveis de referências por meio do protocolo HyperText Transfer Protocol (HTTP). Além disto, as informações referentes aos dados devem ser fornecidas de forma estruturada de acordo com o modelo Resource Description Framework (RDF) [178]. Os dados devem conter links RDF para outros dados (URIs) relacionados, de modo a permitir a navegação por meio de diferentes URIs. 
A ampla adoção desta abordagem por fornecedores de dados na web tem levado à criação de um espaço de dados global, chamado de Web of Data.

Do ponto de vista da interoperabilidade entre ferramentas de software, a abordagem Linked Data permite que as ferramentas acessem a semântica dos dados trocados entre elas, referenciando os conceitos que os descrevem em ontologias, por meio de seus URIs. No entanto, diferentes conceitos (URIs) podem ser atribuídos a um mesmo tipo de informação. Neste caso, a interoperabilidade entre ferramentas que acessam os mesmos tipos de informação, mas descritos com conceitos diferentes, pode ser conseguida por meio de mapeamentos entre estes diferentes conceitos utilizando-se relacionamentos de equivalência.

No contexto da Web Semântica, o framework RDF e a linguagem Web Ontology Language (OWL) $[179,180]$ fornecem a base para o desenvolvimento de ontologias, as quais podem ser utilizadas para a descrição de diferentes entidades de dados. De acordo com a abordagem Linked Data, as ontologias publicadas na web devem ser interligadas por meio de triplas RDF, permitindo mapeamentos entre termos e relacionamentos de diferentes ontologias.

\subsubsection{Resource Description Framework (RDF)}

Resource Description Framework (RDF) [178] consiste de um conjunto de especificações desenvolvidas para a representação de informações na web. RDF fornece um modelo de dados independente de sintaxe para a representação das informações, além de uma sintaxe específica RDF/XML [181].

O modelo de dados RDF baseia-se em grafos. De acordo com este modelo, quaisquer recursos da web podem ser representados por meio de triplas RDF na forma <sujeito-predicadoobjeto>. Cada tripla RDF indica um relacionamento entre informações identificadas por meio de URIs na web (sujeitos e predicados). Além disto, os próprios relacionamentos também são identificados por meio de URIs. As triplas RDF podem ser representadas por meio de grafos RDF (direcionados).

De modo a exemplificar o uso do modelo RDF, a Figura 9 apresenta a representação gráfica de um grafo RDF utilizado para especificar um conjunto de informações biológicas. Este grafo apresenta duas triplas RDF. A tripla < gene-locatedIn-DNA> indica que um gene está localizado 
em uma molécula de DNA. Por sua vez, a tripla <gene-identifiedBy-geneSymbol> indica que um gene pode ser identificado por um símbolo.

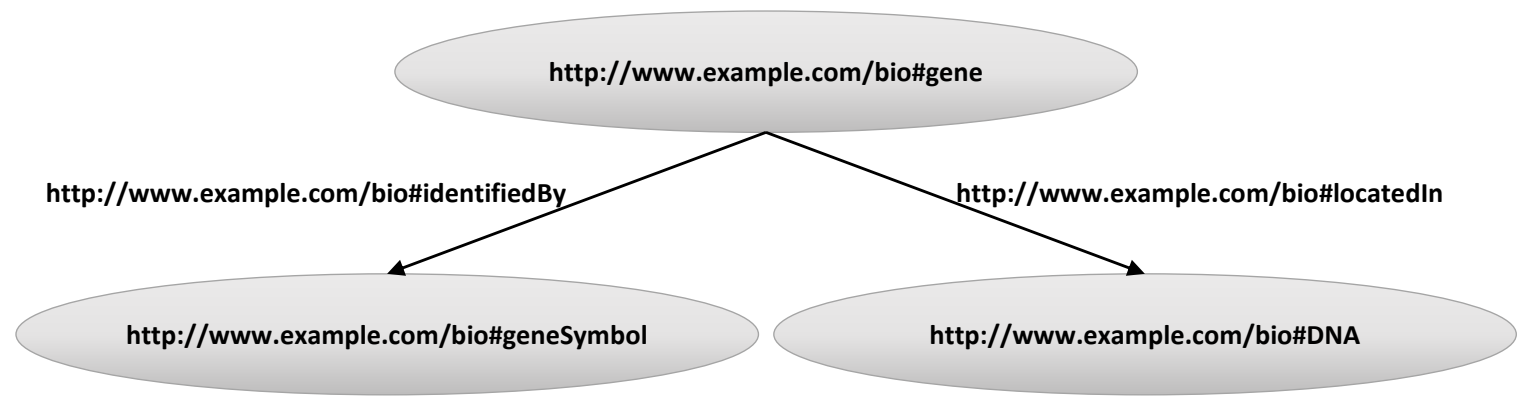

Figura 9: Representação gráfica de um grafo RDF.

Embora o modelo de dados RDF seja independente de sintaxes específicas, a sintaxe RDF/ XML é recomendada para sua codificação, de modo a permitir a troca de informações entre aplicações. Esta sintaxe define um conjunto de tags para a definição de conceitos e relacionamentos entre conceitos. Este conjunto de tags permite a definição de três elementos básicos: recursos, propriedades e valores de propriedades. Tais elementos equivalem a sujeitos, predicados e objetos no modelo de dados RDF. A sintaxe RDF/XML permite a serialização de grafos RDF como documentos XML.

\subsubsection{Web Ontology Language (OWL)}

A linguagem Web Ontology Language 2 (OWL 2) [179,180] é uma linguagem lógica descritiva para a representação de ontologias. Esta linguagem tem sido desenvolvida pela organização W3C OWL Working Group [182] com o objetivo de facilitar o desenvolvimento e o compartilhamento de ontologias na web, bem como permitir o raciocínio automatizado sobre o conteúdo destas ontologias. OWL 2 permite a definição formal de objetos do mundo real (individuals), grupos de objetos com características comuns (classes), axiomas (axioms), relacionamentos entre objetos (object properties) e relacionamentos entre objetos e tipos de dados (data properties) em ontologias.

De modo a exemplificar o uso da linguagem OWL, a Figura 10 apresenta a representação gráfica de um fragmento da ontologia Gene Ontology [167] especificado na linguagem OWL. Cada retângulo representa uma classe OWL, ou seja, um conceito da ontologia. Um relaciona- 
mento contínuo definido entre duas classes representa o axioma OWL subClass $O f$. Este axioma é utilizado para associar uma classe mais específica a uma classe mais geral, de modo a criar uma hierarquia entre as classes na ontologia. Finalmente, um relacionamento tracejado definido entre duas classes representa um elemento OWL object property.

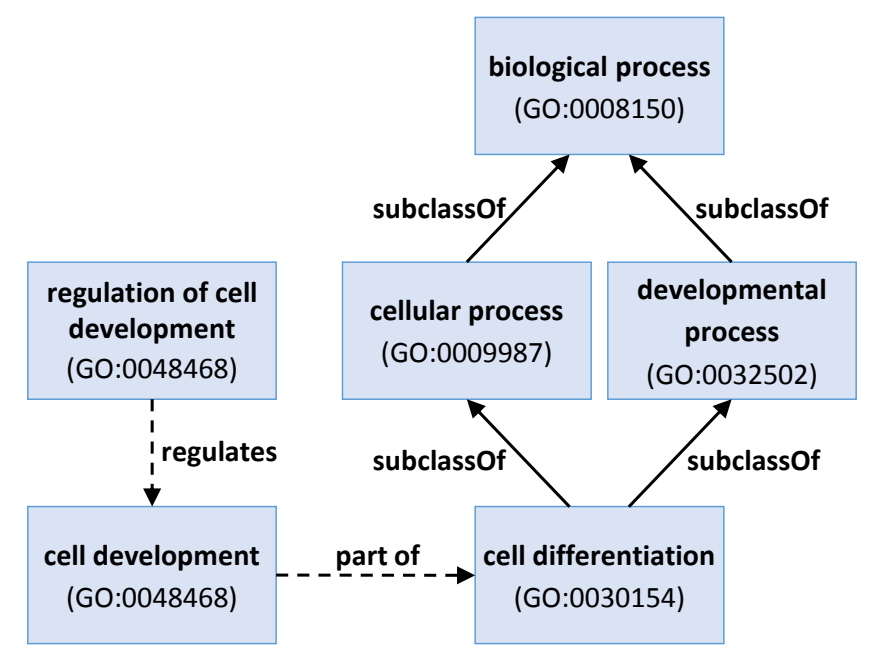

Figura 10: Representação gráfica de um fragmento OWL da ontologia Gene Ontology.

A classe biological process representa um processo biológico, ou seja, um conjunto de eventos moleculares que permitem o funcionamento de unidades biológicas, tais como células e tecidos. Esta classe possui duas subclasses: cellular process, que representa um processo biológico que ocorre em uma ou mais células; e developmental process, que representa um processo biológico que resulta no desenvolvimento de unidades biológicas, tais como células e tecidos. As classes cellular process e developmental process possuem a subclasse cell diferentiation em comum. A classe cell diferentiation representa o processo biológico de diferenciação celular, por meio do qual células não especializadas, tais como células embrionárias, adquirem uma estrutura e/ou funcionalidade específica. A classe cell development representa o processo biológico que resulta no desenvolvimento de uma célula. Esta classe é associada à classe cell diferentiation por meio do relacionamento part of. Este relacionamento indica que o processo de desenvolvimento celular faz parte do processo de diferenciação celular. Finalmente, a classe regulation of cell development representa um processo responsável pela regulação do grau ou frequência com que uma célula progride durante seu desenvolvimento. Esta classe está associada à classe cell development por meio do relacionamento regulates. Este relacionamento indica que o processo de regulação é responsável por regular o desenvolvimento de uma célula. 
De acordo com a especificação OWL 2, uma ontologia pode ser vista como uma estrutura abstrata ou como um grafo RDF. A estrutura abstrata de uma ontologia OWL é definida em termos de seus elementos estruturais, de forma independente de qualquer sintaxe específica. O mapeamento entre os elementos estruturais de uma ontologia e grafos RDF é fornecido em [183].

Uma ontologia na linguagem OWL 2 pode ser serializada e compartilhada em cinco sintaxes distintas: RDF/XML [181], que permite interoperabilidade entre ontologias OWL e é considerada obrigatória de acordo com a especificação OWL 2; OWL/XML [184], que permite o fácil processamento de ontologias OWL por meio de ferramentas XML; Functional Syntax [185], que é utilizada para especificar os elementos estruturais da linguagem OWL; e Manchester Syntax [186] e Turtle [187], que são sintaxes mais simples e de fácil interpretação. No entanto, a maior parte das ontologias é desenvolvida na sintaxe RDF/XML, uma vez que todas as ferramentas de suporte à linguagem OWL 2 fornecem suporte a esta sintaxe. As ontologias OWL são compartilhadas como documentos RDF.

Duas semânticas relacionadas fornecem meios para a atribuição de significados a ontologias OWL: Direct Semantics [188], que atribui significados diretamente aos elementos estruturais das ontologias, e RDF-Based Semantics [189], que atribui significados diretamente aos grafos RDF e assim, indiretamente aos elementos estruturais das ontologias mapeadas a partir dos grafos. Estas duas semânticas são utilizadas por ferramentas de inferência e outras ferramentas de suporte à linguagem OWL.

A especificação da linguagem OWL 2 inclui também a definição de três perfis OWL (sublinguagens) [190] adequados para diferentes tipos de aplicações: OWL 2 Existential Language (EL), Query Language (QL) e Rule Language (RL). Cada perfil contém um subconjunto restrito de elementos estruturais da linguagem. A sublinguagem OWL 2 EL é mais adequada para aplicações que acessam ontologias com grandes quantidades de conceitos e relacionamentos. Esta sublinguagem permite a inferência sobre ontologias com algoritmos em tempo polinomial, capturando de forma relativa o poder de expressividade destas ontologias. A sublinguagem OWL 2 QL é mais adequada para aplicações que acessam ontologias relativamente pequenas e que consultam bases de dados relacionais por meio destas ontologias. Finalmente, a sublinguagem OWL 2 RL é mais adequada para aplicações que acessam ontologias relativamente 
pequenas e que requerem que as inferências realizadas sobre estas ontologias sejam eficientes, mas sem que haja perda do poder de expressividade das ontologias.

Diferentes ferramentas de suporte à linguagem OWL têm sido desenvolvidas. Os editores de ontologias OWL, tais como Protégé [191], TopBraid Composer [192], SWOOP [193] e NeOnToolkit [194], permitem a criação, edição e visualização de ontologias. A ferramenta Protégé é, possivelmente, o editor de ontologias mais utilizado atualmente. Esta ferramenta permite a exportação das ontologias criadas em vários formatos, tais como RDF/XML, OWL/XML e Open Biomedical Ontologies (OBO) [195]. Além disto, diferentes ferramentas de suporte, tais como Fact++ [196], Hermit [197] e RacerPro [198] permitem a realização de inferências em ontologias OWL.

\subsection{SERVIÇOS WEB}

Uma arquitetura de software descreve, de forma abstrata, os componentes de um sistema computacional e as interações entre estes componentes, de modo a fornecer uma visão geral da estrutura do sistema. A arquitetura orientada a serviços [199, 200] baseia-se na utilização de um conjunto de entidades modulares, fracamente acopladas e reusáveis, disponibilizadas como serviços, que de forma integrada fornecem as funcionalidades de um sistema. Serviços representam recursos de software que fornecem uma ou mais funcionalidades definidas por meio de interfaces padronizadas e que podem se comunicar por meio de protocolos de troca de mensagens.

A arquitetura orientada a serviços define um modelo de interação entre dois tipos de entidades: provedor de serviços, que representa uma entidade computacional que fornece um serviço, e consumidor de serviços (cliente), que representa uma entidade computacional que solicita a execução de um serviço. No entanto, uma entidade computacional pode atuar simultaneamente como provedor e consumidor de serviços.

A Figura 11 apresenta o modelo de interação da arquitetura orientada a serviços. Neste modelo de interação, um provedor de serviços fornece a implementação de um ou mais serviços por meio de interfaces padronizadas e especifica seus serviços por meio de descrições de serviços. A descrição de um serviço expõe suas funcionalidades, o formato das mensagens enviadas 
e recebidas, os detalhes técnicos para comunicação com o serviço e sua localização. O provedor de serviços então publica estas informações em páginas web ou em registros de serviços. Os possíveis consumidores de serviços podem então realizar buscas para descobrir serviços com as funcionalidades desejadas e executar os serviços de interesse.

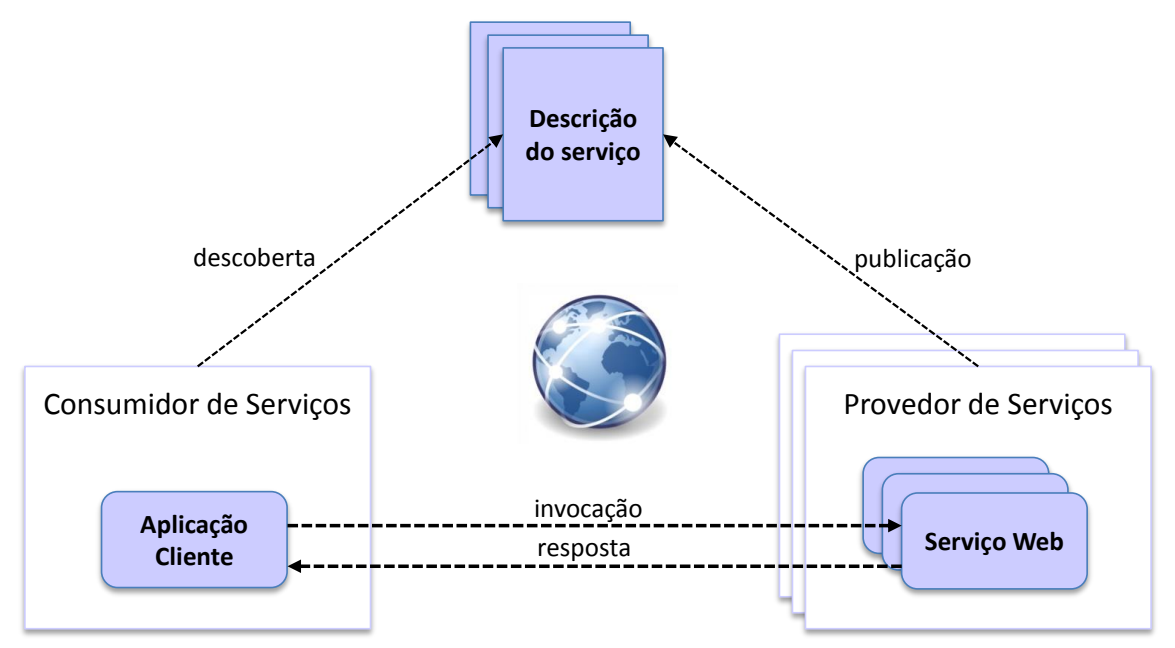

Figura 11: Modelo de interação da arquitetura orientada a serviços

No modelo de interação orientado a serviços, consumidores de serviços realizam buscas em registros públicos para descobrir serviços de interesse. Em princípio, estas buscas podem ser realizadas de forma manual. No entanto, o número crescente de serviços sendo disponibilizado na web tem motivado o uso de sistemas computacionais que dêem suporte à busca automática de serviços. Estas buscas baseiam-se na identificação de equivalências entre termos representando, por exemplo, funcionalidades ou tipos de dados produzidos/consumidos por serviços.

Tipicamente, as informações sobre serviços web são especificadas por meio de linguagens computacionalmente interpretáveis, tais como XML. O uso destas linguagens para a representação de informações facilita a identificação automática de termos sintaticamente equivalentes. No entanto, diferentes provedores de serviços podem especificar as informações sobre seus serviços utilizando linguagens distintas. Além disto, as informações sobre serviços podem ser especificadas em uma mesma linguagem, mas utilizando representações sintáticas distintas. Neste sentido, o mapeamento entre diferentes esquemas de representação pode ser necessário para a identificação de equivalências entre dados sintaticamente distintos, mas com o mesmo significado (semântica). Neste contexto, existe um consenso crescente de que as descrições dos serviços devem possuir semântica processável por computadores [24,25]. A definição explícita 
de semântica permite a atribuição de significados não ambíguos às descrições de serviços, facilitando a realização de mapeamentos entre diferentes esquemas de representação de dados. Desta forma, o uso de semântica pode facilitar o processo de extração e interpretação de informações por sistemas computacionais.

Os serviços web realizam concretamente os princípios da arquitetura orientada a serviços. Serviços web são recursos de software com interfaces bem definidas, os quais podem ser executados de forma remota em computadores distribuídos geograficamente na Internet. A comunicação e troca de informações entre serviços web baseiam-se na troca de mensagens por meio de protocolos-padrão da Internet baseados na linguagem XML. Estes protocolos permitem a interoperação de serviços web desenvolvidos em diferentes linguagens de programação e para diferentes plataformas.

A tecnologia de serviços web fornece recursos para suporte à interoperabilidade de serviços sintaticamente heterogêneos. No entanto, esta tecnologia não oferece suporte à interoperabilidade de serviços do ponto de vista semântico. Neste contexto, as tecnologias da Web Semântica podem ser utilizadas para a atribuição de semântica às descrições de serviços por meio do uso de ontologias. Assim, os serviços web semânticos baseiam-se nas tecnologias de serviços web e da Web Semântica, e representam serviços cujas descrições são semanticamente anotadas com termos provenientes de ontologias [30].

\subsubsection{Desenvolvimento de Serviços Web}

Atualmente, serviços web podem ser desenvolvidos de acordo com duas abordagens principais: Simple Object Access Protocol (SOAP) [201] e Representational State Transfer (REST) [202]. Estas abordagens definem conjuntos de diretrizes para a criação e utilização de serviços por meio da troca e execução de mensagens de requisição e resposta.

\section{Simple Object Access Protocol (SOAP)}

O protocolo Simple Object Access Protocol (SOAP) [201] define um padrão para a criação de requisições/respostas (mensagens XML) e para a interação entre aplicações cliente e serviços web por meio da troca destas mensagens. 
Uma mensagem SOAP é um documento XML definido de acordo com padrões estabelecidos pelo protocolo para a representação de informações. O principal elemento de uma mensagem SOAP é o elemento envelope. Este elemento é obrigatório e identifica o documento XML como uma mensagem SOAP. O elemento envelope contém os elementos header e body. O elemento header é opcional e pode conter informações adicionais de cabeçalho do documento, tais como nome e data de expiração. O elemento body é obrigatório e contém as informações de requisição/resposta a serem transmitidas entre as partes comunicantes. Opcionalmente, o elemento body pode conter um elemento fault, especificando informações sobre o estado e possíveis erros de execução.

Uma vez que os detalhes sobre a identificação e invocação dos recursos computacionais são mantidos dentro de mensagens SOAP, este protocolo pode funcionar sobre qualquer protocolo de transporte. Embora o protocolo SOAP não esteja limitado a protocolos de transporte específicos, a grande maioria dos serviços baseados em SOAP utiliza o protocolo de transporte HyperText Transfer Protocol (HTTP) [203]. Em geral, as mensagens SOAP são trocadas entre aplicações cliente e serviços web por meio do uso do método POST do HTTP. Além disto, as requisições a serviços de um mesmo servidor SOAP são geralmente realizadas referenciando-se um mesmo URI. O servidor SOAP é responsável por desempacotar as mensagens SOAP recebidas e invocar os métodos referenciados dentro destas mensagens. De forma análoga, o servidor SOAP também é responsável por empacotar os resultados de uma invocação em uma mensagem SOAP e enviá-la à aplicação cliente.

\section{Representational State Transfer (REST)}

Representational State Transfer (REST) é um modelo arquitetural cliente-servidor que estabelece um modelo de comportamento entre aplicações cliente e serviços web. Serviços web desenvolvidos de acordo com este modelo são usualmente chamados de serviços web RESTful. O modelo REST estabelece diferentes princípios arquitetônicos que devem ser aplicados no desenvolvimento de serviços. Os princípios arquitetônicos fundamentais do modelo REST incluem:

- Modelo cliente-servidor, segundo o qual uma entidade servidora deve aguardar por requisições aos serviços que oferece. Uma entidade cliente pode enviar uma requisição ao 
servidor de modo a solicitar a realização de um serviço. O servidor pode então aceitar ou rejeitar a requisição e enviar uma resposta ao cliente. Este modelo de interação facilita a portabilidade de aplicações cliente (cliente) para diferentes plataformas e simplifica o desenvolvimento de serviços (servidor). Além disto, a divisão modular do sistema entre entidades cliente e servidor permite que as mesmas sejam desenvolvidas e evoluam de forma independente;

- Interações sem estado, segundo o qual os serviços RESTful não devem manter estado. Desta forma, requisições anteriores não são mantidas pelo servidor e cada requisição do cliente para o servidor deve conter todas as informações necessárias para seu entendimento. Este princípio permite um melhor desempenho dos serviços RESTful e torna a implementação destes serviços mais simples, uma vez que não há a necessidade de se armazenar e manipular informações de estado relacionadas a aplicações cliente específicas;

- Acesso uniforme a recursos, segundo o qual interfaces uniformes devem ser utilizadas para a interação entre entidades cliente e servidor. Este princípio baseia-se em três conceitos principais: recursos, representações e URIs. Todas as informações passíveis de serem referenciadas na web podem ser vistas como recursos e todas as interações com serviços web RESTful destinam-se a acessar recursos. O acesso a um recurso ocorre por meio de uma interface uniforme que fornece métodos de acesso padronizados para a manipulação do mesmo. Os serviços RESTful devem expor um conjunto de recursos identificados de forma exclusiva na web por meio de URIs, permitindo o acesso de aplicações cliente aos recursos. Ao acessar um determinado recurso, a informação retornada a uma aplicação cliente é uma representação do recurso, que reflete seu estado atual. Esta separação entre recursos e representações de recursos permite que um serviço forneça diferentes representações para um mesmo recurso, de modo a prover uma maior flexibilidade para diferentes aplicações cliente. Representações de recursos podem assumir diferentes formatos, tais como XML, HTML e JavaScript Object Notation (JSON) [23];

- Uso de informações em cache, o qual permite que respostas previamente enviadas por serviços RESTful sejam reutilizadas por aplicações cliente em requisições posteriores equivalentes. Em geral, esta característica permite um aumento na eficiência do uso da 
rede uma vez que o número de interações entre aplicações cliente e serviços pode ser reduzido;

- Estruturação do sistema em camadas, segundo o qual o sistema deve ser estruturado em camadas de modo que os componentes de cada camada forneçam serviços para os componentes da camada superior e façam uso dos serviços fornecidos pelos componentes da camada inferior. Este princípio permite, por exemplo, que recursos intermediários, tais como proxies e firewalls, sejam introduzidos entre aplicações cliente e serviços sem que alterações nas interfaces dos mesmos sejam necessárias;

- Código sob demanda, segundo o qual aplicações cliente podem acessar a funcionalidade do servidor por meio de applets ou scripts.

Diferentemente dos serviços baseados em SOAP, os serviços RESTful possuem interfaces uniformes, acessadas somente por meio de métodos HTTP. Assim, esta abordagem é necessariamente construída no topo do protocolo HTTP. Isto permite um maior grau de interoperabilidade entre serviços e a simplificação do desenvolvimento de aplicações cliente que interagem com serviços web RESTful [204]. Além disto, a tecnologia de serviços baseada em REST fornece um modelo de interação mais simples do que a tecnologia de serviços baseada em SOAP [204,205]. Assim, a tecnologia REST tem sido crescentemente utilizada no desenvolvimento de serviços no domínio biomédico [8, 10, 206, 207].

\subsubsection{Descrição de Serviços Web}

Tipicamente, a descrição de um serviço web expõe informações básicas sobre as funcionalidades oferecidas e os formatos de entrada/saída exigidos pelo serviço, bem como informações técnicas para permitir a invocação do mesmo. A publicação destas informações em registros de serviços permite que consumidores (aplicações cliente) realizem buscas por serviços, por exemplo, com base nas funcionalidades especificadas, e executem os serviços de interesse. No entanto, este processo requer que as aplicações cliente sejam capazes de extrair e processar as informações contidas em descrições de serviços de forma automática. Neste sentido, serviços web devem ser descritos usando linguagens computacionalmente interpretáveis. 
Atualmente, as linguagens mais utilizadas para a descrição de serviços web são as linguagens Web Application Description Language (WADL) [208] e Web Services Description Language (WSDL) [209]. Estas linguagens são bastante similares. No entanto, a linguagem WADL é mais simples do que a WSDL e possui um escopo mais limitado [210].

A linguagem Web Application Description Language (WADL) é uma linguagem baseada em XML utilizada para a descrição de aplicações web baseadas em HTTP (tipicamente serviços RESTful). O elemento application é o principal elemento da linguagem WADL. Este elemento contém um conjunto de recursos (elementos resource) oferecidos pelo serviço. Cada recurso é descrito em termos dos métodos HTTP (elementos method) que podem ser utilizados para acessá-lo. Por sua vez, cada método é descrito em termos de suas entradas (elementos request) e saídas (elementos response). Além disto, cada recurso pode estar interligado a outros recursos. Finalmente, o elemento application também contém o formato das mensagens enviadas e recebidas (elemento grammars) pelo serviço.

A linguagem Web Services Description Language (WSDL) é uma linguagem baseada em XML utilizada para a descrição de serviços web SOAP e RESTful. Esta linguagem possui duas versões comumente utilizadas: WSDL 1.1 e WSDL 2.0. O elemento definitions é o principal elemento da versão WSDL 1.1. Este elemento possui cinco subtipos que encapsulam todas as informações sobre um serviço web: message, que descreve de maneira abstrata as mensagens que o serviço envia e recebe; types, que descreve os formatos das mensagens que o serviço envia e recebe; portType, que descreve de maneira abstrata as funcionalidades que o serviço oferece em termos das suas operações, e entradas e saídas das operações; binding, que descreve como o serviço pode ser acessado; e service, que descreve a localização do serviço.

A versão 1.1 da linguagem WSDL permite a descrição de serviços web SOAP e RESTful por meio dos bindings SOAP e HTTP, respectivamente. No entanto, esta versão da linguagem não fornece todos os recursos necessários para a descrição de serviços RESTful. Por exemplo, o binding HTTP da versão WSDL 1.1 permite a especificação de operações de serviços web RESTful somente com os métodos GET e POST do protocolo HTTP. Além disto, todas as operações de uma determinada interface só podem ser especificadas como sendo de um único tipo. Desta forma, a versão 2.0 da linguagem foi desenvolvida com o objetivo de permitir a descrição adequada de serviços web RESTful. 
O elemento description é o principal elemento da versão WSDL 2.0. Este elemento possui quatro subtipos que encapsulam todas as informações sobre um serviço web: types, que descreve os formatos das mensagens que o serviço envia e recebe; interface, que descreve de maneira abstrata as funcionalidades que o serviço oferece em termos das suas operações, e entradas e saídas das operações; binding, que descreve como o serviço pode ser acessado; e service, que descreve a localização do serviço.

Diferentemente da versão 1.1 da linguagem, o binding HTTP da versão WSDL 2.0 permite a especificação de operações de forma individual com os tipos GET, PUT, POST e DELETE. Além disto, a versão WSDL 2.0 permite a descrição de referências a outros serviços web. Estas referências permitem a especificação do URI, da interface e do binding dos serviços referenciados. Finalmente, a versão WSDL 2.0 também fornece um atributo do tipo safe, que indica que uma operação não apresenta efeitos colaterais que alteram o estado, refletindo operações do tipo GET.

Adicionalmente, serviços web RESTful também podem ser descritos em páginas web escritas em HTML ou eXtensible Hypertext Markup Language (XHTML). No entanto, ao contrário da linguagem WSDL, interpretável por sistemas computacionais, as linguagens baseadas em HTML são primariamente concebidas para uso por usuários humanos. Desta forma, alguns micro formatos, tais como Resource Description Framework in Attributes (RDFa) [211] e Gleaning Resource Descriptions from Dialects of Languages (GRDDL) [212], têm sido desenvolvidos de modo a permitir a interpretação automática de descrições de serviços RESTful em HTML. Estes micro formatos fornecem um mecanismo para a adição de semântica a elementos HTML, permitindo assim a interpretação automática destes elementos por sistemas computacionais.

\subsubsection{Publicação de Serviços Web}

Uma vez que as informações sobre um serviço são especificadas em uma descrição de serviço, estas informações podem ser publicadas em um registro de serviços público ou proprietário. A publicação destas informações em um registro permite a posterior descoberta de serviços de interesse por potenciais consumidores de serviços. 


\section{Universal Description, Discovery and Integration (UDDI)}

A especificação Universal Description, Discovery and Integration (UDDI) [213] fornece um padrão para a criação de registros de serviços. Esta especificação permite a classificação, catalogação e gerenciamento de informações sobre serviços web de maneira padronizada. Além disto, a especificação UDDI fornece um conjunto de mecanismos para a publicação e descoberta de serviços nestes registros, também de maneira padronizada.

A especificação UDDI define mecanismos para o gerenciamento de informações relacionadas aos provedores de serviços, aos serviços publicados por estes provedores, bem como às interfaces utilizadas para acessar os serviços. Desta forma, os provedores de serviços podem publicar as descrições de seus serviços em um registro UDDI e os consumidores de serviços são capazes de descobrir serviços de interesse e obter informações necessárias para a execução destes serviços.

Um registro construído de acordo com a especificação UDDI consiste em um conjunto padronizado de estruturas de armazenamento, as quais podem ser utilizadas para armazenar informações sobre serviços e provedores de serviços. A Figura 12 apresenta as principais estruturas de armazenamento definidas em um registro UDDI e os relacionamentos entre as mesmas.

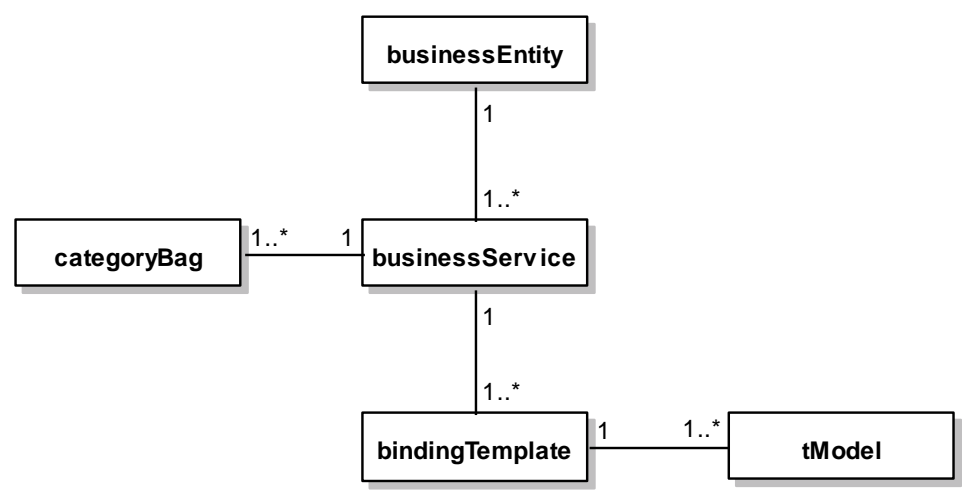

Figura 12: Estruturas de armazenamento de um registro UDDI

A estrutura businessEntity permite o armazenamento de informações sobre um provedor de serviços. Estas informações incluem o nome do provedor, sua descrição, informações de contato, entre outras. Uma estrutura businessEntity pode estar associada a uma ou mais estruturas do tipo businessService. A estrutura businessService permite o armazenamento de diferentes informações sobre um serviço web. Estas informações incluem um identificador exclusivo, o 
nome do serviço, sua descrição, entre outras. O relacionamento entre as estruturas businessEntity e businessService indica que um provedor de serviços pode fornecer um ou mais serviços web, enquanto um serviço web deve ser fornecido por um único provedor de serviços.

Uma estrutura businessService pode estar associada a uma ou mais estruturas do tipo bindingTemplate. A estrutura bindingTemplate permite o armazenamento de informações técnicas necessárias para acessar um determinado serviço web descrito na estrutura businessService. Estas informações incluem a localização do serviço e o protocolo de acesso ao mesmo, entre outras. O relacionamento entre as estruturas businessService e bindingTemplate indica que um serviço pode ser acessado de diferentes formas, por exemplo, por meio de diferentes endereços e/ou utilizando-se diferentes protocolos de acesso. No entanto, uma estrutura bindingTemplate deve estar associada a um único serviço.

Por sua vez, uma estrutura bindingTemplate pode estar associada a uma ou mais estruturas do tipo tModel. A estrutura tModel é uma estrutura de armazenamento genérica, que pode ser utilizada para representar um determinado elemento ou conceito. Tipicamente, a estrutura $t M o$ del pode ser utilizada para armazenar informações sobre a interface de um serviço, tais como operações, protocolos e falhas associadas à execução do serviço. Além disto, a estrutura tModel pode ser utilizada como uma estrutura de categorização que permite classificar elementos UDDI definidos em um registro com base em um determinado critério.

Finalmente, uma estrutura businessService pode estar associada a uma ou mais estruturas do tipo categoryBag. A estrutura categoryBag permite o armazenamento de estruturas de categorização (tModels), utilizadas para classificar um serviço com base em diferentes critérios. No entanto, uma estrutura categoryBag deve estar associada a um único serviço.

\subsection{SERVIÇOS WEB SEMÂNTICOS}

Diferentes abordagens têm sido propostas para a anotação semântica de serviços web, tais como Web Ontology Language for Services (OWL-S) [214, 215], Web Service Modeling Ontology (WSMO) [216, 217], Semantic Annotations for Web Services Description Language (SAWSDL) [218, 219] e Semantic Annotations for REST (SA-REST) [220, 221]. Estas abordagens fornecem um conjunto de mecanismos para a adição de semântica às descrições de 
serviços, permitindo a extração de informações e a interação com os serviços de maneira automática.

\subsubsection{Web Ontology Language for Services $(O W L-S)$}

A Web Ontology Language for Services (OWL-S) [214,215] é uma ontologia de serviços escrita na linguagem OWL. Esta ontologia fornece uma infraestrutura para a descrição semântica de serviços web.

A descrição semântica de um serviço web com a OWL-S é realizada por meio de três (sub) ontologias relacionadas: Service Profile, Service Model e Grounding. A ontologia Service Profile é utilizada para descrever de forma abstrata as funcionalidades que o serviço fornece. Esta ontologia fornece um conjunto de conceitos para a descrição do que um serviço fornece em termos de suas propriedades funcionais e não funcionais. A ontologia Service Model é utilizada para descrever de forma abstrata o padrão de interação exigido para comunicação com o serviço. Esta ontologia fornece um conjunto de conceitos para a descrição de processos de interação com serviços. Finalmente, a ontologia Grounding é utilizada para descrever de forma concreta como interagir com o serviço em termos de formatos de mensagens, protocolos de comunicação e números de portas para invocar o serviço.

Na OWL-S, cada serviço é representado como uma instância da classe Service. Esta classe permite a associação de serviços a um ou mais perfis (instâncias da classe Service Profile), a um modelo de serviço (instância da classe Service Model) e a uma ou mais concretizações (instâncias da classe Service Grounding).

Diferentes ferramentas de suporte à abordagem OWL-S têm sido desenvolvidas. O plugin OWL-S Editor [222] para a ferramenta Protégé fornece um conjunto de recursos para a criação e manutenção de descrições de serviços em OWL-S. A ferramenta Automated Semantic Service Annotation with Machine learning (ASSAM) [223] permite a criação de descrições de serviços OWL-S. A ferramenta CODE [224] fornece suporte à geração de código Java e à criação de descrições de serviços OWL-S. Adicionalmente, esta ferramenta inclui um tradutor WSDL/OWL-S e provê suporte à anotação semântica de serviços WSDL legados. 


\subsubsection{Web Service Modeling Ontology (WSMO)}

A Web Service Modeling Ontology (WSMO) [216,217] fornece um modelo conceitual e uma linguagem formal, a Web Service Modeling Language (WSML) [225], para a descrição de todos os aspectos relacionados aos serviços web. Esta abordagem baseia-se no framework Web Service Modeling Framework (WSMF) [226], o qual assume que as ontologias representam o modelo de dados central na utilização de serviços web semânticos. Assim, todos os aspectos relacionados a serviços devem ser escritos com base em termos providos por ontologias.

A WSMO fornece um modelo conceitual para a descrição semântica de todos os aspectos relevantes aos serviços web. Esta abordagem não somente inclui a maioria dos aspectos de descrição fornecidos pela abordagem OWL-S, mas também considera o uso de mediadores como elementos descritivos. Assim, a WSMO é estruturada de acordo com quatro elementos principais: ontologias, serviços web, objetivos e mediadores. As ontologias fornecem, de maneira formal, a informação semântica necessária para descrever serviços web, objetivos e mediadores. As descrições de serviços especificam as propriedades funcionais e comportamentais de serviços web. Os objetivos representam os requisitos dos consumidores de serviços. Finalmente, os mediadores são elementos que lidam com problemas de interoperabilidade entre ontologias, serviços web e objetivos.

Quatro tipos de mediadores estão disponíveis na especificação da WSMO: mediadores Ontology-Ontology (OO), que resolvem incompatibilidades entre representações de diferentes ontologias; mediadores Goal-Goal (GG), que resolvem incompatibilidades entre representações de diferentes objetivos; mediadores Web service-Goal (WG), que resolvem incompatibilidades entre representações de serviços web e de objetivos; e mediadores Web service-Web service (WW) que resolvem incompatibilidades entre serviços web heterogêneos, permitindo que eles interajam.

Diferentes ferramentas de suporte à abordagem WSMO têm sido desenvolvidas. WSMO Studio [227] é um conjunto de plugins para o ambiente de desenvolvimento Eclipse [228] que permitem a modelagem dos principais elementos da WSMO. A API WSMO4J [229] também permite o desenvolvimento de serviços web semânticos de acordo com o modelo conceitual WSMO. Outras ferramentas de suporte incluem a Web Service Modeling Toolkit (WSMT) 
[230], que fornece recursos para o desenvolvimento de serviços na linguagem WSML, e o ambiente de execução de serviços Web Services Execution Environment (WSMX) [231].

\subsubsection{Semantic Annotations for WSDL (SAWSDL)}

A abordagem Semantic Annotations for Web Services Description Language (SAWSDL) [218, 219] define um conjunto de atributos de extensão que permitem a adição de anotações semânticas a documentos escritos nas linguagens WSDL (versões 1.1 e 2.0) e XML Schema. Três atributos de extensão são definidos nesta abordagem: modelReference, liftingSchemaMapping e loweringSchemaMapping.

A Figura 13 apresenta uma visão geral do uso dos atributos modelReference, liftingSchemaMapping e loweringSchemaMapping. Os retângulos com preenchimento azul indicam componentes das linguagens WSDL ou XML Schema. Os relacionamentos rotulados indicam os atributos de extensão da linguagem SAWSDL. Os retângulos com preenchimento branco indicam conceitos de uma ontologia. Finalmente, os retângulos com preenchimento cinza indicam elementos de dados, tais como dados de mapeamento e dados XML.

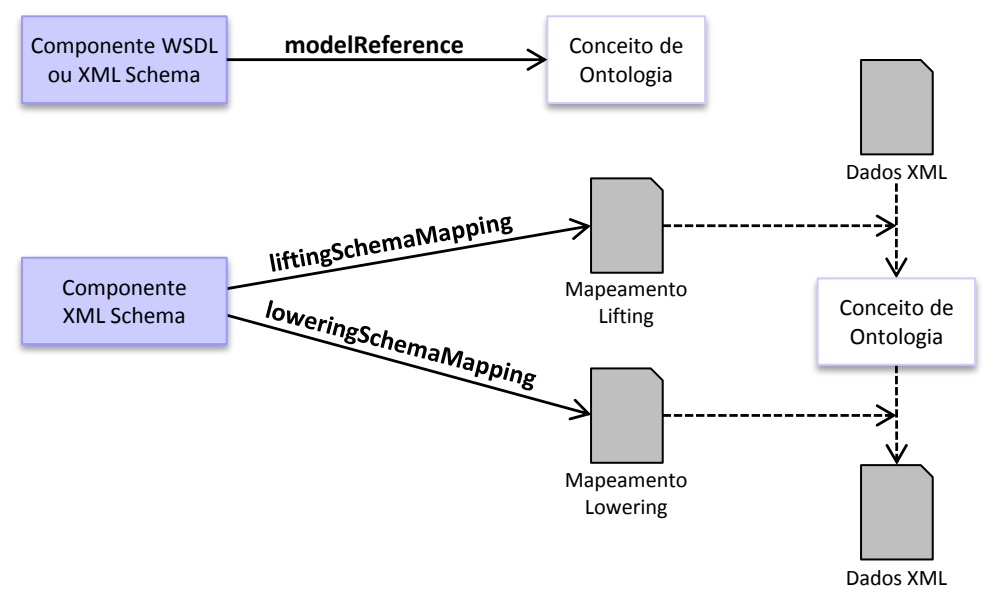

Figura 13: Atributos de extensão da linguagem SAWSDL

$\mathrm{O}$ atributo modelReference pode ser utilizado para associar um elemento WSDL ou XML a um ou mais conceitos de uma ontologia. Este atributo pode ser utilizado para anotar definições de tipos, declarações de elementos e atributos contidos em esquemas XML, bem como elementos WSDL interface, operation e fault. Estas anotações permitem a descrição dos princi- 
pais elementos contidos em um documento WSDL ou em um esquema XML com base em um conjunto de conceitos formalmente definido em uma ontologia. Desta forma, o atributo modelReference permite a descrição semântica dos dados enviados/recebidos e das funcionalidades fornecidas por um serviço web.

Os atributos liftingSchemaMapping e loweringSchemaMapping podem ser utilizados para a anotação de estruturas XML contidas em documentos escritos na linguagem XML Schema. Estes atributos permitem a especificação de mapeamentos entre estruturas XML e conceitos em ontologias. O uso destes atributos permite que diferentes estruturas XML de uma aplicação cliente e de um serviço sejam mapeadas para conceitos de uma ontologia de modo a resolver diferenças sintáticas entre elas e permitir a comunicação entre a aplicação cliente e o serviço.

$\mathrm{O}$ atributo liftingSchemaMapping referencia mapeamentos que especificam como estruturas XML definidas a partir de um esquema XML são transformadas em dados semânticos (conceitos) definidos em ontologias. Desta forma, a entrada do processo de transformação corresponde à estrutura XML anotada com o atributo liftingSchemaMapping e a saída do processo corresponde a conceitos definidos em uma ontologia.

De forma análoga, o atributo loweringSchemaMapping referencia mapeamentos que especificam como dados semânticos (conceitos) definidos em ontologias são transformados em estruturas XML definidas a partir de um esquema XML. Desta forma, a entrada do processo de transformação corresponde a conceitos definidos em uma ontologia e a saída do processo corresponde à estrutura XML anotada com o atributo loweringSchemaMapping.

Diferentes ferramentas de suporte à abordagem SAWSDL têm sido desenvolvidas. Por exemplo, a API Java SAWSDL4J [232] fornece suporte ao desenvolvimento de documentos SAWSDL. A ferramenta Iridescent [233] fornece suporte à definição gráfica de anotações semânticas em descrições WSDL de serviços. Outros exemplos incluem o plugin Radiant [234] para a plataforma Eclipse, que permite a anotação semântica de documentos WSDL e a API Java Woden4SAWSDL [235], que fornece recursos para o desenvolvimento de documentos SAWSDL. 


\subsubsection{Semantic Annotations for REST (SA-REST)}

A abordagem Semantic Annotations for REST (SA-REST) [220, 221] foi concebida para permitir a anotação semântica de serviços web RESTful descritos em páginas web. Esta abordagem define um conjunto de propriedades que permitem a adição de anotações semânticas a documentos escritos nas linguagens HTML ou XHTML.

Três propriedades básicas são definidas nesta abordagem: domain-rel, sem-rel e sem-class. A propriedade domain-rel permite a associação de um recurso a conceitos de uma ontologia utilizados para descrever os domínios de conhecimento ao qual o recurso está associado. A propriedade sem-rel permite a associação de um hyperlink a um conceito de uma ontologia. Finalmente, a propriedade sem-class permite a associação de uma entidade textual ou objeto embutido em um recurso a um conceito de uma ontologia.

De acordo com a abordagem SA-REST, se uma propriedade sem-rel ou sem-class é utilizada para anotar um elemento HTML ou XML, outras propriedades não podem ser adicionadas a este elemento. Por outro lado, o uso da propriedade domain-rel para anotar um elemento HTML ou XHTML não restringe a adição de outras propriedades ao elemento que está sendo anotado.

De forma análoga à abordagem SAWSDL, SA-REST permite a definição de mapeamentos lifting e lowering e pode ser utilizada para associar elementos HTML ou XHTML a um ou mais conceitos de uma ontologia com o uso das três propriedades básicas especificadas. Desta forma, a abordagem SA-REST também permite a descrição semântica dos dados enviados/recebidos e das funcionalidades fornecidas por um serviço web.

Diferentemente do suporte ferramental encontrado para as demais abordagens, suporte ferramental à abordagem SA-REST ainda é limitado. O plugin SA-REST Annotator [236] para o navegador web Firefox permite a anotação de serviços web de acordo com a abordagem SAREST e a publicação destas anotações. O conjunto de ferramentas Kino [237] permite a anotação de serviços web de acordo com a abordagem SA-REST e a busca e seleção de serviços web anotados de acordo com esta abordagem. 


\subsection{COMPOSIÇÃO DE SERVIÇOS WEB}

De modo geral, serviços web (semânticos) podem ser utilizados de forma isolada para a realização de tarefas específicas. No entanto, muitas vezes estes não são capazes de realizar individualmente tarefas mais complexas exigidas pelos usuários. Nestes casos, as funcionalidades de diferentes serviços precisam ser integradas, gerando as chamadas composições de serviços. A composição de serviços permite o reuso de um conjunto de serviços disponíveis, reduzindo o tempo de desenvolvimento de novos serviços com funcionalidades agregadas.

De forma simplificada, uma composição de serviços pode ser vista como uma sequência ordenada (cadeia) de serviços, cada um fornecendo uma funcionalidade específica. Os serviços participantes da composição são interligados de modo que os dados produzidos por um serviço possam ser utilizados como dados de entrada para um próximo serviço definido na cadeia. Assim, a execução ordenada desta sequência de serviços permite a realização de diferentes atividades de processamento em um conjunto de dados, de maneira integrada.

Tipicamente, o processo para a criação e uso de uma composição de serviços envolve cinco etapas: requisição, descoberta, composição, seleção e execução. A primeira etapa consiste na especificação de uma requisição. Esta requisição fornece informações sobre os requisitos e preferências de um usuário para a criação de uma composição. Geralmente, estas informações incluem os objetivos a serem atingidos pelo usuário e os tipos de dados que o usuário deseja processar e/ou produzir. A segunda etapa consiste na realização de buscas em um registro de serviços para a descoberta de serviços capazes de alcançar os objetivos especificados pelo usuário na etapa de requisição. Estas buscas consistem na comparação das informações contidas na requisição do usuário com as informações fornecidas pelas descrições de serviços disponíveis no registro. A terceira etapa consiste na especificação de um plano de composição a partir dos serviços descobertos na etapa anterior. O plano de composição define o conjunto de serviços que serão integrados e o fluxo de execução destes serviços. Uma vez que diferentes serviços podem fornecer uma mesma funcionalidade, vários planos de composição distintos podem ser definidos. Assim, a quarta etapa consiste na seleção de um único plano de composição. Esta seleção pode ser realizada, por exemplo, com base nas preferências do usuário. Finalmente, a quinta etapa consiste na execução do plano de composição selecionado. 
O processo de composição de serviços pode ser realizado com o auxílio de uma plataforma de serviços, isto é, um ambiente computacional que provê suporte à composição e execução de serviços. O processo de composição pode ser realizado de acordo com duas abordagens $[238,239]$ : estática e dinâmica. Na abordagem de composição estática, a especificação de planos de composição é realizada, em geral, por desenvolvedores de software e a execução destes planos de composição pode ser realizada posteriormente pelos usuários, durante a execução da plataforma de serviços. Na abordagem de composição dinâmica, os planos de composição podem ser especificados e executados sob demanda, de acordo com as necessidades dos usuários, durante a execução da plataforma de serviços.

$\mathrm{Na}$ abordagem de composição estática, as etapas do processo de composição de serviços podem ser, em princípio, realizadas de forma manual. Na primeira etapa do processo, o desenvolvedor da plataforma de serviços coleta, de maneira formal ou informal, os requisitos de um grupo de usuários para a especificação de uma requisição. Com base nesta especificação, o desenvolvedor realiza buscas em um registro de serviços para descobrir serviços capazes de alcançar os objetivos definidos na requisição. Estas buscas são realizadas de forma manual. Em seguida, o desenvolvedor define um ou mais planos de composição. Durante a definição de um plano de composição, o desenvolvedor interliga os serviços descobertos na etapa anterior também de forma manual, garantindo que os dados produzidos por cada serviço sejam compatíveis com os dados de entrada do próximo serviço definido na cadeia. Diferentes planos de composição podem ser definidos. Finalmente, um plano de composição pode ser selecionado com base nas preferências identificadas para o grupo de usuários alvo. Este plano de composição é disponibilizado aos usuários e pode então ser executado quando necessário.

A abordagem de composição estática assume que os provedores de serviços são fixos e as funcionalidades oferecidas pelos seus serviços não se alteram em curto prazo. No entanto, o ambiente de serviços web é, em geral, dinâmico, ou seja, os provedores precisam adaptar suas interfaces de serviços, de modo a modificar funcionalidades existentes ou incorporar novas funcionalidades. Neste sentido, a abordagem estática pode ser bastante restritiva. Além disto, esta abordagem pressupõe que os requisitos e preferências de um usuário não se alteram durante a execução de uma composição. No entanto, a maioria dos ambientes requer uma abordagem mais adaptável às possíveis alterações de requisitos. 
A abordagem de composição dinâmica fornece maior flexibilidade em relação à abordagem estática, uma vez que permite a modificação, extensão e adaptação dos planos de composição durante a execução da plataforma de serviços. Neste sentido, os planos de composição podem ser alterados na medida em que os requisitos e preferências do usuário se alteram. Além disto, os serviços definidos em uma composição podem ser dinamicamente substituídos por serviços alternativos, por exemplo, na ocorrência de falhas [32]. A principal vantagem da abordagem de composição dinâmica é permitir a criação de composições mais personalizadas e sensíveis ao contexto dos usuários [240].

Um dos principais objetivos da abordagem de composição dinâmica é fornecer uma composição de forma transparente para os usuários [241]. Neste sentido, esta abordagem requer o uso de mecanismos de suporte (semi) automático às etapas do processo de composição, reduzindo as interações dos usuários com a plataforma de serviços e isentando os usuários dos detalhes técnicos do processo.

\subsubsection{Composição Automática de Serviços Web}

A Figura 14 apresenta uma visão geral do processo de composição automática de serviços. Este processo consiste nas etapas de requisição, descoberta, composição, seleção e execução de serviços. No processo de composição automática de serviços, todas estas etapas são realizadas de forma (semi) automática, com o suporte de um sistema computacional.

No processo de composição (semi) automática de serviços, um usuário especifica seus objetivos e os tipos de dados que deseja processar e/ou produzir com o auxílio de um sistema computacional. Esta especificação pode ser escrita em alguma linguagem lógica ou descritiva. O sistema deve então ser capaz de interpretar de forma automática as descrições dos serviços disponíveis em registros públicos, de modo a descobrir serviços (atômicos ou compostos) que forneçam as funcionalidades e/ou tipos de dados especificados. Em seguida, um plano de composição é produzido de modo a satisfazer os requisitos do usuário. Caso mais de um plano de composição esteja disponível, o sistema pode automaticamente selecionar um único plano para execução com base, por exemplo, em características não funcionais (atributos de qualidade) dos serviços. Estas características podem incluir desempenho, confiabilidade e disponibilidade dos 


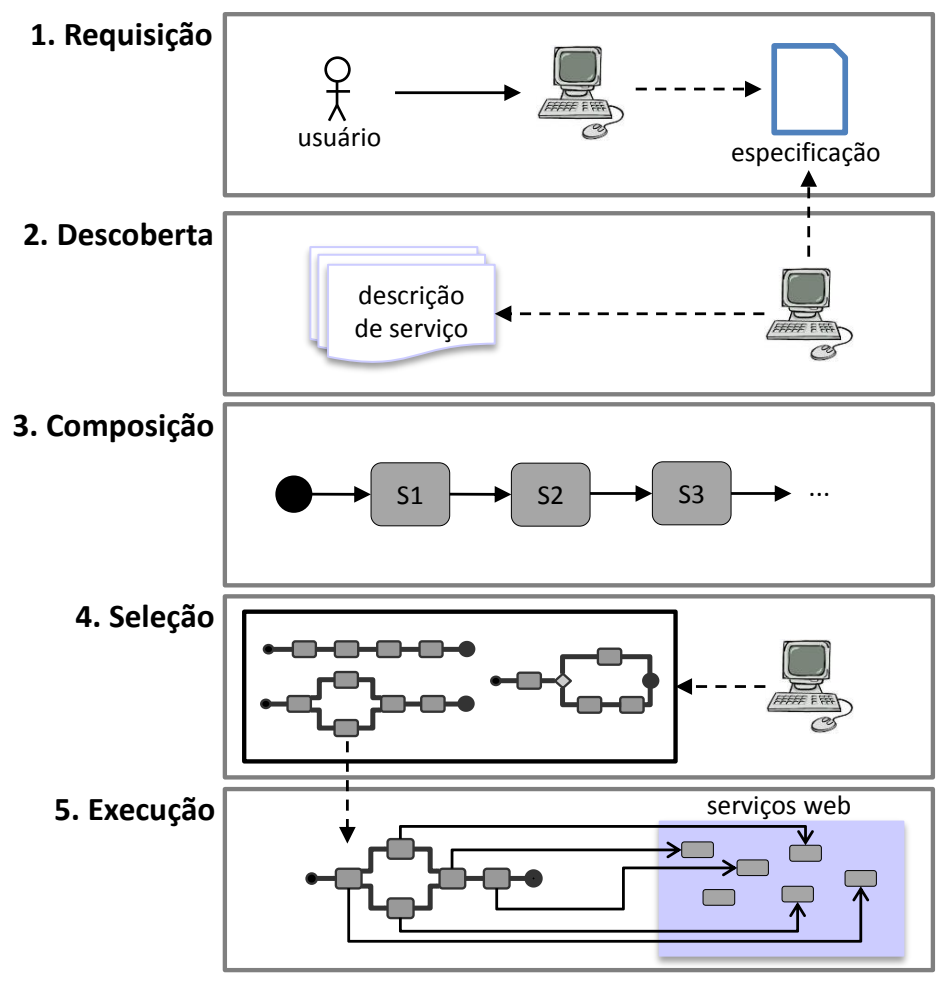

Figura 14: Composição automática de serviços.

serviços, por exemplo. De forma alternativa, a seleção de um plano de composição pode ser realizada pelo usuário com o auxílio do sistema, de forma semi-automática. Finalmente, o plano de composição selecionado pode ser automaticamente executado.

Tipicamente, na etapa de descoberta, o sistema deve ser capaz de interpretar de forma automática as informações contidas em descrições de serviços e extrair, por exemplo, os termos representando as funcionalidades oferecidas pelos serviços. O sistema deve então interpretar as informações contidas na requisição do usuário e extrair os termos representando as funcionalidades desejadas pelo usuário (objetivos). Em seguida, o sistema deve realizar uma comparação entre os termos extraídos a partir dos serviços e da requisição do usuário. Quando uma relação de equivalência (sintática) entre estes termos for identificada, o serviço pode ser considerado relevante no contexto daquela requisição.

De forma similar, na etapa de composição de serviços, o sistema deve ser capaz de interpretar de forma automática as informações contidas em descrições de serviços e extrair, por exemplo, os termos representando os tipos de dados produzidos e consumidos pelos serviços. Um algoritmo pode então ser utilizado para tentar identificar relações de equivalência (sintática) entre os 
termos. Esta atividade tem como objetivo identificar serviços cujos dados de saída possam ser consumidos por outros serviços. Com base nas relações de equivalência identificadas, o sistema deve interligar serviços considerados compatíveis e assim, criar um plano de composição.

As etapas de descoberta e composição de serviços baseiam-se na extração de informações e identificação de equivalências entre termos representando funcionalidades e/ou tipos de dados. Em ambas etapas, as relações de equivalência são estabelecidas apenas com base na sintaxe dos termos representando funcionalidades ou tipos de dados.

De modo geral, as funcionalidades e tipos de dados associados a um serviço são especificados em descrições de serviços por meio de linguagens computacionalmente interpretáveis, tais como esquemas XML. No entanto, diferentes descrições de serviços podem ser especificadas com o uso de linguagens distintas. Além disto, uma mesma linguagem pode ser utilizada para a representação de informações utilizando representações distintas. Nestas situações, a realização de mapeamentos entre linguagens e/ou representações pode ser necessária de modo a permitir a identificação de equivalências semânticas entre termos sintaticamente distintos.

A associação de conceitos presentes em ontologias aos dados apresentados em descrições de serviços permite a atribuição de significados não-ambíguos aos dados, facilitando a identificação automática de equivalências semânticas. Neste contexto, a atribuição de semântica às descrições de serviços tem sido considerada essencial para facilitar a descoberta e composição de serviços de forma automática [24,25]. Além disto, a representação de características nãofuncionais dos serviços, tais como desempenho e disponibilidade, permite a seleção automática de serviços por sistemas computacionais.

\subsubsection{Composição Semântica de Serviços Web}

\section{Integração Semântica de Serviços}

Uma solução completa para a composição automática de serviços web deve considerar a integração dos pontos de vista sintático e semântico. A integração sintática permite que os serviços sejam capazes de trocar dados sintaticamente compatíveis. A integração semântica tem como princípios básicos a utilização de metadados para a descrição dos significados dos dados 
compartilhados por diferentes serviços e o uso de ontologias para permitir o mapeamento de conceitos entre serviços distintos $[6,14]$. A realização de mapeamentos entre a sintaxe e a semântica dos dados permite, por exemplo, que serviços distintos que compartilham dados com sintaxes diferentes, mas com a mesma semântica, sejam capazes de interoperar. Desta forma, esta abordagem permite a atribuição de significados não ambíguos aos dados compartilhados por diferentes ferramentas em um ambiente integrado, possibilitando a troca de dados de forma semanticamente consistente.

A Figura 15 ilustra, de forma genérica, a integração semântica de dois serviços $S_{1}$ e $S_{2}$ que compartilham dados com a mesma semântica $(S)$, mas com sintaxes distintas $\left(X_{1}\right.$ e $\left.X_{2}\right)$. Esta figura ilustra o uso de uma ontologia para a realização de mapeamentos entre a sintaxe e a semântica dos dados compartilhados pelos serviços $S_{1}$ e $S_{2}$, permitindo a troca dos dados entre os serviços de forma semanticamente consistente.

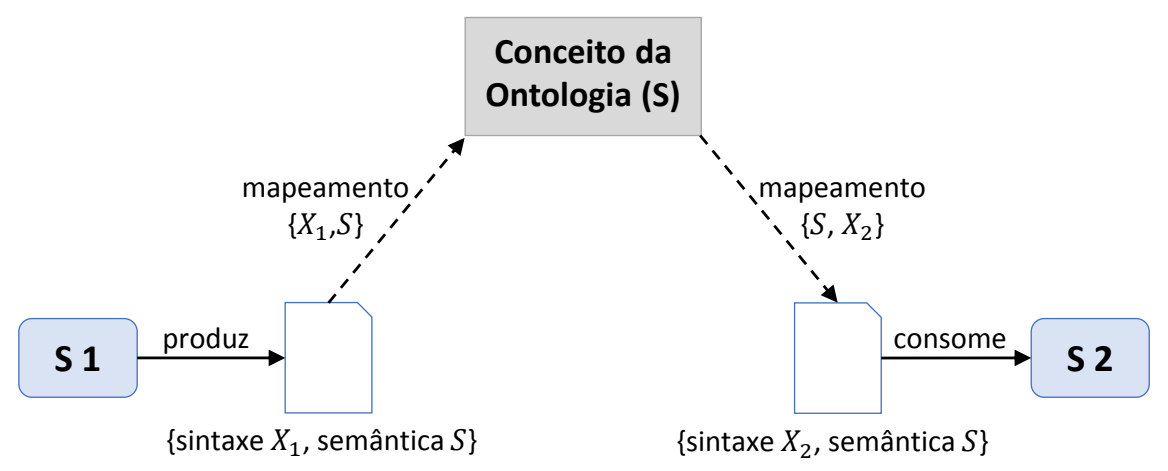

Figura 15: Integração semântica de serviços.

A associação de conceitos presentes em ontologias aos dados apresentados em descrições de serviços permite a atribuição de significados não-ambíguos aos dados. Além disto, o uso explícito de semântica permite que sistemas computacionais realizem inferências para a descoberta de relacionamentos mais complexos entre os dados, que não poderiam ser estabelecidos com base apenas na sintaxe destes dados.

Considere, por exemplo, que um usuário deseje realizar a normalização de um conjunto de dados de microarray. Neste sentido, o usuário poderia construir uma requisição com o uso do termo "microarray data normalization". Durante a etapa de descoberta de serviços, o sistema de suporte seria capaz de encontrar serviços com esta funcionalidade. No entanto, serviços cujas funcionalidades estivessem descritas por meio do termo "gene expression data normalization" 
não seriam considerados compatíveis com a requisição do usuário. Com a associação de conceitos de uma ontologia às funcionalidades do serviço, o sistema seria capaz de realizar inferências na ontologia, determinando, por exemplo, que o termo "microarray data normalization" está semanticamente relacionado ao termo "gene expression data normalization". Assim, serviços capazes de realizar a normalização de dados de expressão gênica também seriam considerados relevantes para o usuário.

\section{Etapas do Processo de Composição}

A Figura 16 apresenta o processo de composição semântica de serviços. Este processo consiste nas mesmas etapas do processo tradicional de composição de serviços web. No entanto, as ontologias e anotações semânticas dos serviços desempenham um papel importante em cada etapa do processo.

Na primeira etapa do processo de composição semântica, o usuário especifica seus objetivos e/ou os tipos de dados que deseja processar/produzir por meio de conceitos presentes em uma ontologia. A criação de uma requisição pelo usuário é geralmente auxiliada por um sistema computacional de suporte. Na segunda etapa, descoberta de serviços, o sistema busca por serviços cujas funcionalidades sejam capazes de alcançar os objetivos especificados pelo usuário em uma requisição. Esta busca se baseia na comparação dos conceitos (de uma ou mais ontologias) utilizados para descrever as funcionalidades dos serviços e os objetivos do usuário, de modo a encontrar relacionamentos de equivalência entre estes conceitos. Além disto, o sistema de suporte busca por serviços cujas entradas e saídas sejam semanticamente equivalentes/relacionadas aos tipos de dados especificados pelo usuário.

$\mathrm{Na}$ terceira etapa, se nenhum serviço adequado for identificado, o sistema tenta gerar uma sequência de serviços (plano de composição) cujas funcionalidades sejam capazes de, conjuntamente, alcançar os objetivos especificados pelo usuário. Nesta etapa, dois serviços podem ser interligados se os dados produzidos por um serviço forem considerados compatíveis com os dados consumidos pelo outro serviço. Uma vez que as entradas/saídas dos serviços estão semanticamente anotadas com conceitos de uma ou mais ontologias, a determinação de compatibilidade entre as entradas e saídas dos serviços é realizada com base na similaridade semântica dos termos utilizados para a descrição destes tipos de dados. 


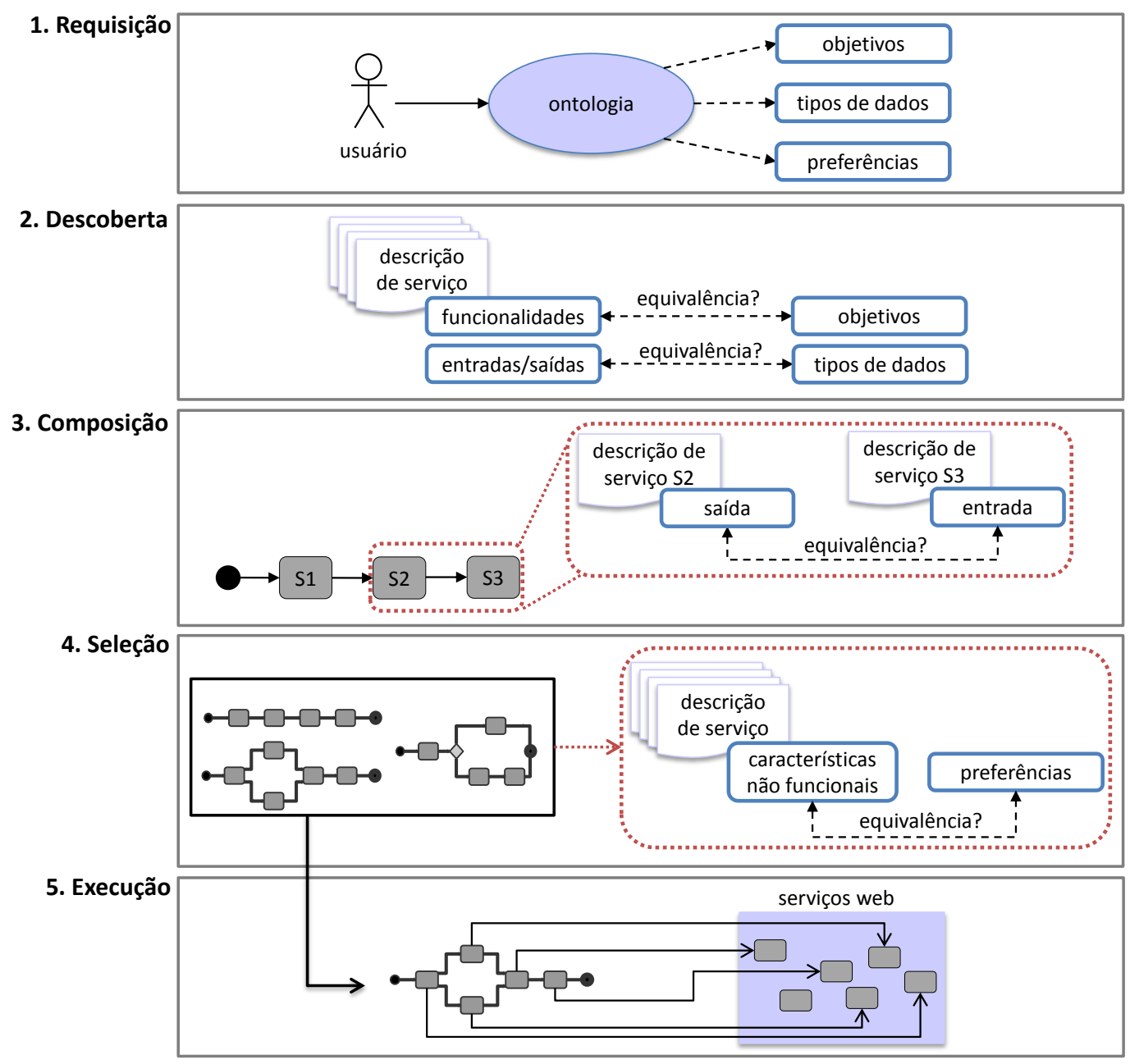

Figura 16: Composição semântica de serviços

De modo geral, a ligação de um serviço a outro para a geração de um plano de composição pode ser realizada de acordo com duas abordagens [242]: forward ou backward. Na abordagem forward, o sistema busca inicialmente por um serviço cuja entrada seja compatível com os dados que o usuário deseja processar. Em seguida, o sistema busca por um serviço cuja entrada seja compatível com a saída gerada pelo serviço anterior na sequência. Esta atividade é realizada de forma iterativa até que os objetivos do usuário sejam atingidos. Na abordagem backward, o sistema busca inicialmente por um serviço cuja saída seja compatível com os dados que o usuário deseja produzir e cuja funcionalidade seja capaz de realizar o objetivo do usuário. Em seguida, o sistema busca por um serviço cuja saída seja compatível com a entrada exigida pelo serviço posterior na sequência (previamente selecionado). Esta atividade é realizada de forma 
iterativa até que os dados que o usuário deseja processar sejam compatíveis com a entrada exigida pelo primeiro serviço definido na sequência.

Diferentes serviços podem fornecer uma mesma funcionalidade, mas com características não funcionais distintas. Por exemplo, dois serviços podem realizar um mesmo tipo de análise em um conjunto de dados, mas com tempos de execução distintos. Além disto, alguns serviços podem fornecer funcionalidades semanticamente similares às funcionalidades desejadas por um usuário. Por exemplo, um usuário pode desejar realizar o agrupamento de dados de expressão gênica e dois serviços distintos podem ser capazes de realizar o agrupamento hierárquico e k-means dos dados, respectivamente. Neste sentido, vários planos de composição podem ser construídos. Na quarta etapa, se vários planos de composição forem produzidos, o sistema pode selecionar um destes planos para execução com base na comparação entre conceitos representando características não funcionais desejadas pelo usuário e fornecidas pelos serviços. Além disto, planos de composição podem ser selecionados com base em métricas de similaridade semântica. De forma alternativa, o sistema pode categorizar os planos de composição com base em métricas de similaridade semântica e/ou características não funcionais dos serviços participantes, apenas auxiliando o usuário na seleção de um único plano de composição. Finalmente, na quinta etapa, o plano de composição selecionado pode ser executado de forma automática. A etapa de execução consiste na invocação individual de cada serviço definido no plano de composição.

\section{Equivalência Semântica}

No processo de composição semântica de serviços, as etapas de descoberta, seleção e composição de serviços baseiam-se na identificação de equivalências/relações entre diferentes termos (conceitos). Tipicamente, a etapa de descoberta envolve a comparação de termos utilizados para descrever as funcionalidades dos serviços e os objetivos do usuário. De forma semelhante, a etapa de composição requer a identificação de compatibilidade (semântica) entre as entradas e saídas dos serviços sendo interligados para a construção de um plano de composição. Finalmente, a seleção de serviços pode ser realizada de forma automática por meio da comparação entre termos representando características não funcionais desejadas pelo usuário e fornecidas pelos serviços. 
De modo a ilustrar o processo de identificação de equivalências/relações entre termos (conceitos), a Figura 17 apresenta a construção de um plano de composição definido por uma sequência de serviços $\left\{S_{1}, S_{2}, S_{3}, \ldots, S_{n}\right\}$. Os serviços $S_{1}$ e $S_{2}$ podem ser interligados se a saída do serviço $S_{1}$ for compatível com a entrada do serviço $S_{2}$. A saída de $S_{1}$ e a entrada de $S_{2}$ estão semanticamente anotadas com termos $A$ e $B$ de uma ontologia, respectivamente.

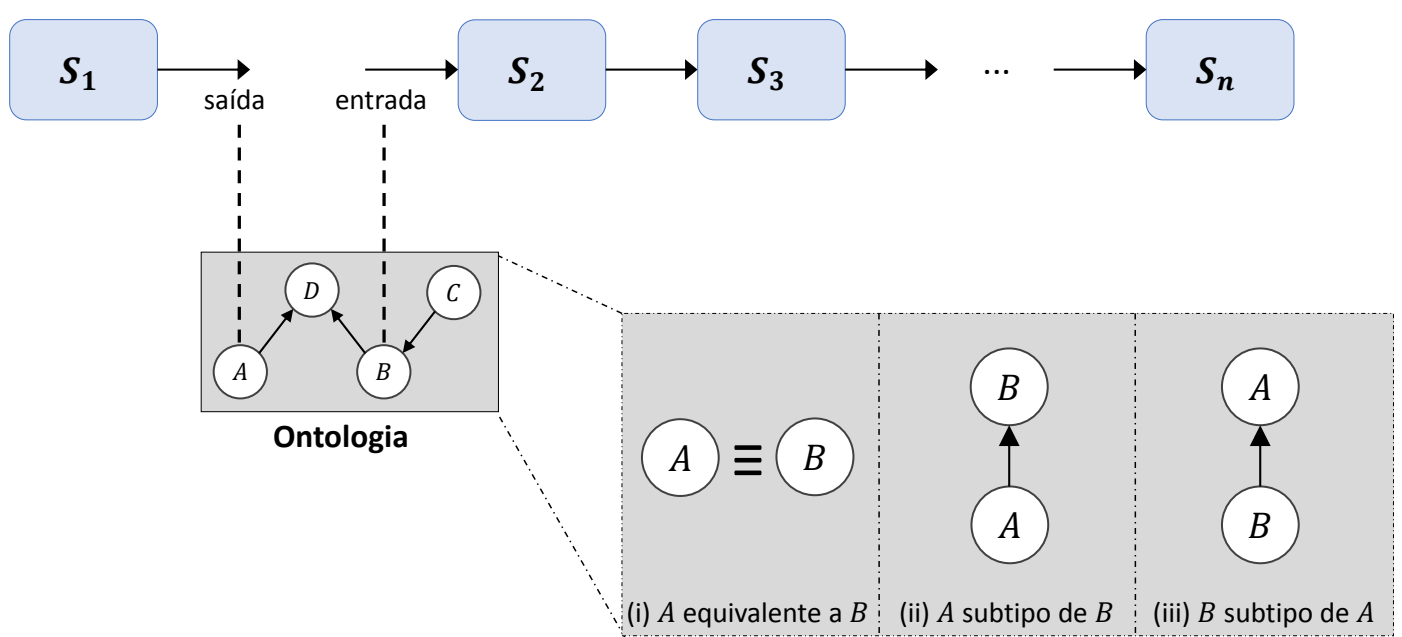

Figura 17: Equivalência semântica entre serviços

A realização de inferências na ontologia com o uso de uma ferramenta de suporte (reasoner) pode identificar três situações: (i) os termos $A$ e $B$ são equivalentes, ou seja, representam um mesmo conceito; (ii) $A$ é um subtipo (direto ou indireto) de $B$; e (iii) $B$ é um subtipo (direto ou indireto) de $A$. Nessas três situações, uma relação semântica pode ser estabelecida entre os termos A e B representando a saída do serviço $S_{1}$ e a entrada do serviço $S_{2}$, respectivamente. No entanto, o grau de similaridade semântica entre os termos $A$ e $B$ é considerado maior em (i) do que em (ii), e maior em (ii) do que em (iii). Neste sentido, o grau de similaridade semântica entre $A$ e $B$ pode ser utilizado para determinar o grau de compatibilidade entre a saída de $S_{1}$ e a entrada de $S_{2}$.

\subsection{ABORDAGENS PARA DESENVOLVIMENTO DE SERVIÇOS WEB SEMÂNTICOS}

Um número crescente de ferramentas de software têm sido adaptadas como serviços web semânticos no domínio biomédico. Contudo, poucas abordagens contemplam o desenvolvimento 
de serviços neste domínio $[33,36]$. Além disto, as abordagens definidas no domínio biomédico fazem uso, em geral, de um conjunto de tecnologias distinto do considerado neste trabalho. Neste sentido, selecionamos também abordagens de desenvolvimento definidas de forma independente de domínio. Dentre as abordagens independentes de domínio, consideramos apenas aquelas que fornecem suporte à criação de serviços RESTful a partir de ferramentas de software existentes e/ou à anotação semântica de serviços com o uso da abordagem SAWSDL.

\section{Semantic Automated Discovery and Integration (SADI)}

No domínio biomédico, o projeto Semantic Automated Discovery and Integration (SADI) [33] fornece um conjunto de diretrizes que devem ser adotadas para o desenvolvimento de serviços web semânticos, bem como um conjunto de ferramentas de suporte que facilitam a criação e descoberta de serviços. A abordagem de desenvolvimento fornecida pelo projeto SADI tem sido crescentemente utilizada para a criação de serviços de análise no domínio [243-245]. Contudo, o projeto SADI fornece suporte apenas ao desenvolvimento de serviços atômicos (única operação) e que não mantenham estado. Além disto, este projeto possui como foco a criação de novos serviços, não fornecendo mecanismos para a adaptação de ferramentas de software já existentes.

Na abordagem SADI, a descrição de um serviço pode ser, em princípio, especificada em qualquer linguagem. Contudo, os serviços SADI são geralmente descritos em documentos RDF estruturados a partir da classe serviceDescription da ontologia MOBY-Mygrid Service Ontology [246]. Além disto, a anotação semântica da descrição de um serviço pode ser realizada com o uso de qualquer ontologia OWL. De acordo com as recomendações fornecidas pelo projeto SADI, todos os dados consumidos e produzidos pelo serviço devem ser instâncias RDF de classes OWL Description Logic (OWL-DL) especificadas na descrição do serviço. Além disto, o URI utilizado para identificar uma instância RDF representando uma saída do serviço deve ser o mesmo utilizado para identificar sua instância RDF de entrada na descrição do serviço, garantindo que os dados produzidos pelo serviço sejam explicitamente relacionados aos dados consumidos por este serviço. Finalmente, o acesso a serviços SADI deve ser realizado apenas por meio dos métodos HTTP GET e POST. Quando um serviço SADI é invocado via método 
GET, a especificação da descrição do serviço deve ser retornada pelo serviço. As funcionalidades de um serviço SADI devem ser acessadas apenas por meio do método POST. Este método é utilizado para o envio de instâncias RDF representando os dados a serem consumidos por um serviço. Quando o serviço recebe os dados de entrada, o mesmo realiza o processamento necessário e retorna as instâncias RDF dos dados produzidos a partir do processamento.

De modo a permitir a criação (semi) automática de serviços web semânticos de acordo com o conjunto de diretrizes apresentado, o projeto SADI fornece um plugin para o editor de ontologias Protégé [191], o qual permite integrar um ambiente de desenvolvimento ao editor. Neste ambiente, um provedor de serviços pode definir uma ontologia para descrever os dados produzidos e consumidos pelo seu serviço e, a partir desta definição, o código-base do serviço pode ser automaticamente gerado.

\section{Extração de modelos REST a partir de serviços orientados a procedimentos}

De forma independente de domínio, Athanasopoulos e Kontogiannis [247] definem um processo dirigido por modelos que permite a criação de serviços RESTful a partir de serviços existentes definidos com base no modelo de interação Remote Procedure Call (RPC), tais como serviços SOAP. Na abordagem proposta, as informações especificadas na descrição WSDL de um serviço são mapeadas para um modelo inicial que descreve as operações do serviço de maneira independente de sintaxe. Este modelo é gradualmente transformado, com o uso de técnicas de processamento de linguagem natural e análise de grafos, de modo a produzir um modelo final, chamado Modelo de Tipos de Recursos. Este modelo fornece a hierarquia de recursos que serão disponibilizados pela interface REST do serviço. Além disto, cada recurso REST apresentado no modelo está associado a uma ou mais operações CRUD (CREATE, READ, UPDATE, DELETE), as quais podem ser diretamente mapeadas para métodos HTTP correspondentes, de modo a permitir o acesso ao recurso na interface REST do serviço. A partir do modelo de Tipos de Recursos, uma descrição WADL do serviço pode ser automaticamente gerada. Finalmente, a partir da descrição WADL, o código-base para o serviço pode ser subsequentemente gerado. Contudo, o trabalho não detalha o processo de geração da descrição WADL e do código-base. 


\section{Adaptação de sistemas web legados com base no metamodelo MIGRARIA}

Echeverria et al. [248] definem um processo dirigido por modelos para a adaptação semiautomática de aplicações web como serviços web RESTful. Este processo tem como objetivo permitir o desenvolvimento de um serviço (adaptador) que forneça uma interface REST para acessar um conjunto de funcionalidades da aplicação web que se deseja adaptar. Inicialmente, um modelo conceitual da aplicação web é automaticamente gerado com o uso de técnicas de engenharia reversa. Este modelo conceitual baseia-se no metamodelo MIGRARIA [249]. A partir do modelo criado, o comportamento do serviço RESTful pode ser gradualmente especificado em cinco etapas. Na primeira etapa, os recursos REST que podem ser fornecidos pela interface do serviço são automaticamente identificados a partir do modelo conceitual da aplicação web. Na segunda etapa, os URIs utilizados para identificar os recursos REST são automaticamente gerados. O refinamento destes URIS, por exemplo para a inclusão de parâmetros adicionais, deve ser realizado de forma manual. Na terceira etapa, os tipos de ações (ex: criação, remoção, edição) que podem ser realizadas nos recursos REST são automaticamente identificados a partir do modelo conceitual da aplicação sendo adaptada. Na quarta etapa, estas ações são mapeadas para os métodos HTTP correspondentes (GET, PUT, POST ou DELETE), os quais serão utilizados para acessar cada recurso REST. Finalmente, na quinta etapa, se algum mapeamento for necessário entre os formatos de dados compartilhados entre o serviço adaptador e a aplicação adaptada, o mesmo deve ser manualmente codificado no serviço.

\section{Migração de sistemas legados para arquiteturas de serviços}

Oldevik et al. [34] apresentam uma abordagem dirigida por modelos para a especificação e geração automática de serviços web SOAP ou RESTful a partir de ferramentas de software existentes. Neste trabalho, os detalhes da arquitetura de integração de um serviço com os recursos computacionais que serão adaptados pelo mesmo são modelados por meio de classes e interfaces na linguagem Unified Modeling Language (UML) [250]. Esta etapa de modelagem é auxiliada por um perfil UML que fornece elementos de modelagem específicos para a representação de ferramentas de software executáveis, bases de dados, bibliotecas nativas e serviços, 
dentre outros. Os aspectos comportamentais do serviço e dos recursos computacionais adaptados são modelados por meio de diagramas de atividades UML. Adicionalmente, os autores fornecem um conjunto de geradores de código que permitem a criação automática de serviços web (adaptadores) a partir dos diagramas de atividades UML previamente especificados.

\section{Processo de desenvolvimento de serviços RESTful dirigido por modelos}

Laitkorpi et al. [251] definem um processo dirigido por modelos para o desenvolvimento de serviços web RESTful. Este processo pode ser utilizado tanto para a criação de novos serviços quanto para a adaptação de ferramentas de software existentes. Na primeira etapa do processo, os requisitos do serviço a ser desenvolvido devem ser especificados por meio de casos de uso e de diagramas de sequência UML de modo a produzir uma especificação funcional do serviço. A especificação funcional do serviço é então transformada em modelos conceituais que capturam os conceitos e relacionamentos necessários para a representação de todas as interações entre o serviço e uma potencial aplicação-cliente. Na etapa final do processo, uma descrição do serviço na linguagem WADL é gerada a partir dos modelos conceituais previamente produzidos. A geração do código do serviço a partir de sua descrição WADL não é abordada pelos autores.

\section{Reengenharia de sistemas legados como serviços RESTful}

Liu et al. [252] definem um processo para a reengenharia de sistemas orientados a dados ou entidades de modo a disponibilizar suas funcionalidades por meio de serviços web RESTful. Neste processo, os recursos de dados/entidades que podem, potencialmente, ser representados como recursos REST são inicialmente identificados por meio da análise do sistema a ser adaptado. Esta etapa de análise consiste no estudo da documentação (modelos) associada ao sistema. $\mathrm{Na}$ segunda etapa do processo, diferentes regras de mapeamento são utilizadas para gerar URIs utilizados para identificar os recursos de dados/entidades. Na terceira etapa, os URIs produzidos são refinados por meio da análise do código-fonte do sistema. Esta etapa inclui também a identificação dos métodos HTTP que podem ser aplicados sobre os URIs produzidos. Finalmente, a 
última etapa do processo consiste na geração automática de interfaces RESTful que fornecem acesso às funcionalidades do sistema sendo adaptado.

Anotação semântica de serviços baseada em uma ontologia multi-domínios

Yadav e Patel [253] descrevem uma abordagem automática para a anotação semântica de serviços de acordo com a abordagem SAWSDL, especificamente com o uso do atributo de extensão modelReference. A abordagem proposta faz uso de conceitos da ontologia multi-domínios DBpedia [254] para a anotação semântica dos serviços. A anotação semântica de um serviço é realizada em três etapas. A primeira etapa consiste na extração de um conjunto de termos utilizados para descrever as operações do serviço, bem como as entradas e saídas de cada operação na descrição WSDL do serviço. Este conjunto de termos é obtido a partir do processamento sintático dos nomes atribuídos aos elementos WSDL Service, Operation, Input e Output. A segunda etapa consiste na realização de inferências na ontologia DBpedia de modo a identificar um conjunto de conceitos da ontologia associados ao conjunto de termos previamente identificado. Finalmente, na terceira etapa, os conceitos da ontologia DBpedia previamente identificados são associados, de forma automática, aos elementos WSDL Operation, Input e Output correspondentes por meio do atributo de extensão SAWSDL modelReference.

Anotação semântica de serviços baseada em um perfil UML

Belouadha et al. [35] apresentam uma abordagem dirigida por modelos para a anotação semântica de serviços web de acordo com a abordagem SAWSDL. Neste trabalho, um serviço web pode ser modelado com o uso de um perfil UML independente da linguagem SAWSDL. Este perfil permite a especificação das interfaces do serviço, suas operações, parâmetros, bem como a associação de conceitos definidos em ontologias. Uma vez que o modelo da interface do serviço é desenvolvido, cada elemento do perfil é mapeado, de forma automática, para uma metaclasse do metamodelo SAWSDL por meio de diferentes regras de transformação pré-definidas. Finalmente, uma descrição WSDL 2.0 do serviço anotada com os atributos de extensão SAWSDL é gerada de forma automática a partir do metamodelo SAWSDL. 
Gordon et al. [37] descrevem uma aplicação real da abordagem SAWSDL no contexto do projeto BioMOBY [255], que tem como objetivo facilitar a interoperabilidade entre ferramentas e/ou bases de dados biológicas. Neste trabalho, os autores apresentam um estudo de caso que ilustra a anotação semântica de um serviço web que permite a análise funcional de genes por meio da base de dados KEGG. Por meio deste estudo de caso, os autores fornecem diretrizes concretas para a anotação semântica de serviços web desenvolvidos de acordo com a arquitetura BioMOBY. Além disto, um sistema de software que permite a anotação semi-automática de descrições de serviços na linguagem WSDL 1.1 com os atributos de extensão da abordagem SAWSDL é apresentado.

\section{Anotação semântica de serviços baseada em ontologias esquemáticas}

Zhang et al. [256] apresentam um método semi-automático para a anotação semântica de elementos XML contidos em documentos WSDL 1.1 de acordo com a abordagem SAWSDL. Neste método, os elementos XML são inicialmente mapeados para conceitos de uma ontologia esquemática na linguagem OWL com base em algumas regras de transformação pré-definidas. Esta ontologia reflete a estrutura dos elementos XML definidos no documento WSDL. Uma vez que a ontologia esquemática é construída, um algoritmo específico é utilizado para calcular a similaridade semântica entre os conceitos desta ontologia e os conceitos contidos em ontologias de domínio. Os conceitos das ontologias de domínio considerados mais relevantes de acordo com o algoritmo, ou seja, com maior grau de similaridade, são utilizados para anotar os respectivos elementos XML com o uso do atributo de extensão modelReference.

\subsection{ABORDAGENS PARA COMPOSIÇÃO DE SERVIÇOS WEB SEMÂNTICOS}

Um número crescente de serviços web semânticos tem sido disponibilizado no domínio biomédico. Estes serviços podem ser individualmente utilizados para a realização de atividades de análise isoladas. Contudo, os estudos realizados no domínio frequentemente envolvem a 
realização de um conjunto de atividades de análise e, consequentemente, o uso integrado de diferentes serviços. Neste contexto, de modo a facilitar a criação de processos de análise integrados, diferentes abordagens têm sido propostas para a composição (semi) automática de serviços web semânticos no domínio biomédico. Dentre as abordagens existentes, algumas fornecem suporte apenas a algumas etapas do processo de composição, como por exemplo a descoberta de serviços, enquanto outras fornecem uma solução completa para o problema de composição semântica de serviços web, considerando todas as etapas envolvidas no processo. As seções a seguir apresentam as principais abordagens de composição consideradas relevantes no contexto deste trabalho.

\section{Plataforma de integração Galaxy}

A plataforma web Galaxy [16,257] foi desenvolvida para fornecer suporte à integração de ferramentas de software no domínio biomédico e tem sido crescentemente utilizada para a realização de diferentes estudos genômicos [258-261]. Esta plataforma fornece um conjunto (extensível) de ferramentas de software que permitem o acesso e a análise de dados provenientes de diferentes bases de dados. Por meio uma interface gráfica web, estas ferramentas individuais podem ser integradas para a criação de um workflow (pipeline) de análise. Durante a criação de um workflow de análise, as ferramentas de interesse podem ser manualmente interligadas pelo usuário, associando-se as saídas produzidas por cada ferramenta às entradas exigidas por outras ferramentas definidas na sequência. Após a criação de um workflow, a plataforma fornece suporte à execução integrada das ferramentas, transferindo automaticamente os dados entre as mesmas.

Embora a plataforma Galaxy facilite a integração sintática de ferramentas no domínio, nenhum suporte é fornecido à integração do ponto de vista semântico. Além disto, a plataforma fornece suporte apenas à inclusão e execução de ferramentas localmente executadas. Neste contexto, de modo a fornecer suporte semi-automático à inclusão, descoberta e composição de serviços web semânticos, Dhamanaskar et. al [40] apresentam uma extensão (plugin) à plataforma Galaxy. Esta extensão fornece um mecanismo para a inclusão de serviços SOAP/REST na plataforma. De modo a incluir um serviço, um usuário deve fornecer a localização (URI) da descrição WSDL/WADL do serviço semanticamente anotado e selecionar as operações do 
serviço que deseja disponibilizar na plataforma. A partir da descrição do serviço, o código necessário para invocar as operações de serviço selecionadas é automaticamente gerado e encapsulado em um programa que pode ser diretamente invocado pela plataforma.

Adicionalmente, a extensão proposta à plataforma Galaxy fornece um mecanismo de descoberta semântica de serviços que auxilia os usuários durante o processo de criação de um workflow (composição), sugerindo serviços relevantes que podem ser incluídos a cada etapa do processo. As sugestões são computadas com base em um algoritmo que identifica, dentre os serviços disponíveis na plataforma, aqueles capazes de fornecer uma funcionalidade especificada pelo usuário por meio de um conceito (URL) de uma ontologia. Além disto, um algoritmo baseado em grafos é utilizado para calcular a compatibilidade semântica entre as saídas dos serviços previamente incluídos no workflow e as entradas de todos os serviços disponíveis na plataforma. Os serviços são classificados de acordo seu valor de similaridade semântica, calculado com base na similaridade entre as funcionalidades, bem como na similaridade entre as entradas e saídas dos serviços. O conjunto de serviços identificado é então apresentado ao usuário, que seleciona um dos serviços para inclusão no workflow. Após a inclusão do serviço, de modo a facilitar a interligação (composição) das suas entradas com as saídas de outros serviços já incluídos, os valores de compatibilidade semântica previamente obtidos são utilizados para fornecer sugestões ao usuário. Com base nestas sugestões, o usuário pode então manualmente interligar as entradas do novo serviço incluído no workflow com as saídas de outros serviços previamente incluídos (composição forward). Suporte à composição backward de serviços também é fornecido.

\section{Plataforma de integração Taverna}

A plataforma Taverna [262] fornece um ambiente de suporte à integração de ferramentas de software locais e remotas, incluindo serviços web SOAP/REST, no domínio biomédico. Esta plataforma fornece uma interface gráfica de usuário que permite a criação e execução de workflows (pipelines) de análise definidos por meio da interligação de múltiplas ferramentas de análise (locais e/ou remotas). De modo a facilitar a criação de workflows de análise, esta plataforma oferece um mecanismo automático para a descoberta (sintática) de ferramentas de interesse. Uma vez que uma ferramenta é incluída no workflow, as entradas/saídas da mesma podem ser 
manualmente interligadas às entradas/saídas de outras ferramentas sintaticamente compatíveis que tenham sido previamente incluídas no workflow. No entanto, nenhum suporte é fornecido à descoberta e integração semântica de ferramentas (serviços).

Withers et. al [42] definem duas extensões à plataforma Taverna que fornecem suporte à descoberta semântica de serviços: os plugins BioMoby e SADI. Estas duas extensões fornecem mecanismos para auxiliar os usuários durante a definição de um workflow de análise no ambiente Taverna sugerindo, de forma iterativa, serviços que sejam capazes de consumir os dados produzidos por outros serviços previamente incluídos no workflow. A descoberta de serviços é realizada apenas com base na compatibilidade semântica entre as entradas e saídas dos serviços, não considerando de forma explícita a funcionalidade fornecida por cada serviço. O uso dos plugins BioMoby e SADI facilita a identificação de serviços semanticamente compatíveis na plataforma Taverna, garantindo assim que os serviços (manualmente) interligados pelo usuário sejam compatíveis.

\section{Plataforma de composição baseada em sugestões}

Ba et. al [263] definem, de maneira formal, uma abordagem semi-automática para a composição de serviços web semânticos. A abordagem proposta é independente de domínio e tem como objetivo guiar os usuários a cada etapa do processo de definição de um workflow de análise (composição), fornecendo sugestões de serviços relevantes e realizando a interligação automática dos serviços selecionados pelo usuário. A interligação dos serviços pode ser realizada de acordo com as abordagens forward ou backward. Adicionalmente, os autores apresentam um protótipo definido para implementar a abordagem de composição de serviços proposta. Este protótipo é utilizado para a realização de um estudo de caso que envolve a análise de dados genômicos com o uso de um conjunto de serviços provenientes do projeto European Molecular Biology Open Software Suite (EMBOSS) [264].

$\mathrm{Na}$ abordagem proposta, durante a criação de um workflow de análise, a inclusão de cada serviço é realizada em três etapas. Na primeira etapa, o usuário seleciona os pontos do workflow que deseja estender, ou seja, um conjunto de entradas/saídas de um ou mais serviços incluídos no workflow que deverão ser interligadas a um novo serviço (extensão). Na segunda etapa, 
a descoberta de serviços de interesse é realizada por meio da identificação de serviços que produzam dados (semanticamente) compatíveis com todas as entradas selecionadas pelo usuário e que consumam dados compatíveis com todas as saídas selecionadas. Uma vez que todas as entradas/saídas são consideradas no processo de descoberta de serviços, quanto maior for o conjunto de entradas/saídas selecionadas, menor será o número de serviços identificados e subsequentemente sugeridos aos usuários. Além disto, os serviços são identificados nesta etapa de modo que duas propriedades sejam satisfeitas: (i) a inserção e posterior interligação de um novo serviço com os outros serviços previamente incluídos no workflow não deve criar um ciclo, ou seja, os dados consumidos por um serviço $S_{x}$ não podem ser produzidos por um serviço $S_{y}$ cujos dados de entrada sejam fornecidos pela saída de $S_{x}$, tal que $x \neq y$; e (ii) cada entrada de cada serviço $S_{x}$ definido no workflow deve ser interligada a, no máximo, uma saída de um serviço $S_{y}$, tal que $x \neq y$. Finalmente, na terceira etapa, os serviços identificados são apresentados ao usuário, que seleciona um dos serviços sugeridos para estender o workflow. $\mathrm{O}$ serviço selecionado é então incluído no workflow e suas entradas/saídas são automaticamente interligadas às entradas/saídas dos serviços correspondentes no workflow. Embora o workflow de análise só possa ser executado quando as entradas de cada serviço definido no workflow tiverem sido interligadas a algum conjunto de dados (ex: saída de outro serviço), a execução do workflow não é abordada em detalhes no trabalho.

\section{Plataforma de composição Sesame}

A plataforma Sesame [39] foi desenvolvida para fornecer suporte semi-automático à descoberta e composição de serviços web semânticos no domínio da bioinformática. Nesta plataforma, a criação de uma composição de serviços é realizada em duas etapas. A primeira etapa consiste na especificação de um workflow semântico, ou seja, um conjunto ordenado de atividades de análise que um usuário deseja realizar e de tipos de dados que um usuário deseja processar e/ou produzir. Estas atividades de análise e tipos de dados são especificados com base em conceitos de uma ontologia. A segunda etapa consiste na especificação de um workflow executável, o qual é derivado a partir do workflow semântico por meio da associação de serviços concretos às atividades de análise previamente definidas. 
Na plataforma Sesame, a especificação de um workflow semântico é realizada de maneira iterativa. Inicialmente, o usuário especifica os tipos de dados que deseja processar por meio de conceitos de uma ontologia OWL chamada Ontology for Bioinformatics Tools and Services (OBTS). Em seguida, a plataforma realiza inferências nesta ontologia de modo a identificar conceitos representando atividades de análise que possam ser, potencialmente, realizadas nos tipos de dados especificados. As atividades de análise identificadas são apresentadas ao usuário, que deve selecionar uma das atividades para inclusão no workflow. Em seguida, a plataforma realiza inferências na ontologia OBTS de modo identificar os tipos de dados produzidos pela atividade de análise previamente selecionada. Caso os tipos de dados produzidos por esta atividade não sejam o resultado esperado pelo usuário, o usuário pode continuar incluindo atividades de análise de maneira iterativa. Caso contrário, a especificação do workflow pode ser finalizada. Uma vez que o workflow semântico é completamente especificado pelo usuário, a plataforma sugere um conjunto de serviços adequado para cada atividade de análise definida no workflow. A descoberta de serviços adequados é realizada com base na similaridade semântica entre os conceitos da ontologia OBTS utilizados para especificar as atividades de análise do workflow e as funcionalidades dos serviços. Após a descoberta dos serviços relevantes pela plataforma, o usuário deve associar um dos serviços sugeridos a cada atividade de análise, de modo a especificar um workflow concreto que pode ser finalmente executado.

\section{Plataforma de composição Bio-jETI}

A plataforma Bio-jETI [38,265] fornece suporte automático à modelagem, execução e gerenciamento de workflows de análise no domínio biomédico. Esta plataforma baseia-se no framework Java Application Building Center (jABC) [266], que fornece uma interface gráfica para a construção de workflows, representados como grafos Service Logic Graphs (SLGs). No framework jABC, um grafo SLG consiste em um conjunto interligado de ferramentas de software, representadas como Service Independent Building Blocks (SIBs). Os SIBs representam estruturas responsáveis pela invocação das ferramentas locais ou remotas, incluindo serviços web SOAP/REST, definidas no workflow. Os SIBs definidos em um workflow também podem representar 
estruturas de controle, tais como loops e condições, utilizadas para determinar a ordem de execução das ferramentas de software definidas no workflow.

$\mathrm{Na}$ plataforma Bio-jETI, a criação de uma composição de serviços é realizada, de forma automática, por meio de dois mecanismos de suporte: síntese e verificação de modelos. O mecanismo de síntese permite a criação de uma composição de serviços (SLG) a partir de uma especificação lógica na linguagem Semantic Linear Time Logic (SLTL). A especificação SLTL determina o conjunto de funcionalidades que um usuário deseja realizar e/ou os tipos de dados que deseja processar ou produzir, descritos por meio de conceitos de uma ou mais ontologias OWL. Com base na especificação SLTL, o mecanismo de síntese tenta identificar, de forma automática, uma sequência linear de serviços (composição) que satisfaça a especificação SLTL. A descoberta de serviços relevantes e a construção de uma composição baseia-se nas anotações semânticas atribuídas às funcionalidades e às entradas/saídas dos serviços por meio de conceitos definidos em uma ou mais ontologias. Uma vez que uma composição de serviços é identificada, o mecanismo de verificação é então utilizado para avaliar as propriedades estáticas da composição, definidas na linguagem Computation Tree Logic (CTL), de modo a detectar problemas no modelo de composição. Estes problemas podem incluir, por exemplo, identificadores de dados indefinidos ou incompatibilidades entre as entradas/saídas de serviços subsequentes na cadeia de composição. Em geral, a resolução desses problemas exige a introdução de passos de processamento adicionais, tais como serviços de conversão no caso de tipos de dados incompatíveis. Assim, quando um problema é detectado na composição, o mecanismo de síntese pode ser novamente utilizado, por exemplo, para identificar uma sequência complementar de serviços. Uma vez que uma composição de serviços (workflow de análise) é completamente especificada na plataforma Bio-jETI, todos os serviços definidos na composição podem ser sequencialmente executados, de forma automática, sem a intervenção do usuário. Cada serviço também pode ser individualmente executado pelo usuário.

\section{Plataforma de composição jORCA}

A plataforma jORCA [41] fornece suporte automático à definição e execução de composições de serviços web (semânticos) no domínio da bioinformática. Esta plataforma é estruturada em 
diferentes componentes independentes. Um conjunto (extensível) de componentes, chamados de accesses, permitem a extração de serviços web a partir de diferentes repositórios de serviços, tais como BioMoby [267] e European Bioinformatics Institute (EBI) [268]. Estes componentes são responsáveis por extrair e mapear os serviços para outro componente, chamado Modular API (MAPI) [269], que fornece uma representação uniforme dos serviços obtidos a partir de diferentes repositórios. Conjuntamente, os componentes MAPI e acesses fornecem o suporte necessário na plataforma jORCA para o acesso a serviços desenvolvidos com base em diferentes tecnologias, incluindo por exemplo serviços BioMoby e serviços baseados na linguagem WSDL. Finalmente, o componente Magallanes [270] fornece suporte à descoberta e composição semântica de serviços web.

Na plataforma jORCA, uma composição de serviços pode ser automaticamente definida com o uso de um algoritmo de composição implementado pelo componente Magallanes. Inicialmente, o usuário especifica a semântica dos tipos de dados que deseja processar e produzir. Os tipos de dados disponíveis podem ser identificados com o suporte do componente Magallanes, que permite a realização de buscas textuais em uma hierarquia semântica de tipos de dados. Uma vez que a semântica dos dados de entrada e de saída é especificada pelo usuário, o algoritmo de composição inicialmente identifica um serviço capaz de processar o tipo de dado de entrada especificado. Seguindo uma abordagem de composição forward, os demais serviços são iterativamente incluídos na composição com base na similaridade semântica entre o tipo de dado de saída do último serviço incluído na cadeia de composição e o tipo de dado de entrada do próximo serviço a ser incluído. O algoritmo de composição é finalizado quando o tipo de dado de saída especificado pelo usuário pode ser produzido por um serviço definido na cadeia de composição (último serviço). Um algoritmo de poda em profundidade é então utilizado para identificar a menor sequência de serviços capaz de processar os tipos de dados de entrada e saída especificados.

A composição de serviços construída pode conter caminhos de execução alternativos. Neste contexto, caso mais de um serviço possa ser utilizado para processar um mesmo tipo de dado, o usuário deve selecionar apenas um dos serviços disponíveis. A seleção de um serviço pode ser realizada com base nas descrições textuais das funcionalidades fornecidas pelos serviços disponíveis. Além disto, apenas uma solução parcial pode ser encontrada pelo algoritmo de 
composição, ou seja, pode haver uma lacuna entre um serviço que produz um determinado tipo de dado e um serviço posterior na cadeia de composição que processa outro tipo de dado. Neste caso, o usuário deve buscar manualmente por serviços capazes de preencher esta lacuna.

Após a especificação completa de uma cadeia de composição, o usuário pode então fornecer os dados de entrada do primeiro serviço definido na cadeia e iniciar sua execução. Os serviços definidos na cadeia de composição são então sequencialmente executados e os resultados intermediários obtidos por cada serviço são armazenados. Os resultados podem ser acessados após o fim da execução de toda a cadeia de composição. 


\section{4}

METODOLOGIA PARA DESENVOLVIMENTO DE SERVIÇOS WEB SEMÂNTICOS

Este capítulo apresenta uma metodologia que definimos para o desenvolvimento de serviços web semânticos [271]. A metodologia proposta tem como objetivo fornecer uma abordagem sistemática tanto para o desenvolvimento de serviços web RESTful quanto para a anotação semântica das descrições dos serviços de acordo com a abordagem SAWSDL, considerando aspectos técnicos relacionados à implementação e anotação semântica dos serviços. Adicionalmente, desenvolvemos um conjunto de ferramentas e artefatos de modelagem para fornecer suporte à aplicação da metodologia proposta no desenvolvimento de serviços web semânticos.

O restante deste capítulo está estruturado da seguinte forma: a Seção 4.1 apresenta uma visão geral da metodologia proposta para o desenvolvimento de serviços web semânticos; as Seções 4.2 à 4.6 apresentam, em detalhes, as atividades da metodologia; a Seção 4.7 apresenta o conjunto de ferramentas desenvolvido para fornecer suporte à aplicação da metodologia; a Seção 4.8 apresenta um perfil UML desenvolvido para a abordagem SAWSDL; finalmente, a Seção 4.9 apresenta as conclusões do capítulo.

\subsection{VIS ÃO GERAL}

No domínio biomédico, um número crescente de ferramentas de análise têm sido adaptadas para serviços web (semânticos) [7-11]. De modo a facilitar a adaptação destas ferramentas, o nosso 
objetivo é definir uma metodologia que permita a criação sistemática de serviços web semânticos a partir de ferramentas de software existentes. A adaptação destas ferramentas de análise como serviços tem como objetivo facilitar a posterior integração (composição) de ferramentas (serviços) e dados no domínio.

A metodologia proposta para o desenvolvimento de serviços web semânticos consiste na realização de diferentes atividades. A Figura 18 apresenta as atividades da metodologia e os artefatos produzidos em cada atividade. Os retângulos com preenchimento azul representam as atividades da metodologia, enquanto os retângulos com abas e preenchimento branco representam os artefatos produzidos pelas atividades.

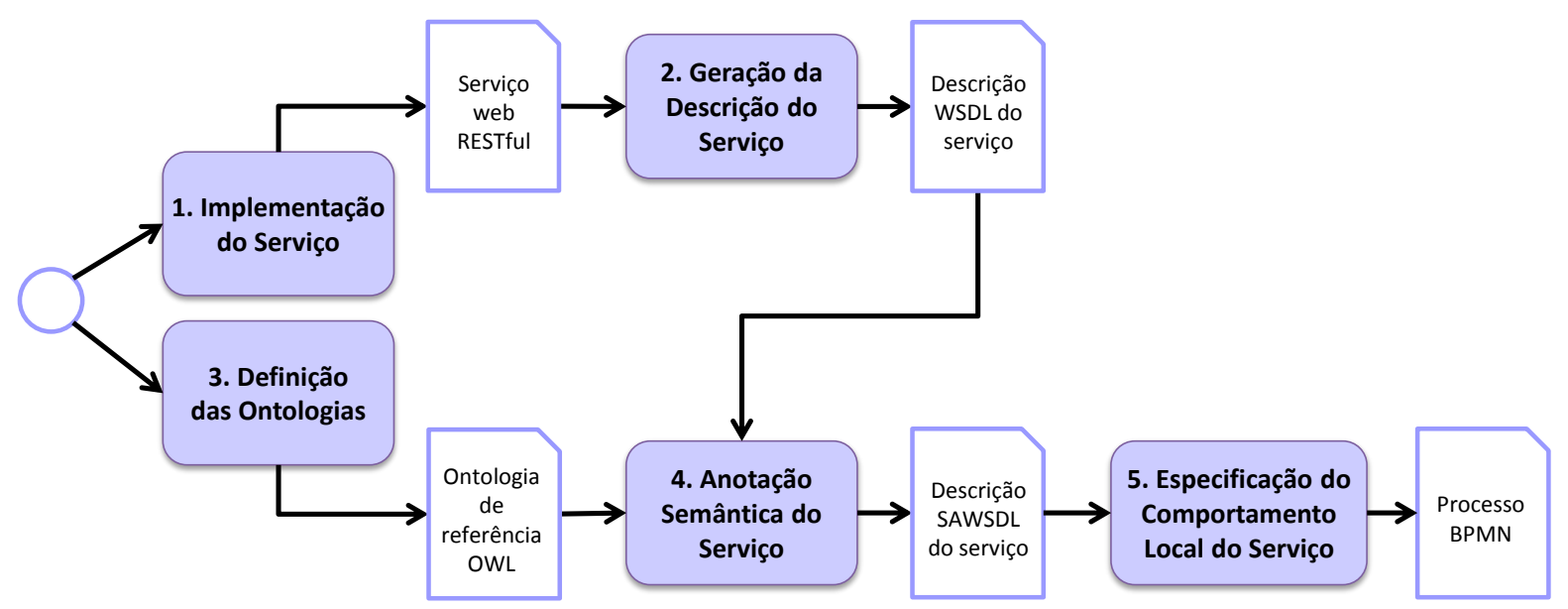

Figura 18: Metodologia proposta para a criação de serviços web semânticos.

A primeira atividade consiste na implementação de um serviço web RESTful a partir de uma ferramenta de software existente. A segunda atividade consiste na geração automática de uma descrição do serviço na linguagem WSDL a partir da implementação do serviço. A terceira atividade consiste na definição de ontologias de domínio e de serviços para suporte à anotação semântica do serviço. Esta atividade pode ser realizada em paralelo com a primeira e segunda atividades da metodologia. Além disto, consideramos que a definição das ontologias é realizada apenas quando estas ontologias não estão disponíveis. A quarta atividade consiste na anotação semântica da descrição WSDL do serviço de acordo com a abordagem SAWSDL. A anotação semântica do serviço faz uso das ontologias definidas na etapa anterior. A quinta e última atividade consiste na especificação do comportamento local do serviço por meio da criação semi-automática de um processo executável na linguagem Business Process Model and 
Notation (BPMN) [272] a partir da descrição WSDL do serviço semanticamente anotada. Cada uma destas atividades é discutida, em detalhes, a seguir.

\subsection{IMPLEMENTAÇÃO DO SERVIÇO}

O principal objetivo desta atividade é criar um serviço web RESTful a partir de uma ferramenta de software existente por meio da implementação de um adaptador (wrapper) para acessar as funcionalidades da ferramenta. De modo geral, adaptadores podem ser utilizados para adaptar as interfaces (incompatíveis) de diferentes ferramentas de software, de modo a permitir a interoperação das mesmas. No contexto deste trabalho, o objetivo do desenvolvimento de um adaptador para uma ferramenta de software existente é disponibilizar um conjunto de funcionalidades desta ferramenta como um serviço web, sem modificar a implementação da ferramenta.

A criação de adaptadores pode ser realizada de acordo com um padrão de projeto bem definido, chamado de Adapter [273]. Na engenharia de software, um padrão de projeto representa uma solução genérica que pode ser aplicada na resolução de um determinado tipo de problema recorrente no desenvolvimento de sistemas de software. Um padrão de projeto fornece, de forma abstrata, uma descrição dos componentes e das interações entre os componentes de um sistema de software. Esta descrição pode então ser utilizada para guiar o desenvolvimento de um determinado sistema de software.

De modo geral, o padrão de projeto Adapter pode ser utilizado em situações em que a interface de uma ferramenta de software precisa ser modificada, de modo a tornar a ferramenta interoperável em um contexto específico, mas mantendo a implementação da mesma inalterada. Este padrão define quatro componentes básicos e os relacionamentos entre eles em um sistema de software. Uma aplicação cliente (componente client) deve se comunicar com outra ferramenta de software (componente adaptee). O adaptador (componente adapter) fornece uma interface modificada (interface target) para o componente adaptee. Quando a aplicação cliente realiza uma requisição ao componente adaptee por meio da interface target, esta requisição é repassada ao adaptador, que realiza a chamada ao componente adaptee por meio de sua interface original. 
No processo de adaptação de uma ferramenta de software como um serviço web, um subconjunto das funcionalidades fornecidas pela ferramenta pode ser acessado por uma ou mais operações do serviço (adaptador). Algumas funcionalidades da ferramenta podem eventualmente ser desconsideradas pelo adaptador, ou seja, podem não ser utilizadas para fornecer o serviço pretendido. Além disto, operações adicionais, que não acessam diretamente a ferramenta de software, podem ser definidas como parte do serviço para permitir o acesso adequado à ferramenta. Por exemplo, uma operação adicional pode ser definida para gerenciar a execução de uma análise sendo realizada pela ferramenta ou para retornar o resultado de uma análise executada.

A Figura 19 apresenta, de forma genérica, a arquitetura de um serviço web implementado como um adaptador para uma ferramenta de software existente.

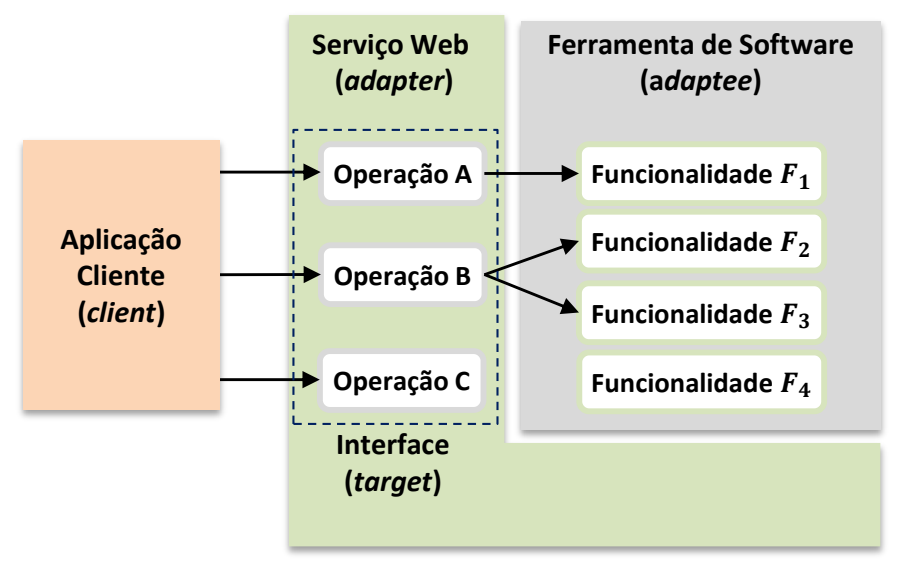

Figura 19: Arquitetura de um serviço web implementado como um adaptador.

Na Figura 19, a ferramenta de software adaptada fornece um conjunto de funcionalidades $F=\left\{F_{1}, F_{2}, F_{3}, F_{4}\right\}$ e o serviço adaptador fornece um conjunto de operações $S=\{A, B, C\}$. As operações $A$ e $B$ do serviço fornecem acesso a diferentes funcionalidades providas pela ferramenta de software. A operação $A$ provê acesso à funcionalidade $F_{1}$ da ferramenta, ao passo que a operação $B$ provê acesso às funcionalidades $F_{2}$ e $F_{3}$. Adicionalmente, a operação $C$ do serviço foi implementada independentemente da ferramenta sendo adaptada. A funcionalidade $F_{4}$ da ferramenta não é acessada pelo serviço.

De acordo com a nossa metodologia, a implementação de um serviço (adaptador) deve ser realizada segundo as seguintes etapas: (i) seleção das principais funcionalidades da ferramenta; 
(ii) definição do modelo de interação; (iii) implementação das operações do serviço; e (iv) teste do serviço. As seções a seguir apresentam, em detalhes, estas quatro etapas.

\section{Seleção das principais funcionalidades da ferramenta}

A ferramenta de software a ser adaptada pode fornecer diferentes funcionalidades. Esta etapa tem como objetivo identificar e selecionar um subconjunto destas funcionalidades para ser acessado pelo serviço adaptador. Uma especificação funcional da ferramenta listando suas principais funcionalidades $F_{1}, F_{2}, F_{3}, \ldots, F_{n}$ deve então ser criada. Esta lista provê uma melhor compreensão das funcionalidades fornecidas pela ferramenta e serve como uma base para a seleção das funcionalidades a serem acessadas pelo serviço.

\section{Definição do modelo de interação}

Uma vez que as principais funcionalidades da ferramenta de software foram identificadas, devese definir um modelo de interação que descreva o conjunto de interações entre o serviço sendo desenvolvido e a ferramenta de software, bem como entre o serviço e as potenciais aplicações cliente. A definição do modelo de interação pode ser realizada em duas etapas por meio da criação de casos de uso e de diagramas de sequência UML [250].

Na primeira etapa, a criação de casos de uso tem como objetivo capturar, de forma abstrata, informações relacionadas à execução das principais funcionalidades a serem fornecidas pelo serviço. Cada caso de uso deve descrever a sequência de interações necessárias entre as entidades externas (aplicação cliente e ferramenta de software sendo adaptada) e o serviço para a realização de um determinado objetivo. Durante a criação dos casos de uso, cada funcionalidade da ferramenta de software selecionada na etapa anterior deve ser associada a pelo menos um caso de uso.

Os casos de uso do serviço podem ser especificados por meio de um diagrama de casos de uso UML. Um diagrama de casos de uso UML fornece uma visão geral dos casos de uso de um sistema, das entidades externas (atores) associadas aos casos de uso e dos relacionamentos entre 
eles. Adicionalmente, uma especificação detalhada de cada caso de uso pode ser fornecida para complementar as informações apresentadas no diagrama.

A especificação detalhada de um caso de uso consiste na descrição textual dos principais aspectos associados ao caso de uso. A Figura 20 apresenta um modelo para a representação textual de um caso de uso. Neste modelo, deve-se especificar o nome, os atores, o objetivo e uma descrição geral do caso de uso. Além disto, é preciso especificar a sequência típica (usual) de eventos associada ao caso de uso. Esta sequência é definida com base na descrição numerada das ações realizadas pelos atores do caso de uso e das ações realizadas pelo sistema (serviço) em resposta às ações dos atores. Adicionalmente, sequências alternativas de eventos podem ser definidas de modo a descrever eventos que ocorrem apenas em situações específicas.

\begin{tabular}{|c|c|c|}
\hline \multicolumn{3}{|c|}{ Caso de Uso: < nome do caso de uso> } \\
\hline Atores & \multicolumn{2}{|c|}{$<$ atores associados ao caso de uso> } \\
\hline Objetivo & \multicolumn{2}{|c|}{$<$ objetivo do caso de uso> } \\
\hline Visão Geral & \multicolumn{2}{|c|}{ <descrição geral do caso de uso> } \\
\hline \multicolumn{3}{|c|}{ Sequência Típica de Eventos } \\
\hline \multicolumn{2}{|c|}{ Ação do Ator } & Resposta do Serviço \\
\hline \multicolumn{2}{|c|}{ 1. <ação do ator> } & 2. <resposta do serviço> \\
\hline \multicolumn{2}{|c|}{ 3. <ação do ator> } & 4. <resposta do serviço> \\
\hline \multicolumn{2}{|c|}{ 5. <ação do ator> } & 6. <resposta do serviço> \\
\hline
\end{tabular}

\section{Figura 20: Modelo para especificação detalhada de um caso de uso.}

$\mathrm{Na}$ segunda etapa da definição de um modelo de interação, deve-se criar um conjunto de diagramas de sequência UML a partir dos casos de uso previamente definidos. A criação de diagramas de sequência tem como objetivo capturar, de forma mais concreta, o conjunto de interações que ocorrem entre o serviço sendo desenvolvido e as entidades externas, ou seja, a ferramenta de software sendo adaptada e potenciais aplicações cliente.

Um diagrama de sequência UML fornece uma visão geral das entidades externas (atores) que interagem diretamente com o serviço, das mensagens trocadas entre estas entidades e o serviço, e da sequência temporal das trocas de mensagens. A identificação do conjunto de mensagens trocadas entre o serviço e as entidades externas permite definir o conjunto de operações que devem ser fornecidas pelo serviço. 
Durante esta etapa, pelo menos um diagrama de sequência deve ser criado para cada sequência típica (normal) de eventos de cada caso de uso previamente definido. Cada diagrama de sequência deve representar o serviço, a ferramenta de software sendo adaptada e a aplicação cliente. Além disto, cada evento definido na sequência típica de eventos deve ser mapeado para uma mensagem no diagrama de sequência. A ordem temporal das trocas de mensagens no diagrama de sequência deve seguir a ordem de eventos definida no caso de uso. Caso sequências alternativas de eventos tenham sido definidas em algum caso de uso, um diagrama de sequência pode ser criado para representar cada uma destas sequências.

Durante a definição do modelo de interação, deve-se levar em consideração que apenas quatro tipos básicos de operações podem ser definidos em serviços RESTful, geralmente chamadas de operações CRUD: CREATE, utilizada para a criação de um recurso no servidor; READ, utilizada para a recuperação de um recurso armazenado no servidor; UPDATE, utilizada para a atualização de um recurso previamente armazenado no servidor; e DELETE, utilizada para a remoção de um recurso previamente armazenado no servidor. Estes diferentes tipos de operações de serviço podem ser utilizados de forma isolada ou combinados na definição de um modelo de interação.

Adicionalmente, a característica "stateless" dos serviços web RESTful deve ser levada em consideração durante a definição do modelo de interação. De acordo com esta característica, cada mensagem de requisição enviada de uma aplicação cliente para um provedor de serviços deve conter todas as informações necessárias para que o provedor de serviços processe a requisição. Como consequência, se necessário, algum mecanismo deve ser utilizado para simular sessões de clientes. Um exemplo de tal mecanismo é o uso de um identificador que associe de forma exclusiva cada sessão de cliente virtual a um workspace (diretório no servidor), de modo que cada workspace seja acessível somente por meio de seu identificador exclusivo. Desta forma, cada workspace mantém todas as informações relacionadas a uma sessão de cliente, incluindo não apenas os dados enviados e processados, mas também o estado de execução das tarefas solicitadas.

Neste trabalho, sugerimos a definição de cinco tipos de operações de serviços de modo a permitir: (i) a geração de identificadores de workspace; (ii) o envio de arquivos a serem processados; (iii) o processamento dos dados; (iv) a verificação do estado de execução de um 
processamento; e (v) a recuperação dos arquivos resultantes de um processamento. Adicionalmente, operações auxiliares que não sejam diretamente necessárias para a execução do serviço podem ser definidas, por exemplo, para permitir a recuperação dos valores disponíveis para um determinado parâmetro.

Após a definição do modelo de interação, cada funcionalidade selecionada da ferramenta de software deve ter sido mapeada para pelo menos uma operação do serviço web. Alternativamente, mais de uma funcionalidade pode ter sido mapeada para uma única operação do serviço.

\section{Implementação das operações do serviço}

Uma vez que o modelo de interação foi definido, todas as operações do serviço definidas no modelo devem ser implementadas. No contexto deste trabalho, a implementação de operações de serviço é realizada com o uso da API Java API for RESTful Web Services (JAX-RS) [274]. A API JAX-RS fornece um conjunto de anotações Java que simplificam o desenvolvimento de serviços RESTful. Com o uso desta API, o desenvolvimento de serviços consiste na construção de um conjunto classes e na adição de anotações JAX-RS aos métodos destas classes.

O serviço RESTful deve ser implementado como uma classe Java e cada operação do serviço deve ser implementada como um método da classe que será responsável por realizar uma funcionalidade específica. Cada método Java deve encapsular todas as chamadas necessárias às funcionalidades da ferramenta de software sendo adaptada. Estas chamadas correspondem a um ou mais métodos da API da ferramenta. A comunicação entre o serviço RESTful e a ferramenta pode ser implementada com o uso da interface de programação Java Native Interface (JNI) [275], a qual permite a comunicação de aplicações Java com aplicações e bibliotecas implementadas em outras linguagens de programação.

Uma vez que as operações do serviço tenham sido implementadas, cada operação deve ser mapeada de forma explícita para um método HTTP correspondente. Operações dos tipos $C R E$ ATE, READ, UPDATE e DELETE devem ser mapeadas respectivamente para os métodos POST, GET, PUT e DELETE do protocolo HTTP. Este mapeamento pode ser realizado por meio das anotações@POST, @GET, @PUT e @DELETE fornecidas pela API JAX-RS. 
De acordo com o modelo REST, qualquer interação com um serviço web RESTful destinase a acessar um recurso. Desta forma, cada serviço deve fornecer um conjunto de recursos web identificados de forma exclusiva por meio de URIs. A anotação @Path fornecida pela API JAX-RS permite a atribuição de URIs a recursos. Além disto, a API JAX-RS fornece diferentes anotações adicionais que podem, opcionalmente, ser associadas aos métodos Java implementados. Por exemplo, as anotações@PathParam e @QueryParam são utilizadas para extrair valores de parâmetros embutidos em URIs e convertê-los para parâmetros de métodos Java. Da mesma forma, as anotações @ Produces e @Consumes podem ser utilizadas para especificar os formatos das representações de recursos que um serviço é capaz de produzir e consumir, respectivamente.

\section{Teste do serviço}

Após a implementação do serviço web RESTful, este precisa ser testado. A etapa de teste tem como objetivos verificar se o comportamento do serviço foi corretamente implementado e corrigir possíveis erros de implementação. Nesta etapa, uma aplicação cliente (simples) deve ser implementada para interagir com o serviço desenvolvido de modo a testá-lo. Esta aplicação cliente pode ser criada, de forma semi-automática, com o uso da implementação de referência Jersey Reference Implementation of JAX-RS [276].

Durante esta etapa, todas as operações do serviço devem ser individualmente testadas de modo a verificar se o comportamento de cada operação foi corretamente implementado e se os resultados esperados são produzidos por cada operação. Uma vez que algumas operações do serviço acessam funcionalidades de uma ferramenta de software existente, o teste destas operações deve verificar se a comunicação com a ferramenta foi corretamente implementada. Além disto, os resultados produzidos por estas operações devem ser os mesmos obtidos quando o acesso às funcionalidades da ferramenta de software é realizado externamente ao serviço. Finalmente, após o teste individual das operações do serviço, pode-se conduzir um teste para cada uma das sequências de execução identificadas no modelo de interação do serviço. Estes testes têm como objetivo verificar se o comportamento integrado das operações do serviço foi corretamente implementado. 


\subsection{GERAÇÃO DA DESCRIÇÃO DO SERVIÇO}

O principal objetivo desta atividade é gerar, de forma automática, uma descrição do serviço na linguagem WSDL 2.0 a partir da implementação Java do serviço. De modo a realizar esta atividade, a ferramenta Java2WSDL fornecida como parte do projeto Apache Axis2/Java [277] pode ser utilizada. Esta ferramenta pode ser acessada por meio do plug-in Axis2 Code Generator para o ambiente de desenvolvimento Eclipse [228]. Opcionalmente, a funcionalidade fornecida pela ferramenta Java2WSDL pode ser acessada por meio de uma tarefa definida em um script Ant [278].

Uma vez que a linguagem WSDL 2.0 pode ser utilizada para a descrição de serviços web SOAP e RESTful, a descrição de serviço gerada pela ferramenta Java2WSDL possui três bindings: SOAP 1.1, SOAP 1.2 e HTTP. Dado que os bindings SOAP não são utilizados para o serviço RESTful desenvolvido, eles podem ser simplesmente ignorados. Os bindings SOAP e suas referências no documento WSDL gerado podem também ser removidos se o desenvolvedor quiser torná-lo mais claro. A remoção pode ser realizada de forma manual ou com o uso de um analisador sintático Java para a manipulação de documentos WSDL 2.0 fornecido como parte do projeto Apache Woden [279]. Este analisador também pode ser utilizado para validar a descrição de serviço WSDL 2.0 gerada.

\subsection{DEFINIÇÃO DAS ONTOLOGIAS}

O objetivo desta atividade é a definição de ontologias de domínio e de serviços, e a criação de referências cruzadas entre elas. Inicialmente, uma ontologia de domínio deve ser definida de modo a fornecer conceitos e relacionamentos para a descrição do domínio de conhecimento ao qual o serviço em desenvolvimento pertence. Uma vez que ontologias de domínio descrevem domínios de conhecimento bem estabelecidos, elas geralmente são estáveis e podem ser utilizadas no desenvolvimento de vários serviços pertencentes ao domínio. Durante esta atividade, deve-se inicialmente procurar por uma ontologia existente apropriada. No entanto, se nenhuma ontologia adequada for identificada, uma nova ontologia de domínio deve ser desenvolvida, preferencialmente fazendo o reuso de conceitos presentes em ontologias já existentes [280-282]. 
O desenvolvimento de ontologias é, em geral, realizado com o auxílio de um especialista do domínio [283].

Em seguida, uma ontologia de serviços deve ser definida de modo a fornecer conceitos e relacionamentos para a descrição das principais funcionalidades fornecidas pelo serviço em desenvolvimento, incluindo conceitos relacionados aos tipos de dados consumidos e produzidos pelo serviço. Consideramos que, em geral, ontologias de serviços são menos estáveis que ontologias de domínio uma vez que precisam frequentemente ser estendidas para incluir conceitos associados a novos serviços desenvolvidos em um mesmo domínio de conhecimento.

Finalmente, após a definição das ontologias de domínio e de serviços, referências cruzadas entre estas duas ontologias precisam ser criadas. Em geral, a definição de referências cruzadas entre conceitos de diferentes ontologias permite qualificar ou enriquecer semanticamente os conceitos $[284,285]$. No contexto deste trabalho, a definição de referências cruzadas tem como objetivo enriquecer semanticamente os conceitos fornecidos pela ontologia de serviços com conceitos provenientes da ontologia de domínio. A criação destas referências é realizada por meio do estabelecimento de relacionamentos entre conceitos provenientes das duas ontologias. Esta atividade é necessária porque alguns conceitos definidos na ontologia de serviços podem ter significados (ligeiramente) distintos em diferentes domínios de conhecimento.

Diferentes metodologias têm sido propostas para o desenvolvimento de ontologias [286-290]. Fernández-López et al. [291] e Corcho et al. [292] fornecem uma revisão das principais metodologias existentes para o desenvolvimento de ontologias. Por exemplo, Uschold et al. [286] estabelecem diferentes etapas para o desenvolvimento de ontologias, que compreendem a identificação do domínio de interesse, a captura, codificação e integração de conceitos e relacionamentos, e a avaliação e documentação das ontologias desenvolvidas. A abordagem proposta por Fernández-López et al. [288], chamada de Methontology, estabelece um processo de desenvolvimento com diferentes etapas, um ciclo de desenvolvimento baseado em protótipos e um conjunto de técnicas que devem ser aplicadas em cada atividade constituinte do processo de desenvolvimento. Gómez-Pérez et al. [290] definem uma metodologia para a reengenharia de ontologias, cujo foco principal é recuperar o modelo conceitual de uma ontologia existente já implementada e transformá-lo em um novo modelo conceitual mais correto e completo, que será reimplementado. Noy et al. [293] fornecem um conjunto de práticas comuns para o desen- 
volvimento de ontologias e definem um processo de desenvolvimento iterativo que compreende diferentes etapas, tais como a determinação do escopo da ontologia, a identificação de ontologias para reuso e a definição de conceitos e relacionamentos da ontologia.

Embora diferentes metodologias possam ser utilizadas para o desenvolvimento das ontologias, não prescrevemos o uso de um processo de desenvolvimento específico para a criação de ontologias de domínio e de serviços no contexto deste trabalho.

No contexto deste trabalho, as ontologias de domínio e de serviços são especificadas por meio da linguagem Web Ontology Language Version 2 (OWL 2) [179, 180]. O desenvolvimento de ontologias na linguagem OWL 2 pode ser realizado com o uso do editor de ontologias Protégé [191]. Este editor provê suporte ao desenvolvimento, edição e visualização de ontologias.

\subsection{ANOTAÇÃO SEMÂNTICA DA DESCRIÇÃO DO SERVIÇO}

O objetivo desta atividade é anotar semanticamente a descrição WSDL gerada para o serviço de acordo com a abordagem SAWSDL. A abordagem SAWSDL foi escolhida para anotar a descrição do serviço uma vez que esta abordagem está alinhada com os padrões e práticas atuais para a definição de descrições de serviços na linguagem WSDL 2.0. Além disto, a abordagem SAWSDL fornece maior flexibilidade do que as abordagens OWL-S e WSMO, uma vez que não especifica padrões para a criação de ontologias de serviços a serem utilizadas para a adição de semântica às descrições dos serviços [219]. A anotação semântica da descrição do serviço também é, em geral, realizada com o auxílio de um especialista do domínio, que tem o conhecimento necessário para mapear corretamente informações semânticas para a descrição do serviço.

A anotação semântica de descrições de serviços de acordo com a abordagem SAWSDL pode ser realizada com o uso de três atributos de extensão: modelReference, liftingSchemaMapping e loweringSchemaMapping. A atividade de anotação semântica de descrições WSDL de serviços de acordo com a abordagem SAWSDL pode ser realizada manualmente. No entanto, o uso de uma ferramenta de suporte, tal como a ferramenta Radiant [234], pode facilitar esta atividade. Opcionalmente, as anotações semânticas definidas podem ser especificadas também por meio 
de uma representação gráfica, tal como um diagrama de classes UML [250], de modo a facilitar a visualização das anotações criadas.

A Figura 21 apresenta um diagrama de classes UML representando os principais elementos de um documento WSDL 2.0 e as anotações SAWSDL com o atributo de extensão modelReference que devem ser realizadas de acordo com a metodologia proposta. Os retângulos (classes UML) com preenchimento branco representam elementos contidos em um documento WSDL. Estes elementos podem ser componentes da linguagem WSDL (estereótipo "wsd12") ou de esquemas XML (estereótipo "Xs"). As classes UML com preenchimento cinza representam conceitos genéricos provenientes de uma ontologia de serviços utilizada no processo de anotação. As agregações UML definidas entre elementos de um documento WSDL indicam elementos contidos como parte de outros elementos. As generalizações UML definidas entre conceitos de ontologias indicam relacionamentos de especialização entre os conceitos. Os relacionamentos de dependência UML indicam que elementos de um documento WSDL referenciam outros elementos. Finalmente, as associações UML estereotipadas como $<<$ modelReference $>>$ representam a associação de elementos WSDL a conceitos de ontologias por meio do atributo de extensão modelReference.

O principal elemento de um documento WSDL 2.0 é o elemento Description. Este elemento contém quatro elementos Types, Interface, Binding e Service. O elemento Types contém elementos XML utilizados para descrever os formatos das mensagens que um serviço envia e recebe. O elemento Interface representa a interface de um serviço. Este elemento contém os elementos Operation e Fault, os quais representam as operações fornecidas pela interface do serviço e as falhas que podem ocorrer quando estas operações são invocadas, respectivamente. O elemento Operation contém os elementos Input e Output, os quais representam as entradas e saídas da operação de um serviço. Os elementos Input e Output referenciam elementos XML contidos no elemento Types de modo a especificar os formatos das mensagens de entrada e saída, respectivamente. O elemento Fault também referencia elementos XML contidos no elemento Types de modo a especificar os formatos das mensagens de falha de um serviço. O elemento Binding descreve como uma interface do serviço pode ser acessada. Desta forma, o elemento Binding referencia uma interface do serviço (elemento Interface). O elemento Service também referencia 


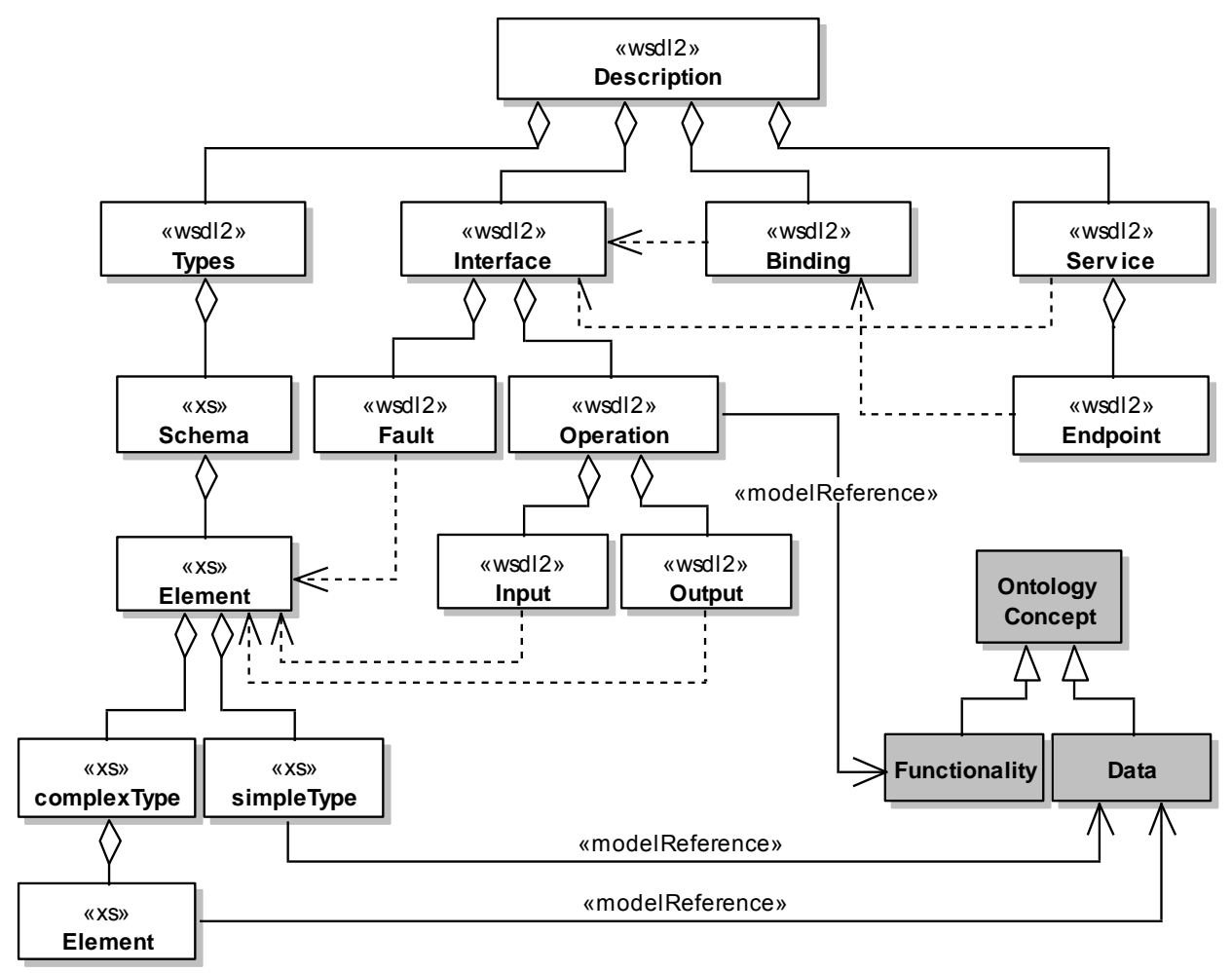

Figura 21: Anotações SAWSDL na metodologia proposta.

uma interface do serviço de modo a descrever sua localização. Finalmente, o elemento Service contém o elemento Endpoint, o qual referencia o elemento Binding.

$\mathrm{O}$ atributo modelReference pode ser utilizado para associar elementos WSDL ou de esquemas XML a conceitos da ontologia de serviços. Segundo a nossa metodologia, este atributo deve ser aplicado às operações WSDL definidas no componente Interface, de modo a associar conceitos da ontologia que descrevem as funcionalidades fornecidas pelas operações do serviço a estes elementos WSDL. Operações de serviço consideradas de propósito geral, tais como operações para a submissão, recuperação e remoção de dados, não precisam ser anotadas. No entanto, as entradas e saídas destas operações devem ser anotadas, de modo a permitir raciocínio automatizado, por exemplo, para propósitos de descoberta e composição de serviços.

Além disto, o atributo modelReference deve ser aplicado às definições de tipos simples/complexos em esquemas XML contidos no elemento WSDL Types de modo a associar conceitos da ontologia que descrevem os tipos de dados das entradas e saídas do serviço a estas definições. Aqui, consideramos que quando um elemento (de alto nível) em um esquema XML é declarado em termos de tipos simples, apenas os tipos simples devem ser anotados com o atributo model- 
Reference. Esta abordagem leva em consideração que a anotação de um tipo simples também se aplica a quaisquer elementos (de alto nível) que utilizam esta definição de tipo.

Quando um elemento (de alto nível) em um esquema XML é declarado em termos de tipos complexos, a anotação dos seus tipos complexos pode ser realizada de acordo com duas abordagens: (i) todos os elementos contidos no tipo complexo são anotados com o atributo modelReference; ou (ii) apenas os tipos complexos em si são anotados. Além disto, é possível combinar estas duas abordagens uma vez que estes tipos de anotações são considerados independentes. Neste caso, os tipos complexos e também seus elementos podem ser anotados com o atributo modelReference. A Figura 21 ilustra apenas a primeira abordagem para a anotação de tipos complexos.

Embora o atributo de extensão modelReference possa ser aplicado a definições de tipos, declarações de elementos e atributos em esquemas XML, bem como a elementos WSDL Interface, Operation e Fault, consideramos a anotação de declarações de elementos (de alto nível) e atributos em esquemas XML, bem como de elementos WSDL Interface e Fault uma atividade opcional no contexto deste trabalho.

No contexto deste trabalho, consideramos a aplicação dos atributos de extensão liftingSchemaMapping e loweringSchemaMapping uma atividade opcional. Os atributos liftingSchemaMapping e loweringSchemaMapping podem ser utilizados para associar componentes de esquemas XML a mapeamentos lifting e lowering, respectivamente. Um mapeamento lifting especifica como estruturas XML podem ser transformadas em dados semânticos definidos a partir de uma ontologia. De forma análoga, um mapeamento lowering especifica como dados semânticos definidos a partir de uma ontologia podem ser transformados em estruturas XML. O uso destes mapeamentos permite, por exemplo, que estruturas XML sintaticamente distintas, mas semanticamente iguais de um cliente e de um serviço sejam mapeadas para um mesmo conceito de uma ontologia de modo a resolver as diferenças sintáticas e permitir a utilização do serviço. De forma geral, mapeamentos lifting podem ser definidos na linguagem Simple Protocol and RDF Query Language (XSLT) [294] e mapeamentos lowering podem ser definidos nas linguagens Simple Protocol and RDF Query Language (SPARQL) [295] e XSLT.

Os atributos de extensão liftingSchemaMapping e loweringSchemaMapping podem ser aplicados a definições de tipos e/ou declarações de elementos de esquemas XML. A anotação de 
uma definição de tipo XML com estes atributos somente é propagada para o elemento no qual a definição de tipo está contida se o elemento em si não estiver declarando nenhum mapeamento. Este mecanismo permite que tipos XML forneçam mapeamentos genéricos, e que elementos especifiquem mapeamentos mais concretos, apropriados para o uso específico daquela definição de tipo.

Após a anotação semântica da descrição WSDL do serviço, o analisador sintático fornecido como parte do projeto Apache Woden pode ser utilizado novamente para validar a anotação semântica do serviço.

\subsection{ESPECIFICAÇÃO DO COMPORTAMENTO LOCAL DO SERVIÇO}

Um serviço web frequentemente expõe um conjunto de operações que, individualmente, fornecem funcionalidades específicas. Algumas operações do serviço podem ser executadas de forma independente umas das outras e em qualquer ordem. No entanto, outras operações devem ser executadas em uma determinada ordem de acordo, por exemplo, com um conjunto de condições e/ou restrições. Assim, um serviço web pode apresentar um comportamento local, ou seja, condições e/ou restrições que determinam a ordem de execução de suas operações.

A descrição WSDL de um serviço define o conjunto de operações fornecido pelo serviço e os detalhes técnicos necessários para a invocação (execução) individual de cada uma das suas operações. No entanto, a ordem em que as operações do serviço devem ser executadas não é especificada na descrição do serviço. De modo a permitir a execução automática do serviço, uma especificação executável do seu comportamento local é necessária. Neste sentido, esta atividade tem como objetivo representar o comportamento local do serviço por meio de uma ou mais especificações executáveis. A disponibilidade destas especificações permite a execução automática do serviço.

O comportamento local de um serviço consiste em um conjunto de tarefas (operações de serviço) que devem ser invocadas em uma determinada ordem para que um objetivo seja realizado. Neste sentido, o comportamento local de um serviço pode ser modelado como um processo, o qual especifica o comportamento de um serviço por meio da definição da ordem em que as operações do serviço devem ser invocadas e as condições e/ou restrições associadas à ordem de 
execução das operações. Neste trabalho, especificamos processos (executáveis) na linguagem Business Process Model and Notation versão 2.0 (BPMN 2.0) [272]. BPMN é uma linguagem baseada em XML que fornece um modelo e uma notação gráfica para a modelagem e execução de processos de negócio de forma padronizada. O principal objetivo da linguagem BPMN é permitir a definição de processos de negócio de forma padronizada e, consequentemente, facilitar o entendimento e o compartilhamento destes processos entre diferentes ferramentas e entidades de negócios.

Na linguagem BPMN, o comportamento local do serviço pode ser modelado como um grafo direcionado (processo). Os vértices do grafo representam elementos de modelagem, tais como eventos, tarefas (operações de serviço) e estruturas de decisão. Por sua vez, as arestas do grafo representam a ordem em que os elementos (vértices) devem ser executados. Adicionalmente, a linguagem BPMN permite a modelagem de estruturas de dados associadas aos elementos (vértices) do grafo. Estas estruturas podem ser modeladas como objetos de dados genéricos ou como entradas e saídas do processo.

De modo a especificar o comportamento local do serviço, cada operação do serviço pode ser modelada como um elemento BPMN Service Task, o qual referencia a definição WSDL da operação. As conexões (arestas) entre os elementos Service Task definem a ordem em que as operações do serviço devem ser executadas. As condições associadas à execução das operações do serviço podem ser modeladas como elementos BPMN Gateway e Event. As entradas e saídas de cada operação, definidas na descrição WSDL do serviço, podem ser modeladas como elementos BPMN Data Input e Data Output, respectivamente. Adicionalmente, os parâmetros do serviço podem ser modelados como elementos BPMN Data Object.

A definição de um processo para representar o comportamento local de um serviço pode ser realizada com o uso de diferentes ferramentas de modelagem BPMN, tais como as ferramentas Activiti [296], Eclipse BPMN2 Modeler [297] e Intalio [298]. Estas ferramentas fornecem suporte (semi) automático ao mapeamento de elementos WSDL definidos na descrição de um serviço para elementos BPMN. No entanto, estas ferramentas fornecem suporte somente à versão 1.1 da linguagem WSDL. Uma vez que a nossa metodologia prescreve o uso da versão 2.0 da linguagem WSDL para a descrição de serviços web RESTful, definimos um mapeamento dos 
elementos definidos na linguagem WSDL 2.0 para elementos definidos na linguagem BPMN 2.0 .

A Figura 22 apresenta os elementos de um processo BPMN 2.0 considerados relevantes no contexto deste trabalho e como os elementos definidos em uma descrição WSDL 2.0 de serviço devem ser mapeados para estes elementos BPMN. As linhas pontilhadas indicam elementos WSDL ou BPMN que referenciam outros elementos. As linhas sólidas representam o mapeamento de elementos WSDL para elementos BPMN.

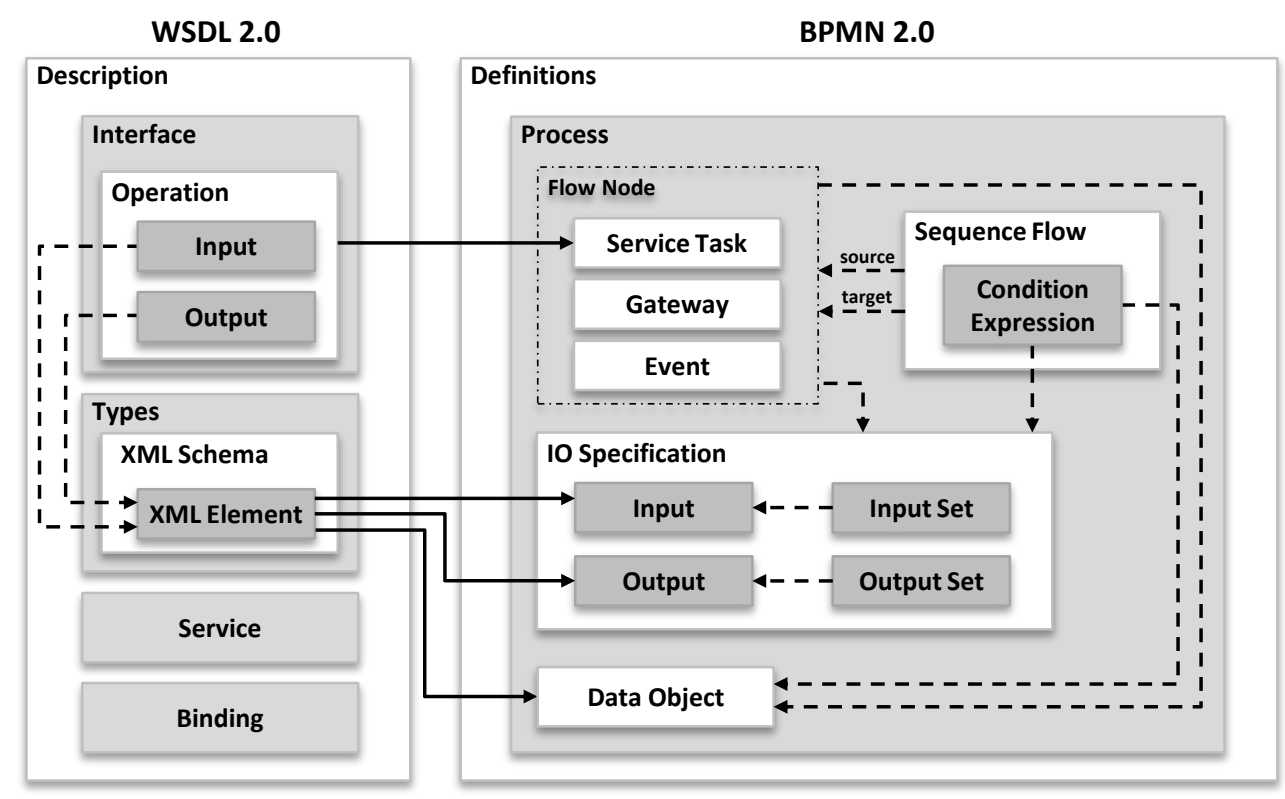

Figura 22: Mapeamento de elementos WSDL para elementos BPMN.

O principal elemento de um documento BPMN 2.0 é o elemento Definitions. Este elemento contém um ou mais elementos Process, cada qual representando um processo executável. Por sua vez, o elemento Process contém um conjunto de elementos Data Object utilizados para representar conjuntos de dados a serem manipulados no escopo de um processo BPMN. Além disto, o elemento Process pode conter um elemento IOSpecification, que define os conjuntos de dados de entrada e saída do processo. O elemento IOSpecification contém um ou mais elementos Input Set e Output Set, os quais representam os conjuntos de dados de entrada que o processo requer previamente à sua execução e os conjuntos de dados de saída que o processo produz como resultado de sua execução, respectivamente. O elemento Input Set referencia um ou mais elementos Input, os quais representam os tipos de dados de entrada do processo. Por 
sua vez, o elemento Output Set referencia um ou mais elementos Output, os quais representam os tipos de dados de saída do processo.

Adicionalmente, o elemento Process contém um conjunto de elementos do tipo Flow Node. Flow Node é um elemento utilizado para representar, de forma abstrata, um vértice (elemento) que pode ser definido em um grafo (processo) BPMN. Os principais elementos do tipo Flow Node são: Service Task, que representa uma atividade responsável pela invocação de uma operação de serviço; Gateway, que representa uma estrutura de decisão que permite a definição de fluxos de execução alternativos em um processo BPMN; e Event, que representa um evento que ocorre durante a execução do processo e pode causar algum impacto no seu fluxo de execução. Os elementos do tipo Flow Node podem referenciar elementos de dados definidos pelos elementos Data Object e/ou IOSpecification. Estas referências podem ser utilizadas, por exemplo, para associar valores de dados a elementos Service Task. Além disto, estas referências permitem, por exemplo, a definição de condições que podem levar à execução de fluxos de execução alternativos, definidos por meio de elementos Gateway, ou que podem disparar a ocorrência de eventos (elementos Events).

Finalmente, o elemento Process contém um conjunto de elementos Sequence Flow. O elemento Sequence Flow é utilizado para modelar um relacionamento entre dois elementos do tipo Flow Node, determinando o fluxo (ordem) de execução destes elementos em um processo BPMN. Cada elemento Sequence Flow conecta um elemento de origem (source) a um elemento de destino (target). O elemento Sequence Flow pode ainda conter um elemento Condition Expression, que representa uma ou mais condições que devem ser cumpridas para a execução do fluxo determinado pelo elemento Sequence Flow. As condições definidas pelo elemento Condition Expression podem referenciar elementos de dados definidos pelos elementos Data Object e/ou IOSpecification. Assim, durante a execução do processo, estas condições podem ser avaliadas com base nos valores destes elementos de dados.

De modo a mapear uma descrição WSDL de serviço para um processo BPMN, o seguinte procedimento deve ser realizado. Inicialmente, cada operação WSDL (elemento Operation) deve ser mapeada para um elemento BPMN Service Task. Em seguida, cada elemento XML definido no elemento WSDL Types e referenciado a partir de um elemento Input de uma operação WSDL deve ser mapeado para um elemento BPMN Input ou Data Object. Se os dados 
de entrada da operação correspondentes ao elemento XML têm que ser fornecidos pelo usuário antes do início da execução do processo, o elemento XML correspondente deve ser mapeado para o elemento BPMN Input. Alternativamente, se os dados de entrada podem ser fornecidos durante a execução do processo, o elemento XML correspondente pode ser mapeado para o elemento BPMN Data Object. De forma similar, cada elemento XML definido no elemento WSDL Types e referenciado a partir de um elemento Output de uma operação WSDL deve ser mapeado para um elemento BPMN Output ou Data Object. Se os dados de saída da operação correspondentes ao elemento XML têm que ser retornados ao usuário ao final da execução do processo, o elemento XML correspondente deve ser mapeado para o elemento BPMN Output. Alternativamente, se os dados de saída da operação são consumidos apenas por outras operações do serviço definidas no processo BPMN e não precisam ser fornecidos ao usuário (ex: identificadores internos), então o elemento XML correspondente pode ser mapeado para o elemento BPMN Data Object.

Uma vez que este mapeamento é realizado, o fluxo de execução das operações de serviço e as condições/restrições associadas à execução do processo ainda precisam ser definidas. Esta tarefa pode ser realizada de forma manual ou com o auxílio de uma ferramenta de modelagem BPMN 2.0 de propósito geral, tal como Activiti [296] e Eclipse BPMN2 Modeler [297]. Estas ferramentas também podem ser utilizadas para validar o processo BPMN criado.

\subsection{FERRAMENTAS DE SUPORTE À METODOLOGIA}

De modo a facilitar o desenvolvimento de serviços web semânticos de acordo com a metodologia proposta, desenvolvemos um conjunto de ferramentas de suporte. Estas ferramentas têm como objetivo facilitar a realização de algumas atividades definidas como parte da metodologia proposta.

\subsubsection{Ferramenta Wsdl2 Creator}

De modo a facilitar a atividade de geração de uma descrição de serviço, desenvolvemos uma ferramenta de suporte, chamada Wsdl2 Creator. Esta ferramenta permite a criação, edição e 
validação de descrições de serviços na linguagem WSDL 2.0. A ferramenta Wsdl2 Creator foi desenvolvida na linguagem Java e está disponível por meio da tecnologia Java Web Start [299]. A Figura 23 apresenta a interface gráfica de usuário da ferramenta Wsdl2 Creator.

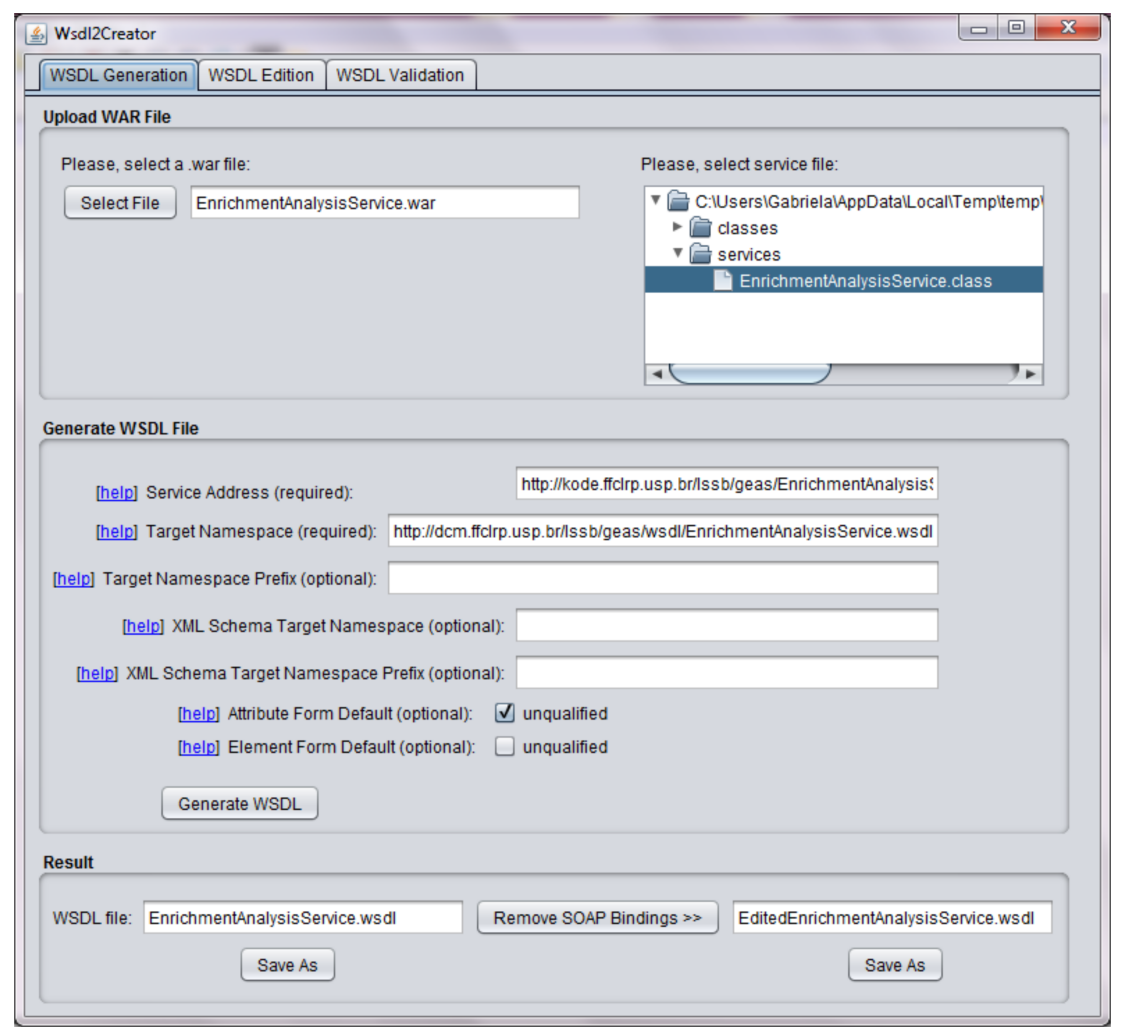

Figura 23: Interface gráfica de usuário da ferramenta Wsdl2 Creator.

Na ferramenta Wsdl2 Creator, a geração da descrição de um serviço a partir de sua implementação é realizada por meio da ferramenta Java2WSDL fornecida como parte do projeto Apache Axis2/Java [277]. As funcionalidades desta ferramenta são acessadas por meio de uma tarefa em um script Ant [278].

Para a geração de uma descrição WSDL de um serviço na ferramenta Wsdl2 Creator, o usuário deve, primeiramente, gerar um arquivo no formato Web application ARchive (WAR) [300] contendo a implementação Java do serviço e classes associadas. Este arquivo pode ser gerado a partir dos principais ambientes de desenvolvimento Java, como por exemplo o ambiente Eclipse [228]. Em seguida, o usuário deve especificar a localização (diretório) do arquivo WAR. Uma vez que a localização do arquivo é especificada, a estrutura interna do arquivo é apresentada ao usuário, que deve então selecionar a classe principal (implementação do serviço) a partir da qual a descrição de serviço será gerada. Após a seleção desta classe, o usuário deve fornecer 
o endereço do serviço e da descrição WSDL do serviço (target namespace). O usuário pode então iniciar a geração da descrição do serviço.

Após a geração da descrição WSDL, o usuário pode recuperar o documento gerado. Opcionalmente, o usuário pode realizar a edição automática do documento gerado, de modo a remover os bindings SOAP e suas referências. Este processo de edição na ferramenta Wsdl2 Creator é realizado por meio do analisador sintático fornecido como parte do projeto Apache Woden [279]. Após o processo de edição, o usuário pode recuperar o documento WSDL editado. Caso a descrição do serviço tenha sido gerada anteriormente ou por meio de outra ferramenta, esta pode ser carregada e editada independentemente do processo de criação da mesma.

O processo de validação tem como objetivo verificar se a sintaxe da descrição de um serviço é válida de acordo com a especificação da linguagem WSDL 2.0. Além disto, a validação de um documento WSDL 2.0 permite verificar se o endereço da descrição do serviço (target namespace) é válido, ou seja, se o documento pode ser referenciado a partir deste endereço. A validação de uma descrição de serviço na ferramenta Wsdl2 Creator é realizada por meio do mesmo analisador sintático utilizado para a edição da descrição do serviço.

Para a validação de uma descrição de serviço na ferramenta Wsdl2 Creator, o usuário deve primeiramente especificar a localização (diretório) de um arquivo no formato WSDL 2.0 contendo a descrição do serviço. Uma vez que a localização do arquivo é especificada, o usuário pode então iniciar a validação da descrição do serviço. Após o processo de validação, o usuário

pode visualizar o resultado desta validação, que mostra possíveis erros sintáticos no documento WSDL especificado.

\subsubsection{Ferramenta Wsdl2Bpmn Mapper}

De modo a facilitar a atividade de especificação do comportamento local de um serviço na linguagem BPMN, desenvolvemos uma ferramenta de suporte, chamada Wsdl2BpmnMapper. Esta ferramenta permite a criação e validação de processos na linguagem BPMN 2.0. A ferramenta Wsdl2Bpmn Mapper foi desenvolvida na linguagem Java e fornece uma interface gráfica de usuário. A Figura 24 apresenta a interface gráfica da ferramenta Wsdl2Bpmn Mapper. 


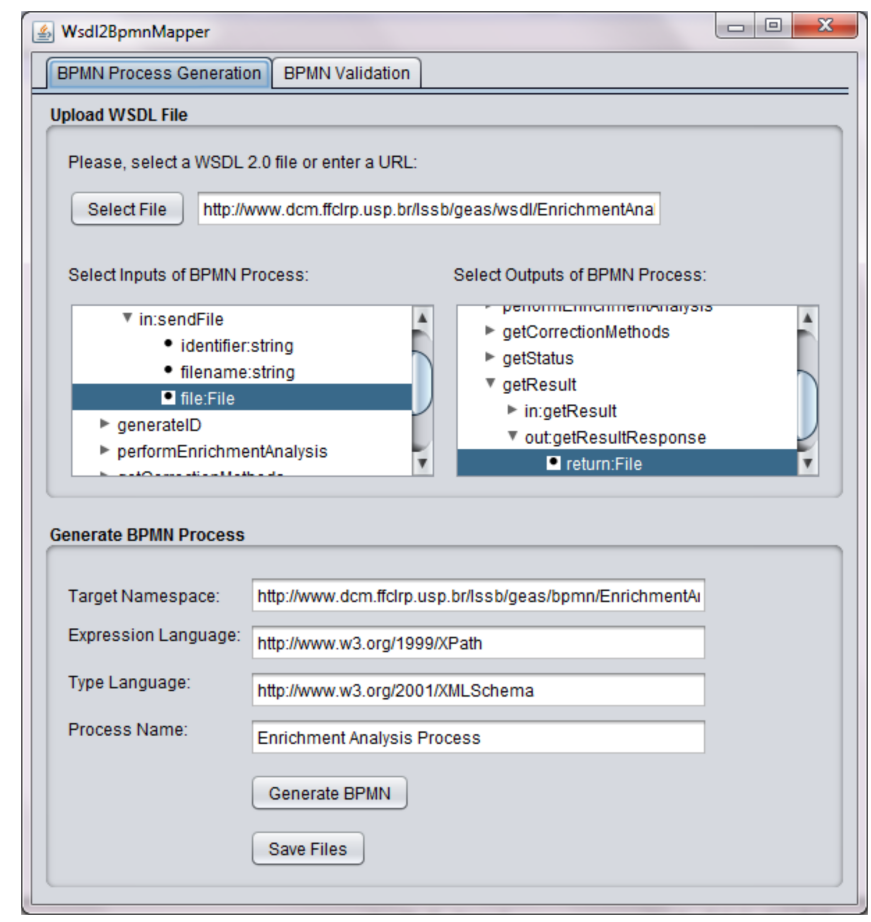

Figura 24: Interface gráfica de usuário da ferramenta Wsdl2Bpmn Mapper.

Na ferramenta Wsdl2Bpmn Mapper, a geração de um processo para a especificação do comportamento local de um serviço é realizada de forma semi-automática a partir da descrição WSDL do serviço. Para isto, esta ferramenta implementa o mapeamento de elementos WSDL para elementos BPMN definido como parte da nossa metodologia (veja Figura 22).

O processamento e extração de informações a partir de descrições WSDL de serviços é realizado na ferramenta Wsdl2Bpmn Mapper por meio do analisador sintático Java fornecido como parte do projeto Apache Woden [279]. A geração e validação de processos BPMN é realizada com o uso da API Java Camunda [301], que fornece recursos para a criação, manipulação e validação de documentos BPMN 2.0.

Para a geração de um processo BPMN na ferramenta Wsdl2Bpmn Mapper, o usuário deve, primeiramente, especificar a localização (diretório ou URL) de um arquivo no formato WSDL contendo a descrição de um serviço. Uma vez que a localização do arquivo WSDL é especificada, a estrutura interna do arquivo é apresentada ao usuário. O usuário deve então selecionar os dados de entrada das operações de serviço que têm que ser fornecidos antes do início da execução do processo BPMN sendo criado. Estes dados serão mapeados para os dados de entrada do processo BPMN (elementos Input). De forma similar, o usuário também deve selecionar os 
dados de saída das operações de serviço que têm que ser retornados ao final da execução do processo sendo criado. Este dados serão mapeados para os dados de saída do processo BPMN (elementos Output). Os demais dados, não selecionados pelo usuário, serão mapeados para estruturas de dados que podem ser manipuladas no escopo do processo BPMN (elementos Data Object). Após a seleção dos dados de entrada e saída do processo, o usuário deve fornecer o nome e o endereço (target namespace) do processo BPMN. O usuário pode então iniciar a geração do processo BPMN.

Após o processo de geração, o usuário pode recuperar o documento BPMN gerado. Este documento especifica um processo que contém um conjunto de elementos BPMN Service Task. Estes elementos referenciam as operações de serviço definidas na descrição WSDL fornecida. Além disto, o processo contém um conjunto de elementos BPMN Input, Output e Data Object que referenciam os elementos de dados definidos na descrição WSDL. No entanto, o fluxo de execução das operações, bem como as condições e/ou restrições que devem ser satisfeitas durante a execução do processo não são definidas. O usuário pode realizar a definição destes elementos adicionais no processo com o uso de qualquer ferramenta de modelagem BPMN de propósito geral.

Uma vez que este processo é especificado, a ferramenta Wsdl2Bpmn Mapper pode ser utilizada para validar o documento BPMN que define o processo. O processo de validação tem como objetivo verificar se a sintaxe do documento BPMN é válida de acordo com a especificação da linguagem BPMN 2.0. Além disto, a validação de um documento BPMN permite verificar se o endereço do documento (targetNamespace) é válido, ou seja, se o documento pode ser referenciado a partir deste endereço.

Para a validação de um documento BPMN na ferramenta Wsdl2Bpmn Mapper, o usuário deve primeiramente especificar a localização (diretório ou URL) do arquivo no formato BPMN que contém a definição do processo. Uma vez que a localização deste arquivo é especificada, o usuário pode então iniciar a sua validação. Após o processo de validação, o usuário pode visualizar o resultado desta validação, que mostra possíveis erros sintáticos no documento BPMN especificado. 


\subsection{PERFIL UML PARA A ABORDAGEM SAWSDL}

A linguagem Unified Modeling Language (UML) [250] é uma linguagem gráfica amplamente utilizada para a modelagem de artefatos computacionais. A ampla aceitação desta linguagem se deve à presença de um conjunto semanticamente rico e bem definido de conceitos de modelagem, à independência da linguagem de metodologias de modelagem específicas e ao amplo conjunto de ferramentas de suporte disponível.

A linguagem UML é definida de acordo com uma abordagem de metamodelagem, segundo a qual os elementos de modelagem fornecidos pela linguagem são especificados a partir dos elementos definidos em um metamodelo, chamado de metamodelo UML. O metamodelo UML define como os elementos da linguagem podem ser instanciados/criados a partir dos elementos definidos no metamodelo. O metamodelo define não apenas os elementos da linguagem, seus atributos e relacionamentos, mas também um conjunto de regras para a combinação de elementos na construção de modelos UML.

A UML é uma linguagem de modelagem de propósito geral que pode ser utilizada para a representação de diferentes domínios de conhecimento. No entanto, o desenvolvimento de modelos para a representação de um domínio de conhecimento específico pode se beneficiar do uso de elementos de modelagem com sintaxe e semântica mais específicas do que as fornecidas pelos elementos genéricos da linguagem.

Para este fim, a linguagem UML fornece dois mecanismos que permitem a adaptação do metamodelo UML, possibilitando assim a definição de elementos de modelagem com sintaxe e semântica específicas. O primeiro mecanismo fornecido pela linguagem consiste na modificação do metamodelo UML, de modo que novos elementos possam ser adicionados e a semântica dos elementos existentes no metamodelo possa ser alterada. O segundo mecanismo consiste na extensão do metamodelo UML por meio da definição de um perfil. A extensão do metamodelo permite a incorporação de restrições adicionais aos elementos definidos no metamodelo de modo a especializar a semântica dos mesmos. No entanto, este segundo mecanismo não permite que a semântica dos elementos existentes no metamodelo seja alterada, garantindo assim que o metamodelo estendido seja facilmente compreendido por projetistas de outros domínios e facilmente suportado por diferentes ferramentas. 
Um perfil UML é um tipo específico de pacote que contém mecanismos de extensão, tais como estereótipos e restrições, para a especialização de elementos do metamodelo UML. Um estereótipo define como uma metaclasse do metamodelo UML pode ser estendida, de modo a incorporar sintaxe e semântica específicas. Uma restrição é um mecanismo de extensão que permite refinar ou adicionar semântica a elementos de modelagem. Além disto, restrições podem ser utilizadas para limitar a maneira como os elementos de um modelo podem ser criados a partir do metamodelo UML. As restrições definidas em um perfil podem ser especificadas por meio de expressões em linguagem natural, mas a utilização de uma linguagem com base formal, tal como a linguagem Object Constraint Language (OCL) [302], permite que a semântica das restrições seja definida de forma não ambígua.

$\mathrm{Na}$ metodologia proposta para o desenvolvimento de serviços, as anotações semânticas atribuídas à descrição de um serviço são realizadas de acordo com a abordagem SAWSDL. Estas anotações são especificadas na descrição do serviço de forma textual. A Figura 25 ilustra uma descrição de serviço semanticamente anotada de acordo com a abordagem SAWSDL. As anotações semânticas SAWSDL são apresentadas em negrito.

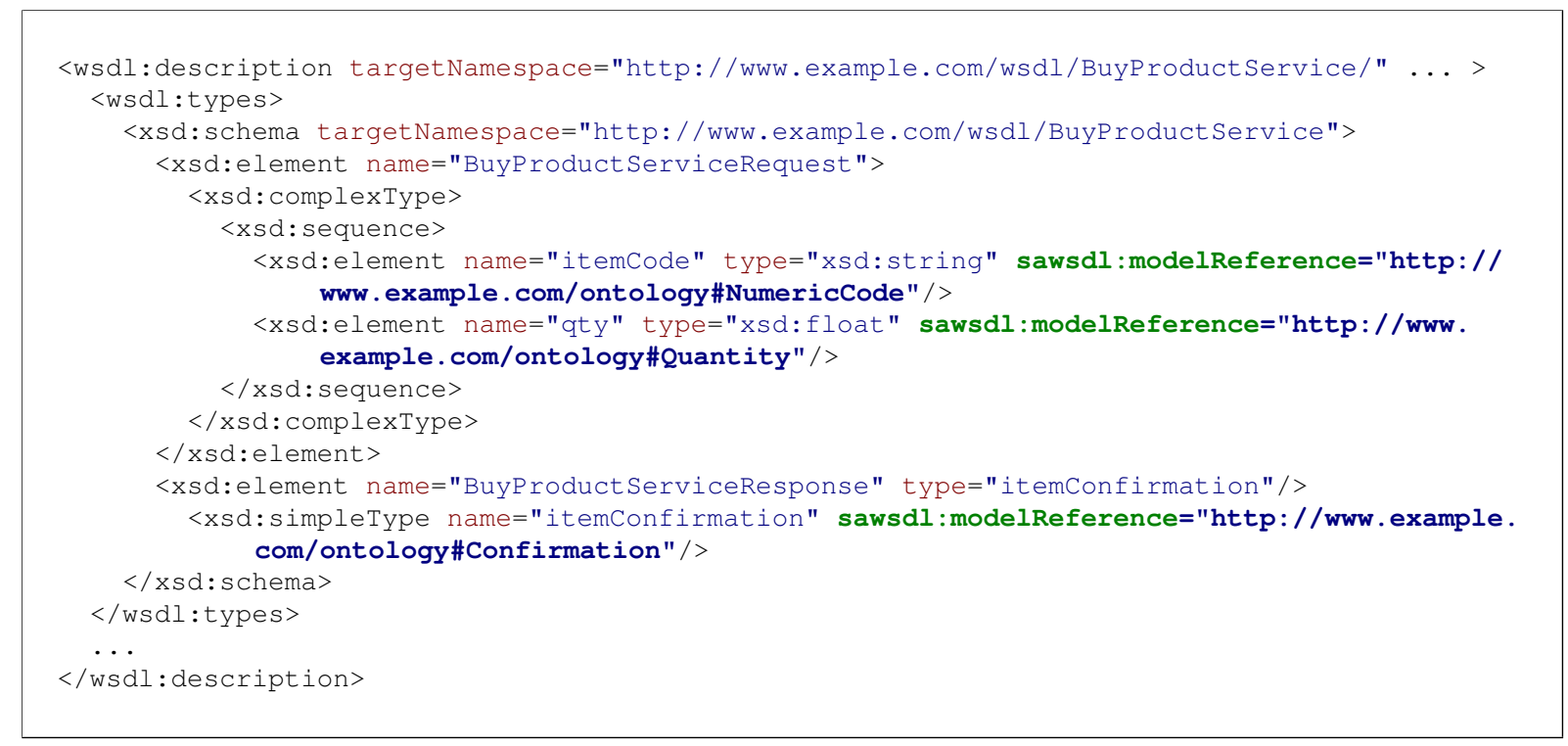

Figura 25: Descrição de serviço anotada com a abordagem SAWSDL.

As anotações SAWSDL atribuídas às descrições de serviços são textuais. Contudo, estas podem também ser especificadas graficamente por meio de diagramas de classes UML. O uso destas representações gráficas pode não apenas facilitar a modelagem e visualização das ano- 
tações, mas também prevenir inconsistências durante a criação das mesmas. Neste contexto, definimos um perfil UML para a abordagem SAWSDL. Este perfil tem como objetivo facilitar a criação de modelos UML para a representação de anotações semânticas realizadas de acordo com a abordagem SAWSDL.

A definição deste perfil tem como objetivo facilitar a representação das anotações semânticas realizadas com o uso do atributo de extensão modelReference. O perfil desenvolvido fornece um conjunto de elementos de modelagem específicos que permitem a representação deste atributo de extensão, de conceitos provenientes de ontologias e de alguns componentes de esquemas XML e da linguagem WSDL 2.0 considerados relevantes no contexto do atributo modelReference. Os elementos description, types, binding e service da linguagem WSDL 2.0 não são considerados relevantes no contexto do atributo modelReference. Assim, não foram definidos como parte do perfil desenvolvido. Apenas o elemento interface e os elementos definidos como parte da interface de um serviço são definidos no perfil. Além disto, apenas os elementos element, simpleType, complexType e attribute de esquemas XML definidos como parte do elemento types da linguagem WSDL 2.0 são definidos no perfil.

Na definição do perfil UML para a abordagem SAWSDL, diferentes estereótipos foram propostos como extensões ao metamodelo UML. A Figura 26 apresenta parte do metamodelo UML considerado relevante para a definição destas extensões, bem como apresenta os estereótipos definidos como extensões da metaclasse Class para a representação de conceitos provenientes de ontologias e de componentes de esquemas XML e da linguagem WSDL 2.0.

Um retângulo com preenchimento branco representa uma metaclasse originalmente definida no metamodelo UML. Metaclasses abstratas possuem seus nomes apresentados em itálico. Um retângulo com preenchimento cinza representa um estereótipo definido como uma extensão ao metamodelo. Uma linha direcionada ou não conectando duas metaclasses representa uma associação UML. Uma linha com um triângulo sem preenchimento em uma das extremidades representa uma generalização UML. Finalmente, uma linha com um triângulo com preenchimento em uma das extremidades representação uma extensão UML.

A metaclasse abstrata Element representa um elemento definido em um modelo UML. Element é a superclasse comum de todas as metaclasses que fazem parte do metamodelo UML. A metaclasse Element é especializada pela metaclasse abstrata NamedElement. A metaclasse 


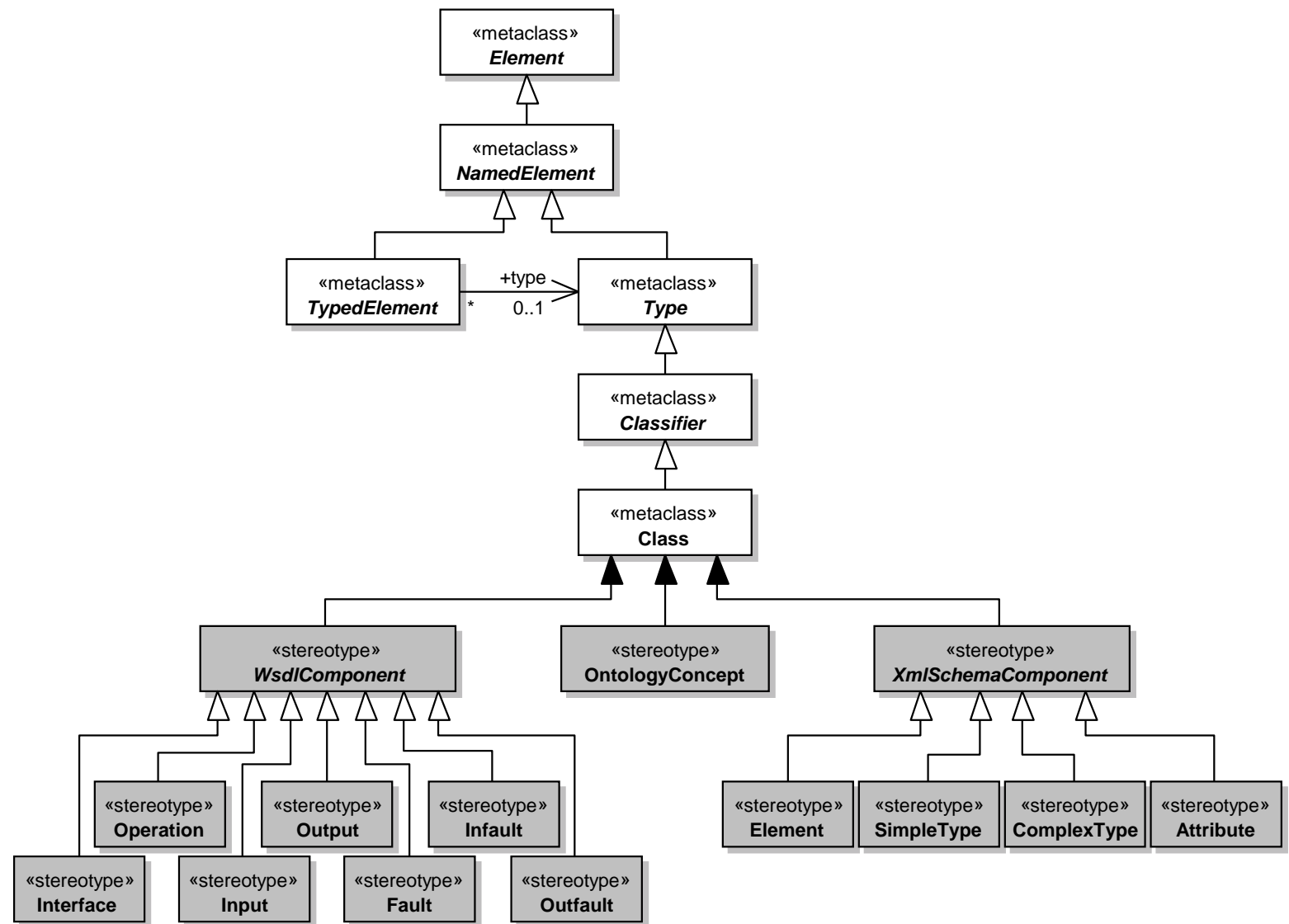

Figura 26: Extensões propostas à metaclasse Class do metamodelo UML.

NamedElement representa um elemento de um modelo que pode ter um nome associado para identificá-lo de forma não ambígua no modelo. Esta metaclasse é especializada pela metaclasse abstrata TypedElement, a qual representa um elemento que possui um nome e um tipo (type) associados. A metaclasse abstrata Type define um conjunto de valores. Elementos (metaclasse TypedElement) associados a um tipo estão restritos a representar apenas valores contidos no conjunto definido pelo seu tipo. A metaclasse Type é especializada pela metaclasse abstrata Classifier, a qual representa um classificador que agrupa instâncias (objetos) com características comuns. A metaclasse Classifier é especializada pela metaclasse Class, a qual representa um conjunto de objetos (instâncias de classes) que compartilham características estruturais e comportamentais em comum.

De modo a definir um perfil UML para a abordagem SAWSDL, inicialmente a metaclasse Class foi estendida pelo estereótipo concreto OntologyConcept, e pelos estereótipos abstratos WsdlComponent e XmlSchemaComponent. O estereótipo OntologyConcept representa um con- 
ceito definido em uma ontologia. Os estereótipos WsdlComponent e XmlSchemaComponent representam componentes da linguagem WSDL 2.0 e de esquemas XML, respectivamente. Estes estereótipos foram definidos apenas para facilitar a estruturação do perfil.

O estereótipo WsdlComponent foi ainda especializado pelos estereótipos Interface, Operation, Input, Output, Fault, Infault e Outfault. O estereótipo Interface representa a interface de um serviço definida em um documento WSDL. O estereótipo Operation representa uma operação definida em uma interface de serviço. Os estereótipos Input e Output representam mensagens que um serviço recebe e envia, respectivamente, quando uma das operações de sua interface é invocada. O estereótipo Fault representa uma falha que pode ocorrer durante a invocação de uma operação de serviço. Os estereótipos Infault e Outfault representam mensagens de falha que um serviço recebe e envia, respectivamente, quando uma falha ocorre durante a invocação de uma das operações de sua interface.

O estereótipo XmlSchemaComponent foi ainda especializado pelos estereótipos Element, Simple Type, Complex Type e Attribute, os quais representam elementos, tipos simples, tipos complexos e atributos definidos em um esquema XML, respectivamente.

Todos os estereótipos concretos definidos a partir dos estereótipos abstratos WsdlComponent e XmlSchemaComponent são associados a estes estereótipos abstratos por meio de relacionamentos de generalização UML. Uma generalização UML representa um relacionamento binário entre um classificador geral e um classificador mais específico. Este relacionamento é utilizado para representar que instâncias do classificador específico são também instâncias do classificador geral e que as características definidas para o classificador geral são herdadas pelo classificador específico.

Diferentes relacionamentos de generalização podem ser agrupados de modo que um único classificador geral seja especializado por diferentes classificadores específicos. Por padrão, quando diferentes classificadores específicos são definidos para um único classificador geral, estes classificadores não podem ter instâncias em comum. Esta característica permite especificar que, se uma classe é estendida por um subtipo do estereótipo WsdlComponent, esta não pode ser estendida por outros subtipos deste estereótipo. De forma análoga, se uma classe é estendida por um subtipo do estereótipo XmlSchemaComponent, esta não pode ser estendida 
por outros subtipos deste estereótipo. Desta forma, por exemplo, se uma classe for estendida pela metaclasse Interface, esta não poderá ser estendida por outro classe, tal como Operation.

Adicionalmente, definimos um conjunto de restrições no perfil que especificam que, se uma classe é estendida por um subtipo do estereótipo WsdlComponent, a mesma não pode ser estendida pelo estereótipo OntologyConcept ou por subtipos do estereótipo XmlSchemaComponent. De forma análoga, uma classe estendida por um subtipo do estereótipo XmlSchemaComponent não pode ser estendida por OntologyConcept ou por subtipos de WsdlComponent. Finalmente, uma classe estendida pelo estereótipo OntologyConcept não pode ser estendida por subtipos de WsdlComponent ou XmlSchemaComponent.

A Figura 27 apresenta os estereótipos propostos como extensões às metaclasses Association e Dependency, bem como parte do metamodelo UML considerado relevante para a definição destes estereótipos. Os estereótipos apresentados foram definidos para a representação do atributo de extensão modelReference da abordagem SAWSDL e de dois tipos de relacionamentos adicionais: references, utilizado para referenciar elementos XML a partir de componentes da linguagem WSDL 2.0; e fault reference, utilizado para referenciar a definição de falhas a partir de mensagens de falha definidas na linguagem WSDL 2.0.

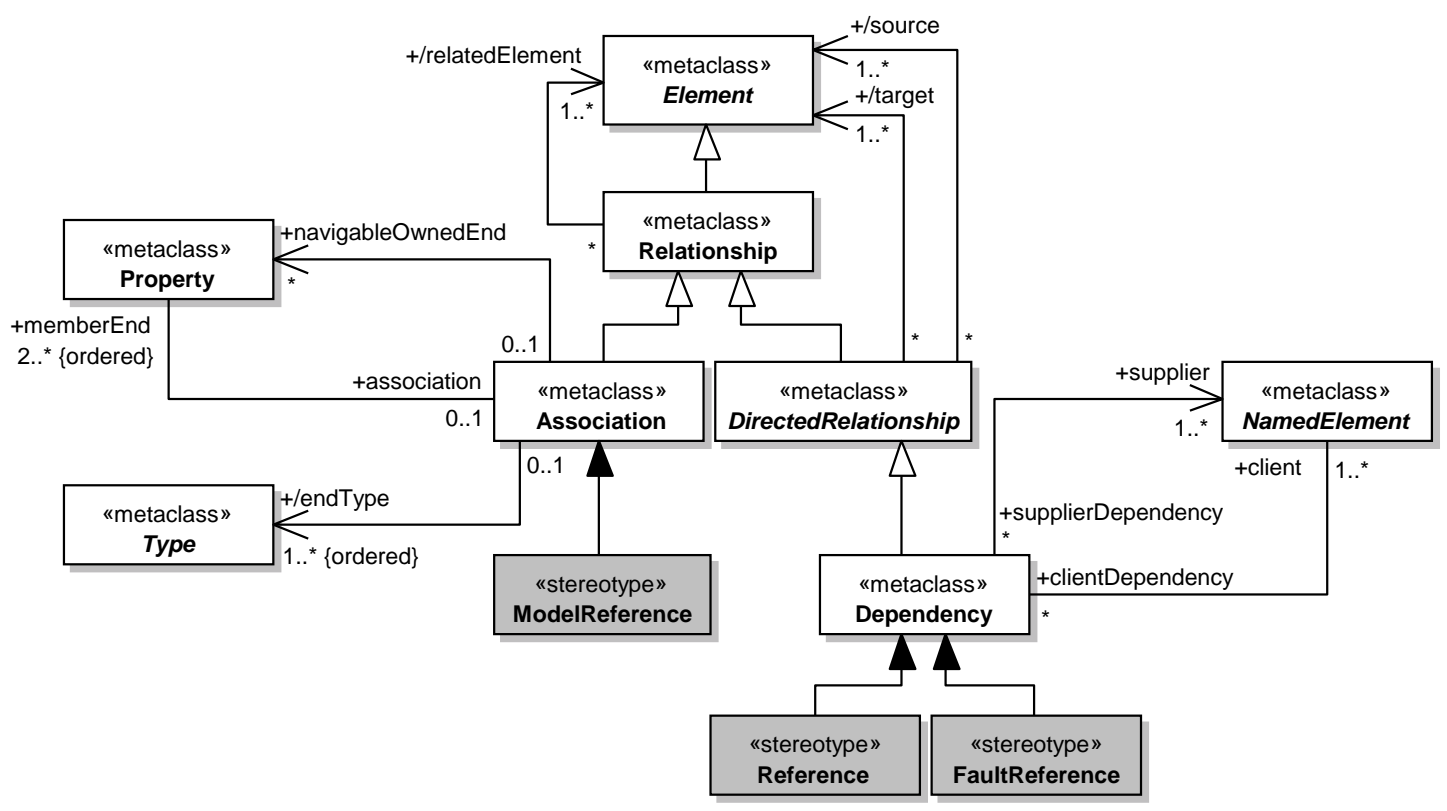

Figura 27: Extensões propostas às metaclasses Association e Dependency do metamodelo UML. 
A metaclasse Element é especializada pela metaclasse Relationship, a qual representa um relacionamento definido entre dois ou mais elementos (relatedElement) de um modelo. A metaclasse Relationship é especializada pela metaclasses DirectedRelationship e Association. A metaclasse abstrata DirectedRelationship representa relacionamentos direcionados entre elementos de origem (source) e de destino (target). Esta metaclasse é especializada pela metaclasse Dependency, a qual representa um relacionamento de dependência definido entre elementos de um modelo. Este relacionamento estabelece que um conjunto de elementos (client) requer outro conjunto de elementos (supplier) para sua (completa) especificação.

De modo a definir um perfil UML para a abordagem SAWSDL, a metaclasse Dependency foi estendida pelos estereótipos Reference e FaultReference. O estereótipo Reference representa um relacionamento utilizado para referenciar elementos XML a partir de componentes da linguagem WSDL 2.0. Uma vez que os elementos XML referenciados permitem a completa especificação dos componentes WSDL que os referenciam e a metaclasse Dependency permite a modelagem deste tipo de dependência, esta metaclasse foi utilizada como base para a representação do estereótipo Reference. O estereótipo FaultReference representa um relacionamento utilizado para referenciar falhas a partir de mensagens de falha na linguagem WSDL 2.0. Uma vez que as falhas referenciadas permitem a completa especificação das mensagens que as referenciam, a metaclasse Dependency também foi utilizada como base para a representação do estereótipo FaultReference.

A metaclasse Association representa um relacionamento semântico entre instâncias. Uma associação deve ter pelo menos duas extremidades (memberEnd), de modo que cada uma delas seja representada por uma propriedade (metaclasse Property) e esteja indiretamente associada a um tipo correspondente (endType). As instâncias de uma associação são conhecidas como links. Assim, uma associação define a existência de links entre instâncias (memberEnd) de classificadores conectados às extremidades da associação. Além disto, uma associação pode ter uma ou mais extremidades navegáveis (navigableOwnedEnd). Uma extremidade navegável pode ser percorrida mais facilmente em tempo de execução partindo dos objetos da extremidade não navegável para os objetos da extremidade navegável. Extremidades navegáveis proveem apenas uma facilidade de navegação, ou seja, não impedem que ferramentas de desenvolvimento de modelos UML naveguem em direção a extremidades não navegáveis. 
Finalmente, para a definição de um perfil UML para a abordagem SAWSDL, a metaclasse Association foi especializada pelo estereótipo ModelReference. O estereótipo ModelReference representa o atributo de extensão modelReference da abordagem SAWSDL, que permite associar um componente de um documento WSDL 2.0 (origem) a um conceito proveniente de uma ontologia (destino). Uma vez que a metaclasse Association permite a associação semântica entre elementos de um modelo, esta metaclasse foi utilizada como base para a definição do estereótipo ModelReference.

De forma resumida, o perfil UML desenvolvido fornece sete estereótipos para a representação de componentes da linguagem WSDL 2.0: $<<$ wsdl interface $>>,<<$ wsdl operation $\rangle>$, $<<w s d l$ fault $>>,<<w s d l$ input $>>,<<w s d l$ output $>>,<<w s d l$ infault $>>$ e $<<w s d l$ outfault $>>$. Além disto, quatro estereótipos foram definidos para a representação de componentes de esquemas XML: $<<x$ s element $>>,<<x$ s simple type $>>,<<x$ s complex type $>>$ e $<<x$ s attribute $>>$. O estereótipo $<<$ ontology concept $>>$ foi definido para a representação de conceitos de ontologias. Finalmente, os estereótipos $<<$ model reference $\rangle>,<<$ references $>>$ e $<<$ fault reference $>>$ foram definidos para a representação do atributo de extensão modelReference e dos relacionamentos references e faultReference, respectivamente. O Apêndice A apresenta uma descrição detalhada de todos os estereótipos definidos no perfil UML desenvolvido, bem como as restrições OCL definidas para os estereótipos.

\subsection{CONCLUS ÃO}

Neste capítulo, apresentamos uma metodologia definida para o desenvolvimento de serviços web semânticos. Esta metodologia tem como objetivo permitir a criação de serviços a partir de ferramentas de software existentes, facilitando assim a adaptação sistemática destas ferramentas. A adaptação de ferramentas como serviços web semânticos tem como objetivo facilitar, posteriormente, o processo de integração (composição) das ferramentas e dados.

A metodologia proposta permite tanto o desenvolvimento quanto a anotação semântica de serviços, fornecendo um conjunto de diretrizes e também considerando aspectos técnicos relacionados ao desenvolvimento e à anotação dos serviços. Além disto, a metodologia proposta prescreve o uso de tecnologias e linguagens bem estabelecidas, tais como REST, WSDL e 
SAWSDL, facilitando a sua aplicação no desenvolvimento de serviços. Finalmente, a metodologia considera a especificação do comportamento local dos serviços criados por meio da linguagem BPMN, permitindo assim a criação de serviços web semânticos complexos.

Adicionalmente, apresentamos um conjunto de ferramentas desenvolvidas para fornecer suporte (semi) automático à realização de algumas atividades da metodologia, de modo a facilitar a sua aplicação no desenvolvimento de serviços. De forma específica, a ferramenta Wsdl2 Creator fornece suporte à criação, edição e validação de descrições WSDL de serviços. A ferramenta Wsdl2Bpmn Mapper fornece suporte à criação e validação de processos BPMN utilizados para especificar o comportamento local de serviços.

Finalmente, embora as anotações SAWSDL atribuídas a uma descrição de serviço sejam especificadas apenas de forma textual, consideramos que a representação gráfica destas anotações pode facilitar a modelagem e visualização das mesmas. Neste sentido, definimos um perfil UML para a abordagem SAWSDL. Este perfil fornece um conjunto de elementos de modelagem específicos que podem ser utilizados para a representação gráfica de anotações SAWSDL de forma padronizada. O uso do perfil proposto tem como objetivo oferecer uma abordagem mais intuitiva para a modelagem gráfica destas anotações do que apenas por meio de representações textuais. 
DESENVOLVIMENTO DE SERVIÇOS WEB SEMÂNTICOS PARA A ANÁlisE DE EXPRESS ÃO GÊNICA

Após a definição de uma metodologia para o desenvolvimento de serviços web semânticos, aplicamos esta metodologia no desenvolvimento de diferentes serviços para a análise de dados de expressão gênica. De modo a permitir a anotação semântica destes serviços, definimos também duas ontologias de suporte. Uma ontologia de domínio, chamada Gene Expression Analysis Ontology (GEXPO) [303], foi definida para o domínio de expressão gênica. Uma ontologia de serviços, chamada Gene Expression Analysis Services Ontology (GEXPASO) [271], foi definida para servir como base para a anotação semântica dos serviços desenvolvidos. Todos os serviços desenvolvidos, bem como as ontologias GEXPO e GEXPASO foram disponibilizados publicamente em um repositório, chamado Gene Expression Analysis Services (GEAS).

O restante deste capítulo está estruturado da seguinte forma: a Seção 5.1 apresenta as ontologias de suporte ao desenvolvimento de serviços para a análise de expressão gênica; a Seção 5.2 apresenta o repositório de serviços Gene Expression Analysis Services (GEAS); a Seção 5.3 apresenta, em detalhes, a aplicação da metodologia proposta no desenvolvimento de um dos serviços disponíveis no repositório GEAS, chamado EnrichmentAnalysis; finalmente, a Seção 5.4 apresenta as conclusões do capítulo. 


\subsection{ONTOLOGIAS DE SUPORTE}

Esta seção apresenta uma visão geral das ontologias de suporte definidas para permitir a anotação semântica de um conjunto representativo de serviços desenvolvidos para a análise de expressão gênica. A ontologia Gene Expression Ontology (GEXPO) foi definida para a descrição do domínio de genômica funcional. Por sua vez, a ontologia Gene Expression Analysis Services Ontology (GEXPASO) foi definida para a descrição de todos os serviços desenvolvidos. Estas duas ontologias estão associadas por meio de um conjunto de referências cruzadas que enriquecem a semântica de conceitos da ontologia GEXPASO com conceitos provenientes da ontologia GEXPO.

\subsubsection{Gene Expression Ontology (GEXPO)}

Diferentes ontologias têm sido propostas no domínio biomédico. Em geral, estas ontologias descrevem aspectos específicos do domínio, tais como processos biológicos, componentes celulares, sequências biológicas, dentre outros. No entanto, não há uma ontologia cujo foco principal seja a descrição do domínio de genômica funcional, embora muitos dos conceitos deste domínio estejam presentes em diferentes ontologias biomédicas. Desta forma, de modo a fornecer uma ontologia de domínio para a aplicação da metodologia proposta no desenvolvimento de serviços para a análise de expressão gênica, desenvolvemos a ontologia Gene Expression Ontology (GEXPO) [303].

A ontologia GEXPO foi criada com o objetivo inicial de agregar os termos do domínio de genômica funcional. Esta ontologia fornece um conjunto de conceitos e relacionamentos para a descrição dos biopolímeros e regiões biológicas envolvidos nos processos de expressão gênica e de medição de expressão gênica. A ontologia GEXPO também apresenta uma classificação dos diferentes tipos de processos experimentais disponíveis para medição de expressão gênica, bem como as plataformas experimentais associadas e os resultados produzidos por cada tipo de processo experimental. Além disto, esta ontologia descreve o processo biológico de expressão gênica e os processos biológicos de hibridização e transcrição reversa, envolvidos no processo de medição de expressão gênica. Finalmente, a ontologia GEXPO descreve os principais pro- 
cessos experimentais de medição de expressão gênica, que incluem microarrays de DNA e RNA-Seq.

Na ontologia GEXPO, a definição do processo de expressão gênica e dos processos experimentais de microarrays de DNA e RNA-Seq foi realizada com base em um modelo comum. A Figura 28 apresenta um diagrama de classes UML representando o modelo utilizado como base para a descrição destes processos na ontologia. Um retângulo (classe UML) representa, de forma abstrata, um conceito da ontologia. Os relacionamentos entre conceitos são apresentados por meio de uma notação similar à proposta por Guardia et al. [304]. O relacionamento part of e seu inverso (has part) são apresentados como agregações UML. Os demais relacionamentos são apresentados como associações UML estereotipadas.

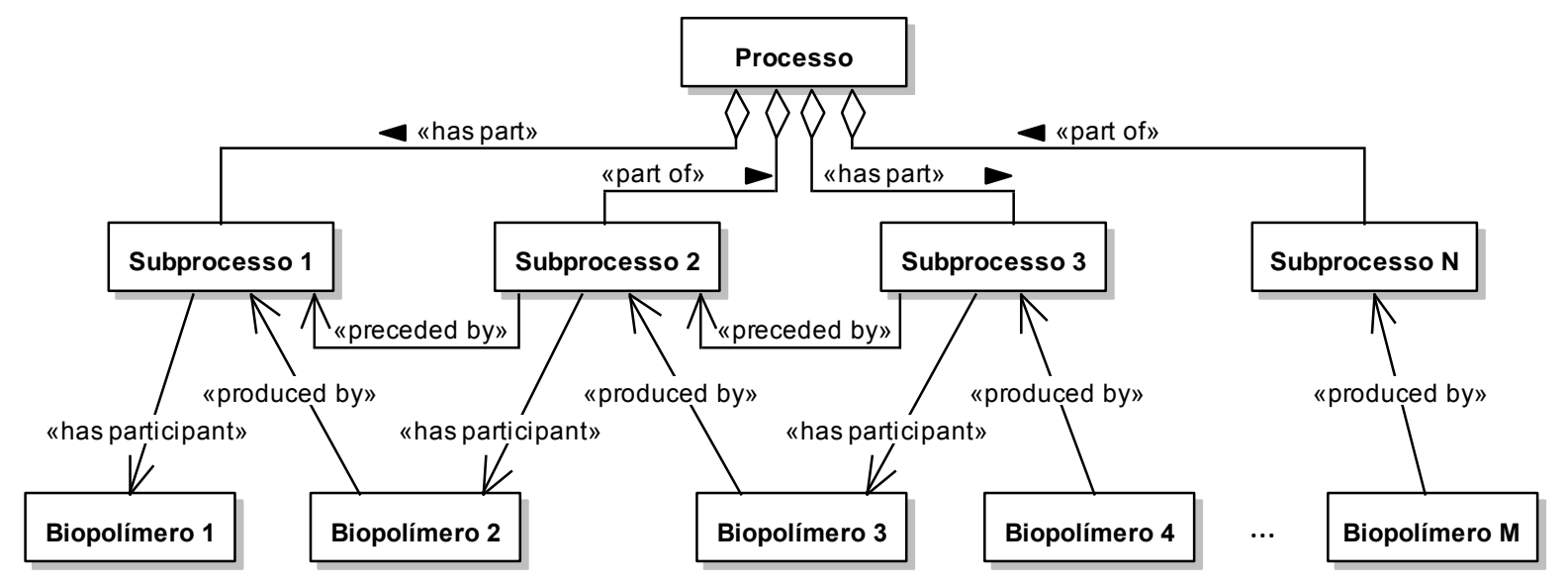

Figura 28: Modelo para descrição de processos na ontologia GEXPO.

Cada processo foi modelado como um conceito da ontologia GEXPO. Além disto, cada processo foi associado a um ou mais subprocessos por meio de relacionamentos part of ou has part. O relacionamento part of foi utilizado quando o subprocesso ocorre exclusivamente como parte de um único processo. O relacionamento has part foi utilizado quando o subprocesso pode ocorrer como parte de diferentes processos. Além disto, relacionamentos preceded by foram definidos entre os subprocessos. Um relacionamento preceded by definido entre dois subprocessos indica que a ocorrência de um subprocesso é precedida pela ocorrência de outro subprocesso.

Adicionalmente, cada subprocesso foi associado a um biopolímero por meio de um relacionamento has participant. Este relacionamento indica a participação do biopolímero no subprocesso. Finalmente, cada subprocesso foi associado a um biopolímero por meio de um re- 
lacionamento produced by. Este relacionamento indica que o biopolímero é produzido pelo subprocesso.

Durante o desenvolvimento da ontologia GEXPO, grande parte dos conceitos que representam biomoléculas envolvidas nos processos descritos na ontologia foram identificados a partir de outras duas ontologias: Gene Ontology (GO) [167] e Sequence Ontology (SO) [305]. A ontologia Gene Ontology possui um conjunto de conceitos e relacionamentos para a descrição de genes e produtos gênicos. Esta ontologia é composta por três sub-ontologias independentes: Cellular Component, que abrange conceitos utilizados na descrição de componentes celulares e extracelulares; Molecular Function, que possui conceitos utilizados na descrição das funções moleculares exercidas por produtos gênicos; e Biological Process, que contém conceitos utilizados na descrição de processos biológicos vitais para os seres vivos. A ontologia Sequence Ontology foi criada para padronizar o vocabulário utilizado nas anotações funcionais de sequências biológicas. Esta ontologia contém um conjunto de conceitos e relacionamentos para a descrição de características e atributos de sequências biológicas.

Além disto, alguns dos relacionamentos definidos na ontologia OBO Relation Ontology [306] foram utilizados para conectar os conceitos definidos na ontologia GEXPO. A ontologia OBO Relation Ontology foi desenvolvida com o intuito de padronizar os relacionamentos utilizados nas ontologias do domínio biomédico. Adicionalmente, relacionamentos específicos foram definidos na ontologia GEXPO para um nível de expressividade adequado.

A Tabela 2 apresenta os relacionamentos utilizados na ontologia GEXPO. A primeira coluna desta tabela contém os relacionamentos provenientes da ontologia OBO Relation Ontology. A segunda coluna contém os novos relacionamentos que foram definidos na ontologia GEXPO.

O relacionamento affected by representa um relacionamento definido entre um processo experimental e uma condição experimental pela qual o processo é afetado. O relacionamento produced by representa um relacionamento definido entre uma entidade resultante de um processo e o processo responsável por sua produção. Finalmente, o relacionamento quantifies representa um relacionamento definido entre um biopolímero e o conceito de quantidade de biopolímero.

A ontologia GEXPO foi desenvolvida com o uso do editor de ontologias Protégé na sintaxe padrão da OWL, ou seja, no formato RDF/XML. O Apêndice B apresenta, em detalhes, a definição da ontologia GEXPO. 


\section{Tabela 2: Relacionamentos da ontologia GEXPO}

\begin{tabular}{|c|c|}
\hline $\begin{array}{c}\text { Relacionamentos da OBO } \\
\text { Relation Ontology }\end{array}$ & Novos Relacionamentos \\
\hline \hline part of & \\
has part & affected by \\
located in & produced by \\
preceded by & quantifies \\
has participant & \\
has agent & \\
derives from & \\
\hline
\end{tabular}

\subsubsection{Gene Expression Analysis Service Ontology (GEXPASO)}

A ontologia Gene Expression Analysis Services Ontology (GEXPASO) [271] foi criada com o propósito de servir como base para a anotação semântica das descrições dos serviços desenvolvidos. Esta ontologia fornece todos os conceitos e relacionamentos necessários para a descrição dos aspectos estruturais e funcionais dos serviços desenvolvidos. Neste sentido, a ontologia GEXPASO fornece uma descrição de todos os tipos de dados consumidos e produzidos pelos serviços, bem como dos processos de análise realizados pelos serviços.

Na ontologia GEXPASO, a definição de todos os processos de análise e serviços associados foi realizada com base em um modelo comum. A Figura 29 apresenta um diagrama de classes UML representando o modelo utilizado como base para a descrição destes processos e serviços na ontologia.

Cada processo de análise foi modelado como um conceito da ontologia GEXPASO. Além disto, cada processo foi associado a um conjunto de dados de entrada e a um conjunto de dados de saída por meio de relacionamentos has participant e produced by, respectivamente. O relacionamento has participant indica que o processo requer os dados de entrada para sua execução. De forma análoga, o relacionamento produced by indica que o processo produz os dados de saída como resultado da sua execução. Além disto, cada processo foi associado a 


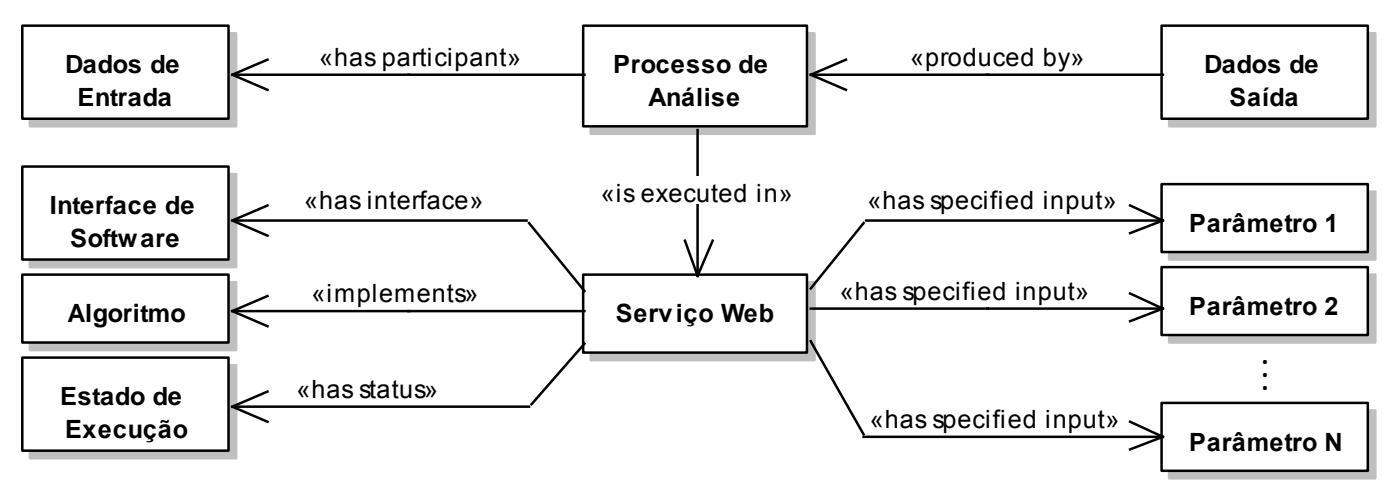

Figura 29: Modelo para descrição de processos e serviços na ontologia GEXPASO.

um serviço web por meio do relacionamento is executed in. Este relacionamento indica que o processo de análise é executado pelo serviço.

Cada serviço foi associado a um conceito representando uma interface de software por meio do relacionamento has interface. Este relacionamento indica que as funcionalidades fornecidas pelo serviço podem ser acessadas por meio de uma interface de software específica. Cada serviço também foi associado a um conceito representando um estado de execução por meio do relacionamento has status. Este relacionamento indica que a execução do processo de análise no serviço possui um estado associado. Adicionalmente, cada serviço foi associado a um algoritmo por meio do relacionamento implements. Este relacionamento indica que o serviço implementa um determinado algoritmo para a realização do processo de análise associado.

Um mesmo processo de análise pode ser executado por diferentes serviços. No entanto, cada serviço pode exigir como entrada um conjunto distinto de parâmetros de análise, os quais determinam como o algoritmo implementado pelo serviço é executado. Estes parâmetros incluem, por exemplo, identificadores de métodos de correção, valores limiares de corte e nível de significância, entre outros. Neste sentido, cada serviço também foi associado a um conjunto de parâmetros por meio de relacionamentos has specified input. Um relacionamento has specified input definido entre o serviço e um parâmetro indica que este serviço requer como entrada um determinado parâmetro.

A ontologia GEXPASO descreve diferentes processos de análise (concretos) realizados pelos serviços desenvolvidos. Os seguintes processos de análise são descritos na ontologia: préprocessamento de dados de microarray Affymetrix, Genepix e Agilent; identificação de genes diferencialmente expressos em dados de microarray (one e two-color) e RNA-Seq; agrupamento 
hierárquico e k-means de dados de microarray one-color e two-color; geração de dendrogramas de amostras e genes; análise de enriquecimento simples e de grupos de genes em dados de expressão gênica; e mapeamento e visualização de dados de expressão gênica em vias/processos biológicos KEGG.

Durante o desenvolvimento da ontologia GEXPASO, alguns conceitos e relacionamentos da ontologia Software Ontology (SWO) [307] foram utilizados. A ontologia Software Ontology foi desenvolvida de modo a prover uma base para a descrição de ferramentas de software. Esta ontologia descreve componentes de software tais como algoritmos, dados e processos. Assim, esta ontologia foi utilizada como base para a definição dos conceitos mais gerais da ontologia GEXPASO. Além disto, alguns dos relacionamentos definidos nas ontologias Software Ontology e OBO Relation Ontology foram utilizados para conectar os conceitos definidos na ontologia GEXPASO. Relacionamentos específicos também foram definidos na ontologia GEXPASO.

A Tabela 3 apresenta os relacionamentos utilizados na ontologia GEXPASO. A primeira coluna desta tabela contém os relacionamentos provenientes da ontologia Software Ontology. A segunda coluna contém os relacionamentos provenientes da ontologia OBO Relation Ontology. A terceira coluna contém os novos relacionamentos que foram definidos na ontologia GEXPASO.

Tabela 3: Relacionamentos da ontologia GEXPASO

\begin{tabular}{|c|c|c|}
\hline $\begin{array}{c}\text { Relacionamentos da } \\
\text { Software Ontology }\end{array}$ & $\begin{array}{c}\text { Relacionamentos da OBO } \\
\text { Relation Ontology }\end{array}$ & Novos Relacionamentos \\
\hline \hline has format specification & & represents \\
has interface & has part & has status \\
has license & has participant & produced by \\
has specified input & participates in & has type \\
has version & & \\
implements & & \\
is encoded in & & \\
is executed in & &
\end{tabular}


O relacionamento represents representa um relacionamento definido entre a representação (textual) de uma entidade e a entidade representada. O relacionamento has status representa um relacionamento definido entre um processo e o conceito de estado de processo. O relacionamento produced by representa um relacionamento definido entre uma entidade resultante de um processo e o processo responsável por sua produção. Finalmente, o relacionamento has type representa um relacionamento definido entre uma entidade e um tipo associado a esta entidade.

A ontologia GEXPASO foi desenvolvida com o uso do editor de ontologias Protégé na sintaxe padrão da OWL (formato RDF/XML). O Apêndice C apresenta, em detalhes, a definição da ontologia GEXPASO.

Após a definição da ontologia GEXPASO, diferentes referências cruzadas foram estabelecidas entre esta ontologia e a ontologia GEXPO. A definição destas referências teve como objetivo enriquecer semanticamente os conceitos fornecidos pela ontologia GEXPASO com conceitos provenientes da ontologia GEXPO. A criação destas referências cruzadas foi realizada por meio do estabelecimento de relacionamentos entre conceitos provenientes das duas ontologias. O Apêndice D apresenta as referências cruzadas definidas entre as ontologias GEXPO e GEXPASO.

\subsection{REPOSITÓRIO GENE EXPRESSION ANALYSIS SERVICES (GEAS)}

A metodologia proposta para o desenvolvimento de serviços web semânticos foi aplicada no desenvolvimento de um conjunto representativo de serviços para a análise de expressão gênica. Estes serviços fornecem suporte à análise de diferentes tipos de dados de expressão gênica, incluindo dados de microarray e de RNA-Seq. Além disto, os serviços desenvolvidos fornecem suporte à realização de diferentes atividades de análise, tais como normalização, identificação de genes diferencialmente expressos e análise funcional, dentre outras.

Todos os serviços desenvolvidos foram agrupados em um repositório público de serviços, chamado Gene Expression Analysis Services (GEAS) [271]. O repositório GEAS está disponível em http://dcm.ffclrp.usp.br/lssb/geas/. Este repositório fornece acesso a todos os serviços desenvolvidos e oferece documentação detalhada sobre cada um dos serviços disponíveis. 
A estrutura do repositório GEAS foi inspirada no tipo de estrutura utilizada no repositório de serviços Database for Annotation, Visualization and Integrated Discovery (DAVID) [308]. O repositório DAVID fornece um conjunto de serviços SOAP que podem ser acessados por bioinformatas de maneira programática, de modo a automatizar a realização de tarefas de usuário. Para cada serviço, o repositório DAVID fornece sua localização, sua descrição WSDL, uma descrição textual das operações do serviço e dos parâmetros de entrada de cada operação, bem como um conjunto de códigos que podem ser utilizados para a acessar as funcionalidades do serviço de maneira programática. Neste sentido, a documentação sobre cada serviço disponível no repositório GEAS está estruturada em seis partes:

1. Descrição geral sobre o serviço, a qual descreve as funcionalidades fornecidas pelo serviço e a ferramenta de software adaptada pelo serviço;

2. Localização do serviço, a qual fornece a URL do endpoint do serviço;

3. Descrição de todas as operações fornecidas pelo serviço, a qual fornece, para cada operação do serviço, a descrição da sua funcionalidade, dos seus parâmetros de entrada e saída e do método HTTP associado;

4. Especificação do comportamento local do serviço, a qual descreve, por meio de um ou mais processos BPMN, o comportamento local do serviço. Além de uma representação textual, cada processo BPMN também é representado graficamente. Esta representação gráfica apresenta o fluxo de execução das operações do serviço e os elementos de dados associados a cada operação. A descrição da notação utilizada para a representação gráfica dos processos também é fornecida para facilitar sua compreensão;

5. Conjunto de códigos na linguagem Java, os quais podem ser utilizados para a acessar as funcionalidades do serviço de maneira programática. Pelo menos dois conjuntos de códigos são disponibilizados, incluindo ao menos um código de cliente e um código de análise. O código de cliente fornece suporte à invocação de cada operação do serviço. O código de análise fornece um exemplo de como o código de cliente pode ser utilizado para invocar as operações do serviço. Adicionalmente, instruções detalhadas para auxiliar os usuários a utilizarem o conjunto de códigos Java são fornecidas; 
6. Descrição WSDL do serviço semanticamente anotada, a qual inclui um arquivo textual no formato WSDL e uma representação gráfica das anotações semânticas SAWSDL atribuídas à descrição do serviço. A representação gráfica das anotações utiliza a notação proposta no perfil UML definido para a abordagem SAWSDL.

Adicionalmente à descrição dos serviços desenvolvidos, as ontologias GEXPO e GEXPASO também foram publicamente disponibilizadas no repositório GEAS.

De modo a estruturar a apresentação dos serviços disponíveis no repositório GEAS, os mesmos foram agrupados em três categorias de acordo com os tipos de dados processados: serviços para dados de microarray, dados de RNA-Seq e dados de expressão gênica em geral. Os serviços pertencentes a cada categoria são apresentados nas subseções a seguir.

\subsubsection{Serviços para Dados de Microarray}

Os seguintes serviços foram desenvolvidos para fornecer suporte à análise de dados de expressão gênica produzidos a partir de plataformas de microarray: MicroAffyNorm, MicroAgilentNorm, MicroGenepixNorm, MicroOneDifferentialAnalysis, MicroTwoDifferentialAnalysis, MicroHCluster, MicroKCluster e MicroHClusterViewer. A Tabela 4 apresenta de forma resumida estes serviços, suas funcionalidades e as ferramentas de software adaptadas por cada serviço.

\section{Serviço MicroAffyNorm}

O serviço MicroAffyNorm permite o pré-processamento de dados de microarray one-color obtidos a partir da plataforma Affymetrix [57]. Este serviço foi implementado como um adaptador para a ferramenta de software R Server [309,310] usando o pacote affy [78,311]. Este pacote é disponibilizado como parte do projeto Bioconductor [312,313].

O serviço MicroAffyNorm requer como entrada um conjunto de dados brutos de microarray one-color obtidos a partir da plataforma Affymetrix. Estes dados podem representar uma ou mais amostras de mRNA (réplicas) associadas a uma ou mais condições experimentais distintas. Os dados de microarray devem ser disponibilizados em um ou mais arquivos no formato CEL [64], de modo que cada arquivo represente uma única condição experimental. Um arquivo no 
Tabela 4: Serviços para a análise de dados de microarray disponíveis no repositório GEAS.

\begin{tabular}{|c|l|c|}
\hline \multicolumn{1}{|c|}{ Serviço } & \multicolumn{1}{|c|}{ Funcionalidade } & Ferramenta \\
\hline \hline MicroAffyNorm & $\begin{array}{l}\text { Pré-processamento de dados de microarray Affyme- } \\
\text { trix }\end{array}$ & pacote R affy \\
\hline MicroAgilentNorm & $\begin{array}{l}\text { Pré-processamento de dados de microarray Agilent } \\
\text { (one-color) }\end{array}$ & pacote R limma \\
\hline MicroGenepixNorm & Pré-processamento de dados de microarray Genepix & pacote R limma \\
\hline MicroOneDifferentialAnalysis & $\begin{array}{l}\text { Identificação de genes diferencialmente expressos } \\
\text { em dados de microarray one-color }\end{array}$ & biblioteca padrão R \\
\hline MicroTwoDifferentialAnalysis & $\begin{array}{l}\text { Identificação de genes diferencialmente expressos } \\
\text { em dados de microarray two-color }\end{array}$ & biblioteca padrão $\mathrm{R}$ \\
\hline MicroHCluster & $\begin{array}{l}\text { Agrupamento hierárquico de dados de microarray } \\
\text { (one/two-color) }\end{array}$ & Cluster 3.0 \\
\hline MicroKCluster & $\begin{array}{l}\text { Agrupamento k-means de dados de microarray } \\
\text { (one/two-color) }\end{array}$ & Cluster 3.0 \\
\hline MicroHClusterViewer & $\begin{array}{l}\text { Visualização de dados de microarray hierarquica- } \\
\text { mente agrupados }\end{array}$ & Java TreeView \\
\hline
\end{tabular}

formato CEL armazena os valores de intensidade obtidos a partir de uma imagem de microarray para cada spot, os desvios padrão destas intensidades e o número de pixels utilizado para o cálculo das intensidades, dentre outras informações. Este arquivo pode ser disponibilizado como um arquivo texto ou como um arquivo binário.

Em geral, o pré-processamento de dados Affymetrix consiste em quatro etapas: correção de background, normalização entre arrays, correção de hibridização cruzada e sumarização. A etapa de correção de hibridização cruzada consiste na correção das intensidades obtidas a partir de sondas que não pareiam perfeitamente com mRNAs de interesse. No serviço MicroAffyNorm, o pré-processamento de dados é realizado com o uso do algoritmo Robust Multi-array Average (RMA) fornecido pelo pacote affy. Este algoritmo realiza as etapas de correção de background, normalização entre arrays e sumarização. No entanto, a etapa de correção de hibridização cruzada não é realizada, uma vez que as intensidades obtidas a partir de sondas que não pareiam perfeitamente com mRNAs de interesse não são consideradas durante as outras etapas.

A Tabela 5 apresenta as etapas de pré-processamento e os métodos utilizados em cada etapa no serviço MicroAffyNorm. 
Tabela 5: Métodos de pré-processamento do serviço MicroAffyNorm.

\begin{tabular}{|c|c|}
\hline Etapa de pré-processamento & Método MicroAffyNorm \\
\hline \hline Correção de background & robust multiarray analysis \\
\hline Normalização entre arrays & quantiles \\
\hline Correção de hibridização cruzada & \\
\hline Sumarização & medianpolish \\
\hline
\end{tabular}

Como resultado do pré-processamento dos dados, o serviço MicroAffyNorm produz um arquivo texto tabular contendo os dados de microarray normalizados. Cada linha deste arquivo contém um identificador de gene e o seu valor de expressão normalizado para cada amostra (colunas). Os valores de expressão gênica são apresentados em escala logarítmica (base 2).

\section{Serviço MicroAgilentNorm}

O serviço MicroAgilentNorm permite o pré-processamento de dados de microarray one-color obtidos a partir da plataforma Agilent [58]. Este serviço foi implementado como um adaptador para a ferramenta de software $\mathrm{R}$ Server usando o pacote limma [82,314]. Este pacote é disponibilizado como parte do projeto Bioconductor.

O serviço MicroAgilentNorm requer como entrada um conjunto de dados brutos de microarray one-color obtidos a partir da plataforma Agilent. Estes dados podem representar uma ou mais amostras de mRNA (réplicas) associadas a uma ou mais condições experimentais distintas. Os dados de microarray devem ser disponibilizados em um ou mais arquivos texto, de modo que cada arquivo represente uma única condição experimental. Um arquivo texto produzido a partir da plataforma Agilent armazena os valores de intensidade obtidos a partir de uma imagem de microarray para cada spot, além de outras informações adicionais.

No serviço MicroAgilentNorm, o pré-processamento de dados é realizado em diferentes etapas. A Tabela 6 apresenta as etapas de pré-processamento e os métodos utilizados em cada etapa.

De forma análoga ao serviço MicroAffymetrixNorm, a etapa de correção de hibridização cruzada também não é realizada no serviço MicroAgilentNorm. Esta etapa não é realizada porque 
Tabela 6: Métodos de pré-processamento do serviço MicroAgilentNorm.

\begin{tabular}{|c|c|}
\hline Etapa de pré-processamento & Método MicroAgilentNorm \\
\hline \hline Correção de background & subtract \\
\hline Normalização entre arrays & quantiles \\
\hline Correção de hibridização cruzada & \\
\hline Sumarização & avereps \\
\hline
\end{tabular}

as intensidades obtidas a partir das sondas que não pareiam perfeitamente com os mRNAs de interesse também não são consideradas durante as outras etapas de pré-processamento.

Como resultado do pré-processamento dos dados, o serviço MicroAgilentNorm produz um arquivo texto tabular contendo os dados de microarray normalizados. Cada linha deste arquivo contém um identificador de gene e o seu valor de expressão normalizado para cada amostra (colunas). Os valores de expressão gênica são apresentados em escala logarítmica (base 2).

\section{Serviço MicroGenepixNorm}

O serviço MicroGenepixNorm permite o pré-processamento de dados de microarray two-color obtidos a partir do sistema de escaneamento Genepix. Este serviço foi implementado como um adaptador para a ferramenta de software R Server usando o pacote limma [82,314]. Este pacote é disponibilizado como parte do projeto Bioconductor.

O serviço MicroGenepixNorm requer como entrada um conjunto de dados brutos de microarray two-color obtidos a partir do sistema de escaneamento Genepix. Estes dados podem representar uma ou mais amostras de mRNA (réplicas) associadas a uma ou mais condições experimentais distintas. Os dados de microarray devem ser disponibilizados em um ou mais arquivos no formato GPR [65], de modo que cada arquivo represente uma única condição experimental. Um arquivo no formato GPR armazena os valores de intensidade obtidos a partir de uma imagem de microarray para cada spot. Além disto, um arquivo neste formato contém informações sobre a estrutura do array, tais como a localização dos spots de DNA, e outras informações adicionais. Este arquivo é disponibilizado apenas como um arquivo texto. 
No serviço MicroGenepixNorm, o pré-processamento de dados é realizado em diferentes etapas. A Tabela 7 apresenta as etapas de pré-processamento e os métodos utilizados em cada etapa.

Tabela 7: Métodos de pré-processamento do serviço MicroGenepixNorm.

\begin{tabular}{|c|c|}
\hline Etapa de pré-processamento & Método MicroGenepixNorm \\
\hline \hline Correção de background & subtract \\
\hline Normalização dentro de arrays & loess \\
\hline Normalização entre arrays & Aquantile \\
\hline Sumarização & loess \\
\hline
\end{tabular}

Como resultado do pré-processamento dos dados, o serviço MicroGenepixNorm produz um arquivo texto tabular contendo os dados de microarray normalizados. Cada linha deste arquivo contém um identificador de gene e o seu valor de expressão normalizado para cada amostra (colunas). Os valores de expressão gênica são apresentados em escala logarítmica (base 2).

\section{Serviço MicroOneDifferentialAnalysis}

O serviço MicroOneDifferentialAnalysis permite a identificação de genes diferencialmente expressos em dados de microarray one-color. Este serviço foi implementado como um adaptador para a ferramenta de software R Server usando bibliotecas padrão da linguagem R.

O serviço MicroOneDifferentialAnalysis requer como entrada um conjunto de dados de microarray one-color normalizados. Estes dados podem representar uma ou mais amostras de mRNA (réplicas) associadas a duas condições experimentais distintas. Os dados associados a cada condição experimental devem ser disponibilizados separadamente em dois arquivos texto tabulares. Cada linha dos arquivos deve conter um identificador de gene e o seu valor de expressão normalizado e em escala logarítmica (base 2). Cada coluna dos arquivos deve representar uma amostra.

No serviço MicroOneDifferentialAnalysis, a identificação de genes diferencialmente expressos pode ser realizada com o uso dos métodos fold change ou teste t de Student. Para realizar a análise fold change, o serviço requer como entrada um parâmetro adicional, que consiste em 
um valor limiar de corte para a seleção dos genes. Para realizar a análise t de Student, o serviço requer como entrada três parâmetros adicionais: um número real representando o nível de significância do teste; um número real representando um valor limiar de corte para a seleção dos genes; e um identificador representando um método de correção de múltiplos testes.

A Tabela 8 apresenta os métodos de correção de múltiplos testes que podem ser utilizados no serviço MicroOneDifferentialAnalysis e os identificadores associados a cada método. Farcomeni [315] apresenta, em detalhes, a descrição destes métodos de correção de múltiplos testes.

Tabela 8: Métodos de correção de múltiplos testes do serviço MicroOneDifferentialAnalysis.

\begin{tabular}{|c|c|}
\hline Método de correção & Identificador \\
\hline \hline Bonferroni Correction & bonferroni \\
\hline BY Correction & BY \\
\hline Hochberg Correction & hochberg \\
\hline Holm Correction & holm \\
\hline Hommel Correction & hommel \\
\hline False Discovery Rate (FDR) / BH Correction & BH \\
\hline
\end{tabular}

Como resultado da análise, o serviço MicroOneDifferentialAnalysis produz um arquivo texto tabular contendo uma lista de genes diferencialmente expressos. Quando a análise é realizada com o uso do método fold change, cada linha deste arquivo contém apenas o identificador exclusivo de cada gene. Quando a análise é realizada com o uso do método t de Student, cada linha do arquivo contém o identificador exclusivo de cada gene, bem como o valor da estatística de teste t e o valor-p associados. Adicionalmente, se algum método de correção é aplicado na análise t de Student, cada linha do arquivo contém também um valor-p ajustado.

\section{Serviço MicroTwoDifferentialAnalysis}

O serviço MicroTwoDifferentialAnalysis permite a identificação de genes diferencialmente expressos em dados de microarray two-color. Este serviço foi implementado como um adaptador para a ferramenta de software R Server usando bibliotecas padrão da linguagem R. 
O serviço MicroTwoDifferentialAnalysis requer como entrada um conjunto de dados de microarray two-color normalizados. Estes dados podem representar uma ou mais amostras de mRNA (réplicas) associadas a duas condições experimentais distintas. Os dados devem ser disponibilizados em um único arquivo texto tabular. Cada linha do arquivo deve conter um identificador de gene e o seu valor de expressão normalizado e em escala logarítmica (base 2). Cada coluna do arquivo deve representar uma amostra.

De forma semelhante ao serviço MicroOneDifferentialAnalysis, a identificação de genes diferencialmente expressos no serviço MicroTwoDifferentialAnalysis também pode ser realizada com o uso dos métodos fold change ou teste t de Student. O serviço MicroTwoDifferentialAnalysis requer como entrada os mesmos parâmetros de análise que o serviço MicroOneDifferentialAnalysis. Como resultado da análise, o serviço MicroTwoDifferentialAnalysis também produz um arquivo texto tabular contendo uma lista de genes diferencialmente expressos.

\section{Serviço MicroHCluster}

O serviço MicroHCluster permite o agrupamento hierárquico de dados de microarray normalizados (one e two-color). Este serviço foi implementado como um adaptador para a ferramenta de software Cluster 3.0 [316].

O serviço MicroHCluster requer como entrada um conjunto de dados de microarray normalizados. Estes dados podem representar uma ou mais amostras de mRNA (réplicas) associadas a duas ou mais condições experimentais distintas. Os dados devem ser disponibilizados em um único arquivo texto tabular. Cada linha do arquivo deve conter um identificador de gene e o seu valor de expressão normalizado. Cada coluna do arquivo deve representar uma amostra.

No serviço MicroHCluster, os dados de microarray podem ser hierarquicamente agrupados em amostras ou em genes. Para realizar o agrupamento dos dados, o serviço requer como entrada dois parâmetros adicionais: um identificador representando um método de agrupamento hierárquico e um identificador representando uma métrica de similaridade.

A Tabela 9 apresenta os métodos que podem ser utilizados para o agrupamento hierárquico no serviço MicroHCluster. D'haeseleer [147] apresenta, em detalhes, a descrição destes métodos de agrupamento. 
Tabela 9: Métodos de agrupamento do serviço MicroHCluster.

\begin{tabular}{|c|c|}
\hline Método de Agrupamento & Identificador \\
\hline \hline Ligação média & pairwise average-linkage \\
\hline Ligação de centroides & pairwise centroid-linkage \\
\hline Ligação completa & pairwise complete-linkage \\
\hline Ligação simples & pairwise single-linkage \\
\hline
\end{tabular}

A Tabela 10 apresenta as métricas de similaridade que podem ser utilizadas para o agrupamento hierárquico no serviço MicroHCluster. Jiang et al. [155] apresenta, em detalhes, a descrição destas métricas de similaridade.

Tabela 10: Métricas de similaridade do serviço MicroHCluster.

\begin{tabular}{|c|c|}
\hline Métrica de similaridade & Identificador \\
\hline \hline City-block distance & city-block distance \\
\hline Euclidean distance & euclidean distance \\
\hline Kendall's Tau & kendalls tau \\
\hline Pearson correlation & pearson correlation \\
\hline Pearson correlation (absolute value) & pearson correlation (absolute value) \\
\hline Spearman's rank correlation & spearmans rank correlation \\
\hline Uncentered correlation & uncentered correlation \\
\hline Uncentered correlation (absolute value) & uncentered correlation (absolute value) \\
\hline
\end{tabular}

Como resultado da análise, o serviço MicroHCluster produz dois arquivos texto tabulares contendo os dados de microarray agrupados. Quando o agrupamento de amostras é realizado, um dos arquivos (formato .atr) apresenta a hierarquia de amostras gerada a partir do agrupamento dos dados. Cada linha deste arquivo representa um agrupamento, contendo um identificador exclusivo para o agrupamento, identificadores exclusivos dos dois elementos (amostras) agrupados e um valor numérico que indica o grau de similaridade do agrupamento. $\mathrm{O}$ outro arquivo (formato .cdt) apresenta os dados originais com as colunas (amostras) reordenadas de acordo 
com o resultado do agrupamento. Este arquivo contém duas linhas adicionais, que apresentam os identificadores exclusivos e os pesos numéricos atribuídos a cada amostra, respectivamente. Os identificadores gerados para cada amostra são os mesmos utilizados no arquivo atr para a representação das amostras agrupadas.

Quando o agrupamento de genes é realizado, um dos arquivos (formato .gtr) apresenta a hierarquia de genes gerada a partir do agrupamento dos dados. Cada linha deste arquivo representa um agrupamento, contendo um identificador exclusivo para o agrupamento, identificadores exclusivos dos dois elementos (genes) agrupados e um valor numérico que indica o grau de similaridade do agrupamento. O outro arquivo (formato .cdt) apresenta os dados originais com as linhas (genes) reordenadas de acordo com o resultado do agrupamento. Este arquivo contém duas colunas adicionais, que apresentam os identificadores exclusivos e os pesos numéricos atribuídos a cada gene, respectivamente. Os identificadores gerados para cada gene são os mesmos utilizados no arquivo .gtr para a representação dos genes agrupados.

\section{Serviço MicroKCluster}

O serviço MicroKCluster permite o agrupamento k-means de dados de microarray normalizados (one e two-color). Este serviço foi implementado como um adaptador para a ferramenta de software Cluster 3.0 [316].

O serviço MicroKCluster requer como entrada um conjunto de dados de microarray normalizados. Estes dados podem representar uma ou mais amostras de mRNA (réplicas) associadas a duas ou mais condições experimentais distintas. Os dados devem ser disponibilizados em um único arquivo texto tabular. Cada linha do arquivo deve conter um identificador de gene e o seu valor de expressão normalizado. Cada coluna do arquivo deve representar uma amostra.

No serviço MicroKCluster, os dados de microarray podem ser agrupados por amostras ou genes. Para realizar o agrupamento dos dados, o serviço requer como entrada três parâmetros adicionais: um número inteiro positivo representando a quantidade de grupos $(\mathrm{K})$ a ser considerada no agrupamento; um número inteiro positivo representando a quantidade de vezes que o algoritmo k-means deve ser executado; e um identificador representando uma métrica de similaridade. O serviço MicroKCluster permite a aplicação das mesmas métricas de similaridade disponíveis para o serviço MicroHCluster (Tabela 10). 
Como resultado da análise, o serviço MicroKCluster produz dois arquivos texto tabulares contendo os dados de microarray agrupados. Quando o agrupamento de amostras é realizado, um dos arquivos (formato .kag) apresenta a lista de amostras e os grupos aos quais as mesmas foram atribuídas durante o agrupamento dos dados. Cada linha deste arquivo contém o identificador exclusivo de cada amostra e o identificador exclusivo do grupo ao qual a amostra foi atribuída. O outro arquivo (formato .cdt) apresenta os dados originais com as colunas (amostras) reordenadas de acordo com o resultado do agrupamento. Este arquivo contém duas linhas adicionais que apresentam os identificadores exclusivos e os pesos numéricos atribuídos a cada amostra, respectivamente. Os identificadores gerados para cada amostra são os mesmos utilizados no arquivo .kag para a representação das amostras agrupadas.

Quando o agrupamento de genes é realizado, um dos arquivos (formato .kgg) apresenta a lista de genes e os grupos aos quais os mesmos foram atribuídos durante o agrupamento dos dados. Cada linha deste arquivo contém o identificador exclusivo de cada gene e o identificador exclusivo do grupo ao qual o gene foi atribuído. O outro arquivo (formato .cdt) apresenta os dados originais com as linhas (genes) reordenadas de acordo com o resultado do agrupamento. Este arquivo contém duas colunas adicionais, que apresentam os identificadores exclusivos e os pesos numéricos atribuídos a cada gene, respectivamente. Os identificadores gerados para cada gene são os mesmos utilizados no arquivo .kgg para a representação dos genes agrupados.

\section{Serviço MicroHClusterViewer}

O serviço MicroHClusterViewer permite a visualização de dados de microarray one-color ou two-color que tenham sido hierarquicamente agrupados. Este serviço foi implementado como um adaptador para a ferramenta de software Java TreeView [317].

O serviço MicroHClusterViewer requer como entrada um conjunto de dados de microarray hierarquicamente agrupados em amostras ou em genes. Estes dados devem ser disponibilizados em dois arquivos texto tabulares. Para a visualização de agrupamentos de amostras, o serviço MicroHClusterViewer requer um arquivo no formato atr e um arquivo no formato .cdt. $\mathrm{O}$ arquivo .atr deve conter a hierarquia de amostras gerada a partir do agrupamento dos dados. Cada linha deste arquivo deve conter um identificador exclusivo do agrupamento, identificadores exclusivos dos dois elementos (amostras) agrupados e um valor numérico que indica o grau de 
similaridade do agrupamento. Por sua vez, o arquivo .cdt deve conter dados de microarray normalizados com as colunas (amostras) reordenadas de acordo com o resultado do agrupamento. Cada linha deste arquivo deve conter um identificador de gene e o seu valor de expressão normalizado. Cada coluna do arquivo deve representar uma amostra. Além disto, este arquivo deve conter duas linhas adicionais, que apresentem os identificadores exclusivos e os pesos numéricos atribuídos a cada amostra, respectivamente. Os identificadores de cada amostra devem ser os mesmos utilizados no arquivo .atr para a representação das amostras agrupadas.

Para a visualização de agrupamentos de genes, o serviço MicroHClusterViewer requer um arquivo no formato .gtr e um arquivo no formato .cdt. O arquivo .gtr deve conter a hierarquia de genes gerada a partir do agrupamento dos dados. Cada linha deste arquivo deve conter um identificador exclusivo do agrupamento, identificadores exclusivos dos dois elementos (genes) agrupados e um valor numérico que indica o grau de similaridade do agrupamento. Por sua vez, o arquivo .cdt deve conter dados de microarray normalizados com as linhas (genes) reordenadas de acordo com o resultado do agrupamento. Cada linha deste arquivo deve conter um identificador de gene e o seu valor de expressão normalizado. Cada coluna do arquivo deve representar uma amostra. Além disto, este arquivo deve conter duas colunas adicionais, que apresentem os identificadores exclusivos e os pesos numéricos atribuídos a cada gene, respectivamente. Os identificadores de cada gene devem ser os mesmos utilizados no arquivo .gtr para a representação dos genes agrupados.

Como resultado, o serviço MicroHClusterViewer produz um arquivo no formato .png, contendo um dendrograma de amostras/genes. Este dendrograma fornece uma representação gráfica do agrupamento hierárquico dos dados de microarray.

\subsubsection{Serviço para Dados de RNA-Seq}

O serviço RnaSeqDifferentialAnalysis foi especificamente desenvolvido para fornecer suporte à análise de dados de expressão gênica produzidos a partir de plataformas de RNA-Seq. A Tabela 11 apresenta de forma resumida este serviço, sua funcionalidade e a ferramenta de software adaptada pelo mesmo. 
Tabela 11: Serviço para a análise de dados de RNA-Seq disponível no repositório GEAS.

\begin{tabular}{|c|l|c|}
\hline Serviço & \multicolumn{1}{|c|}{ Funcionalidade } & Ferramenta \\
\hline \hline RnaSeqDifferentialAnalysis & $\begin{array}{l}\text { Identificação de genes diferencialmente expressos } \\
\text { em dados de RNA-Seq }\end{array}$ & pacote R DESeq2 \\
\hline
\end{tabular}

O serviço RnaSeqDifferentialAnalysis permite a identificação de genes diferencialmente expressos em dados de RNA-Seq. Este serviço foi implementado como um adaptador para a ferramenta de software R Server usando o pacote DESeq2 [146]. Este pacote é disponibilizado como parte do projeto Bioconductor.

O serviço RnaSeqDifferentialAnalysis requer como entrada um conjunto de dados de contagens de genes obtidos a partir da sumarização de dados de RNA-Seq que tenham sido previamente mapeados para um genoma de referência. A análise diferencial de dados brutos de RNA-Seq não é suportada. Estes dados podem representar uma ou mais amostras de mRNA (réplicas) associadas a duas condições experimentais distintas. Os dados devem ser disponibilizados em um ou mais arquivos texto tabulares, de modo que cada arquivo represente uma única amostra associada a uma condição experimental. Cada linha do arquivo deve conter um identificador de gene e o número de reads mapeados para o gene correspondente, representando seu valor absoluto de expressão.

No serviço RnaSeqDifferentialAnalysis, a identificação de genes diferencialmente expressos é realizada com o uso de um modelo baseado na distribuição binomial negativa. Para a identificação de genes diferencialmente expressos, o serviço RnaSeqDifferentialAnalysis requer a especificação de quais amostras estão associadas a cada condição experimental. Além disto, o serviço requer como entrada três parâmetros adicionais: um número real representando o nível de significância considerado na análise; um número real representando um valor limiar de corte para a seleção dos genes; e um valor booleano indicando se o método de correção de múltiplos testes False Discovery Rate (FDR) [103] deve ser aplicado na análise.

Como resultado da análise, o serviço RnaSeqDifferentialAnalysis produz um arquivo texto tabular contendo uma lista de genes diferencialmente expressos. Cada linha deste arquivo contém o identificador exclusivo de cada gene, bem como o valor médio de expressão, o valor fold change em escala logarítmica (base 2), o valor de erro padrão para o valor fold change, o valor 
da estatística de teste e o valor-p associados. Adicionalmente, quando o método de correção de múltiplos testes FDR é aplicado, cada linha do arquivo contém também o valor-p ajustado para cada gene.

\subsubsection{Serviços para Dados de Expressão Gênica}

Os seguintes serviços foram desenvolvidos para fornecer suporte à análise de dados de expressão gênica obtidos não apenas a partir de plataformas de microarray e RNA-Seq, mas também a partir de outras tecnologias: EnrichmentAnalysis, DAVID-REST, GeneSetEnrichmentAnalysis e KeggPathwayViewer. A Tabela 12 apresenta de forma resumida estes serviços, suas funcionalidades e as ferramentas de software adaptadas por cada serviço.

Tabela 12: Serviços para a análise de dados de expressão gênica disponíveis no repositório GEAS.

\begin{tabular}{|c|l|c|}
\hline Serviço & \multicolumn{1}{|c|}{ Funcionalidade } & Ferramenta \\
\hline \hline EnrichmentAnalysis & $\begin{array}{l}\text { Análise de enriquecimento de dados de expressão } \\
\text { gênica }\end{array}$ & pacote R gProfileR \\
\hline DAVID-REST & $\begin{array}{l}\text { Análise de enriquecimento de dados de expressão } \\
\text { gênica }\end{array}$ & serviço SOAP DAVID \\
\hline GeneSetEnrichmentAnalysis & $\begin{array}{l}\text { Análise de enriquecimento de grupos de genes em } \\
\text { dados de expressão gênica }\end{array}$ & pacote R gage \\
\hline KeggPathwayViewer & $\begin{array}{l}\text { Mapeamento e visualização de dados de expressão } \\
\text { gênica em vias/processos biológicos KEGG }\end{array}$ & pacote R pathview \\
\hline
\end{tabular}

\section{Serviço EnrichmentAnalysis}

O serviço EnrichmentAnalysis permite a análise de enriquecimento de dados de expressão gênica. Este serviço foi implementado como um adaptador para a ferramenta de software R Server usando o pacote gProfileR [318].

O serviço EnrichmentAnalysis requer como entrada uma lista de identificadores de genes. Os tipos de identificadores aceitos pelo serviço incluem os símbolos oficiais dos genes, bem como identificadores nos formatos Affymetrix, Entrez [319] ou Ensembl [320,321]. A lista 
de identificadores de genes deve ser fornecida em um único arquivo texto. Cada linha deste arquivo deve conter um identificador de gene.

No serviço EnrichmentAnalysis, a análise de enriquecimento é realizada com base em termos contidos nas ontologias Gene Ontology [167] e Human Phenotype Ontology [322], bem como nas bases de dados de anotação KEGG [169], REACTOME [168], MicroCosm [323], Biological General Repository for Interaction Datasets (BioGRID) [324] e TRANSFAC [170]. A análise de enriquecimento nestas ontologias e bases de dados é realizada com o uso do teste hipergeométrico.

Para a realização de uma análise, o serviço requer como entrada dois parâmetros adicionais: um identificador representando um método de correção de múltiplos testes e um identificador representando uma espécie biológica.

A Tabela 13 apresenta os métodos de correção de múltiplos testes que podem ser utilizados no serviço EnrichmentAnalysis e os identificadores associados a cada método. Farcomeni [315] apresenta, em detalhes, a descrição destes métodos de correção de múltiplos testes.

Tabela 13: Métodos de correção de múltiplos testes do serviço EnrichmentAnalysis.

\begin{tabular}{|c|c|}
\hline Método de Correção & Identificador \\
\hline \hline Bonferroni Correction & bonferroni \\
\hline False Discovery Rate (FDR) / BH Correction & $\mathrm{fdr}$ \\
\hline Set Counts and Sizes (SCS) Correction & $\mathrm{gSCS}$ \\
\hline
\end{tabular}

O serviço EnrichmentAnalysis permite a análise de 112 espécies distintas, incluindo Homo sapiens, organismos-modelo, tais como Saccharomyces cerevisiae e Drosophila melanogaster, além de diferentes classes de espécies cujos genomas foram anotados como parte do projeto Ensembl [320,321]. A Tabela 14 apresenta os organismos-modelo e as classes de espécies do projeto Ensembl que podem ser analisados no serviço EnrichmentAnalysis.

Como resultado da análise, o serviço EnrichmentAnalysis produz um arquivo texto tabular contendo uma lista de termos biológicos enriquecidos (valor $-p<0.05$ ). Cada linha deste arquivo contém um termo biológico associado a um identificador exclusivo. Além disto, cada linha contém o valor- $p$ de enriquecimento obtido, a quantidade total de genes do genoma do 
Tabela 14: Organismos-modelo e classes de espécies Ensembl do serviço EnrichmentAnalysis.

\begin{tabular}{|c|c|}
\hline Organismo-modelo & Classe de espécie Ensembl \\
\hline \hline Caenorhabditis elegans & \\
Danio rerio & Ensembl Animal \\
Drosophila melanogaster & Ensembl Plants \\
Mus musculus & Ensembl Metazoa \\
Rattus norvegicus & Ensembl Fungi \\
Saccharomyces cerevisiae & \\
\hline
\end{tabular}

organismo anotados com o respectivo termo biológico, a quantidade de genes da lista que foram analisados na base de dados, a quantidade de genes da lista anotados com o termo biológico, um valor de precisão, um valor de recall e os identificadores dos genes da lista anotados com o termo biológico. Os valores de precisão e de recall indicam a fração de genes da lista anotados com o termo biológico e a fração dos genes do genoma do organismo que apresentam-se anotados na base de dados sob análise e que são anotados com o termo biológico, respectivamente.

\section{Serviço DAVID-REST}

O serviço DAVID-REST permite a análise de enriquecimento de dados de expressão gênica. Este serviço foi implementado como um adaptador para o serviço web SOAP DAVID-WS [7].

O serviço DAVID-REST requer como entrada uma lista de identificadores de genes. Os identificadores de genes podem estar nos formatos das bases de dados Entrez Genes [319], Ensembl [320,321], GenBank [325] ou Reference Sequence (RefSeq) [326]. Adicionalmente, o serviço DAVID-REST permite o uso de identificadores de genes nos formatos definidos em bases de dados específicas para algumas espécies. Estas bases de dados incluem FlyBase [327], Mouse Genome Informatics [328], Rat Genome Database [329], Saccharomyces Genome Database [330], Arabidopsis Information Resource [331], WormBase [332] e Zebrafish Model Organism Database [333]. A lista de identificadores de genes deve ser fornecida em um único arquivo texto. Cada linha deste arquivo deve conter um identificador de gene. 
No serviço DAVID-REST, a análise de enriquecimento de dados de expressão gênica é realizada com o uso do teste estatístico exato de Fisher. Para a realização de uma análise, o serviço DAVID-REST requer como entrada cinco parâmetros adicionais: um endereço de email para autenticação (somente usuários cadastrados podem usar o serviço), um valor limiar de corte de sobre-representação de termos, um valor limiar de corte para o número mínimo de genes que devem estar associados a cada termo de anotação, um identificador representando o tipo dos identificadores de genes fornecidos e uma lista de identificadores representando de categorias de anotação.

O serviço DAVID-REST permite a análise de enriquecimento de 82 categorias de anotação classificadas em 8 tipos distintos. A Tabela 15 apresenta os tipos de anotação que podem ser analisados no serviço DAVID-REST e alguns exemplos de cada tipo.

Tabela 15: Tipos de categorias de anotação do serviço DAVID-REST.

\begin{tabular}{|c|c|}
\hline Tipo de categoria de anotação & Exemplos \\
\hline \hline Gene Ontology & Biological Process; Cellular Component; Molecular Function \\
\hline Protein Domains & Protein Families (PFAM); InterPro; Protein Data Bank (PDB) \\
\hline Pathways & BioCarta, Reactome Pathway Database, KEGG \\
\hline General Annotations & Cytoband, Online Mendelian Inheritance in Man (OMIM) \\
\hline Functional Categories & Clusters of Orthologous Groups (COG) Ontology \\
\hline Protein-Protein Interaction & BIND, TRANScription FACtor database \\
\hline Literature & PubMed; Gene Reference into Function (GeneRIF) \\
\hline Disease & Genetic Association Database \\
\hline
\end{tabular}

Como resultado da análise, o serviço DAVID-REST produz um arquivo texto tabular contendo uma lista de termos biológicos enriquecidos. Cada linha deste arquivo contém um termo biológico associado a um tipo de categoria de anotação e a um identificador exclusivo. Além disto, cada linha contém a quantidade e porcentagem de genes da lista anotados com o termo biológico, o valor- $p$ de enriquecimento obtido, os valores- $p$ ajustados pelos métodos de correção de múltiplos testes Bonferroni [99], Benjamini [104] e False Discovery Rate (FDR) [103]. Finalmente, cada linha contém os identificadores dos genes da lista anotados com o termo biológico. 


\section{Serviço GeneSetEnrichmentAnalysis}

O serviço GeneSetEnrichmentAnalysis permite a análise de enriquecimento de grupos de genes em dados de expressão gênica. Este serviço foi implementado como um adaptador para a ferramenta de software R Server usando o pacote gage [334]. Este pacote é disponibilizado como parte do projeto Bioconductor.

O serviço GeneSetEnrichmentAnalysis requer como entrada um conjunto de dados de expressão gênica normalizados. Estes dados podem representar uma ou mais amostras de mRNA (réplicas) associadas a duas condições experimentais distintas. Os dados devem ser disponibilizados em um único arquivo texto tabular. Cada linha do arquivo deve conter um identificador de gene e o seu valor de expressão normalizado e em escala logarítmica (base 2). Cada coluna do arquivo deve representar uma amostra.

Adicionalmente, o serviço requer como entrada os conjuntos de genes anotados com os termos biológicos provenientes das ontologias e/ou bases de dados de anotação que se deseja analisar. Estes dados devem ser disponibilizados em um único arquivo texto tabular, no formato .gmt (gene matrix transposed). Em geral, arquivos .gmt são disponibilizados pelas ontologias ou bases de dados de anotação. Cada linha do arquivo .gmt deve conter um termo biológico (primeira coluna) e os identificadores dos genes associados ao termo (demais colunas).

No serviço GeneSetEnrichmentAnalysis, a análise de enriquecimento de grupos de genes é realizada com o uso do método Generally Applicable Gene-set Enrichment (GAGE). Para a realização de uma análise, o serviço GeneSetEnrichmentAnalysis requer a especificação de quais amostras estão associadas a cada condição experimental. Além disto, o serviço requer como entrada dois parâmetros adicionais: um identificador representando o design do experimento (valores paired ou unpaired) e um valor booleano indicando se o método de correção de múltiplos testes False Discovery Rate (FDR) [103] deve ser aplicado na análise.

Como resultado da análise, o serviço GeneSetEnrichmentAnalysis produz um arquivo texto tabular contendo uma lista de termos biológicos enriquecidos. Cada linha deste arquivo contém um termo biológico de anotação. Além disto, cada linha contém o valor- $p$ de enriquecimento obtido, o valor médio das estatísticas de teste, a quantidade de genes anotados com o termo biológico e os identificadores dos genes analisados que encontram-se anotados com o termo 
biológico. Adicionalmente, se o método de correção FDR é aplicado, cada linha do arquivo contém também um valor- $p$ ajustado.

\section{Serviço KeggPathwayViewer}

O serviço KeggPathwayViewer permite a visualização de dados de expressão gênica em grafos representando vias ou processos biológicos na base de dados Kyoto Encyclopedia of Genes and Genomes (KEGG) [169]. Este serviço foi implementado como um adaptador para a ferramenta de software R Server usando o pacote pathview [335]. Este pacote é disponibilizado como parte do projeto Bioconductor.

O serviço KeggPathwayViewer requer como entrada um conjunto de dados de expressão gênica normalizados. Estes dados podem representar uma ou mais amostras de mRNA (réplicas) associadas a múltiplas condições experimentais. Os dados devem ser disponibilizados em um único arquivo texto tabular. Cada linha do arquivo deve conter um identificador de gene e o seu valor de expressão normalizado. Cada coluna do arquivo deve representar uma amostra. Os tipos de identificadores de genes aceitos pelo serviço KeggPathwayViewer incluem os símbolos oficiais dos genes, os nomes dos genes, bem como identificadores de genes nos formatos das bases de dados Entrez Genes [319] e Ensembl [320,321].

Para a geração de um grafo KEGG contendo dados de expressão gênica, o serviço KeggPathwayViewer requer como entrada três parâmetros adicionais: um identificador representando um grafo armazenado na base de dados KEGG, um identificador representando o tipo dos identificadores de genes fornecidos nos dados de expressão normalizados e um identificador representando uma espécie biológica.

O serviço KeggPathwayViewer permite a geração de grafos KEGG associados a 43 espécies distintas, incluindo Homo sapiens e organismos-modelo tais como Drosophila melanogaster, Rattus norvegicus e Saccharomyces cerevisiae. A Tabela 16 apresenta todos os organismosmodelo que podem ser analisados no serviço KeggPathwayViewer.

Como resultado, o serviço KeggPathwayViewer produz um arquivo no formato .png. Este arquivo fornece uma representação gráfica de uma via ou processo biológico KEGG contendo os dados de expressão fornecidos para análise. 
Tabela 16: Organismos-modelo do serviço KeggPathwayViewer.

\begin{tabular}{|c|c|c|}
\hline \multicolumn{3}{|c|}{ Organismo-modelo } \\
\hline \hline Anopheles gambiae & Arabidopsis thaliana & Bos taurus \\
Caenorhabditis elegans & Canis familiaris & Danio rerio \\
Drosophila melanogaster & E coli strain K12 & E coli strain Sakai \\
Gallus gallus & Macaca mulatta & Mus musculus \\
Pan troglodytes & Plasmodium falciparum & Rattus norvegicus \\
Saccharomyces cerevisiae & Sus scrofa & Xenopus laevis \\
\hline
\end{tabular}

\subsection{DESENVOLVIMENTO DO SERVIÇO ENRICHMENTANALYSIS}

De modo a ilustrar a aplicação da metodologia proposta para o desenvolvimento de serviços web semânticos, esta seção apresenta, em detalhes, a aplicação da metodologia no desenvolvimento de um dos serviços disponíveis no repositório GEAS, chamado EnrichmentAnalysis.

A primeira atividade da metodologia consiste na implementação de um serviço RESTful a partir de uma ferramenta de software existente. A segunda atividade consiste na geração automática da descrição WSDL do serviço. A terceira atividade consiste na definição de ontologias de domínio e de serviços para suporte à anotação semântica do serviço. A quarta atividade consiste na anotação semântica da descrição WSDL do serviço de acordo com a abordagem SAWSDL. Finalmente, a quinta atividade consiste na especificação do comportamento local do serviço por meio da criação de um processo BPMN. As seções a seguir apresentam, em detalhes, a realização de cada uma destas atividades no desenvolvimento do serviço EnrichmentAnalysis.

\subsubsection{Implementação do Serviço}

O serviço EnrichmentAnalysis foi implementado como um adaptador para a ferramenta de software g:GOSt. Esta ferramenta faz parte do conjunto de ferramentas g:Profiler [336,337], disponível por meio do pacote $\mathrm{R}$ gProfileR [318]. O pacote gProfileR fornece três funcionalidades principais: (i) conversão de identificadores de genes para diferentes formatos de bases de 
dados; (ii) mapeamento de genes ortólogos (com sequências conservadas) entre diferentes organismos; e (iii) análise de enriquecimento simples de listas de identificadores de genes. Apenas esta última funcionalidade foi selecionada para ser acessada por meio do serviço.

\section{Definição do modelo de interação}

Na primeira etapa da definição do modelo de interação, definimos um único caso de uso para o serviço EnrichmentAnalysis. Este caso de uso possui uma sequência típica e duas sequências alternativas de eventos. A Figura 30 apresenta um fragmento da especificação do caso de uso definido para o serviço EnrichmentAnalysis, contendo apenas a sequência típica de eventos associada a este serviço.

\begin{tabular}{|c|l|}
\hline \multicolumn{2}{|c|}{ Caso de Uso: Realizar análise de enriquecimento simples } \\
\hline Atores & $\begin{array}{l}\text { Aplicação cliente (iniciador) } \\
\text { Ferramenta gProfileR }\end{array}$ \\
\hline Objetivo & $\begin{array}{l}\text { Realizar análise de enriquecimento simples de uma lista de identificadores de } \\
\text { genes. }\end{array}$ \\
\hline Visão Geral & $\begin{array}{l}\text { Identificar termos biológicos de ontologias e/ou bases de dados associados em } \\
\text { maior proporção a genes de interesse definidos em uma lista. }\end{array}$ \\
\hline
\end{tabular}

\begin{tabular}{|c|c|}
\hline \multicolumn{2}{|c|}{ Sequência Típica de Eventos } \\
\hline Ação do Ator & Resposta do Serviço \\
\hline $\begin{array}{l}\text { 1. Este caso de uso é iniciado quando a aplicação } \\
\text { cliente solicita um identificador exclusivo para a } \\
\text { realização de uma análise. }\end{array}$ & $\begin{array}{l}\text { 2. O serviço gera um identificador exclusivo e cria um } \\
\text { diretório associado a este identificador para o } \\
\text { armazenamento de dados. }\end{array}$ \\
\hline $\begin{array}{l}\text { 3. A aplicação cliente solicita o armazenamento de } \\
\text { uma lista contendo identificadores de genes. }\end{array}$ & $\begin{array}{l}\text { 4. O serviço armazena os dados no diretório associado } \\
\text { ao identificador previamente gerado. }\end{array}$ \\
\hline $\begin{array}{l}\text { 5. A aplicação cliente solicita a realização da análise } \\
\text { de enriquecimento simples na lista de identificadores } \\
\text { de genes previamente armazenada pelo serviço. }\end{array}$ & $\begin{array}{l}\text { 6. O serviço realiza uma chamada à ferramenta } \\
\text { gProfileR para a realização da análise solicitada na } \\
\text { lista previamente armazenada. }\end{array}$ \\
\hline $\begin{array}{l}\text { 7. A aplicação cliente solicita os dados resultantes da } \\
\text { análise. }\end{array}$ & $\begin{array}{l}\text { 8. O serviço recupera os dados resultantes da análise e } \\
\text { os envia para a aplicação cliente. }\end{array}$ \\
\hline
\end{tabular}

Figura 30: Caso de uso definido para o serviço EnrichmentAnalysis.

Na segunda etapa da definição do modelo de interação para o serviço EnrichmentAnalysis, definimos um diagrama de sequência UML para cada sequência de eventos definida no caso de uso previamente apresentado. Este diagrama apresenta a sequência ordenada de interações que devem ocorrer entre o serviço EnrichmentAnalysis e as entidades externas (aplicação cliente 
e pacote $g$ ProfileR) para a realização de uma análise de enriquecimento simples em dados de expressão gênica.

A Figura 31 apresenta o diagrama de sequência UML definido para a sequência típica de eventos associada ao serviço EnrichmentAnalysis. Cada retângulo rotulado representa uma entidade que participa de uma interação. Uma linha vertical tracejada representa a linha de tempo associada a uma entidade participante, de modo que o ponto superior da linha indica um instante de tempo inicial. Uma linha conectando as linhas de tempo de duas entidades participantes representa uma mensagem trocada entre estas entidades. Uma linha com uma seta preenchida em uma das extremidades indica uma mensagem de comunicação síncrona (requisição e resposta), enquanto uma linha com uma seta sem preenchimento indica uma mensagem de comunicação assíncrona.

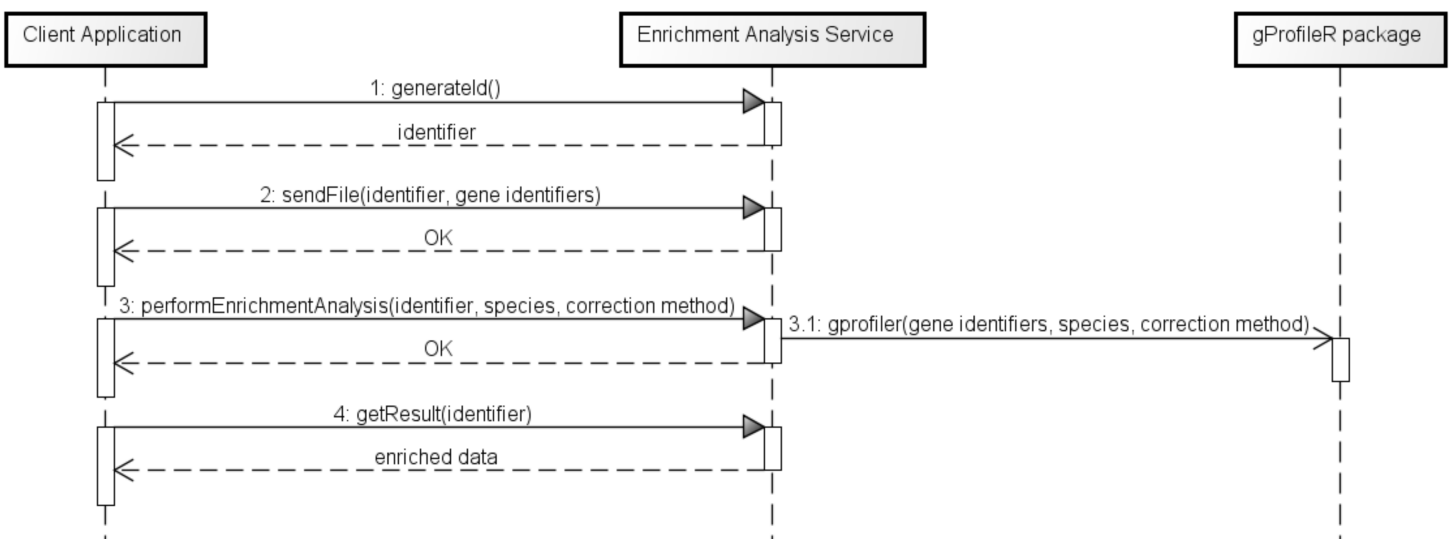

Figura 31: Diagrama de sequência UML definido para o serviço EnrichmentAnalysis.

\section{Implementação das operações do serviço}

O modelo de interação definido para o serviço EnrichmentAnalysis contém sete operações: generateID, sendFile, performEnrichmentAnalysis, getCorrectionMethods, getSpecies, getStatus e getResult. Todas as operações foram implementadas com o uso da API JAX-RS. As operações sendFile e performEnrichmentAnalysis foram implementadas como operações do tipo CREATE, uma vez que permitem a criação de diferentes recursos no servidor. As demais operações foram implementadas como operações do tipo $R E A D$, uma vez que permitem a recuperação de dife- 
rentes recursos previamente armazenados no servidor. A operação performEnrichmentAnalysis foi diretamente mapeada para a funcionalidade selecionada do pacote gProfile $R$.

A operação generateID cria um workspace (diretório) associado a um identificador exclusivo e retorna este identificador. O diretório criado é utilizado para armazenar um arquivo texto contendo uma lista de identificadores de genes a ser analisada, um arquivo texto contendo o resultado produzido durante a análise de enriquecimento e um arquivo contendo o estado de execução das análises solicitadas.

A operação sendFile permite o envio de um arquivo texto contendo uma lista de identificadores de genes. Esta operação requer como entradas o identificador fornecido pela operação generateID, o arquivo texto a ser armazenado (objeto File) e o nome do arquivo. Caso o identificador fornecido seja inválido, uma exceção é gerada. Caso esta operação seja invocada uma segunda vez, o arquivo previamente armazenado é automaticamente substituído pelo novo arquivo.

A operação performEnrichmentAnalysis realiza a análise de enriquecimento da lista de identificadores de genes previamente enviada ao serviço por meio da operação sendFile. A operação performEnrichmentAnalysis requer como entradas o identificador fornecido pela operação generateID, um identificador representando a espécie sendo estudada e um identificador representando o método de correção de múltiplos testes a ser aplicado na análise. Caso algum identificador fornecido seja inválido, uma exceção é gerada.

A análise de enriquecimento é realizada por uma ferramenta externa chamada $\mathrm{R}$ Server usando o pacote gProfileR. A comunicação entre as linguagens Java e R ocorre por meio do pacote Rserve [309,310], que permite a integração de programas escritos em Java com a ferramenta R Server usando uma conexão TCP. Como resultado da análise, um arquivo texto tabular contendo uma lista de termos biológicos enriquecidos (valor $-p<0.05)$ é produzido.

No serviço EnrichmentAnalysis, a implementação de representações de recursos em XML foi facilitada com o uso da API Java Architecture for XML Binding (JAXB) [338, 339]. Esta API fornece mecanismos para a manipulação de documentos XML em Java. As operações getCorrectionMethods e getSpecies do serviço retornam objetos JAXB representando arquivos XML. O objeto JAXB retornado pela operação getCorrectionMethods contém uma lista dos identificadores representando todos os métodos de correção de múltiplos testes que podem ser 
aplicados na análise de enriquecimento simples e suas respectivas descrições. O objeto JAXB retornado pela operação getSpecies contém uma lista dos nomes e respectivos identificadores de todas as espécies biológicas que podem ser analisadas no serviço EnrichmentAnalysis.

A operação getStatus requer como entrada o identificador fornecido pela operação generateID e retorna o estado de execução de uma análise sendo realizada pelo serviço. Caso o identificador fornecido seja inválido ou não haja um processo de análise em execução quando esta operação for invocada, uma exceção é gerada. O estado de execução de uma análise pode assumir os valores running, finished ou failure. A execução da operação performEnrichmentAnalysis inicia a execução de um processo, externo ao serviço EnrichmentAnalysis, responsável pela análise de enriquecimento. Uma thread responsável pelo gerenciamento do estado de execução da análise é então inicializada e o estado de execução é atualizado com o valor running. Se o processo externo terminar sua execução normalmente, ou seja, se a análise de enriquecimento ocorrer da forma esperada, a thread responsável pelo gerenciamento da análise atualiza o estado de execução da análise com o valor finished. Caso contrário, se o arquivo a ser processado (armazenado no workspace) não estiver no formato requerido ou se o workspace estiver vazio, o estado de execução da análise é atualizado com o valor failure.

Finalmente, a operação getResult permite a recuperação do arquivo texto contendo uma lista de termos biológicos enriquecidos resultante da análise dos dados submetidos. Esta operação deve ser invocada apenas quando a análise dos dados submetidos for concluída com sucesso, ou seja, quando o estado atual da análise possuir o valor finished. Caso esta operação seja invocada antes do término de uma análise ou após o término de uma análise mal sucedida, uma exceção é gerada. A operação getResult requer como entrada apenas o identificador fornecido pela operação generateID. Caso o identificador fornecido seja inválido, uma exceção é gerada.

Depois que todas as operações do serviço foram implementadas como métodos Java, estas foram mapeadas para métodos HTTP específicos. Os métodos Java sendFile e performEnrichmentAnalysis foram anotados com a anotação @POST fornecida pela API JAX-RS. Os demais métodos Java foram anotados com a anotação @ GET. Além disto, todos os métodos Java implementados foram anotados com a anotação @Path. A anotação @PathParam também foi associada a todos os parâmetros definidos nos métodos Java. 
A Tabela 17 apresenta as operações do serviço EnrichmentAnalysis, os tipos das operações (CRUD) e os métodos REST utilizados para a implementação das mesmas.

Tabela 17: Operações do serviço EnrichmentAnalysis, tipos CRUD e métodos REST associados.

\begin{tabular}{|c|c|c|}
\hline Operação do serviço & Tipo CRUD & Método REST \\
\hline \hline $\begin{array}{c}\text { generateID } \\
\text { getCorrectionMethods } \\
\text { getSpecies } \\
\text { getStatus } \\
\text { getResult }\end{array}$ & READ & GET \\
\hline $\begin{array}{c}\text { sendFile } \\
\text { performEnrichmentAnalysis }\end{array}$ & CREATE & POST \\
\hline
\end{tabular}

Teste do serviço

Após a implementação das operações do serviço, uma aplicação cliente foi criada com o uso da implementação de referência Jersey Reference Implementation of JAX-RS para testar o serviço EnrichmentAnalysis desenvolvido.

Durante a atividade de teste, todas as operações do serviço foram testadas individualmente e a comunicação com a ferramenta gProfileR foi verificada. Além disto, um teste foi realizado para cada fluxo de execução identificado pelos diagramas de sequência definidos para o serviço EnrichmentAnalysis.

\subsubsection{Geração da Descrição do Serviço}

Após a implementação do serviço EnrichmentAnalysis, uma descrição para o serviço na linguagem WSDL 2.0 foi gerada, de forma automática, a partir de sua implementação. Em seguida, os bindings SOAP e as referências aos bindings definidos na descrição do serviço foram au- 
tomaticamente removidos. Finalmente, a descrição WSDL do serviço foi validada. Estas três atividades foram realizadas com o uso da ferramenta de suporte Wsdl2 Creator.

A Figura 32 apresenta um fragmento da descrição WSDL do serviço EnrichmentAnalysis.

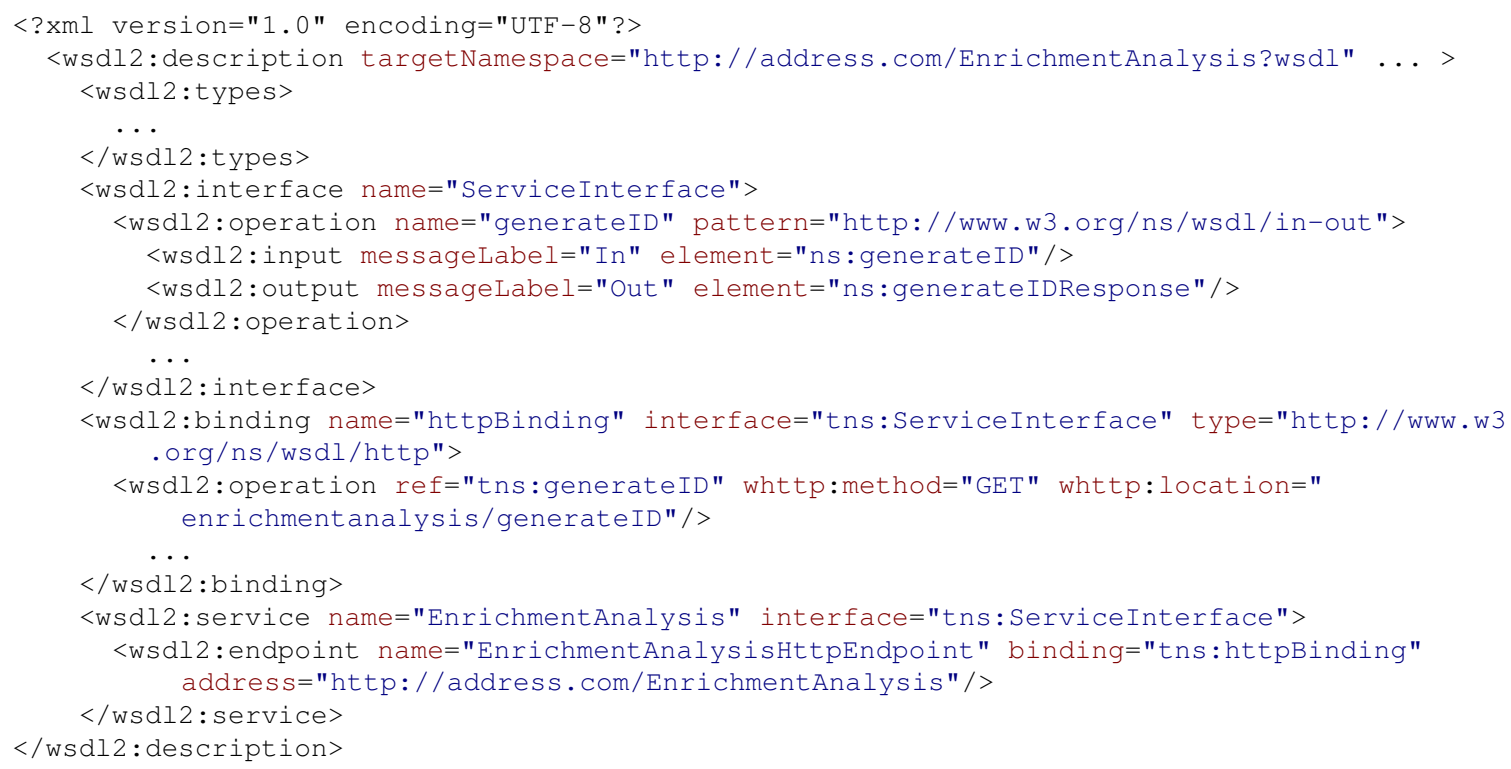

Figura 32: Descrição WSDL do serviço EnrichmentAnalysis.

\subsubsection{Definição das Ontologias}

De modo geral, a cada novo serviço desenvolvido, novos conceitos são necessários na ontologia de serviços. Assim, de modo a permitir a anotação semântica da descrição WSDL do serviço EnrichmentAnalysis, definimos um conjunto de conceitos e de relacionamentos entre conceitos na ontologia GEXPASO.

A Figura 33 apresenta um diagrama de classes UML representando o conjunto de conceitos e relacionamentos da ontologia GEXPASO utilizado para a anotação semântica do serviço EnrichmentAnalysis. Cada classe UML representa um conceito da ontologia. As classes com preenchimento branco representam conceitos novos introduzidos na ontologia GEXPASO e a classe com preenchimento cinza representa um conceito proveniente da ontologia GEXPO. Todos os relacionamentos definidos entre classes (conceitos) são apresentados por meio de uma notação 
similar à proposta por Guardia et al. [304]. O relacionamento is a é apresentado como uma generalização UML estereotipada como $<<i$ s $a>>$. O relacionamento has part é apresentado como uma agregação UML estereotipada como $<<$ has part $>>$. Os demais relacionamentos são apresentados como associações UML estereotipadas.

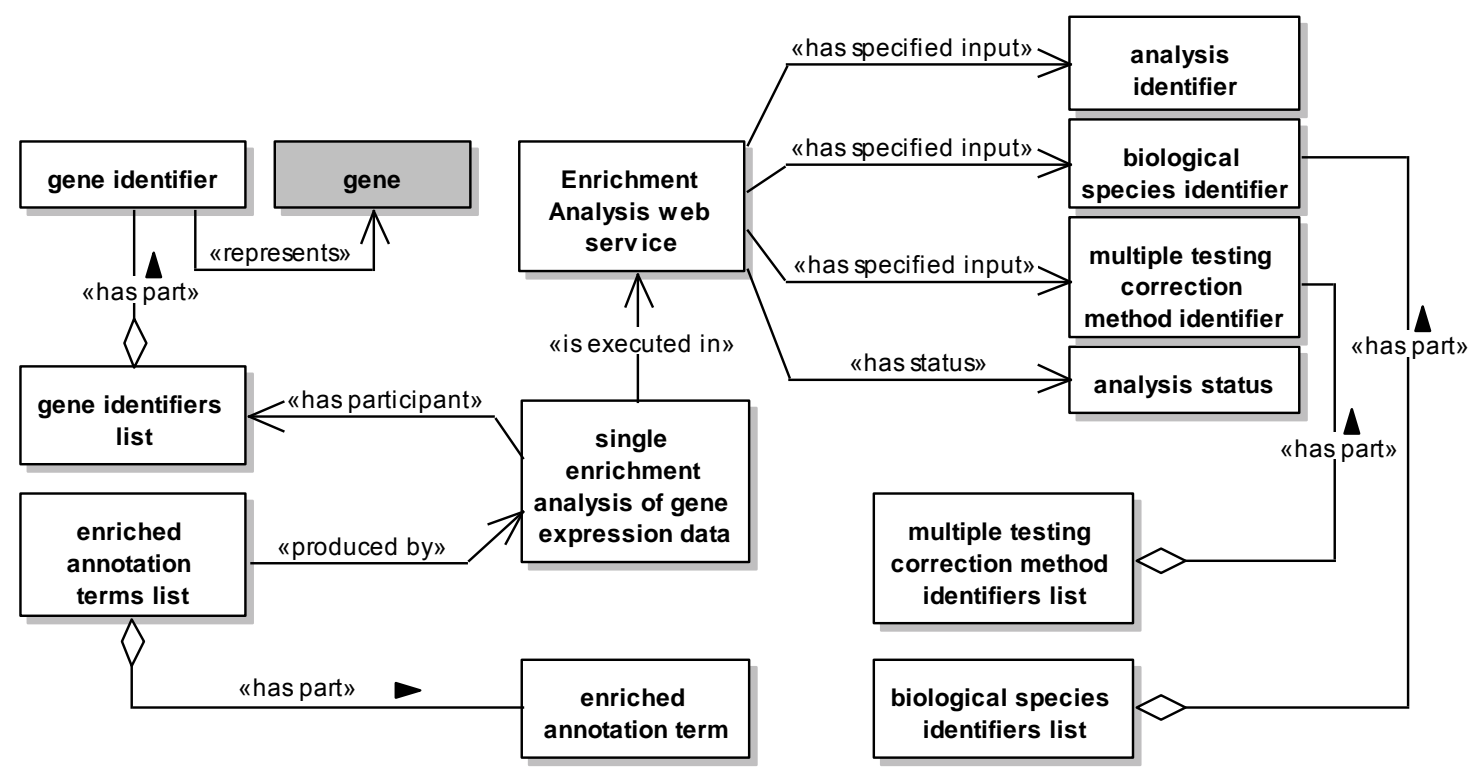

Figura 33: Fragmento da ontologia GEXPASO para a anotação semântica do serviço EnrichmentAnalysis.

A classe single enrichment analysis of gene expression data representa o processo de análise de enriquecimento simples de dados de expressão gênica. Esta classe está associada à classe gene identifiers list por meio do relacionamento has participant. Este relacionamento indica que o processo de análise de enriquecimento simples requer uma lista contendo identificadores de genes. A lista representada pela classe gene identifiers list está associada à classe gene identifier por meio do relacionamento has part, indicando que esta lista contém um ou mais identificadores de genes. Além disto, a classe gene identifier está associada à classe gene por meio do relacionamento represents, indicando que identificadores de genes são utilizados para representar genes.

As classes single enrichment analysis of gene expression data e enriched annotation terms list estão associadas por meio do relacionamento produced by. Este relacionamento indica que uma lista de termos biológicos de anotação enriquecidos é produzida pelo processo de análise de enriquecimento simples. A lista representada pela classe enriched annotation terms list está 
associada à classe enriched annotation term por meio do relacionamento has part, indicando que esta lista contém um ou mais termos biológicos de anotação enriquecidos.

Além disto, a classe single enrichment analysis of gene expression data está associada à classe EnrichmentAnalysis web service por meio do relacionamento is executed in. Este relacionamento indica que o processo de análise de enriquecimento simples é executado pelo serviço EnrichmentAnalysis.

A classe EnrichmentAnalysis web service está associada à classe analysis identifier por meio do relacionamento has specified input, indicando que o serviço EnrichmentAnalysis requer como parâmetro de entrada um identificador de análise. De forma análoga, o relacionamento has specified input também foi definido entre a classe EnrichmentAnalysis web service e as classes biological species identifier e multiple testing correction method identifier, indicando que este serviço requer também como parâmetros de entrada um identificador de uma espécie biológica e um identificador do método de correção de múltiplos testes. A classe biological species identifier está associada à classe biological species identifiers list por meio do relacionamento has part. Este relacionamento indica que a lista representada pela classe biological species identifiers list possui um ou mais identificadores de espécies biológicas. De forma análoga, o relacionamento has part também foi definido entre as classes multiple testing correction method identifier e multiple testing correction method identifiers list.

Finalmente, a classe EnrichmentAnalysis web service está associada à classe analysis status por meio do relacionamento has status. Este relacionamento indica que a execução de uma análise de enriquecimento simples no serviço EnrichmentAnalysis possui um estado associado.

\subsubsection{Anotação Semântica da Descrição do Serviço}

Nesta atividade, a anotação semântica da descrição WSDL do serviço EnrichmentAnalysis foi realizada com base no conjunto de conceitos e relacionamentos da ontologia GEXPASO previamente apresentado na Figura 33. A anotação semântica da descrição do serviço foi realizada com o auxílio do plug-in Radiant para o ambiente de desenvolvimento Eclipse.

$\mathrm{O}$ atributo de extensão modelReference foi utilizado para associar as operações WSDL do serviço EnrichmentAnalysis, bem como as entradas e saídas das operações, a conceitos da onto- 
logia GEXPASO. Neste contexto, este atributo de extensão foi utilizado para a descrição semântica das funcionalidades e das entradas e saídas associadas às diferentes operações do serviço. As entradas e saídas de cada operação WSDL do serviço EnrichmentAnalysis são especificadas com base em elementos de esquemas XML definidos na especificação WSDL. Todos estes elementos são declarados em termos de tipos complexos. A anotação semântica destes elementos com o atributo de extensão modelReference foi realizada por meio da associação de todos os elementos contidos nos tipos complexos a conceitos da ontologia GEXPASO. Esta abordagem foi utilizada porque os elementos contidos em um tipo complexo correspondem a conceitos da ontologia de serviços definida.

A saída da operação WSDL generateID referencia o elemento XML generateIDResponse. Este elemento consiste de um tipo de complexo formado pelo elemento return. O elemento return foi associado à classe analysis identifier da ontologia GEXPASO por meio do relacionamento model reference. Este relacionamento indica que a operação generateID produz como saída um identificador de análise.

A entrada da operação WSDL sendFile referencia o elemento XML sendFile. Este elemento consiste de um tipo complexo formado pelos elementos identifier, filename e file. Os elementos identifier, filename e file foram associados às classes analysis identifier, file identifier e gene identifiers list da ontologia GEXPASO por meio de relacionamentos model reference, respectivamente. Estes relacionamentos indicam que a operação sendFile requer como entradas um identificador de análise, um identificador de arquivo e uma lista de identificadores de genes.

A Figura 34 apresenta um diagrama de classes UML representando a estrutura sintática das anotações semânticas atribuídas à operação performEnrichmentAnalysis. Este diagrama foi definido com o uso do perfil UML proposto para a abordagem SAWSDL. Assim, os conceitos da ontologia GEXPASO e os componentes da linguagem WSDL 2.0 e de esquemas XML são apresentados como classes UML estereotipadas. O atributo de extensão modelReference é apresentado como uma associação UML estereotipada. O relacionamento references é apresentado como uma dependência UML estereotipada. Finalmente, agregações UML são utilizadas para indicar elementos contidos como parte de outros.

A operação WSDL performEnrichmentAnalysis foi associada à classe single enrichment analysis of gene expression data da ontologia GEXPASO por meio do relacionamento model re- 


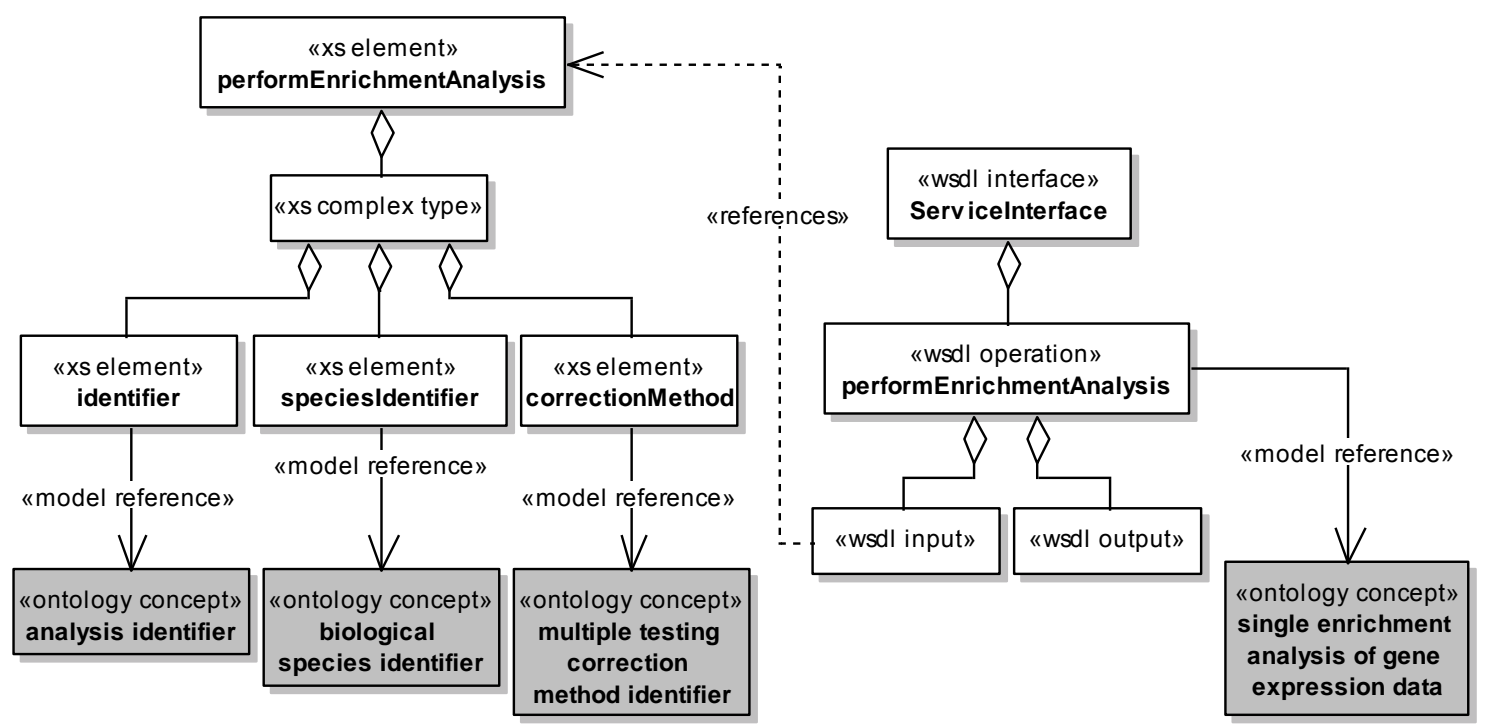

Figura 34: Anotação semântica da operação performEnrichmentAnalysis do serviço EnrichmentAnalysis.

ference. Este relacionamento indica que a operação performEnrichmentAnalysis é responsável pela realização de uma análise de enriquecimento simples em dados de expressão gênica. A entrada da operação WSDL performEnrichmentAnalysis referencia o elemento XML performEnrichmentAnalysis (relacionamento references). Este elemento consiste de um tipo complexo (xs complex type) formado pelos elementos identifier, speciesIdentifier e correctionMethod. Os elementos identifier, speciesIdentifier e correctionMethod foram associados às classes analysis identifier, biological species identifier e multiple testing correction method identifier da ontologia GEXPASO por meio de relacionamentos model reference, respectivamente. Estes três relacionamentos indicam que a operação performEnrichmentAnalysis requer como entradas um identificador de análise, um identificador de espécie biológica e um identificador de método de correção de múltiplos testes.

A saída da operação WSDL getSpecies referencia o elemento XML getSpeciesResponse. Este elemento consiste de um tipo complexo formado pelo elemento return. O elemento return foi associado à classe biological species identifiers list da ontologia GEXPASO por meio do relacionamento model reference. Este relacionamento indica que a operação getSpecies produz como saída uma lista de identificadores representando diferentes espécies biológicas.

A saída da operação WSDL getCorrectionMethods referencia o elemento XML getCorrectionMethodsResponse. Este elemento consiste de um tipo complexo formado pelo elemento 
return. O elemento return foi associado à classe multiple testing correction method identifiers list da ontologia GEXPASO por meio do relacionamento model reference. Este relacionamento indica que a operação getCorrectionMethods produz como saída uma lista de identificadores de métodos de correção de múltiplos testes.

A entrada da operação WSDL getStatus referencia o elemento XML getStatus. Este elemento consiste de um tipo complexo formado pelo elemento identifier. O elemento identifier foi associado à classe analysis identifier da ontologia GEXPASO por meio do relacionamento model reference. Este relacionamento indica que a operação getStatus requer como entrada um identificador de análise. A saída da operação WSDL getStatus referencia o elemento XML getStatusResponse. Este elemento consiste de um tipo complexo formado pelo elemento return. O elemento return foi associado à classe analysis status da ontologia GEXPASO por meio do relacionamento model reference. Este relacionamento indica que a operação getStatus produz como saída o estado de execução atual de uma análise.

A entrada da operação WSDL getResult referencia o elemento XML getResult. Este elemento consiste de um tipo complexo formado pelo elemento identifier. O elemento identifier foi associado à classe analysis identifier da ontologia GEXPASO por meio do relacionamento model reference. Este relacionamento indica que a operação getResult requer como entrada um identificador de análise. A saída da operação WSDL getResult referencia o elemento XML getResultResponse. Este elemento consiste de um tipo complexo formado pelo elemento return. O elemento return foi associado à classe enriched annotation terms list da ontologia GEXPASO por meio do relacionamento model reference. Este relacionamento indica que a operação getResult produz como saída uma lista de termos biológicos de anotação enriquecidos.

Após a adição das anotações semânticas à descrição WSDL do serviço EnrichmentAnalysis, a descrição do serviço foi novamente validada com o uso da ferramenta de suporte Wsdl2 Creator.

\subsubsection{Especificação do Comportamento Local do Serviço}

Após a anotação semântica da descrição WSDL do serviço EnrichmentAnalysis, geramos um processo na linguagem BPMN 2.0 para descrever o comportamento local do serviço. O processo BPMN foi inicialmente gerado, de forma semi-automática, a partir da descrição do serviço 
semanticamente anotada. A geração do processo foi realizada com o uso da ferramenta de suporte Wsdl2Bpmn Mapper.

No processo BPMN gerado, cada operação WSDL do serviço EnrichmentAnalysis foi mapeada para um elemento BPMN Service Task. A entrada da operação WSDL sendFile foi mapeada para o conjunto de dados de entrada do processo (elemento Input), uma vez que os dados consumidos por esta operação do serviço devem ser fornecidos antes do início da execução do processo. De forma similar, a saída da operação WSDL getResult foi mapeada para o conjunto de dados de saída do processo (elemento Output), uma vez que os dados produzidos por esta operação do serviço devem ser retornados ao final da execução do processo. As demais entradas e saídas das operações WSDL do serviço EnrichmentAnalysis foram mapeadas para elementos BPMN do tipo Data Object, cujos valores podem ser manipulados no escopo do processo durante sua execução.

Após a definição inicial do processo BPMN na ferramenta Wsdl2Bpmn Mapper, definimos o fluxo de execução das operações do serviço e as condições/restrições associadas à execução do processo com o uso da ferramenta de modelagem Activiti [296]. A Figura 35 apresenta uma representação gráfica do processo BPMN criado para especificar o comportamento local do serviço EnrichmentAnalysis.

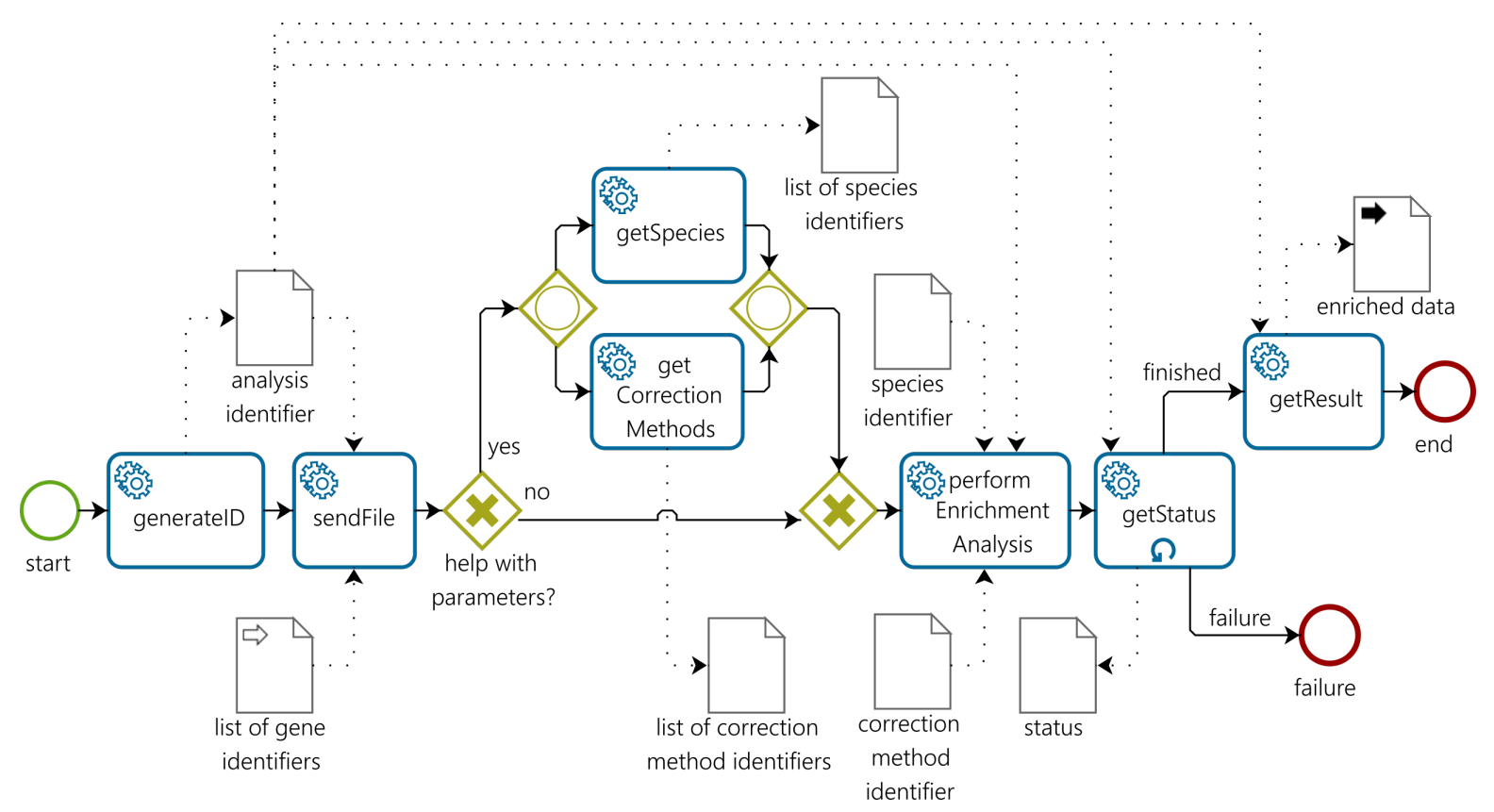

Figura 35: Especificação BPMN do comportamento local do serviço EnrichmentAnalysis. 
Antes da execução do processo, o usuário deve fornecer a lista de identificadores de genes que deseja analisar. Esta lista é armazenada no conjunto de dados de entrada do processo (estrutura list of gene identifiers). Quando a execução do processo é iniciada, a operação generateId é inicialmente executada. Esta operação retorna um identificador de análise, cujo valor é armazenado na estrutura de dados analysis identifier do processo. Em seguida, a operação sendFile pode ser executada. Esta operação recebe como entrada o valor do identificador de análise armazenado na estrutura de dados analysis identifier e a lista de identificadores de genes previamente armazenada na estrutura de dados list of gene identifiers.

A seguir, o usuário pode solicitar auxílio para selecionar os parâmetros da análise por meio da execução das operações getSpecies e getCorrectionMethods. A operação getSpecies retorna uma lista de identificadores representando todas as espécies biológicas que podem ser selecionadas para a análise. Os valores desta lista são armazenados na estrutura de dados list of species identifiers. A operação getCorrectionMethods retorna uma lista de identificadores representando todos os métodos de correção de múltiplos testes que podem ser selecionados para a análise. Os valores desta lista são armazenados na estrutura de dados list of correction method identifiers. Após a execução (opcional) das operações auxiliares getSpecies e getCorrectionMethods, a operação performEnrichmentAnalysis pode ser executada. Alternativamente, se o usuário não precisar de auxílio para selecionar os parâmetros da análise, a operação performEnrichmentAnalysis pode ser diretamente executada.

Antes da execução da operação performEnrichmentAnalysis, o processo solicita ao usuário os parâmetros da análise. Caso as operações getSpecies e/ou getCorrectionMethods tenham sido previamente executadas, as listas de identificadores armazenadas nas estruturas de dados list of species identifiers e/ou list of correction method identifiers são apresentadas ao usuário para auxiliá-lo na seleção dos parâmetros da análise. O usuário então fornece os parâmetros da análise. Estes parâmetros incluem o identificador da espécie biológica que o usuário deseja analisar e o identificador do método de correção de múltiplos testes que o usuário deseja aplicar na análise. Uma vez que o usuário fornece estes parâmetros, o valor do identificador da espécie biológica é armazenado na estrutura de dados species identifier e o valor do identificador do método de correção é armazenado na estrutura de dados correction method identifier. 
A operação performEnrichmentAnalysis pode então ser executada. Esta operação recebe como entradas o valor do identificador de análise armazenado na estrutura de dados analysis identifier, bem como os valores dos parâmetros armazenados nas estruturas de dados species identifier e correction method identifier. Após a execução da operação performEnrichmentAnalysis, a operação getStatus pode ser executada. A operação getStatus recebe como entrada o valor do identificador de análise armazenado na estrutura de dados analysis identifier e retorna o estado atual de execução da análise sendo realizada pelo serviço. O valor do estado de execução é então armazenado na estrutura de dados status. A operação getStatus pode ser iterativamente executada até que a execução da análise seja finalizada, ou seja, o valor armazenado na estrutura status seja diferente de "running".

Finalmente, quando a execução da análise é finalizada, o valor armazenado na estrutura status é avaliado pelo processo. Caso o valor armazenado seja "failure", ou seja, alguma falha tenha ocorrido durante a realização da análise, o processo é interrompido. Caso o valor armazendo seja "finished", ou seja, a análise tenha ocorrido da forma esperada, a operação getResult pode ser executada. A operação getResult recebe como entrada o valor do identificador de análise armazenado na estrutura de dados analysis identifier e retorna os dados resultantes da análise. Estes dados são armazenados no conjunto de dados de saída do processo (estrutura enriched data). O processo é então finalizado e o conjunto de dados de saída do processo pode ser fornecido ao usuário, quando solicitado.

Após a definição completa do processo BPMN que especifica o comportamento local do serviço EnrichmentAnalysis, o documento BPMN contendo a definição do processo foi validado com o uso da ferramenta Wsdl2Bpmn Mapper.

\subsection{CONCLUS ÃO}

Neste capítulo apresentamos a aplicação da metodologia proposta para a criação de serviços web semânticos no desenvolvimento de um conjunto representativo de serviços que permitem a realização de diferentes atividades de análise em dados de expressão gênica, incluindo dados de microarray (one/two-color) e de RNA-Seq. 
Estes serviços foram desenvolvidos a partir de diferentes ferramentas/pacotes disponíveis para a análise de expressão gênica, facilitando assim a utilização das ferramentas adaptadas. Os serviços desenvolvidos podem ser utilizados individualmente para a realização de diferentes atividades de análise em dados de expressão gênica. No entanto, a anotação semântica dos serviços com termos provenientes de ontologias tem como objetivo facilitar, posteriormente, a composição (semi) automática dos serviços para a criação de cenários de análise integrados.

A anotação semântica de todos os serviços foi realizada com o uso das ontologias de suporte GEXPO e GEXPASO. Embora estas ontologias de suporte tenham sido definidas considerandose apenas os aspectos estruturais e funcionais dos serviços desenvolvidos, as mesmas podem, potencialmente, ser utilizadas para a anotação semântica de outros serviços de análise de expressão gênica. Neste sentido, a ontologia GEXPO pode ser estendida para incluir outras tecnologias e/ou processos experimentais de medição de expressão gênica. De forma complementar, a ontologia GEXPASO pode ser estendida para incluir processos de análise e tipos de dados relevantes para a anotação semântica de novos serviços.

Os serviços desenvolvidos foram agrupados no repositório público de serviços GEAS. Este repositório fornece não apenas acesso a todos serviços, mas também documentação detalhada sobre cada serviço disponível. Desta forma, o repositório GEAS facilita o acesso e a utilização dos serviços desenvolvidos para a análise de expressão gênica.

Finalmente, de modo a facilitar o entendimento da nossa metodologia para a criação de serviços web semânticos, descrevemos em detalhes a sua aplicação no desenvolvimento de um serviço para a análise de enriquecimento simples de dados de expressão gênica, chamado EnrichmentAnalysis. Esta descrição detalhada tem como objetivo reduzir o tempo de aprendizado da nossa metodologia, facilitando assim a sua aplicação para a adaptação de outras ferramentas de análise como serviços web semânticos. 


\section{COMPOSIÇÃO DE SERVIÇOS WEB SEMÂNTICOS PARA ANÁLISE DE EXPRESS ÃO GÊNICA}

Este capítulo apresenta uma solução para a composição de serviços web semânticos para a análise de expressão gênica. De modo a posicionar a nossa abordagem, inicialmente identificamos as etapas típicas de um estudo de análise de expressão gênica e definimos um processo de composição para capturar estas etapas. Em seguida, definimos uma arquitetura em camadas para dar suporte às etapas do processo de composição. Esta arquitetura tem como objetivo fornecer um nível de abstração que permita aos usuários (biologistas) focar nas questões de pesquisa biológicas, isentado-os dos detalhes técnicos do processo de composição. A seguir, definimos uma estratégia para a composição de serviços web semânticos para a análise de expressão gênica. Finalmente, apresentamos a plataforma de suporte desenvolvida para implementar e validar a arquitetura e a estratégia definidas para a composição de serviços, chamada Semantic Services Composition (SemanticSCo).

O restante deste capítulo está estruturado da seguinte forma: a Seção 6.1 apresenta as etapas típicas de um estudo de análise de expressão gênica e o processo de composição de serviços definido para capturar estas etapas; a Seção 6.2 apresenta a arquitetura proposta para a composição semântica de serviços; a Seção 6.3 apresenta a estratégia definida para a composição semântica de serviços; a Seção 6.4 apresenta uma visão geral da plataforma SemanticSCo; a Seção 6.5 apresenta os módulos de suporte à criação e publicação de serviços da plataforma SemanticSCo; a Seção 6.6 apresenta os módulos de suporte à composição e execução de serviços 
da plataforma SemanticSCo; a Seção 6.7 exemplifica a criação de um cenário para a análise de expressão gênica na plataforma SemanticSCo; finalmente, a Seção 6.8 apresenta as conclusões do capítulo.

\subsection{PROCESSO DE COMPOSIÇÃO DE SERVIÇOS}

De modo a posicionar a nossa abordagem para a composição de serviços para a análise de expressão gênica, inicialmente identificamos as etapas típicas de um estudo de análise de expressão gênica e definimos um processo para a composição de serviços com base nas etapas identificadas.

\subsubsection{Estudo de Expressão Gênica}

De modo geral, um estudo de expressão gênica pode ser realizado em cinco etapas [109, 340]: planejamento do experimento, realização do experimento, análise dos dados, interpretação dos resultados e validação dos resultados. A Figura 36 apresenta uma representação BPMN das etapas de um estudo de expressão gênica e da ordem em que estas etapas são, em geral, realizadas. Os círculos (eventos) indicam o início/fim do estudo. Cada retângulo representa uma etapa. Finalmente, cada losango (gateway) representa um ponto de decisão.

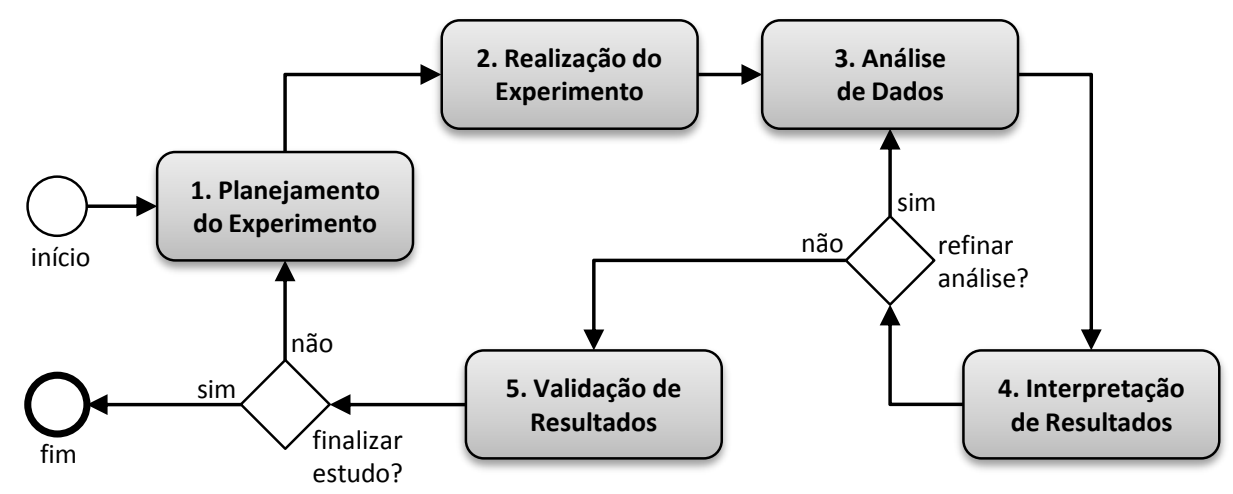

Figura 36: Etapas de um estudo de expressão gênica.

Inicialmente, um biologista planeja a realização do experimento para a obtenção dos dados de expressão gênica. Este planejamento inclui a definição detalhada do propósito do estudo, 
seleção da tecnologia mais adequada para a realização do estudo (ex: microarrays de DNA [1] ou RNA-Seq [3]), definição das amostras biológicas a serem analisadas, uso de réplicas técnicas/biológicas, entre outros. A próxima etapa consiste na realização do experimento para a obtenção dos dados de expressão gênica. Esta etapa envolve a extração e manipulação das amostras biológicas de interesse, bem como a medição dos níveis de expressão associados aos genes contidos nas amostras. Em seguida, os dados de expressão gênica obtidos são então analisados. De modo geral, um biologista ou bioinformata é responsável por definir e executar uma sequência de atividades de análise a serem realizadas nos dados. Estas atividades podem incluir a normalização dos dados, a identificação de genes diferencialmente expressos, o agrupamento e/ou a análise funcional dos dados, entre outras.

Após a análise dos dados, os resultados obtidos são então interpretados por um biologista/bioinformata. Caso os resultados da análise sejam considerados insatisfatórios, a análise pode ser refinada por meio da inclusão (ou alteração) de atividades de análise consideradas relevantes somente após a interpretação dos resultados. O refinamento da análise pode ser um processo iterativo. Caso contrário, os resultados obtidos podem ser validados por meio da realização de outros experimentos. De modo geral, a etapa de validação consiste na aplicação de técnicas mais sensitivas (ex: RT-PCR [54]) para a quantificação dos níveis de expressão gênica de um subconjunto de genes de interesse identificados durante a etapa de análise dos dados. A validação dos resultados pode completar o estudo ou identificar elementos que justifiquem a realização de um novo estudo de expressão gênica.

\subsubsection{Composição de Serviços para a Análise de Expressão Gênica}

Silva et al. [341] definem um processo genérico para a composição semântica de serviços web. Este processo é definido em termos das diferentes atividades que devem ser realizadas durante a composição de serviços e dos tipos de usuários responsáveis pela realização de cada atividade. Com base na definição deste processo e nas etapas identificadas para a realização de estudos de expressão gênica, definimos as etapas que consideramos necessárias para o processo de composição de serviços web semânticos para a análise de expressão gênica. A Figura 37 apresenta 
o processo de composição proposto e os tipos de usuários que participam das diferentes fases deste processo.

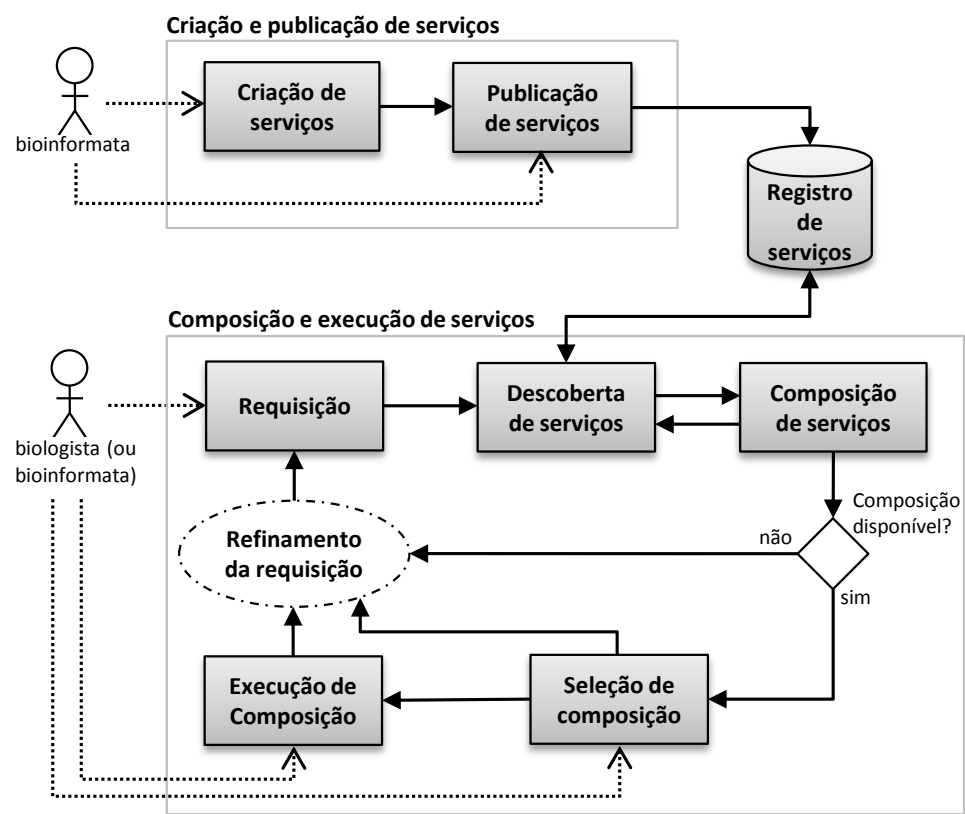

Figura 37: Processo de composição de serviços para análise de expressão gênica.

O processo de composição de serviços é dividido em duas fases principais: criação/publicação e composição/execução de serviços. A fase de criação/publicação de serviços consiste no desenvolvimento de serviços web semânticos e na publicação das informações sobre os serviços desenvolvidos em um registro de serviços. A fase de composição/execução de serviços corresponde à etapa de análise de dados de um estudo de expressão gênica, a qual consiste na definição e execução de um conjunto de atividades de análise nos dados disponíveis.

As subseções a seguir apresentam, em detalhes, estas fases do processo de composição de serviços proposto.

\section{Criação e Publicação de Serviços}

A primeira fase do processo de composição compreende o desenvolvimento de serviços web semânticos como adaptadores para ferramentas de suporte à análise de expressão gênica já existentes. Estes serviços disponibilizam uma ou mais funcionalidades destas ferramentas por meio de interfaces web padronizadas. Uma vez que os serviços estão disponíveis, os mesmos 
podem então ser utilizados como componentes das composições criadas na segunda fase do processo.

Nesta primeira fase, um bioinformata é responsável pela criação e publicação de serviços web semânticos. A etapa de criação de serviços consiste no desenvolvimento dos serviços e na especificação (semântica) de informações relevantes sobre os serviços desenvolvidos. Por sua vez, a etapa de publicação de serviços consiste na publicação destas informações (semânticas) em um registro de serviços, de modo a permitir a descoberta de serviços de interesse na fase de composição.

No contexto deste trabalho, prescrevemos a criação de serviços de acordo com a metodologia proposta no Capítulo 4. Neste sentido, a etapa de criação de serviços inclui tanto a implementação do serviço quanto a criação de uma descrição de serviço associada. Esta descrição de serviço especifica as operações fornecidas pelo serviço, os tipos de dados produzidos/consumidos pelo serviço, sua localização e detalhes técnicos utilizados na comunicação com o serviço. Adicionalmente, a etapa de criação de um serviço inclui a anotação semântica da descrição do serviço com termos provenientes de uma ou mais ontologias. A anotação semântica de descrições de serviços tem como objetivo atribuir significados não-ambíguos às operações de serviços e aos dados trocados entre diferentes serviços, de modo a facilitar a composição (semi) automática de serviços. Finalmente, consideramos que a etapa de criação de serviços inclui também a especificação do comportamento local do serviço, ou seja, a ordem em que as operações do serviço podem ser invocadas. Após a criação dos serviços de acordo com a nossa metodologia, as descrições semânticas e as especificações de comportamento dos serviços criados são então disponibilizadas (publicadas) em um registro de serviços.

\section{Composição e Execução de Serviços}

A primeira etapa do processo de composição de serviços consiste na especificação de uma requisição. Nesta etapa, um biologista (ou bioinformata) indica, de forma iterativa, seus requisitos para a criação de uma composição de serviços. No contexto deste trabalho, consideramos que o resultado da etapa de requisição deve ser uma sequência de atividades de análise que o biologista deseja realizar e os tipos de dados que se deseja processar com termos provenientes de uma ontologia. Chamamos esta sequência de atividades e tipos de dados de workflow abstrato. 
As próximas etapas do processo são a descoberta e a composição de serviços. A etapa de descoberta consiste na realização de buscas semânticas no registro de serviços para a identificação de serviços adequados aos requisitos especificados pelo biologista na etapa de requisição. Se nenhum serviço adequado for identificado, o sistema tenta gerar (automaticamente) uma composição de serviços, de modo que as funcionalidades fornecidas individualmente pelos serviços sejam capazes de, conjuntamente, realizar os requisitos especificados pelo biologista. Durante a etapa de composição, buscas adicionais no registro de serviços podem ser realizadas caso serviços complementares sejam necessários na composição sendo criada.

Após a etapa de composição de serviços, um conjunto de composições pode ser obtido. Se este conjunto estiver vazio, o biologista pode reformular sua requisição. Caso contrário, a próxima etapa consiste na seleção de uma composição. Nesta etapa, o biologista seleciona a composição de serviços mais adequada aos seus propósitos. Neste ponto, o biologista pode refinar ainda mais sua requisição de modo a incluir/modificar atividades de análise e/ou os tipos de dados que deseja processar. Caso sua requisição seja alterada, todas as etapas anteriores do processo devem ser realizadas novamente. Caso contrário, isto é, a requisição do biologista tenha sido completamente especificada e uma composição de serviços final seja selecionada, esta composição pode então ser executada. De modo a considerar a característica exploratória dos estudos de expressão gênica, a etapa de refinamento de requisição também pode ser realizada após a etapa de execução. Neste ponto, os dados do biologista já foram analisados e os resultados obtidos já foram interpretados, possivelmente identificando a necessidade de realizar outras atividades de análise nos dados.

No contexto da análise de expressão gênica, um biologista ou bioinformata pode guiar o processo de composição de serviços, desempenhando um papel direto em algumas etapas deste processo. Neste contexto, consideramos que biologistas são usuários que possuem um profundo conhecimento biológico sobre os processos de análise de expressão gênica, mas não necessariamente conhecimento computacional extenso dos serviços e tipos de dados disponíveis no domínio. Assim, quando a composição é guiada por um biologista, este é responsável por fornecer requisitos, selecionar uma composição adequada aos seus objetivos e de acordo com suas preferências pessoais, e executar a composição selecionada para a realização de análises em um conjunto de dados. 
De forma contrária, consideramos que bioinformatas são usuários com um conhecimento computacional extenso dos serviços e tipos de dados disponíveis no domínio. No entanto, estes usuários podem ou não ter um conhecimento biológico extenso sobre os processos de análise de expressão gênica. Desta forma, quando o processo de composição é guiado por um bioinformata, consideramos que o principal objetivo é a criação de uma composição de serviços que será, potencialmente, executada por um biologista para a análise de um conjunto de dados. Assim, o bioinformata não desempenha, em princípio, um papel direto na etapa de execução da composição. Além disto, quando um bioinformata guia o processo de composição, uma composição final pode ser disponibilizada como um novo serviço e publicada no registro de serviços, de modo a facilitar seu reuso.

\subsection{ARQUITETURA DE COMPOSIÇÃO}

Uma vez que serviços web semânticos são criados, o objetivo final é integrar semanticamente estes serviços (processos) de modo a criar um workflow de análise de dados de expressão gênica.

Durante a definição de um workflow de análise, um biologista pode especificar um conjunto ordenado de atividades de análise a serem realizadas nos dados de expressão gênica. Dado que o biologista pode não possuir um conhecimento extenso dos serviços disponíveis no domínio, este idealmente deve ser capaz de definir um workflow abstrato em termos de um conjunto de funcionalidades e dos tipos de dados que deseja processar, ao invés de criar um workflow concreto contendo os serviços desejados. Uma vez que um workflow abstrato é especificado, uma composição de serviços pode então ser subsequentemente derivada a partir desta especificação. De modo a lidar com estes requisitos, definimos uma arquitetura em camadas para fornecer suporte ao processo de composição semântica de serviços para a análise de expressão gênica apresentado na Seção 6.1.2.

A Figura 38 apresenta a arquitetura proposta, destacando suas camadas e as interações entre estas camadas. Cada camada fornece um conjunto de componentes cujas funcionalidades podem ser acessadas pelos componentes da camada (imediatamente) superior e acessa as funcionalidades fornecidas pelo conjunto de componentes da camada (imediatamente) inferior. 

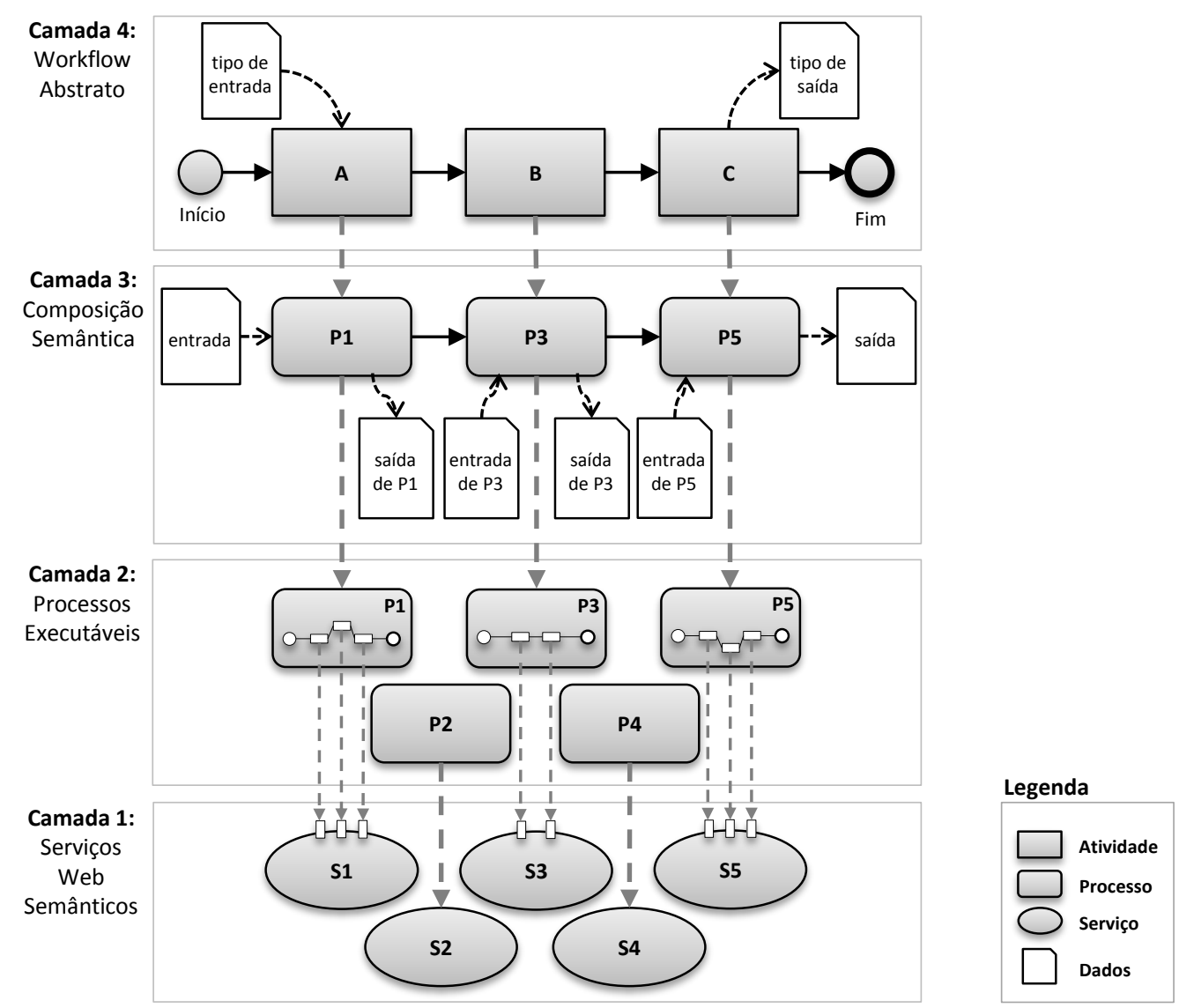

Figura 38: Arquitetura de composição de serviços para análise de expressão gênica.

A camada 1 representa a camada inferior da nossa arquitetura. Esta camada contém um conjunto de serviços web semânticos desenvolvidos para a análise de expressão gênica. A definição de um processo executável (concreto) a partir de um serviço tem como objetivo permitir a execução automática das operações do serviço. Assim, a camada 2 contém um conjunto de processos executáveis. Cada processo executável consiste em uma sequência de operações de serviço que, conjuntamente, determinam o comportamento local de um serviço web semântico contido na camada 1 da arquitetura. Na camada 3, o processo de composição semântica em si é realizado para integrar os processos executáveis contidos na camada 2. Neste sentido, a camada 3 incorpora mecanismos para a descoberta semântica de processos executáveis contidos na camada 2, bem como para a composição semântica destes processos. Na camada 3 , os processos são interligados de modo que os dados produzidos por um processo possam ser utilizados como dados de entrada para o próximo processo definido na cadeia de composição. Esta camada tem como objetivo produzir um processo executável (serviço composto) capaz de satisfazer os obje- 
tivos de análise especificados na camada superior da nossa arquitetura. Finalmente, a camada 4 especifica um workflow abstrato, o qual consiste em uma sequência de atividades e tipos de dados de entrada/saída que, conjuntamente, determinam os objetivos de análise de um usuário. As atividades e tipos de dados do workflow abstrato são especificados com termos provenientes de uma ontologia. A camada 4 fornece um alto nível de abstração para dar suporte aos usuários no processo de composição, permitindo que os usuários projetem um workflow abstrato para a análise de expressão gênica a partir do qual uma composição de serviços concreta possa ser subsequentemente derivada.

\subsection{ESTRATÉGIA DE COMPOSIÇÃO}

No domínio biomédico, a composição manual de serviços tem se tornado um grande desafio devido ao crescente número de serviços e formatos de dados que precisam ser manipulados pelos usuários (biologistas) [15]. Em contraste, abordagens de composição automáticas assumem que os usuários sejam capazes de fornecer um conjunto de requisitos completo e preciso no início do processo de composição. Por isso acreditamos que a composição automática de serviços também seja uma estratégia inadequada para o domínio de genômica funcional, dada a natureza iterativa e exploratória dos estudos de expressão gênica.

De forma alternativa, abordagens de composição semi-automáticas permitem que os usuários controlem a criação de composições de forma interativa. Além disto, a composição semiautomática de serviços permite a especificação gradual dos requisitos do biologista conforme o estudo é realizado, ao mesmo tempo em que fornece suporte ao biologista durante as atividades de descoberta e composição de serviços.

Assim, optamos pela definição de uma estratégia semi-automática para a composição de serviços de análise de expressão gênica. A Figura 39 apresenta uma representação baseada em BPMN da nossa estratégia de composição.

De acordo com a nossa estratégia, uma composição de serviços pode ser criada de acordo com os seguintes passos:

1. O biologista seleciona um (novo) conjunto de dados de entrada. 


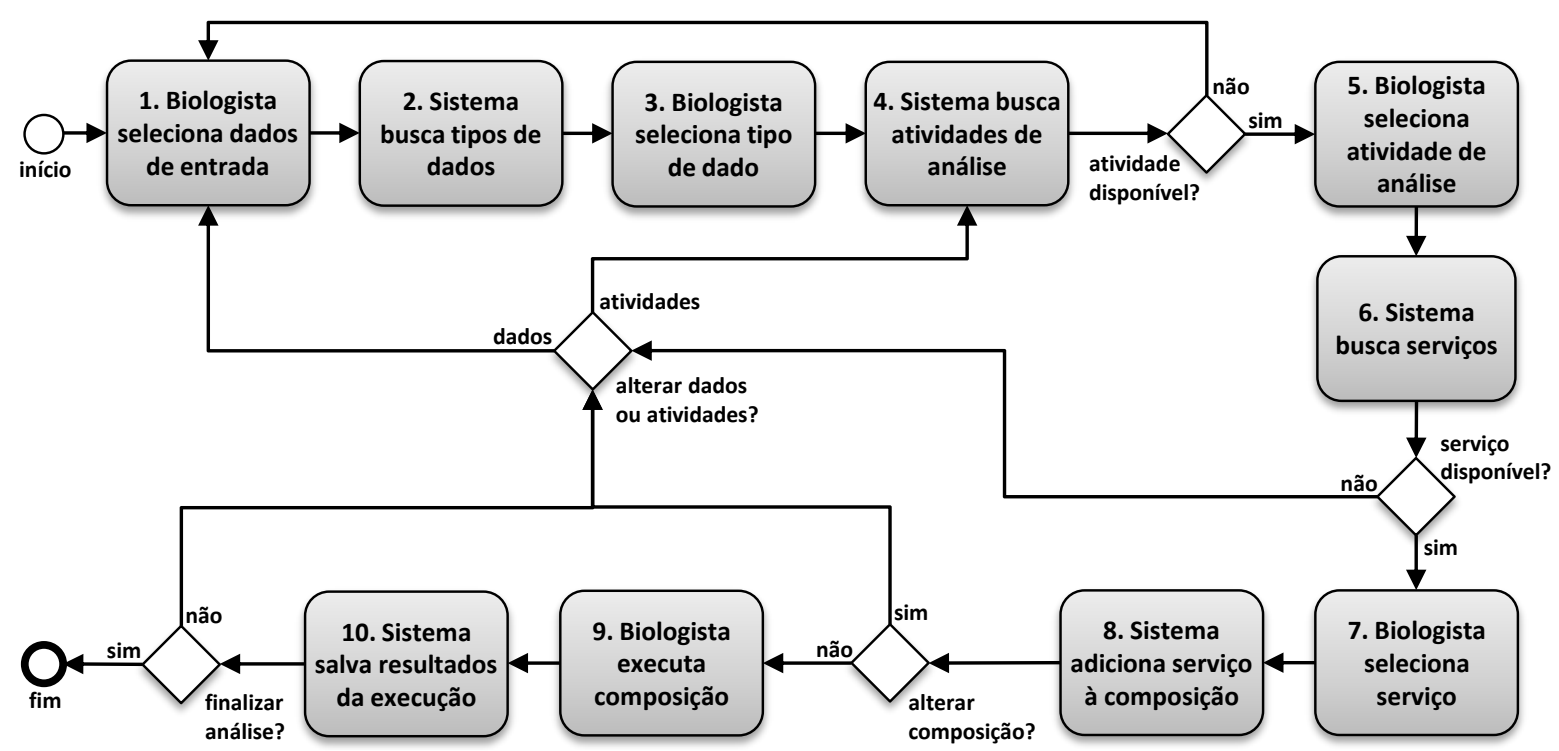

Figura 39: Estratégia de composição para análise de expressão gênica.

2. O sistema de suporte busca, com base na ontologia de serviços, tipos de dados que possam ser utilizados para especificar a semântica do conjunto de dados selecionado. Uma lista de tipos de dados é apresentada ao biologista.

3. O biologista seleciona um dos tipos de dados sugeridos de modo a especificar a semântica do conjunto de dados selecionado.

4. O sistema de suporte tenta encontrar atividades de análise que possam ser realizadas nos dados disponíveis, com base na ontologia de serviços. Os dados disponíveis incluem dados fornecidos pelo biologista e dados produzidos por cada serviço da cadeia de composição. Uma lista de atividades de análise é apresentada ao biologista. Se nenhuma atividade de análise for identificada, o biologista realiza a etapa 1 novamente para refinar a semântica dos dados previamente especificados, por exemplo, utilizando termos mais específicos.

5. O biologista seleciona uma das atividades de análise sugeridas.

6. O sistema de suporte tenta encontrar um serviço ou uma composição de serviços capaz de realizar a atividade de análise selecionada e que aceite os dados disponíveis como entrada. Uma lista de serviços disponíveis é apresentada ao biologista. Se nenhum serviço for identificado, o biologista realiza novamente a etapa 1 para refinar a semântica dos dados 
previamente especificados ou a etapa 4 para alterar a atividade de análise previamente selecionada.

7. O biologista seleciona um dos serviços sugeridos.

8. O sistema adiciona o serviço selecionado à composição sendo construída. Se o biologista quiser definir um conjunto de dados adicional, a etapa 1 pode ser realizada novamente. Alternativamente, se o biologista quiser adicionar novas atividades de análise, a etapa 4 pode ser realizada novamente.

9. O biologista executa um ou mais serviços definidos na composição.

10. Após a execução dos serviços, o sistema de suporte salva os resultados da execução. Neste ponto, as etapas 1 e/ou 4 podem ser realizadas novamente se o biologista quiser estender a composição com novos conjuntos de dados e/ou atividades de análise, respectivamente. Caso contrário, o processo de análise é finalizado.

\subsection{VISÃO GERAL DA PLATAFORMA SEMANTICSCO}

Após a definição de uma abordagem para a composição semântica de serviços para a análise de expressão gênica, desenvolvemos uma plataforma, chamada Semantic Services Composition (SemanticSCo), para implementar a arquitetura e estratégia de composição propostas.

A plataforma SemanticSCo foi desenvolvida como uma adaptação do framework Adaptable DynamiCoS (A-DynamiCoS) [342,343]. Este framework fornece suporte à composição de serviços web semânticos em diferentes domínios de aplicação por meio de um processo centrado no usuário. Neste sentido, o framework visa atender, sob demanda, as necessidades específicas de diferentes tipos de usuários durante a criação e execução de composições de serviços.

De modo a desenvolver a plataforma SemanticSCo, adaptamos o framework A-DynamiCoS levando-se em consideração as características específicas do domínio de expressão gênica, bem como os aspectos técnicos dos serviços web semânticos desenvolvidos para a análise de expressão gênica que estão disponíveis no repositório GEAS. 
A plataforma SemanticSCo foi desenvolvida na linguagem Java. Esta plataforma é estruturada em seis módulos básicos. Os módulos Composite Service Enactment, Coordinator, Service Composition e Composition and Execution Context foram adaptados do framework ADynamiCoS e fornecem suporte (semi) automático à fase de criação/execução de composições de serviços do processo de composição definido na Seção 6.1.2. Adicionalmente, definimos um novo módulo, chamado Service Creation and Publication, que fornece suporte à fase de criação/publicação de serviços web semânticos do processo de composição proposto. Finalmente, um novo módulo, chamado Service Registry, foi desenvolvido na plataforma SemanticSCo para o armazenamento das informações sobre os serviços incorporados à plataforma. A Figura 40 apresenta os módulos básicos da plataforma SemanticSCo e as relações entre estes módulos.

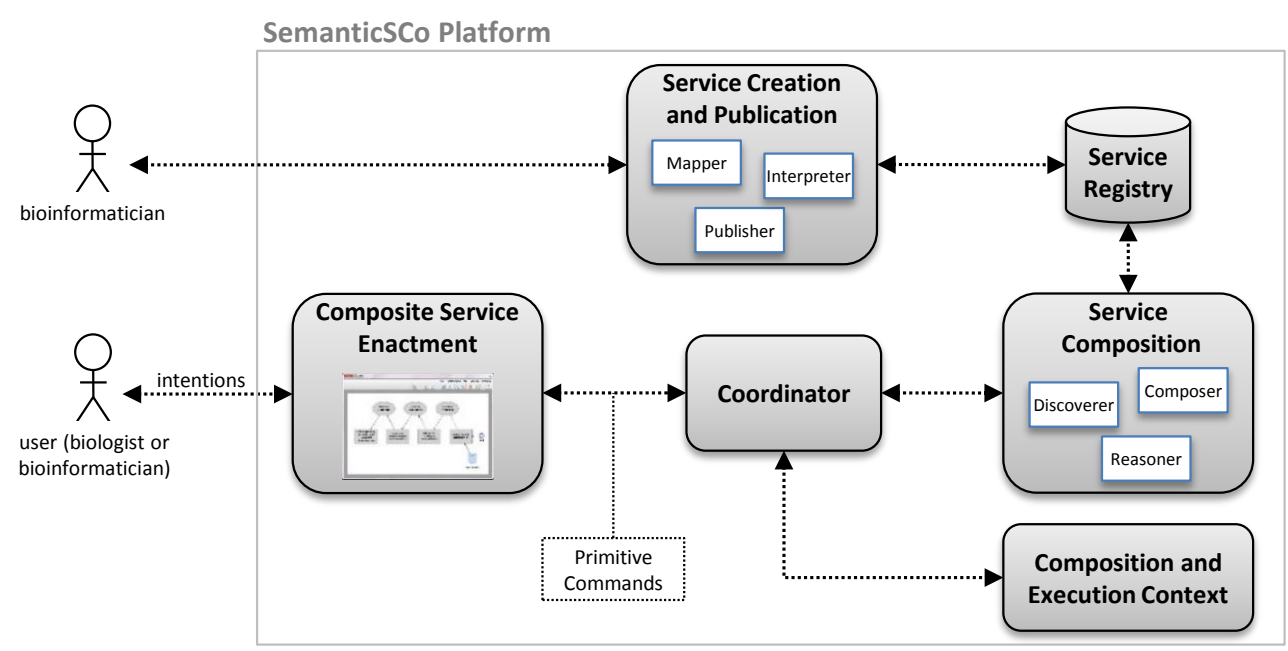

Figura 40: Módulos básicos da plataforma SemanticSCo.

O módulo Service Creation and Publication foi desenvolvido para dar suporte aos bioinformatas durante a criação e publicação de serviços web semânticos no módulo Service Registry. O módulo Service Registry representa um registro (base de informações) de serviços web semânticos disponíveis. Este registro armazena informações que permitem a posterior descoberta de serviços de interesse durante a criação de uma composição. O módulo Service Creation and Publication fornece uma infraestrutura de suporte para facilitar o desenvolvimento de serviços web semânticos de acordo com a metodologia proposta, bem como para a incorporação destes serviços na nossa plataforma de composição.

Os demais módulos da plataforma SemanticSCo foram desenvolvidos para dar suporte aos usuários (biologistas ou bioinformatas) durante a criação e execução de composições de ser- 
viços web semânticos. O módulo Composite Service Enactment fornece uma interface gráfica para a criação e execução de composições de serviços. Este módulo é responsável por coletar as intenções dos usuários e mapeá-las para comandos computacionais (Primitive Commands) que indicam quais atividades do processo de composição devem ser realizadas. Assim, este módulo realiza a mediação entre os usuários e o módulo Coordinator. O módulo Coordinator recebe os comandos produzidos pelo módulo Composite Service Enactment e mapeia estes comandos para invocações aos módulos Service Composition e Composition and Execution Context. Assim, o módulo Coordinator realiza a mediação entre o módulo Composite Service Enactment e os módulos Service Composition e Composition and Execution Context. O módulo Service Composition fornece suporte (semi) automático a todas as atividades do processo de composição de serviços. Cada atividade do processo de composição é suportada por um conjunto independente de (sub)componentes. Finalmente, o módulo Composition and Execution Context é responsável por armazenar um conjunto de informações associadas à criação e execução de composições de serviços.

No framework A-DynamiCoS, o módulo Service Composition é estruturado por meio de um conjunto de componentes que permitem, individualmente, a realização de cada etapa do processo de composição de serviços. Por sua vez, o módulo Coordinator é responsável por coordenar as invocações aos componentes básicos do módulo Service Composition para a realização das diferentes etapas do processo de composição. Esta estrutura do framework fornece suporte à composição de serviços de forma flexível, permitindo assim que as diferentes etapas do processo de composição sejam realizadas, sob demanda, de acordo com as necessidades dos usuários [342,343].

O framework A-DynamiCoS foi projetado para dar suporte ao processo de composição de serviços em diferentes domínios de aplicação, visando diferentes tipos de usuário. Neste sentido, os módulos Coordinator, Service Composition e Composition and Execution Context são genéricos e desta forma, podem ser reutilizados em diferentes domínios de aplicação. No entanto, a implementação disponível do framework A-DynamiCos (http://www.dynamicos.sourceforge. net) fornece suporte apenas à composição de serviços que contenham uma única operação. Além disto, esta implementação do framework foi projetada para dar suporte à composição de serviços web desenvolvidos de acordo com o protocolo SOAP e semanticamente anotados 
com o uso da linguagem SPATEL [344]. Assim, realizamos uma série de adaptações nas implementações dos módulos Coordinator, Service Composition e Composition and Execution Context para fornecer suporte à composição de serviços RESTful desenvolvidos de acordo com o conjunto de tecnologias e linguagens propostas como parte da nossa metodologia.

Em contraste, o módulo Composite Service Enactment foi projetado de acordo com os requisitos específicos do domínio de aplicação e as características do conjunto de usuários que participará do processo de composição. No contexto deste trabalho, desenvolvemos o módulo Composite Service Enactment com base nos requisitos do processo de análise expressão gênica e nas características dos usuários do domínio, ou seja, biologistas e bioinformatas.

\subsection{SUPORTE À CRIAÇÃO E PUBLICAÇÃO DE SERVIÇOS}

Na plataforma SemanticSCo, os módulos Service Creation and Publication e Service Registry fornecem suporte à primeira fase do processo de composição proposto na Seção 6.1.2, a qual consiste na criação e publicação de serviços web semânticos. Estes módulos são apresentados em detalhes nas subseções a seguir.

\subsubsection{Módulo Service Registry}

Na metodologia proposta para a criação de serviços web semânticos, as informações sobre um serviço são especificadas por meio de uma descrição WSDL 2.0 e um processo BPMN 2.0. Após a criação do serviço, estas informações precisam ser publicadas em um registro de serviços (base de informações) para permitir, posteriormente, a descoberta de serviços de interesse. Neste trabalho, o módulo Service Registry representa o registro de serviços desenvolvido na plataforma SemanticSCo, o qual foi desenvolvido com base na especificação UDDI [213].

A especificação UDDI fornece diretrizes e mecanismos para a publicação de informações extraídas a partir de descrições de serviços na linguagem WSDL 1.1 [345]. No entanto, nenhum suporte é fornecido à versão 2.0 da linguagem WSDL. Além disto, embora registros UDDI sejam primariamente utilizados para a publicação e descoberta de serviços, informações sobre outros recursos de software, tais como processos BPEL e BPMN, também podem ser geren- 
ciadas por meio de um registro UDDI. Neste sentido, a especificação UDDI também fornece diretrizes e mecanismos para a publicação de informações extraídas a partir de processos especificados na linguagem Business Process Execution Language (BPEL) [346]. No entanto, nenhum suporte é fornecido para a publicação de processos definidos na linguagem BPMN.

De modo a permitir a publicação de informações sobre serviços especificados nas linguagens WSDL 2.0 e BPMN 2.0, o módulo Service Registry utiliza um conjunto de estruturas de categorização (tModels) previamente definidas para o armazenamento de informações extraídas a partir de descrições de serviços especificadas na linguagem WSDL 1.1 [345]. Estas estruturas são utilizadas para armazenar informações extraídas a partir de elementos comuns às versões 1.1 e 2.0 da linguagem WSDL. Adicionalmente, o módulo Service Registry faz uso de um novo conjunto de estruturas de categorização que definimos como extensões do modelo UDDI. Estas estruturas foram definidas neste trabalho para permitir o armazenamento de informações extraídas a partir de elementos WSDL 2.0 não definidos na versão 1.1 da linguagem, bem como de anotações semânticas SAWSDL e elementos BPMN 2.0.

Seis estruturas de categorização foram reutilizadas no módulo Service Registry. A estrutura WSDL Entity Type é utilizada para indicar que um elemento UDDI representa um elemento WSDL específico (ex: binding). No contexto deste trabalho, esta estrutura é utilizada para a criação de dois tipos de elementos: Interface tModel e Binding tModel. A estrutura XML Namespace é utilizada para associar um namespace a um elemento UDDI. A estrutura $X M L$ Local Name é utilizada para associar um nome a um elemento UDDI do tipo businessService. A estrutura Protocol Categorization é utilizada para associar um protocolo a um elemento UDDI. Finalmente, a estrutura REST Protocol é utilizada para indicar que um serviço pode ser acessado por meio do protocolo HTTP utilizando o estilo arquitetural REST.

Adicionalmente, cinco novas estruturas de categorização foram definidas no módulo Service Registry. A Tabela 18 apresenta, de forma resumida, estas estruturas de categorização definidas como extensões do modelo UDDI e as respectivas descrições de uso destas estruturas. O Apêndice E apresenta, em detalhes, as estruturas de extensão propostas.

No contexto deste trabalho, o módulo Service Registry foi implementado como um banco de dados MySQL [347]. A criação deste componente foi realizada com o uso da API Java jUDDI (versão 3.2) [348]. Esta API fornece um modelo das estruturas básicas de armazenamento de- 
Tabela 18: Estruturas de categorização definidas como extensões UDDI.

\begin{tabular}{|c|l|}
\hline Estrutura de categorização & \multicolumn{1}{c|}{ Descrição } \\
\hline \hline BPMN Entity Type & $\begin{array}{l}\text { Esta estrutura é utilizada para indicar que um elemento UDDI do } \\
\text { tipo } \text { tModel representa um processo BPMN. Assim, esta estrutura } \\
\text { permite a criação de elementos UDDI do tipo Process tModel }\end{array}$ \\
\hline WSDL Interface Reference & $\begin{array}{l}\text { Esta estrutura é utilizada para associar um elemento UDDI do } \\
\text { tipo Interface tModel a um elemento UDDI do tipo tModel }\end{array}$ \\
\hline Functionality Reference & $\begin{array}{l}\text { Esta estrutura é utilizada para associar um conceito de uma on- } \\
\text { tologia (URI) representando uma funcionalidade de um serviço a } \\
\text { um elemento UDDI do tipo businessService }\end{array}$ \\
\hline Input Reference & $\begin{array}{l}\text { Esta estrutura é utilizada para associar um conceito de uma onto- } \\
\text { logia (URI) representando os dados de entrada de um serviço a } \\
\text { um elemento UDDI do tipo businessService }\end{array}$ \\
\hline Output Reference & $\begin{array}{l}\text { Esta estrutura é utilizada para associar um conceito de uma onto- } \\
\text { logia (URI) representando os dados de saída de um serviço a um } \\
\text { elemento UDDI do tipo businessService }\end{array}$ \\
\hline
\end{tabular}

finidas na especificação UDDI e ainda fornece mecanismos para a publicação e descoberta de serviços. O modelo fornecido pela API foi utilizado para gerar, de forma automática, as estruturas básicas de armazenamento no módulo Service Registry, ou seja, as tabelas do banco de dados, com o uso do framework Java Hibernate [349]. Este framework fornece recursos para mapear, de forma automática, modelos orientados a objetos para bases de dados relacionais. Adicionalmente, a API jUDDI fornece mecanismos para a inclusão automática de novas estruturas de armazenamento. Estes mecanismos foram utilizados para a inclusão das estruturas de categorização definidas como extensões do modelo UDDI.

\subsubsection{Módulo Service Creation and Publication}

O módulo Service Creation and Publication fornece suporte a determinadas atividades do processo de desenvolvimento de serviços web semânticos proposto no Capítulo 4. Adicionalmente, este módulo provê suporte à publicação no módulo Service Registry dos serviços desenvolvidos. Diferentes ferramentas foram desenvolvidas para prover o suporte necessário ao funcionamento 
deste módulo da plataforma SemanticSCo. A Figura 41 apresenta a estrutura do módulo Service Creation and Publication.

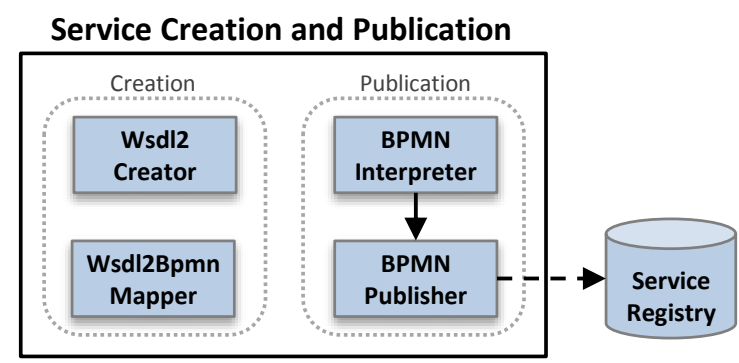

Figura 41: Estrutura do módulo Service Creation and Publication.

No módulo Service Creation and Publication, os componentes Wsdl2 Creator e Wsdl2Bpmn Mapper fornecem suporte à criação de serviços web semânticos. Cada um destes componentes foi desenvolvido como uma ferramenta distinta. Adicionalmente, os componentes BPMN Interpreter e BPMN Publisher fornecem, conjuntamente, suporte à publicação no módulo Service Registry de informações extraídas a partir de serviços.

\section{Criação de Serviços}

No Capítulo 4, definimos uma metodologia para a criação de serviços web semânticos para a análise de expressão gênica. Além da metodologia, apresentamos duas ferramentas de suporte desenvolvidas na linguagem Java: Wsdl2 Creator e Wsdl2Bpmn Mapper. A ferramenta Wsdl2 Creator fornece suporte (semi) automático à criação, edição e validação de descrições de serviços na linguagem WSDL 2.0. Por sua vez, a ferramenta Wsdl2Bpmn Mapper fornece suporte à criação (semi) automática de processos na linguagem BPMN 2.0 para a especificação do comportamento local dos serviços. As ferramentas Wsdl2 Creator e Wsdl2Bpmn Mapper foram incorporadas à plataforma SemanticSCo para facilitar a criação de serviços na plataforma. Contudo, estas ferramentas também podem ser utilizadas de forma independente da plataforma. Informações adicionais sobre estas ferramentas são apresentadas no Capítulo 4 (ver Seção 4.7).

\section{Publicação de Serviços}

A publicação de um serviço no módulo Service Registryé realizada em duas etapas. Na primeira etapa, o componente BPMN Interpreter realiza a leitura do documento BPMN que especifica 
o comportamento local do serviço e extrai um conjunto de informações relevantes. Este componente também é responsável pela leitura do documento WSDL referenciado a partir do documento BPMN e pela extração de informações complementares, tais como anotações SAWSDL. No componente BPMN Interpreter, as APIs Java Activiti [296] e Apache Woden [279] são utilizadas para o processamento de documentos BPMN e WSDL, respectivamente. Na segunda etapa, o componente BPMN Publisher realiza, de forma automática, o mapeamento das informações extraídas no componente BPMN Interpreter para a publicação no módulo Service Registry. A API jUDDI é utilizada para a publicação destas informações.

A Figura 42 resume o mapeamento das informações extraídas a partir de elementos BPMN e WSDL para a publicação no módulo Service Registry, a qual é realizada pelo componente BPMN Publisher. As linhas pontilhadas indicam elementos que referenciam outros elementos. As linhas sólidas representam o mapeamento de elementos WSDL ou BPMN para o módulo Service Registry. O Apêndice F apresenta em detalhes o mapeamento de elementos WSDL e BPMN para o módulo Service Registry.

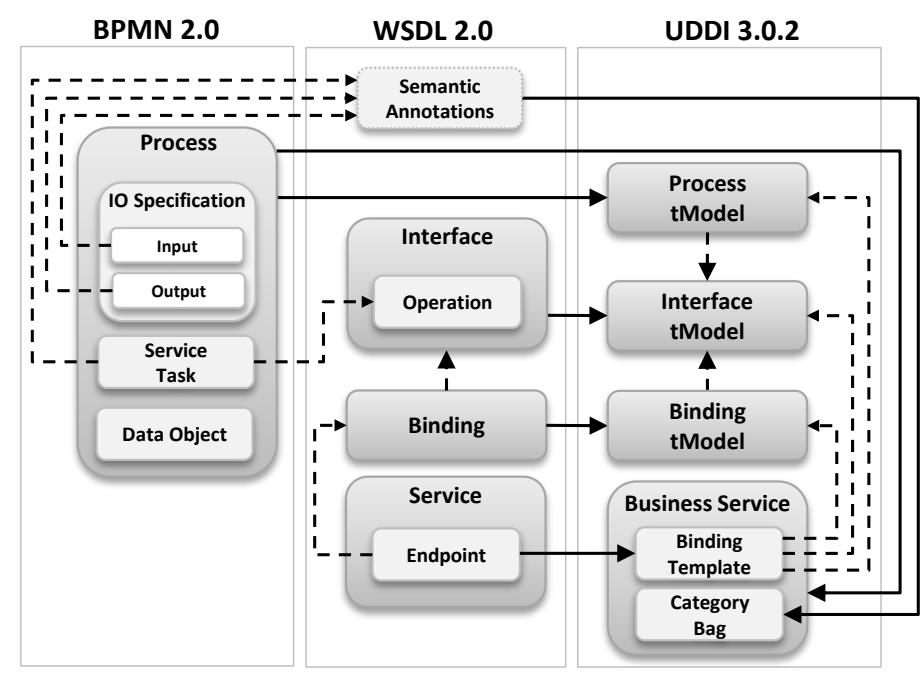

Figura 42: Mapeamento de um serviço para a publicação no módulo Service Registry.

O ponto de partida do mapeamento é um processo BPMN que captura o comportamento local de um serviço. Um processo BPMN consiste em um conjunto ordenado de Service Tasks (tarefas). Cada Service Task referencia um elemento WSDL Operation, representando uma operação fornecida pela interface do serviço (elemento WSDL Interface). De modo a publicar um serviço no módulo Service Registry, o elemento WSDL Interface é inicialmente mapeado para 
o elemento UDDI Interface tModel. O elemento WSDL Binding que referencia o elemento WSDL Interface é então mapeado para o elemento UDDI Binding tModel. Em seguida, o processo BPMN é mapeado para o elemento UDDI Process tModel. Os elementos UDDI Binding tModel e Process tModel referenciam o elemento UDDI Interface tModel. Na sequência, o processo BPMN também é mapeado para o elemento UDDI Business Service. O elemento WSDL Endpoint que referencia o elemento WSDL Binding é então mapeado para o elemento UDDI Binding Template, definido como parte do elemento UDDI Business Service. O elemento UDDI Binding Template referencia os elementos UDDI Binding tModel, Interface tModel e Process tModel. Finalmente, cada anotação semântica SAWSDL indiretamente referenciada pelos elementos BPMN Service Task, Input e Output, é mapeada para um elemento UDDI Category Bag, definido como parte do elemento Business Service.

Os componentes BPMN Interpreter e BPMN Publisher foram integrados em uma única ferramenta standalone, chamada SemanticSCo Publisher, que fornece uma interface gráfica para a publicação de serviços no módulo Service Registry. A Figura 43 apresenta a interface gráfica da ferramenta SemanticSCo Publisher. Nesta ferramenta, o usuário inicialmente seleciona um arquivo contendo o processo BPMN a ser publicado ou fornece a URL da localização do documento BPMN. O usuário pode então fornecer uma descrição textual do processo. Finalmente, o processo pode ser publicado, de forma automática, no módulo Service Registry.

\subsubsection{Representação de Serviços}

No framework A-DynamiCoS, um serviço consiste em um recurso computacional que fornece uma única operação e assim, apresenta um comportamento local trivial. Cada serviço incorporado ao framework é representado como uma tupla $S=<I D$, Desc, Endpoint, I, O, P, E, F, $N F>$, onde $I D$ representa um identificador exclusivo do serviço, Desc representa uma descrição textual do serviço, EndPoint representa a localização do serviço, I representa o conjunto de dados de entrada do serviço, $O$ representa o conjunto de dados de saída do serviço, $P$ representa o conjunto de pré-condições para a execução do serviço, $E$ representa o conjunto de efeitos resultantes da execução do serviço, $F$ representa o conjunto de funcionalidades fornecidas pelo serviço e NF representa o conjunto de propriedades não-funcionais do serviço. 


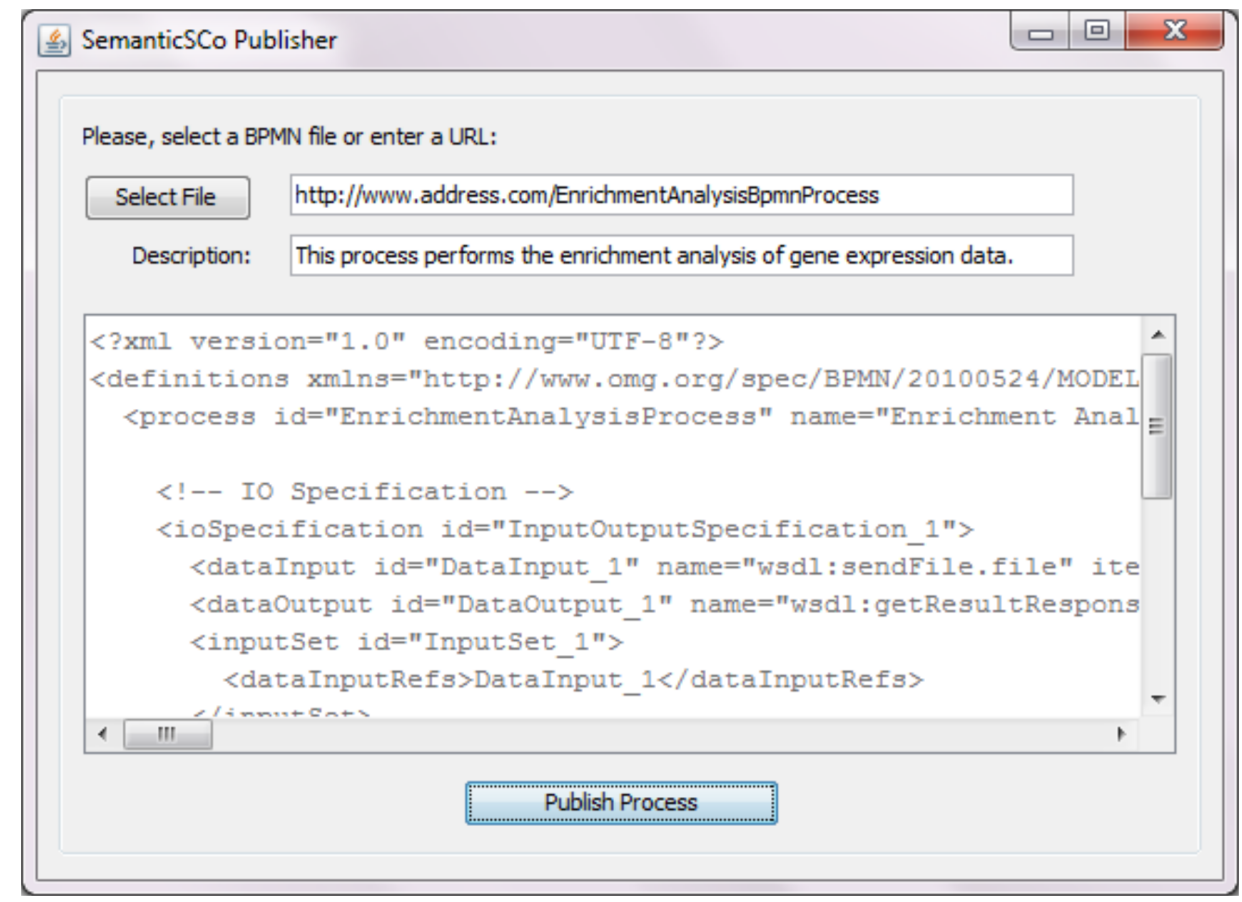

Figura 43: Interface gráfica para publicação de serviços na plataforma SemanticSCo.

Na plataforma SemanticSCo, todos os serviços são criados com base na metodologia proposta para o desenvolvimento de serviços web semânticos. Assim, diferentemente do framework ADynamiCoS, um serviço consiste em um recurso computacional que fornece um conjunto de operações. Além disto, o desenvolvimento dos serviços é realizado com base em linguagens e tecnologias distintas das consideradas no framework A-DynamiCoS. Desta forma, algumas adaptações foram necessárias para a representação dos serviços na plataforma SemantiSCo.

De acordo com a nossa metodologia para o desenvolvimento de serviços, cada serviço é especificado por meio de um ou mais processos BPMN. Cada processo BPMN especifica um (sub)conjunto de operações do serviço e a ordem com que estas operações devem ser executadas. Portanto, cada serviço incorporado à plataforma SemanticSCo é representado como um processo BPMN. Adicionalmente, adaptamos a plataforma de modo a fornecer suporte à definição de múltiplas instâncias de um mesmo processo em uma composição. Esta modificação permite, por exemplo, que uma mesma atividade de análise apareça repetidas vezes em uma composição.

A Figura 44 apresenta um diagrama de classes UML representando a estrutura conceitual de um processo (instância) incorporado à plataforma SemanticSCo. Cada retângulo (classe 
UML) representa um conceito. Na plataforma SemanticSCo, cada conceito é traduzido para diferentes estruturas, tais como elementos XML e classes Java. As agregações UML definidas entre classes indicam conceitos contidos como parte de outros conceitos. As multiplicidades entre os conceitos relacionados também são apresentadas.

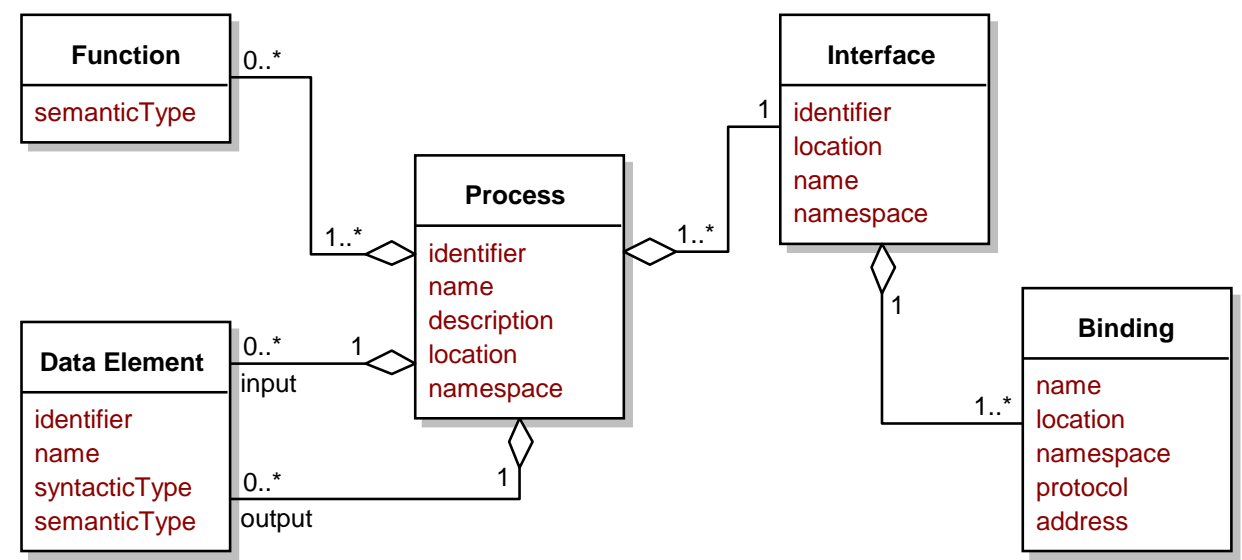

Figura 44: Estrutura de um serviço (processo) na plataforma SemanticSCo.

Um processo BPMN (classe Process) possui um identificador exclusivo, um nome e uma descrição textual. A representação de um processo inclui também a localização (URL) do documento BPMN que o define e o namespace no qual o processo está definido.

Cada processo BPMN pode estar associado a um conjunto de funcionalidades (classe Function) que são fornecidas pelas operações de serviço referenciadas pelo processo. A representação de uma funcionalidade inclui apenas a sua semântica (conceito de uma ontologia). Uma mesma funcionalidade pode ser associada a diferentes processos. Além disto, um processo BPMN pode estar associado a um conjunto de dados de entrada (relacionamento input) e saída (relacionamento output). Cada elemento de dados possui um identificador exclusivo e um nome. A representação de um elemento de dados inclui também a sua sintaxe e a sua semântica (conceito de uma ontologia). Cada elemento de dados unicamente identificado está exclusivamente associado a um único processo.

De modo geral, um processo BPMN pode ser utilizado para especificar uma composição (manual) de serviços. Neste contexto, um processo BPMN pode referenciar uma ou mais interfaces WSDL (classe Interface). Cada interface descreve um conjunto de operações fornecido por um determinado serviço. No entanto, restringimos a utilização de processos BPMN apenas para a especificação do comportamento local dos serviços. Neste sentido, cada processo BPMN está 
associado a uma única interface WSDL, que descreve as operações de um serviço referenciadas no processo BPMN. Uma interface possui um identificador exclusivo e um nome. A representação de uma interface inclui também a localização (URL) do documento WSDL que a define e o namespace no qual a interface está definida. Uma mesma interface pode estar associada a múltiplos processos BPMN.

Finalmente, cada interface está associada a um ou mais bindings WSDL (classe Binding). Um binding descreve como as operações de serviço definidas pela interface podem ser acessadas. Cada binding possui um nome e especifica um protocolo de acesso e um endereço por meio do qual as operações de serviço podem ser acessadas. A representação de um binding inclui também a localização (URL) do documento WSDL que o define e o namespace no qual o binding está definido. Cada binding é exclusivamente associado a uma única interface.

\subsection{SUPORTE À COMPOSIÇÃO E EXECUÇÃO DE SERVIÇOS}

Na plataforma SemanticSCo, os módulos Service Registry, Composite Service Enactment, Coordinator, Service Composition e Composition and Execution Context fornecem suporte à segunda fase do processo de composição proposto na Seção 6.1.2, a qual consiste na composição e execução de serviços web semânticos. O módulo Service Registry é apresentado na Seção 6.5.1. Os demais módulos são apresentados em detalhes nas subseções a seguir.

\subsubsection{Comandos Primitivos}

Na plataforma SemanticSCo, a comunicação entre os módulos Composite Service Enactment e Coordinator é realizada por meio de um conjunto de comandos primitivos. Cada comando primitivo permite que o módulo Composite Service Enactment solicite ao módulo Coordinator a execução de um determinado comportamento. Além disto, cada comando primitivo especifica os formatos das mensagens de requisição e de resposta que devem ser trocadas entre estes dois módulos.

Neste trabalho, reutilizamos o conjunto de comandos primitivos originalmente definido no framework A-DynamiCoS. No entanto, uma vez que alteramos a representação dos serviços 
(processos) na nossa plataforma, alguns parâmetros das mensagens de requisição e resposta definidos pelos comandos primitivos reutilizados foram adaptados. Além disto, estendemos o conjunto de comandos primitivos com a definição de novos comandos.

Um conjunto de nove comandos primitivos foi definido na plataforma SemanticSCo, os quais podem ser utilizados para solicitar a realização de diferentes atividades associadas ao processo de composição de serviços. Estes comandos primitivos são apresentados a seguir:

1. DISCOVER_INPUT_SEMANTICS: comando utilizado para requisitar um conjunto de conceitos de uma ontologia para serem utilizados na especificação semântica de um conjunto de dados;

2. DISCOVER_FUNCTION_SEMANTICS: comando utilizado para requisitar um conjunto de conceitos de uma ontologia, os quais representam atividades de análise (funcionalidades) que podem ser realizadas em um determinado tipo de dado especificado por um conceito de uma ontologia (URL);

3. DISCOVER_SERVICES: comando utilizado para requisitar a descoberta semântica de serviços que forneçam um conjunto de funcionalidades ou sejam capazes de processar um conjunto de tipos de dados. As funcionalidades e tipos de dados são especificados por meio de conceitos de uma ontologia (URLs);

4. INCLUDE_SERVICES: comando utilizado para requisitar a inclusão de um conjunto de serviços na composição sendo criada. Este comando permite que cada serviço seja apenas incluído na cadeia de composição sem realizar a interligação do serviço com outros serviços definidos na cadeia;

5. RESOLVE_SERVICES: comando utilizado para requisitar a descoberta semântica de serviços capazes de produzir os tipos de dados exigidos como entrada para um conjunto de serviços especificado;

6. VALIDATE_INPUTS: comando utilizado para requisitar a validação de um conjunto de dados de entrada de um serviço que tenha sido previamente inserido na composição. A validação dos dados de entrada de um serviço consiste em associar um conjunto de dados fornecido pelo usuário à entrada do serviço; 
7. COMPOSE_SERVICES: comando utilizado para requisitar a composição (interligação) forward ou backward de dois serviços previamente inseridos na composição por meio do comando INCLUDE_SERVICES, de modo que o conjunto de dados produzido por um dos serviços seja associado à entrada do outro serviço;

8. GET_EXECUTABLE_SERVICES: comando utilizado para requisitar o conjunto de serviços que podem ser executados. Um serviço está pronto para execução quando todos os dados de entrada exigidos para sua execução estão disponíveis. Estes dados podem ser fornecidos pelo usuário ou produzidos como saída de um serviço anterior na cadeia de composição;

9. ADD_TO_CONTEXT: comando utilizado para requisitar o armazenamento de um conjunto de dados produzido como resultado da execuçaõ de um conjunto de serviços.

Os comandos RESOLVE_SERVICES, GET_EXECUTABLE_SERVICES e ADD_TO_CONTEXT foram utilizados sem adaptação na plataforma SemanticSCo. Os comandos DISCOVER_SERVICES, INCLUDE_SERVICES e VALIDATE_INPUTS foram adaptados a partir dos comandos originalmente definidos no framework A-DynamiCoS. Finalmente, os comandos DISCOVER_INPUT_SEMANTICS,DISCOVER_FUNCTION_SEMANTICS e COMPOSE_SERVICES foram adicionados. Além disto, alguns dos comandos primitivos reutilizados foram renomeados com novos identificadores mais representativos de suas funcionalidades.

Todos os comandos primitivos foram definidos na linguagem XML Schema Definitions (XSD) [350,351]. A definição XSD de cada comando primitivo especifica o formato das mensagens de requisição XML que podem ser emitidas pelo módulo Composite Service Enactment ao módulo Coordinator e o formato das mensagens de resposta XML que podem ser emitidas pelo módulo Coordinator ao módulo Composite Service Enactment.

Após a definição dos comandos primitivos, utilizamos a API Java JAXB (versão 2.2.4) [338, 339] para gerar automaticamente o código necessário ao módulo Composite Service Enactment para a construção das mensagens de requisição XML a serem enviadas ao módulo Coordinator e para a extração de informações das mensagens de resposta XML recebidas a partir módulo Coordinator. De forma semelhante, no módulo Coordinator, a API JAXB também foi utilizada para gerar o código necessário para extrair informações das mensagens de requisição XML 
recebidas a partir do módulo Composite Service Enactment e para a construção das mensagens de resposta XML a serem enviadas ao módulo Composite Service Enactment.

\subsubsection{Módulo Composite Service Enactment}

O módulo Composite Service Enactment provê suporte aos usuários da plataforma (biologistas ou bioinformatas) para que os mesmos dirijam o processo de composição de serviços e executem os workflows de análise criados. Este módulo é responsável por capturar as intenções de um usuário e mapear estas intenções para comandos primitivos que podem ser entendidos pelo módulo Coordinator. Assim, o módulo Composite Service Enactment permite que um usuário dirija o processo de composição de forma transparente, isentando-o dos detalhes do processo de criação e execução de uma composição de serviços. A Figura 45 apresenta a estrutura do módulo Composite Service Enactment na plataforma SemanticSCo.

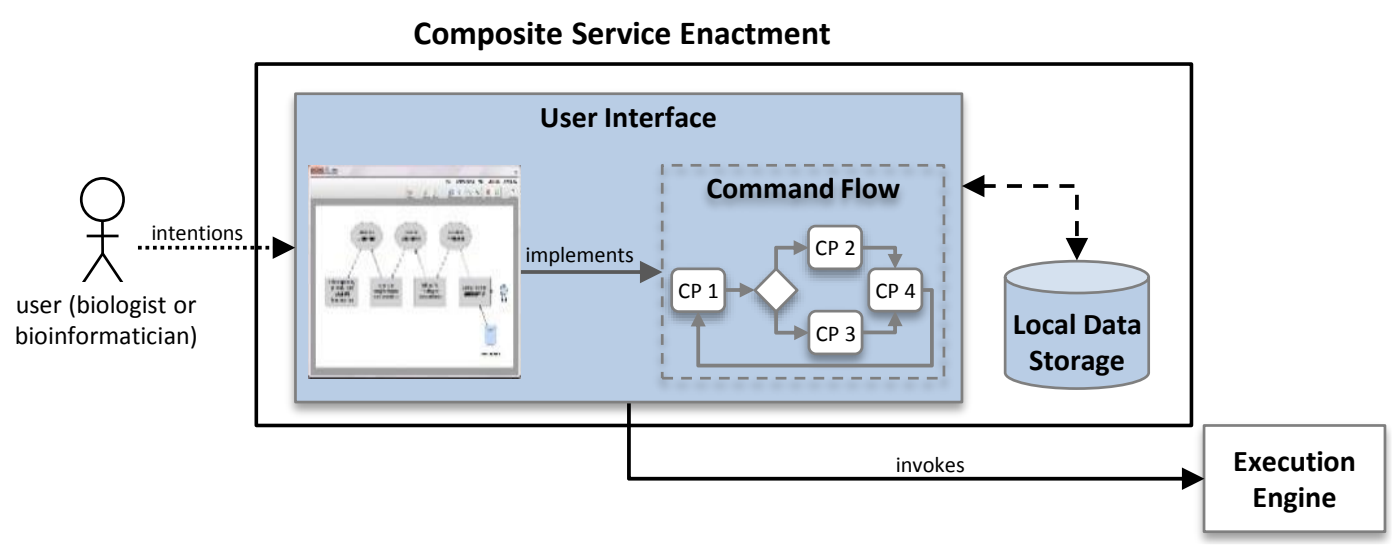

Figura 45: Estrutura do módulo Composite Service Enactment.

O módulo Composite Service Enactment possui um componente chamado User Interface, que representa uma interface gráfica definida para permitir a interação dos usuários (biologistas ou bioinformatas) com a plataforma SemanticSCo. O componente User Interface é responsável pela interação com os usuários, capturando entre outras informações, as intenções dos usuários em relação ao processo de composição. Estas intenções são então traduzidas para comandos primitivos, os quais são enviados ao módulo Coordinator (veja Figura 40).

O componente User Interface implementa um fluxo de comandos (Command Flow), de forma transparente aos usuários. Este fluxo de comandos especifica a sequência com que os comandos 
primitivos definidos na plataforma SemanticSCo podem ser utilizados pelo módulo Composite Service Enactment para solicitar ao módulo Coordinator a realização das atividades associadas ao processo de composição. Além disto, quando um usuário solicita a execução de um ou mais serviços definidos em uma composição, o componente User Interface é responsável por invocar um mecanismo de execução externo (Execution Engine). Este mecanismo é, por sua vez, responsável por executar o(s) serviço(s) solicitado(s). Adicionalmente, quando um usuário fornece um conjunto de dados, o componente User Interface faz uso do componente Local Data Storage para a armazenar localmente os dados fornecidos. Os dados produzidos pela execução dos serviços são armazenados de forma persistente no módulo Composition and Execution Context por meio do módulo Coordinator. No entanto, o componente Local Data Storage também é utilizado para armazenar temporariamente estes dados, durante a execução da plataforma, de modo a otimizar a recuperação dos mesmos, quando solicitados pelo usuário.

O framework A-DynamiCoS considera que diferentes usuários, possivelmente em domínios distintos, podem apresentar diferentes requisitos durante o processo de composição de serviços. Estas diferenças fazem com que cada usuário conduza o processo de composição de uma determinada maneira, fazendo uso dos comandos primitivos em uma ordem específica. Neste sentido, o módulo Composite Service Enactment da plataforma SemanticSCo foi desenvolvido para capturar as necessidades de biologistas e bioinformatas de maneira adequada e flexível, de modo a acomodar as necessidades individuais destes usuários durante a criação e execução de composições de serviços.

\section{User Interface}

O componente User Interface representa uma interface gráfica de usuário desenvolvida na linguagem Java. Esta interface fornece suporte à definição gráfica de workflows (abstratos) de análise pelos usuários. Um workflow abstrato de análise consiste em um conjunto de tipos de dados que um usuário deseja processar e de atividades de análise que o usuário deseja realizar nos dados disponíveis. Os tipos de dados e atividades de análise são especificados por meio de conceitos de uma ontologia de serviços. No componente User Interface, um workflow de análise pode ser especificado utilizando um subconjunto de elementos gráficos da linguagem BPMN. A especificação gráfica destes elementos é realizada com o uso da API JGraphX [352], 
que fornece recursos para a criação e edição de elementos gráficos em diagramas de propósito geral.

O componente User Interface fornece suporte não apenas à especificação de um workflow de análise, mas também à associação concreta de serviços web semânticos às atividades de análise definidas em um workflow. Uma vez que uma composição de serviços é (parcialmente) especificada, um usuário pode invocar a execução de um ou mais serviços definidos na composição por meio da nossa interface gráfica. A execução destes serviços é realizada por um mecanismo de execução externo (Execution Engine). Uma vez que os serviços web semânticos integrados à plataforma SemanticSCo são especificados como processos executáveis BPMN, qualquer mecanismo de execução BPMN pode ser utilizado para dar suporte à execução dos serviços incluídos na plataforma. No contexto deste trabalho, utilizamos o mecanismo de execução de processos BPMN fornecido pela plataforma BPM Activiti [296]. Assim, a execução dos serviços é delegada à plataforma de execução Activiti e a plataforma SemanticSCo apenas gerencia e armazena as informações consumidas e produzidas durante a execução dos serviços.

A Figura 46 apresenta a interface gráfica de usuário desenvolvida na plataforma SemanticSCo para fornecer suporte à criação e execução de cenários de análise (composições de serviços) por biologistas e bioinformatas, bem como as principais funcionalidades disponíveis nesta interface.

A criação de um cenário de análise por um usuário na nossa interface gráfica pode ser realizada de acordo com as seguintes etapas. Inicialmente, o usuário inclui um conjunto de dados que deseja analisar e associa um conceito de uma ontologia de serviços aos dados (ex: Agilent one-color microarray data), de modo a atribuir semântica aos dados. Em seguida, o usuário iterativamente seleciona atividades de análise (conceitos de uma ontologia) a serem realizadas nos dados disponíveis, por exemplo, microarray data normalization. Para cada atividade de análise selecionada, o sistema sugere uma lista de serviços disponíveis. O usuário então seleciona um serviço web para realizar cada atividade de análise. Uma vez que um serviço é associado a uma atividade de análise e os dados de entrada do serviço são fornecidos, sua execução pode ser disparada pelo usuário. Durante a execução do serviço, parâmetros de análise adicionais podem ser solicitados ao usuário. Após a execução do serviço, os dados resultantes da análise podem ser salvos localmente pelo usuário. Adicionalmente, após a execução (individual) de um ou mais serviços, o usuário pode alterar a composição de serviços criada. Nesta etapa, o 


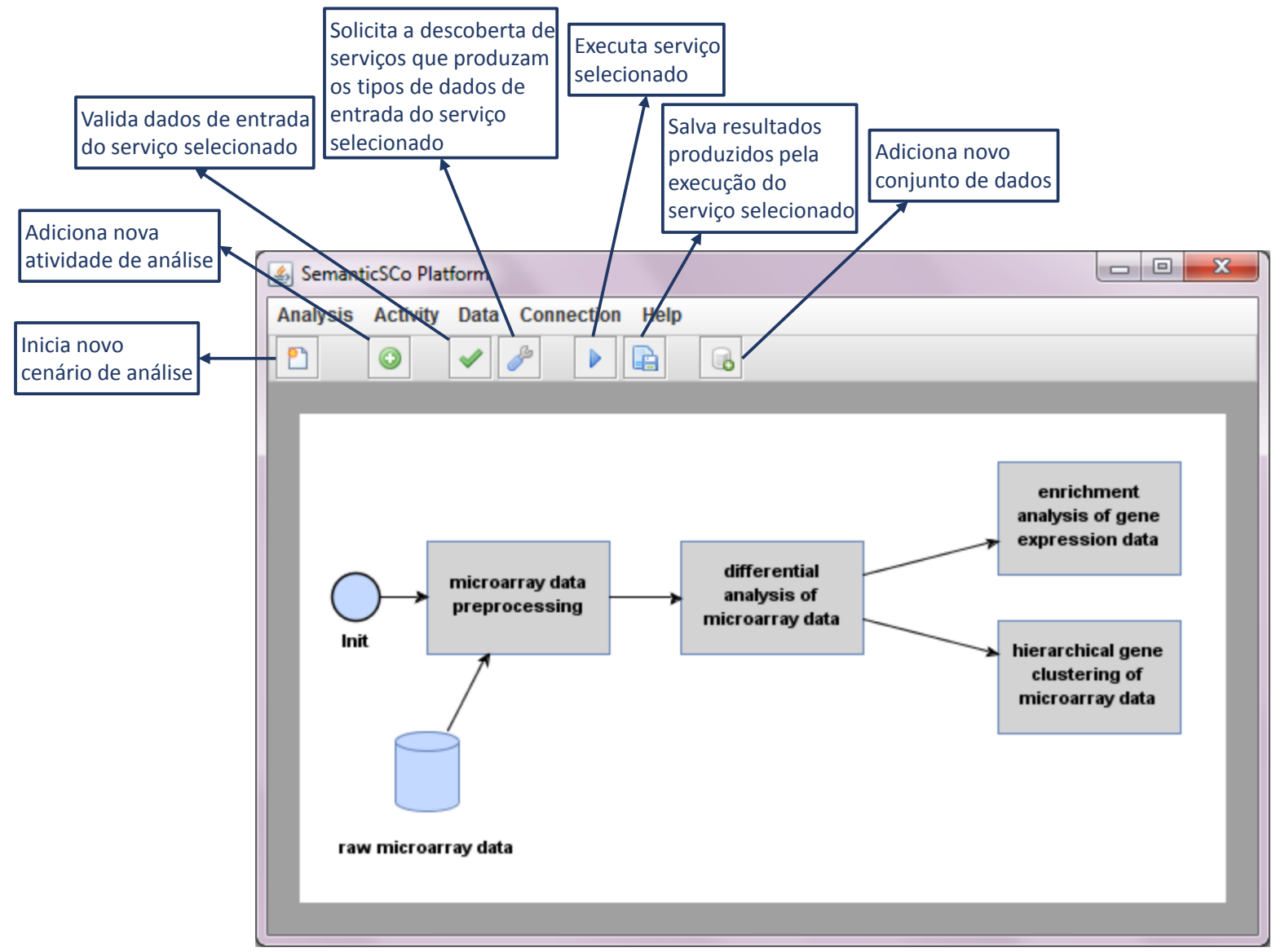

Figura 46: Interface gráfica de usuário na plataforma SemanticSCo.

usuário pode inserir novos conjuntos de dados e/ou novas atividades de análise que considerar necessárias

Os serviços definidos em um cenário de análise podem ser individualmente executados quando seus dados de entrada estiverem disponíveis. Os dados de entrada de cada serviço podem ser fornecidos pelo usuário ou podem ser produzidos como saída de um outro serviço definido no cenário. Considere, por exemplo, um cenário de análise definido por uma sequência de serviços $\left\{S_{1}, S_{2}, S_{3}, \ldots, S_{n}\right\}$, em que um conjunto de dados fornecido pelo usuário é consumido pelo serviço $S_{1}$, os dados produzidos pelo serviço $S_{1}$ são consumidos pelo serviço $S_{2}$, os dados produzidos pelo serviço $S_{2}$ são consumidos pelo serviço $S_{3}$ e assim sucessivamente. Neste cenário, o serviço $S_{1}$ pode ser inicialmente executado. Quando os dados de saída do serviço $S_{1}$ estiverem disponíveis, a execução do serviço $S_{2}$ pode então ser disparada. Em seguida, quando 
os dados de saída do serviço $S_{2}$ estiverem disponíveis, a execução do serviço $S_{3}$ pode então ser disparada e assim sucessivamente, até que o serviço $S_{n}$ seja executado.

\section{Command Flow}

O fluxo de comandos (Command Flow) implementado pelo componente User Interface define a ordem com que os comandos primitivos podem ser emitidos pelo módulo Composite Service Enactment ao módulo Coordinator para solicitar a realização de diferentes atividades associadas ao processo de composição. No entanto, a ordem de invocação dos comandos primitivos deve seguir algumas regras. Por exemplo, o comando VALIDATE_INPUTS só pode ser utilizado para solicitar a validação das entradas de um serviço se este serviço tiver sido previamente incluído na composição por meio do comando INCLUDE_SERVICES. Neste caso, há uma relação de dependência entre os comandos VALIDATE_INPUTS e INCLUDE_SERVICES.

De modo a capturar as relações de dependência entre os comandos primitivos da plataforma SemanticSCo, um novo grafo de dependências foi definido. Este grafo foi utilizado, de forma implícita, como base para a implementação do fluxo de comandos (Command Flow) da plataforma SemanticSCo. A Figura 47 apresenta o grafo de dependências definido no contexto deste trabalho.

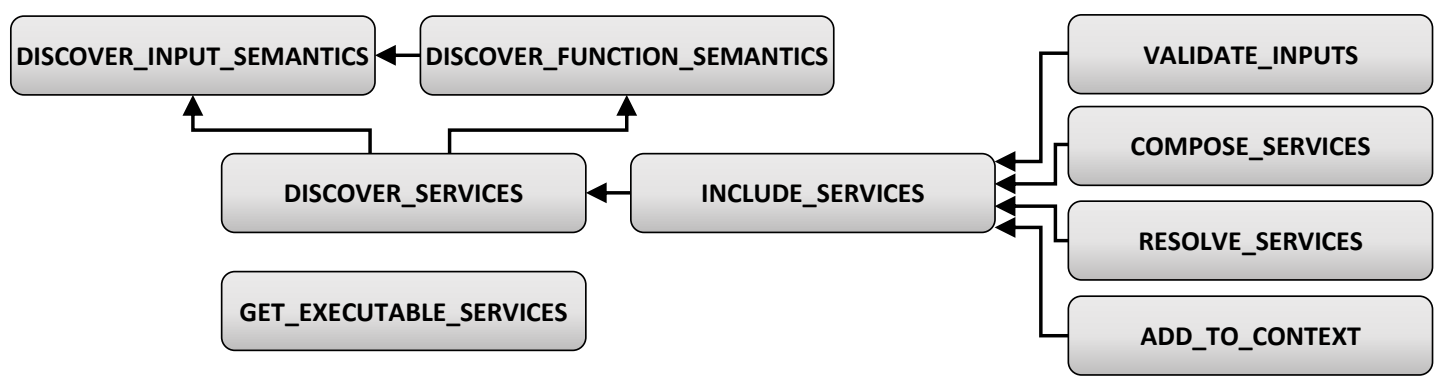

Figura 47: Grafo de dependências da plataforma SemanticSCo.

O comando DISCOVER_FUNCTION_SEMANTICS só pode ser utilizado para realizar a descoberta de funcionalidades associadas a um tipo de dado de entrada previamente descoberto por meio do comando DISCOVER_INPUT_SEMANTICS. O comando DISCOVER_SERVICES só pode ser utilizado para realizar a descoberta de serviços com base em funcionalidades e tipos de dados de entrada previamente descobertos por meio dos comandos DISCOVER_FUNCTION_SEMANTICS e DISCOVER_INPUT_SEMANTICS, respectivamente. O comando INCLUDE_- 
SERVICES só pode ser utilizado para selecionar um serviço que tenha sido previamente descoberto por meio do comando DISCOVER_SERVICES. O comando VALIDATE_INPUTS só pode ser utilizado para validar os dados de entrada de um serviço que tenha sido previamente inserido na composição por meio do comando INCLUDE_SERVICES. Da mesma forma, os comandos COMPOSE_SERVICES, RESOLVE_SERVICES e ADD_TO_CONTEXT só podem ser utilizados se o comando INCLUDE_SERVICES tiver sido previamente utilizado. Finalmente, o comando GET_EXECUTABLE_SERVICES não apresenta dependências com outros comandos, podendo ser utilizado a qualquer momento sem qualquer restrição.

O fluxo de comandos da plataforma SemanticSCo implementa a estratégia definida para a composição de serviços web semânticos para a análise de expressão gênica (veja Figura 39), de modo que cada atividade da estratégia de composição é suportada por um ou mais comandos primitivos. Este fluxo de comandos é codificado no componente User Interface. A Figura 48 apresenta uma representação baseada em BPMN do fluxo de comandos codificado pela plataforma SemanticSCo. Os círculos (eventos) indicam o início/fim da execução do fluxo de comandos. Cada retângulo (atividade) representa a invocação (automática) de um comando primitivo. Finalmente, cada losango (gateway) representa um ponto de decisão.

Inicialmente, o usuário pode incluir via componente User Interface um ou mais conjuntos de dados que deseja analisar. Após incluir cada conjunto de dados, o comando DISCOVER_INPUT_SEMANTICS é invocado. Este comando é utilizado para solicitar uma lista de conceitos de uma ontologia que podem ser utilizados para especificar a semântica dos dados. Esta lista é então apresentada ao usuário, o qual seleciona um dos conceitos que especificam a semântica dos dados.

Em seguida, o usuário pode iterativamente incluir uma ou mais atividades de análise que deseja realizar nos dados. Para incluir uma atividade de análise, o comando DISCOVER_FUNCTION_SEMANTICS é inicialmente invocado para solicitar uma lista de conceitos de uma ontologia representando atividades de análise que podem ser realizadas nos tipos de dados disponíveis. Os dados disponíveis consistem nos dados incluídos pelo usuário e nos dados produzidos por cada serviço previamente incluído na composição. Caso nenhuma atividade de análise seja encontrada, o usuário pode refinar a semântica dos seus dados. Caso contrário, uma lista de atividades de análise disponíveis é apresentada e o usuário seleciona a atividade que deseja re- 


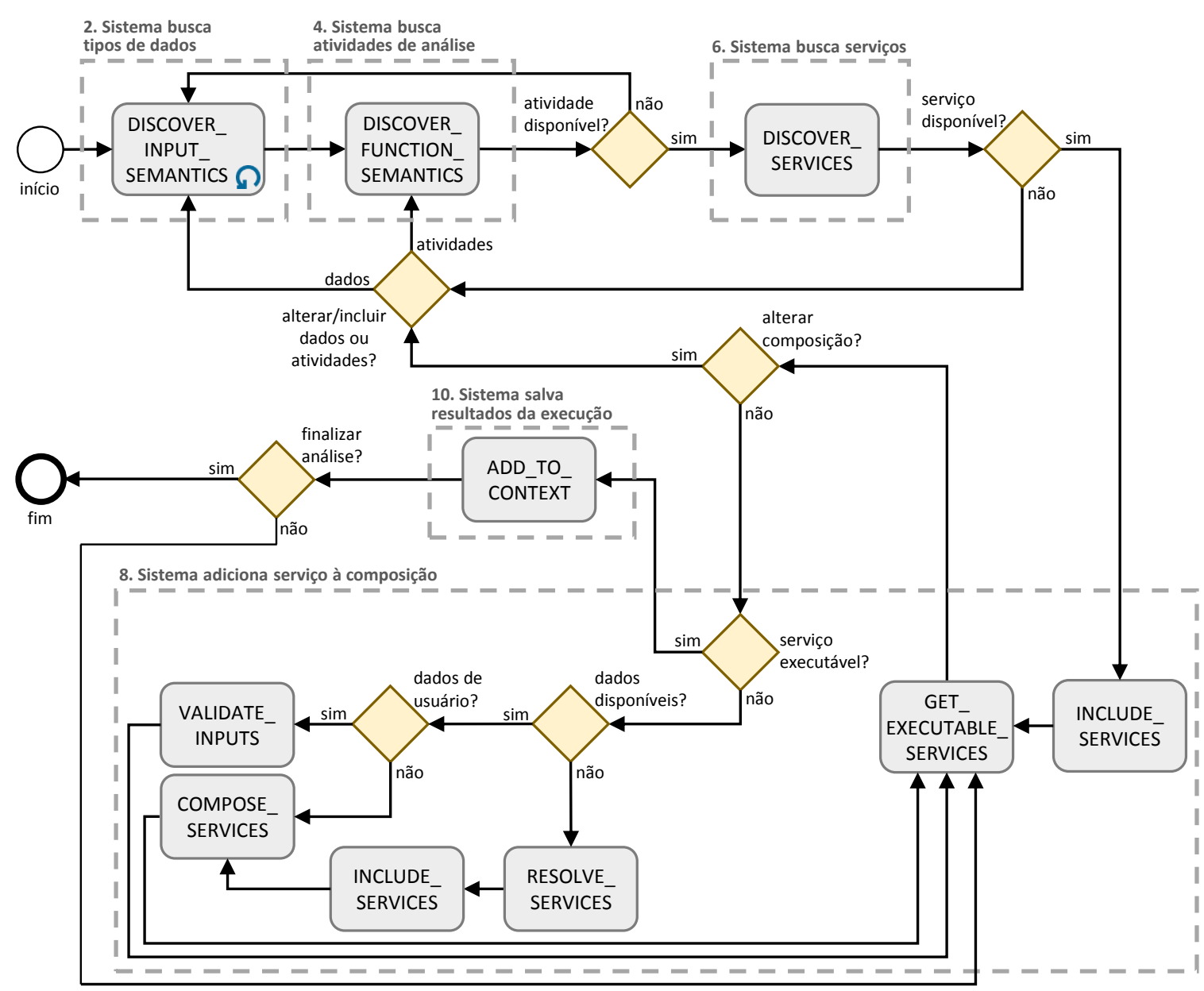

Figura 48: Fluxo de comandos codificado pela plataforma SemanticSCo.

alizar. Em seguida, o comando DISCOVER_SERVICES é invocado para solicitar a descoberta de serviços que realizem a atividade de análise selecionada. Estes serviços também devem ser capazes de processar os tipos de dados disponíveis. Caso nenhum serviço seja encontrado, o usuário pode novamente refinar a semântica dos seus dados ou selecionar outra atividade de análise. Caso contrário, uma lista de serviços disponíveis é apresentada e o usuário seleciona um dos serviços apresentados. O comando INCLUDE_SERVICES é então invocado para solicitar a inclusão do serviço selecionado pelo usuário na composição sendo criada. No entanto, este serviço não é interligado a outros serviços definidos na composição, ou seja, os dados de entrada do serviço ainda não são associados aos dados produzidos por um outro serviço.

Quando um novo serviço é incluído na composição, o comando GET_EXECUTABLE_SERVICES é invocado para solicitar a lista de serviços que estão prontos para serem executados. Neste ponto, o usuário pode incluir um novo conjunto de dados ou uma nova atividade de análise. Al- 
ternativamente, se o serviço não estiver pronto para execução, ou seja, se os dados de entrada exigidos pelo serviço ainda não foram fornecidos, o usuário pode validar os dados de entrada do serviço. Na etapa de validação, uma lista de opções disponíveis para a validação dos dados de entrada do serviço é apresentada ao usuário. Esta lista pode incluir os conjuntos de dados previamente fornecidos pelo usuário e/ou os dados de saída fornecidos por outros serviços previamente incluídos na composição. Neste ponto, três opções são possíveis:

1. Se o usuário selecionar um item da lista representando um conjunto de dados previamente fornecido pelo usuário, o comando VALIDATE_INPUTS é invocado para solicitar a associação do conjunto de dados à entrada do serviço.

2. Se o usuário selecionar um item da lista representando a saída de outro serviço definido na composição, o comando COMPOSE_SERVICES é invocado para solicitar a associação da saída do serviço que foi selecionada à entrada do serviço que está sendo validada (composição forward).

3. Se a lista de opções disponíveis para a validação dos dados de entrada do serviço estiver vazia, o usuário pode solicitar a descoberta de serviços que produzam dados compatíveis com os dados de entrada do serviço que se deseja validar. O comando $R E$ SOLVE_SERVICES é então invocado para solicitar a descoberta de serviços capazes de produzir o conjunto de dados exigido como entrada para o serviço sendo validado. Como resultado, uma lista de serviços disponíveis é apresentada ao usuário, o qual seleciona um dos serviços apresentados. Quando um serviço é selecionado pelo usuário, o comando INCLUDE_SERVICES é invocado para solicitar a inclusão do serviço selecionado na composição. Finalmente, o comando COMPOSE_SERVICES é invocado para solicitar a associação da entrada do serviço sendo validada com a saída do serviço selecionado (composição backward).

Quando os dados de entrada de um serviço são validados, o comando GET_EXECUTABLE_SERVICES é novamente invocado para solicitar a lista atualizada de serviços que estão prontos para execução. Neste ponto, o usuário pode inserir novos conjuntos de dados e/ou atividades de análise. De forma alternativa, caso o serviço não esteja pronto para execução, ou seja, todos os dados de entrada exigidos pelo serviço ainda não tenham sido fornecidos, o usuário 
pode validar os demais dados de entrada do serviço. Caso contrário, o usuário pode solicitar sua execução. Após a execução do serviço, o comando ADD_TO_CONTEXT é invocado para solicitar o armazenamento dos resultados produzidos pelo serviço. Adicionalmente, o usuário pode salvar os dados produzidos pela execução do serviço localmente. Após o armazenamento dos resultados, caso o usuário deseje continuar o processo de análise, o comando GET_EXECUTABLE_SERVICES é novamente invocado para solicitar a lista atualizada de serviços que estão prontos para execução. Neste ponto, a composição de serviços pode ser novamente alterada com a inserção de novos conjuntos de dados e/ou atividades de análise. Caso contrário, a análise é finalizada.

\subsubsection{Módulo Coordinator}

Na plataforma SemanticSCo, o módulo Coordinator é responsável por mediar as interações entre o módulo Composite Service Enactment e os módulos Service Composition e Composition and Execution Context, de modo a coordenar as invocações aos componentes básicos destes módulos para a realização de diferentes atividades solicitadas pelos usuários. A Figura 49 apresenta a estrutura do módulo Coordinator na plataforma SemanticSCo e as interações deste módulo com os módulos Composite Service Enactment, Service Composition e Composition and Execution Context.

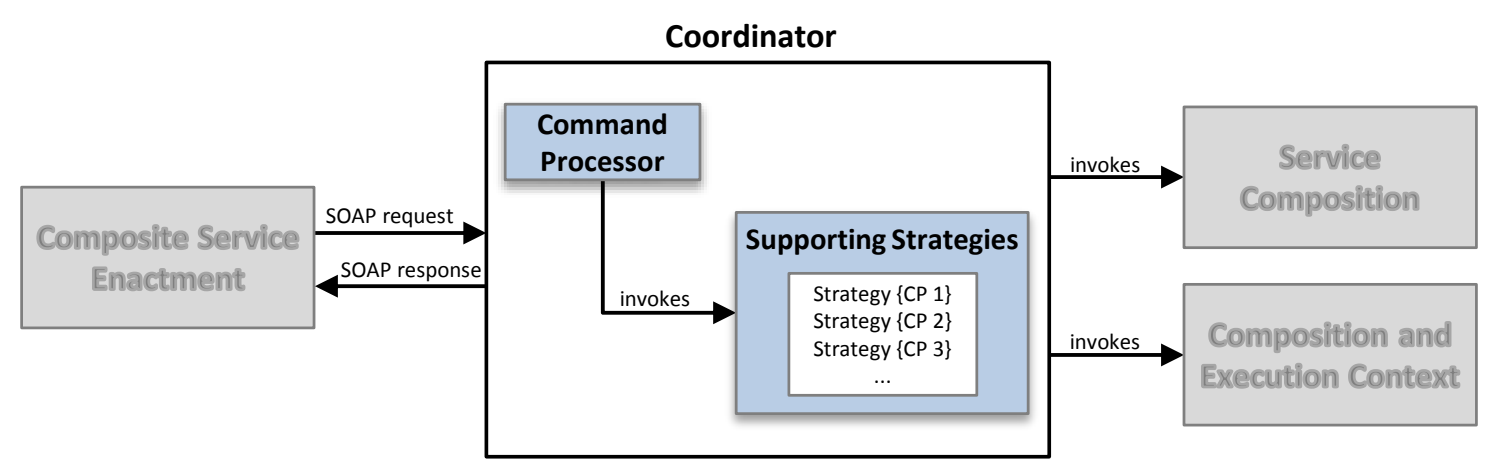

Figura 49: Estrutura do módulo Coordinator.

O módulo Coordinator define um componente, chamado Command Processor, que é responsável por processar as mensagens de requisição recebidas a partir do módulo Composite Service Enactment e invocar a execução das estratégias de suporte definidas pelo componente 
Supporting Strategies. Cada estratégia de suporte implementa um comportamento específico associado a cada comando primitivo da plataforma SemanticSCo. Neste sentido, cada estratégia de suporte determina os componentes básicos do módulo Service Composition que são invocados pelo módulo Coordinator e a ordem de invocação destes componentes. Adicionalmente, cada estratégia de suporte determina o conjunto de informações associadas aos processos de composição e execução de serviços que deve ser armazenado no módulo Composition and Execution Context via módulo Coordinator. O Apêndice G apresenta a definição XSD dos comandos primitivos definidos na plataforma SemanticSCo, bem como as estratégias de suporte implementadas pelo módulo Coordinator associadas a estes comandos.

Na plataforma SemanticSCo, o módulo Coordinator foi implementado como uma classe Java e disponibilizado como um serviço web SOAP, que fornece três operações: startSession, clearSession e coordinate. A operação startSession permite a criação de uma nova sessão de usuário, ou seja, um novo processo de composição. Cada sessão de usuário está associada a um identificador exclusivo, que é retornado pela operação startSession quando a mesma é invocada. A operação clearSession permite que uma sessão de usuário pré-existente seja finalizada e excluída. Finalmente, a operação coordinate pode ser invocada para solicitar a realização de alguma atividade do processo de composição, por exemplo, a descoberta ou seleção de serviços de interesse.

A invocação da operação coordinate é realizada por meio de uma mensagem de requisição que contém três parâmetros: o identificador da sessão de usuário, o tipo de requisição (comando primitivo) e um conjunto de parâmetros associados à requisição. Quando uma mensagem de requisição é recebida pelo módulo Coordinator, o identificador da sessão de usuário é extraído e utilizado para recuperar as informações associadas ao processo de composição e execução de serviços no módulo Composition and Execution Context. A sessão de usuário é então (re) ativada e a mensagem de requisição é repassada ao componente Command Processor. Este componente foi implementado como um método do módulo Coordinator e é responsável por processar a mensagem recebida, extrair o tipo da requisição e invocar a execução da estratégia de suporte associada. Cada estratégia de suporte também foi implementada como um método do módulo Coordinator. Durante a execução de uma estratégia de suporte, os parâmetros (informações) da mensagem de requisição são extraídos e validados com base nas informações 
recuperadas a partir do módulo Composition and Execution Context. Caso os parâmetros sejam inválidos, uma resposta de erro é enviada ao módulo Composite Service Enactment e a execução da estratégia de suporte é abortada. Caso os parâmetros sejam válidos, a estratégia de suporte invoca um conjunto de componentes básicos do módulo Service Composition e solicita o armazenamento das informações necessárias no módulo Composition and Execution Context. Finalmente, uma mensagem de resposta é construída e enviada ao módulo Composite Service

\section{Enactment.}

O módulo Coordinator da plataforma SemanticSCo foi desenvolvido como uma adaptação do módulo originalmente definido no framework A-DynamiCoS. Uma vez que o conjunto de comandos primitivos originalmente definido no framework foi adaptado no contexto deste trabalho, as estratégias de suporte associadas a alguns destes comandos também foram adaptadas no módulo Coordinator. O componente Command Processor foi definido no framework ADynamiCoS de forma genérica e extensível, isto é, independente do conjunto de comandos primitivos e das estratégias de suporte associadas aos comandos primitivos. Assim, este componente foi reutilizado sem modificações no contexto deste trabalho.

\subsubsection{Módulo Service Composition}

O módulo Service Composition é estruturado em diferentes componentes que fornecem as funcionalidades para a realização das etapas do processo de composição: requisição, descoberta, seleção e composição. Cada componente do módulo Service Composition foi implementado como uma classe Java distinta. A Figura 50 apresenta a estrutura do módulo Service Composition. Um retângulo representa um componente interno do módulo Service Composition. Retângulos com preenchimento branco indicam componentes que foram adaptados a partir dos componentes originalmente definidos no framework A-DynamiCoS. Retângulos com preenchimento azul indicam novos componentes desenvolvidos na plataforma SemanticSCo. Uma seta contínua definida entre dois componentes indica que um dos componentes é responsável pela invocação do outro. Finalmente, setas tracejadas indicam o fluxo de informações entre componentes. 


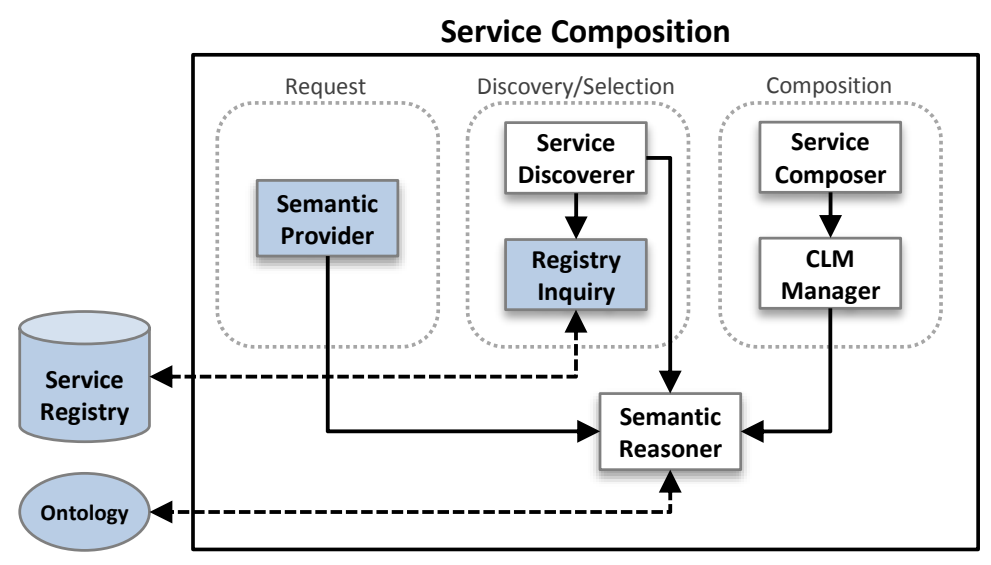

Figura 50: Estrutura do módulo Service Composition.

No módulo Service Composition, desenvolvemos um novo componente, chamado Semantic Provider, que fornece suporte à criação de requisições de serviços. Os componentes Service Discoverer e Registry Inquiry foram desenvolvidos para fornecer suporte à descoberta semântica de serviços. Originalmente, no framework A-DynamiCoS, a descoberta de serviços era realizada por meio de um único componente. Na plataforma SemanticSCo, o componente Service Discoverer foi desenvolvido como uma adaptação do componente originalmente definido no framework A-DynamiCoS e faz uso de um novo componente, chamado Registry Inquiry, que é responsável pela realização de buscas no módulo Service Registry. A definição destes dois componentes de suporte à descoberta semântica de serviços teve como objetivo fornecer maior flexibilidade à plataforma, facilitando assim posteriores modificações. De modo a fornecer suporte à composição de serviços na plataforma SemanticSCo, adaptamos a implementação de dois componentes originalmente definidos no framework A-DynamiCoS: Service Composer e CLM Manager. O componente Service Composer fornece mecanismos para a composição de serviços e faz uso do componente CLM Manager, que é responsável por processar e armazenar os valores de similaridade semântica entre os serviços disponíveis para composição. Finalmente, adaptamos a implementação de um componente auxiliar chamado Semantic Reasoner. Este componente fornece mecanismos para a realização de inferências em uma ontologia, sendo utilizado pelos componentes Semantic Provider, Service Discoverer e CLM Manager. 


\section{Requisição de Serviços}

Para criar uma requisição de serviços na plataforma SemanticSCo, um usuário deve especificar um workflow abstrato. Um workflow abstrato especifica um conjunto de tipos de dados que o usuário deseja processar e uma sequência de atividades de análise (funcionalidades) que o usuário deseja realizar nos tipos de dados especificados. Estas informações são especificadas por meio de conceitos presentes em uma ontologia.

De modo a fornecer suporte à criação de uma requisição de serviços, definimos um novo componente na plataforma SemanticSCo, chamado Semantic Provider. Este componente é responsável por fornecer um conjunto de conceitos de uma ontologia que podem ser utilizados para especificar a semântica dos dados que um usuário deseja processar. Além disto, dado um conjunto de conceitos representando os tipos de dados fornecidos por um usuário e/ou produzidos por um serviço, o componente Semantic Provider permite a descoberta de conceitos representando atividades de análise (funcionalidades) que podem ser realizadas nos tipos de dados disponíveis.

A descoberta de conceitos em uma ontologia no componente Semantic Provider é auxiliada pelo componente Semantic Reasoner, que permite a realização de inferências na ontologia. Originalmente, o componente Semantic Reasoner permitia a descoberta de classes equivalentes, subclasses e superclasses de uma determinada classe (conceito) de uma ontologia. No entanto, este componente não fazia a distinção entre subclasses diretas e indiretas, nem entre superclasses diretas e indiretas. Na plataforma SemanticSCo, o componente Semantic Reasoner foi estendido de modo a permitir a descoberta de classes equivalentes, de subclasses diretas e indiretas e de superclasses diretas e indiretas de uma determinada classe (conceito) da ontologia. Esta extensão foi definida para permitir uma melhor caracterização dos tipos de relacionamentos definidos entre conceitos. Adicionalmente, este componente pode ser utilizado, por exemplo, para a descoberta das classes associadas a uma determinada classe de interesse por meio de um relacionamento pré-especificado, como por exemplo, o relacionamento has participant.

O componente Semantic Reasoner foi implementado com o uso da API Java OWL-API (versão 3.4.3) [353, 354], que permite a manipulação de ontologias especificadas na linguagem 
OWL 2. Além disto, este componente faz uso da API Java Pellet (versão 2.3.1) [355], que permite a realização de inferências em ontologias OWL 2.

\section{Descoberta e Seleção de Serviços}

O processo de descoberta de serviços consiste na realização de buscas no módulo Service Registry para encontrar serviços que sejam capazes de atender às necessidades especificadas em uma requisição de serviços. Estas buscas baseiam-se na comparação de conceitos de uma ontologia utilizados para descrever, por exemplo, as funcionalidades dos serviços e as atividades de análise (funcionalidades) especificadas na requisição, de modo a encontrar relacionamentos de equivalência semântica entre os conceitos. Com base no tipo de relacionamento estabelecido entre os conceitos em uma ontologia é possível calcular o grau de similaridade semântica entre estes conceitos. De modo geral, a similaridade semântica entre conceitos pode ser utilizada em diferentes aplicações e domínios de conhecimento, por exemplo, para facilitar a recuperação, agrupamento, classificação e integração de informações [356-361]. No contexto deste trabalho, o grau de similaridade semântica entre conceitos é utilizado para determinar se os serviços são compatíveis com as necessidades especificadas na requisição de serviços.

Diferentes abordagens têm sido utilizadas para o cálculo do grau de similaridade semântica entre conceitos (classes) de uma ontologia [362-365]. De modo geral, estas abordagens determinam o grau de similaridade semântica entre duas classes por meio da contagem do número de arestas, ou seja, relacionamentos de especialização, definidos entre as classes. Quanto menor a distância (número de arestas) entre duas classes, maior é o grau de similaridade semântica entre as mesmas.

O framework A-DynamiCoS considera quatro tipos de relacionamentos para o cálculo do grau de similaridade semântica entre conceitos (classes). Seja $C_{\text {serv }}$ uma classe utilizada para descrever um serviço e $C_{r e q}$ uma classe especificada em uma requisição de serviços, os seguintes tipos de relacionamentos são considerados: Exact, quando $C_{\text {serv }}$ e $C_{r e q}$ são equivalentes; PlugIn, quando $C_{\text {serv }}$ é uma subclasse direta de $C_{r e q}$; Subsume, quando $C_{\text {serv }}$ é uma superclasse direta de $C_{r e q}$; e Disjoint, quando não há equivalência entre as classes $C_{\text {serv }}$ e $C_{\text {req. }}$. A ordem do grau de similaridade semântica associado a estes relacionamentos é dada por $\{$ Exact $>$ PlugIn $>$ Subsume $>$ Disjoint $\}$. 
No contexto deste trabalho, considerando-se a estratégia básica das abordagens de cálculo de similaridade semântica, estendemos o conjunto de relacionamentos originalmente considerados no framework A-DynamiCoS para o cálculo do grau de similaridade semântica entre conceitos. Esta extensão considera que os relacionamentos do tipo PlugIn e Subsume podem ainda ser classificados em diretos ou indiretos. Uma vez que o grau de similaridade semântica entre dois conceitos é maior quando os mesmos estão relacionados de forma direta (menor distância) do que quando o relacionamento entre eles for apenas indireto, a extensão proposta permite estabelecer um grau de similaridade maior/menor entre dois conceitos quando os mesmos estão relacionados de forma direta/indireta.

A Tabela 19 apresenta os tipos de relacionamentos considerados pelo componente Service Discoverer para a classificação de serviços e os valores de similaridade semântica associados. Nesta tabela, $C_{\text {serv }}$ representa uma classe (conceito) utilizada para descrever uma informação sobre um serviço (ex: funcionalidade oferecida) e $C_{r e q}$ representa uma classe (conceito) utilizada para especificar uma informação na requisição de serviços (ex:funcionalidade desejada).

Tabela 19: Relacionamentos para o cálculo de similaridade semântica entre conceitos.

\begin{tabular}{|c|c|}
\hline Relacionamento & Grau de similaridade \\
\hline \hline$C_{\text {serv }}$ e $C_{r e q}$ são equivalentes & 5.0 \\
\hline$C_{\text {serv }}$ é uma subclasse direta de $C_{r e q}$ & 4.0 \\
\hline$C_{\text {serv }}$ é uma subclasse indireta de $C_{r e q}$ & 3.0 \\
\hline$C_{\text {serv }}$ é uma superclasse direta de $C_{r e q}$ & 2.0 \\
\hline$C_{\text {serv }}$ é uma superclasse indireta de $C_{r e q}$ & 1.0 \\
\hline$C_{\text {serv }}$ e $C_{r e q}$ não são equivalentes & 0.0 \\
\hline
\end{tabular}

Na plataforma SemanticSCo, o processo de descoberta semântica de serviços é realizado pelo componente Service Discoverer. Este componente faz uso do componente Registry Inquiry, que é responsável pela realização de buscas no módulo Service Registry. Estas buscas são realizadas no componente Registry Inquiry com o uso da função Inquiry fornecida pela API Java jUDDI. Adicionalmente, o componente Service Discoverer faz uso do componente auxiliar Semantic Reasoner, que permite a realização de inferências nas ontologias utilizadas para descrever os 
conceitos especificados nas descrições dos serviços e na requisição de serviços. No contexto da descoberta de serviços, este componente é utilizado para a descoberta de classes equivalentes, subclasses e superclasses das classes (conceitos) utilizadas para a especificação da requisição de serviços.

No framework A-DynamiCoS, o componente Service Discoverer fornecia suporte à descoberta de serviços com base em dois tipos de informação: tipos de dados produzidos pelos serviços (dados de saída) ou funcionalidades fornecidas pelo serviços. Já na plataforma SemanticSCo, o componente Service Discoverer permite a realização de dois tipos de descoberta de serviços: descoberta baseada em dados de saída e descoberta baseada em funcionalidades e/ou dados de entrada.

Na descoberta baseada em dados de saída, o componente Service Discoverer realiza buscas por serviços que sejam capazes de produzir os tipos de dados especificados em uma requisição de serviços. Neste tipo de descoberta, o valor de similaridade semântica atribuído a um serviço é calculado como a agregação dos valores de similaridade atribuídos a todos os conceitos que representam parâmetros de saída do serviço. Na descoberta de serviços baseada em dados de saída, o cálculo do valor de similaridade semântica de um serviço é realizado de acordo com a Equação 1:

$$
S_{\text {serv }}=\frac{\sum_{i=1}^{N} S_{s a i ́ d a}}{N}
$$

Onde $S_{\text {saída }}$ indica o valor de similaridade semântica atribuído ao parâmetro de saída $i$ do serviço e $N$ indica o número total de parâmetros de saída do serviço.

$\mathrm{Na}$ descoberta baseada em funcionalidades e/ou dados de entrada, o componente Service Discoverer realiza buscas por serviços que forneçam as funcionalidades especificadas em uma requisição de serviços e/ou que sejam capazes de processar os tipos de dados especificados na requisição. Neste tipo de descoberta, o valor de similaridade semântica atribuído a um serviço é calculado como a agregação dos valores de similaridade atribuídos a todos os conceitos que representam funcionalidades e parâmetros de entrada do serviço. Na descoberta de serviços baseada em funcionalidades e/ou dados de entrada, o cálculo do valor de similaridade semântica de um serviço é realizado de acordo com a Equação 2: 


$$
S_{\text {serv }}=\alpha \times \frac{\sum_{i=1}^{N} S_{\text {func }_{i}}}{N}+(1-\alpha) \times \frac{\sum_{j=1}^{M} S_{\text {entrada }_{j}}}{M} \text {, tal que } \alpha>0,5
$$

Onde $S_{f_{u n c}}$ indica o valor de similaridade semântica atribuído à funcionalidade $i$ do serviço, $N$ indica o número total de funcionalidades oferecidas pelo serviço, $S_{\text {entrada }}$ indica o valor de similaridade semântica atribuído ao parâmetro de entrada $j$ do serviço, $M$ indica o número total de parâmetros de entrada do serviço, $\alpha$ indica o peso atribuído às funcionalidades do serviço e $(1-\alpha)$ indica o peso atribuído aos parâmetros de entrada do serviço.

Uma vez que o conjunto de funcionalidades especificado por um usuário na requisição de serviços é, potencialmente, mais relevante ao usuário do que os tipos de dados que o serviço é capaz de processar, consideramos que o peso $\alpha$ atribuído às funcionalidades do serviço deva ser maior do que o peso atribuído aos parâmetros de entrada do serviço $(1-\alpha)$.

No contexto deste trabalho, com base em um conjunto representativo de serviços incorporado à plataforma, definimos $\alpha=0,6$. Com este valor, o componente Service Discoverer é capaz de descobrir serviços que forneçam as funcionalidades de interesse, levando também em consideração os tipos de dados que os serviços são capazes de processar. O estabelecimento de um valor ótimo ao parâmetro de descoberta $\alpha$ requer testes adicionais com base em diferentes conjuntos de serviços. Embora o ajuste ótimo deste parâmetro esteja fora do escopo deste trabalho, o valor de $\alpha$ pode ser facilmente modificado no componente Service Discoverer da plataforma SemanticSCo por se tratar de um parâmetro do componente.

Após a descoberta de um conjunto de serviços de interesse, o componente Service Discoverer também fornece suporte à seleção semi-automática de serviços. Neste sentido, este componente é responsável por classificar os serviços encontrados com base no grau de similaridade semântica entre os conceitos utilizados para descrever os serviços e os conceitos especificados na requisição de serviços. Como resultado, este componente produz uma lista de serviços, ordenada de forma decrescente pelo grau de similaridade semântica atribuído a cada serviço descoberto. Assim, os serviços semanticamente mais compatíveis com a requisição de serviços são apresentados no topo da lista. Esta lista é fornecida ao usuário, facilitando a seleção dos serviços de interesse. 


\section{Composição de Serviços}

No framework A-DynamiCoS, o processo de composição de serviços é realizado em duas etapas. Na primeira etapa, o componente CLM Manager processa o conjunto de serviços selecionados pelo usuário (antes da composição) e organiza estes serviços em uma matriz Causal Link Matrix (CLM) [366, 367]. A Figura 51 apresenta, de forma genérica, a representação de uma matriz CLM. As linhas $i$ e colunas $j$ da matriz representam os dados de entrada e saída de todos os serviços selecionados, respectivamente. Cada célula $\{i, j\}$ da matriz armazena o valor de similaridade semântica $S S_{i j}$ definido entre os conceitos utilizados para representar os dados de entrada (entrad $a_{i}$ ) e saída (saída $a_{j}$ de dois serviços.

\begin{tabular}{|c|c|c|c|c|c|}
\hline & Saída $_{\mathbf{1}}$ & Saída $_{\mathbf{2}}$ & Saída $_{\mathbf{3}}$ & $\ldots$ & Saída $_{\boldsymbol{M}}$ \\
\hline Entrada $_{\mathbf{1}}$ & $S S_{11}$ & $S S_{12}$ & $S S_{13}$ & $\ldots$ & $S S_{1 M}$ \\
\hline Entrada $_{\mathbf{2}}$ & $S S_{21}$ & $S S_{22}$ & $S S_{23}$ & $\ldots$ & $S S_{2 M}$ \\
\hline Entrada $_{\mathbf{3}}$ & $S S_{31}$ & $S S_{32}$ & $S S_{33}$ & $\ldots$ & $S S_{3 M}$ \\
\hline$\ldots$ & $\ldots$ & $\ldots$ & $\ldots$ & $\ldots$ & $S S_{4 M}$ \\
\hline Entrada $_{N}$ & $S S_{N 1}$ & $S S_{N 2}$ & $S S_{N 3}$ & $\ldots$ & $S S_{N M}$ \\
\hline
\end{tabular}

Figura 51: Representação de uma matriz CLM.

A matriz CLM armazena os valores de similaridade semântica definidos entre todos os conceitos utilizados para representar os tipos de dados produzidos e consumidos pelos serviços selecionados. Assim, esta matriz pode ser utilizada para determinar se os dados produzidos por um serviço são compatíveis com os dados consumidos por outro serviço, ou seja, se estes dois serviços podem ser interligados durante a criação de uma composição.

Durante a construção da matriz CLM, para cada célula da matriz ( $\left\{\right.$ Entrada $\left.\left._{i}, S_{a i ́ d a j}\right\}\right)$, o componente CLM Manager consulta o componente auxiliar Semantic Reasoner, que permite a descoberta de classes equivalentes, subclasses e superclasses das classes (conceitos) utilizadas para a descrição dos tipos de dados consumidos $\left(E_{n}\right.$ trada $\left.a_{i}\right)$ e produzidos $\left(\right.$ Saída $a_{j}$ pelos serviços. O cálculo do valor de similaridade semântica entre dois conceitos é determinado com base no tipo de relacionamento estabelecido entre estes conceitos na ontologia. O componente CLM Manager considera os mesmos tipos de relacionamentos definidos no componente de su- 
porte à descoberta e seleção de serviços (Tabela 19). Esta foi a principal adaptação realizada no componente CLM Manager.

Na segunda etapa do processo de composição, o componente Service Composer realiza a interligação (composição) dos serviços previamente armazenados na matriz CLM. No componente Service Composer, uma composição de serviços é representada como um grafo direcionado. Cada nó do grafo representa um serviço (processo). Cada aresta definida entre dois nós (serviços) representa a interligação (composição) entre os dados de saída de um serviço e os dados de entrada do outro serviço. Uma vez que os serviços podem, possivelmente, processar um ou mais dados de entrada e produzir um ou mais dados de saída, múltiplas arestas podem ser definidas entre dois serviços (nós). No componente Service Composer, a manipulação de grafos de composição é realizada com o uso da API Java jGraphT (versão 0.7.3) [368].

O componente Service Composer fornece mecanismos para a inserção de serviços na cadeia (grafo) de composição de acordo com duas abordagens: forward e backward. Na abordagem forward, este componente verifica se os dados consumidos pelo serviço que está sendo inserido na cadeia de composição são semanticamente compatíveis com os dados produzidos pelo serviço anterior na cadeia (previamente selecionado). Na abordagem backward, o componente Service Composer verifica se os dados produzidos pelo serviço que está sendo inserido na cadeia de composição são semanticamente compatíveis com os dados consumidos pelo serviço posterior na cadeia (previamente selecionado). Adicionalmente, uma vez que o componente Service Composer fornece mecanismos independentes para a inserção forward e backward de serviços, este componente pode ser utilizado para a criação de cadeias de composição de maneira bidirecional (forward e backward).

No componente Service Composer, a verificação de compatibilidade entre os tipos de dados consumidos e produzidos pelos serviços é realizada com base nas informações previamente armazenadas na matriz CLM por meio do componente CLM Manager. Caso os dados entre os serviços sejam compatíveis, ou seja, o grau de similaridade semântica entre os conceitos utilizados para representar os dados compartilhados entre os serviços $\left(\left\{E n t r a d a_{i}\right.\right.$,Saída $\left.\left.a_{j}\right\}\right)$ seja maior do que zero, o componente Service Composer realiza a interligação (forward ou backward) dos serviços no grafo de composição. Este componente verifica ainda se a ligação criada entre os serviços não gerou uma situação de deadlock, ou seja, se os dados consumidos por um serviço 
$S_{2}$ são produzidos por um serviço $S_{1}$ cujos dados de entrada são fornecidos pela saída de $S_{2}$. Em caso positivo, a ligação entre os serviços no grafo de composição é desfeita.

\subsubsection{Módulo Composition and Execution Context}

O módulo Composition and Execution Context é responsável por armazenar, de forma persistente, um conjunto de informações associadas a um processo de composição de serviços. $\mathrm{Na}$ plataforma SemanticSCo, cada processo de composição está associado a uma sessão de usuário. Assim, quando uma nova sessão de usuário é criada, uma nova instância da classe principal do módulo Composition and Execution Context é criada e associada à nova sessão de usuário. Assim, este módulo permite o gerenciamento de múltiplas sessões de usuário (composições) de forma simultânea na plataforma SemanticSCo.

Além disto, os componentes desenvolvidos como parte do módulo Service Composition não mantêm estado, ou seja, eles oferecem um conjunto de funcionalidades, mas não armazenam as informações resultantes. Por exemplo, quando a descoberta de serviços é solicitada ao módulo Service Composition, os componentes responsáveis pela descoberta realizam a busca de serviços e retornam uma lista de serviços de interesse. No entanto, esta lista de serviços não é armazenada no módulo Service Composition, mas sim no módulo Composition and Execution Context (via módulo Coordinator).

O módulo Composition and Execution Context é utilizado para armazenar informações associadas tanto à criação de um processo de composição quanto à execução dos serviços definidos em uma composição. As informações armazenadas durante a criação de um processo de composição incluem os serviços descobertos pelo módulo Service Composition, os serviços selecionados pelo usuário, o grafo de composição sendo criado e a matriz CLM utilizada para armazenar a compatibilidade semântica entre os serviços descobertos. Adicionalmente, todas as informações recuperadas a partir do módulo Service Registry sobre cada serviço (processo) são armazenadas no módulo Composition and Execution Context.

O módulo Composition and Execution Context também é utilizado para armazenar informações associadas à execução dos serviços definidos em uma composição. Estas informações incluem os dados e os valores dos parâmetros fornecidos pelos usuários para a execução de 
cada serviço. Adicionalmente, os dados produzidos após a execução de cada serviço são armazenados no módulo Composition and Execution Context. Estes dados podem ser utilizados como entrada para a execução de outros serviços definidos em uma composição. Cada dado armazenado no módulo Composition and Execution Context está associado a um identificador exclusivo, um valor, uma sintaxe e um conceito de uma ontologia especificando sua semântica.

Na plataforma SemanticSCo, o módulo Composition and Execution Context foi implementado como uma classe Java. Esta classe contém uma série de listas de objetos que armazenam os diferentes tipos de informações associados a uma composição de serviços (sessão de usuário).

\subsection{CENÁRIO DE ANÁLISE}

Na plataforma SemanticSCo, o processo de criação e execução de cenários de análise é realizado de acordo com o fluxo de comandos codificado no componente User Interface. De modo a exemplificar este processo, a Figura 52 apresenta uma sequência possível de etapas que podem ser realizadas na plataforma SemanticSCo para criar e executar um cenário hipotético para a análise de dados de microarray (one ou two-color). Neste cenário, o usuário realiza inicialmente a normalização de um conjunto de dados brutos de microarray. Em seguida, o usuário realiza o agrupamento hierárquico dos dados de microarray normalizados. Uma vez que os resultados obtidos não são satisfatórios, o usuário decide então identificar o conjunto de genes diferencialmente expressos nos dados e realizar apenas o agrupamento dos genes identificados. Finalmente, o usuário realiza a análise de enriquecimento do conjunto de genes diferencialmente expressos para identificar as funcionalidades associadas a estes genes.

$\mathrm{Na}$ primeira etapa, o usuário inclui um conjunto de dados brutos de microarray. Após a inclusão dos dados, o comando DISCOVER_INPUT_SEMANTICS é invocado para solicitar uma lista de conceitos que podem ser utilizados para especificar a semântica dos dados. Esta lista é então apresentada ao usuário, que seleciona o conceito "raw microarray data".

$\mathrm{Na}$ segunda etapa, o usuário solicita a inclusão de uma atividade de análise. O comando DISCOVER_FUNCTION_SEMANTICS é então invocado para solicitar uma lista de conceitos representando atividades de análise que podem ser realizadas nos dados fornecidos pelo usuário ("raw microarray data"). A atividade de análise "microarray data preprocessing" é então 


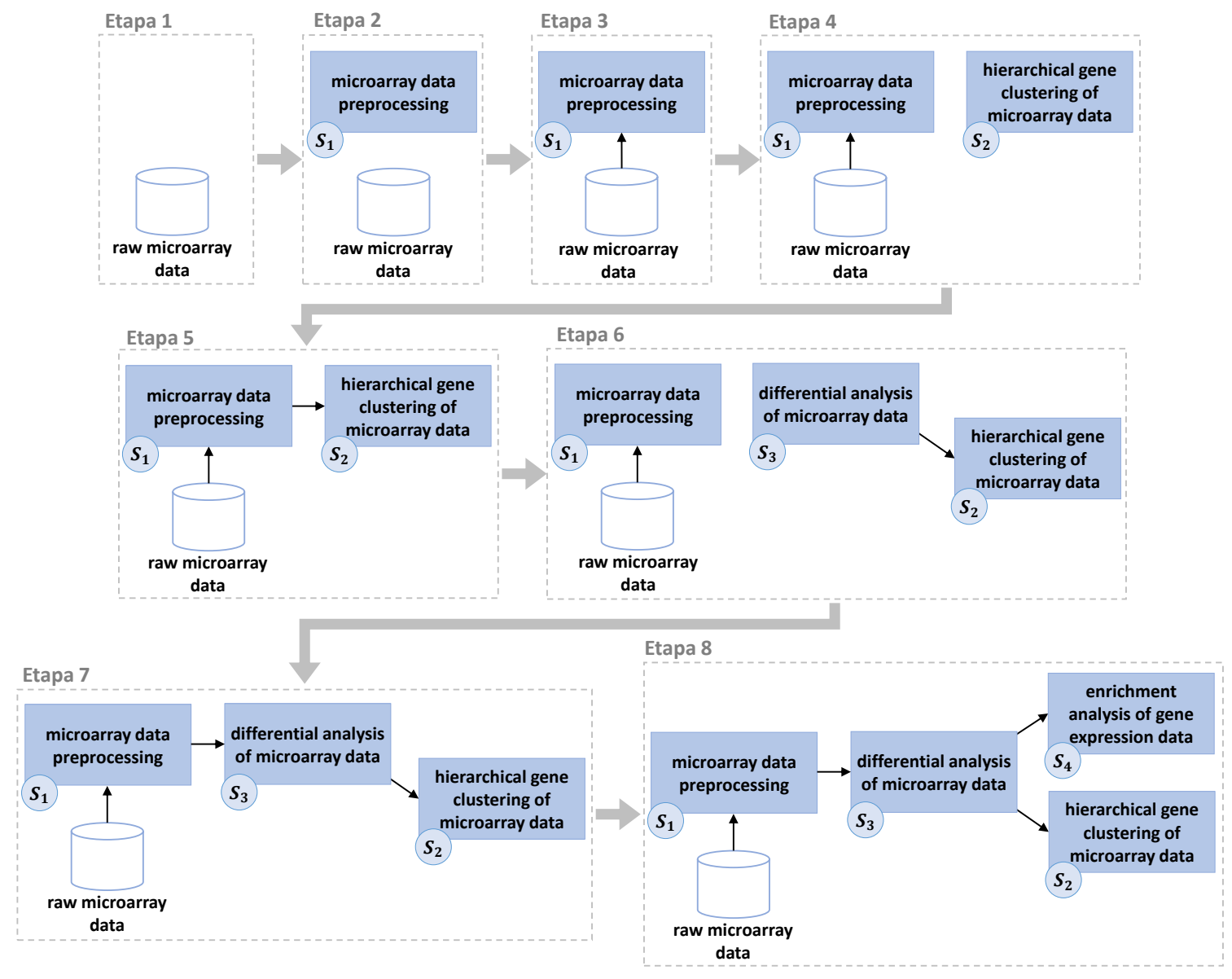

Figura 52: Cenário para análise de dados de microarray na plataforma SemanticSCo.

selecionada pelo usuário. Em seguida, o comando DISCOVER_SERVICES é invocado para solicitar a descoberta de serviços que sejam capazes de processar os dados de microarray fornecidos e que realizem a atividade de análise selecionada, ou seja, o pré-processamento dos dados. Uma lista de serviços disponíveis é apresentada e o usuário seleciona o serviço $S_{1}$. O comando INCLUDE_SERVICES é então invocado para solicitar a inclusão do serviço $S_{1}$ na composição sendo criada. Uma vez que o serviço é incluído na composição, o comando GET_EXECUTABLE_SERVICES é invocado para solicitar a lista de serviços que estão prontos para execução. Neste ponto, o serviço $S_{1}$ ainda não pode ser executado porque seus dados de entrada não estão disponíveis.

Na terceira etapa, o usuário solicita a validação dos dados de entrada do serviço $S_{1}$. Uma lista de opções disponíveis para a validação dos dados é apresentada ao usuário, que seleciona o conjunto de dados brutos de microarray previamente fornecido. Em seguida, o co- 
mando VALIDATE_INPUTS é invocado para solicitar a associação do conjunto de dados à entrada do serviço $S_{1}$. Uma vez que os dados de entrada do serviço são validados, o comando GET_EXECUTABLE_SERVICES é invocado para solicitar a lista atualizada de serviços que estão prontos para execução. Neste ponto, o serviço $S_{1}$ já pode ser executado.

$\mathrm{Na}$ quarta etapa, o usuário solicita a inclusão de uma nova atividade de análise. O comando DISCOVER_FUNCTION_SEMANTICS é invocado para solicitar uma lista de conceitos representando atividades de análise que podem ser realizadas nos dados disponíveis. Os dados disponíveis consistem no conjunto de dados fornecido pelo usuário ("raw microarray data") e nos dados de saída do serviço $S_{1}$ ("normalized microarray data"). A atividade de análise "hierarchical gene clustering of microarray data" é então selecionada pelo usuário. Em seguida, o comando DISCOVER_SERVICES é invocado para solicitar a descoberta de serviços que sejam capazes de processar os dados disponíveis e que realizem a atividade de análise selecionada, ou seja, o agrupamento hierárquico de genes. Uma lista de serviços disponíveis é apresentada e o usuário seleciona o serviço $S_{2}$. O comando INCLUDE_SERVICES é então invocado para solicitar a inclusão do serviço $S_{2}$ na composição. Uma vez que o serviço é incluído na composição, o comando GET_EXECUTABLE_SERVICES é invocado para solicitar a lista atualizada de serviços que estão prontos para execução. Neste ponto, apenas o serviço $S_{1}$ pode ser executado.

$\mathrm{Na}$ quinta etapa, o usuário solicita a validação dos dados de entrada do serviço $S_{2}$. Uma lista de opções disponíveis para a validação dos dados é apresentada ao usuário. O usuário seleciona os dados de saída do serviço $S_{1}$. O comando COMPOSE_SERVICES é então invocado para solicitar a associação dos dados de saída do serviço $S_{1}$ aos dados de entrada do serviço $S_{2}$ (composição forward). Uma vez que os dados de $S_{1}$ e $S_{2}$ são associados, o comando GET_EXECUTABLE_SERVICES é invocado para solicitar a lista atualizada de serviços que estão prontos para execução. Neste ponto, apenas o serviço $S_{1}$ pode ser executado. $\mathrm{O}$ usuário então solicita a execução do serviço $S_{1}$. Após sua execução, o comando $A D D \_T O \_C O N T E X T$ é invocado para solicitar o armazenamento dos dados de microarray normalizados produzidos pela execução do serviço $S_{1}$. Em seguida, o comando GET_EXECUTABLE_SERVICES é novamente invocado para solicitar a lista atualizada de serviços que estão prontos para execução. Neste ponto, os dados produzidos pelo serviço $S_{1}$ já estão disponíveis como entrada para o serviço $S_{2}$, que pode então ser executado. O usuário solicita a execução do serviço $S_{2}$. Após sua 
execução, o comando $A D D \_T O \_C O N T E X T$ é novamente invocado para solicitar o armazenamento dos dados produzidos pelo serviço $S_{2}$. O usuário então interpreta os resultados produzidos pelo agrupamento de genes nos dados e decide primeiramente identificar o conjunto de genes diferencialmente expressos nos dados normalizados, para então realizar o agrupamento apenas deste conjunto de genes.

Assim, na sexta etapa, o usuário solicita a descoberta de serviços que produzam dados compatíveis com os dados de entrada do serviço $S_{2}$. O comando RESOLVE_SERVICES é então invocado. Como resultado, uma lista de serviços disponíveis é apresentada ao usuário, que seleciona o serviço $S_{3}$ para a identificação de genes diferencialmente expressos nos dados. O comando INCLUDE_SERVICES é invocado para solicitar a inclusão do serviço $S_{3}$ na composição. Após a inclusão do serviço, o comando COMPOSE_SERVICES é invocado para solicitar a associação dos dados de saída do serviço $S_{3}$ aos dados de entrada do serviço $S_{2}$ (composição backward). Uma vez que os dados de $S_{3}$ e $S_{2}$ são associados, o comando GET_EXECUTABLE_SERVICES é invocado para solicitar a lista atualizada de serviços que estão prontos para execução. Neste ponto, apenas o serviço $S_{1}$ pode ser executado.

$\mathrm{Na}$ sétima etapa, o usuário solicita a validação dos dados de entrada do serviço $S_{3}$. Uma lista de opções disponíveis para a validação dos dados é apresentada ao usuário. O usuário seleciona os dados de saída do serviço $S_{1}$. O comando COMPOSE_SERVICES é então invocado para solicitar a associação dos dados de saída do serviço $S_{1}$ aos dados de entrada do serviço $S_{3}$ (composição forward). Uma vez que os dados de $S_{1}$ e $S_{3}$ são associados, o comando GET_EXECUTABLE_SERVICES é novamente invocado para solicitar a lista atualizada de serviços que estão prontos para execução. Neste ponto, apenas os serviços $S_{1}$ e $S_{3}$ podem ser executados.

$\mathrm{Na}$ oitava etapa, o usuário solicita a inclusão de uma nova atividade de análise. O comando DISCOVER_FUNCTION_SEMANTICS é invocado para solicitar uma lista de conceitos representando atividades de análise que podem ser realizadas nos dados disponíveis. Os dados disponíveis consistem no conjunto de dados fornecido pelo usuário ("raw microarray data") e nos dados de saída dos serviços $S_{1}$ ("normalized microarray data"), $S_{2}$ ("hierarchically clustered microarray data") e $S_{3}$ ("gene identifiers list"). A atividade de análise "enrichment analysis of gene expression data" é então selecionada pelo usuário. Em seguida, o comando DISCO- 
VER_SERVICES é invocado para solicitar a descoberta de serviços que sejam capazes de processar os dados disponíveis e que realizem a atividade de análise selecionada, ou seja, a análise de enriquecimento de dados de expressão gênica. Uma lista de serviços disponíveis é apresentada e o usuário seleciona o serviço $S_{4}$. O comando INCLUDE_SERVICES é então invocado para solicitar a inclusão do serviço $S_{4}$ na composição. Uma vez que o serviço é incluído na composição, o comando GET_EXECUTABLE_SERVICES é invocado para solicitar a lista atualizada de serviços que estão prontos para execução. Neste ponto, apenas os serviços $S_{1}$ e $S_{3}$ podem ser executados. O usuário então solicita a validação dos dados de entrada do serviço $S_{4}$. Uma lista de opções disponíveis para a validação dos dados é apresentada ao usuário. O usuário seleciona os dados de saída do serviço $S_{3}$ e o comando COMPOSE_SERVICES é então invocado para solicitar a associação dos dados de saída do serviço $S_{3}$ aos dados de entrada do serviço $S_{4}$ (composição forward). Uma vez que os dados de $S_{3}$ e $S_{4}$ são associados, o comando GET_EXECUTABLE_SERVICES é novamente invocado para solicitar a lista atualizada de serviços que estão prontos para execução.

Neste ponto, apenas os serviços $S_{1}$ e $S_{3}$ podem ser executados. Uma vez que o serviço $S_{1}$ já foi executado e os dados de microarray normalizados produzidos pela sua execução estão disponíveis como entrada para o serviço $S_{3}$, o usuário solicita a execução do serviço $S_{3}$. Após sua execução, o comando $A D D \_T O \_C O N T E X T$ é invocado para solicitar o armazenamento da lista de identificadores de genes diferencialmente expressos produzida pela execução do serviço $S_{3}$. Em seguida, o comando GET_EXECUTABLE_SERVICES é novamente invocado para solicitar a lista atualizada de serviços que estão prontos para execução. Neste ponto, os dados produzidos pelo serviço $S_{3}$ já estão disponíveis como entrada para os serviços $S_{2}$ e $S_{4}$, que podem então ser executados. Após a execução destes serviços, o comando ADD_TO_CONTEXT é finalmente invocado para solicitar o armazenamento dos dados produzidos pelos serviços.

\subsection{CONCLUS ÃO}

Neste capítulo, apresentamos uma solução completa para a composição de serviços web semânticos para a análise de expressão gênica. De modo a posicionar a nossa abordagem, definimos inicialmente um processo para a composição de serviços. O processo de composição proposto 
considera as principais etapas envolvidas em um estudo de análise de expressão gênica, bem como os diferentes tipos de usuário envolvidos no processo, ou seja, biologistas e bioinformatas. Acreditamos que a definição explícita deste processo facilita o desenvolvimento de abordagens mais adequadas ao domínio e aos seus usuários.

Em seguida, definimos uma arquitetura para a composição de serviços web semânticos. A nossa arquitetura é estruturada em camadas, de modo que cada camada fornece um conjunto de componentes cujas funcionalidades podem ser acessadas pelos componentes da camada (imediatamente) superior e acessa as funcionalidades fornecidas pelo conjunto de componentes da camada (imediatamente) inferior. Esta estrutura modular em camadas fomenta o uso dos componentes pré-definidos em cada camada da arquitetura e fornece flexibilidade à arquitetura, facilitando sua modificação e/ou extensão. Além disto, a nossa arquitetura foi projetada para fornecer um alto nível de abstração, permitindo que usuários com diferentes níveis de conhecimento computacional sejam capazes de definir workflows de análise para a realização de estudos de expressão gênica.

Na sequência, implementamos uma plataforma chamada SemanticSCo para prover suporte à arquitetura e processo de composição propostos. A plataforma SemanticSCo fornece suporte (semi) automático à criação e execução de composições de serviços web semânticos. Esta plataforma foi projetada levando-se em consideração as características do domínio de expressão gênica e fornece suporte a todas as atividades envolvidas no processo de composição semântica de serviços: requisição, descoberta, seleção, composição e execução. Além disto, a plataforma foi projetada considerando-se os aspectos técnicos dos serviços web semânticos desenvolvidos de acordo com a nossa metodologia e disponibilizados no repositório GEAS. Neste sentido, a plataforma SemanticSCo fornece suporte não apenas à composição, mas também ao desenvolvimento e incorporação de serviços RESTful semanticamente anotados de acordo com a abordagem SAWSDL. Adicionalmente, a plataforma SemanticSCo suporta a definição e composição de serviços complexos, ou seja, que prescrevem um comportamento local.

Finalmente, dado que diferentes usuários podem ter requisitos e necessidades distintos durante o processo de composição de serviços, estes usuários podem dirigir o processo de composição de diferentes maneiras. De modo a acomodar estas diferenças, a plataforma SemanticSCo suporta uma estratégia de composição flexível por meio da definição de caminhos alternativos 
que permitem que os usuários decidam, de acordo com as suas necessidades, quais atividades do processo de composição devem ser realizadas. Desta forma, as necessidades de indivíduos específicos podem ser capturadas durante o processo de criação e execução de composições de serviços na plataforma. 
De modo a testar as funcionalidades da plataforma SemanticSCo e demonstrar sua utilidade, todos os serviços desenvolvidos para a análise de expressão gênica disponíveis no repositório GEAS foram inicialmente incorporados à plataforma. A incorporação destes serviços à plataforma foi realizada por meio da publicação das informações relevantes sobre os serviços no módulo Service Registry. Após a incorporação dos serviços, diferentes cenários (integrados) de análise de expressão gênica foram definidos na plataforma SemanticSCo por meio da composição semi-automática dos serviços disponíveis. Estes cenários foram utilizados para reproduzir diferentes estudos de expressão gênica documentados na literatura. De modo a selecionar estudos de expressão gênica relevantes, priorizamos estudos recentes que permitiam o uso de um maior conjunto de serviços, bem como o uso de dados de expressão gênica obtidos a partir de diferentes plataformas e tecnologias.

O restante deste capítulo está estruturado da seguinte forma: a Seção 7.1 apresenta a estratégia que utilizamos para a criação dos cenários de composição; a Seção 7.2 apresenta um estudo de caso definido para a análise de dados de microarray provenientes da plataforma Agilent; a Seção 7.3 apresenta um estudo de caso definido para a análise de dados de microarray provenientes da plataforma Affymetrix; a Seção 7.4 apresenta um estudo de caso definido para a análise de dados de RNA-Seq provenientes da plataforma de sequenciamento Illumina; finalmente, a Seção 7.5 apresenta as conclusões do capítulo. 


\subsection{ESTRATÉGIA PARA A CRIAÇÃO DOS CENÁRIOS DE COMPOSIÇÃO}

Para a definição de cada cenário de composição, selecionamos inicialmente um estudo de expressão gênica documentado na literatura a ser utilizado como base para a definição do cenário. Para a seleção dos estudos base, priorizamos estudos recentes que realizavam atividades de análise que poderiam ser suportadas pelo conjunto de serviços disponível na plataforma SemanticSCo. Além disto, selecionamos estudos que faziam uso de dados de expressão gênica obtidos a partir de diferentes plataformas e tecnologias.

Em seguida, identificamos a sequência de atividades de análise e as ferramentas de software utilizadas para a realização de cada atividade de análise no estudo selecionado. Uma vez que as atividades de análise e ferramentas correspondentes foram identificadas, selecionamos, dentre o conjunto de serviços disponíveis no repositório GEAS, aqueles que poderiam ser utilizados para realizar cada atividade de análise especificada.

Após a seleção de um conjunto adequado de serviços, identificamos a necessidade de pequenas adaptações nos dados produzidos por alguns serviços de modo a facilitar a utilização destes dados como entrada para outros serviços. Estas adaptações incluem, por exemplo, o particionamento/concatenação de dados e a filtragem/conversão de identificadores de genes. Grande parte das adaptações foram identificadas para atender ao design dos estudos base.

Considere, por exemplo, o uso integrado de dois serviços genéricos $S_{1}$ e $S_{2}$. O serviço $S_{1}$ realiza a identificação de genes diferencialmente expressos em um conjunto de dados. O serviço $S_{2}$ recebe como entrada a lista de genes produzida pelo serviço $S_{1}$ e realiza a análise de enriquecimento funcional destes genes. Em princípio, estes dois serviços podem ser utilizados de forma integrada sem a realização de adaptações nos dados compartilhados entre os mesmos. No entanto, algumas adaptações podem ser necessárias quando consideramos o uso destes serviços para a realização de um determinado estudo de expressão gênica no qual a análise de enriquecimento funcional dos genes reprimidos e induzidos seja realizada separadamente. No contexto de tal estudo, a lista de genes diferencialmente expressos produzida pelo serviço $S_{1}$ precisa ser primeiramente particionada em dois conjuntos de dados distintos (genes reprimidos e induzidos). Uma vez que esta adaptação é realizada, as duas listas resultantes, contendo os genes reprimidos e induzidos, podem então ser separadamente analisadas pelo serviço $S_{2}$. 
De modo a implementar estas adaptações, desenvolvemos um conjunto de conectores de software que fornecem suporte automático à adaptação dos dados trocados entre diferentes serviços. Um conector de software é um elemento arquitetural utilizado para acomodar diferentes tipos de interações entre componentes ou elementos de dados de um sistema de software por meio da definição de um conjunto de regras que governam estas interações [369]. De modo geral, conectores de software permitem a transferência de dados e/ou controle entre diferentes componentes de um sistema de software. O uso de conectores de software na integração de ferramentas de análise de expressão gênica já foi discutido em detalhes por Miyazaki et al. [303].

Neste trabalho, desenvolvemos um conjunto de conectores de software para facilitar a realização de estudos de expressão gênica específicos. No entanto, estes conectores foram desenvolvidos para fornecer funcionalidades de propósito geral e assim, podem ser utilizados em outros cenários de análise semelhantes. Os conectores de software foram inicialmente desenvolvidos como aplicações standalone com base na metodologia de desenvolvimento proposta por Miyazaki et al. [303]. Em seguida, as funcionalidades fornecidas por estas aplicações foram disponibilizadas como serviços web RESTful. A adaptação dos conectores de software como serviços foi realizada com base nas atividades da metodologia apresentada no Capítulo 4. Contudo, uma vez que estes serviços fornecem apenas funcionalidades básicas de propósito geral, ou seja, não suportam atividades específicas de análise de expressão gênica, apenas as entradas e saídas dos serviços foram semanticamente anotadas com conceitos da ontologia GEXPASO. Todos os serviços de adaptação desenvolvidos foram então incorporados à plataforma SemanticSCo. O Apêndice H apresenta, em detalhes, os serviços de adaptação desenvolvidos.

\subsection{ANÁlise DE DADOS DE MICROARRAY AGILENT}

O primeiro estudo de caso foi definido para a análise de dados de microarray one-color provenientes da plataforma Agilent. As seções a seguir apresentam o estudo utilizado como base para a definição do cenário de composição, a criação do cenário na plataforma SemanticSCo, a execução detalhada do cenário e, finalmente, os resultados obtidos a partir da sua execução. 


\subsubsection{Estudo Base}

O primeiro cenário de composição definido na plataforma SemanticSCo foi utilizado para a análise de um conjunto de dados de microarray Agilent (one-color) disponível na base de dados ArrayExpress, sob número de acesso E-MEXP-3905. Este conjunto de dados foi obtido a partir de amostras de células estromais mesenquimais multipotentes (CTMs) derivadas da medula óssea que foram obtidas de doadores saudáveis e de pacientes diagnosticados com esclerose múltipla e tratados com terapia de imunossupressão em altas doses seguida de transplante autólogo de células-tronco hematopoiéticas (TACTH) [370,371].

No estudo base, duas análises comparativas foram realizadas entre conjuntos de dados distintos. Na primeira parte do estudo, a análise comparativa dos perfis de expressão gênica das CTMs isoladas de pacientes com esclerose múltipla antes do transplante (grupo pré-TACTH) e de doadores saudáveis (grupo controle) foi realizada para investigar alterações nos perfis de expressão gênica dos pacientes com esclerose múltipla. Na segunda parte do estudo, a análise comparativa dos perfis de expressão gênica das CTMs isoladas de pacientes com esclerose múltipla antes (grupo pré-TACTH) e após o procedimento de TACTH (grupo pós-TACTH) foi realizada para investigar se o transplante foi capaz de reverter as alterações observadas no transcritoma das CTMs do grupo pré-TACTH.

A mesma sequência de atividades e ferramentas de análise foram utilizadas para a realização das duas partes do estudo base. Inicialmente, os dados de microarray brutos foram normalizados com o uso do pacote R "limma” [82]. Na sequência, os dados de microarray normalizados foram submetidos a uma análise de expressão diferencial. Nesta etapa, a identificação dos genes diferencialmente expressos foi realizada com o uso de um modelo linear e do método empírico de Bayes implementados também no pacote R "limma" (fold-change $\geq 2,0$; valor$p<0,01)$. Finalmente, os genes induzidos e reprimidos foram separadamente submetidos a uma análise de enriquecimento funcional na ferramenta de software DAVID (Versão 6.7) [372]. Estas análises foram realizadas considerando-se tanto as vias biológicas da base de dados KEGG, quanto as três categorias da ontologia GO: "processos biológicos", "funções moleculares" e "componentes celulares". 
No estudo realizado para investigar as diferenças entre os perfis de expressão gênica dos grupos pré-TACTH e controle, um conjunto de 618 genes diferencialmente expressos foi identificado, dos quais 248 genes estavam reprimidos e 370 induzidos nas CTMs do grupo pré-TACTH em relação ao grupo controle.

Os genes diferencialmente expressos considerados relevantes no contexto do estudo foram classificados em quatro categorias de interesse: "cytokine (receptor)", "chemokine (receptor)", "cell adhesion" e "transcription factor". Na categoria "cytokine (receptor)", os genes IGF2, IL17RD e IL17RE foram reprimidos e os genes BDNF, DDR2, GDF15, IL10, IL13RA1, IL1F6, IL6, LTA e NRG4 foram induzidos no grupo pré-TACTH. Na categoria "chemokine (receptor)", os genes CCL7, CKLF, CXCL12 e CXCL5 foram reprimidos e os genes CCL15 e CCL3L3 foram induzidos no grupo pré-TACTH. Na categoria "cell adhesion", os genes AD AMTS3, AD AMTS4, AD AMTS7, CDH24, CDH7, COL7 A1 e ITGA10 foram reprimidos e os genes ADAM21, ADAMTS13, ADAMTSL4, ALAM, COL20A1, COL3A1, CTGF, ESAM, IGSF11, ITGA9, ITGAL, LAMC3 e VTN foram induzidos no grupo préTACTH. Finalmente, na categoria "transcription factor", os genes CDX2, CREB5, EP300, ETV1, LZTS1, MAFA, NFIC, NFIX, SMARCA4, SOLH, TCF19, UHRF1, ZFP36L2 e ZNF85 foram reprimidos e os genes EPAS1, FOXE1, FOXI1, GCM1, HAND1, HNF1B, IKZF4, MYOG, NR5A2, POU4F2, RB1, STAT4 e STAT5B foram induzidos no grupo préTACTH.

A análise de enriquecimento funcional dos genes diferencialmente expressos revelou que os genes reprimidos no grupo pré-TACTH estavam associados em diferentes proporções aos processos biológicos de transcrição $(14,9 \%)$, regulação de transcrição $(3,2 \%)$ e ativação de células $\mathrm{T}(2,5 \%)$, entre outros. Além disto, os genes reprimidos foram associados às funções moleculares de ligação ao DNA $(17,8 \%)$ e de atividade reguladora de GTPase $(5,0 \%)$. A análise também revelou que os genes induzidos no grupo pré-TACTH estavam associados aos processos biológicos de sinalização de proteínas receptoras acopladas à proteína $\mathrm{G}(10,6 \%)$, cascatas de sinalização intracelular $(8,9 \%)$, processos homeostáticos $(7,6 \%)$ e transporte de íons $(7,6 \%)$, entre outros. Adicionalmente, os genes induzidos foram associados às funções moleculares de transporte transmembrana $(5,4 \%)$, atividade de canais iônicos $(4,9 \%)$ e ligação a ânions $(1,9 \%)$. Os genes induzidos também foram associados aos componentes celulares da 
membrana $(37,7 \%)$ e da membrana plasmática $(29,5 \%)$, e a regiões extramoleculares $(14,9 \%)$. Finalmente, 2,7\% dos genes induzidos foram associados à sinalização de cálcio (via biológica KEGG).

No estudo realizado para investigar as diferenças entre os perfis de expressão gênica dos grupos pré-TACTH e pós-TACTH, um conjunto de 81 genes diferencialmente expressos foi identificado. A maioria destes genes estavam induzidos nas CTMs do grupo pós-TACTH.

A análise de enriquecimento funcional revelou que os genes induzidos no grupo pós-TACTH estavam associados em diferentes proporções aos processos biológicos de montagem de proteínas complexas $(8,1 \%)$, organização de cromossomos $(8,1 \%)$ e replicação de DNA $(6,8 \%)$, entre outros. Além disto, a análise revelou que os genes estavam associados às funções moleculares de ligação ao RNA (17,5\%) e constituintes estruturais de ribossomos $(6,8 \%)$. Os genes também foram associados a componentes celulares do lúmen nuclear $(14,9 \%)$ e complexo de ribonucleoproteínas $(13,5 \%)$. Finalmente, 5,4\% dos genes estavam associados a ribossomos (via biológica KEGG).

\subsubsection{Definição do Cenário na Plataforma SemanticSCo}

O primeiro cenário de composição foi definido para a análise integrada de dados de microarray one-color produzidos por meio da plataforma Agilent. A Figura 53 destaca as principais etapas realizadas na plataforma SemanticSCo para a criação deste cenário de composição.

Na primeira etapa, selecionamos o conjunto de arquivos utilizados para armazenar os dados brutos de microarray one-color Agilent a serem analisados e então selecionamos o conceito Agilent one-color microarray raw data para especificar a semântica dos dados. Após a inclusão dos dados na plataforma, selecionamos o serviço MicroAgilentNorm para realizar a atividade de análise Agilent one-color microarray data preprocessing. Em seguida, associamos os dados previamente incluídos na plataforma à entrada do serviço MicroAgilentNorm.

Na segunda etapa, selecionamos o serviço de adaptação ASl para particionar os dados de microarray normalizados produzidos pelo serviço MicroAgilentNorm em dois conjuntos de dados independentes, cada um associado a uma única condição experimental. Em seguida, associamos a saída do serviço MicroAgilentNorm à entrada do serviço AS1. 


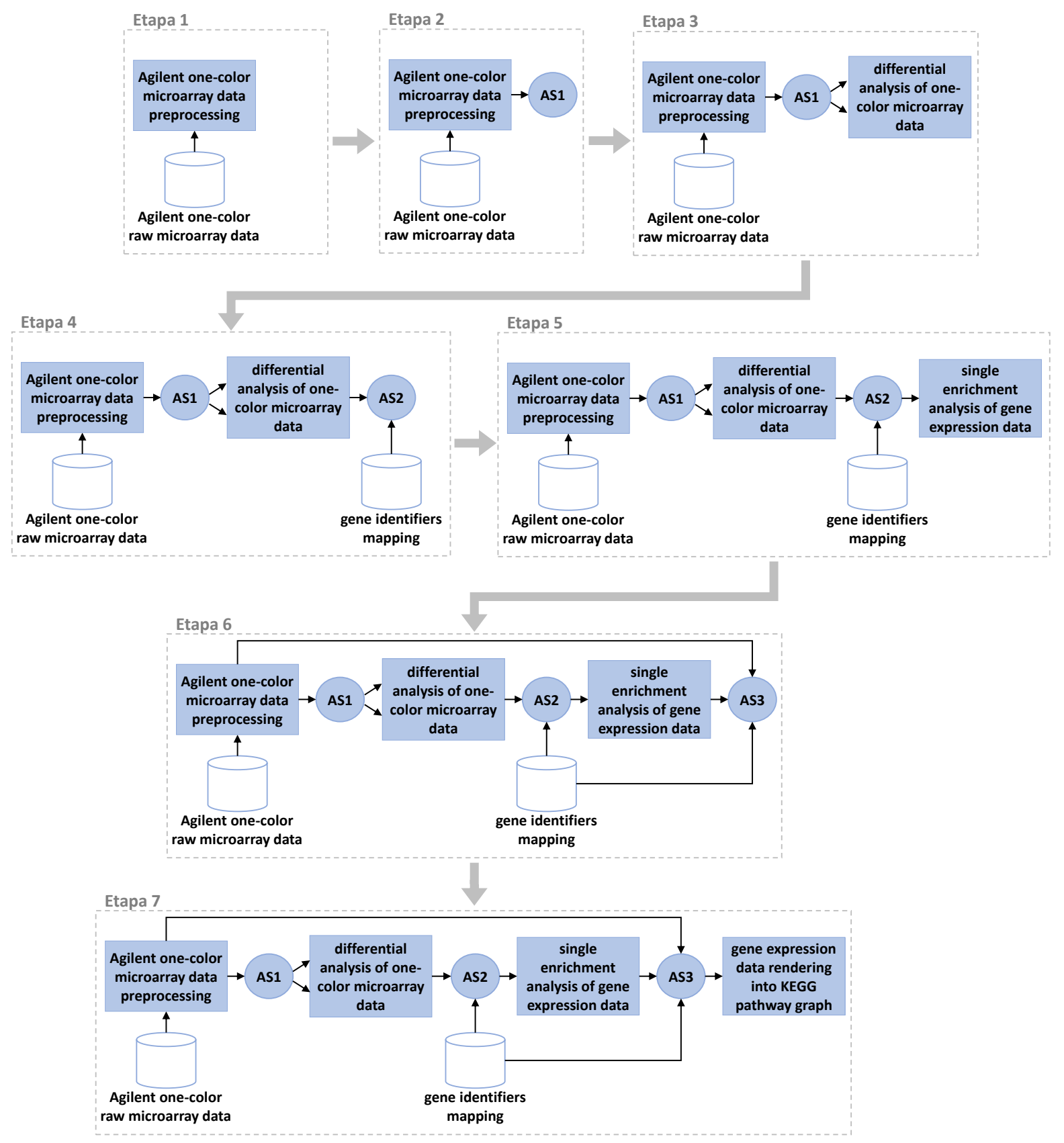

Figura 53: Criação do cenário de composição para a análise de dados de microarray Agilent na plataforma SemanticSCo.

$\mathrm{Na}$ terceira etapa, selecionamos o serviço MicroOneDifferentialAnalysis para realizar a atividade de análise differential analysis of one-color microarray data. Em seguida, associamos as duas saídas do serviço AS1 às duas entradas correspondentes do serviço MicroOneDifferentialAnalysis. 
Na quarta etapa, selecionamos o serviço de adaptação $A S 2$ para converter a lista de identificadores de genes produzida pelo serviço MicroOneDifferentialAnalysis e particionar esta lista em dois conjuntos de dados independentes (genes reprimidos e induzidos). Em seguida, associamos a saída do serviço MicroOneDifferentialAnalysis à entrada correspondente do serviço AS2. Uma vez que o serviço $A S 2$ também requer como entrada um arquivo utilizado para armazenar o mapeamento entre identificadores de genes, selecionamos este arquivo e utilizamos o conceito gene identifiers mapping para especificar a semântica dos dados. Após a inclusão dos dados de mapeamento na plataforma, associamos estes dados à entrada correspondente do serviço AS2.

Na quinta etapa, selecionamos o serviço DAVID-REST para realizar a atividade de análise single enrichment analysis of gene expression data. Em seguida, associamos uma das saídas do serviço AS2 à entrada do serviço DAVID-REST.

Na sexta etapa, selecionamos o serviço de adaptação $A S 3$ para filtrar os dados de microarray normalizados produzidos pelo serviço MicroAgilentNorm com base nos conjuntos de genes funcionalmente enriquecidos em vias biológicas KEGG que foram identificados pelo serviço DAVID-REST. Em seguida, associamos as saídas dos serviços MicroAgilentNorm e DAVIDREST às duas entradas correspondentes do serviço AS3. Adicionalmente, associamos os dados de mapeamento previamente incluídos na plataforma à entrada correspondente do serviço AS3.

Finalmente, na sétima etapa, selecionamos o serviço KeggPathwayViewer para realizar a atividade de análise gene expression data rendering into KEGG pathway graph. Em seguida, associamos uma das saídas do serviço AS3 à entrada do serviço KeggPathwayViewer.

No cenário definido, quatro atividades de análise são realizadas na seguinte ordem: normalização dos dados, identificação de genes diferencialmente expressos a partir dos dados normalizados, análise de enriquecimento funcional dos genes diferencialmente expressos para a identificação de um conjunto relevante de processos e vias biológicas associados aos genes e visualização das vias biológicas da base de dados Kyoto Encyclopedia of Genes and Genomes (KEGG) [169] identificadas a partir da análise de enriquecimento. Este mesmo cenário foi utilizado para reproduzir as duas partes do estudo base na plataforma SemanticSCo. A Figura 54 ilustra a estrutura final deste cenário de análise na plataforma SemanticSCo. 


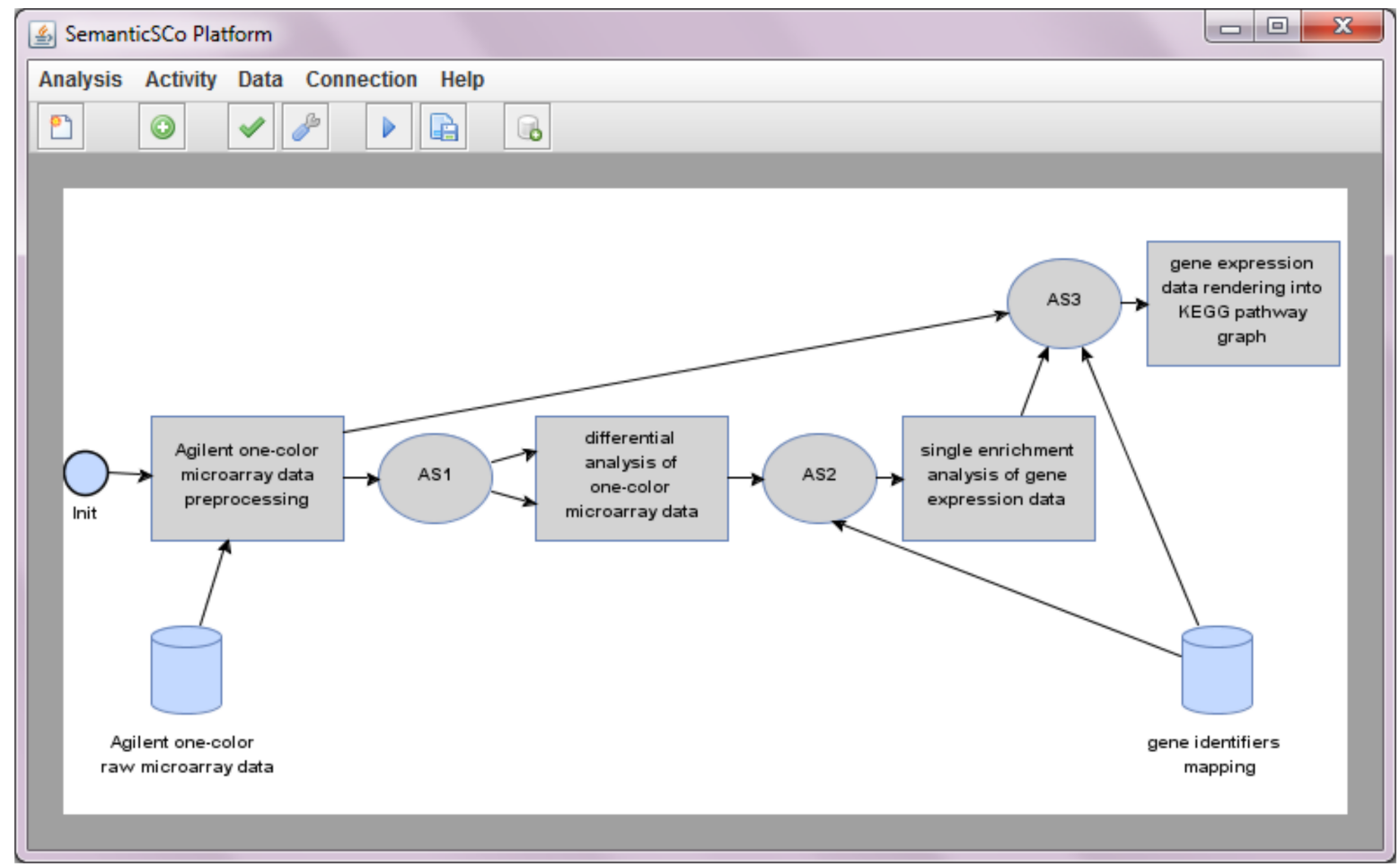

Figura 54: Cenário de composição para a análise de dados de microarray Agilent na plataforma SemanticSCo.

\subsubsection{Execução do Cenário de Análise}

De modo a facilitar a compreensão do primeiro cenário de análise criado na plataforma SemanticSCo, a Figura 55 apresenta a sua execução para a realização da primeira parte do estudo base com foco no fluxo de dados entre os serviços. Um retângulo representa um arquivo de dados, enquanto um retângulo com as bordas arredondadas representa um serviço RESTful. Um círculo pontilhado representa um serviço de adaptação RESTful. Finalmente, as setas indicam o fluxo de dados e/ou controle.

Inicialmente, o serviço MicroAgilentNorm recebe como entrada diferentes arquivos utilizados para armazenar os dados de microarray Agilent (one-color), cada um representando uma amostra biológica distinta. Apenas os dados das amostras referentes aos grupos pré-TACTH e controle são fornecidos como entrada para o serviço MicroAgilentNorm. Este serviço realiza a normalização dos dados e produz como saída um único arquivo multi-colunas contendo os dados de expressão normalizados para todas as amostras, de modo que cada amostra está representada em uma coluna do arquivo. A seguir, o serviço AS1 recebe como entrada o arquivo 


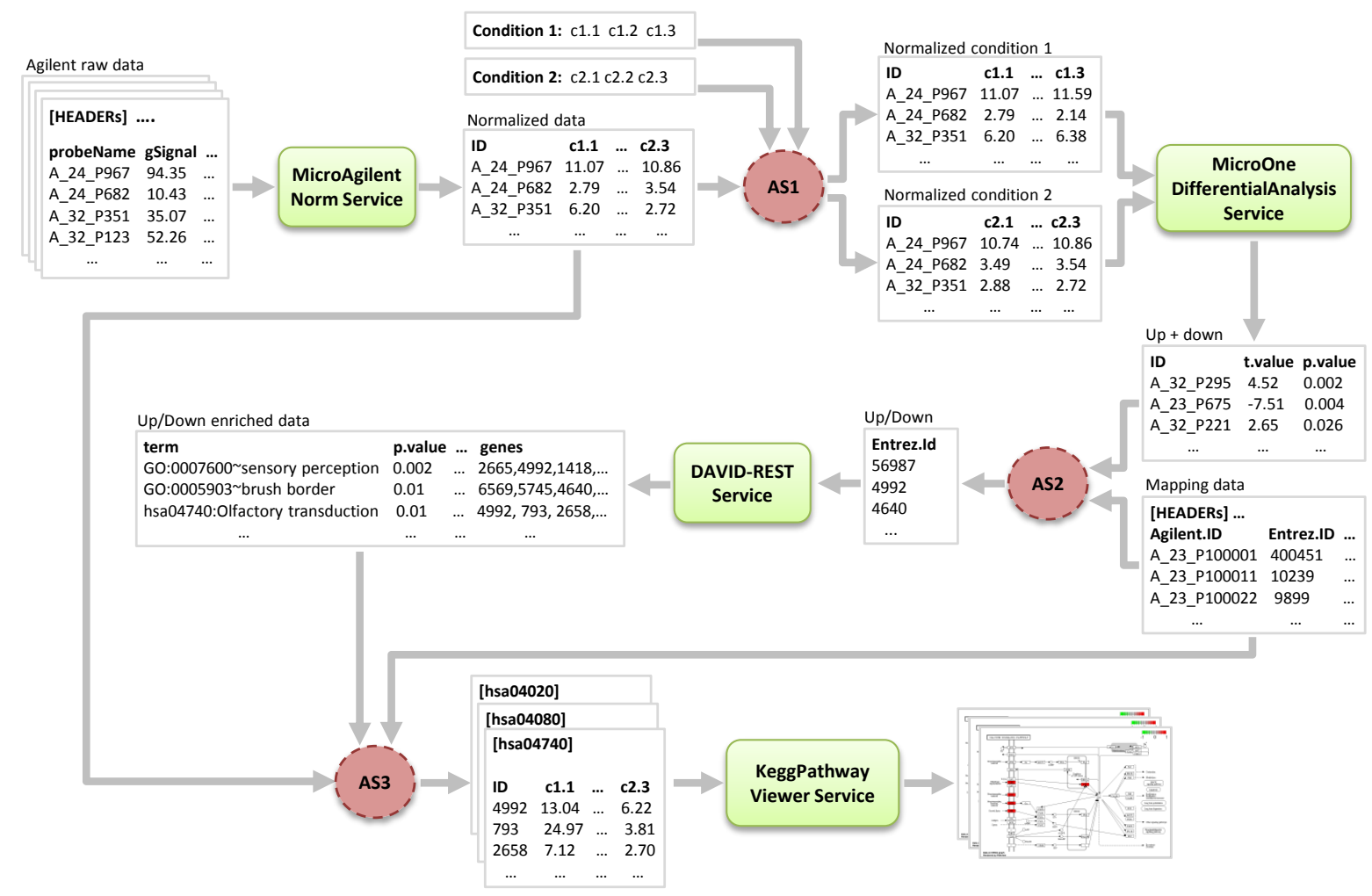

Figura 55: Execução do cenário de análise de dados de microarray Agilent.

produzido pelo serviço MicroAgilentNorm. O serviço ASl então particiona os dados de expressão normalizados de acordo com as duas condições experimentais: pré-TACTH e controle. Este serviço produz como saída dois arquivos multi-colunas contendo os dados de microarray normalizados, particionados de acordo com as duas condições experimentais. Neste sentido, o serviço ASl também recebe como entrada dois parâmetros especificando o conjunto de amostras (colunas) associado a cada uma das condições experimentais, respectivamente.

Na sequência, o serviço MicroOneDifferentialAnalysis recebe como entrada os dois arquivos produzidos pelo serviço $A S 1$ e três parâmetros adicionais: valor limiar de corte $(2,0)$, nível de significância do teste $(0,05)$ e método de correção de múltiplos testes (none). O serviço MicroOneDifferentialAnalysis realiza então a seleção dos transcritos cujos valores de expressão tenham sido duas vezes (parâmetro) maiores/menores entre as condições experimentais pré-TACTH e controle. Como resultado, o serviço MicroOneDifferentialAnalysis produz uma lista de identificadores de transcritos diferencialmente expressos. O serviço AS2 recebe como entrada a lista produzida pelo serviço MicroOneDifferentialAnalysis. O serviço AS2 então converte os identificadores de transcritos Agilent armazenados na lista para os respectivos identificadores 
de genes da base de dados Entrez [319]. Esta conversão é realizada pelo serviço com base em um arquivo de mapeamento também fornecido como entrada. Este arquivo de mapeamento foi obtido a partir da base de dados Gene Expression Omnibus (GEO), disponível sob número de acesso GPL6480. Uma vez que a lista de identificadores é convertida, a mesma é então particionada em duas listas distintas, cada uma representando genes induzidos e reprimidos no grupo pré-TACTH, respectivamente.

A seguir, os serviços DAVID-REST, AS3 e KeggPathwayViewer são executados sequencialmente duas vezes de modo a processar cada uma das listas produzidas pelo serviço AS2 (genes induzidos e reprimidos) separadamente. Para cada execução, o serviço DAVID-REST recebe como entrada uma das listas produzidas pelo serviço $A S 2$ e cinco parâmetros adicionais: endereço de email para autenticação, valor limiar de corte de sobre-representação (0.1), número mínimo de genes (2), tipo dos identificadores de genes fornecidos (ENTREZ_GENE_$I D)$ e lista de categorias de anotação (GO_BP_FAT,GO_CC_FAT,GO_MF_FAT, KEGG_PATHWAY). O serviço DAVID-REST realiza o enriquecimento funcional dos genes armazenados na lista, ou seja, a identificação das vias biológicas KEGG e termos da ontologia GO mais relevantes associados aos genes de interesse. A seguir, o serviço AS3 recebe como entrada os dados resultantes da análise de enriquecimento funcional no serviço DAVID-REST e os dados normalizados que foram produzidos pelo serviço MicroAgilentNorm. O serviço AS3 realiza então a seleção das vias biológicas KEGG e dos genes associados a cada via nos dados resultantes da análise de enriquecimento. Para cada via biológica KEGG selecionada, o serviço AS3 filtra os dados normalizados, selecionando apenas os valores de expressão dos genes associadas àquela via biológica e armazenando estes valores em um arquivo multi-colunas, de modo que cada amostra é representada em uma coluna do arquivo. O serviço AS3 também recebe como entrada um arquivo de mapeamento que é utilizado para converter os identificadores de transcritos Agilent representados nos dados normalizados para os identificadores de genes Entrez correspondentes. O serviço $A S 3$ recebe como entrada o mesmo arquivo de mapeamento previamente fornecido como entrada para o serviço AS2. Finalmente, o serviço KeggPathwayViewer recebe como entrada um dos arquivos produzidos pelo serviço AS3 e três parâmetros adicionais: identificador de grafo KEGG (ex: 04740), tipo dos identificadores de genes fornecidos (ENTREZ_GENE_ID) e identificador da espécie biológica (hsa). O serviço KeggPathway- 
Viewer produz uma imagem da via biológica KEGG (grafo) mostrando os dados de expressão gênica correspondentes. O serviço KeggPathwayViewer é executado múltiplas vezes, uma vez para cada arquivo produzido pelo serviço AS3.

\subsubsection{Análise Comparativa dos Grupos Pré-TACTH e Controle}

No estudo realizado para investigar as diferenças nos perfis de expressão gênica das CTMs obtidas a partir de pacientes com esclerose múltipla antes do transplante (grupo pré-TACTH) e de doadores saudáveis (grupo controle), o serviço MicroOneDifferentialAnalysis identificou um conjunto de 487 genes diferencialmente expressos ( fold-change $\geq 2,0$; valor- $p<0,05$ ). Deste conjunto de genes, 234 genes estavam reprimidos e 253 induzidos nas CTMs do grupo pré-TACTH em relação ao grupo controle.

O serviço MicroOneDifferentialAnalysis identificou apenas um subconjunto dos genes reprimidos $(33,1 \%)$ e induzidos $(48,1 \%)$ previamente identificados no estudo original. Estas diferenças nos resultados podem ser explicadas pelo uso de métodos estatísticos distintos. No serviço MicroOneDifferentialAnalysis, a identificação de genes diferencialmente expressos é realizada por meio do teste t de Student. Em contraste, no estudo original, os genes diferencialmente expressos foram identificados com o uso de um modelo linear e do método empírico de Bayes no pacote R “limma” [82], o qual possui um maior poder de detecção de diferenças de expressão, principalmente em experimentos com tamanhos amostrais menores, em comparação ao teste t de Student [373].

De forma análoga ao estudo original, a partir do conjunto de genes diferencialmente expressos, identificamos os genes pertencentes a quatro categorias de interesse: "cytokine (receptor)", "chemokine (receptor)", "cell adhesion" e "transcription factor". A classificação dos genes nestas categorias foi realizada com base em informações da base de dados Entrez [319] e da ontologia Gene Ontology (GO) [167]. A Tabela 20 apresenta a classificação dos genes reprimidos/induzidos nestas categorias de interesse.

Identificamos um conjunto de 27 genes pertencentes à categoria "cytokine (receptor)", dos quais 9 genes encontram-se reprimidos e 18 induzidos nas CTMs do grupo pré-TACTH em relação ao grupo controle. Deste conjunto, apenas o gene IL17RD (reprimido) e os genes GDF15, 
Tabela 20: Classificação dos genes reprimidos/induzidos no grupo pré-TACTH.

\begin{tabular}{l|l|l}
\hline Categoria & Genes reprimidos & Genes induzidos \\
\hline \hline cytokine (receptor) & $\begin{array}{l}\text { ADAMTS4, ASB9, CD46, CKLF, } \\
\text { CXCL5, DAGLA, IL17RD*, PUS7, } \\
\text { TNFRSF4 }\end{array}$ & $\begin{array}{l}\text { AKAP6, BMP5, CA2, CCL3L3, CD86, } \\
\text { CEACAM1, CYP17A1, DAB1, DDIT3, } \\
\text { GDF15, INHBC, LTA*, MAVS, } \\
\text { MUC5AC, NRG4*, S1PR2, TERT, } \\
\text { THPO }\end{array}$ \\
\hline chemokine (receptor) & $\begin{array}{l}\text { CKLF*, CXCL5*, MICA, MICB } \\
\text { cell adhesion }\end{array}$ & $\begin{array}{l}\text { AHSG, CCL3L3*, CD86, CHIA, } \\
\text { MAVS, S1PR2 }\end{array}$ \\
\hline transcription factor & $\begin{array}{l}\text { ADAMTS4, BEX1, BEX2, E2F8, } \\
\text { FOXB1, KIAA1549, KLF6, PIAS4, } \\
\text { PKNOX2, SOLH*, SOX17, SUFU, } \\
\text { TCF19*, TMPRSS2, TNFRS4, } \\
\text { ZBTB49, ZNF516 }\end{array}$ & $\begin{array}{l}\text { ALAS2, BSCR4, ELF5, ERBB4, ETV3, GDF15, } \\
\text { OTX1, PCDH1, POU4F2*, POU5F2, } \\
\text { PTGER3, SOX8, TERT }\end{array}$ \\
\hline \hline
\end{tabular}

*Genes também identificados como relevantes no estudo original

LTA e NRG4 (induzidos) foram também identificados como relevantes no estudo original. Na categoria "chemokine (receptor)", identificamos um conjunto de 10 genes, dos quais 4 genes encontram-se reprimidos e 6 induzidos nas CTMs do grupo pré-TACTH. Deste conjunto, apenas os genes $C K L F$ e CXCL5 (reprimidos) e o gene CCL3L3 (induzido) foram originalmente identificados como relevantes. Na categoria "cell adhesion", identificamos um conjunto de 6 genes, dos quais 3 encontram-se reprimidos e 3 induzidos nas CTMs do grupo pré-TACTH. Deste conjunto, apenas o gene ADAMTS4 (reprimido) foi originalmente identificado como relevante. Finalmente, identificamos um conjunto de 38 genes na categoria "transcription factor", dos quais 17 encontram-se reprimidos e 21 induzidos nas CTMs do grupo pré-TACTH. Deste conjunto, apenas os genes SOLH e TCF19 (reprimidos) e o gene POU4F2 (induzido) foram originalmente identificados como relevantes. A relevância do conjunto de genes identificados sem correspondência com os genes identificados no estudo original precisa ser investigada. Contudo, a realização de investigações adicionais está fora do escopo deste trabalho.

Após a identificação dos genes diferencialmente expressos nas CTMs do grupo de pacientes pré-TACTH em relação ao grupo controle, realizamos o enriquecimento funcional destes genes por meio do serviço DAVID-REST. Esta análise de enriquecimento funcional foi realizada 
considerando-se as vias biológicas da base de dados KEGG, bem como as três categorias da ontologia GO: "processos biológicos", "funções moleculares" e "componentes celulares".

Em relação aos genes reprimidos no grupo pré-TACTH, a análise de enriquecimento funcional revelou alterações na expressão de genes associados a diferentes processos biológicos e funções moleculares da ontologia GO. Componentes celulares da GO e vias biológicas KEGG não foram identificados como relevantes nesta análise. A Figura 56 apresenta a proporção de genes reprimidos que foram identificados nas categorias da ontologia GO consideradas relevantes.

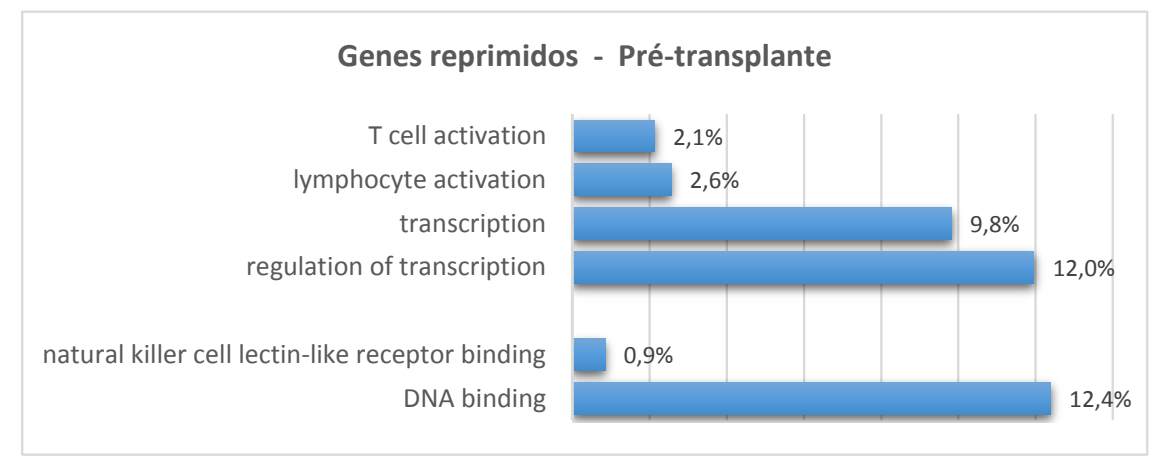

Figura 56: Proporção de genes reprimidos no grupo pré-TACTH identificados nas categorias da ontologia GO. Os agrupamentos indicam, de cima para baixo, as categorias GO "processos biológicos" e "funções moleculares".

De forma semelhante aos resultados obtidos no estudo original, o serviço DAVID-REST identificou que os genes reprimidos no grupo pré-TACTH estão associados em maior proporção aos processos biológicos de regulação de transcrição $(12,0 \%)$ e transcrição $(9,8 \%)$, bem como à função molecular de ligação ao DNA $(12,4 \%)$. No entanto, os valores absolutos de genes identificados em cada processo biológico ou função molecular difere dos valores obtidos no estudo original uma vez que os genes diferencialmente expressos submetidos à análise pelo serviço DAVID-REST incluem apenas um subconjunto dos genes diferencialmente expressos identificados no estudo original.

Em relação aos genes induzidos no grupo pré-TACTH, a análise de enriquecimento funcional revelou alterações na expressão de genes associados a diferentes processos biológicos, componentes celulares e funções moleculares da ontologia GO, bem como a duas vias biológicas da 
base de dados KEGG. A Figura 57 apresenta a proporção de genes induzidos que foram identificados nas categorias da ontologia GO e vias biológicas KEGG consideradas relevantes.

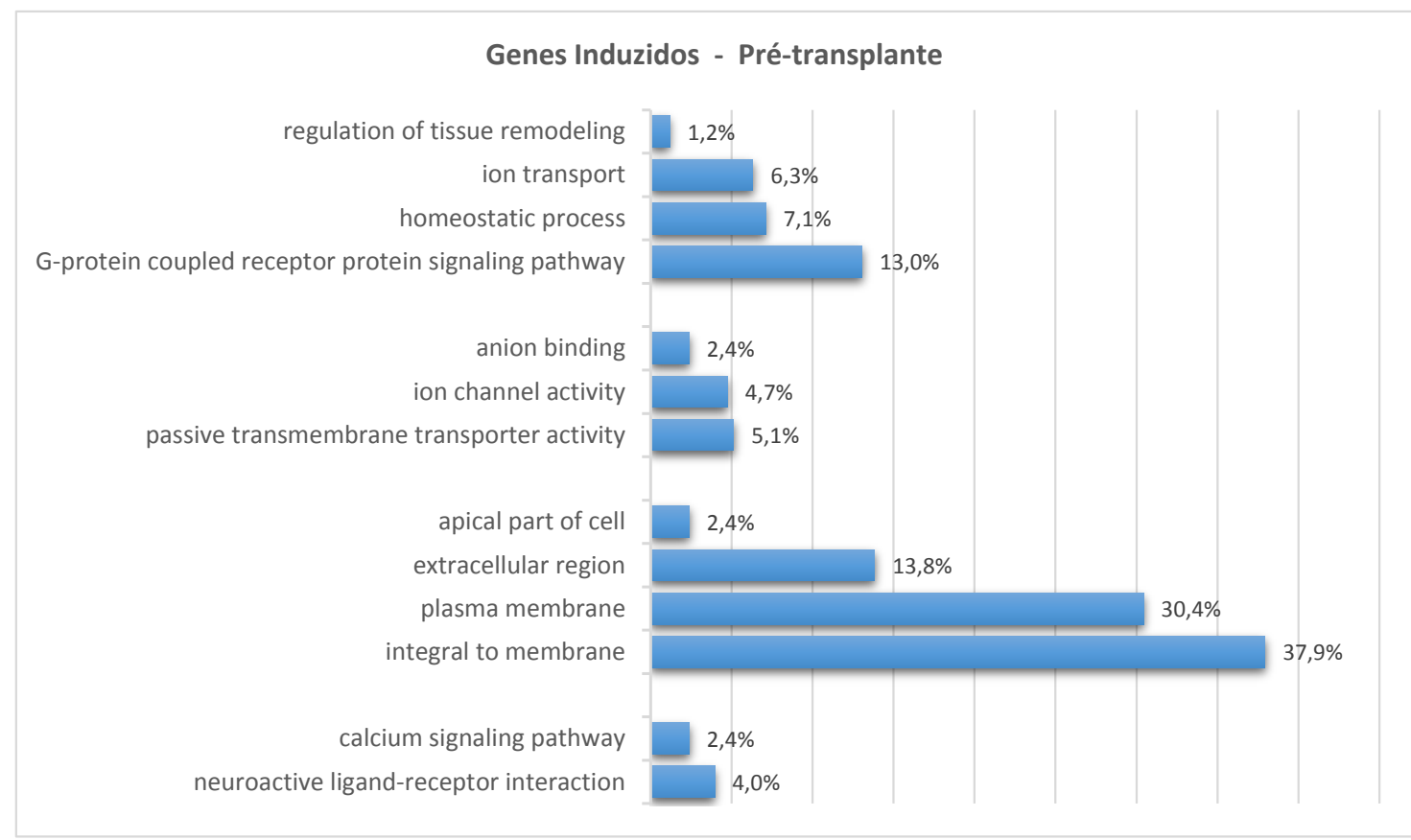

Figura 57: Proporção de genes induzidos no grupo pré-TACTH identificados nas categorias da ontologia GO e vias biológicas KEGG relevantes. Os agrupamentos indicam, de cima para baixo, as categorias GO "processos biológicos", "funções moleculares", "componentes celulares” e as vias biológicas KEGG.

De forma semelhante aos resultados obtidos no estudo original, o serviço DAVID-REST identificou que os genes induzidos no grupo pré-TACTH estão associados em maior proporção ao processo biológico de sinalização de proteínas receptoras acopladas à proteína $\mathrm{G}(13,0 \%)$, aos componentes celulares da membrana $(37,9 \%)$, membrana plasmática $(30,4 \%)$ e à regiões extracelulares $(13,8 \%)$. De forma análoga aos resultados obtidos no enriquecimento funcional dos genes reprimidos, os valores absolutos dos genes induzidos que foram identificados em cada processo/via biológico, função molecular ou componente celular difere dos valores obtidos no estudo original.

A análise de enriquecimento funcional no serviço DAVID-REST também revelou que os genes induzidos no grupo pré-TACTH estão envolvidos em duas vias biológicas: "neuroactive ligand-receptor interaction" (4,0\%) e "calcium signaling pathway" (2,4\%). O serviço KeggPathwayViewer foi utilizado para visualizar estas vias biológicas. A Figura 58 ilustra os genes 
diferencialmente expressos mapeados para a via biológica KEGG "neuroactive ligand-receptor interaction". Cada retângulo representa um gene identificado nas amostras de CTMs obtidas a partir de pacientes com esclerose múltipla antes do procedimento TACTH e de doadores saudáveis. Os genes induzidos são apresentados em retângulos com preenchimento em vermelho.

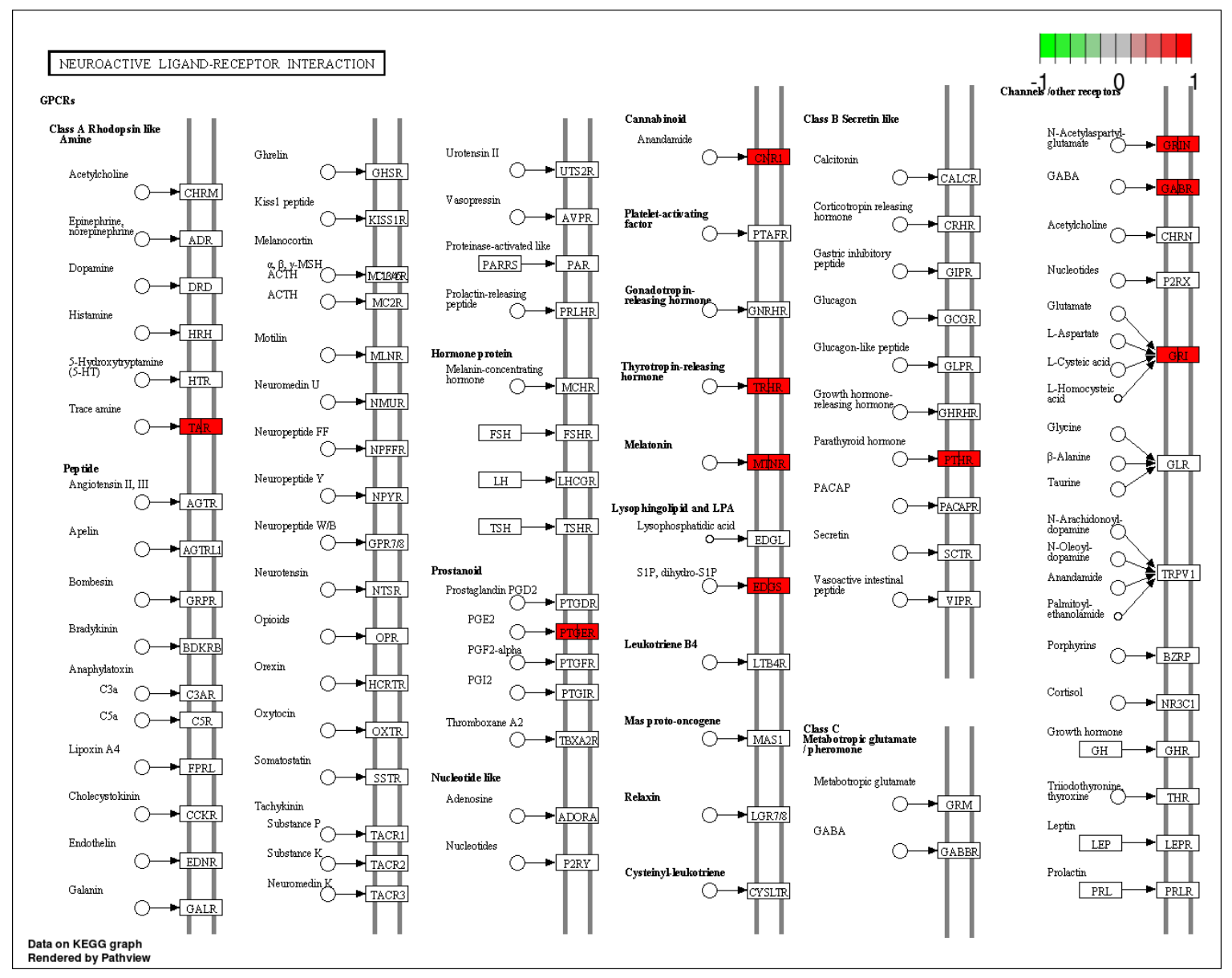

Figura 58: Genes mapeados para a via biológica KEGG neuroactive ligand-receptor interaction.

\subsubsection{Análise Comparativa dos Grupos Pré-TACTH e Pós-TACTH}

No estudo realizado para investigar as diferenças nos perfis de expressão gênica das CTMs obtidas a partir de pacientes com esclerose múltipla antes (grupo pré-TACTH) e após (grupo pós-TACTH) a realização do transplante, o serviço MicroOneDifferentialAnalysis identificou um conjunto de 75 genes diferencialmente expressos ( fold-change $\geq 2,0$; valor-p $<0,05$ ). 
Todos os genes identificados estavam induzidos nas amostras de CTMs obtidas dos pacientes após o transplante.

O serviço MicroOneDifferentialAnalysis identificou apenas um subconjunto dos genes induzidos previamente identificados no estudo original $(22,2 \%)$. De forma análoga à análise comparativa dos grupos pré-TACTH e controle, a diferença nos resultados da análise dos grupos pré-TACTH e pós-TACTH também pode ser explicada pelo uso de métodos estatísticos distintos.

Após identificação dos genes diferencialmente expressos nas CTMs do grupo de pacientes pós-TACTH em relação ao grupo pré-TACTH, realizamos o enriquecimento funcional destes genes por meio do serviço DAVID-REST. A análise de enriquecimento funcional revelou alterações na expressão de genes associados a diferentes processos biológicos, componentes celulares e funções moleculares da ontologia GO, bem como a uma via biológicas da base de dados KEGG. A Figura 59 apresenta a proporção de genes induzidos que foram identificados nas categorias da ontologia GO e vias biológicas KEGG consideradas relevantes.

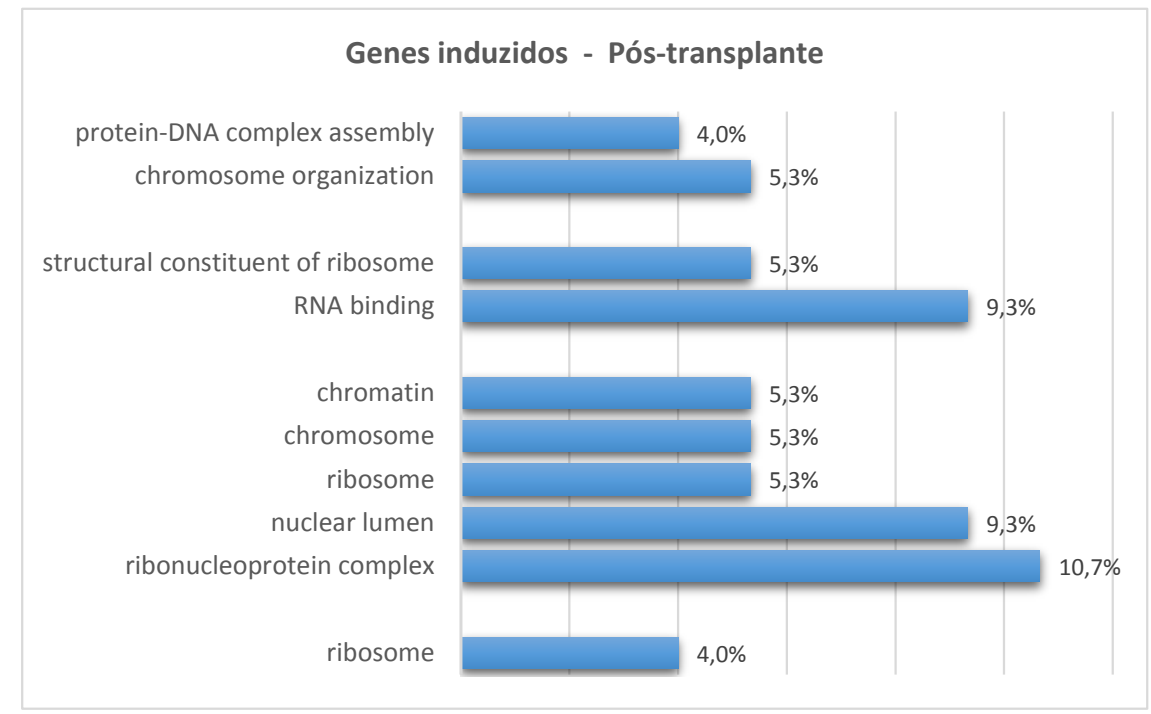

Figura 59: Proporção de genes induzidos no grupo pós-TACTH identificados nas categorias da ontologia GO e vias biológicas KEGG relevantes. Os agrupamentos indicam, de cima para baixo, as categorias GO "processos biológicos", "funções moleculares", "componentes celulares" e as vias biológicas KEGG.

De forma semelhante aos resultados obtidos no estudo original, o serviço DAVID-REST identificou que os genes induzidos no grupo pós-TACTH estão associados em maior proporção à 
função molecular de ligação ao RNA $(9,3 \%)$ e aos componentes celulares do lúmen nuclear $(9,3 \%)$ e complexo de ribonucleoproteínas (10,7\%). No entanto, os valores absolutos de genes identificados em cada processo/via biológico, função molecular ou componente celular difere dos valores obtidos no estudo original uma vez que os genes diferencialmente expressos submetidos à análise pelo serviço DAVID-REST incluem apenas um subconjunto dos genes diferencialmente expressos identificados no estudo original.

Adicionalmente, também de forma semelhante ao estudo original, a análise de enriquecimento funcional revelou um conjunto de genes envolvido na via biológica KEGG "ribosome" (4,0\%). O serviço KeggPathwayViewer também foi utilizado para visualizar esta via biológica.

\subsection{ANÁLISE DE DADOS DE MICROARRAY AFFYMETRIX}

O segundo estudo de caso foi definido para a análise de dados de microarray one-color provenientes da plataforma Affymetrix. As seções a seguir apresentam o estudo utilizado como base para a definição do cenário de composição, a criação do cenário na plataforma SemanticSCo, a execução detalhada do cenário e, finalmente, os resultados obtidos a partir da sua execução.

\subsubsection{Estudo Base}

O segundo cenário de composição definido na plataforma SemanticSCo foi utilizado para a análise de um conjunto de dados de microarray Affymetrix (one-color) disponível na base de dados Gene Expression Omnibus (GEO), sob número de acesso GSE69719. Este conjunto de dados foi obtido a partir de amostras cerebrais de peixes-zebra (espécie Danio rerio) pertencentes a quatro grupos distintos [374]: (i) bystanders to interacting conspecifics (BIC), que compreende indivíduos que observaram com atenção a interação de outros dois indivíduos em situação de conflito; (ii) bystanders attentive to non-interacting conspecifics (BANIC), que compreende indivíduos que observaram com atenção a interação de outros dois indivíduos em situação de não-conflito; (iii) bystanders inattentive to non-interacting conspecifcs (BINIC), que compreende indivíduos que observaram, de forma inatenta, a interação de outros dois indivíduos em 
situação de não-conflito; e (iv) isolated fish (ISOL), que compreende indivíduos socialmente isolados (grupo controle).

O principal objetivo do estudo base foi investigar as alterações no perfil de expressão gênica de células cerebrais de peixes-zebra associadas ao mecanismo de eavesdropping social. Este mecanismo consiste na habilidade de um indivíduo adquirir informações a partir da observação das interações entre outros indivíduos da mesma espécie de modo a ajustar, subsequentemente, seu comportamento social.

No estudo base, os dados de microarray brutos foram inicialmente normalizados com o uso do método Robust Multi-array Average (RMA) [375,376]. Na sequência, os dados de microarray normalizados foram submetidos a uma análise de expressão diferencial. Nesta etapa, os grupos BIC, BANIC e BINIC foram separadamente comparados ao grupo ISOL (controle). A identificação de genes diferencialmente expressos foi realizada com o uso de um modelo linear e do método empírico de Bayes implementados no pacote $\mathrm{R}$ "limma" ( $\log _{2}$ (fold-change) $>1,1 ;$ valor- $p<0,05)$. Após a análise diferencial dos dados, todos os genes diferencialmente expressos obtidos nos três grupos testados foram conjuntamente submetidos a uma análise de agrupamento hierárquico. Esta análise de agrupamento foi realizada com o uso do método de ligação média e a métrica de distância city-block, também conhecida como Manhattan.

Paralelamente a estas análises, os dados normalizados também foram submetidos a uma análise de enriquecimento funcional de grupos de genes para a identificação de genes diferencialmente expressos associados, conjuntamente, a diferentes processos e vias biológicas. Para a realização do enriquecimento funcional, os identificadores de transcritos Affymetrix contidos nos dados normalizados foram inicialmente mapeados para os respectivos identificadores de genes da base de dados Entrez [319]. O mapeamento foi realizado com base em informações das bases de dados Bioconductor [313], National Center for Biotechnology Information (NCBI) [377] e biomart [378]. Os identificadores de transcritos foram mapeados para um total de 21.224 identificadores exclusivos de genes, os quais foram então submetidos à análise de enriquecimento. Nesta atividade de análise, os grupos BIC, BANIC e BINIC também foram separadamente comparados ao grupo ISOL (controle). A análise de enriquecimento funcional de grupos de genes foi realizada com o uso do pacote $\mathrm{R}$ "gage" [334] (valor- $p<0,1)$. Estas análises foram realizadas considerando-se as vias biológicas das bases de dados KEGG e 
WikiPathways [379], bem como as três categorias da ontologia GO: "processos biológicos", "funções moleculares" e "componentes celulares".

A análise de expressão diferencial realizada entre as amostras dos grupos BIC e ISOL (controle) identificou um conjunto de 8 genes diferencialmente expressos, compreendendo os genes BTG2, DNAJB5, EGR4, FOS, MSH4, NPAS4A, NPAS4B e NR4A1. Todos estes genes estavam induzidos nas amostras do grupo BIC. A análise diferencial realizada entre as amostras dos grupos BANIC e ISOL identificou um conjunto de 11 genes diferencialmente expressos, dos quais 4 genes estavam reprimidos (C25HXorf38, DAP1B, FTR50 e $S O G A 3 B$ ) e 7 estavam induzidos (EGR4, FOS, NPAS4A, NR4A1, PCDH2AB7, PCDHGA10 e ZNF507) nas amostras do grupo BANIC. A análise diferencial realizada entre as amostras dos grupos BINIC e ISOL identificou um conjunto de 3 genes diferencialmente expressos, compreendendo os genes OSBPL1A, PCDH2AB7 e PCDHGA10. Todos estes genes estavam induzidos nas amostras do grupo BINIC. Adicionalmente, do conjunto de genes induzidos nas amostras do grupo BANIC, 4 genes (EGR4, FOS, NPAS4A e NR4A1) também estavam induzidos nas amostras do grupo BIC e 2 genes (PCDH2AB7 e PCDHGA10) também estavam induzidos nas amostras do grupo BINIC.

$\mathrm{Na}$ análise de agrupamento hierárquico realizada a partir dos genes diferencialmente expressos, as amostras dos grupos ISOL e BINIC foram isoladamente agrupadas. Em contrapartida, as amostras dos grupos BIC e BANIC foram conjuntamente agrupadas. Além disto, como esperado, as amostras do grupo BINIC apresentaram-se mais similares às amostras do grupo ISOL do que dos demais grupos. Finalmente, a análise de agrupamento revelou um conjunto de 8 genes com um perfil de expressão similar nas amostras de todos os grupos, sugerindo que estes genes compartilham um padrão de coexpressão. Este conjunto compreende os genes BTG2, DNAJB5, EGR4, FOS, MSH4, NPAS4A, NPAS4B e NR4A1. Todos estes genes foram induzidos no grupo BIC, sugerindo que os mesmos desempenham um papel importante neste grupo comportamental.

A análise de enriquecimento funcional realizada entre as amostras dos grupos BIC e ISOL (controle) com base na ontologia GO revelou grupos de genes diferencialmente expressos associados em diferentes proporções aos processos biológicos de transcrição $(1,4 \%)$, transdução de sinal mediada por GTPases $(0,5 \%)$ e metabolismo de lipídios $(0,3 \%)$, entre outros. Esta aná- 
lise também revelou grupos de genes associados às funções moleculares de fator de transcrição $(1,8 \%)$ e de proteína tirosina fosfatase $(0,2 \%)$, bem como a componentes celulares da membrana mitocondrial $(0,2 \%)$. Adicionalmente, a análise de enriquecimento funcional realizada com base em informações de vias biológicas revelou grupos de genes associados em diferentes proporções às vias KEGG de sinalização MAPK $(0,5 \%)$ e fototransdução $(0,1 \%)$, bem como às vias Wikipathways de sinalização FGF $(0,3 \%)$ e biossíntese de colesterol $(0,1 \%)$, entre outras.

A análise de enriquecimento funcional realizada entre as amostras dos grupos BANIC e ISOL com base na ontologia GO revelou grupos de genes diferencialmente expressos associados em diferentes proporções aos processos biológicos de percepção visual $(0,2 \%)$ e resposta de defesa a bactérias $(0,1 \%)$, entre outros. Esta análise também revelou grupos de genes associados às funções moleculares de endopeptidase $(0,4 \%)$, transferase $(0,1 \%)$ e receptor de citocina $(0,1 \%)$. Adicionalmente, a análise de enriquecimento funcional realizada com base em informações de vias biológicas revelou grupos de genes associados à via KEGG de fosforilação oxidativa $(0,2 \%)$ e à via Wikipathways de sinalização FGF $(0,3 \%)$.

A análise de enriquecimento funcional realizada entre as amostras dos grupos BINIC e ISOL com base na ontologia GO revelou grupos de genes diferencialmente expressos associados em diferentes proporções aos processos biológicos de regulação positiva de transcrição $(0,1 \%)$, resposta de defesa a bactérias $(0,1 \%)$ e processamento de RNA $(0,1 \%)$, entre outros. Esta análise também revelou grupos de genes associados às funções moleculares de ligação à região regulatória do DNA $(0,1 \%)$ e endopeptidase $(0,2 \%)$. Finalmente, a análise de enriquecimento funcional realizada com base em informações de vias biológicas revelou grupos de genes associado às vias KEGG de fosforilação oxidativa $(0,2 \%)$ e de ribossomos $(0,2 \%)$, bem como às vias Wikipathways de cadeia de transporte de elétrons $(0,2 \%)$ e de biossíntese de colesterol $(0,1 \%)$, entre outras.

\subsubsection{Definição do Cenário na Plataforma SemanticSCo}

O segundo cenário de composição foi definido para a análise integrada de dados de microarray one-color produzidos por meio da plataforma Affymetrix. A Figura 60 destaca as principais etapas realizadas na plataforma SemanticSCo para a criação deste cenário de composição. 


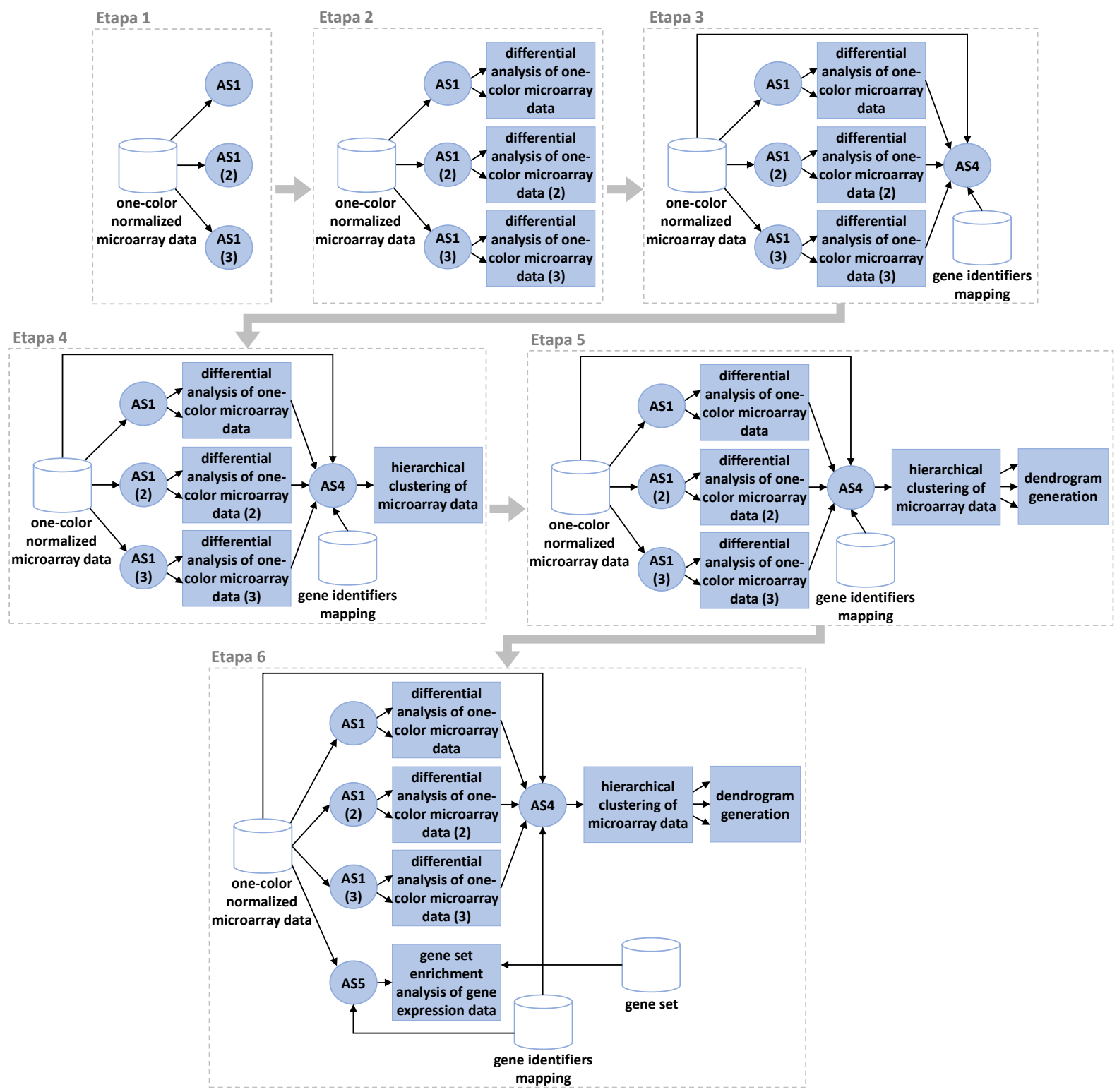

Figura 60: Criação do cenário de composição para a análise de dados de microarray Affymetrix na plataforma SemanticSCo.

Na primeira etapa, selecionamos o arquivo utilizado para armazenar os dados de microarray one-color normalizados referentes aos grupos experimentais ISOL, BIC, BANIC e BINIC. Selecionamos então o conceito one-color normalized microarray data para especificar a semântica dos dados selecionados. Após a inclusão dos dados na plataforma, selecionamos uma instância do serviço de adaptação $A S 1$ para particionar os dados normalizados em dois conjuntos de dados independentes, cada um associado a um grupo experimental distinto: ISOL e BIC. Na sequência, duas instâncias adicionais do serviço AS1 foram selecionadas para particionar os 
dados normalizados. A segunda instância do serviço AS1 (2) particiona os dados com base nos grupos ISOL e BANIC. A terceira instância do serviço AS1 (3) particiona os dados com base nos grupos ISOL e BINIC. Em seguida, associamos os dados normalizados previamente incluídos na plataforma às entradas correspondentes das três instâncias do serviço AS1.

Na segunda etapa, selecionamos uma instância do serviço MicroOneDifferentialAnalysis para realizar a atividade de análise differential analysis of one-color microarray data nos conjuntos de dados produzidos pela primeira instância do serviço $A S 1$. Em seguida, associamos as duas saídas desta instância do serviço AS1 às duas entradas correspondentes do serviço MicroOneDifferentialAnalysis. Na sequência, duas instâncias adicionais do serviço MicroOneDifferentialAnalysis foram selecionadas para a realização das atividades de análise differential analysis of one-color microarray data (2) e (3). Associamos então as duas saídas das instâncias 2 e 3 do serviço AS1 às duas entradas correspondentes das instâncias 2 e 3 do serviço MicroOneDifferentialAnalysis, respectivamente.

Neste cenário, incluímos três instâncias do serviço $A S 1$ e três instâncias do serviço $M i c r o O$ neDifferentialAnalysis uma vez que os dados resultantes das análises realizadas pelas instâncias do serviço MicroOneDifferentialAnalysis precisam ser concomitantemente fornecidos para a atividade de análise posterior.

$\mathrm{Na}$ terceira etapa, selecionamos o serviço de adaptação AS4 para filtrar os dados normalizados com base nas listas de identificadores de genes produzidas pelas três instâncias do serviço MicroOneDifferentialAnalysis e para converter os identificadores de genes contidos nos dados normalizados. Em seguida, associamos os dados normalizados previamente incluídos na plataforma e as saídas das três instâncias do serviço MicroOneDifferentialAnalysis às entradas correspondentes do serviço AS4. Uma vez que o serviço AS4 também requer como entrada um arquivo utilizado para armazenar o mapeamento entre identificadores de genes, selecionamos este arquivo e utilizamos o conceito gene identifiers mapping para especificar a semântica dos dados. Após a inclusão dos dados de mapeamento na plataforma, associamos estes dados à entrada correspondente do serviço AS4.

Na quarta etapa, selecionamos o serviço MicroHCluster para realizar a atividade de análise hierarchical clustering of microarray data. Em seguida, associamos a saída do serviço AS4 à entrada do serviço MicroHCluster. 
$\mathrm{Na}$ quinta etapa, selecionamos o serviço MicroHClusterViewer para realizar a atividade de análise dendrogram generation. Em seguida, associamos as três saídas do serviço MicroHCluster às entradas correspondentes do serviço MicroHClusterViewer.

Na sexta etapa, selecionamos o serviço de adaptação AS5 para filtrar os dados normalizados com base em grupos experimentais de interesse e para converter os identificadores de genes contidos nos dados normalizados. Em seguida, associamos os dados normalizados e os dados de mapeamento previamente incluídos na plataforma às entradas correspondentes do serviço AS5. Selecionamos então o serviço GeneSetEnrichmentAnalysis para realizar a atividade de análise gene set enrichment analysis of gene expression data e associamos a saída do serviço AS5 à entrada correspondente do serviço GeneSetEnrichmentAnalysis. Uma vez que o serviço GeneSetEnrichmentAnalysis também requer como entrada um arquivo utilizado para armazenar os conjuntos de genes de interesse, selecionamos este arquivo e utilizamos o conceito gene set para especificar a semântica dos dados. Finalmente, após a inclusão dos dados na plataforma, associamos estes dados à entrada correspondente do serviço GeneSetEnrichmentAnalysis.

No cenário definido, três atividades de análise são realizadas na seguinte ordem: identificação de genes diferencialmente expressos, análise de agrupamento hierárquico dos genes diferencialmente expressos e visualização dos dados gerados a partir da análise de agrupamento. De forma independente, este cenário também compreende a realização da atividade de análise de enriquecimento funcional de grupos de genes para a identificação de genes diferencialmente expressos associados, conjuntamente, a processos e vias biológicas de interesse. A Figura 61 ilustra a estrutura final deste cenário de análise na plataforma SemanticSCo.

\subsubsection{Execução do Cenário de Análise}

De modo a facilitar a compreensão do segundo cenário de análise criado na plataforma SemanticSCo, a Figura 62 apresenta a sua execução para a realização do estudo base com foco no fluxo de dados entre os serviços. Um retângulo representa um arquivo de dados, enquanto um retângulo com as bordas arredondadas representa um serviço RESTful. Um círculo pontilhado representa um serviço de adaptação RESTful. Finalmente, as setas indicam o fluxo de dados e/ou controle. 


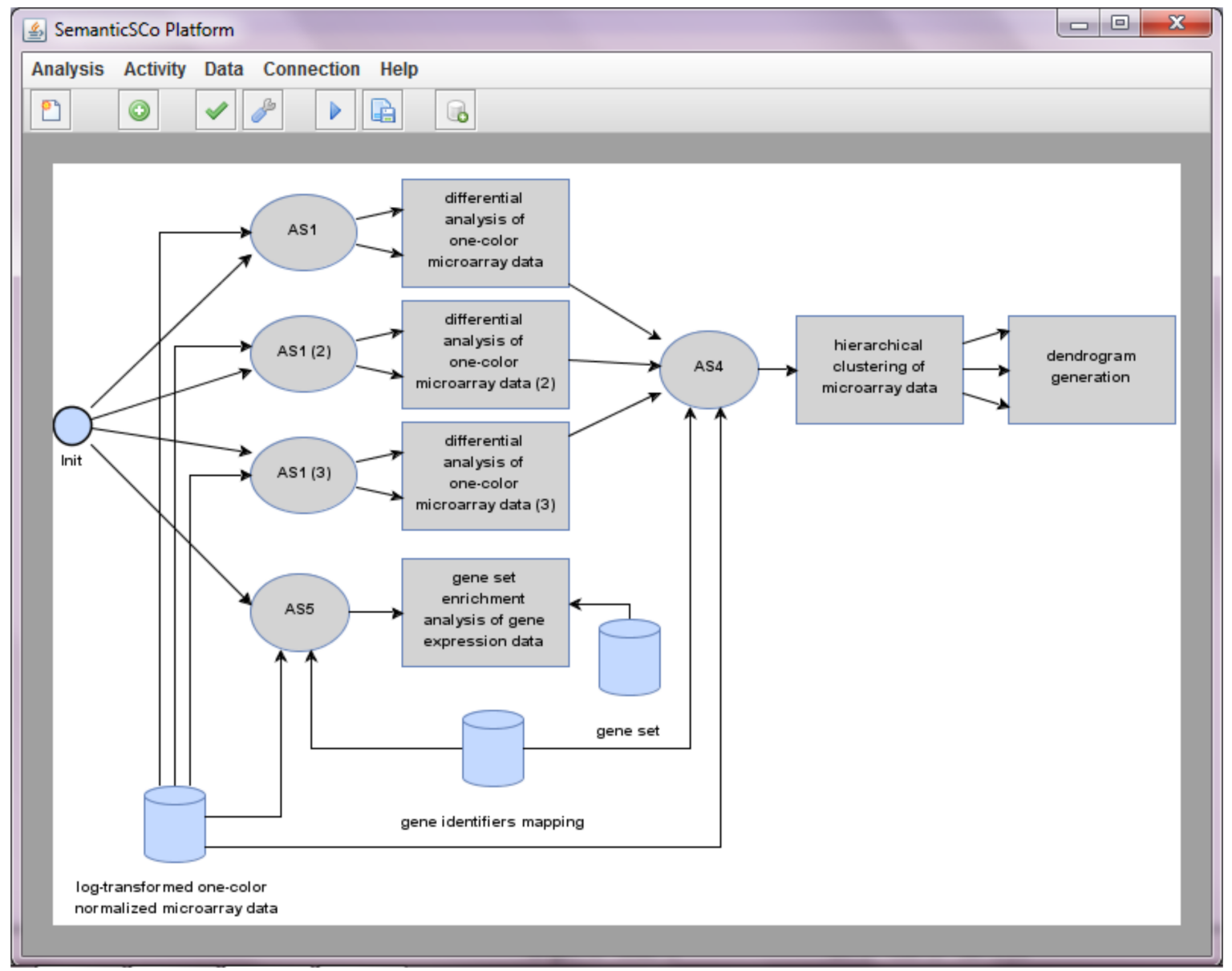

Figura 61: Cenário de composição para a análise de dados de microarray Affymetrix na plataforma SemanticSCo.

Inicialmente, cada instância do serviço $A S 1$ recebe como entrada um arquivo multi-colunas utilizado para armazenar os dados de microarray one-color normalizados das amostras referentes a todas as condições experimentais, de modo que cada amostra está representada em uma coluna do arquivo. Adicionalmente, cada instância do serviço AS1 recebe como entrada dois parâmetros especificando o conjunto de amostras (colunas) associado a cada uma das condições experimentais, respectivamente. A primeira instância do serviço ASl particiona os dados normalizados de acordo com as condições experimentais ISOL e BIC. A segunda instância serviço particiona os dados normalizados de acordo com as condições experimentais ISOL e BANIC. A terceira instância serviço particiona os dados normalizados de acordo com as condições experimentais ISOL e BINIC. Cada instância do serviço AS1 produz como saída dois arquivos multi-colunas contendo os dados de microarray normalizados, particionados de acordo com as condições experimentais especificadas. 


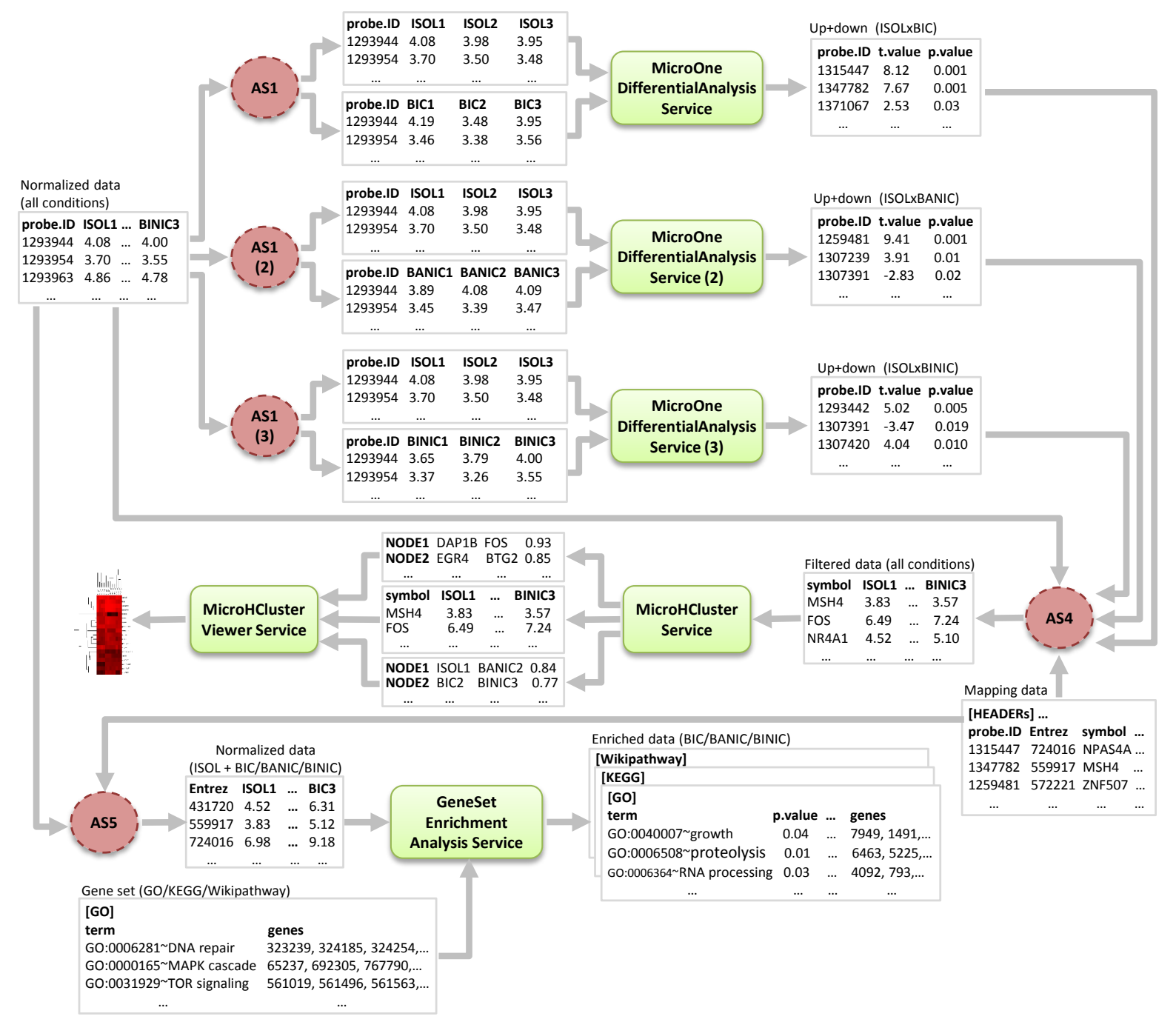

Figura 62: Execução do cenário de análise de dados de microarray Affymetrix.

Na sequência, as instâncias 1, 2 e 3 do serviço MicroOneDifferentialAnalysis recebem como entrada os dois arquivos produzidos pelas instâncias 1, 2 e 3 do serviço $A S 1$, respectivamente. Adicionalmente, todas as instâncias do serviço MicroOneDifferentialAnalysis recebem como entrada três parâmetros adicionais: valor limiar de corte $(1,1)$, nível de significância do teste $(0,05)$ e método de correção de múltiplos testes (none). Cada instância do serviço MicroOneDifferentialAnalysis realiza então a seleção dos transcritos diferencialmente expressos entre as condições experimentais fornecidas como entrada: ISOL e BIC/BANIC/BINIC. Como resultado, cada instância do serviço MicroOneDifferentialAnalysis produz uma lista de identificadores de transcritos diferencialmente expressos. 
O serviço AS4 então recebe como entrada os dados normalizados e as listas produzidas pelas três instâncias do serviço MicroOneDifferentialAnalysis. O serviço AS4 filtra os dados normalizados, selecionando apenas os transcritos diferencialmente expressos com base nas listas fornecidas e converte os identificadores de transcritos Affymetrix contidos nos dados normalizados para os respectivos símbolos de genes. Esta conversão é realizada pelo serviço com base em um arquivo de mapeamento também fornecido como entrada. Este arquivo de mapeamento foi obtido a partir da base de dados Gene Expression Omnibus (GEO), disponível sob número de acesso GPL20312. O serviço AS4 produz como saída um arquivo multi-colunas contendo apenas os valores de expressão normalizados dos genes diferencialmente expressos nas amostras referentes a todas as condições experimentais, de modo que cada amostra está representada em uma coluna do arquivo.

A seguir, o serviço MicroHCluster recebe como entrada o arquivo produzido pelo serviço AS4 e dois parâmetros adicionais: método de agrupamento (pairwise average-linkage) e métrica de similaridade (city-block distance). O serviço MicroHCluster realiza então o agrupamento hierárquico dos dados e produz como resultado três arquivos, utilizados para armazenar a hierarquia de amostras, a hierarquia de genes e os dados originais com as linhas e colunas reordenadas de acordo com o resultado do agrupamento, respectivamente. O serviço MicroHClusterViewer recebe como entrada os três arquivos produzidos pelo serviço MicroHCluster e produz então um dendrograma de amostras e genes a partir dos dados fornecidos.

Em uma análise paralela, o serviço AS5 recebe como entrada o arquivo multi-colunas utilizado para armazenar os dados de microarray normalizados das amostras referentes a todas as condições experimentais, de modo que cada amostra está representada em uma coluna do arquivo. Este serviço também recebe como entrada um parâmetro especificando o conjunto de amostras (colunas) de interesse que devem ser filtrados nos dados. O serviço AS5 então filtra apenas as amostras de interesse nos dados normalizados e converte os identificadores de transcritos Affymetrix contidos nos dados para os respectivos identificadores de genes da base de dados Entrez. Esta conversão é realizada pelo serviço com base em um arquivo de mapeamento também fornecido como entrada. O serviço AS5 recebe como entrada o mesmo arquivo de mapeamento previamente fornecido como entrada para o serviço $A S 4$. O serviço AS5 produz como saída um arquivo multi-colunas contendo os valores de expressão normalizados dos genes ape- 
nas nas amostras de interesse, de modo que cada amostra está representada em uma coluna do arquivo. O serviço AS5 é executado três vezes de modo a filtrar diferentes conjuntos de dados, selecionados a cada execução do serviço: (i) ISOL e BIC; (ii) ISOL e BANIC; e (iii) ISOL e BINIC.

A cada execução do serviço AS5, o serviço GeneSetEnrichmentAnalysis recebe como entrada o arquivo produzido pelo serviço AS5 e dois parâmetros adicionais: design do experimento (unpaired) e um valor booleano (true) indicando que o método de correção de múltiplos testes False Discovery Rate (FDR) [103] deve ser aplicado. Adicionalmente, o serviço GeneSetEnrichmentAnalysis requer como entrada um arquivo utilizado para armazenar os conjuntos de genes associados a diferentes processos/vias biológicos. De modo a reproduzir o estudo base, realizamos a análise de enriquecimento funcional no serviço GeneSetEnrichmentAnalysis considerando cinco arquivos distintos, os quais incluem os conjuntos de genes das três categorias da ontologia GO e das bases de dados KEGG e WikiPathways. Neste sentido, a cada execução do serviço AS5, o serviço GeneSetEnrichmentAnalysis é executado cinco vezes, uma para cada arquivo de conjunto de genes fornecido.

\subsubsection{Análise Comparativa dos Grupos BIC, BANIC e BINIC}

$\mathrm{Na}$ análise de expressão diferencial realizada entre as amostras dos grupos BIC e ISOL, o serviço MicroOneDifferentialAnalysis identificou um conjunto de 8 genes diferencialmente expressos, compreendendo todos os genes identificados no estudo original. Todos os genes também estavam induzidos nas amostras do grupo BIC. Na análise comparativa entre as amostras dos grupos BANIC e ISOL, o serviço MicroOneDifferentialAnalysis identificou um conjunto de 12 genes diferencialmente expressos. Este conjunto compreende os 4 genes reprimidos previamente identificados no estudo original, os 7 genes induzidos previamente identificados no estudo original e um gene adicional ( $P C D H 2 A B 6)$, o qual estava reprimido nas amostras do grupo BANIC. Na análise comparativa entre as amostras dos grupos BINIC e ISOL, o serviço MicroOneDifferentialAnalysis identificou um conjunto de 6 genes diferencialmente expressos. Este conjunto compreende os 3 genes induzidos previamente identificados no estudo original e 
três genes adicionais: PCDH2AB6, PCDH2G5 e UGT5C2. O gene PCDH2G5 estava induzido e os genes PCDH2AB6 e UGT5C2 estavam reprimidos nas amostras do grupo BINIC.

Resultados similares ao estudo original também foram obtidos em relação aos genes diferencialmente expressos identificados em comum entre as amostras do grupo BANIC e dos grupos BIC e BINIC. Os 4 genes induzidos em comum nas amostras dos grupos BANIC e BIC, bem como os 2 genes induzidos em comum nas amostras dos grupos BANIC e BINIC também foram identificados pelo serviço MicroOneDifferentialAnalysis. Além disto, o gene PCDH2AB6 adicionalmente identificado pelo serviço apresentou-se reprimido tanto nas amostras do grupo BANIC quanto nas amostras do grupo BINIC.

A Figura 63 apresenta um diagrama de Venn representando, de forma resumida, os resultados obtidos na análise diferencial dos perfis de expressão das amostras dos grupos BIC, BANIC e BINIC.

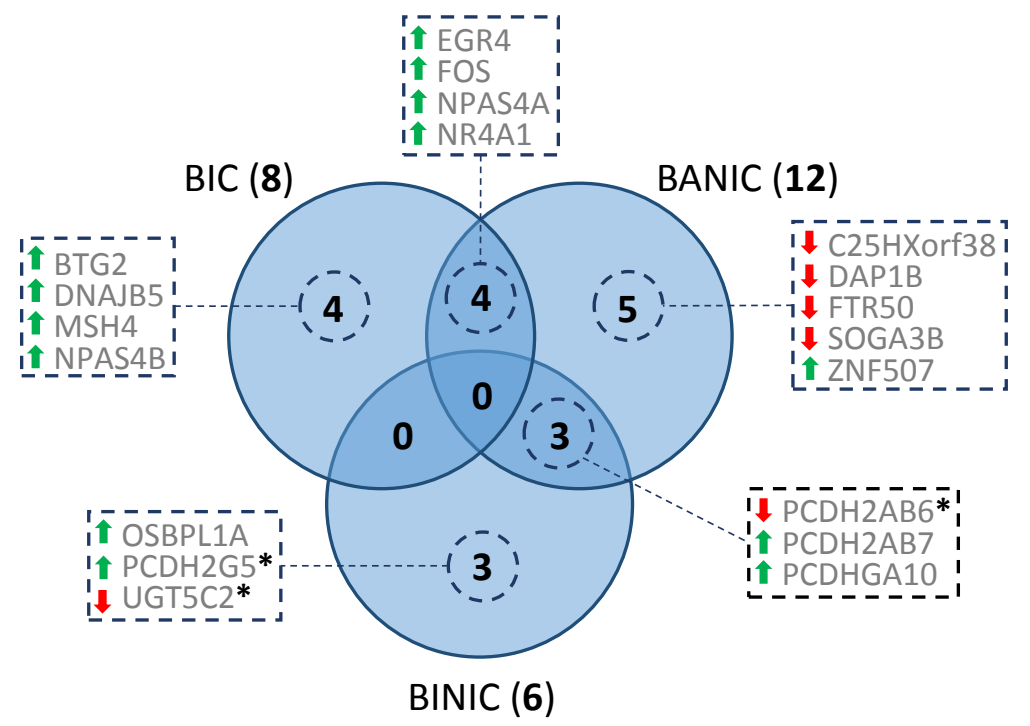

Figura 63: Genes diferencialmente expressos entre amostras dos grupos BIC, BANIC e BINIC. As setas para cima e para baixo indicam genes induzidos e reprimidos, respectivamente. Os asteriscos indicam genes adicionais identificados em relação ao estudo original.

O serviço MicroOneDifferentialAnalysis identificou todos os genes diferencialmente expressos previamente identificados no estudo original. Além disto, o serviço identificou um conjunto adicional de genes, cuja relevância precisa ainda ser investigada. Contudo, a realização de investigações adicionais está fora do escopo deste trabalho. As diferenças nos resultados podem ser explicadas pelo uso de métodos estatísticos distintos. No serviço MicroOneDifferentialAnalysis, 
a identificação de genes diferencialmente expressos foi realizada por meio do teste t de Student. Em contraste, no estudo original, os genes diferencialmente expressos foram identificados com o uso de um modelo linear e do método empírico de Bayes no pacote $\mathrm{R}$ "limma” [82]. O método utilizado no estudo original possui, em geral, um maior poder de detecção de diferenças de expressão em comparação ao teste t de Student [373]. Contudo, para este conjunto de dados específico, o teste t de Student identificou um conjunto maior de genes.

Após a identificação de genes diferencialmente expressos no serviço MicroOneDifferentialAnalysis, todos os genes identificados nos três grupos testados foram conjuntamente submetidos a uma análise de agrupamento hierárquico por meio do serviço MicroHCluster. Após a realização do agrupamento hierárquico dos dados, o serviço MicroHClusterViewer foi utilizado para visualizar os resultados do agrupamento. A Figura 64 ilustra o agrupamento hierárquico dos genes diferencialmente expressos nas amostras dos grupos ISOL, BIC, BANIC, BINIC.

De forma semelhante aos resultados obtidos no estudo original, na análise de agrupamento hierárquico realizada pelo serviço MicroHCluster, as amostras dos grupos ISOL e BINIC foram isoladamente agrupadas e as amostras dos grupos BIC e BANIC foram conjuntamente agrupadas. Contudo, as amostras do grupo BINIC apresentaram-se mais similares às amostras dos grupos BIC e BANIC, do que do grupo ISOL. Finalmente, o serviço MicroHCluster identificou um conjunto de 8 genes com um perfil de expressão similar, compreendendo os mesmos genes identificados no estudo original: BTG2, DNAJB5, EGR4, FOS, MSH4, NPAS4A, NPAS4B e NR4A1. Todos estes genes foram induzidos no grupo BIC. Os resultados obtidos na análise de agrupamento realizada pelo serviço MicroHCluster diferem ligeiramente dos resultados obtidos no estudo original uma vez que os genes diferencialmente expressos submetidos à análise pelo serviço incluem alguns genes adicionais em relação ao estudo original.

Para a realização da análise de enriquecimento funcional de grupos de genes entre as amostras dos grupos ISOL e BIC/BANIC/BINIC, o serviço de adaptação AS5 realizou inicialmente o mapeamento dos identificadores de transcritos Affymetrix contidos nos dados normalizados para os respectivos identificadores de genes da base de dados Entrez. Os identificadores de transcritos foram mapeados para um total de 21.065 identificadores exclusivos de genes, os quais foram então submetidos à análise de enriquecimento pelo serviço GeneSetEnrichmentAnalysis. 


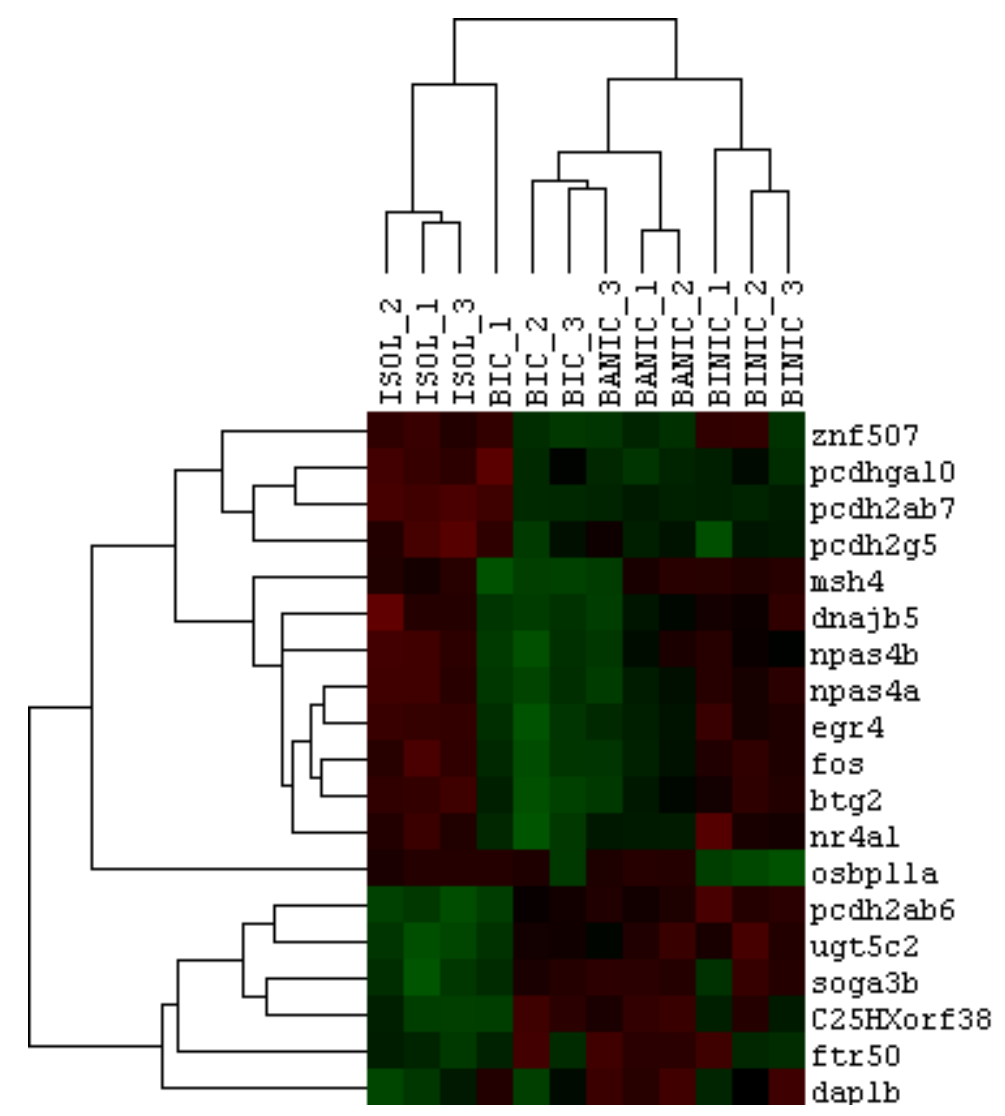

Figura 64: Agrupamento hierárquico dos genes diferencialmente expressos nas amostras dos grupos ISOL, BIC, BANIC, BINIC. As linhas apresentam o agrupamento dos genes e as colunas apresentam o agrupamento das amostras. Os níveis de expressão normalizados dos genes nas diferentes amostras são representados em verde (genes induzidos) e vermelho (genes reprimidos).

$\mathrm{Na}$ análise de enriquecimento funcional realizada entre as amostras dos grupos BIC e ISOL, o serviço GeneSetEnrichmentAnalysis identificou grupos de genes diferencialmente expressos associados a diferentes processos biológicos, componentes celulares e funções moleculares da ontologia GO, bem como a diferentes vias biológicas das bases de dados KEGG e Wikipathways. A Figura 65 apresenta a proporção de genes diferencialmente expressos no grupo BIC que foram identificados nas categorias da ontologia GO e vias biológicas KEGG e Wikipathways consideradas relevantes.

De forma semelhante aos resultados obtidos no estudo original, o serviço GeneSetEnrichmentAnalysis identificou genes diferencialmente expressos nas amostras do grupo BIC associados em maior proporção aos processos biológicos de transcrição $(2,0 \%)$, metabolismo de lipídios $(2,0 \%)$ e transdução de sinal mediada por GTPases $(1,8 \%)$, às funções moleculares de fator de 


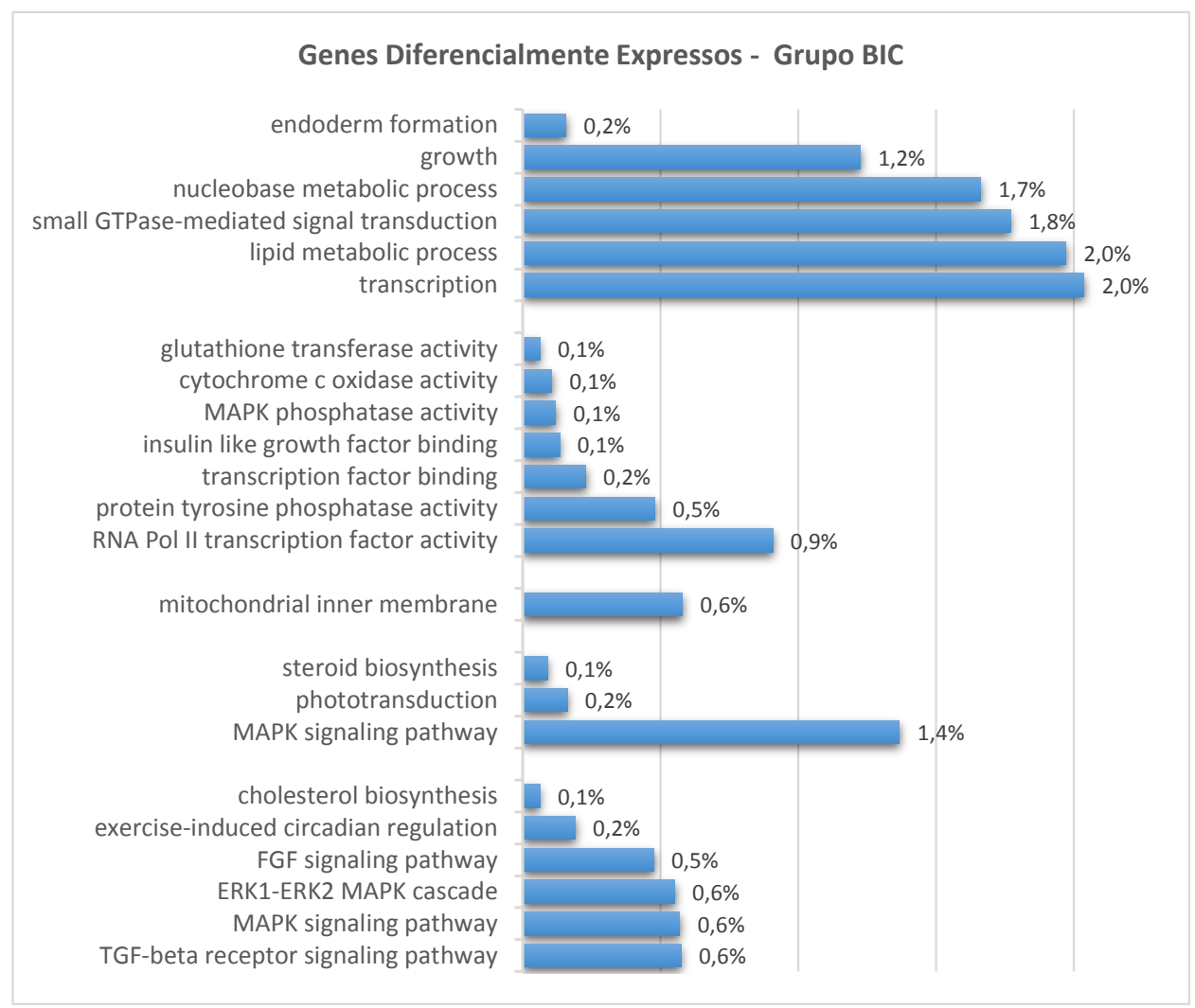

Figura 65: Proporção de genes diferencialmente expressos no grupo BIC identificados nas categorias da ontologia GO e vias biológicas. Os agrupamentos indicam, de cima para baixo, as categorias GO "processos biológicos", "funções moleculares", "componentes celulares" e as vias biológicas KEGG e Wikipathways.

transcrição $(0,9 \%)$ e de proteína tirosina fosfatase $(0,5 \%)$, bem como a componentes celulares da membrana mitocondrial (0,6\%). A análise de enriquecimento no serviço GeneSetEnrichmentAnalysis também revelou grupos de genes associados em diferentes proporções às vias KEGG de sinalização MAPK $(1,4 \%)$ e fototransdução $(0,2 \%)$, bem como às vias Wikipathways de sinalização FGF $(0,5 \%)$ e biossíntese de colesterol (0,1\%), entre outras.

$\mathrm{Na}$ análise de enriquecimento funcional realizada entre as amostras dos grupos BANIC e ISOL, o serviço GeneSetEnrichmentAnalysis identificou grupos de genes diferencialmente expressos associados a diferentes processos biológicos e funções moleculares da ontologia GO, bem como a diferentes vias biológicas das bases de dados KEGG e Wikipathways. A Figura 66 apresenta a proporção de genes diferencialmente expressos no grupo BANIC que foram identificados nas categorias da ontologia GO e vias biológicas KEGG e Wikipathways consideradas relevantes. 


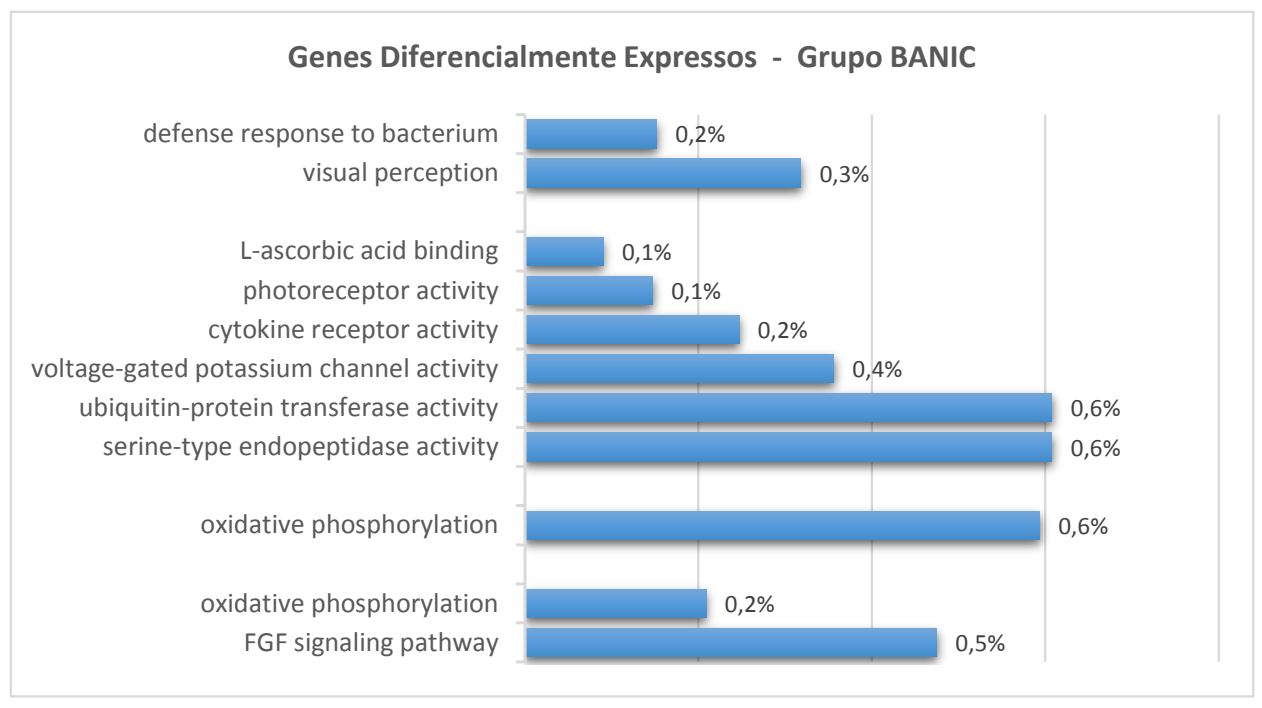

Figura 66: Proporção de genes diferencialmente expressos no grupo BANIC identificados nas categorias da ontologia GO e vias biológicas. Os agrupamentos indicam, de cima para baixo, as categorias GO "processos biológicos", "funções moleculares" e as vias biológicas KEGG e Wikipathways.

De forma semelhante aos resultados obtidos no estudo original, o serviço GeneSetEnrichmentAnalysis identificou genes diferencialmente expressos nas amostras do grupo BANIC associados em diferentes proporções aos processos biológicos de percepção visual (0,3\%) e resposta de defesa a bactérias $(0,2 \%)$, bem como às funções moleculares de endopeptidase $(0,6 \%)$, transferase $(0,6 \%)$ e receptor de citocina $(0,2 \%)$. A análise de enriquecimento no serviço GeneSetEnrichmentAnalysis também revelou grupos de genes associados à via KEGG de fosforilação oxidativa $(0,6 \%)$ e à via Wikipathways de sinalização FGF $(0,5 \%)$.

$\mathrm{Na}$ análise de enriquecimento funcional realizada entre as amostras dos grupos BINIC e ISOL, o serviço GeneSetEnrichmentAnalysis identificou grupos de genes diferencialmente expressos associados a diferentes processos biológicos e funções moleculares da ontologia GO, bem como a diferentes vias biológicas das bases de dados KEGG e Wikipathways. A Figura 67 apresenta a proporção de genes diferencialmente expressos no grupo BINIC que foram identificados nas categorias da ontologia GO e vias biológicas KEGG e Wikipathways consideradas relevantes.

De forma semelhante aos resultados obtidos no estudo original, o serviço GeneSetEnrichmentAnalysis identificou genes diferencialmente expressos nas amostras do grupo BINIC asso- 


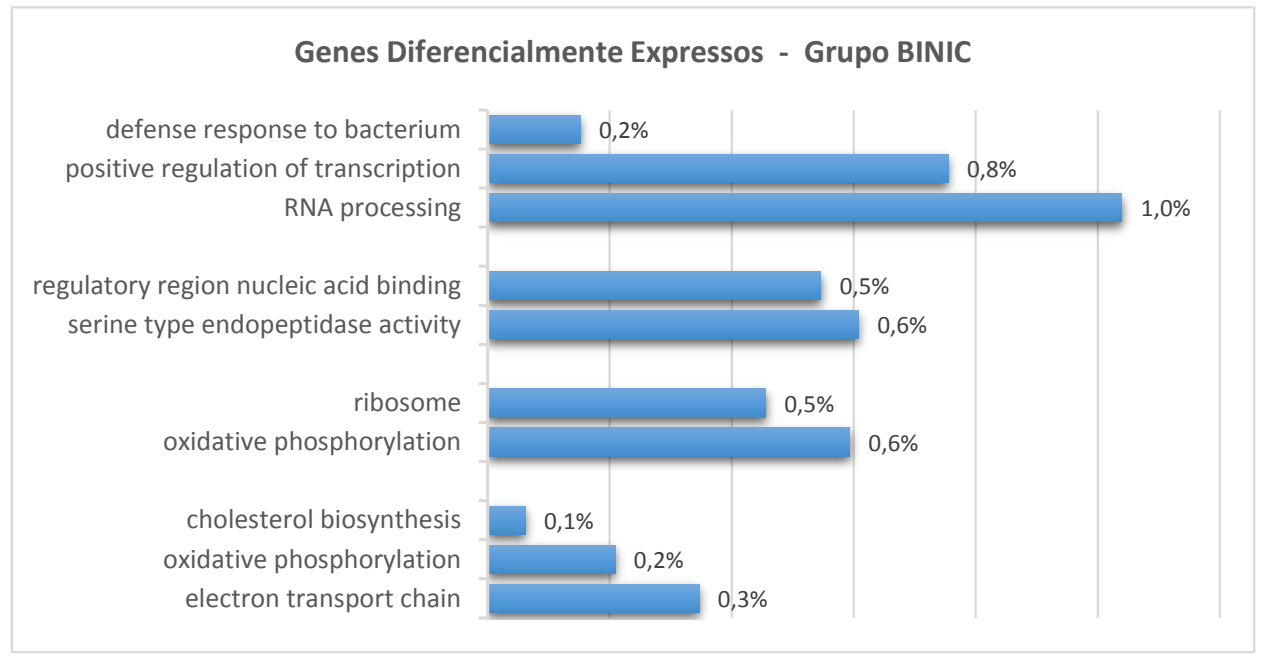

Figura 67: Proporção de genes diferencialmente expressos no grupo BINIC identificados nas categorias da ontologia GO e vias biológicas. Os agrupamentos indicam, de cima para baixo, as categorias GO "processos biológicos", "funções moleculares" e as vias biológicas KEGG e Wikipathways.

ciados em diferentes proporções aos processos biológicos de processamento de RNA $(1,0 \%)$, regulação positiva de transcrição $(0,8 \%)$ e resposta de defesa a bactérias $(0,2 \%)$, bem como às funções moleculares de endopeptidase $(0,6 \%)$ e de ligação à região regulatória do DNA $(0,5 \%)$. A análise de enriquecimento no serviço GeneSetEnrichmentAnalysis também revelou grupos de genes associados às vias KEGG de fosforilação oxidativa $(0,6 \%)$ e de ribossomos $(0,5 \%)$, bem como às vias Wikipathways de cadeia de transporte de elétrons $(0,3 \%)$ e de biossíntese de colesterol $(0,1 \%)$.

Nas análises de enriquecimento funcional realizadas entre as amostras do grupo ISOL e as amostras dos grupos BIC, BANIC e BINIC, os valores absolutos de genes identificados pelo serviço GeneSetEnrichmentAnalysis em cada processo/via biológico diferem dos valores obtidos no estudo original uma vez que os genes submetidos à análise pelo serviço, compreendendo um total de 21.065 genes, incluem apenas um subconjunto dos genes submetidos à mesma análise no estudo original (21.224). A diferença na quantidade de genes submetidos à análise deve-se ao uso de diferentes arquivos de mapeamento para a realização da conversão dos identificadores de transcritos Affymetrix para os respectivos identificadores de genes Entrez. No estudo original, o mapeamento foi realizado com base em informações das bases de dados Bioconductor, 
NCBI e biomart. Neste trabalho, o arquivo de mapeamento foi obtido a partir da base de dados GEO.

\subsection{ANÁLISE DE DADOS DE RNA-SEQ ILLUMINA}

O terceiro estudo de caso foi definido para a análise de dados de RNA-Seq provenientes da plataforma de sequenciamento Illumina HiSeq 2500. As seções a seguir apresentam o estudo utilizado como base para a definição do cenário de composição, a criação do cenário na plataforma SemanticSCo, a execução detalhada do cenário e, finalmente, os resultados obtidos a partir da sua execução.

\subsubsection{Estudo Base}

O terceiro cenário de composição definido na plataforma SemanticSCo foi utilizado para a análise de um conjunto de dados de RNA-Seq disponível na base de dados Gene Expression Omnibus (GEO), sob número de acesso GSE61966. Este conjunto de dados foi obtido a partir de amostras de melanócitos tumorais da linhagem 501Mel e melanócitos normais imortalizados da linhagem Hermes 3A, obtidas em condições experimentais distintas: supressão si/shRNA do gene Brahma-related gene-1 (BRG1), supressão si/shRNA do gene microphthalmia-associated transcription factor (MITF) e não-supressão dos genes BRG1/MITF (controle) [380].

Um dos objetivos do estudo base foi investigar os efeitos do fator de transcrição MITF e do remodelador de cromatina BRG1 nos perfis de expressão dos melanócitos. De modo a atingir este objetivo, duas análises comparativas foram separadamente realizadas entre conjuntos de dados distintos. Na primeira parte do estudo, foi realizada a análise comparativa apenas dos perfis de expressão gênica dos melanócitos tumorais nas três condições experimentais. $\mathrm{Na}$ segunda parte do estudo, foi realizada a análise comparativa apenas dos perfis de expressão gênica dos melanócitos normais nas três condições experimentais.

As mesmas atividades e ferramentas de análise foram utilizadas para a realização das duas partes do estudo base. Inicialmente, dois grupos de dados de RNA-Seq distintos foram sepa-

radamente submetidos à análise de expressão diferencial $\left(\log _{2}(\right.$ fold-change $)>1,0$; valor- 
$p<0,05)$. O primeiro grupo analisado, chamado de shBRG1, consiste nas amostras obtidas a partir de melanócitos com supressão do gene BRG1 e melanócitos de controle. O segundo grupo analisado, chamado de shMITF, consiste nas amostras obtidas a partir de melanócitos com supressão do gene MITF e melanócitos de controle. Em seguida, os genes que encontravam-se induzidos e reprimidos em comum nos grupos shBRG1 e shMITF foram identificados. Finalmente, os genes induzidos e reprimidos encontrados em comum (grupo shBRG1-shMITF) foram separadamente submetidos a uma análise de enriquecimento funcional na versão web da ferramenta de software DAVID (https://david.ncifcrf.gov/). Estas análises foram realizadas considerando-se apenas a categoria "processos biológicos” da ontologia GO.

No estudo realizado para investigar os perfis de expressão gênica dos melanócitos tumorais, a análise diferencial do grupo shBRG1 identificou um conjunto de 9.516 genes diferencialmente expressos. Deste conjunto de genes, 4.089 estavam reprimidos e 5.427 estavam induzidos nos melanócitos com supressão do gene BRG1. A análise diferencial do grupo shMITF identificou um conjunto de 1.348 genes diferencialmente expressos, dos quais 601 estavam reprimidos e 747 estavam induzidos nos melanócitos com supressão do gene MITF. Do conjunto de genes diferencialmente expressos identificado no grupo shMITF, 361 genes $(60,1 \%)$ encontravam-se reprimidos e 269 genes (36\%) induzidos também no grupo shBRG1.

Dentre os genes induzidos no grupo shMITF, um conjunto de 21 genes potencialmente responsáveis pelo fenótipo Senescence-Associated Secretory Phenotype (SASP) foi identificado, incluindo os genes BDNF, CCL2, CTGF, CYR61, DKK1, FGF1, IL10, IL11, IL16, IL24, IL8, LIF, NOV, PDGFA, PDGFB, PDGFC, PDGFD, SERPINB2, SERPINE1, TDGF1 e VEGFC. Dentre estes 21 genes, 14 também encontravam-se induzidos no grupo shBRG1: BDNF, CTGF, CYR61, DKK1, FGF1, IL24, IL8, LIF, PDGFA, PDGFB, PDGFC, SERPINB2, SERPINE1 e VEGFC. Com base nestes resultados, os autores concluem que a supressão dos genes BRG1/MITF de fato induz a senescência dos melanócitos tumorais.

A análise de enriquecimento funcional dos genes diferencialmente expressos revelou que os genes reprimidos nos melanócitos tumorais do grupo shBRG1-shMITF estavam associados em diferentes proporções aos processos biológicos de sinalização intracelular (12,3\%), regulação de transcrição $(5,1 \%)$, divisão celular $(4,8 \%)$, fissão de organelas $(3,8 \%)$, mitose $(3,8 \%)$ e plasticidade sináptica $(2,1 \%)$. Adicionalmente, os genes induzidos nos melanócitos tumo- 
rais do grupo shBRG1-shMITF foram associados aos processos biológicos de adesão celular $(10,8 \%)$, regulação de proliferação celular $(10,8 \%)$, organização de projeção celular $(7,1 \%)$, morfogênese celular $(6,6 \%)$, angiogênese $(5,7 \%)$ e migração celular $(5,7 \%)$.

No estudo realizado para investigar os perfis de expressão gênica dos melanócitos normais, a análise diferencial do grupo shBRG1 identificou um conjunto de 1.558 genes diferencialmente expressos. Deste conjunto de genes, 587 estavam reprimidos e 971 estavam induzidos nos melanócitos com supressão do gene BRG1. A análise diferencial do grupo shMITF identificou um conjunto de 1.421 genes diferencialmente expressos, dos quais 757 estavam reprimidos e 664 estavam induzidos nos melanócitos com supressão do gene MITF. Do conjunto de genes diferencialmente expressos identificado no grupo shBRG1, 226 genes $(38,5 \%)$ encontravam-se reprimidos e 249 genes $(25,6 \%)$ induzidos também no grupo shMITF.

A análise de enriquecimento funcional dos genes diferencialmente expressos revelou que os genes reprimidos nos melanócitos normais do grupo shBRG1-shMITF estavam associados em diferentes proporções aos processos biológicos de sinalização intracelular (10, 6\%), adesão celular $(7,4 \%)$, fosforilação $(6,7 \%)$, regulação de apoptose $(4,5 \%)$, regulação de morfogênese celular $(2,4 \%)$ e oligomerização de proteínas $(2,2 \%)$. Finalmente, os genes induzidos nos melanócitos normais do grupo shBRG1-shMITF foram associados aos processos biológicos de regulação de proliferação celular $(11,1 \%)$, regulação de transcrição $(9,0 \%)$, sinalização celular $(8,4 \%)$, resposta a estímulos endógenos $(6,3 \%)$, desenvolvimento vascular $(5,7 \%)$ e regulação de moção celular $(4,6 \%)$.

\subsubsection{Definição do Cenário na Plataforma SemanticSCo}

O terceiro cenário de composição foi definido para a análise integrada de dados de RNA-Seq produzidos por meio da plataforma de sequenciamento Illumina. A Figura 68 destaca as principais etapas realizadas na plataforma SemanticSCo para a criação deste cenário de composição.

Na primeira etapa, selecionamos o conjunto de arquivos utilizados para armazenar as tabelas de contagens de genes de RNA-Seq associadas ao grupo shBRG1, ou seja, referentes às amostras com supressão do gene BRG1 e às amostras de controle. Selecionamos então o conceito RNA-Seq count data table para especificar a semântica dos dados selecionados. Após a inclu- 


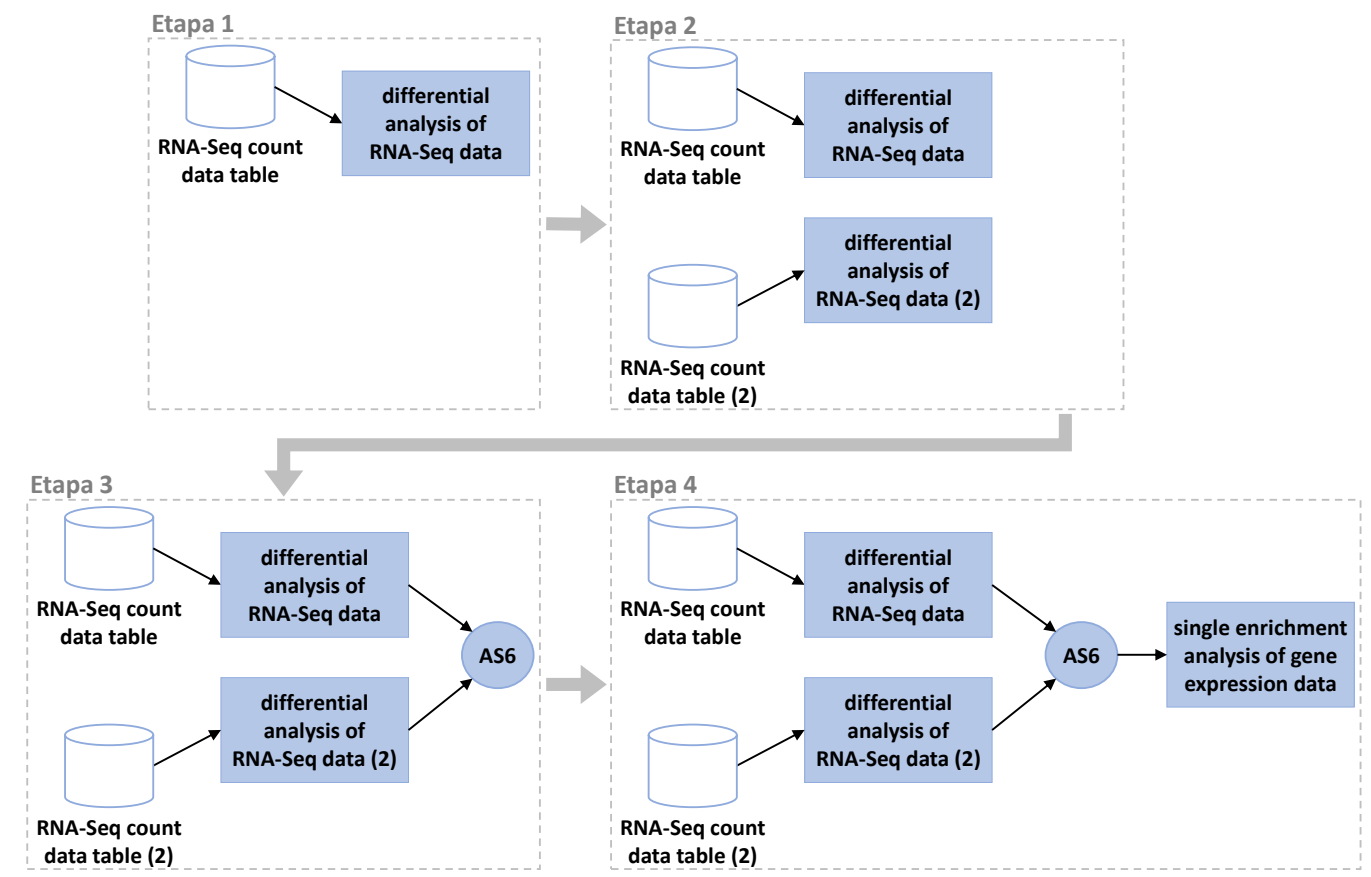

Figura 68: Criação do cenário de composição para a análise de dados de RNA-Seq na plataforma SemanticSCo.

são dos dados na plataforma, selecionamos o serviço RnaSeqDifferentialAnalysis para realizar a atividade de análise differential analysis of RNA-Seq data. Em seguida, associamos os dados do grupo shBRG1 previamente incluídos na plataforma à entrada do serviço RnaSeqDifferentialAnalysis.

Na segunda etapa, selecionamos o conjunto de arquivos utilizados para armazenar as tabelas de contagens de genes de RNA-Seq associadas ao grupo shMITF, que compreende as amostras com supressão do gene BRG1 e as amostras de controle. Selecionamos novamente o conceito RNA-Seq count data table (2) para especificar a semântica dos dados selecionados. Após a inclusão dos dados na plataforma, selecionamos uma nova instância do serviço RnaSeqDifferentialAnalysis para realizar a atividade de análise differential analysis of RNA-Seq data (2). Em seguida, associamos os dados do grupo shMITF previamente incluídos na plataforma à entrada do serviço RnaSeqDifferentialAnalysis. Neste cenário, incluímos duas instâncias do serviço RnaSeqDifferentialAnalysis uma vez que os dados resultantes das análises realizadas pelas instâncias do serviço precisam ser concomitantemente fornecidos para as atividades de análise posteriores. 
$\mathrm{Na}$ terceira etapa, selecionamos o serviço de adaptação AS6 para processar as listas de identificadores de genes produzidas pelas duas instâncias do serviço RnaSeqDifferentialAnalysis de modo a extrair os genes reprimidos e induzidos em comum nas duas listas para dois conjuntos de dados independentes. Em seguida, associamos as saídas das duas instâncias do serviço RnaSeqDifferentialAnalysis às entradas correspondentes do serviço AS6.

Finalmente, na quarta etapa, selecionamos o serviço DAVID-REST para realizar a atividade de análise single enrichment analysis of gene expression data. Em seguida, associamos uma das saídas do serviço AS6 à entrada do serviço DAVID-REST.

No cenário definido, duas atividades de análise são realizadas na seguinte ordem: identificação de genes diferencialmente expressos e análise de enriquecimento funcional dos genes diferencialmente expressos para a identificação de um conjunto relevante de processos biológicos associados aos genes de interesse. Este mesmo cenário foi utilizado para reproduzir as duas partes do estudo base na plataforma SemanticSCo. A Figura 69 ilustra a estrutura final deste cenário de análise na plataforma SemanticSCo.

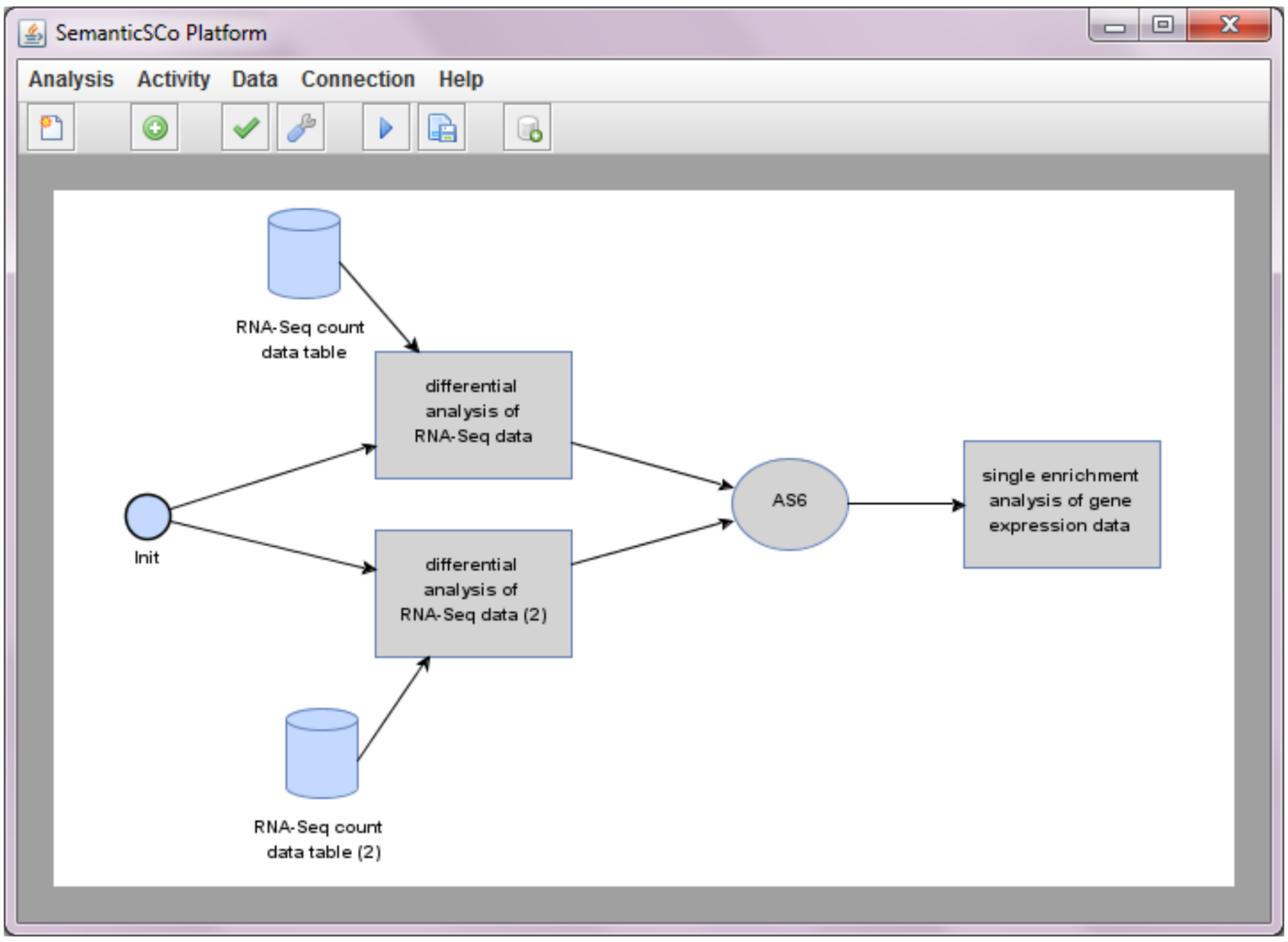

Figura 69: Cenário de composição para a análise de dados de RNA-Seq na plataforma SemanticSCo. 


\subsubsection{Execução do Cenário de Análise}

De modo a facilitar a compreensão do terceiro cenário de análise criado na plataforma SemanticSCo, a Figura 70 apresenta a sua execução para a realização da primeira parte do estudo base com foco no fluxo de dados entre os serviços. Um retângulo representa um arquivo de dados, enquanto um retângulo com as bordas arredondadas representa um serviço RESTful. Um círculo pontilhado representa um serviço de adaptação RESTful. Finalmente, as setas indicam o fluxo de dados e/ou controle.

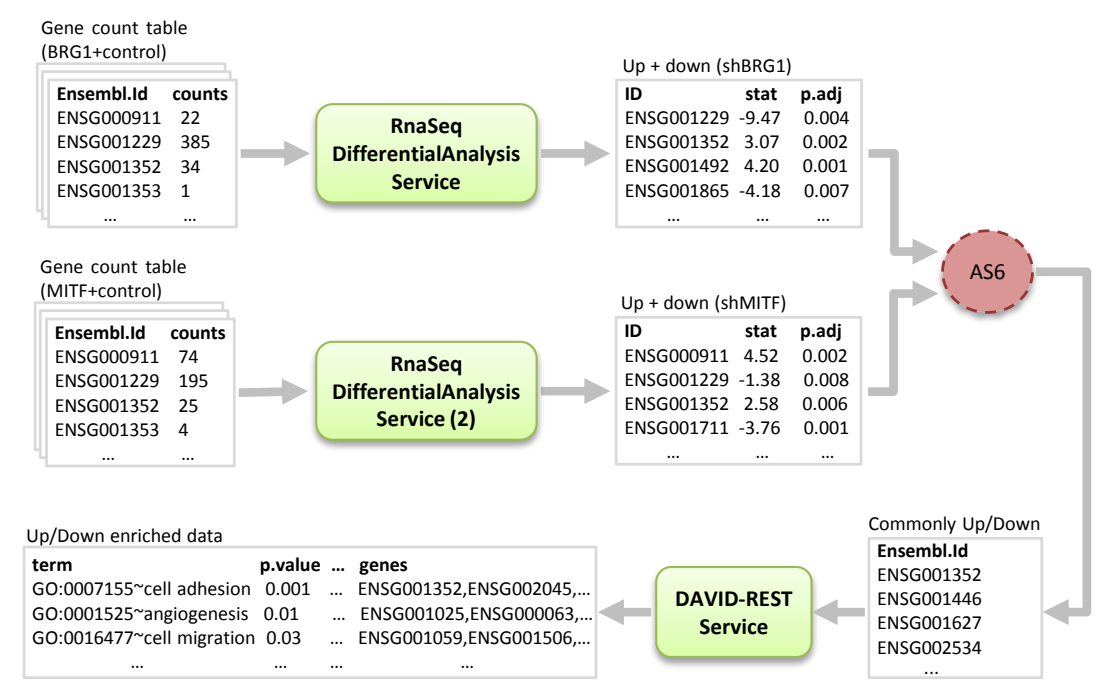

Figura 70: Execução do cenário de análise de dados de RNA-Seq.

Inicialmente, o serviço RnaSeqDifferentialAnalysis recebe como entrada diferentes arquivos utilizados para armazenar as tabelas de contagens de genes de RNA-Seq, cada uma representando uma amostra biológica distinta. Apenas as tabelas das amostras de melanócitos do grupo shBRG1 são fornecidas como entrada para o serviço RnaSeqDifferentialAnalysis. Adicionalmente, este serviço recebe três parâmetros adicionais: valor limiar de corte em escala logarítmica na base $2(1,0)$, nível de significância do teste $(0,05)$ e um valor booleano indicando que o método de correção de múltiplos testes False Discovery Rate (FDR) [103] deve ser aplicado. O serviço RnaSeqDifferentialAnalysis realiza então a seleção dos genes cujos valores de expressão tenham sido duas vezes (parâmetro) maiores/menores entre as amostras com supressão do gene BRG1 e de controle. Como resultado, este serviço produz uma lista de identificadores de genes diferencialmente expressos no grupo shBRG1. 
De forma análoga, a segunda instância do serviço RnaSeqDifferentialAnalysis recebe como entrada as tabelas de contagens de genes de RNA-Seq das amostras de melanócitos do grupo shMITF. Os mesmos valores de parâmetros são fornecidos como entrada. Como resultado, este serviço produz uma lista de identificadores de genes diferencialmente expressos no grupo shMITF.

Na sequência, o serviço AS6 recebe como entrada as listas de genes diferencialmente expressos produzidas pelas duas instâncias do serviço RnaSeqDifferentialAnalysis. O serviço AS6 então extrai os genes reprimidos e induzidos em comum nas duas listas para dois conjuntos de dados independentes. Como resultado, este serviço produz duas listas, cada uma representando genes induzidos e reprimidos em comum no grupo shBRG1-shMITF, respectivamente.

Finalmente, o serviço DAVID-REST é executado sequencialmente duas vezes de modo a processar cada uma das listas produzidas pelo serviço AS6 (genes induzidos e reprimidos) separadamente. Para cada execução, o serviço DAVID-REST recebe como entrada uma das listas produzidas pelo serviço AS6 e cinco parâmetros adicionais: endereço de email para autenticação, valor limiar de corte de sobre-representação (0.1), número mínimo de genes (2), tipo dos identificadores de genes fornecidos (ENSEMBL_GENE_ID) e categoria de anotação (GO_BP_FAT). O serviço DAVID-REST realiza o enriquecimento funcional dos genes armazenados na lista, ou seja, a identificação dos processos biológicos da ontologia GO mais relevantes associados aos genes de interesse.

\subsubsection{Análise Comparativa de Melanócitos Tumorais}

No estudo realizado para investigar os efeitos do fator de transcrição MITF e do remodelador de cromatina BRG1 nos perfis de expressão de melanócitos tumorais, o serviço RnaSeqDifferentialAnalysis identificou um conjunto de 8.730 genes diferencialmente expressos no grupo shBRG1. Deste conjunto de genes, 3.925 genes estavam reprimidos e 4.805 estavam induzidos nos melanócitos com supressão do gene BRG1. Na análise diferencial do grupo shMITF, o serviço RnaSeqDifferentialAnalysis identificou um conjunto de 1.294 genes diferencialmente expressos. Deste conjunto de genes, 539 genes estavam reprimidos e 755 estavam induzidos nos melanócitos com supressão do gene MITF. Do conjunto de genes diferencialmente expres- 
sos identificado no grupo shMITF, 337 genes $(62,5 \%)$ encontravam-se reprimidos e 284 genes $(37,6 \%)$ induzidos também no grupo shBRG1. A Figura 71 apresenta um diagrama de Venn representando, de forma resumida, os resultados obtidos na análise diferencial dos perfis de expressão de melanócitos tumorais.

\section{Melanócitos Tumorais}
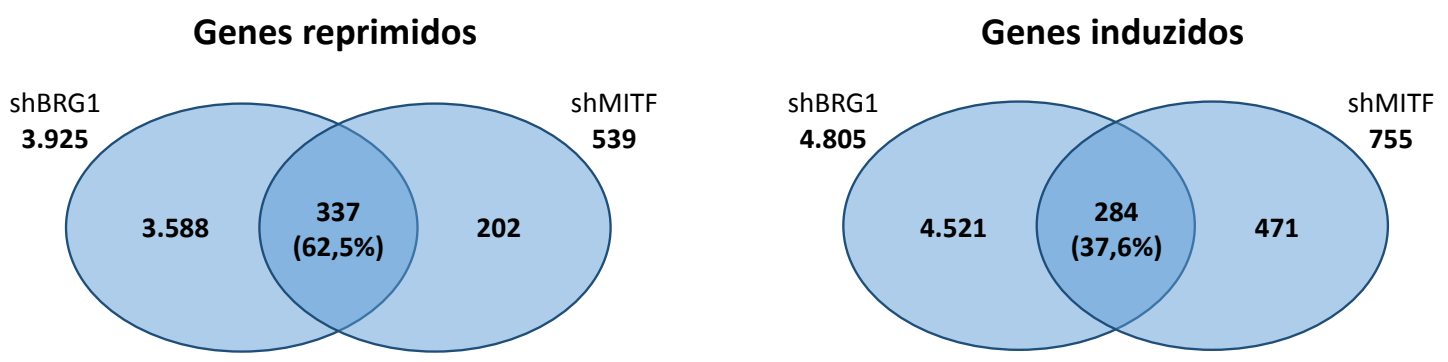

Figura 71: Genes diferencialmente expressos entre amostras de melanócitos tumorais.

Cerca de $90 \%$ dos genes diferencialmente expressos identificados no estudo original também foram identificados pelo serviço RnaSeqDifferentialAnalysis. Em relação ao grupo shBRG1, o serviço identificou $95,6 \%$ dos genes reprimidos e $88,1 \%$ dos genes induzidos previamente identificados no estudo original. Em relação ao grupo shMITF, o serviço identificou 85, 9\% dos genes reprimidos e $94,2 \%$ dos genes induzidos previamente identificados no estudo original. Resultados similares também foram obtidos em relação aos genes diferencialmente expressos identificados em comum entre os grupos shBRG1 e shMITF: $89,5 \%$ dos genes reprimidos e $96,3 \%$ dos genes induzidos previamente identificados no estudo original também foram identificados pelo serviço RnaSeqDifferentialAnalysis.

Estas diferenças nos resultados podem ser possivelmente explicadas pelo uso de métodos estatísticos distintos. No serviço RnaSeqDifferentialAnalysis, a identificação de genes diferencialmente expressos é realizada com o uso de um modelo baseado na distribuição binomial negativa. Contudo, informações sobre o método estatístico utilizado no estudo original não foram fornecidas.

O conjunto de 21 genes induzidos no grupo shMITF que foram associados ao fenótipo SASP no estudo original também foi identificado pelo serviço RnaSeqDifferentialAnalysis, com exceção do gene $N O V$. Deste conjunto, os 14 genes que também encontravam-se induzidos no 
grupo shBRG1 no estudo original foram também identificados pelo serviço RnaSeqDifferentialAnalysis.

Após a identificação dos genes que encontravam-se diferencialmente expressos em comum nos melanócitos tumorais dos grupos shBRG1 e shMITF, realizamos o enriquecimento funcional destes genes por meio do serviço DAVID-REST. Esta análise de enriquecimento funcional foi realizada considerando-se apenas a categoria "processos biológicos" da ontologia GO.

Em relação aos genes reprimidos no grupo shBRG1-shMITF, a análise de enriquecimento funcional revelou alterações na expressão de genes associados aos processos biológicos de sinalização celular, ciclo celular e mitose, entre outros. A Figura 72 apresenta a proporção de genes reprimidos que foram identificados nos processos biológicos da ontologia GO considerados relevantes.

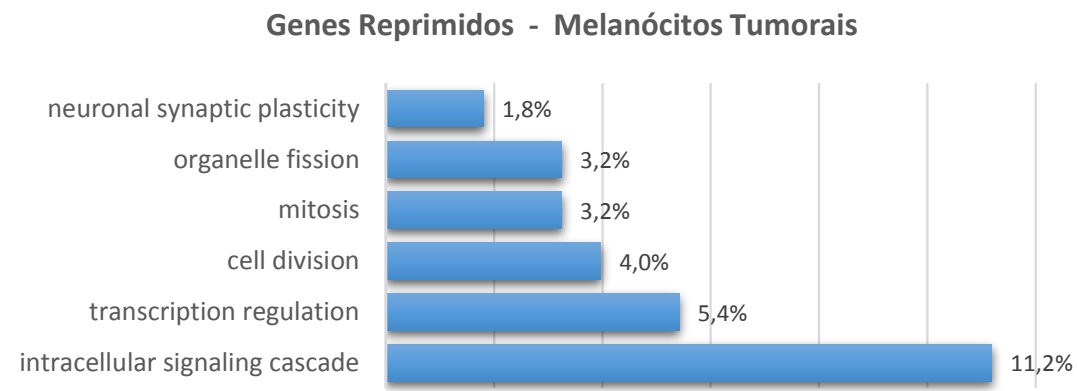

Figura 72: Proporção de genes reprimidos nos melanócitos tumorais identificados na categoria "processos biológicos" da ontologia GO.

O serviço DAVID-REST identificou que os genes reprimidos nos melanócitos tumorais estão associados em proporções similares aos mesmos processos biológicos considerados relevantes no estudo original. No entanto, os valores absolutos de genes identificados em cada processo biológico diferem ligeiramente dos valores obtidos no estudo original uma vez que os genes diferencialmente expressos submetidos à análise pelo serviço DAVID-REST incluem apenas um subconjunto dos genes diferencialmente expressos identificados no estudo original.

Em relação aos genes induzidos no grupo shBRG1-shMITF, a análise de enriquecimento funcional revelou alterações na expressão de genes associados aos processos biológicos de adesão celular, migração celular e angiogênese, entre outros. A Figura 73 apresenta a proporção de ge- 
nes induzidos que foram identificados nos processos biológicos da ontologia GO considerados relevantes.

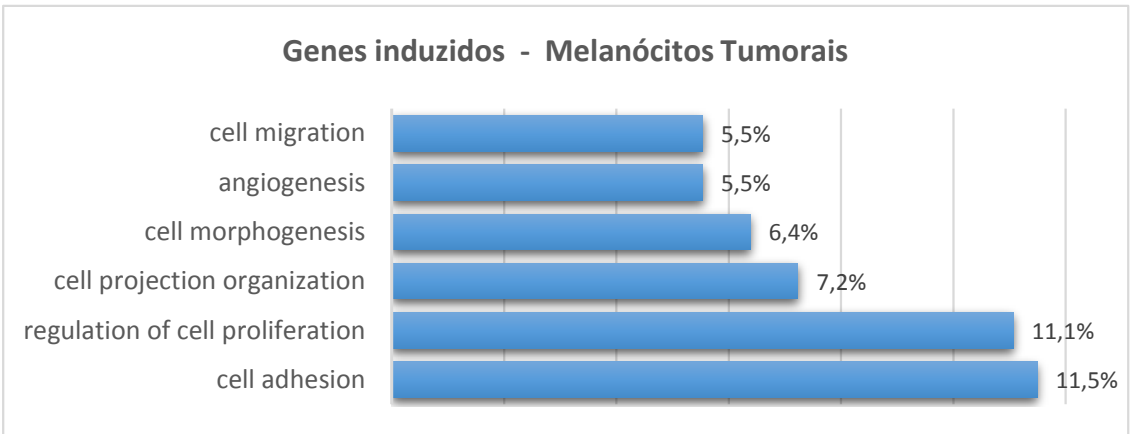

Figura 73: Proporção de genes induzidos nos melanócitos tumorais identificados na categoria "processos biológicos" da ontologia GO.

O serviço DAVID-REST identificou que os genes induzidos nos melanócitos tumorais estão associados em proporções similares aos mesmos processos biológicos considerados relevantes no estudo original. Contudo, de forma análoga aos resultados obtidos no enriquecimento funcional dos genes reprimidos, os valores absolutos dos genes induzidos que foram identificados em cada processo biológico diferem ligeiramente dos valores obtidos no estudo original.

\subsubsection{Análise Comparativa de Melanócitos Normais}

No estudo realizado para investigar os efeitos do fator de transcrição MITF e do remodelador de cromatina BRG1 nos perfis de expressão de melanócitos normais, o serviço RnaSeqDifferentialAnalysis identificou um conjunto de 1.129 genes diferencialmente expressos no grupo shBRG1. Deste conjunto de genes, 459 genes estavam reprimidos e 670 estavam induzidos nos melanócitos com supressão do gene BRG1. Na análise diferencial do grupo shMITF, o serviço RnaSeqDifferentialAnalysis identificou um conjunto de 887 genes diferencialmente expressos. Deste conjunto de genes, 531 genes estavam reprimidos e 356 estavam induzidos nos melanócitos com supressão do gene MITF. Do conjunto de genes diferencialmente expressos identificado no grupo shBRG1, 140 genes (30,5\%) encontravam-se reprimidos e 123 genes $(18,4 \%)$ induzidos também no grupo shMITF. A Figura 74 apresenta um diagrama de Venn 
representando, de forma resumida, os resultados obtidos na análise diferencial dos perfis de expressão de melanócitos normais.

\section{Melanócitos Normais}
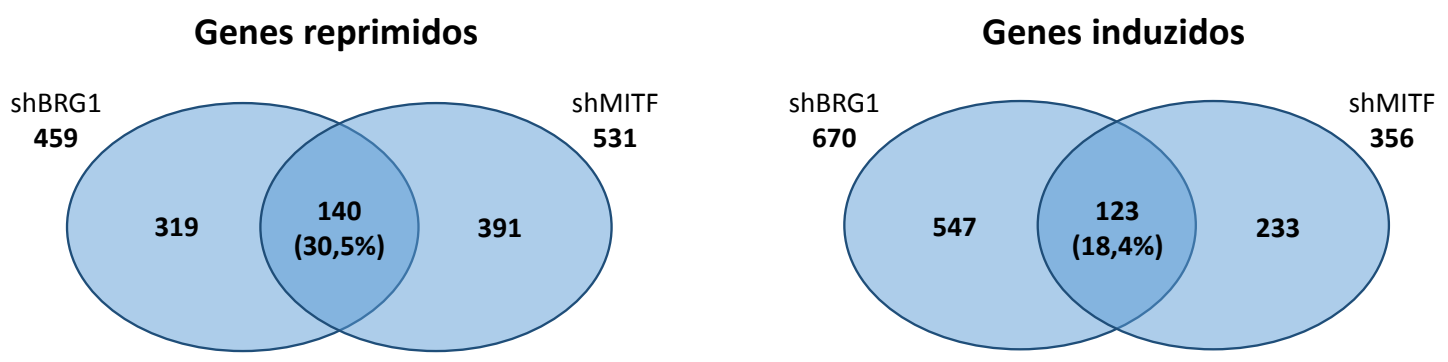

Figura 74: Genes diferencialmente expressos entre amostras de melanócitos normais.

Cerca de $63 \%$ dos genes diferencialmente expressos identificados no estudo original também foram identificados pelo serviço RnaSeqDifferentialAnalysis. Em relação ao grupo shBRG1, o serviço identificou $78,2 \%$ dos genes reprimidos e $69,0 \%$ dos genes induzidos previamente identificados no estudo original. Em relação ao grupo shMITF, o serviço identificou 56,7\% dos genes reprimidos e $48,0 \%$ dos genes induzidos previamente identificados no estudo original. Finalmente, em relação aos genes diferencialmente expressos identificados em comum entre os grupos shBRG1 e shMITF: $58,0 \%$ dos genes reprimidos e $48,2 \%$ dos genes induzidos previamente identificados no estudo original também foram identificados pelo serviço RnaSeqDifferentialAnalysis.

De forma análoga à análise comparativa dos melanócitos tumorais, as diferenças observadas nos resultados em relação ao estudo original podem também ser possivelmente explicadas pelo uso de métodos estatísticos distintos. No entanto, informações sobre o método estatístico utilizado no estudo original não foram fornecidas.

Após a identificação dos genes que encontravam-se diferencialmente expressos em comum nos melanócitos normais dos grupos shBRG1 e shMITF, realizamos o enriquecimento funcional destes genes por meio do serviço DAVID-REST. Esta análise de enriquecimento funcional foi realizada considerando-se apenas a categoria "processos biológicos" da ontologia GO.

Em relação aos genes reprimidos no grupo shBRG1-shMITF, a análise de enriquecimento funcional revelou alterações na expressão de genes associados aos processos biológicos de sinalização intracelular, adesão celular e regulação de morfogênese celular, entre outros. A Figura 
75 apresenta a proporção de genes reprimidos que foram identificados nos processos biológicos da ontologia GO considerados relevantes.

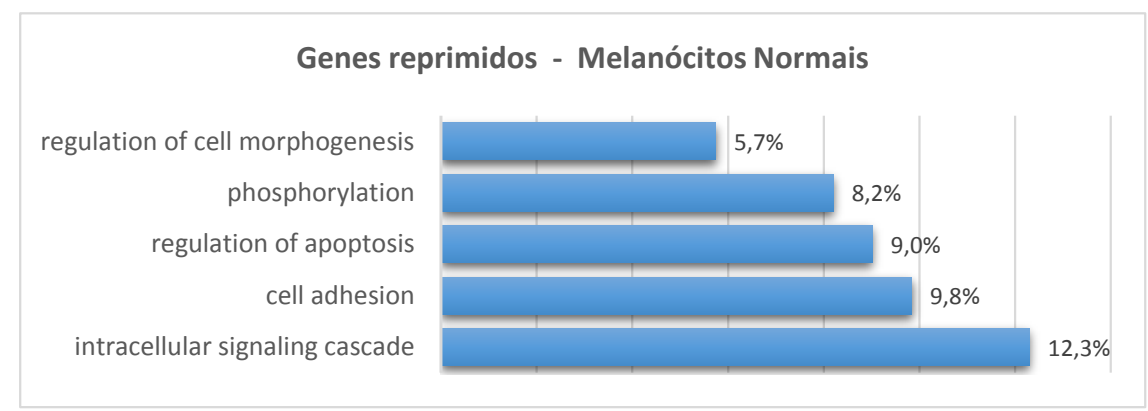

Figura 75: Proporção de genes reprimidos nos melanócitos normais identificados na categoria "processos biológicos" da ontologia GO.

De forma semelhante aos resultados obtidos no estudo original, o serviço DAVID-REST identificou que os genes reprimidos nos melanócitos normais estão associados em maior proporção aos processos biológicos de sinalização intracelular (12,3\%) e adesão celular (9,8\%). Apenas o processo biológico de oligomerização de proteínas identificado como relevante no estudo original não foi encontrado pelo serviço DAVID-REST. Os valores absolutos de genes identificados em cada processo biológico diferem dos valores obtidos no estudo original uma vez que os genes diferencialmente expressos submetidos à análise pelo serviço DAVID-REST incluem apenas um subconjunto dos genes diferencialmente expressos identificados no estudo original.

Em relação aos genes induzidos no grupo shBRG1-shMITF, a análise de enriquecimento funcional revelou alterações na expressão de genes associados aos processos biológicos de sinalização celular e regulação de proliferação celular, entre outros. A Figura 76 apresenta a proporção de genes induzidos que foram identificados nos processos biológicos da ontologia GO considerados relevantes.

De forma semelhante aos resultados obtidos no estudo original, o serviço DAVID-REST identificou que os genes reprimidos nos melanócitos normais estão associados em maior proporção aos processos biológicos de regulação de proliferação celular $(12,8 \%)$ e regulação de transcrição $(12,0 \%)$. No entanto, de forma análoga aos resultados obtidos no enriquecimento dos genes reprimidos, os valores absolutos dos genes identificados em cada processo biológico diferem dos valores obtidos no estudo original. 


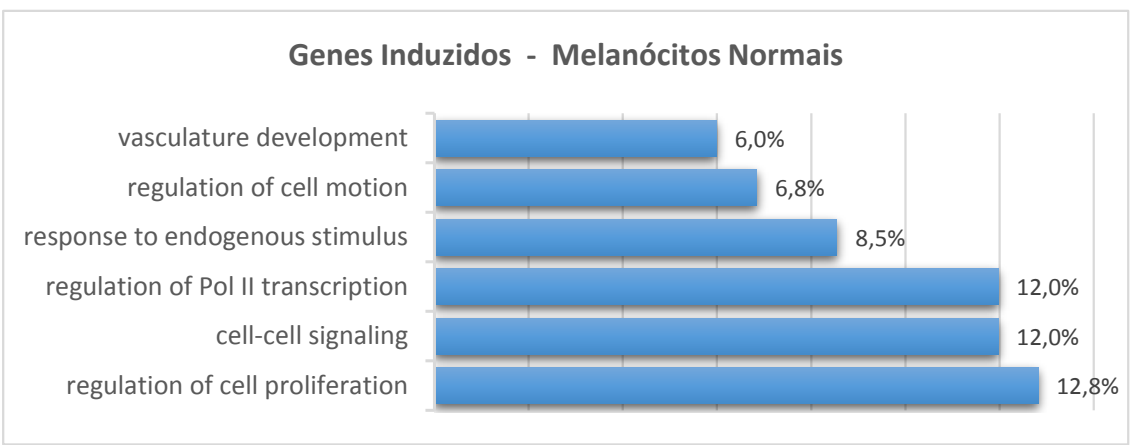

Figura 76: Proporção de genes induzidos nos melanócitos normais identificados na categoria "processos biológicos" da ontologia GO.

\subsection{CONCLUS ÃO}

Neste capítulo, apresentamos a definição de diferentes cenários de composição de serviços na plataforma SemanticSCo. Estes cenários foram definidos para testar as funcionalidades fornecidas pela plataforma e demonstrar sua utilidade por meio da realização de diferentes estudos de análise de expressão gênica. Neste sentido, os cenários de composição foram definidos e executados para reproduzir partes de diferentes estudos de análise de expressão gênica documentados na literatura. Estes estudos incluem a realização de diferentes atividades de análise em tipos de dados obtidos a partir de plataformas e tecnologias de medição de expressão gênica distintas.

A interface fornecida pela plataforma SemanticSCo facilitou a definição gráfica dos cenários de composição utilizados para reproduzir os estudos de expressão gênica. Além disto, a definição e execução dos cenários de composição na plataforma foi facilitada devido ao suporte fornecido a todas as atividades do processo de composição, incluindo a descoberta e seleção de atividades de análise e serviços relevantes, bem como a composição (interligação) de serviços semanticamente compatíveis e a execução (integrada) dos serviços. Adicionalmente, a plataforma forneceu suporte flexível à definição dos cenários de análise, permitindo o refinamento das composições de serviços criadas após a execução de um (sub)conjunto de serviços. Este processo de refinamento permitiu tanto a inclusão gradual de novas atividades de análise e serviços, quanto a modificação de atividades e serviços previamente selecionados durante a definição dos cenários. Finalmente, a plataforma SemanticSCo também facilitou a execução 
dos cenários de análise integrados, permitindo a invocação individual de cada serviço definido na composição e transferindo os dados entre os serviços de maneira automática.

De modo geral, os resultados obtidos pela execução dos cenários de análise na plataforma SemanticSCo foram semelhantes aos resultados apresentados nos estudos originais. Contudo, como esperado, algumas diferenças foram observadas nos resultados devido ao uso de métodos estatísticos distintos. Além disto, algumas informações relevantes, tais como as ferramentas e parâmetros de análise utilizados nos estudos originais, não foram fornecidas, dificultando assim a reprodução dos estudos na plataforma e evidenciando a necessidade de suporte à reprodutibilidade de estudos de expressão gênica.

Um aspecto importante para a reprodução de um estudo é a disponibilidade de dados e informações detalhadas sobre cada atividade de análise realizada nos dados e as respectivas ferramentas de análise utilizadas, bem como os parâmetros aplicados em cada análise. Embora suporte à reprodutibilidade não tenha sido o foco atual deste trabalho e assim, ainda seja limitado na plataforma SemanticSCo, a infraestrutura desenvolvida já fornece mecanismos para a coleta e armazenamento de parte das informações necessárias neste contexto. Estes mecanismos têm como objetivo facilitar, em trabalhos futuros, a inclusão de recursos de suporte ao gerenciamento de informações contextuais pelos usuários na plataforma. 


\section{CONCLUSÃO}

Este projeto teve como objetivo investigar o desenvolvimento e composição de serviços web semânticos no domínio de análise de expressão gênica. Este capítulo apresenta uma discussão das principais contribuições e limitações do trabalho, bem como uma comparação da solução proposta com outras soluções já existentes na literatura. Finalmente, apresentamos algumas considerações finais sobre o trabalho e traçamos algumas direções para pesquisas futuras.

O restante deste capítulo está estruturado da seguinte forma: a Seção 8.1 apresenta as principais contribuições deste trabalho; a Seção 8.2 posiciona o nosso trabalho em relação às principais soluções existentes e discute suas limitações; finalmente, a Seção 8.3 apresenta direções para pesquisas futuras.

\subsection{PRINCIPAIS CONTRIBUIÇÕES}

Estudos de análise de expressão gênica frequentemente requerem o uso integrado de uma série de ferramentas de software. No entanto, o processo de integração manual de ferramentas pode ser propenso a erros devido à grande quantidade de ferramentas e formatos de dados disponíveis. Assim, suporte à integração (semi) automática de ferramentas tem se tornado bastante desejável. Neste contexto, este projeto teve como objetivo investigar o desenvolvimento de serviços web semânticos a partir de ferramentas de software existentes e o suporte automático à integração (composição) destes serviços. 


\subsubsection{Metodologia para o Desenvolvimento de Serviços Web Semânticos}

Nos últimos anos, serviços web semânticos têm sido crescentemente utilizados no domínio de genômica funcional para a realização de diferentes atividades de análise. Neste sentido, diferentes ferramentas de software existentes, disponíveis por exemplo em versões standalone ou por meio de páginas web, têm sido adaptadas como serviços web semânticos. Neste trabalho, definimos inicialmente uma metodologia integrada para a criação de serviços web semânticos a partir de ferramentas de software existentes visando sistematizar o processo de criação e disponibilização de serviços no domínio. A metodologia proposta aborda não apenas a implementação de serviços web RESTful, mas também a anotação semântica das descrições dos serviços de acordo com a abordagem SAWSDL. Além disto, nossa metodologia considera o desenvolvimento de serviços complexos, ou seja, serviços que apresentam um comportamento local definido por meio de condições e/ou restrições as quais determinam a ordem de execução de suas operações. Assim, de modo a facilitar a execução automática dos serviços desenvolvidos, a metodologia contempla também a especificação BPMN do comportamento local dos serviços. Nossa metodologia fornece diretrizes concretas e detalhes técnicos, facilitando deste modo a adaptação sistemática de ferramentas de software.

Adicionalmente, desenvolvemos um conjunto de ferramentas de suporte que facilitam a aplicação da metodologia proposta no desenvolvimento de serviços. Estas ferramentas fornecem suporte (semi) automático à realização de algumas atividades da metodologia, incluindo a geração de descrições WSDL e de especificações BPMN dos serviços. Finalmente, definimos também um perfil UML que facilita a criação de modelos para a representação gráfica das anotações semânticas realizadas de acordo com a abordagem SAWSDL. Esta representação gráfica fornece uma forma mais intuitiva para capturar e representar as anotações semânticas atribuídas aos serviços.

\subsubsection{Serviços para a Análise de Expressão Gênica}

Após a definição de uma metodologia para o desenvolvimento de serviços web semânticos, a mesma foi aplicada no desenvolvimento de um conjunto representativo de serviços para a aná- 
lise de dados de expressão gênica. Estes serviços foram criados a partir de ferramentas de software desenvolvidas com base em diferentes tecnologias. Os serviços criados a partir destas ferramentas fornecem suporte à análise de diferentes tipos de dados de expressão gênica, incluindo dados de microarray (one-color e two-color) e de RNA-Seq. Além disto, os serviços permitem a realização de diversas atividades de análise nos dados, incluindo normalização, análise de expressão diferencial, agrupamento hierárquico e k-means, análise de enriquecimento funcional e de grupos de genes, bem como suporte à visualização de alguns tipos de dados, tais como dados de agrupamento e dados de vias biológicas. Todos os serviços desenvolvidos estão publicamente disponíveis no repositório de serviços Gene Expression Analysis Services (GEAS). Este repositório fornece documentação detalhada sobre cada serviço disponível, facilitando assim o uso dos serviços para a realização de diferentes atividades de análise de expressão gênica.

\subsubsection{Ontologias de Suporte}

De modo a permitir a anotação semântica dos serviços disponíveis no repositório, definimos também duas ontologias de suporte. A ontologia de domínio GEXPO foi definida para descrever os conceitos básicos associados ao domínio de expressão gênica, incluindo o processo de expressão gênica e processos experimentais de medição associados. A ontologia de serviços GEXPASO foi definida para descrever as principais atividades de análise e tipos de dados disponíveis no domínio, bem como os aspectos estruturais e funcionais dos serviços desenvolvidos. Esta ontologia serviu como base para a anotação semântica dos serviços desenvolvidos. As ontologias GEXPO e GEXPASO também estão publicamente disponíveis no repositório GEAS, podendo ser utilizadas na anotação semântica de outros serviços desenvolvidos neste domínio.

\subsubsection{Abordagem para a Composição de Serviços Web Semânticos}

Em geral, a adaptação de ferramentas de software como serviços web semânticos tem por objetivo facilitar a posterior integração (composição) de ferramentas (serviços) e dados. Neste contexto, de forma complementar à nossa metodologia, definimos uma abordagem para a com- 
posição de serviços web semânticos adequada aos requisitos do domínio de análise de expressão gênica. De modo a posicionar a nossa abordagem de composição, identificamos inicialmente as etapas típicas de um estudo de análise de expressão gênica e definimos então um processo de composição de serviços web semânticos capaz de capturar estas etapas. O processo proposto considera não apenas as etapas envolvidas na composição de serviços, ou seja, requisição, descoberta, seleção, composição e execução de serviços, mas também as etapas anteriores de criação e publicação de serviços individuais em um registro de serviços.

O processo de composição de serviços foi definido neste trabalho considerando-se a natureza exploratória da maioria dos estudos de expressão gênica. Neste sentido, o nosso processo considera a criação e refinamento graduais de uma composição de serviços, bem como o refinamento de uma composição que tenha sido (parcialmente) executada por um usuário. Adicionalmente, como parte da definição do processo de composição, caracterizamos de forma explícita o papel desempenhado por diferentes tipos de usuário (biologistas ou bioinformatas) durante as fases de criação/publicação e composição/execução de serviços. A definição explícita deste processo facilitou a identificação dos principais requisitos para a composição de serviços no domínio de expressão gênica, permitindo o desenvolvimento de uma solução adequada ao domínio e seus usuários.

Em seguida, de modo a fornecer suporte ao processo de composição proposto, definimos uma arquitetura de composição estruturada em quatro camadas. Esta arquitetura fornece um alto nível de abstração, permitindo que usuários com um conhecimento computacional não tão extenso também sejam capazes de guiar um processo de composição de serviços de maneira adequada. Adicionalmente, a nossa arquitetura foi projetada para fornecer suporte ao acesso, composição e execução automática de serviços web semânticos simples ou complexos, ou seja, definidos com base em uma ou múltiplas operações, respectivamente.

\subsubsection{Plataforma de Suporte à Composição}

De modo a implementar a arquitetura proposta e fornecer suporte ao processo de composição de serviços web semânticos definido para o domínio de expressão gênica, desenvolvemos a plataforma SemanticSCo. Esta plataforma fornece suporte (semi) automático à definição e 
execução de composições de serviços, visando facilitar a realização de processos integrados de análise no domínio.

A plataforma SemanticSCo foi desenvolvida como uma adaptação do framework de composição A-DynamiCoS [342,343]. Este framework foi definido a partir de uma arquitetura estruturada em duas camadas, correspondentes às camadas 1 e 3 da nossa arquitetura. Neste sentido, o framework originalmente fornecia suporte apenas à criação de composições de serviços concretas, definidas como um conjunto de serviços simples (única operação). De modo a permitir a criação de workflows de análise abstratos a partir dos quais composições de serviços concretas possam ser derivadas, bem como a incorporação de serviços simples e complexos em uma composição, as camadas 2 e 4 da nossa arquitetura foram implementadas na plataforma SemanticSCo, como parte da principal adaptação do framework A-DynamiCoS.

Na plataforma SemanticSCo, o suporte à definição de processos executáveis (camada 2) foi implementado em dois módulos novos: Service Registry e Service Creation and Publication. O módulo Service Registry representa um registro para o armazenamento de informações sobre os processos executáveis (serviços) incorporados à plataforma. No módulo Service Creation and Publication, o componente Wsdl2Bpmn Mapper foi criado para fornecer suporte à criação de processos executáveis na linguagem BPMN e os componentes BPMN Interpreter e BPMN Publisher para fornecer suporte à publicação dos processos criados no módulo Service Registry. Além disto, de modo a permitir a incorporação e gerenciamento das informações associadas aos processos executáveis, alteramos os esquemas XML e classes Java originalmente definidos no framework A-DynamiCoS para a representação de informações sobre serviços. Finalmente, os mecanismos de suporte à definição de workflows de análise abstratos (camada 4) foram implementados no módulo Service Composition da plataforma SemanticSCo, em um novo componente chamado Semantic Provider.

Entre as principais adaptações realizadas na plataforma SemanticSCo em relação ao framework A-DynamiCos, incluímos mecanismos para permitir a incorporação e gerenciamento de serviços web semânticos desenvolvidos de acordo com as tecnologias e linguagens prescritas em nossa metodologia para a criação de serviços, ou seja, REST, WSDL 2.0, SAWSDL e BPMN. Mecanismos para permitir a inclusão de múltiplas instâncias de um mesmo processo (serviço) em uma composição também foram incluídos. Em relação à descoberta de serviços, o 
componente Service Discoverer originalmente definido no framework A-DynamiCoS fornecia suporte à descoberta de serviços apenas com base nas funcionalidades fornecidas pelo serviços. Na plataforma SemanticSCo, este componente foi adaptado para permitir a realização do processo de descoberta com base não apenas nas funcionalidades, mas também nos dados de entrada dos serviços. Finalmente, o módulo Composite Service Enactment da plataforma SemanticSCo foi adaptado para fornecer suporte à estratégia de composição proposta para o domínio de análise de expressão gênica, de modo a acomodar as necessidades individuais dos usuários do domínio, biologistas e bioinformatas, durante a criação e execução de composições de serviços.

\subsection{DISCUSS ÃO}

\subsubsection{Desenvolvimento de Serviços Web Semânticos}

No domínio biomédico, suporte à integração (semi) automática de ferramentas de software tem se tornado bastante desejável. Neste contexto, um número crescente de ferramentas de software têm sido disponibilizadas como serviços web semânticos para facilitar a criação de processos de análise integrados no domínio. Contudo, acreditamos que a criação de serviços web semânticos ainda não tenha sido suficientemente abordada neste domínio. Por exemplo, o projeto SADI [33] especifica um padrão arquitetônico de suporte à criação e integração de serviços web semânticos no domínio biomédico. No entanto, a criação de serviços SADI baseia-se em uma especificação de arquitetura de serviços não padronizada. Além disto, diferentemente da nossa abordagem, que baseia-se no uso das linguagens SAWSDL e OWL (versão 2) para a representação de dados e modelagem semântica, o projeto SADI baseia-se no uso das linguagens RDF e OWL (versão 1).

De modo semelhante à metodologia proposta neste trabalho, algumas abordagens têm sido definidas para o desenvolvimento de serviços web a partir de ferramentas de software existentes. Estas abordagens consideram a criação (semi) automática de serviços de acordo com o padrão arquitetural REST, mas geralmente são definidas de forma independente de domínio e não fornecem suporte à anotação semântica de serviços. Por exemplo, Oldevik et al. [34] apresentam 
uma abordagem dirigida por modelos para a especificação e geração automática de serviços web baseados em SOAP ou REST a partir de ferramentas de software existentes. Neste trabalho, os autores fornecem um perfil UML que é utilizado para a modelagem da ferramenta de software sendo adaptada e um conjunto de geradores de código que pode ser utilizado para a criação automática do serviço web (adaptador) a partir dos modelos UML previamente especificados.

Athanasopoulos e Kontogiannis [247] definem um processo dirigido por modelos para a criação de serviços RESTful a partir de serviços baseados em outras tecnologias, tais como SOAP. Nesta abordagem, as informações especificadas na descrição WSDL de um serviço legado são inicialmente mapeadas para um modelo independente de sintaxe. Este modelo é gradualmente transformado de modo a produzir um modelo de tipos de recursos, a partir do qual uma descrição WADL do serviço pode ser automaticamente derivada. Uma vantagem desta abordagem é que a adaptação de um serviço baseia-se apenas na sua descrição WSDL, não exigindo assim que o código-fonte do serviço esteja disponível. No entanto, nesta abordagem os serviços desenvolvidos são descritos na linguagem WADL, a qual possui um escopo mais limitado que a linguagem WSDL. Além disto, o processo de geração de uma descrição WADL e do códigobase do serviço a partir desta descrição não é abordada em detalhes pelos autores.

De forma semelhante, Laitkorpi et al. [251] introduzem um processo dirigido por modelos para o desenvolvimento de serviços web RESTful. Este processo pode ser utilizado tanto para a criação de novos serviços quanto para a adaptação de ferramentas de software existentes. No processo proposto, os requisitos do serviço a ser desenvolvido são inicialmente identificados e utilizados para a criação de uma especificação funcional do serviço, a partir da qual uma descrição de serviço na linguagem WADL pode ser automaticamente gerada. Contudo, de forma semelhante à abordagem apresentada anteriormente, a geração do código-fonte dos serviços a partir destas descrições WADL também não é abordada pelos autores.

Liu et al. [252] definem um processo para a reengenharia de sistemas orientados a dados/entidades que permite disponibilizar suas funcionalidades por meio de serviços web RESTful. Neste processo, os recursos de dados/entidades que podem ser representados como recursos REST são inicialmente identificados. A seguir, diferentes regras de mapeamento são utilizadas para a geração de URIs utilizados para identificar os recursos de dados/entidades. Os URIs gerados são então refinados por meio da análise do código-fonte do sistema. Finalmente, as 
interfaces RESTful utilizadas para fornecer acesso às funcionalidades do sistema podem ser automaticamente geradas. Ao contrário da nossa metodologia, este processo de desenvolvimento requer acesso ao código-fonte da ferramenta sendo adaptada. Assim, a aplicação deste processo não é possível quando o código-fonte da ferramenta que se deseja adaptar não se encontra disponível.

Outras abordagens têm como foco a anotação semântica de serviços web de acordo com a abordagem SAWSDL. Por exemplo, Yadav e Patel [253] descrevem uma abordagem automática para a anotação semântica de serviços com o uso da ontologia DBpedia [254]. A anotação semântica de um serviço é realizada a partir da análise sintática de sua descrição WSDL de modo a identificar termos relevantes. Por meio da realização de inferências na ontologia, um conjunto de conceitos relacionados aos termos de interesse é automaticamente identificado e utilizado para anotar os elementos correspondentes na descrição WSDL do serviço. No entanto, esta abordagem apresenta duas principais limitações: a identificação de conceitos relevantes baseiase apenas na sintaxe dos elementos definidos na descrição WSDL do serviço e a abordagem é limitada a uma ontologia específica.

Belouadha et al. [35] apresentam uma abordagem dirigida por modelos para a anotação SAWSDL de serviços web. Nesta abordagem, as interfaces, operações e parâmetros de um serviço web, bem como as anotações semânticas destes elementos são inicialmente modelados com o uso de um perfil UML independente da linguagem SAWSDL. Uma vez que o modelo UML do serviço é definido, um conjunto de regras de transformação é utilizado para mapear, de forma automática, os elementos do modelo para uma descrição de serviço anotada na linguagem SAWSDL.

Zhang et al. [256] apresentam um método semi-automático para a anotação SAWSDL de elementos de esquemas XML definidos em descrições de serviços na linguagem WSDL 1.1. Com base em um conjunto de regras de transformação, os elementos XML são inicialmente mapeados para elementos OWL de uma ontologia esquemática. Os conceitos mais relevantes são então automaticamente identificados e utilizados para anotar os elementos XML definidos na descrição WSDL do serviço.

Por fim, Gordon et al. [37] descrevem uma aplicação real da abordagem SAWSDL no contexto do projeto BioMOBY [255] de modo a fornecer diretrizes para a anotação semântica de 
serviços. Neste trabalho, os autores também apresentam um sistema de software que permite a anotação semi-automática de descrições de serviços na linguagem WSDL 1.1 com os atributos de extensão da abordagem SAWSDL. Contudo, suporte à versão 2.0 da linguagem WSDL ainda não é fornecido.

De maneira análoga à nossa proposta, a maioria das abordagens de desenvolvimento fornecem suporte (semi) automático à realização de parte das atividades prescritas para o desenvolvimento de serviços web semânticos. No entanto, a nossa metodologia fornece também diretrizes concretas em relação aos aspectos técnicos associados ao desenvolvimento e à anotação dos serviços, os quais não são contemplados pela maioria das abordagens. Além disto, ao contrário das abordagens estudadas, a metodologia proposta neste trabalho contempla não apenas a criação de serviços simples definidos por meio de uma única operação de serviço, mas também de serviços complexos definidos por meio de um conjunto de operações, as quais devem ser executadas de acordo com um conjunto de condições e/ou restrições.

As abordagens de desenvolvimento documentadas na literatura consideram, de forma independente, o desenvolvimento de serviços web RESTful a partir de ferramentas de software ou a anotação semântica destes serviços. Em contraste, o nosso trabalho fornece uma solução integrada que abrange tanto a implementação de serviços quanto a anotação semântica dos serviços implementados. O desenvolvimento de serviços web semânticos pode ser, em princípio, realizado com o uso de duas abordagens independentes. Entretanto, o uso combinado de tais abordagens possivelmente requer algumas adaptações de modo a torná-las compatíveis. Adicionalmente, muitas abordagens dirigidas por modelos e, em geral, específicas para um domínio de aplicação, têm sido reportadas na literatura. Contudo, os trabalhos existentes não contemplam o domínio de análise de expressão gênica.

Diversas ferramentas de software (standalone) já encontram-se disponíveis para a execução de uma ou mais atividades de análise de expressão gênica. Neste contexto, o foco principal da metodologia proposta é facilitar o desenvolvimento de um serviço web utilizado para adaptar uma ferramenta de software existente e a anotação semântica deste serviço com conceitos de uma ontologia. O desenvolvimento de novos serviços que não adaptam ferramentas existentes não é contemplado pela metodologia proposta. Todavia, para permitir o desenvolvimento de tais serviços, apenas a atividade da metodologia que prescreve a implementação dos serviços pode- 
ria ser estendida de modo a incluir um conjunto adequado de atividades de desenvolvimento que forneçam suporte ao ciclo de desenvolvimento de software completo. As demais atividades da nossa metodologia não precisariam ser, em princípio, modificadas.

A metodologia proposta baseia-se em um conjunto de aspectos técnicos associados ao desenvolvimento de serviços web semânticos, dificultando sua aplicação por usuários que não possuam um conhecimento computacional adequado. No entanto, bioinformatas e profissionais de TI envolvidos em atividades de suporte à análise de expressão gênica podem se beneficiar da nossa abordagem sistemática para o desenvolvimento de serviços web semânticos para a análise de expressão gênica, uma vez que estes representam os usuários alvo da nossa metodologia.

No domínio de genômica funcional, nosso trabalho fornece a primeira metodologia para o desenvolvimento e anotação semântica de serviços web RESTful a partir de ferramentas de software existentes. Em contraste com outras abordagens de desenvolvimento no domínio biomédico, por exemplo o projeto SADI, a metodologia proposta neste trabalho fornece uma solução genérica que não restringe o tipo e/ou estrutura dos serviços desenvolvidos. Desta forma, fornecemos uma solução mais flexível para o desenvolvimento e reuso de serviços por meio da adaptação de diferentes tipos de ferramentas de software para a análise de expressão gênica.

A arquitetura orientada a serviços tem sido crescentemente utilizada no desenvolvimento de sistemas computacionais em diversos domínios de conhecimento. Os benefícios do desenvolvimento baseado em serviços incluem o rápido desenvolvimento de aplicações a um menor custo uma vez que os serviços podem ser reusados na criação de novos serviços, além do aumento de confiabilidade dos serviços desenvolvidos por meio do reuso de soluções que já foram previamente testadas. Em particular, nosso trabalho incentiva o desenvolvimento de novos serviços e o subsequente reuso de tais serviços no domínio de análise de expressão gênica. Além disto, embora nossa metodologia tenha sido definida para este domínio específico, a mesma pode ser facilmente estendida para outros domínios de conhecimento biológicos.

\subsubsection{Composição de Serviços Web Semânticos}

Diferentes plataformas de software têm sido propostas para fornecer suporte à composição de serviços web semânticos no domínio biomédico. De forma similar à plataforma SemanticSCo, 
a maioria destas plataformas segue uma estratégia semi-automática para a composição de serviços, sugerindo iterativamente os serviços mais adequados a serem incluídos pelo usuário em uma composição sendo construída. Todavia, grande parte das abordagens existentes no domínio apresentam apenas uma solução parcial para o problema de composição, fornecendo suporte somente a algumas atividades de processo de composição, como por exemplo, a descoberta ou seleção de serviços. Por exemplo, Withers et. al [42] apresentam duas extensões definidas para dar suporte à descoberta semântica de serviços na plataforma Taverna. Estas extensões são utilizadas para sugerir ao usuário, de forma iterativa, um conjunto de serviços que sejam capazes de consumir os tipos de dados produzidos por cada serviço precedente incluído na composição, facilitando assim a inclusão de serviços semanticamente compatíveis. Contudo, a funcionalidade fornecida por cada serviço não é explicitamente considerada na abordagem proposta e assim, um usuário deve ser capaz de selecionar serviços adequados com base apenas no seu conhecimento sobre as funcionalidades oferecidas pelos serviços disponíveis no domínio.

A criação/publicação, requisição e seleção de serviços não é abordada no contexto da plataforma Taverna. Em contraste, a plataforma SemanticSCo apresenta uma solução completa para a composição semântica de serviços, fornecendo suporte a todas as atividades definidas no processo de composição, ou seja, criação, publicação, requisição, descoberta, composição, seleção e execução de serviços.

Algumas abordagens de composição definidas no domínio biomédico, tais como as plataformas Bio-jETI [38] e Sesame [39], assumem que os biologistas (ou bioinformatas) devem especificar uma composição de serviços (workflow de análise) de acordo com seus requisitos e, uma vez que a composição é completamente especificada, a mesma pode então ser implantada e executada. No entanto, considerando-se a natureza exploratória dos estudos de expressão gênica, os requisitos de um biologista podem alterar-se durante a realização de um estudo de acordo, por exemplo, com a interpretação de alguns resultados biológicos intermediários. Neste sentido, a plataforma SemanticSCo fornece um suporte mais flexível aos biologistas durante o processo de composição de serviços, dado que as etapas de especificação e execução de uma composição podem ser intercaladas de modo a permitir que um biologista aplique os conhecimentos biológicos obtidos durante o processo de composição. Uma vez que o biologista adquire um maior 
conhecimento durante o processo de composição, o mesmo pode decidir sobre como proceder com o processo e, por exemplo, refinar o workflow de análise previamente especificado.

Adicionalmente, a maioria das abordagens assume que os usuários finais (biologistas) responsáveis por guiar o processo de composição possuem algum conhecimento técnico sobre os serviços disponíveis no domínio e suas funcionalidades subjacentes. Estas abordagens geralmente fornecem mecanismos para facilitar a criação de um workflow de análise concreto, o qual consiste em um conjunto de serviços web (automaticamente) interligados. Por exemplo, Dhamanaskar et. al [40] propõem um conjunto de extensões que permite a descoberta e composição de serviços web semânticos na plataforma Galaxy. De forma semelhante à nossa abordagem, a composição de serviços com o uso destas extensões pode ser realizada de acordo com as abordagens forward ou backward, fornecendo flexibilidade aos usuários durante a criação de workflows de análise. Contudo, estas extensões fornecem mecanismos para auxiliar um usuário durante a criação de um workflow de análise concreto, sugerindo um conjunto adequado de serviços para inclusão em cada etapa da criação do workflow. Em contraste, a plataforma SemanticSCo foi projetada para fornecer um nível maior de abstração aos usuários. Na nossa plataforma, um usuário pode especificar seus requisitos de forma abstrata, ou seja, em termos das funcionalidades que deseja e dos tipos de dados que deseja processar e/ou produzir. Uma vez que um workflow abstrato é (parcialmente) especificado, a plataforma fornece mecanismos para a descoberta e composição de serviços capazes de atingir os objetivos (requisitos) especificados no workflow abstrato. Este nível de abstração permite que os usuários (biologistas) se concentrem mais nas questões biológicas de interesse do que em detalhes técnicos sobre os serviços disponíveis.

Um outro exemplo é a abordagem de composição proposta por Ba et. al [263]. Esta abordagem tem por objetivo auxiliar os usuários durante a especificação de um workflow de análise concreto (composição de serviços), sugerindo serviços cujas entradas/saídas sejam semanticamente compatíveis com os serviços previamente incluídos no workflow. Contudo, ao contrário da abordagem de descoberta implementada pela plataforma SemanticSCo, as funcionalidades desejadas pelo usuário e fornecidas pelos serviços não são explicitamente consideradas durante a descoberta de serviços relevantes. 
De forma semelhante à plataforma SemanticSCo, a plataforma Sesame [39] fornece um alto nível de abstração de modo a permitir que os usuários especifiquem um workflow de análise abstrato, ou seja, um conjunto ordenado de atividades de análise e tipos de dados que se deseja processar/produzir. Durante a especificação deste workflow, a plataforma Sesame auxilia os usuários sugerindo atividades de análise que podem ser incluídas a cada etapa. Estas sugestões baseiam-se nos relacionamentos entre as atividades de análise e suas entradas/saídas definidos em uma ontologia de serviços. Uma vez que um workflow abstrato é completamente especificado pelo usuário, a plataforma sugere uma lista de serviços disponíveis para cada atividade de análise incluída no workflow. No entanto, estas sugestões baseiam-se apenas na compatibilidade semântica entre as atividades de análise e as anotações semânticas que especificam as funcionalidades dos serviços. Assim, o usuário deve ser capaz de resolver incompatibilidades semânticas entre os tipos de dados processados e consumidos por serviços subjacentes incluídos na cadeia de composição.

Em contraste à estratégia semi-automática de composição adotada na plataforma SemanticSCo, algumas plataformas de software têm sido desenvolvidas para fornecer suporte completamente automático à composição de serviços no domínio biomédico. Por exemplo, na plataforma jORCA [41], um usuário deve inicialmente especificar a semântica dos dados que deseja processar e produzir. Uma vez que a semântica dos dados é especificada, um algoritmo de composição identifica, de forma automática, a menor sequência linear de serviços capaz de produzir os tipos de dados de saída a partir dos tipos de dados de entrada especificados. Este algoritmo de composição identifica iterativamente quais serviços podem produzir os tipos de dados exigidos como entrada para o próximo serviço definido na cadeia de composição. Dois serviços são considerados compatíveis e assim, podem ser interligados, se a saída de um dos serviços é semanticamente compatível com a entrada do próximo serviço definido na cadeia de composição.

Um outro exemplo de suporte totalmente automático à composição de serviços é fornecido pela plataforma Bio-jETI [38]. Esta plataforma fornece suporte à criação, execução e gerenciamento de serviços no domínio biomédico. Na plataforma Bio-jETI, a composição de serviços web semânticos é realizada por meio de dois mecanismos: síntese e verificação de modelos. O mecanismo de síntese é utilizado para identificar, de forma automática, uma sequência li- 
near de serviços que satisfaça um conjunto de requisitos de usuário, os quais são especificados em termos de funcionalidades desejadas e tipos de dados a serem processados/produzidos. O mecanismo de verificação permite avaliar propriedades da composição construída de modo a identificar possíveis problemas, tais como incompatibilidades semânticas entre os dados compartilhados entre diferentes serviços.

Tanto a plataforma jORCA quanto a plataforma Bio-jETI fornecem suporte à composição automática de serviços, isentando os usuários da tarefa de resolver incompatibilidades entre os tipos de dados de entrada e saída de diferentes serviços. Contudo, estas abordagens assumem que os usuários sejam capazes de fornecer um conjunto completo e preciso de requisitos no início do processo de criação de uma composição de serviços. Embora as plataformas jORCA e Bio-jETI possam ser úteis para a definição de workflows de análise em alguns domínios de aplicação biológicos, acreditamos que estas plataformas não forneçam a solução mais adequada ao domínio de expressão gênica, no qual os biologistas iterativamente adquirem conhecimento técnico e biológico (requisitos) conforme o processo de composição vai sendo realizado.

A Tabela 21 sumariza os principais recursos fornecidos pela plataforma de composição SemanticSCo e apresenta uma comparação com outras plataformas existentes. Estes recursos incluem suporte à serviços RESTful (complexos), nível de automação da descoberta e composição de serviços, nível de abstração do processo de composição, suporte a todas as atividades do processo de composição, bem como suporte à intercalação das atividades de especificação e execução de uma composição de serviços.

Atualmente, a criação de composições de serviços na plataforma SemanticSCo limita-se ao conjunto de serviços disponíveis no repositório GEAS. No entanto, suporte é provido tanto para o desenvolvimento de novos serviços web semânticos quanto para a incorporação (publicação) destes serviços na plataforma. Neste contexto, fornecemos uma metodologia e ferramentas de suporte ao desenvolvimento de serviços web semânticos para a análise de expressão gênica de maneira sistemática [271], bem como mecanismos para a publicação automática dos serviços criados no registro de serviços implementado na plataforma SemanticSCo. Uma vez que são publicados no registro, os serviços incorporados podem então ser manipulados pelos componentes de suporte à descoberta, composição e execução de serviços na plataforma. Além disto, embora os serviços atualmente disponíveis na plataforma SemanticSCo tenham sido semanticamente 
Tabela 21: Principais recursos fornecidos pela plataforma SemanticSCo e outras plataformas de composição.

\begin{tabular}{|l|c|c|c|c|c|c|}
\hline Plataforma & $\begin{array}{c}\text { Suporte } \\
\text { a REST }\end{array}$ & $\begin{array}{c}\text { Suporte a } \\
\text { serviços } \\
\text { complexos }\end{array}$ & $\begin{array}{c}\text { Nível de } \\
\text { automação }\end{array}$ & $\begin{array}{c}\text { Nível de } \\
\text { abstração }\end{array}$ & $\begin{array}{c}\text { Suporte ao } \\
\text { processo de } \\
\text { composição }\end{array}$ & $\begin{array}{c}\text { Intercalação } \\
\text { especifiçãão/ } \\
\text { execução }\end{array}$ \\
\hline SemanticSCo & $\operatorname{sim}$ & $\operatorname{sim}$ & semi & alto & $\operatorname{sim}$ & sim \\
\hline $\begin{array}{l}\text { Extensão } \\
\text { Taverna [22] }\end{array}$ & $\operatorname{sim}$ & não & semi & baixo & não & sim \\
\hline $\begin{array}{l}\text { Extensão } \\
\text { Galaxy [23] }\end{array}$ & $\operatorname{sim}$ & não & semi & baixo & não & sim \\
\hline Ba et. al [24] & ----- & não & semi & baixo & não & ----- \\
\hline Sesame [25] & ----- & não & semi & alto & não & não \\
\hline jORCA [26] & $\operatorname{sim}$ & não & automático & baixo & não & sim \\
\hline Bio-jETI [27] & $\operatorname{sim}$ & não & automático & baixo & não & não \\
\hline
\end{tabular}

anotados com conceitos da ontologia GEXPASO, a plataforma não se limita à realização de inferências apenas nesta ontologia. Neste sentido, a plataforma SemanticSCo fornece suporte à incorporação, descoberta e composição de serviços semanticamente anotados com conceitos provenientes de quaisquer ontologias OWL.

De modo geral, um biologista está interessado não apenas nos resultados finais obtidos durante um estudo de análise de expressão gênica, mas também em resultados intermediários produzidos durante o processo de análise. Assim, a plataforma SemanticSCo fornece acesso a todos os resultados produzidos ao longo do processo de composição, permitindo a interpretação dos resultados passo a passo pelos usuários. Um outro aspecto de um estudo de expressão gênica é a sua reprodutibilidade, que depende da disponibilidade de informações relacionadas ao contexto no qual o estudo está sendo realizado. Estas informações podem incluir, por exemplo, o conjunto de atividades de análise que foram realizadas nos dados e a ordem de realização das atividades, os parâmetros aplicados em cada análise e as ferramentas de software que foram utilizadas para a realização de cada análise. Embora suporte à reprodutibilidade ainda seja limitado na plataforma SemanticSCo, a nossa infraestrutura de suporte já fornece mecanismos para a coleta e armazenamento de informações de contexto. Tais mecanismos facilitam a inclusão futura de recursos para o gerenciamento destas informações pelos usuários na plataforma SemanticSCo. 
Até o presente momento, nenhuma abordagem foi especificamente definida para a composição de serviços web semânticos no domínio de genômica funcional. Acreditamos que a nossa abordagem de composição, implementada na plataforma SemanticSCo, representa uma solução adequada a este domínio, uma vez que considera suas principais características e usuários, ou seja, biologistas e bioinformatas. Embora nossa abordagem tenha sido especificamente definida para fornecer suporte ao domínio de genômica funcional, acreditamos que outros domínios de aplicação biológicos com requisitos semelhantes também possam beneficiar-se da solução apresentada neste trabalho.

Nos últimos anos, o uso explícito de semântica tem sido considerado essencial para permitir a composição (semi) automática de serviços em diferentes domínios de aplicação, inclusive no domínio biomédico. No contexto deste trabalho, apresentamos uma solução completa para a composição semântica de serviços no domínio de expressão gênica e implementamos a solução proposta na plataforma SemanticSCo. De modo a demonstrar a utilidade da nossa plataforma de suporte, incorporamos os serviços de análise de expressão gênica disponíveis no repositório GEAS ao registro de serviços da plataforma e utilizamos então parte dos serviços para a criação de três cenários (integrados) de análise. Estes cenários de análise foram definidos na plataforma SemanticSCo por meio da composição semi-automática dos serviços disponíveis e foram utilizados para reproduzir estudos de expressão gênica documentados na literatura. Durante a criação dos cenários na nossa plataforma, as anotações semânticas atribuídas aos serviços disponíveis no registro foram utilizadas para a realização de inferências sobre as funcionalidades, entradas e saídas dos serviços, facilitando a descoberta, seleção e composição dos serviços.

No primeiro estudo de caso, reproduzimos um conjunto específico de resultados apresentado em [370,371]. Neste primeiro estudo, a análise de expressão diferencial entre os grupos préTACTH, pós-TACTH e controle revelou apenas 40,3\% dos genes diferencialmente expressos relatados no estudo original. No segundo estudo de caso, reproduzimos parte dos resultados apresentados em [374]. Neste estudo, a análise de expressão diferencial entre os grupos BIC, BANIC, BINIC e ISOL identificou 100\% dos genes diferencialmente expressos relatados no estudo original, bem como alguns genes adicionais. Finalmente, no terceiro estudo de caso reproduzimos os resultados apresentados em [380]. Neste estudo, a análise de expressão diferencial entre amostras de melanócitos (normais e tumorais) revelou 85, 1\% dos genes diferencialmente 
expressos relatados no estudo original. De modo geral, nos três estudos de caso, as análises de enriquecimento funcional revelaram genes diferencialmente expressos associados a categorias GO e vias biológicas semelhantes às identificadas nos estudos originais correspondentes.

As diferenças dos resultados obtidos nestes três estudos de caso em relação aos resultados originais não indicam necessariamente uma limitação dos nossos serviços, uma vez que utilizamos um conjunto distinto de ferramentas e métodos estatísticos daqueles considerados para a realização das diferentes atividades de análise nos estudos originais. Além disto, a relevância biológica dos resultados adicionais obtidos nos estudos de caso ainda precisa ser investigada, mas a realização destas investigações está fora do escopo deste trabalho.

\subsection{TRABALHOS FUTUROS}

De modo a fornecer suporte à atividade de anotação semântica de serviços da nossa metodologia, definimos um perfil UML para a abordagem SAWSDL. Embora o perfil possa ser utilizado em qualquer ferramenta de modelagem UML de propósito geral, o desenvolvimento de uma ferramenta de suporte à construção de modelos com base neste perfil pode beneficiar os bioinformatas durante a anotação SAWSDL dos seus serviços. O desenvolvimento de uma ferramenta de anotação gráfica adequada pode permitir não apenas a visualização e edição de modelos UML, mas também a verificação automática de inconsistências nos modelos criados. Adicionalmente, uma ferramenta baseada no nosso perfil poderia fornecer recursos para o mapeamento automático das informações definidas em um modelo UML para uma descrição WSDL de serviço semanticamente anotada.

A metodologia definida para a criação de serviços web semânticos foi aplicada no desenvolvimento de um conjunto representativo de serviços. Os serviços desenvolvidos fornecem suporte a algumas atividades de análise frequentemente realizadas em dados de expressão gênica. Neste contexto, novos serviços podem ser desenvolvidos para fornecer suporte a outras atividades de análise não consideradas neste trabalho, tais como análise de predição de classes, análise de correlação, construção de redes regulatórias de genes e análise de expressão diferencial para múltiplas condições, entre outras. 
Na plataforma SemanticSCo, os processos de descoberta, seleção e composição de serviços baseiam-se na realização de inferências em uma ou mais ontologias para determinar a similaridade semântica entre os conceitos utilizados na descrição das funcionalidades e entradas/saídas dos serviços disponíveis. O grau de similaridade semântica entre duas classes (conceitos) de uma ontologia é determinado com base em quatro tipos de relacionamentos que podem ser definidos entre as mesmas: equivalência, subclasse direta ou indireta, superclasse direta ou indireta e não-equivalência. Entretanto, por questões de desempenho, quando uma classe é subclasse ou superclasse indireta de outra, não consideramos a quantidade de classes intermediárias (distância) entre estas classes para o cálculo do grau de similaridade semântica. Neste sentido, uma investigação aprofundada das abordagens existentes para o cálculo do grau de similaridade semântica e a definição de uma abordagem mais eficiente para a inclusão da distância entre classes no cálculo de similaridade semântica pode beneficiar os processos de descoberta/composição na plataforma SemanticSCo.

Diferentes mecanismos facilitam a criação e execução de composições de serviços na plataforma SemanticSCo. Por exemplo, durante a criação de um workflow de análise (composição de serviços), um conjunto adequado de atividades de análise é iterativamente sugerido ao usuário para inclusão em cada etapa da criação do workflow. Atualmente, quando um usuário solicita a inclusão de uma nova atividade de análise, a plataforma SemanticSCo realiza a descoberta de atividades relevantes com base na semântica de todas as atividades de análise e tipos de dados associados previamente incluídos no workflow. Um recurso adicional poderia ser incluído na plataforma para permitir o processo de descoberta apenas com base em um conjunto de atividades selecionado pelo usuário. A inclusão de tal recurso poderia ser realizada modificando-se apenas o módulo Composite Service Enactment, uma vez que o suporte à descoberta de serviços foi implementado de maneira flexível na plataforma.

Como discutido anteriormente, um aspecto importante de um estudo de expressão gênica é a sua reprodutibilidade. Embora suporte à reprodutibilidade ainda seja limitado na plataforma SemanticSCo, alguns mecanismos para a coleta e armazenamento de informações de contexto associadas às composições de serviços criadas já estão disponíveis em nossa plataforma. Em trabalhos futuros, estes mecanismos podem ser utilizados para a inclusão de recursos que permitam o gerenciamento destas informações pelos usuários na plataforma SemanticSCo. 
Além disto, a versão atual da interface gráfica da plataforma SemanticSCo ainda não fornece recursos para armazenar, de forma persistente, um workflow de análise criado por um usuário e para permitir a sua posterior recuperação. Neste contexto, uma possibilidade é o uso de uma linguagem de modelagem de processos, tal como a linguagem BPMN, para a representação dos workflows criados por um usuário. Com o uso de uma linguagem como BPMN, um workflow de análise pode ser armazenado de forma dinâmica como uma representação baseada em XML e posteriormente recuperado. $\mathrm{O}$ uso desta linguagem poderia facilitar também o armazenamento de informações de contexto, tais como parâmetros de análise, necessárias para a reprodução de estudos de expressão gênica.

Após a definição (parcial) de um workflow de análise na plataforma SemanticSCo, um usuário pode invocar a execução de cada serviço incluído no workflow por meio da interface gráfica de usuário da plataforma SemanticSCo. Quando a execução de um serviço é solicitada pelo usuário, a interface é responsável por invocar um mecanismo de execução externo que executa o serviço desejado. Atualmente, a interface de usuário fornece suporte apenas à execução individual dos serviços, de modo que suporte automático à execução sequencial de todos os serviços definidos em um workflow de análise ainda não é fornecido. A inclusão de tal mecanismo requer que o fluxo de execução dos serviços definidos em um workflow seja modelado de forma explícita. Novamente, a linguagem BPMN poderia ser utilizada para a especificação deste fluxo de execução como um processo. Uma vez que tal processo BPMN esteja disponível, sua execução pode então ser automatizada com o uso de mecanismos de execução externos, tais como a plataforma BPM Activiti, utilizada na plataforma SemanticSCo para a execução de processos (serviços) individuais.

A plataforma SemanticSCo fornece uma interface gráfica de usuário para facilitar a criação e execução de composições de serviços. Esta interface é responsável por capturar as intenções de um usuário (biologista ou bioinformata) em relação ao processo de composição e traduzilas para comandos computacionais que são interpretados e executados pela plataforma. Atualmente, a interface de usuário da plataforma está disponível apenas em uma versão standalone. De modo a facilitar a definição de workflows de análise na nossa plataforma, acreditamos que o desenvolvimento de uma versão web da nossa interface de usuário possa beneficiar usuários com diferentes níveis de conhecimentos computacionais. 
Finalmente, de modo a testar as funcionalidades e demonstrar a utilidade da plataforma SemanticSCo, realizamos três estudos de caso para a análise integrada de dados de expressão gênica obtidos a partir de diferentes estudos já documentados na literatura. Contudo, estudos adicionais podem ser realizados para avaliar a plataforma em relação a outros aspectos não considerados neste trabalho, tais como confiabilidade, desempenho, eficiência, qualidade, viabilidade e usabilidade. A realização destes estudos complementares requer não apenas a definição de métricas adequadas, tais como tempo de resposta médio, precisão e revocação, mas também a seleção de métodos de avaliação apropriados [381]. As informações obtidas a partir de tais estudos poderiam então ser utilizadas para identificar possíveis melhorias na plataforma e permitir assim, o refinamento da solução proposta. 
1. Guardia GDA, Ferreira Pires L, da Silva EG, de Farias CRG. SemanticSCo: a platform to support the semantic composition of gene expression analysis services. Em submissão (2016).

2. Guardia GDA, Ferreira Pires L, Vêncio RZN, Malmegrim KCR, de Farias CRG. A methodology for the development of RESTful semantic web services for gene expression analysis. PLoS ONE. 2015;10(7):1-28. doi:10.1371/journal.pone.0134011.

3. Miyazaki FA, Guardia GDA, Vêncio RZN, de Farias CRG. Semantic integration of gene expression analysis tools and data sources using software connectors. BMC Genomics. 2013;14(Suppl 6):S2. doi:10.1186/1471-2164-14-S6-S2.

4. Guardia GDA, Vêncio RZN, de Farias CRG. A UML profile for the OBO Relation Ontology. BMC Genomics. 2012;13(Suppl 5):S3. doi:10.1186/1471-2164-13-S5-S3. 
[1] Butte A. The use and analysis of microarray data. Nature Reviews Drug Discovery. 2002;1(12):951-960. doi:10.1038/nrd961.

[2] Allison DB, Cui X, Page GP, Sabripour M. Microarray data analysis: from disarray to consolidation and consensus. Nature Reviews Genetics. 2006;7(1):55-65. doi:10.1038/nrg1749.

[3] Wang Z, Gerstein M, Snyder M. RNA-Seq: a revolutionary tool for transcriptomics. Nature Reviews Genetics. 2009;10(1):57-63. doi:10.1038/nrg2484.

[4] Neerincx PBT, Leunissen JAM. Evolution of web services in bioinformatics. Briefings in Bioinformatics. 2005;6(2):178-188. doi:10.1093/bib/6.2.178.

[5] Zhang Z, Cheung K, Townsend JP. Bringing Web 2.0 to bioinformatics. Briefings in Bioinformatics. 2009;10(1):1-10. doi:10.1093/bib/bbn041.

[6] Romano P. Automation of in-silico data analysis processes through workflow management systems. Briefings in Bioinformatics. 2008;9(1):57-68. doi:10.1093/bib/bbm056.

[7] Jiao X, Sherman BT, Huang DW, Stephens R, Baseler MW, Lane HC, et al. DAVIDWS: a stateful web service to facilitate gene/protein list analysis. Bioinformatics. 2012;28(13):1805-1806. doi:10.1093/bioinformatics/bts251.

[8] Goujon M, McWilliam H, Li W, Valentin F, Squizzato S, Paern J, et al. A new bioinformatics analysis tools framework at EMBL-EBI. Nucleic Acids Research. 2010;38(Suppl 2):W695-W699. doi:10.1093/nar/gkq313. 
[9] Pettifer S, Ison J, Kalaš M, Thorne D, McDermott P, Jonassen I, et al. The EMBRACE web service collection. Nucleic Acids Research. 2010;38(Suppl 2):W683W688. doi:10.1093/nar/gkq297.

[10] Hekkelman ML, te Beek TAH, Pettifer SR, Thorne D, Attwood TK, Vriend G. WIWS: a protein structure bioinformatics Web service collection. Nucleic Acids Research. 2010;38(Suppl 2):W719-W723. doi:10.1093/nar/gkq453.

[11] Kawashima S, Katayama T, Sato Y, Kanehisa M. KEGG API: a web service using SOAP/WSDL to access the KEGG system. Genome Informatics. 2003;14:673-674. doi:10.11234/gi1990.14.673.

[12] Stein L. Creating a bioinformatics nation. Nature. 2002;417(6885):119-120. doi:10.1038/417119a.

[13] Kumar S, Dudley J. Bioinformatics software for biologists in the genomics era. Bioinformatics. 2007;23(14):1713-1717. doi:10.1093/bioinformatics/btm239.

[14] Pettifer S, Thorne D, McDermott P, Marsh J, Villéger A, Kell DB, et al. Visualising biological data: a semantic approach to tool and database integration. BMC Bioinformatics. 2009;10(Suppl 6):S19. doi:10.1186/1471-2105-10-S6-S19.

[15] Ghosh S, Matsuoka Y, Asai Y, Hsin KY, Kitano H. Software for systems biology: from tools to integrated platforms. Nature Reviews Genetics. 2011;12(12):821-832. doi:10.1038/nrg3096.

[16] Goecks J, Nekrutenko A, Taylor J, The Galaxy Team. Galaxy: a comprehensive approach for supporting accessible, reproducible, and transparent computational research in the life sciences. Genome Biology. 2010;11(8):1-13. doi:10.1186/gb-2010-11-8-r86.

[17] Bartocci E, Corradini F, Merelli E, Scortichini L. BioWMS: a web-based workflow management system for bioinformatics. BMC Bioinformatics. 2007;8(Suppl 1):S2. doi:10.1186/1471-2105-8-S1-S2. 
[18] Hull D, Wolstencroft K, Stevens R, Goble C, Pocock MR, Li P, et al. Taverna: A Tool for Building and Running Workflows of Services. Nucleic Acids Research. 2006;34(Suppl 2):W729-W732. doi:10.1093/nar/gk1320.

[19] Shannon PT, Reiss DJ, Bonneau R, Baliga NS. The Gaggle: an open-source software system for integrating bioinformatics software and data sources. BMC Bioinformatics. 2006;7(1):1-13. doi:10.1186/1471-2105-7-176.

[20] Al-Shahrour F, Minguez P, Vaquerizas JM, Conde L, Dopazo J. BABELOMICS: a suite of web tools for functional annotation and analysis of groups of genes in high-throughput experiments. Nucleic Acids Research. 2005;33(Suppl 2):W460-W464. doi:10.1093/nar/gki456.

[21] Bolchini D, Finkelstein A, Perrone V, Nagl S. Better bioinformatics through usability analysis. Bioinformatics. 2009;25(3):406-412. doi:10.1093/bioinformatics/btn633.

[22] Syu Y, Fanjiang Y, Kuo J, Ma S. A review of the automatic web service composition surveys. In: Proceedings of the IEEE International Conference on Semantic Computing (ICSC); 16-18 Jun. 2014; Newport Beach. IEEE; 2014. p. 199-202. doi:10.1109/ICSC.2014.41.

[23] JavaScript Object Notation (JSON). [acesso 12 Maio 2016]. Disponível em: [http://www. json.org/].

[24] Cardoso J, Sheth A. Introduction to semantic web services and web process composition. In: Cardoso J, Sheth A, editors. Semantic Web Services and Web Process Composition. First International Workshop on SWSWPC; 6 Jul. 2004; San Diego. Berlin: Springer; 2005. p. 1-13. doi:10.1007/978-3-540-30581-1_1.

[25] Charif Y, Sabouret N. An overview of semantic web services composition approaches. In: Benslimane D, Ghedira C, Maamar Z, editors. Proceedings of the First International Workshop on Context for Web Services (CWS); 5 Jul. 2005; Paris. Elsevier; 2006. p. 33-41. (Electronic Notes in Theoretical Computer Science; vol. 146, no. 1). doi:10.1016/j.entcs.2005.11.005. 
[26] Sheth A, Verma K, Gomadam K. Semantics to energize the full services spectrum. Communications of the ACM. 2006;49(7):55-61. doi:10.1145/1139922.1139949.

[27] Berners-Lee T, Hendler J, Lassila O. The Semantic Web. Scientific American. 2001;284(5):29-37.

[28] Horrocks I. Ontologies and the semantic web. Communications of the ACM. 2008;51(12):58-67. doi:10.1145/1409360.1409377.

[29] Gruber TR. Toward principles for the design of ontologies used for knowledge sharing. International Journal of Human-Computer Studies. 1995;43(5-6):907-928. doi:10.1006/ijhc.1995.1081.

[30] McIlraith SA, Son TC, Zeng H. Semantic web services. IEEE Intelligent Systems. 2001;16(2):46-53. doi:10.1109/5254.920599.

[31] Kumar S, Mishra RB. Semantic web service composition. IETE Technical Review. 2008;25(3):105-121. doi:10.4103/02564602.2008.10876650.

[32] Burstein M, Bussler C, Finin T, Huhns MN, Paolucci M, Sheth AP, et al. A semantic web services architecture. IEEE Internet Computing. 2005;9(5):72-81. doi:10.1109/MIC.2005.96.

[33] Wilkinson MD, Vandervalk B, McCarthy L. The Semantic Automated Discovery and Integration (SADI) web service design-pattern, API and reference implementation. Journal of Biomedical Semantics. 2011;2(1):1-23. doi:10.1186/2041-1480-2-8.

[34] Oldevik J, Olsen GK, Brönner U, Bodsberg NR. Model-driven migration of scientific legacy systems to service-oriented architectures. In: Fuhr A, Riediger V, Hasselbring W, Bruntink M, Kontogiannis K, editors. Proceedings of the First International Workshop on Model-Driven Software Migration (MDSM); 1 Mar. 2011; Oldenburg. CEUR Workshop Proceedings; 2011. p. 4-7.

[35] Belouadha F, Omrana H, Roudies O. A model-driven approach for composing SAWSDL semantic web services. International Journal of Computer Science Issues. 2010;7(2):715. 
[36] Gessler DGG, Schiltz GS, May GD, Avraham S, Town CD, Grant D, et al. SSWAP: A Simple Semantic Web Architecture and Protocol for semantic web services. BMC Bioinformatics. 2009;10(1):1-21. doi:10.1186/1471-2105-10-309.

[37] Gordon PMK, Sensen CW. Creating bioinformatics semantic web services from existing web services: a real-world application of SAWSDL. In: Proceedings of the IEEE International Conference on Web Services (ICWS); 23-26 Set. 2008; Beijing. IEEE; 2008. p. 608-614. doi:10.1109/ICWS.2008.112.

[38] Lamprecht A. The Bio-jETI framework. In: Lamprecht A, editor. User-Level Workflow Design: A Bioinformatics Perspective. Berlin: Springer; 2013. p. 31-61. doi:10.1007/978-3-642-45389-2_2.

[39] Zhang L, Wang Y, Xuan P, Duvall A, Lowe J, Wang Y, et al. Sesame: a new bioinformatics semantic workflow design system. In: IEEE International Conference on Bioinformatics and Biomedicine (BIBM); 18-21 Dez. 2013; Shanghai. IEEE; 2013. p. 504-508. doi:10.1109/BIBM.2013.6732546.

[40] Dhamanaskar A, Cotterell ME, Zheng J, Kissinger JC, Stoeckert Jr CJ, Miller JA. Suggestions for Galaxy workflow design using semantically annotated services. In: Proceedings of the 7th International Conference on Formal Ontology in Information Systems (FOIS); 24-27 Jul. 2012; Graz; 2012. p. 29-42.

[41] Karlsson J, Trelles O. jORCA and Magallanes sailing together towards integration of web services. In: Freitas AT, Navarro A, editors. Bioinformatics for Personalized Medicine. 10th Spanish Symposium JBI; 27-29 Out. 2010; Torremolinos. Berlin: Springer; 2012.p. 94-101. doi:10.1007/978-3-642-28062-7_11.

[42] Withers D, Kawas E, McCarthy L, Vandervalk B, Wilkinson M. Semantically-guided workflow construction in Taverna: the SADI and BioMoby plug-ins. In: Margaria T, Steffen B, editors. Leveraging Applications of Formal Methods, Verification, and Validation. 4th International Symposium on Leveraging Applications (ISoLA); 18-21 Out. 2010; Heraklion. Berlin: Springer; 2010. p. 301-312. doi:10.1007/978-3-642-165580_26. 
[43] DiBernardo M, Pottinger R, Wilkinson M. Semi-automatic web service composition for the life sciences using the BioMoby semantic web framework. Journal of Biomedical Informatics. 2008;41(5):837-847. doi:10.1016/j.jbi.2008.02.005.

[44] International Human Genome Sequencing Consortium. Initial sequencing and analysis of the human genome. Nature. 2001;409(6822):860-921. doi:10.1038/35057062.

[45] Venter JC, Adams MD, Myers EW, Li PW, Mural RJ, Sutton GG, et al. The sequence of the human genome. Science. 2001;291(5507):1304-1351. doi:10.1126/science.1058040.

[46] Liu XS. Getting started in tiling microarray analysis. PLoS Computational Biology. 2007;3(10):1-3. doi:10.1371/journal.pcbi.0030183.

[47] Sanger F, Nicklen S, Coulson AR. DNA sequencing with chain-terminating inhibitors. Proceedings of the National Academy of Sciences. 1977;74(12):5463-5467.

[48] Brenner S, Johnson M, Bridgham J, Golda G, Lloyd DH, Johnson D, et al. Gene expression analysis by massive parallel signature sequencing (MPSS) on microbead arrays. Nature Biotechnology. 2000;18(6):630-634. doi:10.1038/76469.

[49] Shiraki T, Kondo S, Katayama S, Waki K, Kasukawa T, Kawaji H, et al. Cap analysis gene expression for high-throughput analysis of transcriptional starting point and identification of promoter usage. Proceedings of the National Academy of Sciences. 2003;100(26):15776-15781. doi:10.1073/pnas.2136655100.

[50] Velculescu VE, Zhang L, Vogelstein B, Kinzler KW. Serial analysis of gene expression. Science. 1995;270(5235):484-487. doi:10.1126/science.270.5235.484.

[51] Metzker ML. Sequencing technologies - the next generation. Nature Reviews Genetics. 2010;11(1):31-46. doi:10.1038/nrg2626.

[52] Ozsolak F, Milos PM. RNA sequencing: advances, challenges and opportunities. Nature Reviews Genetics. 2011;12(2):87-98. doi:10.1038/nrg2934.

[53] Schadt EE, Turner S, Kasarskis A. A window into third-generation sequencing. Human Molecular Genetics. 2010;19(R2):R227-R240. doi: 10.1093/hmg/ddq416. 
[54] Heid CA, Stevens J, Livak KJ, Williams PM. Real time quantitative PCR. Genome Research. 1996;6(10):986-994. doi:10.1101/gr.6.10.986.

[55] Simon RM, Dobbin K. Experimental design of DNA microarray experiments. Biotechniques. 2003;34(Suppl 1):S16-S21.

[56] Do JH, Choi D. Normalization of microarray data: single-labeled and dual-labeled arrays. Molecules and Cells. 2006;22(3):254-261.

[57] Dalma-Weiszhausz DD, Warrington J, Tanimoto EY, Miyada CG. The Affymetrix

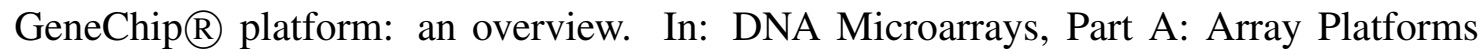
and Wet-Bench Protocols. vol. 410 of Methods in Enzymology. Academic Press; 2006. p. 3-28. doi:10.1016/S0076-6879(06)10001-4.

[58] Yin H, Killeen K. The fundamental aspects and applications of Agilent HPLC-Chip. Journal of Separation Science. 2007;30(10):1427-1434. doi:10.1002/jssc.200600454.

[59] Kuhn K, Baker SC, Chudin E, Lieu M, Oeser S, Bennett H, et al. A novel, highperformance random array platform for quantitative gene expression profiling. Genome Research. 2004;14(11):2347-2356. doi:10.1101/gr.2739104.

[60] Genepix Microarray Scanner. [acesso 12 Maio 2016]. Disponível em: [http://www. moleculardevices.com/systems/microarray-scanners].

[61] Brazma A, Hingamp P, Quackenbush J, Sherlock G, Spellman P, Stoeckert C, et al. Minimum information about a microarray experiment (MIAME) - toward standards for microarray data. Nature Genetics. 2001;29(4):365-372. doi:10.1038/ng1201-365.

[62] Spellman PT, Miller M, Stewart J, Troup C, Sarkans U, Chervitz S, et al. Design and implementation of microarray gene expression markup language (MAGE-ML). Genome Biology. 2002;3(9):1-9.

[63] Rayner TF, Rocca-Serra P, Spellman PT, Causton HC, Farne A, Holloway E, et al. A simple spreadsheet-based, MIAME-supportive format for microarray data: MAGE-TAB. BMC Bioinformatics. 2006;7(1):1-18. doi:10.1186/1471-2105-7-489. 
[64] Affymetrix CEL File Format. [acesso 12 Maio 2016]. Disponível em: [http://www.stat. lsa.umich.edu/ kshedden/Courses/Stat545/Notes/AffxFileFormats/cel.html].

[65] Genepix GPR File Format. [acesso 12 Maio 2016]. Disponível em: [http://mdc.custhelp. com/app/answers/detail/a_id/18883/kw/18883].

[66] Parkinson H, Kapushesky M, Shojatalab M, Abeygunawardena N, Coulson R, Farne A, et al. ArrayExpress - a public database of microarray experiments and gene expression profiles. Nucleic Acids Research. 2007;35(Suppl 1):D747-D750. doi:10.1093/nar/gk1995.

[67] Barrett T, Troup DB, Wilhite SE, Ledoux P, Rudnev D, Evangelista C, et al. NCBI GEO: mining tens of millions of expression profiles - database and tools update. Nucleic Acids Research. 2007;35(Suppl 1):D760-D765. doi:10.1093/nar/gk1887.

[68] Simple Omnibus Format in Text (SOFT). [acesso 12 Maio 2016]. Disponível em: [http: //www.ncbi.nlm.nih.gov/geo/info/soft.html].

[69] MIAME Notation in Markup Language (MINiML). [acesso 12 Maio 2016]. Disponível em: [http://www.ncbi.nlm.nih.gov/geo/info/MINiML.html].

[70] Illumina Genome Analyzer. [acesso 12 Maio 2016]. Disponível em: [http://www. illumina.com/systems/sequencing-platform-comparison.html].

[71] Applied Biosystems SOLiD System. [acesso 12 Maio 2016]. Disponível em: [http://www.lifetechnologies.com/br/en/home/life-science/sequencing/ next-generation-sequencing/solid-next-generation-sequencing.html].

[72] Roche 454 GS FLX. [acesso 12 Maio 2016]. Disponível em: [http://454.com/products/ gs-flx-system/index.asp].

[73] Cock PJA, Fields CJ, Goto N, Heuer ML, Rice PM. The Sanger FASTQ file format for sequences with quality scores, and the Solexa/Illumina FASTQ variants. Nucleic Acids Research. 2010;38(6):1767-1771. doi: 10.1093/nar/gkp1137. 
[74] Tseng GC, Oh M, Rohlin L, Liao JC, Wong WH. Issues in cDNA microarray analysis: quality filtering, channel normalization, models of variations and assessment of gene effects. Nucleic Acids Research. 2001;29(12):2549-2557. doi:10.1093/nar/29.12.2549.

[75] Bullard JH, Purdom E, Hansen KD, Dudoit S. Evaluation of statistical methods for normalization and differential expression in mRNA-Seq experiments. BMC Bioinformatics. 2010;11(1):1-13. doi:10.1186/1471-2105-11-94.

[76] Yang YH, Speed T. Design issues for cDNA microarray experiments. Nature Reviews Genetics. 2002;3(8):579-588. doi:10.1038/nrg863.

[77] Zakharkin SO, Kim K, Mehta T, Chen L, Barnes S, Scheirer KE, et al. Sources of variation in Affymetrix microarray experiments. BMC Bioinformatics. 2005;6(1):214224. doi:10.1186/1471-2105-6-214.

[78] Gautier L, Cope L, Bolstad BM, Irizarry RA. affy - analysis of Affymetrix GeneChip data at the probe level. Bioinformatics. 2004;20(3):307-315. doi:10.1093/bioinformatics/btg405.

[79] $\mathrm{Wu}$ Z. A review of statistical methods for preprocessing oligonucleotide microarrays. Statistical Methods in Medical Research. 2009;18(6):533-541. doi:10.1177/0962280209351924.

[80] Dudoit S, Yang YH, Callow MJ, Speed TP. Statistical methods for identifying differentially expressed genes in replicated cDNA microarray experiments. Statistica Sinica. 2002;12(1):111-139.

[81] Kerr MK, Martin M, Churchill GA. Analysis of variance for gene expression microarray data. Journal of Computational Biology. 2000;7(6):819-837. doi:10.1089/10665270050514954.

[82] Smyth GK. Limma: linear models for microarray data. In: Gentleman R, Carey VJ, Huber W, Irizarry RA, Dudoit S, editors. Bioinformatics and Computational Biology Solutions Using R and Bioconductor. New York: Springer; 2005. p. 397-420. doi:10.1007/0387-29362-0_23. 
[83] Schena M, Shalon D, Heller R, Chai A, Brown PO, Davis RW. Parallel human genome analysis: microarray-based expression monitoring of 1000 genes. Proceedings of the National Academy of Sciences. 1996;93(20):10614-10619.

[84] DeRisi JL, Iyer VR, Brown PO. Exploring the metabolic and genetic control of gene expression on a genomic scale. Science. 1997;278(5338):680-686. doi:10.1126/science.278.5338.680.

[85] Jeffery IB, Higgins DG, Culhane AC. Comparison and evaluation of methods for generating differentially expressed gene lists from microarray data. BMC Bioinformatics. 2006;7(1):1-16. doi:10.1186/1471-2105-7-359.

[86] Bigler J, Rand HA, Kerkof K, Timour M, Russell CB. Cross-study homogeneity of psoriasis gene expression in skin across a large expression range. PLoS ONE. 2013;8(1):1-15. doi:10.1371/journal.pone.0052242.

[87] Zhang J, He Q, Liu QY, Guo W, Deng XM, Zhang WW, et al. Differential gene expression profile in pig adipose tissue treated with/without clenbuterol. BMC Genomics. 2007;8(1):1-12. doi:10.1186/1471-2164-8-433.

[88] Hsu C, Lee W. Detecting differentially expressed genes in heterogeneous diseases using half Student's t-test. International Journal of Epidemiology. 2010;39(6):1597-1604. doi:10.1093/ije/dyq093.

[89] Wang N, Yang C, Xie F, Sun L, Su X, Wang Y, et al. Gadd45a: a novel diabetesassociated gene potentially linking diabetic cardiomyopathy and baroreflex dysfunction. PLoS ONE. 2012;7(12):e49077. doi:10.1371/journal.pone.0049077.

[90] Almansa R, Socias L, Sanchez-Garcia M, Martín-Loeches I, del Olmo M, Andaluz-Ojeda D, et al. Critical COPD respiratory illness is linked to increased transcriptomic activity of neutrophil proteases genes. BMC Research Notes. 2012;5(1):1-8. doi:10.1186/17560500-5-401. 
[91] Baldi P, Long AD. A Bayesian framework for the analysis of microarray expression data: regularized t-test and statistical inferences of gene changes. Bioinformatics. 2001;17(6):509-519. doi:10.1093/bioinformatics/17.6.509.

[92] Tusher VG, Tibshirani R, Chu G. Significance analysis of microarrays applied to the ionizing radiation response. Proceedings of the National Academy of Sciences. 2001;98(9):5116-5121.

[93] Lönnstedt I, Speed T. Replicated microarray data. Statistica Sinica. 2002;12(1):31-46.

[94] Hatfield GW, Hung S, Baldi P. Differential analysis of DNA microarray gene expression data. Molecular Microbiology. 2003;47(4):871-877. doi:10.1046/j.13652958.2003.03298.x.

[95] Cui X, Churchill GA. Statistical tests for differential expression in cDNA microarray experiments. Genome Biology. 2003;4(4):210. doi:10.1186/gb-2003-4-4-210.

[96] Pan W. A comparative review of statistical methods for discovering differentially expressed genes in replicated microarray experiments. Bioinformatics. 2002;18(4):546-554. doi:10.1093/bioinformatics/18.4.546.

[97] Berquó ES, Souza JMP, Gotlieb SLD. Bioestatística. 2nd ed. São Paulo: EPU; 1987. 368 p.

[98] Dudoit S, Shaffer JP, Boldrick JC. Multiple hypothesis testing in microarray experiments. Statistical Science. 2003;18(1):71-103.

[99] Bland JM, Altman DG. Multiple significance tests: the Bonferroni method. BMJ. 1995;310(6973):170. doi:10.1136/bmj.310.6973.170.

[100] Holm S. A simple sequentially rejective multiple test procedure. Scandinavian Journal of Statistics. 1979;6(2):65-70.

[101] Hochberg Y. A sharper Bonferroni procedure for multiple tests of significance. Biometrika. 1988;75(4):800-802. doi:10.1093/biomet/75.4.800. 
[102] Hommel G. A stagewise rejective multiple test procedure based on a modified Bonferroni test. Biometrika. 1988;75(2):383-386. doi:10.1093/biomet/75.2.383.

[103] Benjamini Y, Hochberg Y. Controlling the false discovery rate: a practical and powerful approach to multiple testing. Journal of the Royal Statistical Society Series B (Methodological). 1995;57(1):289-300.

[104] Benjamini Y, Yekutieli D. The control of the false discovery rate in multiple testing under dependency. The Annals of Statistics. 2001;29(4):1165-1188.

[105] Yang X, Liu D, Liu F, Wu J, Zou J, Xiao X, et al. HTQC: a fast quality control toolkit for Illumina sequencing data. BMC Bioinformatics. 2013;14(1):1-4. doi:10.1186/14712105-14-33.

[106] Patel RK, Jain M. NGS QC Toolkit: a toolkit for quality control of next generation sequencing data. PloS ONE. 2012;7(2):1-7. doi:10.1371/journal.pone.0030619.

[107] Cox MP, Peterson DA, Biggs PJ. SolexaQA: At-a-glance quality assessment of Illumina second-generation sequencing data. BMC Bioinformatics. 2010;11(1):1-6. doi:10.1186/1471-2105-11-485.

[108] Schmieder R, Edwards R. Quality control and preprocessing of metagenomic datasets. Bioinformatics. 2011;27(6):863-864. doi:10.1093/bioinformatics/btr026.

[109] Wolf JBW. Principles of transcriptome analysis and gene expression quantification: an RNA-seq tutorial. Molecular Ecology Resources. 2013;13(4):559-572. doi:10.1111/1755-0998.12109.

[110] Martin JA, Wang Z. Next-generation transcriptome assembly. Nature Reviews Genetics. 2011;12(10):671-682. doi:10.1038/nrg3068.

[111] Oshlack A, Robinson MD, Young MD. From RNA-seq reads to differential expression results. Genome Biology. 2010;11(12):1-10. doi:10.1186/gb-2010-11-12-220.

[112] Vijay N, Poelstra JW, Künstner A, Wolf JBW. Challenges and strategies in transcriptome assembly and differential gene expression quantification. A comprehensive in si- 
lico assessment of RNA-seq experiments. Molecular Ecology. 2013;22(3):620-634. doi:10.1111/mec.12014.

[113] Fonseca NA, Rung J, Brazma A, Marioni JC. Tools for mapping high-throughput sequencing data. Bioinformatics. 2012;28(24):3169-3177. doi:10.1093/bioinformatics/bts605.

[114] Thorvaldsdóttir H, Robinson JT, Mesirov JP. Integrative Genomics Viewer (IGV): highperformance genomics data visualization and exploration. Briefings in Bioinformatics. 2013;14(2):178-192. doi:10.1093/bib/bbs017.

[115] Quinlan AR, Hall IM. BEDTools: a flexible suite of utilities for comparing genomic features. Bioinformatics. 2010;26(6):841-842. doi:10.1093/bioinformatics/btq033.

[116] Lawrence M, Huber W, Pagès H, Aboyoun P, Carlson M, Gentleman R, et al. Software for computing and annotating genomic ranges. PLoS Computational Biology. 2013;9(8):110. doi:10.1371/journal.pcbi.1003118.

[117] Anders S, Pyl PT, Huber W. HTSeq - A Python framework to work with high-throughput sequencing data. Bioinformatics. 2015;31(2):166-169. doi:10.1093/bioinformatics/btu638.

[118] Liao Y, Smyth GK, Shi W. featureCounts: an efficient general purpose program for assigning sequence reads to genomic features. Bioinformatics. 2014;30(7):923-930. doi:10.1093/bioinformatics/btt656.

[119] Oshlack A, Wakefield MJ. Transcript length bias in RNA-seq data confounds systems biology. Biology Direct. 2009;4(1):1-10. doi:10.1186/1745-6150-4-14.

[120] Pickrell JK, Marioni JC, Pai AA, Degner JF, Engelhardt BE, Nkadori E, et al. Understanding mechanisms underlying human gene expression variation with RNA sequencing. Nature. 2010;464(7289):768-772. doi:10.1038/nature08872.

[121] Dillies M, Rau A, Aubert J, Hennequet-Antier C, Jeanmougin M, Servant N, et al. A comprehensive evaluation of normalization methods for Illumina high-throughput RNA sequencing data analysis. Briefings in Bioinformatics. 2013;14(6):671-683. doi:10.1093/bib/bbs046. 
[122] Robinson MD, Oshlack A. A scaling normalization method for differential expression analysis of RNA-seq data. Genome Biology. 2010;11(3):1-9. doi:10.1186/gb-2010-11$3-\mathrm{r} 25$.

[123] Anders S, Huber W. Differential expression analysis for sequence count data. Genome Biology. 2010;11(10):1-12. doi:10.1186/gb-2010-11-10-r106.

[124] Risso D, Schwartz K, Sherlock G, Dudoit S. GC-content normalization for RNA-Seq Data. BMC Bioinformatics. 2011;12(1):1-17. doi:10.1186/1471-2105-12-480.

[125] Hansen KD, Irizarry RA, WU Z. Removing technical variability in RNA-seq data using conditional quantile normalization. Biostatistics. 2012;13(2):204-216. doi:10.1093/biostatistics/kxr054.

[126] Bolstad BM, Irizarry RA, Åstrand M, Speed TP. A comparison of normalization methods for high density oligonucleotide array data based on variance and bias. Bioinformatics. 2003;19(2):185-193. doi:10.1093/bioinformatics/19.2.185.

[127] Mortazavi A, Williams BA, McCue K, Schaeffer L, Wold B. Mapping and quantifying mammalian transcriptomes by RNA-Seq. Nature Methods. 2008;5(7):621-628. doi:10.1038/nmeth.1226.

[128] Andrade-Lima LC, Veloso A, Paulsen MT, Menck CFM, Ljungman M. DNA repair and recovery of RNA synthesis following exposure to ultraviolet light are delayed in long genes. Nucleic Acids Research. 2015;43(5):2744-2756. doi:10.1093/nar/gkv148.

[129] Johnson KR, Hindmarch CCT, Salinas YD, Shi Y, Greenwood M, Hoe SZ, et al. A RNASeq analysis of the rat supraoptic nucleus transcriptome: effects of salt loading on gene expression. PLoS ONE. 2015;10(4):1-28. doi:10.1371/journal.pone.0124523.

[130] Prensner JR, Sahu A, Iyer MK, Malik R, Chandler B, Asangani IA, et al. The lncRNAs PCGEM1 and PRNCR1 are not implicated in castration resistant prostate cancer. Oncotarget. 2014;5(6):1434-1438. doi:10.18632/oncotarget.1846. 
[131] Li XZ, Roy CK, Dong X, Bolcun-Filas E, Wang J, Han BW, et al. An ancient transcription factor initiates the burst of piRNA production during early meiosis in mouse testes. Molecular Cell. 2013;50(1):67-81. doi:10.1016/j.molcel.2013.02.016.

[132] Ariani A, Di Baccio D, Romeo S, Lombardi L, Andreucci A, Lux A, et al. RNA sequencing of Populus $x$ canadensis roots identifies key molecular mechanisms underlying physiological adaption to excess zinc. PLoS ONE. 2015;10(2):1-20. doi:10.1371/journal.pone.0117571.

[133] Pallavi B, Shankar KM, Abhiman PB, Iqlas A. Identification of putative genes involved in parasitism in the anchor worm, Lernaea cyprinacea by de novo transcriptome analysis. Experimental Parasitology. 2015;153:191-197. doi:10.1016/j.exppara.2015.03.014.

[134] Bawa P, Zackaria S, Verma M, Gupta S, Srivatsan R, Chaudhary B, et al. Integrative analysis of normal long intergenic non-coding RNAs in prostate cancer. PLoS ONE. 2015;10(5):1-14. doi:10.1371/journal.pone.0122143.

[135] Combes M, Hueber Y, Dereeper A, Rialle S, Herrera J, Lashermes P. Regulatory divergence between parental alleles determines gene expression patterns in hybrids. Genome Biology and Evolution. 2015;7(4):1110-1121. doi:10.1093/gbe/evv057.

[136] Rapaport F, Khanin R, Liang Y, Pirun M, Krek A, Zumbo P, et al. Comprehensive evaluation of differential gene expression analysis methods for RNA-seq data. Genome Biology. 2013;14(9):1-13. doi:10.1186/gb-2013-14-9-r95.

[137] Marioni JC, Mason CE, Mane SM, Stephens M, Gilad Y. RNA-seq: an assessment of technical reproducibility and comparison with gene expression arrays. Genome Research. 2008;18(9):1509-1517. doi:10.1101/gr.079558.108.

[138] Li J, Witten DM, Johnstone IM, Tibshirani R. Normalization, testing, and false discovery rate estimation for RNA-sequencing data. Biostatistics. 2012;13(3):523-538. doi:10.1093/biostatistics/kxr031. 
[139] Auer PL, Doerge RW. A two-stage Poisson model for testing RNA-seq data. Statistical Applications in Genetics and Molecular Biology. 2011;10(1):1-26. doi:10.2202/15446115.1627.

[140] Robinson MD, Smyth GK. Moderated statistical tests for assessing differences in tag abundance. Bioinformatics. 2007;23(21):2881-2887. doi:10.1093/bioinformatics/btm453.

[141] Srivastava S, Chen L. A two-parameter generalized Poisson model to improve the analysis of RNA-seq data. Nucleic Acids Research. 2010;38(17):e170. doi:10.1093/nar/gkq670.

[142] Auer PL, Doerge RW. Statistical design and analysis of RNA sequencing data. Genetics. 2010;185(2):405-416. doi:10.1534/genetics.110.114983.

[143] Robinson MD, McCarthy DJ, Smyth GK. edgeR: a Bioconductor package for differential expression analysis of digital gene expression data. Bioinformatics. 2010;26(1):139-140. doi:10.1093/bioinformatics/btp616.

[144] Di Y, Schafer DW, Cumbie JS, Chang JH. The NBP negative binomial model for assessing differential gene expression from RNA-Seq. Statistical Applications in Genetics and Molecular Biology. 2011;10(1):1-28. doi:10.2202/1544-6115.1637.

[145] Soneson C, Delorenzi M. A comparison of methods for differential expression analysis of RNA-seq data. BMC Bioinformatics. 2013;14(1):1-18. doi:10.1186/1471-2105-14-91.

[146] Love MI, Huber W, Anders S. Moderated estimation of fold change and dispersion for RNA-seq data with DESeq2. Genome Biology. 2014;15(12):1-21. doi:10.1186/s13059014-0550-8.

[147] D'haeseleer P. How does gene expression clustering work? Nature Biotechnology. 2005;23(12):1499-1502. doi:10.1038/nbt1205-1499.

[148] Brazma A, Vilo J. Gene expression data analysis. FEBS letters. 2000;480(1):17-24. doi:10.1016/S0014-5793(00)01772-5. 
[149] Shannon W, Culverhouse R, Duncan J. Analyzing microarray data using cluster analysis. Pharmacogenomics. 2003;4(1):41-52. doi:10.1517/phgs.4.1.41.22581.

[150] Eisen MB, Spellman PT, Brown PO, Botstein D. Cluster analysis and display of genome-wide expression patterns. Proceedings of the National Academy of Sciences. 1998;95(25):14863-14868.

[151] Hartigan JA, Wong MA. Algorithm AS 136: A k-means clustering algorithm. Applied statistics. 1979;28(1):100-108.

[152] Kohonen T. The self-organizing map. Proceedings of the IEEE. 1990;78(9):1464-1480. doi:10.1109/5.58325.

[153] Jolliffe IT. Principal Component Analysis. 2nd ed. Springer Series in Statistics. New York: Springer-Verlag; 2002. 488 p.

[154] Quackenbush J. Computational analysis of microarray data. Nature Reviews Genetics. 2001;2(6):418-427. doi:10.1038/35076576.

[155] Jiang D, Tang C, Zhang A. Cluster analysis for gene expression data: a survey. IEEE Transactions on Knowledge and Data Engineering. 2004;16(11):1370-1386. doi:10.1109/TKDE.2004.68.

[156] Peixoto LL, Wimmer ME, Poplawski SG, Tudor JC, Kenworthy CA, Liu S, et al. Memory acquisition and retrieval impact different epigenetic processes that regulate gene expression. BMC Genomics. 2015;16(Suppl 5):S5. doi:10.1186/1471-2164-16-S5-S5.

[157] Calon A, Lonardo E, Berenguer-Llergo A, Espinet E, Hernando-Momblona X, Iglesias M, et al. Stromal gene expression defines poor-prognosis subtypes in colorectal cancer. Nature Genetics. 2015;47(4):320-329. doi:10.1038/ng.3225.

[158] Moignard V, Woodhouse S, Haghverdi L, Lilly AJ, Tanaka Y, Wilkinson AC, et al. Decoding the regulatory network of early blood development from single-cell gene expression measurements. Nature Biotechnology. 2015;33(3):269-276. doi:10.1038/nbt.3154. 
[159] Welch JD, Baran-Gale J, Perou CM, Sethupathy P, Prins JF. Pseudogenes transcribed in breast invasive carcinoma show subtype-specific expression and ceRNA potential. BMC Genomics. 2015;16(1):1-16. doi:10.1186/s12864-015-1227-8.

[160] Ikeda K, Tomimoto S, Tsuchiya S, Hamagami K, Shintani N, Sugimoto Y, et al. Comparative gene expression profiles in pancreatic islets associated with agouti yellow mutation and PACAP overexpression in mice. Biochemistry and Biophysics Reports. 2015;2:179_ 183. doi:10.1016/j.bbrep.2015.06.006.

[161] Ryan PT, Ó’Maoiléidigh DS, Drost H, Kwaśniewska K, Gabel A, Grosse I, et al. Patterns of gene expression during Arabidopsis flower development from the time of initiation to maturation. BMC Genomics. 2015;16(1):1-12. doi:10.1186/s12864-015-1699-6.

[162] Lissner MM, Thomas BJ, Wee K, Tong A, Kollmann TR, Smale ST. Age-related gene expression differences in monocytes from human neonates, young adults, and older adults. PLoS ONE. 2015;10(7):1-18. doi:10.1371/journal.pone.0132061.

[163] Liu Y, Morley M, Brandimarto J, Hannenhalli S, Hu Y, Ashley EA, et al. RNASeq identifies novel myocardial gene expression signatures of heart failure. Genomics. 2015;105(2):83-89. doi:10.1016/j.ygeno.2014.12.002.

[164] Khatri P, Drăghici S. Ontological analysis of gene expression data: current tools, limitations, and open problems. Bioinformatics. 2005;21(18):3587-3595. doi:10.1093/bioinformatics/bti565.

[165] Curtis RK, Orešič M, Vidal-Puig A. Pathways to the analysis of microarray data. Trends in Biotechnology. 2005;23(8):429-435. doi:10.1016/j.tibtech.2005.05.011.

[166] Dopazo J. Functional interpretation of microarray experiments. Omics: a journal of integrative biology. 2006;10(3):398-410. doi:10.1089/omi.2006.10.398.

[167] Ashburner M, Ball CA, Blake JA, Botstein D, Butler H, Cherry JM, et al. Gene Ontology: tool for the unification of biology. Nature Genetics. 2000;25(1):25-29. doi:10.1038/75556. 
[168] Joshi-Tope G, Gillespie M, Vastrik I, D’Eustachio P, Schmidt E, de Bono B, et al. Reactome: a knowledgebase of biological pathways. Nucleic Acids Research. 2005;33(Suppl 1):D428-D432. doi:10.1093/nar/gki072.

[169] Kanehisa M, Goto S. KEGG: Kyoto Encyclopedia of Genes and Genomes. Nucleic Acids Research. 2000;28(1):27-30. doi:10.1093/nar/28.1.27.

[170] Matys V, Fricke E, Geffers R, Gößling E, Haubrock M, Hehl R, et al. TRANSFAC®: transcriptional regulation, from patterns to profiles. Nucleic Acids Research. 2003;31(1):374-378. doi:10.1093/nar/gkg108.

[171] Huang DW, Sherman BT, Lempicki RA. Bioinformatics enrichment tools: paths toward the comprehensive functional analysis of large gene lists. Nucleic Acids Research. 2009;37(1):1-13. doi:10.1093/nar/gkn923.

[172] Osier MV, Zhao H, Cheung K. Handling multiple testing while interpreting microarrays with the Gene Ontology Database. BMC Bioinformatics. 2004;5(1):1-7. doi:10.1186/1471-2105-5-124.

[173] Antezana E, Kuiper M, Mironov V. Biological knowledge management: the emerging role of the semantic web technologies. Briefings in Bioinformatics. 2009;10(4):392-407. doi:10.1093/bib/bbp024.

[174] Grossmann G, Thiagarajan R, Schrefl M, Stumptner M. Conceptual modeling approaches for dynamic web service composition. In: Kaschek R, Delcambre L, editors. The Evolution of Conceptual Modeling: From a Historical Perspective towards the Future of Conceptual Modeling. Berlin: Springer; 2011. p. 180-204. doi:10.1007/978-3-64217505-3_9.

[175] Heath T, Bizer C. Linked Data: Evolving the Web into a Global Data Space. 1st ed. Synthesis Lectures on the Semantic Web: Theory and Technology. San Rafael: Morgan \& Claypool; 2011. 136 p. 
[176] Bizer C, Heath T, Berners-Lee T. Linked data - the story so far. International Journal on Semantic Web and Information Systems. 2009;5(3):1-22. doi:10.4018/jswis.2009081901.

[177] Berners-Lee T, Fielding R, Masinter L. Uniform Resource Identifier (URI): Generic Syntax; 2005 61p. Report No.: RFC 3986.

[178] World Wide Web Consortium. RDF 1.1 Concepts and Abstract Syntax; 2014.

[179] World Wide Web Consortium. OWL 2 Web Ontology Language Primer (Second Edition); 2012.

[180] World Wide Web Consortium. OWL 2 Web Ontology Language Document Overview (Second Edition); 2012.

[181] World Wide Web Consortium. RDF 1.1 XML Syntax; 2014.

[182] W3C OWL Working Group. [acesso 12 Maio 2016]. Disponível em: [http://www.w3. org/2007/OWL/wiki/OWL_Working_Group].

[183] World Wide Web Consortium. OWL 2 Web Ontology Language Mapping to RDF Graphs (Second Edition); 2012.

[184] World Wide Web Consortium. OWL 2 Web Ontology Language XML Serialization (Second Edition); 2012.

[185] World Wide Web Consortium. OWL 2 Web Ontology Language Structural Specification and Functional-Style Syntax (Second Edition); 2012.

[186] World Wide Web Consortium. OWL 2 Web Ontology Language Manchester Syntax (Second Edition); 2012.

[187] World Wide Web Consortium. RDF 1.1 Turtle; 2014.

[188] World Wide Web Consortium. OWL 2 Web Ontology Language Direct Semantics (Second Edition); 2012. 
[189] World Wide Web Consortium. OWL 2 Web Ontology Language RDF-Based Semantics (Second Edition); 2012.

[190] World Wide Web Consortium. OWL 2 Web Ontology Language Profiles (Second Edition); 2012.

[191] Knublauch H, Fergerson RW, Noy NF, Musen MA. The Protégé OWL plugin: an open development environment for semantic web applications. In: McIlraith SA, Plexousakis D, van Harmelen F, editors. The Semantic Web - ISWC 2004. Third International Semantic Web Conference; 7-11 Nov. 2004; Hiroshima. Berlin: Springer; 2004. p. 229-243. doi:10.1007/978-3-540-30475-3_17.

[192] TopBraid Composer. [acesso 12 Maio 2016]. Disponível em: [http://www.topquadrant. com/tools/modeling-topbraid-composer-standard-edition/].

[193] SWOOP. [acesso 12 Maio 2016]. Disponível em: [http://code.google.com/p/swoop/].

[194] NeOn-Toolkit. [acesso 12 Maio 2016]. Disponível em: [http://www.neon-toolkit.org/].

[195] OBO Format. [acesso 12 Maio 2016]. Disponível em: [http://owlcollab.github.io/ oboformat/doc/obo-syntax.html].

[196] Fact++. [acesso 12 Maio 2016]. Disponível em: [http://owl.cs.manchester.ac.uk/fact++/].

[197] Hermit. [acesso 12 Maio 2016]. Disponível em: [http://hermit-reasoner.com/].

[198] RacerPro. [acesso 12 Maio 2016]. Disponível em: [http://www.racer-systems.com/].

[199] Papazoglou MP. Service-oriented computing: concepts, characteristics and directions. In: Proceedings of the Fourth International Conference on Conference on Web Information Systems Engineering (WISE); 10-12 Dez. 2003. IEEE; 2003. p. 3-12. doi:10.1109/WISE.2003.1254461.

[200] Valipour MH, Amirzafari B, Maleki KN, Daneshpour N. A brief survey of software architecture concepts and service oriented architecture. In: Proceedings of the 2 nd IEEE International Conference on Computer Science and Information Technology (ICCSIT); 8-11 Ago. 2009; Beijing. IEEE; 2009. p. 34-38. doi:10.1109/ICCSIT.2009.5235004. 
[201] World Wide Web Consortium. SOAP Version 1.2 Part 1: Messaging Framework (Second edition); 2007.

[202] Fielding RT. Architectural styles and the design of network-based software architectures [PhD thesis]. [Irvine]: University of California; 2000. 179 p.

[203] Fielding R, Gettys J, Mogul J, Frystyk H, Masinter L, Leach P, et al. Hypertext Transfer Protocol - HTTP/1.1. Internet Engineering Task Force (IETF); 1999. 176p. Report No.: RFC 2616.

[204] Pautasso C, Zimmermann O, Leymann F. Restful web services vs. "big" web services: making the right architectural decision. In: Proceedings of the 17th International Conference on World Wide Web; Beijing. New York: ACM; 2008. p. 805-814. doi:10.1145/1367497.1367606.

[205] Benslimane D, Dustdar S, Sheth A. Services mashups: the new generation of web applications. IEEE Internet Computing. 2008;12(5):13-15. doi:10.1109/MIC.2008.110.

[206] The UniProt Consortium. Activities at the Universal Protein Resource (UniProt). Nucleic Acids Research. 2014;42(D1):D191-D198. doi:10.1093/nar/gkt1140.

[207] KEGG REST-API. [acesso 12 Maio 2016]. Disponível em: [http://www.kegg.jp/kegg/ rest/].

[208] World Wide Web Consortium. Web Application Description Language (WADL); 2009.

[209] World Wide Web Consortium. Web Services Description Language (WSDL) Version 2.0 Part1: Core Language; 2007.

[210] Takase T, Makino S, Kawanaka S, Ueno K, Ferris C, Ryman A. Definition languages for RESTful web services: WADL vs. WSDL 2.0. IBM Research. 2008;p. 1-11.

[211] World Wide Web Consortium. RDFa Core 1.1 - Third Edition; 2015.

[212] World Wide Web Consortium. Gleaning Resource Descriptions from Dialects of Languages (GRDDL); 2007. 
[213] OASIS. UDDI Version 3.0.2; 2004.

[214] World Wide Web Consortium. OWL-S: Semantic Markup for Web Services; 2004.

[215] Martin D, Paolucci M, McIlraith S, Burstein M, McDermott D, McGuinness D, et al. Bringing semantics to web services: the OWL-S approach. In: Cardoso J, Sheth A, editors. Semantic Web Services and Web Process Composition. First International Workshop SWSWPC; 6 Jul. 2004; San Diego. Berlin: Springer; 2005. p. 26-42. doi:10.1007/978-3-540-30581-1_4.

[216] World Wide Web Consortium. Web Service Modeling Ontology (WSMO); 2005.

[217] Roman D, Keller U, Lausen H, de Bruijn J, Lara R, Stollberg M, et al. Web Service Modeling Ontology. Applied Ontology. 2005;1(1):77-106.

[218] World Wide Web Consortium. Semantic annotations for WSDL and XML Schema; 2007.

[219] Kopecky J, Vitvar T, Bournez C, Farrell J. SAWSDL: semantic annotations for WSDL and XML Schema. IEEE Internet Computing. 2007;11(6):60-67. doi:10.1109/MIC.2007.134.

[220] World Wide Web Consortium. SA-REST: Semantic Annotation of Web Resources; 2010.

[221] Sheth AP, Gomadam K, Lathem J. SA-REST: semantically interoperable and easier-to-use services and mashups. IEEE Internet Computing. 2007;11(6):91-94. doi:10.1109/MIC.2007.133.

[222] Elenius D, Denker G, Martin D, Gilham F, Khouri J, Sadaati S, et al. The OWL-S editor - a development tool for semantic web services. In: Gómez-Pérez A, Euzenat J, editors. The Semantic Web: Research and Applications. Second European Semantic Web Conference (ESWC); 29 Maio 2005; Heraklion. Berlin: Springer; 2005. p. 78-92. doi:10.1007/11431053_6.

[223] Heß A, Johnston E, Kushmerick N. ASSAM: a tool for semi-automatically annotating semantic web services. In: McIlraith SA, Plexousakis D, van Harmelen F, editors. The Semantic Web - ISWC 2004. Third International Semantic Web Conference; 7-11 Nov. 
2004; Hiroshima. Berlin: Springer; 2004. p. 320-334. doi:10.1007/978-3-540-304753_23.

[224] Srinivasan N, Paolucci M, Sycara K. CODE: a development environment for OWL-S web services. Pittsburgh: Carnegie Mellon University; 2005. 15p. Report No.: CMU-RITR-05-48.

[225] World Wide Web Consortium. Web Service Modeling Language (WSML); 2005.

[226] Fensel D, Bussler C. The Web Service Modeling Framework WSMF. Electronic Commerce Research and Applications. 2002;1(2):113 - 137. doi:10.1016/S15674223(02)00015-7.

[227] Dimitrov M, Simov A, Momtchev V, Konstantinov M. WSMO studio - a semantic web services modelling environment for WSMO. In: Franconi E, Kifer M, May W, editors. The Semantic Web: Research and Applications. 4th European Semantic Web Conference (ESWC); June 3-7 Jun. 2007; Innsbruck. Berlin: Springer; 2007. p. 749-758. doi:10.1007/978-3-540-72667-8_53.

[228] Eclipse IDE for Java EE Developers. [acesso 12 Maio 2016]. Disponível em: [http: //www.eclipse.org/downloads/moreinfo/jee.php].

[229] WSMO4J. [acesso 12 Maio 2016]. Disponível em: [http://wsmo4j.sourceforge.net/].

[230] Kerrigan M, Mocan A, Tanler M, Fensel D. The Web Service Modeling Toolkit - an integrated development environment for semantic web services. In: Franconi E, Kifer M, May W, editors. The Semantic Web: Research and Applications. 4th European Semantic Web Conference (ESWC); June 3-7 Jun. 2007; Innsbruck. Berlin: Springer; 2007. p. 789-798. doi:10.1007/978-3-540-72667-8_57.

[231] World Wide Web Consortium. Web Service Execution Environment (WSMX); 2005.

[232] SAWSDL4J. [acesso 12 Maio 2016]. Disponível em: [http://lsdis.cs.uga.edu/projects/ meteor-s/opensource/sawsdl4j/]. 
[233] Stavropoulos TG, Vrakas D, Vlahavas I. Iridescent: a tool for rapid semantic annotation of web service descriptions. In: Proceedings of the 3rd International Conference on Web Intelligence, Mining and Semantics (WIMS); 2013; Madrid. New York: ACM; 2013. p. 12:1-12:9. doi:10.1145/2479787.2479797.

[234] Gomadam K, Verma K, Brewer D, Sheth AP, Miller JA. Radiant: a tool for semantic annotation of web services. In: 4th International Semantic Web Conference (ISWC); 6-10 Nov. 2005; Galway; 2005. Demo paper.

[235] Woden4SAWSDL. [acesso 12 Maio 2016]. Disponível em: [http://lsdis.cs.uga.edu/ projects/meteor-s/opensource/woden4sawsdl/].

[236] SA-REST Annotator. [acesso 12 Maio 2016]. Disponível em: [http://sourceforge.net/ projects/sarestannotator/].

[237] Ranabahu A, Parikh P, Panahiazar M, Sheth A, Logan-Klumpler F. Kino: a generic document management system for biologists using SA-REST and faceted search. In: Proceedings of the fifth IEEE International Conference on Semantic Computing (ICSC); 18-21 Set. 2011; Palo Alto. IEEE; 2011. p. 205-208. doi:10.1109/ICSC.2011.79.

[238] Rao J, Su X. A survey of automated web service composition methods. In: Cardoso J, Sheth A, editors. Proceedings of the 1st International Workshop on Semantic Web Services and Web Process Composition (SWSWPC); 6 Jul. 2004; San Diego. Berlin: Springer; 2005. p. 43-54. doi:10.1007/978-3-540-30581-1_5.

[239] Khadka R, Sapkota B. An evaluation of dynamic web service composition approaches. In: van Sinderen MJ, Sapkota B, editors. Proceedings of the 4th International Workshop on Architectures, Concepts and Technologies for Service Oriented Computing (ACT4SOC); 23 Jul. 2010; Athens. Portugal: SciTePress; 2010. p. 67-79.

[240] da Silva EMG, Ferreira Pires L, van Sinderen MJ. Dynamic composition of services: why, where and how. In: Cordeiro J, van Sinderen MJ, Shishkov BB, editors. Proceedings of the Second International Workshop on Enterprise Systems and Technology (IWEST); 23 Maio 2008; Enschede. INSTICC Press; 2008. p. 73-85. 
[241] Milanovic N, Malek M. Current solutions for web service composition. IEEE Internet Computing. 2004;8(6):51-59. doi:10.1109/MIC.2004.58.

[242] Küster U, Stern M, König-Ries B. A classification of issues and approaches in automatic service composition. In: Zirpins C, Ortiz G, Lamersdorf W, Emmerich W, editors. Proceedings of the 1st International Workshop on Engineering Service Compositions (WESC); 1 Dez. 2005; Amsterdam; 2005. p. 25-33.

[243] González AR, Callahan A, Cruz-Toledo J, Garcia A, Aranguren ME, Dumontier M, et al. Automatically exposing OpenLifeData via SADI semantic web services. Journal of Biomedical Semantics. 2014;5(1):1-12. doi:10.1186/2041-1480-5-46.

[244] Bukhari AC, Klein A, Baker CJO. Towards interoperable BioNLP semantic web services using the SADI framework. In: Baker CJO, Butler G, Jurisica I, editors. Data Integration in the Life Sciences. 9th International Conference DILS; 11-12 Jul. 2013; Montreal. Berlin: Springer; 2013. p. 69-80. doi:10.1007/978-3-642-39437-9_6.

[245] Riazanov A, Laurila JB, Baker CJ. Deploying mutation impact text-mining software with the SADI Semantic Web Services framework. BMC Bioinformatics. 2011;12(Suppl 4):S6. doi:10.1186/1471-2105-12-S4-S6.

[246] The MOBY-Mygrid Service Ontology. [acesso 12 Maio 2016]. Disponível em: [www. mygrid.org.uk/mygrid-moby-service].

[247] Athanasopoulos M, Kontogiannis K. Extracting REST resource models from procedureoriented service interfaces. Journal of Systems and Software. 2015;100:149-166. doi:10.1016/j.jss.2014.10.038.

[248] Echeverria RR, Macias F, Pavon VM, Conejero JM, Figueroa FS. Legacy web application modernization by generating a REST service layer. IEEE Latin America Transactions. 2015;13(7):2379-2383. doi:10.1109/TLA.2015.7273801.

[249] Rodríguez-Echeverría R, Pavón VM, Macías F, Conejero JM, Clemente PJ, SánchezFigueroa F. Generating a conceptual representation of a legacy web application. In: Lin 
X, Manolopoulos Y, Srivastava D, Huang G, editors. Web Information Systems Engineering - WISE. 14th International Conference; 13-15 Out. 2013; Nanjing. Berlin: Springer; 2013. p. 231-240. doi:10.1007/978-3-642-41154-0_17.

[250] Object Management Group. Unified Modeling Language (UML) Version 2.5; 2015.

[251] Laitkorpi M, Selonen P, Systa T. Towards a model-driven process for designing RESTful web services. In: Proceedings of the IEEE International Conference on Web Services (ICWS); 6-10 Jul. 2009; Los Angeles. IEEE; 2009. p. 173-180. doi:10.1109/ICWS.2009.63.

[252] Liu Y, Wang Q, Zhuang M, Zhu Y. Reengineering legacy systems with RESTful web service. In: Proceedings of the 32nd Annual IEEE International Computer Software and Applications Conference (COMPSAC); 28 Jul. 2008; Turku. IEEE; 2008. p. 785-790. doi:10.1109/COMPSAC.2008.89.

[253] Yadav HN, Patel RV. DBpedia based SAWSDL for semantic web services. In: Proceedings of the 2nd International Conference on Computing for Sustainable Global Development (INDIACom); 11-13 Mar. 2015; New Delhi. IEEE; 2015. p. 35-39.

[254] Lehmann J, Isele R, Jakob M, Jentzsch A, Kontokostas D, Mendes PN, et al. DBpedia - a large-scale, multilingual knowledge base extracted from Wikipedia. Semantic Web. 2015;6(2):167-195. doi:10.3233/SW-140134.

[255] Wilkinson MD, Links M. BioMOBY: an open source biological web services proposal. Briefings in Bioinformatics. 2002;3(4):331-341. doi:10.1093/bib/3.4.331.

[256] Zhang M, Duan Z, Zhao C. Semi-automatically annotating data semantics to web services using ontology mapping. In: Proceedings of the 12th International Conference on Computer Supported Cooperative Work in Design (CSCWD); 16-18 Abr. 2008; Xi'an. IEEE; 2008. p. 470-475. doi:10.1109/CSCWD.2008.4537024.

[257] Giardine B, Riemer C, Hardison RC, Burhans R, Elnitski L, Shah P, et al. Galaxy: a platform for interactive large-scale genome analysis. Genome Research. 2005;15(10):14511455. doi:10.1101/gr.4086505. 
[258] Butcher LM, Ito M, Brimpari M, Morris TJ, Soares FAC, Ahrlund-Richter L, et al. NonCG DNA methylation is a biomarker for assessing endodermal differentiation capacity in pluripotent stem cells. Nature Communications. 2016;7. doi:10.1038/ncomms 10458.

[259] Tremblay É, Thibault M, Ferretti E, Babakissa C, Bertelle V, Bettolli M, et al. Gene expression profiling in necrotizing enterocolitis reveals pathways common to those reported in Crohn's disease. BMC Medical Genomics. 2016;9(1):1-12. doi:10.1186/s12920-0160166-9.

[260] Rolfe SA, Strelkov SE, Links MG, Clarke WE, Robinson SJ, Djavaheri M, et al. The compact genome of the plant pathogen Plasmodiophora brassicae is adapted to intracellular interactions with host Brassica spp. BMC Genomics. 2016;17(1):1-15. doi:10.1186/s12864-016-2597-2.

[261] Thorpe P, Cock PJA, Bos J. Comparative transcriptomics and proteomics of three different aphid species identifies core and diverse effector sets. BMC Genomics. 2016;17(1):1-18. doi:10.1186/s12864-016-2496-6.

[262] Wolstencroft K, Haines R, Fellows D, Williams A, Withers D, Owen S, et al. The Taverna workflow suite: designing and executing workflows of Web Services on the desktop, web or in the cloud. Nucleic Acids Research. 2013;41(W1):W557-W561. doi:10.1093/nar/gkt328.

[263] Ba M, Ferré S, Ducassé M. Safe suggestions based on type convertibility to guide workflow composition. In: Esposito F, Pivert O, Hacid M, Rás WZ, Ferilli S, editors. Foundations of Intelligent Systems. 22nd International Symposium ISMIS; 21-23 Out. 2015; Lyon. Cham: Springer International Publishing; 2015. p. 230-236. doi:10.1007/978-3319-25252-0_25.

[264] Rice P, Longden I, Bleasby A. EMBOSS: The European Molecular Biology Open Software Suite. Trends in Genetics. 2000;16(6):276-277. doi:10.1016/S01689525(00)02024-2. 
[265] Lamprecht AL, Margaria T, Steffen B. Bio-jETI: a framework for semantics-based service composition. BMC Bioinformatics. 2009;10(Suppl 10):S8. doi:10.1186/1471-210510-S10-S8.

[266] Steffen B, Margaria T, Nagel R, Jörges S, Kubczak C. Model-driven development with the jABC. In: Bin E, Ziv A, Ur S, editors. Hardware and Software, Verification and Testing. Second International Haifa Verification Conference (HVC); 23-26 Out. 2006; Haifa. Berlin: Springer; 2006. p. 92-108. doi:10.1007/978-3-540-70889-6_7.

[267] BioMoby Repository. [acesso 12 Maio 2016]. Disponível em: [http://www.biomoby. org/].

[268] EBI Repository. [acesso 12 Maio 2016]. Disponível em: [http://www.ebi.ac.uk/].

[269] Karlsson J, Trelles O. MAPI: a software framework for distributed biomedical applications. Journal of Biomedical Semantics. 2013;4(1):1-12. doi:10.1186/2041-1480-4-4.

[270] Ríos J, Karlsson J, Trelles O. Magallanes: a web services discovery and automatic workflow composition tool. BMC Bioinformatics. 2009;10(1):1-12. doi:10.1186/14712105-10-334.

[271] Guardia GDA, Ferreira Pires L, Vêncio RZN, Malmegrim KCR, de Farias CRG. A methodology for the development of RESTful semantic web services for gene expression analysis. PLoS ONE. 2015;10(7):1-28. doi:10.1371/journal.pone.0134011.

[272] Object Management Group. Business Process Model and Notation (BPMN) Version $2.0 .2 ; 2013$.

[273] Gamma E, Helm R, Johnson R, Vlissides J. Adapter. In: Design Patterns: Elements of Reusable Object-Oriented Software. Addison-Wesley; 1995. p. 121-130.

[274] Sun Microsystems. JAX-RS: Java API for RESTful Web Services; 2009.

[275] Java Native Interface (JNI) Version 6.0. [acesso 12 Maio 2016]. Disponível em: [http: //docs.oracle.com/javase/6/docs/technotes/guides/jni/]. 
[276] Jersey Reference Implementation of JAX-RS. [acesso 12 Maio 2016]. Disponível em: [http://jersey.java.net/].

[277] Projeto Apache Axis2/Java. [acesso 12 Maio 2016]. Disponível em: [http://axis.apache. org/axis2/java/core/].

[278] Apache Ant Project. [acesso 12 Maio 2016]. Disponível em: [http://ant.apache.org/].

[279] Projeto Apache Woden. [acesso 12 Maio 2016]. Disponível em: [http://ws.apache.org/ woden/].

[280] Shah T, Rabhi F, Ray P, Taylor K. A guiding framework for ontology reuse in the biomedical domain. In: Proceedings of the 47th Hawaii International Conference on System Sciences (HICSS); 6-9 Jan. 2014; Waikoloa. IEEE; 2014. p. 2878-2887. doi:10.1109/HICSS.2014.360.

[281] Poveda-Villalón M, Suárez-Figueroa MC, Gómez-Pérez A. The landscape of ontology reuse in Linked Data. In: Proceedings of the 1st Ontology Engineering in a Data-driven World (OEDW); 9 Out. 2012; Galway. Berlin: Springer; 2012. p. [11].

[282] Uschold M, Healy M, Williamson K, Clark P, Woods S. Ontology reuse and application. In: Proceedings of the International Conference on Formal Ontology in Information Systems (FOIS); 1998. p. [15].

[283] Mizoguchi R, Vanwelkenhuysen J, Ikeda M. Task ontology for reuse of problem solving knowledge. In: Mars NJI, editor. Towards Very Large Knowledge Bases. IOS Press; 1995. p. 46-59.

[284] Wächter T, Fabian G, Schroeder M. DOG4DAG: Semi-automated ontology generation in OBO-Edit and Protégé. In: Proceedings of the 4th International Workshop on Semantic Web Applications and Tools for the Life Sciences (SWAT4LS); 7-9 Dez. 2011; London. New York: ACM; 2012. p. 119-120. doi:10.1145/2166896.2166926.

[285] Uschold M, Gruninger M. Ontologies: principles, methods and applications. The Knowledge Engineering Review. 1996;11(2):93-136. doi:10.1017/S0269888900007797. 
[286] Uschold M, King M. Towards a methodology for building ontologies. Edinburgh: University of Edinburgh; 1995. 12p. Report No.: AIAI-TR-183. Presented at: Workshop on Basic Ontological Issues in Knowledge Sharing, held in conjunction with IJCAI-95.

[287] Grüninger M, Fox MS. Methodology for the design and evaluation of ontologies. In: Workshop on Basic Ontological Issues in Knowledge Sharing. International Joint Conference on Artificial Intelligence; 1995. p. 1-10.

[288] Fernández-López M, Gómez-Pérez A, Juristo N. Methontology: from ontological art towards ontological engineering. In: Proceedings of the Ontological Engineering AAAI97 Spring Symposium Series; 24-26 Mar. 1997; Palo Alto. American Asociation for Artificial Intelligence; 1997. p. 33-40.

[289] Benjamins VR, Fensel D. The ontological engineering initiative (KA) 2. In: Guarino N, editor. Proceedings of the International Conference on Formal Ontologies in Information Systems (FOIS); Jun. 1998; Trento. IOS-Press; 1998. p. 287-301.

[290] Gómez-Pérez A, Rojas-Amaya MD. Ontological reengineering for reuse. In: Fensel D, Studer R, editors. Knowledge Acquisition, Modeling and Management. 11th European Workshop EKAW'99; 26-29 Maio 1999; Dagstuhl Castle. Berlin: Springer; 1999. p. 139-156. doi:10.1007/3-540-48775-1_9.

[291] Fernández-López M, Gómez-Pérez A. Overview and analysis of methodologies for building ontologies. The Knowledge Engineering Review. 2002;17(2):129-156. doi:10.1017/S0269888902000462.

[292] Corcho O, Fernández-López M, Gómez-Pérez A. Methodologies, tools and languages for building ontologies. Where is their meeting point? Data \& Knowledge Engineering. 2003;46(1):41-64. doi:10.1016/S0169-023X(02)00195-7.

[293] Noy NF, McGuinness DL. Ontology development 101: a guide to creating your first ontology. Stanford: Stanford Medical Informatics; 2001. 25p. Report No.: SMI-20010880 .

[294] World Wide Web Consortium. XSL Transformations (XSLT) Version 3.0; 2015. 
[295] World Wide Web Consortium. SPARQL 1.1 Overview; 2013.

[296] Activiti BPM Platform. [acesso 12 Maio 2016]. Disponível em: [http://www.activiti. org/].

[297] Eclipse BPMN2 Modeler. [acesso 12 Maio 2016]. Disponível em: [https://www.eclipse. org/bpmn2-modeler/].

[298] Intalio Platform. [acesso 12 Maio 2016]. Disponível em: [http://www.intalio.com/].

[299] Java Web Start. [acesso 12 Maio 2016]. Disponível em: [http://www.oracle.com/ technetwork/java/javase/javawebstart/index.html].

[300] WAR File Format. [acesso 12 Maio 2016]. Disponível em: [http://help.eclipse.org/juno/ index.jsp?topic=\%2Forg.eclipse.wst.webtools.doc.user\%2Ftopics\%2Fcwwarovr.html].

[301] Camunda Java API. [acesso 12 Maio 2016]. Disponível em: [https://camunda.com/bpm/ features/implement/].

[302] Object Management Group. Object Constraint Language (OCL) Version 2.4; 2014.

[303] Miyazaki FA, Guardia GDA, Vêncio RZN, de Farias CRG. Semantic integration of gene expression analysis tools and data sources using software connectors. BMC Genomics. 2013;14(Suppl 6):S2. doi:10.1186/1471-2164-14-S6-S2.

[304] Guardia GDA, Vêncio RZN, de Farias CRG. A UML profile for the OBO Relation Ontology. BMC Genomics. 2012;13(Suppl 5):S3. doi:10.1186/1471-2164-13-S5-S3.

[305] Eilbeck K, Lewis SE, Mungall CJ, Yandell M, Stein L, Durbin R, et al. The Sequence Ontology: a tool for the unification of genome annotations. Genome Biology. 2005;6(5):112. doi:10.1186/gb-2005-6-5-r44.

[306] Smith B, Ceusters W, Klagges B, Köhler J, Kumar A, Lomax J, et al. Relations in biomedical ontologies. Genome Biology. 2005;6(5):1-15. doi:10.1186/gb-2005-6-5-r46.

[307] Software Ontology. [acesso 12 Maio 2016]. Disponível em: [http://www.ebi.ac.uk/efo/ swo]. 
[308] DAVID Web Service Repository. [acesso 12 Maio 2016]. Disponível em: [https://david. ncifcrf.gov/content.jsp?file=WS.html].

[309] Urbanek S. Rserve - A fast way to provide R functionality to applications. In: Hornik F K Leisch, Zeileis A, editors. Proceedings of the 3rd International Workshop on Distributed Statistical Computing (DSC); 20-22 Mar. 2003; Vienna; 2003. .

[310] Rserve Package. [acesso 12 Maio 2016]. Disponível em: [http://cran.r-project.org/web/ packages/Rserve/index.html].

[311] Affy Package. [acesso 12 Maio 2016]. Disponível em: [http://www.bioconductor.org/ packages/release/bioc/html/affy.html].

[312] Gentleman RC, Carey VJ, Bates DM, Bolstad B, Dettling M, Dudoit S, et al. Bioconductor: open software development for computational biology and bioinformatics. Genome Biology. 2004;5(10):1-16. doi:10.1186/gb-2004-5-10-r80.

[313] Projeto Bioconductor. [acesso 12 Maio 2016]. Disponível em: [http://www.bioconductor. org/].

[314] Limma Package. [acesso 12 Maio 2016]. Disponível em: [http://www.bioconductor.org/ packages/release/bioc/html/limma.html].

[315] Farcomeni A. A review of modern multiple hypothesis testing, with particular attention to the false discovery proportion. Statistical Methods in Medical Research. 2007;p. 1-42. doi:10.1177/0962280206079046.

[316] de Hoon MJL, Imoto S, Nolan J, Miyano S. Open source clustering software. Bioinformatics. 2004;20(9):1453-1454. doi:10.1093/bioinformatics/bth078.

[317] Saldanha AJ. Java Treeview - extensible visualization of microarray data. Bioinformatics. 2004;20(17):3246-3248. doi:10.1093/bioinformatics/bth349.

[318] Package gProfileR Version 0.61. [acesso 12 Maio 2016]. Disponível em: [http://cran. r-project.org/web/packages/gProfileR/gProfileR.pdf]. 
[319] Maglott D, Ostell J, Pruitt KD, Tatusova T. Entrez Gene: gene-centered information at NCBI. Nucleic Acids Research. 2005;33(Suppl 1):D54-D58. doi:10.1093/nar/gki031.

[320] Flicek P, Ahmed I, Amode MR, Barrell D, Beal K, Brent S, et al. Ensembl 2013. Nucleic Acids Research. 2013;41(D1):D48-D55. doi:10.1093/nar/gks1236.

[321] Kersey PJ, Lawson D, Birney E, Derwent PS, Haimel M, Herrero J, et al. Ensembl Genomes: extending Ensembl across the taxonomic space. Nucleic Acids Research. 2010;38(Suppl 1):D563-D569. doi:10.1093/nar/gkp871.

[322] Robinson PN, Mundlos S. The human phenotype ontology. Clinical Genetics. 2010;77(6):525-534. doi:10.1111/j.1399-0004.2010.01436.x.

[323] Griffiths-Jones S, Grocock RJ, van Dongen S, Bateman A, Enright AJ. miRBase: microRNA sequences, targets and gene nomenclature. Nucleic Acids Research. 2006;34(Suppl 1):D140-D144. doi:10.1093/nar/gkj112.

[324] Stark C, Breitkreutz B, Reguly T, Boucher L, Breitkreutz A, Tyers M. BioGRID: a general repository for interaction datasets. Nucleic Acids Research. 2006;34(Suppl 1):D535D539. doi:10.1093/nar/gkj109.

[325] Benson DA, Clark K, Karsch-Mizrachi I, Lipman DJ, Ostell J, Sayers EW. GenBank. Nucleic Acids Research. 2015;43(D1):D30-D35. doi:10.1093/nar/gku1216.

[326] O'Leary NA, Wright MW, Brister JR, Ciufo S, Haddad D, McVeigh R, et al. Reference sequence (RefSeq) database at NCBI: current status, taxonomic expansion, and functional annotation. Nucleic Acids Research. 2016;44(D1):D733-D745. doi:10.1093/nar/gkv1189.

[327] dos Santos G, Schroeder AJ, Goodman JL, Strelets VB, Crosby MA, Thurmond J, et al. FlyBase: introduction of the Drosophila melanogaster Release 6 reference genome assembly and large-scale migration of genome annotations. Nucleic Acids Research. 2015;43(D1):D690-D697. doi:10.1093/nar/gku1099. 
[328] Eppig JT, Richardson JE, Kadin JA, Ringwald M, Blake JA, Bult CJ. Mouse Genome Informatics (MGI): reflecting on 25 years. Mammalian Genome. 2015;26(7-8):272-284. doi:10.1007/s00335-015-9589-4.

[329] Shimoyama M, De Pons J, Hayman GT, Laulederkind SJF, Liu W, Nigam R, et al. The Rat Genome Database 2015: genomic, phenotypic and environmental variations and disease. Nucleic Acids Research. 2015;43(D1):D743-D750. doi:10.1093/nar/gku1026.

[330] Costanzo MC, Engel SR, Wong ED, Lloyd P, Karra K, Chan ET, et al. Saccharomyces genome database provides new regulation data. Nucleic Acids Research. 2014;42(D1):D717-D725. doi:10.1093/nar/gkt1158.

[331] Lamesch P, Berardini TZ, Li D, Swarbreck D, Wilks C, Sasidharan R, et al. The Arabidopsis Information Resource (TAIR): improved gene annotation and new tools. Nucleic Acids Research. 2012;40(D1):D1202-D1210. doi:10.1093/nar/gkr1090.

[332] Howe KL, Bolt BJ, Cain S, Chan J, Chen WJ, Davis P, et al. WormBase 2016: expanding to enable helminth genomic research. Nucleic Acids Research. 2016;44(D1):D774D780. doi:10.1093/nar/gkv1217.

[333] Ruzicka L, Bradford YM, Frazer K, Howe DG, Paddock H, Ramachandran S, et al. ZFIN, The zebrafish model organism database: Updates and new directions. genesis. 2015;53(8):498-509. doi:10.1002/dvg.22868.

[334] Luo W, Friedman MS, Shedden K, Hankenson KD, Woolf PJ. GAGE: generally applicable gene set enrichment for pathway analysis. BMC Bioinformatics. 2009;10(1):1-17. doi:10.1186/1471-2105-10-161.

[335] Luo W, Brouwer C. Pathview: an R/Bioconductor package for pathway-based data integration and visualization. Bioinformatics. 2013;29(14):1830-1831. doi: 10.1093/bioinformatics/btt285.

[336] Reimand J, Kull M, Peterson H, Hansen J, Vilo J. g: Profiler - a web-based toolset for functional profiling of gene lists from large-scale experiments. Nucleic Acids Research. 2007;35(Suppl 2):W193-W200. doi:10.1093/nar/gkm226. 
[337] Reimand J, Arak T, Vilo J. g: Profiler - a web server for functional interpretation of gene lists (2011 update). Nucleic Acids Research. 2011;39(Suppl 2):W307-W315. doi:10.1093/nar/gkr378.

[338] Sun Microsystems. The Java Architecture for XML Binding (JAXB) 2.0; 2006.

[339] Java Architecture for XML Binding (JAXB) 2.0. [acesso 12 Maio 2016]. Disponível em: [http://jaxb.java.net/].

[340] Slonim DK, Yanai I. Getting started in gene expression microarray analysis. PLoS Computational Biology. 2009;5(10):1-4. doi:10.1371/journal.pcbi.1000543.

[341] Silva E, Martínez López J, Ferreira Pires L, van Sinderen M. Defining and prototyping a life-cycle for dynamic service composition. In: Proceedings of the Second International Workshop on Architectures, Concepts and Technologies for Service Oriented Computing (ACT4SOC); 5 Jul. 2008; Porto; 2008. p. 79-90.

[342] Goncalves da Silva EM. User-centric service composition - towards personalised service composition and delivery [PhD thesis]. [Enschede]: University of Twente; 2011. 233 p.

[343] da Silva EG, Ferreira Pires L, van Sinderen M. A-DynamiCoS: a flexible framework for user-centric service composition. In: Proceedings of the IEEE 16th International Enterprise Distributed Object Computing Conference (EDOC); 10-14 Set. 2012; Beijing. IEEE; 2012. p. 81-92. doi:10.1109/EDOC.2012.19.

[344] Almeida JP, Baravaglio A, Belaunde M, Falcarin P, Kovacs E. Service creation in the SPICE service platform. In: Proceedings of the 17th Wireless World Research Forum Meeting (WWRF17); Nov. 2006. Heidelberg: Wireless World Research Forum; 2006. p. $1-7$.

[345] OASIS. Using WSDL in a UDDI Registry, Version 2.0.2 - Technical Note; 2004.

[346] OASIS. Using BPEL4WS in a UDDI registry - Technical Note; 2004.

[347] MySQL. [acesso 12 Maio 2016]. Disponível em: [http://www.mysql.com/].

[348] Apache jUDDI. [acesso 12 Maio 2016]. Disponível em: [http://juddi.apache.org/]. 
[349] Hibernate. [acesso 12 Maio 2016]. Disponível em: [http://www.hibernate.org/].

[350] World Wide Web Consortium. XML Schema Definition Language (XSD) 1.1 Part 1: Structures; 2012.

[351] World Wide Web Consortium. XML Schema Definition Language (XSD) 1.1 Part 2: Datatypes; 2012.

[352] API JGraphX. [acesso 12 Maio 2016]. Disponível em: [https://www.github.com/jgraph/ jgraphx].

[353] Horridge M, Bechhofer S. The OWL API: A Java API for OWL ontologies. Semantic Web. 2011;2(1):11-21. doi:10.3233/SW-2011-0025.

[354] The OWL API. [acesso 12 Maio 2016]. Disponível em: [http://owlapi.sourceforge.net/].

[355] Sirin E, Parsia B, Grau BC, Kalyanpur A, Katz Y. Pellet: a practical OWL-DL reasoner. Web Semantics: Science, Services and Agents on the World Wide Web. 2007;5(2):51-53. doi:10.1016/j.websem.2007.03.004.

[356] Batet M, Sánchez D. Contributions on semantic similarity and its applications to data privacy. In: Navarro-Arribas G, Torra V, editors. Advanced Research in Data Privacy. Springer International Publishing; 2015. p. 129-149. doi:10.1007/978-3-319-09885-2_8.

[357] Janowicz K, Raubal M, Kuhn W. The semantics of similarity in geographic information retrieval. Journal of Spatial Information Science. 2011;2:29-57. doi:10.5311/JOSIS.2011.2.3.

[358] Xu W, Callison-Burch C, Dolan WB. SemEval-2015 Task 1: Paraphrase and semantic similarity in Twitter (PIT). In: Proceedings of the 9th International Workshop on Semantic Evaluation (SemEval); 4-5 Jun. 2015; Denver; 2015. p. [11].

[359] Zare M, Pahl C, Nilashi M, Salim N, Ibrahim O. A review of semantic similarity measures in biomedical domain using SNOMED-CT. Journal of Soft Computing and Decision Support Systems. 2015;2(6):1-13. 
[360] Clark T, Roos M. Recent applications of web semantics in eLifeScience. Web Semantics: Science, Services and Agents on the World Wide Web. 2014;29:1-2. doi:10.1016/j.websem.2014.11.005.

[361] Pesquita C, Faria D, Falcão AO, Lord P, Couto FM. Semantic similarity in biomedical ontologies. PLoS Computational Biology. 2009;5(7):1-12. doi:10.1371/journal.pcbi.1000443.

[362] del Pozo A, Pazos F, Valencia A. Defining functional distances over Gene Ontology. BMC Bioinformatics. 2008;9(1):1-15. doi:10.1186/1471-2105-9-50.

[363] Wu X, Zhu L, Guo J, Zhang D, Lin K. Prediction of yeast protein-protein interaction network: insights from the Gene Ontology and annotations. Nucleic Acids Research. 2006;34(7):2137-2150. doi:10.1093/nar/gk1219.

[364] Wu H, Su Z, Mao F, Olman V, Xu Y. Prediction of functional modules based on comparative genome analysis and Gene Ontology application. Nucleic Acids Research. 2005;33(9):2822-2837. doi:10.1093/nar/gki573.

[365] Yu H, Gao L, Tu K, Guo Z. Broadly predicting specific gene functions with expression similarity and taxonomy similarity. Gene. 2005;352:75-81. doi:10.1016/j.gene.2005.03.033.

[366] Lécué F, Silva E, Ferreira Pires L. A framework for dynamic web services composition. In: Gschwind T, Pautasso C, editors. Emerging Web Services Technology, Volume II. Basel: Birkhäuser Basel; 2008. p. 59-75. doi:10.1007/978-3-7643-8864-5_5.

[367] Lécué F, Leger A. Semantic web service composition based on a closed world assumption. In: Proceedings of 4th European Conference on Web Services (ECOWS); Dez. 2006; Zurich. IEEE; 2006. p. 233-242. doi:10.1109/ECOWS.2006.35.

[368] jGraphT: Java graph API. [acesso 12 Maio 2016]. Disponível em: [http://jgrapht.org/].

[369] Mehta NR, Medvidovic N, Phadke S. Towards a taxonomy of software connectors. In: Proceedings of the 22nd International Conference on Software Engineering (ICSE); 4-11 Jun. 2000; Limerick. New York: ACM; 2000. p. 178-187. doi:10.1145/337180.337201. 
[370] de Oliveira GLV, de Lima KWA, Colombini AM, Pinheiro DG, Panepucci RA, Palma PVB, et al. Bone marrow mesenchymal stromal cells isolated from multiple sclerosis patients have distinct gene expression profile and decreased suppressive function compared with healthy counterparts. Cell Transplantation. 2015;24(2):151-165. doi:10.3727/096368913X675142.

[371] de Oliveira GLV. Análise da expressão gênica por microarrays de células-tronco hematopoéticas e mesenquimais de pacientes com esclerose múltipla [PhD thesis]. [Ribeirão Preto]: Universidade de São Paulo; 2013. 165 p.

[372] Huang DW, Sherman BT, Lempicki RA. Systematic and integrative analysis of large gene lists using DAVID bioinformatics resources. Nature Protocols. 2009;4(1):44-57. doi:10.1038/nprot.2008.211.

[373] Jeanmougin M, de Reynies A, Marisa L, Paccard C, Nuel G, Guedj M. Should we abandon the t-test in the analysis of gene expression microarray data: a comparison of variance modeling strategies. PLoS ONE. 2010;5(9):1-9. doi:10.1371/journal.pone.0012336.

[374] Lopes JS, Abril-de-Abreu R, Oliveira RF. Brain transcriptomic response to social eavesdropping in zebrafish (Danio rerio). PLoS ONE. 2015;10(12):1-21. doi:10.1371/journal.pone.0145801.

[375] Irizarry RA, Bolstad BM, Collin F, Cope LM, Hobbs B, Speed TP. Summaries of Affymetrix GeneChip probe level data. Nucleic Acids Research. 2003;31(4):e15. doi:10.1093/nar/gng015.

[376] Irizarry RA, Hobbs B, Collin F, Beazer YD, Antonellis KJ, Scherf U, et al. Exploration, normalization, and summaries of high density oligonucleotide array probe level data. Biostatistics. 2003;4(2):249-264. doi:10.1093/biostatistics/4.2.249.

[377] National Center for Biotechnology Information (NCBI). [acesso 12 Maio 2016]. Disponível em: [http://www.ncbi.nlm.nih.gov].

[378] BioMart Project. [acesso 12 Maio 2016]. Disponível em: [http://www.biomart.org/]. 
[379] Kelder T, Pico AR, Hanspers K, van Iersel MP, Evelo C, Conklin BR. Mining biological pathways using WikiPathways web services. PLoS ONE. 2009;4(7):1-4. doi:10.1371/journal.pone.0006447.

[380] Laurette P, Strub T, Koludrovic D, Keime C, Le Gras S, Seberg H, et al. Transcription factor MITF and remodeller BRG1 define chromatin organisation at regulatory elements in melanoma cells. eLife. 2015;4:e06857. doi:10.7554/eLife.06857.

[381] Hevner AR, March ST, Park J, Ram S. Design science in information systems research. MIS Quarterly. 2004;28(1):75-105. 
Esta seção apresenta em detalhes o perfil UML desenvolvido para a representação de anotações semânticas atribuídas às descrições de serviços de acordo com a abordagem SAWSDL. As Figuras 79 - 80 apresentam os estereótipos definidos no perfil. Para cada estereótipo concreto definido no perfil, apresentamos uma notação que pode ser utilizada para representá-lo. Estereótipos abstratos não possuem sintaxe e notação definidas. Além disto, para cada estereótipo definido no perfil, apresentamos uma breve descrição e a classe (base) a partir da qual o estereótipo é estendido. Adicionalmente, apresentamos as restrições que devem ser aplicadas aos elementos estendidos por alguns estereótipos. Estas restrições são apresentadas de forma textual e também por meio de expressões OCL.

A Figura 77 apresenta o estereótipo definido para a representação de conceitos de uma ontologia.

\begin{tabular}{|c|c|c|}
\hline Estereótipo & Classe Base & Descrição \\
\hline $\begin{array}{c}\text { «ontology concept» } \\
\text { Name }\end{array}$ & Class & $\begin{array}{l}<<\text { ontology concept }>>\text { representa um conceito definido em uma } \\
\text { ontologia. }\end{array}$ \\
\hline \multicolumn{3}{|l|}{ Restrição } \\
\hline \multicolumn{2}{|c|}{$\begin{array}{l}\text { context OntologyConcept inv: } \\
\text { self.base_Class.extension_WsdlComponent.oclIsUndefined() and } \\
\text { self.base_Class.extension_XmlSchemaComponent.oclIsUndefined() }\end{array}$} & $\begin{array}{l}\text { cept > não pode ser estereotipada como um subtipo de } \\
\text { defined() and } \\
\text { clIsUndefined() }\end{array}$ \\
\hline
\end{tabular}

Figura 77: Estereótipo para a representação de conceitos de uma ontologia. 
A Figura 78 apresenta os estereótipos definidos para a representação de componentes da linguagem WSDL 2.0.

\begin{tabular}{|c|c|c|}
\hline Estereótipo & Classe Base & Descrição \\
\hline WsdlComponent & Class & $\begin{array}{l}\text { WsdlComponent é um estereótipo abstrato que representa um } \\
\text { componente da linguagem Web Services Description Language } \\
\text { Versão } 2.0 \text { (WSDL 2.0). }\end{array}$ \\
\hline \multicolumn{3}{|l|}{ Restrição } \\
\hline \multicolumn{3}{|c|}{$\begin{array}{l}\text { [1] Uma classe estereotipada como um subtipo de WsdlComponent não po } \\
\text { XmlSchemaComponent ou como <<ontology concept }>>\text { : } \\
\text { context WsdlComponent inv: } \\
\text { self.base_Class.extension_XmlSchemaComponent.oclIsUndefined() and } \\
\text { self.base_Class.extension_OntologyConcept.oclIsUndefined() }\end{array}$} \\
\hline Estereótipo & Classe Base & Descrição \\
\hline $\begin{array}{l}\text { «wsdl interface» } \\
\text { Interface Name }\end{array}$ & WsdlComponent & $\begin{array}{l}\text { <<wsdl interface〉> representa o componente Interface da linguagem } \\
\text { WSDL 2.0. Este componente representa uma interface de um serviço } \\
\text { web. Uma interface descreve um conjunto de operações fornecidas por } \\
\text { um serviço. }\end{array}$ \\
\hline Estereótipo & Classe Base & Descrição \\
\hline $\begin{array}{l}\text { «wsdl operation» } \\
\text { Operation Name }\end{array}$ & WsdlComponent & $\begin{array}{l}\text { <<wsdl operation〉> representa o componente Operation da linguagem } \\
\text { WSDL 2.0. Este componente representa uma operação da interface de } \\
\text { um serviço web. Uma operação descreve um conjunto de mensagens } \\
\text { que um serviço web envia e/ou recebe. }\end{array}$ \\
\hline Estereótipo & Classe Base & Descrição \\
\hline $\begin{array}{l}\text { «wsdl fault» } \\
\text { Fault Name }\end{array}$ & WsdlComponent & $\begin{array}{l}\text { <<wsdl fault〉> representa o componente Fault da linguagem WSDL } \\
\text { 2.0. Este componente representa uma falha que pode ocorrer durante a } \\
\text { invocação de uma operação da interface de um serviço web. Uma falha } \\
\text { descreve um conjunto de mensagens de falha que um serviço web } \\
\text { envia e/ou recebe. }\end{array}$ \\
\hline Estereótipo & Classe Base & Descrição \\
\hline «wsdl input» & WsdlComponent & $\begin{array}{l}\text { <<wsdl input〉> representa o componente Message Reference da } \\
\text { linguagem WSDL } 2.0 \text {, cujo atributo de direção assume o valor in. Este } \\
\text { componente representa uma mensagem que um serviço web recebe } \\
\text { quando uma das operações de sua interface é invocada. }\end{array}$ \\
\hline Estereótipo & Classe Base & Descrição \\
\hline «wsdl output» & WsdlComponent & $\begin{array}{l}\text { <<wsdl output〉> representa o componente Message Reference da } \\
\text { linguagem WSDL 2.0, cujo atributo de direção assume o valor } \text { out. } \\
\text { Este componente representa uma mensagem que um serviço web envia } \\
\text { quando uma das operações de sua interface é invocada. }\end{array}$ \\
\hline Estereótipo & Classe Base & Descrição \\
\hline «wsdl infault» & WsdlComponent & $\begin{array}{l}<<\text { wsdl infault } \gg>\text { representa o componente Fault Reference da } \\
\text { linguagem WSDL } 2.0 \text {, cujo atributo de direção assume o valor in. Este } \\
\text { componente representa uma mensagem de falha que um serviço web } \\
\text { recebe quando uma falha ocorre durante a invocação de uma das } \\
\text { operações de sua interface. }\end{array}$ \\
\hline Estereótipo & Classe Base & Descrição \\
\hline «wsdl outfault» & WsdlComponent & $\begin{array}{l}\text { <<wsdl outfault 〉> representa o componente Fault Reference da } \\
\text { linguagem WSDL 2.0, cujo atributo de direção assume o valor out. } \\
\text { Este componente representa uma mensagem de falha que um serviço } \\
\text { web envia quando uma falha ocorre durante a invocação de uma das } \\
\text { operações de sua interface. }\end{array}$ \\
\hline
\end{tabular}

Figura 78: Estereótipos para a representação de componentes da linguagem WSDL 2.0.

A Figura 79 apresenta os estereótipos definidos para a representação de componentes de esquemas XML. 


\begin{tabular}{|c|c|c|}
\hline Estereótipo & Classe Base & Descrição \\
\hline XmlSchemaComponent & Class & $\begin{array}{l}\text { XmlSchemaComponent é um estereótipo abstrato que representa um } \\
\text { componente de um esquema XML. }\end{array}$ \\
\hline \multicolumn{3}{|r|}{ 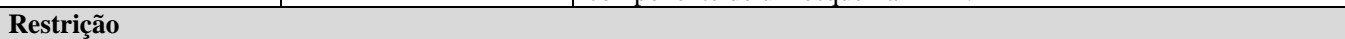 } \\
\hline \multicolumn{3}{|c|}{$\begin{array}{l}\text { [1] Uma classe estereotipada como um subtipo de XmlSchemaComponent não pode ser estereotipada como um subtipo de } \\
\text { WsdlComponent ou como <<ontology concept }>>\text { : } \\
\text { context XmlSchemaComponent inv: } \\
\text { self.base_Class.extension_WsdlComponent.oclIsUndefined() and } \\
\text { self.base_Class.extension_OntologyConcept.oclIsUndefined() }\end{array}$} \\
\hline Estereótipo & Classe Base & Descrição \\
\hline $\begin{array}{l}\text { «Xs element» } \\
\text { Element Name }\end{array}$ & XmlSchemaComponent & $\begin{array}{l}\text { <<xs element〉> representa um elemento definido em um esquema } \\
\text { XML. }\end{array}$ \\
\hline Estereótipo & Classe Base & Descrição \\
\hline $\begin{array}{l}\text { «Xs simple type" } \\
\text { Type Name }\end{array}$ & XmlSchemaComponent & $\begin{array}{l}\text { <<xs simple type >> representa um tipo simples definido em um } \\
\text { esquema XML. Um tipo simples fornece informações e restrições } \\
\text { sobre os valores de atributos ou elementos. }\end{array}$ \\
\hline \begin{tabular}{|l} 
Estereótipo \\
\end{tabular} & Classe Base & Descrição \\
\hline $\begin{array}{l}\text { "xs complex type» } \\
\text { Type Name }\end{array}$ & XmlSchemaComponent & $\begin{array}{l}<<x s \text { complex type }>>\text { representa um tipo complexo definido em um } \\
\text { esquema XML. Um tipo complexo fornece informações e restrições } \\
\text { sobre os valores de atributos ou elementos e pode conter outros } \\
\text { atributos e elementos. }\end{array}$ \\
\hline Estereótipo & Classe Base & Descrição \\
\hline $\begin{array}{l}\text { «xs attribute» } \\
\text { Attribute Name }\end{array}$ & XmlSchemaComponent & $\begin{array}{l}<<x s \text { attribute >> representa um atributo definido em um esquema } \\
\text { XML. }\end{array}$ \\
\hline
\end{tabular}

Figura 79: Estereótipos para a representação de componentes de esquemas XML.

A Figura 80 apresenta o estereótipo definido para a representação de um relacionamento adicional utilizado para referenciar falhas a partir de mensagens de falhas definidas na linguagem WSDL 2.0.

\begin{tabular}{|c|c|c|}
\hline Estereótipo & Classe Base & Descrição \\
\hline "fault reference» _ - > & Dependency & $\begin{array}{l}\langle<\text { fault reference > representa um relacionamento utilizado } \\
\text { para associar uma mensagem de falha que um serviço web } \\
\text { envia/recebe à definição de uma falha na interface do serviço. }\end{array}$ \\
\hline \multicolumn{3}{|l|}{ Restrições } \\
\hline \multicolumn{3}{|c|}{ 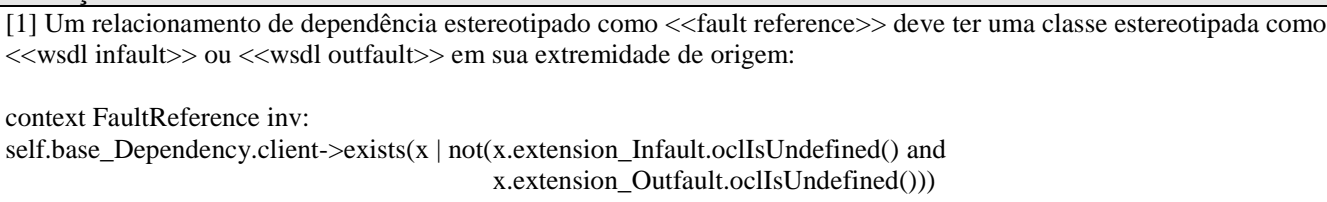 } \\
\hline \multicolumn{3}{|c|}{$\begin{array}{l}\text { [2] Um relacionamento de dependência estereotipado como <<fault reference }\rangle \text { deve ter uma classe estereotipada como } \\
\langle<\text { wsdl fault 〉> em sua extremidade de destino: }\end{array}$} \\
\hline
\end{tabular}

Figura 80: Estereótipo para a representação do relacionamento faultReference. 
A Figura 81 apresenta o estereótipo definido para a representação de um relacionamento adicional utilizado para referenciar elementos XML a partir de componentes da linguagem WSDL 2.0 .

\begin{tabular}{|c|c|c|}
\hline Estereótipo & Classe Base & Descrição \\
\hline «references» & Dependency & $\begin{array}{l}\text { <<references >> representa um relacionamento utilizado para } \\
\text { associar um componente da linguagem WSDL } 2.0 \text { (origem) a } \\
\text { um elemento definido em um esquema XML (destino) que é } \\
\text { referenciado por este componente. }\end{array}$ \\
\hline \multicolumn{3}{|l|}{ Restrições } \\
\hline \multicolumn{3}{|c|}{ 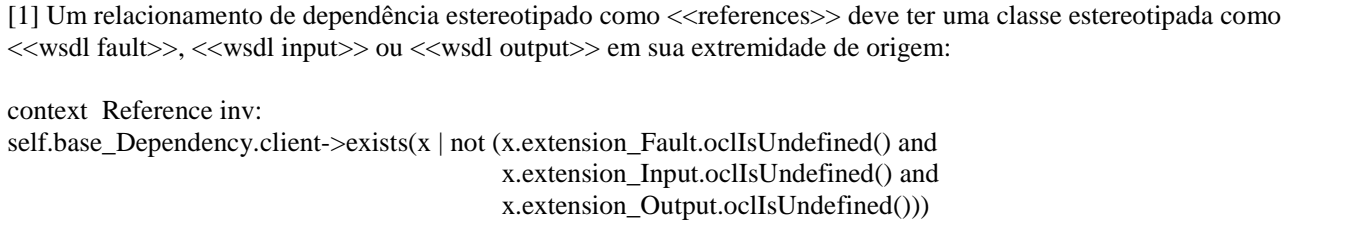 } \\
\hline \multicolumn{3}{|c|}{$\begin{array}{l}\text { [2] Um relacionamento de dependência estereotipado como }<<\text { references }>>\text { deve ter uma classe estereotipada como }<<x s \\
\text { element }>>\text { em sua extremidade de destino: }\end{array}$} \\
\hline
\end{tabular}

Figura 81: Estereótipo para a representação do relacionamento references.

Finalmente, a Figura 82 apresenta o estereótipo definido para a representação do atributo de extensão modelReference da abordagem SAWSDL. 


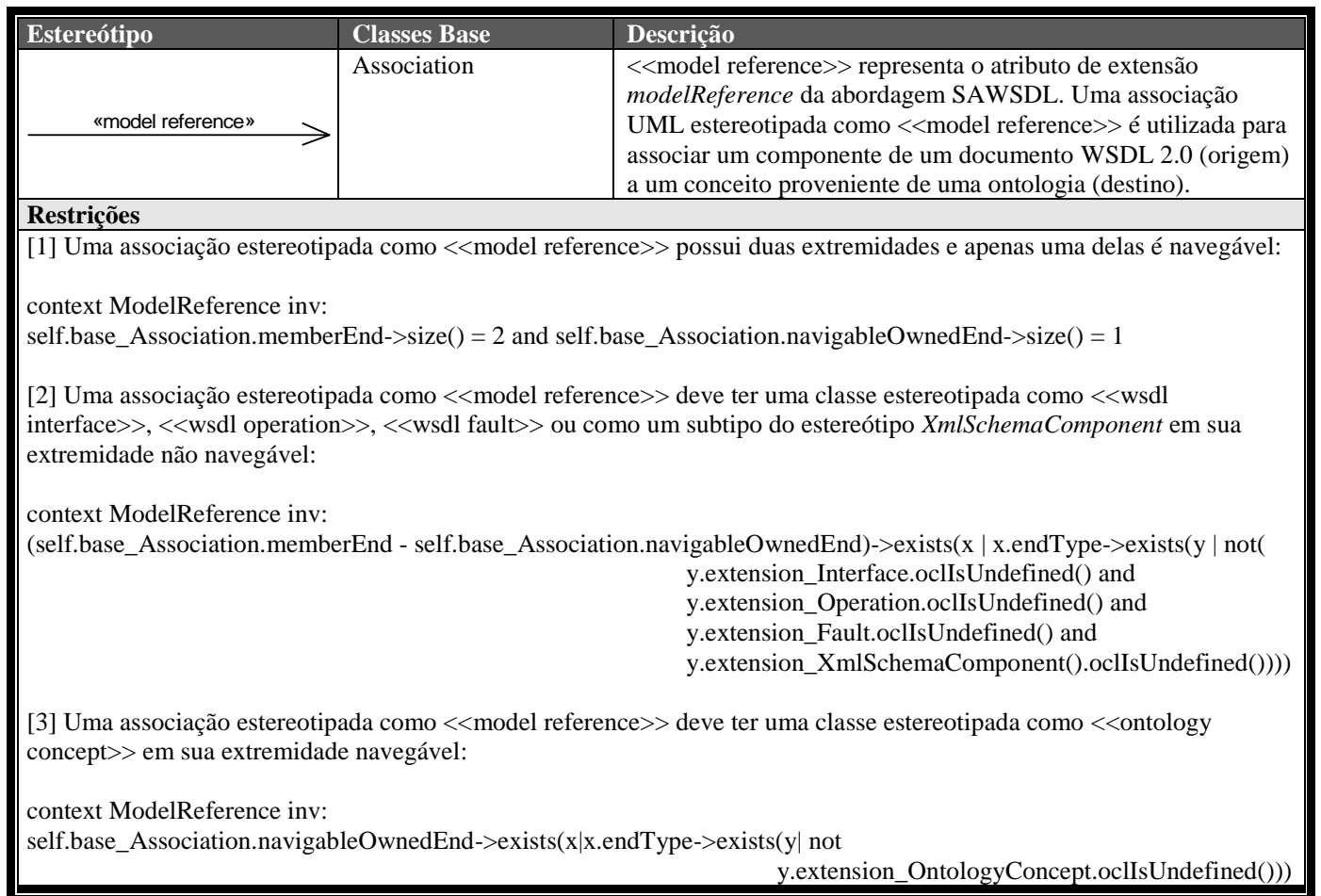

Figura 82: Estereótipo para a representação do atributo de extensão modelReference da abordagem SAWSDL. 


\section{GENE EXPRESSION ONTOLOGY (GEXPO)}

A ontologia Gene Expression Ontology (GEXPO) foi criada com o objetivo de agregar os termos do domínio de genômica funcional. Todas as classes da ontologia GEXPO foram definidas como subclasses da classe OWL Thing. As Figuras 83 - 87 apresentam os conceitos e relacionamentos definidos na ontologia GEXPO por meio de diagramas de classe UML. Apenas os conceitos e relacionamentos da ontologia GEXPO relevantes para a aplicação da metodologia proposta são apresentados graficamente usando UML. Um retângulo (classe UML) representa um conceito da ontologia. Os retângulos com preenchimento branco representam conceitos novos introduzidos nesta ontologia e os retângulos com preenchimento cinza representam conceitos oriundos de outras ontologias. Os relacionamentos entre conceitos são apresentados por meio de uma notação similar à proposta por Guardia et al. [304]. O relacionamento is a é apresentado como uma generalização UML estereotipada como is $a$. O relacionamento part of e seu inverso (has part) são apresentados como agregações UML estereotipadas como part of e has part, respectivamente. Os demais relacionamentos são apresentados como associações UML estereotipadas. 
A Figura 83 apresenta os principais biopolímeros e regiões biológicas envolvidos nos processos de expressão gênica e de medição de expressão gênica. Todos os conceitos apresentados em retângulos com preenchimento cinza representam conceitos da ontologia Sequence Ontology.

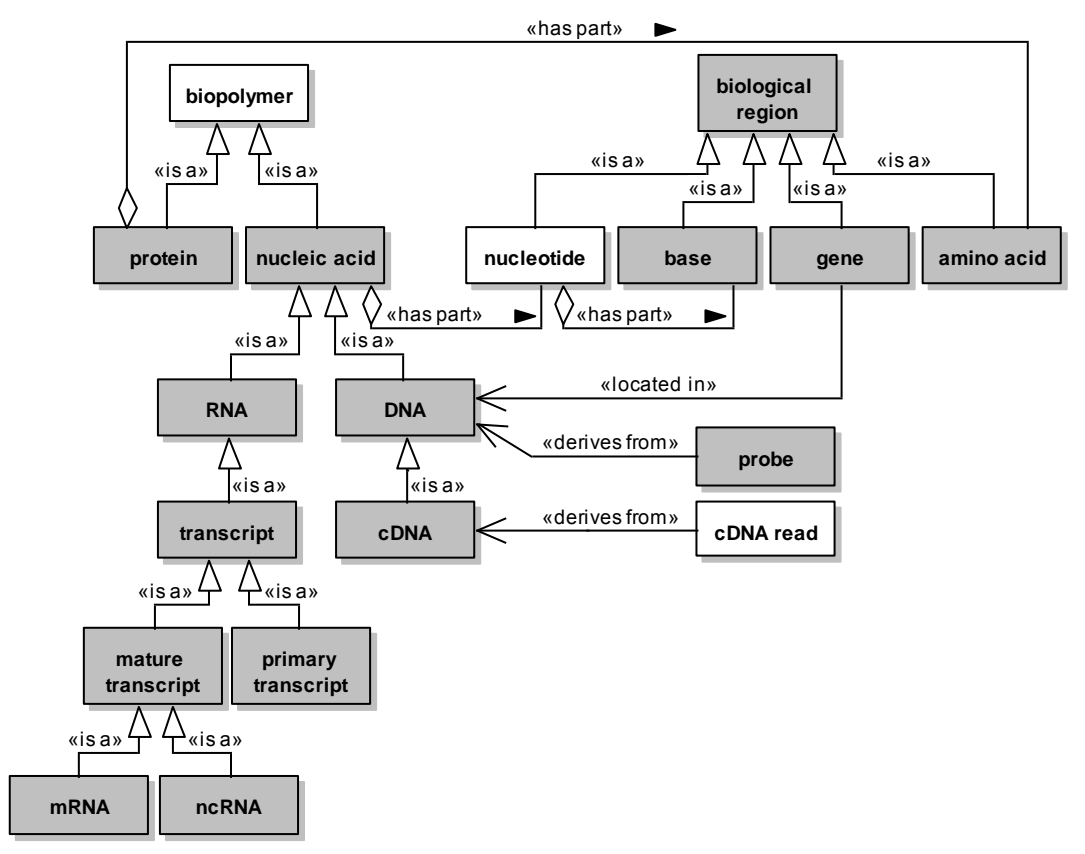

Figura 83: Regiões biológicas e biopolímeros.

A classe biopolymer representa uma macromolécula polimérica produzida por um ser vivo. Esta classe é especializada pelas classes protein e nucleic acid. A classe protein representa uma sequência de aminoácidos interligados. A classe nucleic acid representa uma sequência de nucleotídeos interligados. Esta classe é especializada pelas classes DNA e RNA.

A classe $D N A$ representa uma molécula de ácido desoxirribonucleico e está associada à classe gene por meio do relacionamento located in, indicando que genes estão localizados em moléculas de DNA. A classe DNA também está associada à classe probe por meio do relacionamento derives from, indicando que uma sonda de DNA é derivada a partir de uma molécula de DNA. A classe probe representa um fragmento de uma molécula de DNA (sonda) utilizado para detectar experimentalmente a presença de moléculas de cDNA. A classe DNA é especializada pela classe cDNA, a qual representa uma molécula de DNA complementar. A classe $c D N A$ está associada à classe $c D N A$ read por meio do relacionamento derives from, indicando que um read de DNA 
é derivado a partir de uma molécula de cDNA. A classe $c D N A$ read representa um fragmento de uma molécula de cDNA sequenciado, o qual é utilizado para quantificar moléculas de cDNA experimentalmente.

A classe RNA representa uma molécula de ácido ribonucleico. Esta classe é especializada pela classe transcript, a qual representa uma molécula de RNA sintetizada a partir de uma molécula-molde de DNA. Por sua vez, a classe transcript é especializada pelas classes primary transcript e mature transcript. A classe primary transcript representa uma molécula de RNA que requer modificações para se tornar funcional. A classe mature transcript representa uma molécula de RNA que passou pelas modificações necessárias para se tornar funcional. A classe mature transcript é especializada pelas classes $n c R N A$ e $m R N A$, as quais representam RNAs não codificantes e RNAs mensageiros, respectivamente.

Adicionalmente, a classe biological region representa uma região de uma sequência biológica. Esta classe é especializada pelas classes nucleotide, base, gene e amino acid. A classe base representa uma base nitrogenada. Esta classe está associada à classe nucleotide por meio do relacionamento has part, indicando que nucleotídeos são constituídos por bases nitrogenadas. De forma análoga, a classe nucleotide está associada à classe nucleic acid por meio do relacionamento has part, indicando que ácidos nucleicos são constituídos por nucleotídeos. Finalmente, a classe amino acid representa um aminoácido. Esta classe está associada à classe protein por meio do relacionamento has part, indicando que proteínas são constituídas por aminoácidos.

\section{PROCESSOS BIOLÓGICOS}

A Figura 84 apresenta uma visão geral dos processos biológicos envolvidos na expressão gênica e em sua medição. Os conceitos representados pelas classes biological process, gene expression, transcription, RNA processing, translation, protein maturation e reverse transcription são oriundos da ontologia Gene Ontology. Os demais conceitos apresentados em retângulos com preenchimento cinza representam conceitos oriundos da ontologia Sequence Ontology.

A classe biological process (subclasse de process) representa uma sequência de eventos moleculares. Esta classe é especializada pelas classes hybridization e reverse transcription. A classe hybridization representa o processo de hibridização em que duas ou mais sequências nu- 


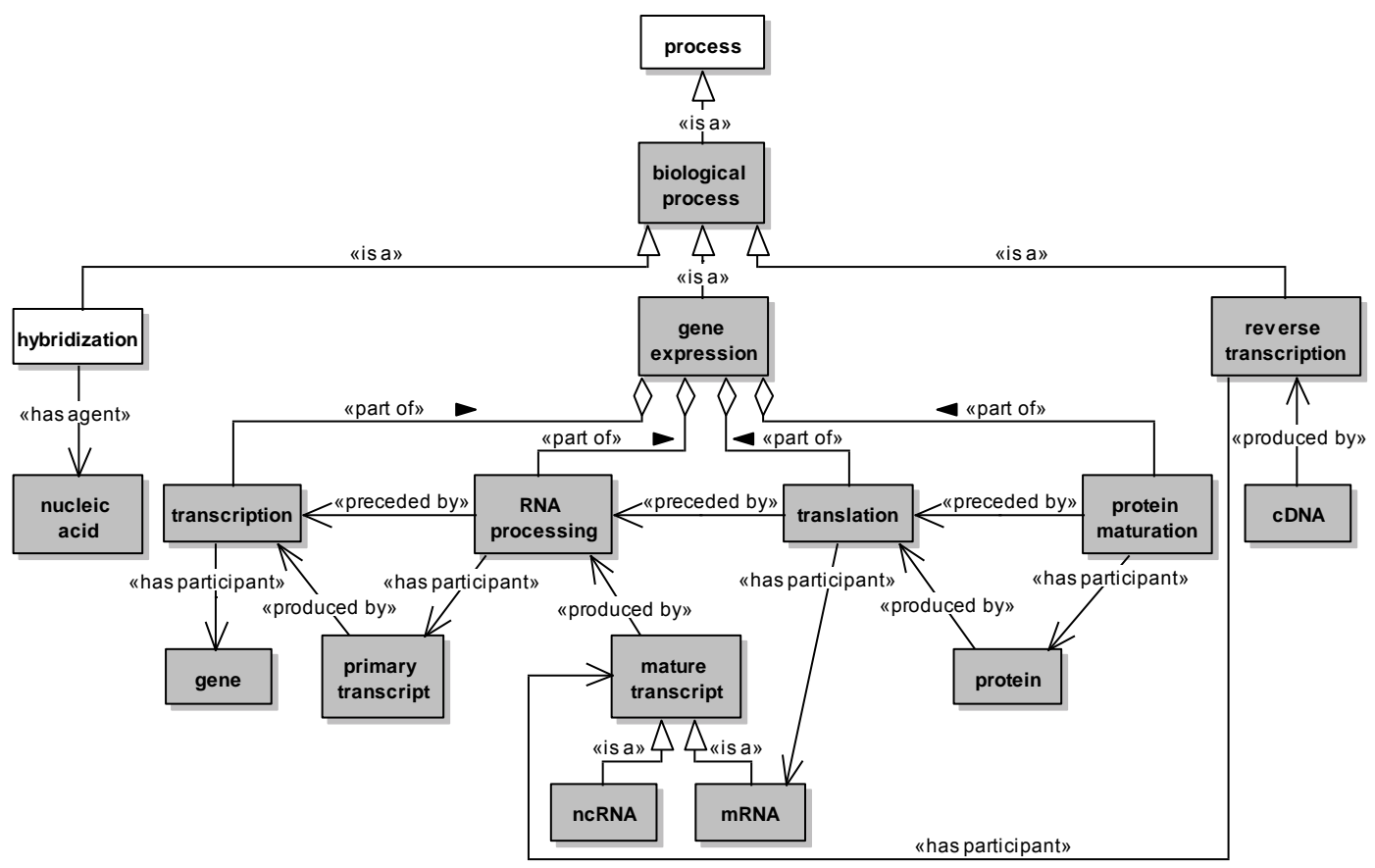

Figura 84: Processos biológicos envolvidos na expressão gênica e em sua medição.

cleotídicas complementares, representadas pela classe nucleic acid, estabelecem ligações não covalentes, pareando-se. O relacionamento has agent definido entre as classes hybridization e nucleic acid indica que sequências nucleotídicas são responsáveis pela ocorrência do processo de hibridização. A classe reverse transcription representa o processo de produção de moléculas de DNA complementar (classe $c D N A$ ) a partir de transcritos maduros (classe mature transcript). O relacionamento has participant definido entre as classes reverse transcription e mature transcript indica a participação de transcritos maduros no processo de transcrição reversa. $\mathrm{O}$ relacionamento produced by definido entre as classes $c D N A$ e reverse transcription indica que moléculas de DNA complementar são produzidas pelo processo de transcrição reversa.

A classe gene expression representa um processo biológico cujo objetivo principal é a geração de produtos gênicos, ou seja, RNAs codificantes e não codificantes. As classes transcription, RNA processing, translation e protein maturation representam diferentes subprocessos da classe gene expression, e estão associadas à mesma por meio de relacionamentos part of. A classe transcription representa a produção de um transcrito primário (classe primary transcript) a partir das informações codificadas em um gene (classe gene). O relacionamento has participant definido entre as classes transcription e gene indica a participação de genes no processo de transcrição. O relacionamento produced by definido entre as classes primary trans- 
cript e transcription indica que transcritos primários são produzidos a partir do processo de transcrição. A classe RNA processing representa a realização de modificações em um transcrito primário (classe primary transcript), tais como poliadenilação e splicing (remoção de íntrons). Este processo gera um transcrito maduro (classe mature transcript), que pode ser um RNA não codificante (classe $n c R N A$ ) ou um RNA mensageiro (classe $m R N A$ ). O relacionamento has participant definido entre as classes $R N A$ processing e primary transcript indica a participação de transcritos primários no processamento de RNAs. O relacionamento produced by definido entre as classes mature transcript e RNA processing indica que transcritos maduros são produzidos a partir do processamento de RNAs. A classe translation representa a tradução de um mRNA (classe $m R N A$ ) em uma proteína (classe protein). O relacionamento has participant definido entre as classes translation e $m R N A$ indica a participação de RNAs mensageiros no processo de tradução. O relacionamento produced by definido entre as classes protein e translation indica que proteínas são produzidas a partir do processo de tradução. Finalmente, a classe protein maturation representa a realização de modificações químicas em uma proteína (classe protein), de modo a torná-la funcional. O relacionamento has participant definido entre as classes protein maturation e protein indica a participação de proteínas no processo de maturação.

$\mathrm{O}$ relacionamento preceded by definido entre as classes protein maturation e translation indica que a ocorrência do processo de maturação de uma proteína é precedida pela ocorrência do processo de tradução. Este relacionamento também está definido entre as classes translation e $R N A$ processing, e entre as classes $R N A$ processing e transcription.

\section{PROCESSOS DE MEDIÇÃO DE EXPRESSÃO GÊNICA}

A Figura 85 apresenta uma visão geral dos processos experimentais de medição de expressão gênica.

A classe biological experimental process (subclasse de process) representa um processo experimental biológico em geral, ou seja, qualquer procedimento realizado com o uso de materiais biológicos ou com o uso de ferramentas computacionais, que tenha como objetivo a realização de novas descobertas biológicas. Esta classe está associada à classe experimental condition por meio do relacionamento affected by, indicando que processos experimentais são afetados 


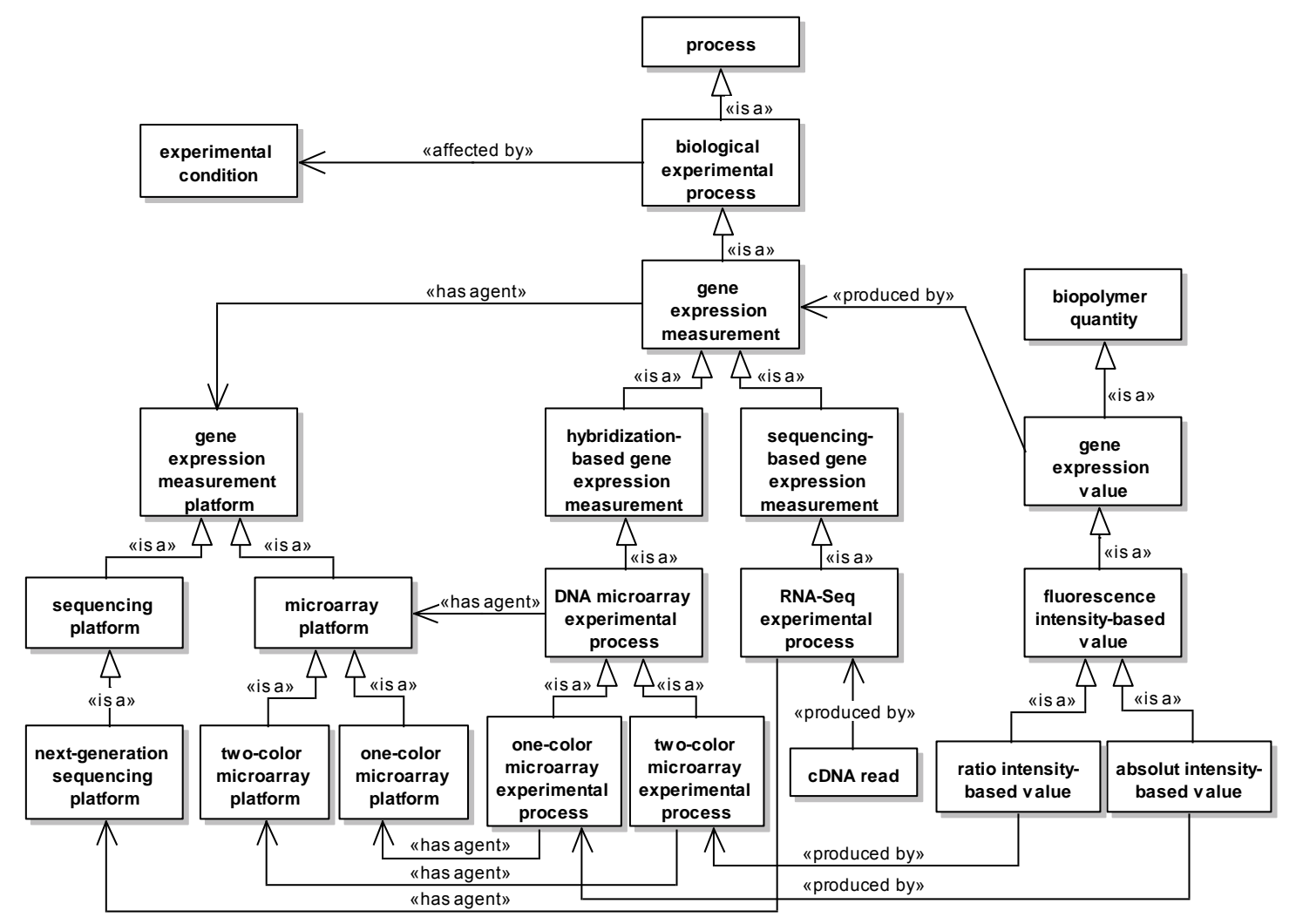

Figura 85: Processo de medição de expressão gênica.

por diferentes condições experimentais. A classe gene expression measurement representa um processo experimental específico cujo objetivo principal é a quantificação dos produtos gênicos produzidos a partir da expressão de um gene. O relacionamento has agent definido entre as classes gene expression measurement e gene expression measurement platform indica que plataformas de medição de expressão gênica são responsáveis pela realização de processos de medição.

A classe gene expression measurement platform é especializada pelas classes sequencing platform e microarray platform, as quais representam plataformas para a realização de sequenciamentos e experimentos de microarray, respectivamente. A classe sequencing platform é ainda especializada pela classe next-generation sequencing platform, a qual representa plataformas para a realização de sequenciamentos de nova geração. A classe next-generation sequencing platform possui as instâncias Illumina Genome Analyzer, Applied Biosystems SOLiD e Roche/454FLX (não apresentadas na figura), as quais representam plataformas de sequenciamento de nova geração específicas. A classe microarray platform é especializada pelas classes 
one-color microarray platform e two-color microarray platform, as quais representam plataformas para a realização de experimentos de microarray one-color e two-color, respectivamente. A classe one-color microarray platform possui as instâncias Affymetrix, Illumina e Agilent (não apresentadas na figura), as quais representam plataformas de microarray one-color específicas. A classe two-color microarray platform possui a instância Agilent (não apresentada na figura), a qual representa uma plataforma de microarray two-color específica.

O processo de medição de expressão gênica pode se basear em abordagens que utilizam hibridização ou sequenciamento para a quantificação de produtos gênicos. Desta forma, a classe gene expression measurement é especializada pelas classes hibridization-based gene expression measurement e sequencing-based gene expression measurement, respectivamente. A classe hibridization-based gene expression measurement é especializada pela classe DNA microarray experimental process, a qual representa um processo experimental de microarray de DNA. O relacionamento has agent definido entre as classes DNA microarray experimental process e microarray platform indica que processos experimentais de microarray são realizados por plataformas de microarray.

Um processo experimental de microarray de DNA pode ser de dois tipos: one-color (classe one-color microarray experimental process) ou two-color (classe two-color microarray experimental process). O relacionamento has agent definido entre as classes one-color microarray experimental process e one-color microarray platform indica que experimentos de microarray one-color são realizados por plataformas de microarray one-color. De forma análoga, o relacionamento has agent definido entre as classes two-color microarray experimental process e two-color microarray platform indica que experimentos de microarray two-color são realizados por plataformas de microarray two-color.

A classe sequencing-based gene expression measurement está associada à classe sequencing platform por meio do relacionamento has agent (não apresentado na figura). Este relacionamento indica que experimentos de medição de expressão gênica baseados em sequenciamento são realizados por plataformas de sequenciamento. A classe sequencing-based gene expression measurement é especializada pela classe $R N A-S e q$ experimental process, a qual representa o processo experimental de sequenciamento de RNA (RNA-Seq). O relacionamento has agent definido entre as classes RNA-Seq experimental process e next-generation sequencing platform 
indica que experimentos de RNA-Seq são realizados por plataformas de sequenciamento de nova geração.

A classe gene expression value especializa a classe biopolymer quantity. Gene expression value representa um valor que quantifica os produtos gênicos produzidos a partir da expressão de um gene. O relacionamento produced by definido entre as classes gene expression value e gene expression measurement indica que os valores de expressão de um gene são produzidos por um processo de medição de expressão gênica. A classe gene expression value é especializada pela classe fluorescence intensity-based value.

A classe fluorescence intensity-based value representa o valor de expressão de um gene obtido a partir de um processo experimental de microarray de DNA (relacionamento não apresentado na figura). Esta classe é especializada pelas classes absolut intensity-based value e ratio intensity-based value, as quais representam valores de expressão gênica absolutos e relativos, respectivamente. O relacionamento produced by definido entre as classes absolut intensitybased value e one-color microarray experimental process indica que valores de expressão absolutos são obtidos a partir de experimentos de microarray one-color. De forma análoga, o relacionamento produced by definido entre as classes ratio intensity-based value e two-color microarray experimental process indica que valores de expressão relativos são obtidos a partir de experimentos de microarray two-color.

Finalmente, a classe $c D N A$ read representa um fragmento de cDNA sequenciado, o qual é utilizado para quantificar moléculas de cDNA experimentalmente. O relacionamento produced by definido entre as classes $c D N A$ read e RNA-Seq experimental process indica que fragmentos de cDNA sequenciados são obtidos a partir de experimentos de RNA-Seq.

\section{Microarray de DNA}

A Figura 86 apresenta uma visão geral de um experimento de microarray de DNA. Os conceitos representados pelas classes probe, mature transcript e $c D N A$ são oriundos da ontologia Sequence Ontology. O conceito representado pela classe reverse transcription é oriundo da ontologia Gene Ontology. 


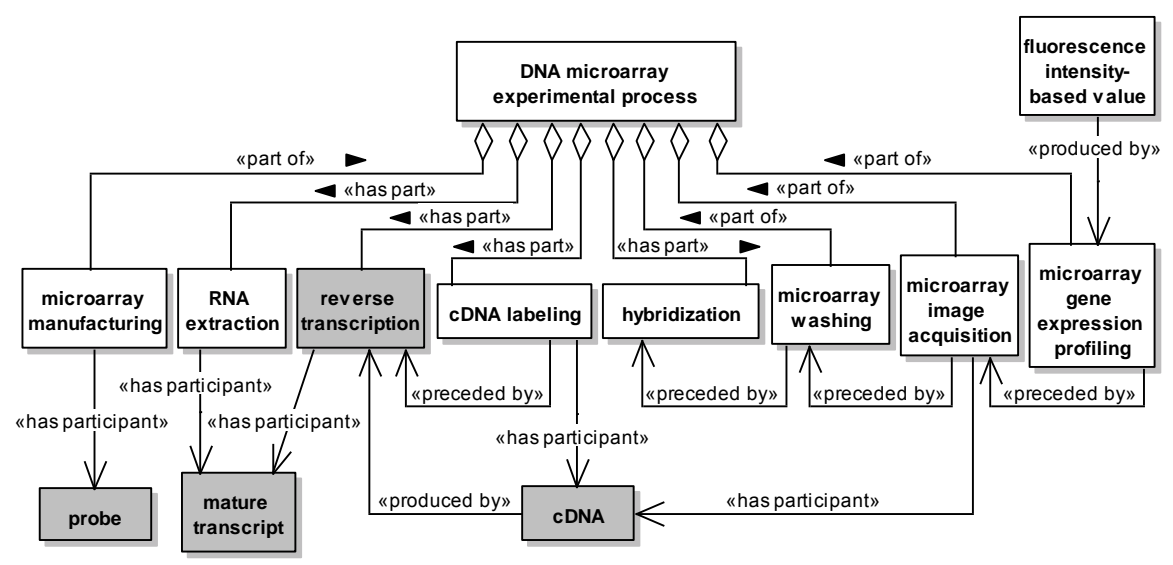

Figura 86: Experimento de microarray de DNA.

A classe DNA microarray experimental process representa um processo experimental de microarray de DNA. O principal objetivo deste processo é a quantificação dos produtos gênicos produzidos por um gene como resultado de sua expressão. As classes microarray manufacturing, microarray washing, microarray image acquisition e microarray gene expression profiling representam diferentes subprocessos da classe DNA microarray experimental process. Estas classes estão associadas à classe DNA microarray experimental process por meio de relacionamentos part of, uma vez que os subprocessos representados por estas classes sempre ocorrem como parte de experimentos de microarray de DNA. As classes RNA extraction, reverse transcription, cDNA labeling e hybridization também representam subprocessos da classe DNA microarray experimental process. No entanto, estas classes representam subprocessos que podem existir como parte de outros processos biológicos ou experimentais. Assim, estas classes foram associados à classe DNA microarray experimental process por meio de relacionamentos has part.

A classe microarray manufacturing representa a produção de um chip de microarray com sondas de DNA (classe probe) de interesse. O relacionamento has participant definido entre as classes microarray manufacturing e probe indica a participação de sondas de DNA no processo de produção de um chip de microarray. A classe RNA extraction representa a extração de moléculas de RNA a partir de células de interesse. O relacionamento has participant definido entre as classes RNA extraction e mature transcript indica a participação de moléculas de RNA maduras no processo de extração de RNA. A classe reverse transcription representa o processo biológico de transcrição reversa, que envolve a produção de moléculas de cDNA a partir de transcritos 
maduros. O relacionamento has participant definido entre as classes reverse transcription $\mathrm{e}$ mature transcript indica que transcritos maduros participam do processo de transcrição reversa. O relacionamento produced by definido entre as classes $c D N A$ e reverse transcription indica que moléculas de cDNA são produzidas pelo processo de transcrição reversa.

A classe $c D N A$ labeling representa o processo pelo qual moléculas de cDNA são marcadas com substâncias fluorescentes. O relacionamento has participant definido entre as classes cDNA labeling e cDNA indica a participação de moléculas de cDNA no processo de marcação. A classe hybridization representa o processo biológico de hibridização de ácidos nucléicos. Em um experimento de microarray, a hibridização ocorre entre moléculas de DNA (sondas) e moléculas de cDNA. A classe microarray washing representa o processo de remoção de moléculas de cDNA não hibridizadas com sondas de interesse. As moléculas são removidas lavando-se o chip de microarray. A classe microarray image acquisition representa a obtenção de uma imagem de microarray. Uma imagem de microarray é produzida excitando-se as moléculas de cDNA previamente marcadas com um laser e escaneando-se o chip de microarray para medir a emissão destas moléculas. O relacionamento has participant definido entre as classes $m i$ croarray image acquisition e $c D N A$ indica a participação de moléculas de cDNA no processo de obtenção de uma imagem de microarray. Finalmente, a classe microarray gene expression profiling representa o processo de obtenção de valores de expressão gênica baseados em fluorescência (classe fluorescence intensity-based value) em um experimento de microarray a partir da imagem previamente produzida.

O relacionamento preceded by definido entre as classes $c D N A$ labeling e reverse transcription indica que a ocorrência do processo de marcação de moléculas de cDNA é precedida pela ocorrência do processo de transcrição reversa. Este relacionamento também está definido entre as classes microarray washing e hybridization, microarray image acquisition e microarray washing, e entre as classes microarray gene expression profiling e microarray image acquisition. 
A Figura 87 apresenta uma visão geral de um experimento de sequenciamento de RNA (RNASeq). Os conceitos representados pelas classes mature transcript e $c D N A$ são oriundos da ontologia Sequence Ontology. O conceito representado pela classe reverse transcription é oriundo da ontologia Gene Ontology.

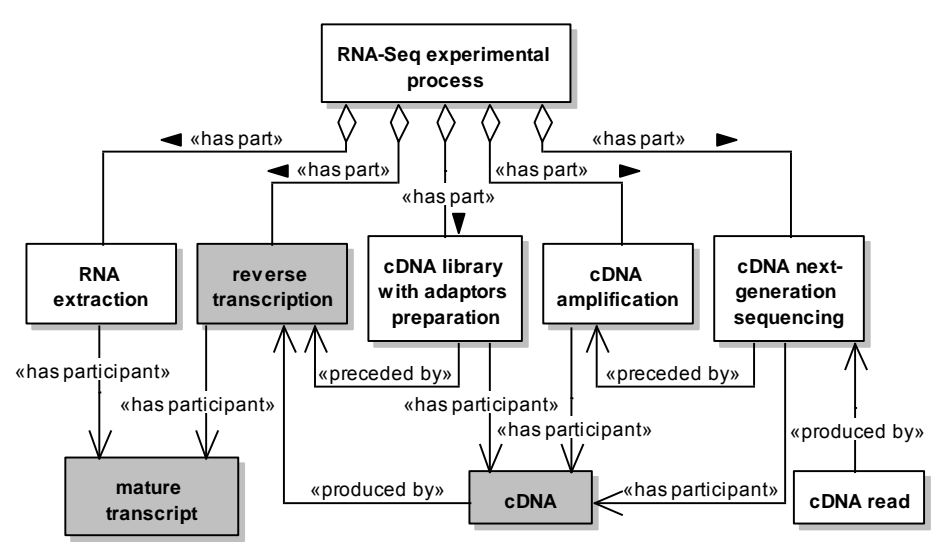

Figura 87: Experimento de sequenciamento de RNA.

A classe RNA-Seq experimental process representa um processo experimental de sequenciamento de RNA (RNA-Seq). O principal objetivo deste processo é determinar a sequência de moléculas de RNA. O sequenciamento destas moléculas pode ser utilizado para quantificar os produtos gênicos produzidos por um gene como resultado de sua expressão. As classes $R N A$ extraction, reverse transcription, cDNA library with adaptors preparation, cDNA amplification e $c D N A$ next-generation sequencing representam subprocessos da classe RNA-Seq experimental process. Estas classes representam subprocessos que podem existir como parte de outros processos biológicos ou experimentais e assim, foram associados à classe RNA-Seq experimental process por meio de relacionamentos has part.

A classe RNA extraction representa a extração de moléculas de RNA a partir de células de interesse. O relacionamento has participant definido entre as classes RNA extraction e mature transcript indica a participação de moléculas de RNA maduras no processo de extração de RNA. A classe reverse transcription representa o processo biológico de transcrição reversa, que envolve a produção de moléculas de cDNA a partir de transcritos maduros. O relacionamento has participant definido entre as classes reverse transcription e mature transcript indica que 
transcritos maduros participam do processo de transcrição reversa. O relacionamento produced by definido entre as classes $c D N A$ e reverse transcription indica que moléculas de cDNA são produzidas pelo processo de transcrição reversa. A classe cDNA library with adaptors preparation representa a preparação de uma biblioteca de moléculas de cDNA com adaptadores. $\mathrm{O}$ relacionamento has participant definido entre as classes cDNA library with adaptors preparation e cDNA indica a participação de moléculas de cDNA no processo de preparação de uma biblioteca.

A classe $c D N A$ amplification representa o processo de amplificação de uma molécula de cDNA, de modo a criar cópias desta molécula. O relacionamento has participant definido entre as classes $c D N A$ amplification e $c D N A$ indica a participação de moléculas de cDNA no processo de amplificação. A classe $c D N A$ next-generation sequencing representa o processo de sequenciamento de moléculas de cDNA por meio de tecnologias de sequenciamento de nova geração de modo a produzir reads de cDNA. O relacionamento has participant definido entre as classes $c D N A$ next-generation sequencing e $c D N A$ indica a participação de moléculas de cDNA no processo de sequenciamento. O relacionamento produced by) definido entre as classes cDNA read e cDNA next-generation sequencing indica que reads de cDNA são produzidos pelo processo de sequenciamento.

O relacionamento preceded by definido entre as classes cDNA library with adaptors preparation e reverse transcription indica que a preparação de uma biblioteca de cDNA com adaptadores é precedida pela ocorrência do processo de transcrição reversa. Este relacionamento também está definido entre as classes cDNA next-generation sequencing e cDNA amplification. 
A ontologia Gene Expression Analysis Services Ontology (GEXPASO) [271] foi criada para servir como base para a anotação semântica das descrições dos serviços desenvolvidos no contexto deste trabalho. Todas as classes da ontologia GEXPASO foram definidas como subclasses da classe OWL Thing. As Figuras 88 - 102 apresentam os conceitos e relacionamentos definidos na ontologia GEXPASO por meio de diagramas de classe UML. Apenas os conceitos e relacionamentos da ontologia GEXPASO relevantes para a aplicação da metodologia proposta são apresentados graficamente usando UML. Um retângulo (classe UML) representa um conceito da ontologia. Os retângulos com preenchimento branco representam conceitos novos introduzidos nesta ontologia e os retângulos com preenchimento cinza representam conceitos oriundos da ontologia Software Ontology. Os relacionamentos entre conceitos são apresentados por meio de uma notação similar à proposta por Guardia et al. [304]. O relacionamento is a é apresentado como uma generalização UML estereotipada como is a. O relacionamento has part é apresentado como uma agregação UML estereotipada como has part. Os demais relacionamentos são apresentados como associações UML estereotipadas. 
Esta seção apresenta uma visão geral dos conceitos e relacionamentos definidos na ontologia GEXPASO para a descrição dos tipos de dados de expressão gênica associados aos serviços desenvolvidos.

A Figura 88 apresenta uma visão geral dos dados de microarray associados aos serviços desenvolvidos para a análise destes tipos de dados.

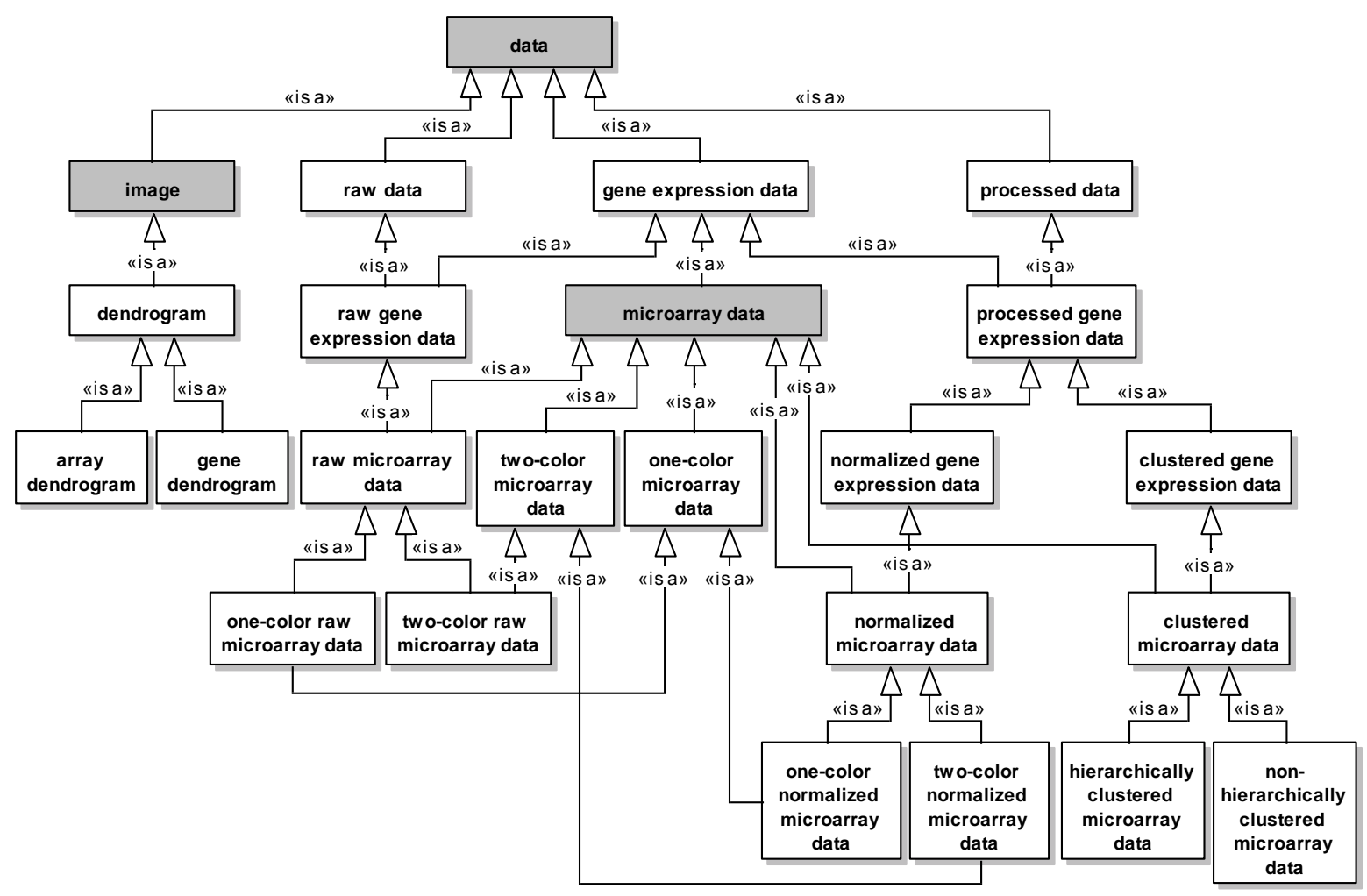

Figura 88: Dados de microarray.

A classe data representa itens de dados. Esta classe é especializada pelas classes gene expression data, image, raw data e processed data. As classes image, raw data e processed data representam imagens, dados brutos (não processados após sua geração) e dados que foram computacionalmente processados, respectivamente. A classe gene expression data representa dados (brutos ou processados) produzidos a partir de experimentos de medição de expressão gênica. Esta classe é especializada pela classe microarray data para representar dados (brutos ou processados) produzidos a partir de experimentos de microarray. 
A classe image é especializada pela classe dendrogram, a qual representa um diagrama hierárquico utilizado para ilustrar a disposição de grupos produzidos pelo agrupamento agrupamento hierárquico de dados de microarray. A classe dendrogram é especializada pelas classes array dendrogram e gene dendrogram, as quais representam dendrogramas de arrays e de genes, respectivamente. As classes array dendrogram e gene dendrogram foram também modeladas como subtipos da classe microarray data (relacionamentos não apresentados na figura).

A classe raw gene expression data representa dados de expressão gênica brutos contendo os níveis de expressão obtidos em um experimento de medição. Neste sentido, esta classe especializa tanto a classe gene expression data quanto a classe raw data. A classe raw gene expression data é especializada pela classe raw microarray data, a qual representa dados de microarray brutos obtidos a partir de um experimento de microarray. Neste sentido, a classe raw microarray data especializa também a classe microarray data. A classe raw microarray data é especializada pelas classes one-color raw microarray data e two-color raw microarray data. Estas duas classes representam dados de microarray brutos obtidos a partir de experimentos de microarray one-color e two-color, respectivamente. Assim, estas duas classes foram também modeladas como subtipos das classes one-color microarray data e two-color microarray data, respectivamente.

A classe processed gene expression data representa dados de expressão gênica que foram computacionalmente processados. Neste sentido, esta classe especializa tanto a classe gene expression data quanto a classe processed data. A classe processed gene expression é especializada pelas classes normalized gene expression data e clustered gene expression data. A classe normalized gene expression data representa dados de expressão gênica que passaram por um processo de normalização. Esta classe é especializada pela classe normalized microarray data, a qual representa dados de microarray que passaram por um processo de normalização. Neste sentido, a classe normalized microarray data especializa também a classe microarray data. A classe normalized microarray data é especializada pelas classes one-color normalized microarray data e two-color normalized microarray data, as quais representam dados de microarray one-color e two-color normalizados, respectivamente.

Finalmente, a classe clustered gene expression data representa dados de expressão gênica que passaram por um processo de agrupamento. Esta classe é especializada pela classe cluste- 
red microarray data, a qual representa dados de microarray que passaram por um processo de agrupamento. Neste sentido, a classe clustered microarray data especializa também a classe $m i$ croarray data. A classe clustered microarray data é especializada pelas classes hierarchically clustered microarray data e non-hierarchically clustered microarray data, as quais representam dados de microarray que passaram por um processo de agrupamento hierárquico e não hierárquico, respectivamente.

A Figura 89 apresenta uma visão geral dos dados de RNA-Seq associados aos serviços desenvolvidos para a análise destes tipos de dados.

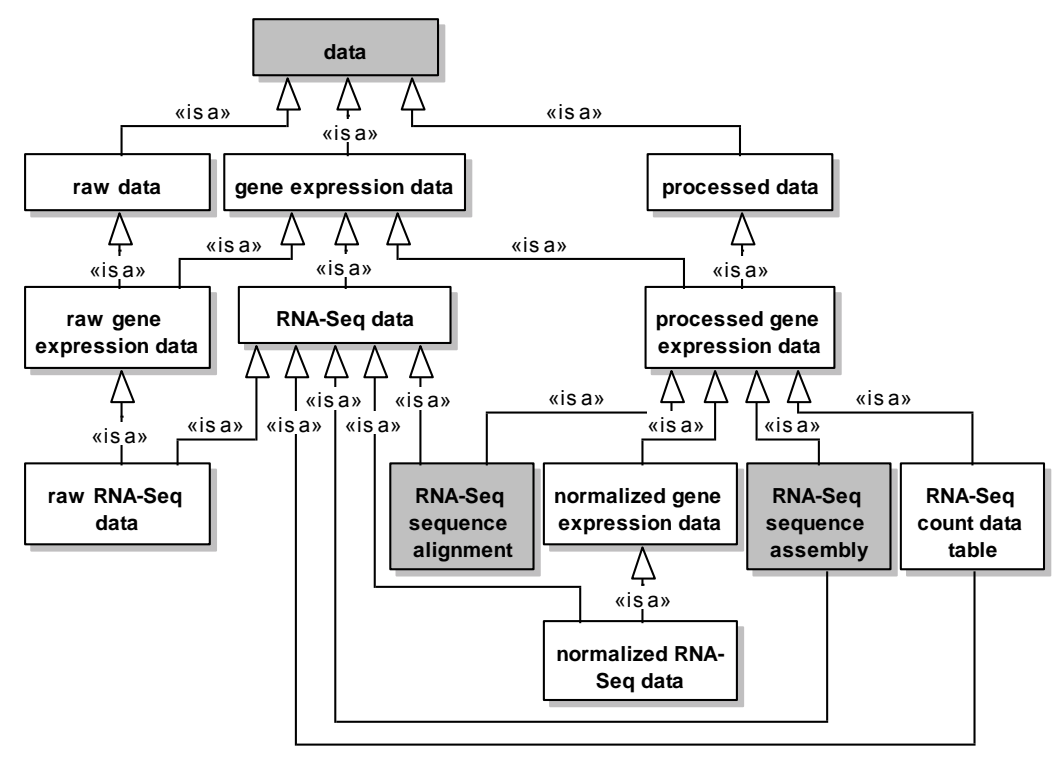

Figura 89: Dados de RNA-Seq.

A classe data representa itens de dados. Esta classe é especializada pelas classes gene expression data, raw data e processed data. As classes raw data e processed data representam dados brutos e dados que foram computacionalmente processados, respectivamente. A classe gene expression data representa dados (brutos ou processados) produzidos a partir de experimentos de medição de expressão gênica. Esta classe é especializada pela classe RNA-Seq data para representar dados (brutos ou processados) produzidos a partir de experimentos de RNA-Seq.

A classe raw gene expression data representa dados de expressão gênica brutos. Neste sentido, esta classe especializa tanto a classe gene expression data quanto a classe raw data. A classe raw gene expression data é especializada pela classe raw RNA-Seq data, a qual representa 
dados de RNA-Seq brutos obtidos a partir de um experimento de RNA-Seq. Neste sentido, a classe raw RNA-Seq data especializa também a classe RNA-Seq data.

A classe processed gene expression data representa dados de expressão gênica que foram computacionalmente processados. Neste sentido, esta classe especializa tanto a classe gene expression data quanto a classe processed data. A classe processed gene expression é especializada pelas classes normalized gene expression data, RNA-Seq sequence alignment, RNA-Seq sequence assembly e RNA-Seq count data table. A classe normalized gene expression data representa dados de expressão gênica que passaram por um processo de normalização. Esta classe é especializada pela classe normalized RNA-Seq data, a qual representa dados de RNA-Seq que passaram por um processo de normalização. Neste sentido, a classe normalized RNA-Seq data especializa também a classe RNA-Seq data.

A classe RNA-Seq sequence alignment representa dados de RNA-Seq que foram alinhados a um genoma de referência. A classe RNA-Seq sequence assembly representa dados de RNASeq que passaram por um processo de reconstrução (de novo) de sequências de DNA. A classe RNA-Seq count data table representa dados de RNA-Seq que passaram por um processo de sumarização. As classes RNA-Seq sequence alignment, RNA-Seq sequence assembly e RNASeq count data table especializam também a classe RNA-Seq data.

SERVIÇOS PARA DADOS DE MICROARRAY

Esta seção apresenta os conceitos e relacionamentos definidos na ontologia GEXPASO para a descrição dos aspectos estruturais e funcionais dos serviços desenvolvidos para a análise de dados de microarray.

A Figura 90 apresenta uma visão geral do processo de pré-processamento de dados de microarray Affymetrix no serviço MicroAffyNorm.

A classe Affymetrix microarray data preprocessing representa o processo de pré-processamento de dados de microarray provenientes da plataforma Affymetrix. As classes background correction, between arrays normalization e summarization representam diferentes subprocessos da classe Affymetrix microarray data preprocessing. Assim, cada uma destas classes está asso- 


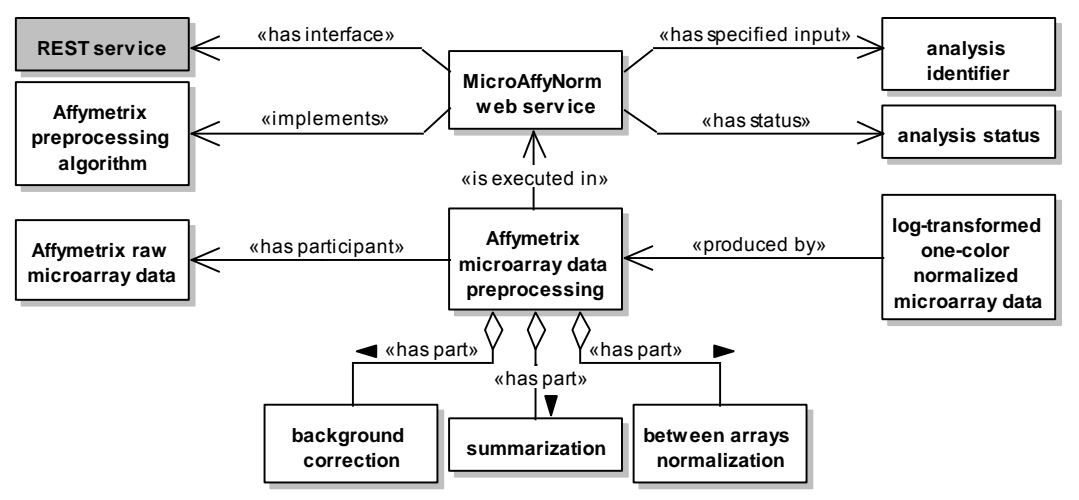

Figura 90: Pré-processamento de dados Affymetrix no serviço MicroAffyNorm.

ciada à classe Affymetrix microarray data preprocessing por meio de um relacionamento has part.

O processo de análise representado pela classe Affymetrix microarray data preprocessing está associado à classe Affymetrix raw microarray data por meio do relacionamento has participant. A classe Affymetrix raw microarray data especializa a classe one-color raw microarray data (relacionamento não apresentado na Figura 88). O relacionamento has participant indica que o processo de pré-processamento requer dados de microarray brutos provenientes da plataforma de microarray Affymetrix para sua execução. Além disto, a classe Affymetrix microarray data preprocessing está associada à classe log-transformed one-color normalized microarray data por meio do relacionamento produced by. A classe log-transformed one-color normalized microarray data especializa a classe one-color normalized microarray data (relacionamento não apresentado na Figura 88). O relacionamento produced by indica que dados de microarray one-color normalizados e em escala logarítmica (base 2) são produzidos a partir do pré-processamento de dados Affymetrix. Adicionalmente, a classe Affymetrix microarray data preprocessing está associada à classe MicroAffyNorm web service por meio do relacionamento is executed in. Este relacionamento indica que o processo de pré-processamento de dados Affymetrix é executado no serviço MicroAffyNorm.

A classe MicroAffyNorm web service está associada à classe REST service por meio do relacionamento has interface, indicando que as funcionalidades do serviço MicroAffyNorm podem ser acessadas por meio de uma interface REST. A classe MicroAffyNorm web service também está associada à classe Affymetrix preprocessing algorithm por meio do relacionamento implements, indicando que o serviço MicroAffyNorm implementa um algoritmo específico para 
o pré-processamento de dados Affymetrix. Este algoritmo é representado pela instância robust multiarray analysis (não apresentada na figura) da classe Affymetrix preprocessing algorithm. Adicionalmente, a classe MicroAffyNorm web service está associada à classe analysis status por meio do relacionamento has status, indicando que a execução do processo de préprocessamento no serviço possui um estado associado. Finalmente, a classe MicroAffyNorm web service está associada à classe analysis identifier por meio do relacionamento has specified input, indicando que o serviço MicroAffyNorm requer como entrada um identificador de análise.

A Figura 91 apresenta uma visão geral do processo de pré-processamento de dados de microarray Agilent no serviço MicroAgilentNorm.

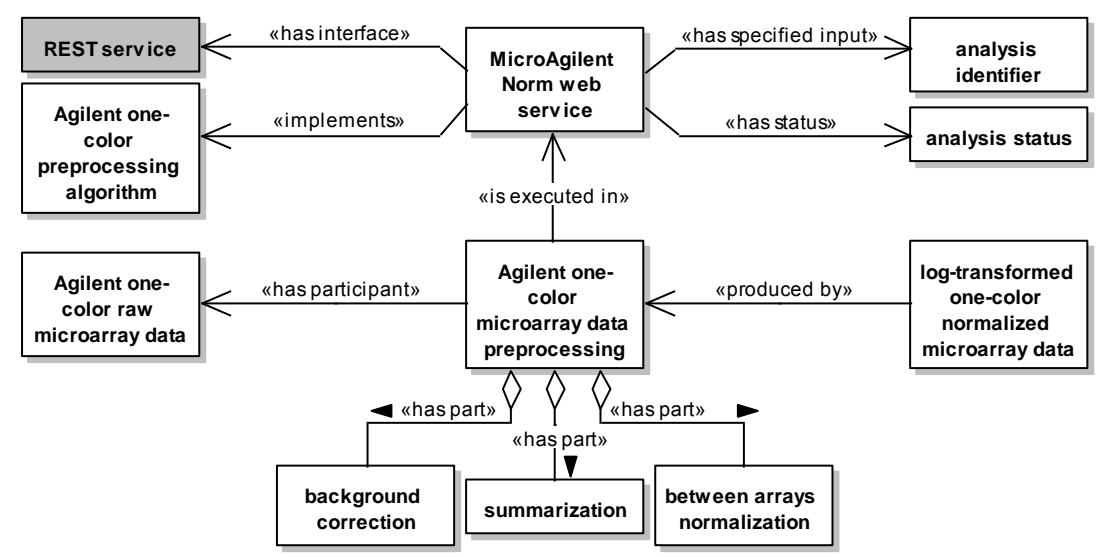

Figura 91: Pré-processamento de dados Agilent no serviço MicroAgilentNorm.

A classe Agilent one-color microarray data preprocessing representa o processo de préprocessamento de dados de microarray one-color provenientes da plataforma Agilent. As classes background correction, between arrays normalization e summarization representam diferentes subprocessos da classe Agilent one-color microarray data preprocessing. Assim, cada uma destas classes está associada à classe Agilent one-color microarray data preprocessing por meio de um relacionamento has part.

O processo de análise representado pela classe Agilent one-color microarray data preprocessing está associado à classe Agilent one-color raw microarray data por meio do relacionamento has participant. A classe Agilent one-color raw microarray data especializa a classe one-color raw microarray data (relacionamento não apresentado na Figura 88). O relacionamento has participant indica que o processo de pré-processamento requer dados de microarray brutos provenientes da plataforma de microarray Agilent (one-color) para sua execução. Além disto, a 
classe Agilent one-color microarray data preprocessing está associada à classe log-transformed one-color normalized microarray data por meio do relacionamento produced by. A classe logtransformed one-color normalized microarray data especializa a classe one-color normalized microarray data (relacionamento não apresentado na Figura 88). O relacionamento produced by indica que dados de microarray one-color normalizados e em escala logarítmica (base 2) são produzidos a partir do pré-processamento de dados Agilent. Adicionalmente, a classe Agilent one-color microarray data preprocessing está associada à classe MicroAgilentNorm web service por meio do relacionamento is executed in. Este relacionamento indica que o processo de pré-processamento de dados Agilent é executado no serviço MicroAgilentNorm.

A classe MicroAgilentNorm web service está associada à classe REST service por meio do relacionamento has interface, indicando que as funcionalidades do serviço MicroAgilentNorm podem ser acessadas por meio de uma interface REST. A classe MicroAgilentNorm web service também está associada à classe Agilent one-color preprocessing algorithm por meio do relacionamento implements, indicando que o serviço MicroAgilentNorm implementa algoritmos específicos para o pré-processamento de dados one-color Agilent. Estes algoritmos são representados pelas instâncias quantile e subtract (não apresentadas na figura) da classe Agilent one-color preprocessing algorithm. Adicionalmente, a classe MicroAgilentNorm web service está associada à classe analysis status por meio do relacionamento has status, indicando que a execução do processo de pré-processamento no serviço possui um estado associado. Finalmente, a classe MicroAgilentNorm web service está associada à classe analysis identifier por meio do relacionamento has specified input, indicando que o serviço MicroAgilentNorm requer como entrada um identificador de análise.

A Figura 92 apresenta uma visão geral do processo de pré-processamento de dados de microarray Genepix no serviço MicroGenepixNorm.

A classe Genepix microarray data preprocessing representa o processo de pré-processamento de dados de microarray provenientes do sistema de escaneamento Genepix. As classes background correction, between arrays normalization, within arrays normalization e summarization representam diferentes subprocessos da classe Genepix microarray data preprocessing. Assim, cada uma destas classes está associada à classe Genepix microarray data preprocessing por meio de um relacionamento has part. 


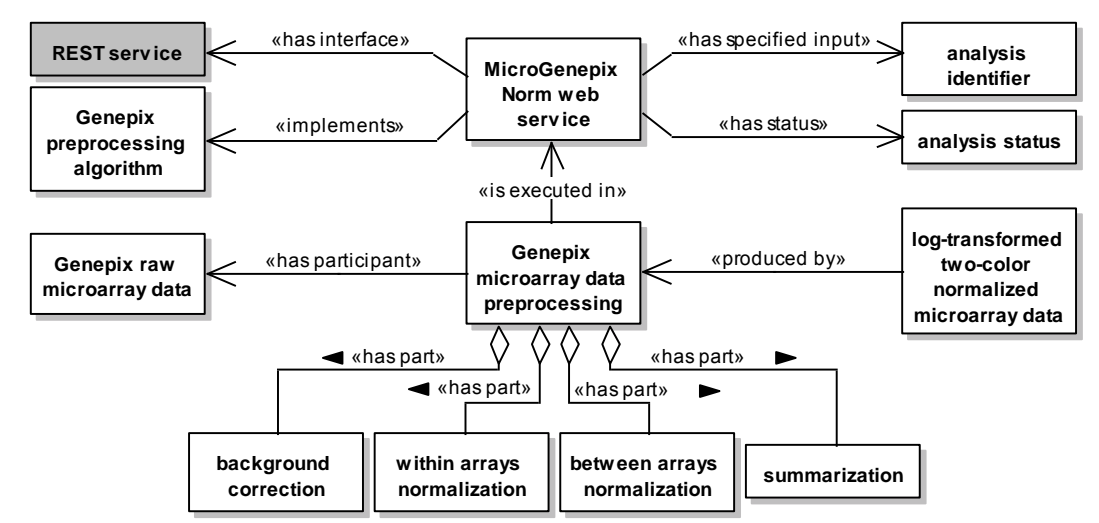

Figura 92: Pré-processamento de dados Genepix no serviço MicroGenepixNorm.

O processo de análise representado pela classe Genepix microarray data preprocessing está associado à classe Genepix raw microarray data por meio do relacionamento has participant. A classe Genepix raw microarray data especializa a classe two-color raw microarray data (relacionamento não apresentado na Figura 88). O relacionamento has participant indica que o processo de pré-processamento requer dados de microarray brutos provenientes do sistema de escaneamento Genepix para sua execução. Além disto, a classe Genepix microarray data preprocessing está associada à classe log-transformed two-color normalized microarray data por meio do relacionamento produced by. A classe log-transformed two-color normalized microarray data especializa a classe two-color normalized microarray data (relacionamento não apresentado na Figura 88). O relacionamento produced by indica que dados de microarray two-color normalizados e em escala logarítmica (base 2) são produzidos a partir do pré-processamento de dados Genepix. Adicionalmente, a classe Genepix microarray data preprocessing está associada à classe MicroGenepixNorm web service por meio do relacionamento is executed in. Este relacionamento indica que o processo de pré-processamento de dados Genepix é executado no serviço MicroGenepixNorm.

A classe MicroGenepixNorm web service está associada à classe REST service por meio do relacionamento has interface, indicando que as funcionalidades do serviço MicroGenepixNorm podem ser acessadas por meio de uma interface REST. A classe MicroGenepixNorm web service também está associada à classe Genepix preprocessing algorithm por meio do relacionamento implements, indicando que o serviço MicroGenepixNorm implementa algoritmos específicos para o pré-processamento de dados Genepix. Estes algoritmos são representados pelas instân- 
cias Aquantile, loess e subtract (não apresentadas na figura) da classe Genepix preprocessing algorithm. Adicionalmente, a classe MicroGenepixNorm web service está associada à classe analysis status por meio do relacionamento has status, indicando que a execução do processo de pré-processamento no serviço possui um estado associado. Finalmente, a classe MicroGenepixNorm web service está associada à classe analysis identifier por meio do relacionamento has specified input, indicando que o serviço MicroGenepixNorm requer como entrada um identificador de análise.

A Figura 93 apresenta uma visão geral do processo de análise diferencial de dados de microarray one-color no serviço MicroOneDifferentialAnalysis.

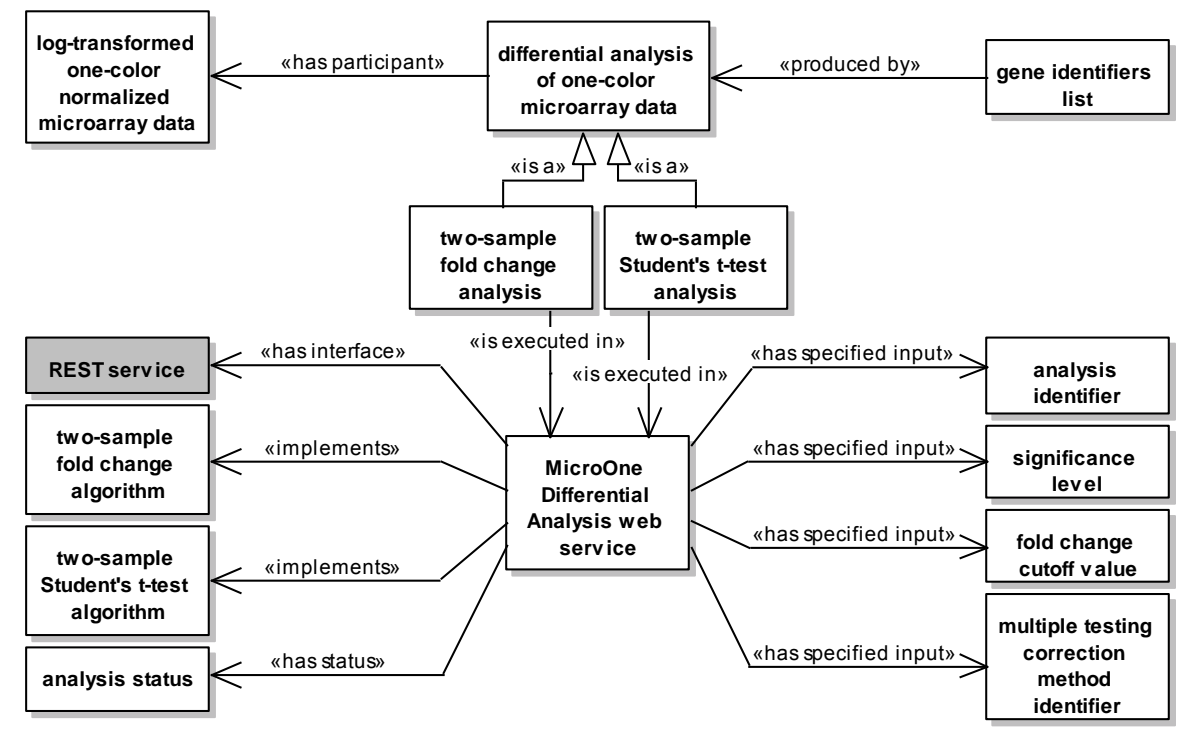

Figura 93: Análise diferencial de dados de microarray one-color no serviço MicroOneDifferentialAnalysis.

A classe differential analysis of one-color microarray data representa o processo de identificação de genes diferencialmente expressos em dados de microarray one-color. Esta classe está associada à classe log-transformed one-color normalized microarray data por meio do relacionamento has participant. A classe log-transformed one-color normalized microarray data especializa a classe one-color normalized microarray data (relacionamento não apresentado na Figura 88). O relacionamento has participant indica que o processo de análise diferencial requer dados de microarray one-color normalizados e em escala logarítmica para sua execução. Além disto, a classe differential analysis of one-color microarray data está associada à classe gene identifiers list por meio do relacionamento produced by. A classe gene identifiers 
list especializa a classe gene expression data (relacionamento não apresentado na Figura 88). O relacionamento produced by indica que uma lista de identificadores de genes é produzida a partir da análise diferencial de dados de microarray.

O processo de análise representado pela classe differential analysis of one-color microarray data é ainda especializado pelas classes two-sample fold change analysis e two-sample Student's t-test analysis. A classe two-sample fold change analysis representa o processo por meio do qual genes em duas amostras (condições) distintas são identificados como diferencialmente expressos se as diferenças entre os valores absolutos de expressão dos genes nas duas amostras forem maiores que um valor limiar de corte pré-determinado. A classe two-sample Student's t-test analysis representa o processo de análise estatístico teste t de Student, o qual pode ser utilizado para determinar se genes em duas amostras (condições) distintas podem ser considerados diferencialmente expressos. Os processos representados pelas classes two-sample fold change analysis e two-sample Student's t-test analysis estão associados à classe MicroOneDifferentialAnalysis web service por meio de relacionamentos is executed in, indicando que estes processos são executados no serviço MicroOneDifferentialAnalysis.

A classe MicroOneDifferentialAnalysis web service está associada à classe REST service por meio do relacionamento has interface, indicando que as funcionalidades do serviço MicroOneDifferentialAnalysis podem ser acessadas por meio de uma interface REST. A classe MicroOneDifferentialAnalysis web service também está associada às classes two-sample fold-change algorithm e two-sample Student's t-test algorithm por meio de relacionamentos implements, indicando que o serviço MicroOneDifferentialAnalysis implementa algoritmos específicos para os testes fold change e t de Student entre duas amostras, respectivamente. Além disto, a classe MicroOneDifferentialAnalysis web service está associada à classe analysis status por meio do relacionamento has status, indicando que a execução do processo de análise diferencial no serviço possui um estado associado.

Finalmente, a classe MicroOneDifferentialAnalysis web service está associada à classe analysis identifier por meio do relacionamento has specified input. Este relacionamento indica que o serviço MicroOneDifferentialAnalysis requer como entrada um identificador de análise. De forma análoga, o relacionamento has specified input também foi definido entre a classe MicroOneDifferentialAnalysis web service e as classes significance level, fold change cutoff value e 
multiple testing correction method identifier, indicando que o serviço MicroOneDifferentialAnalysis requer também como entradas um nível de significância, um valor limiar de corte e um identificador de método de correção de múltiplos testes.

A Figura 94 apresenta uma visão geral do processo de análise diferencial de dados de microarray two-color no serviço MicroTwoDifferentialAnalysis.

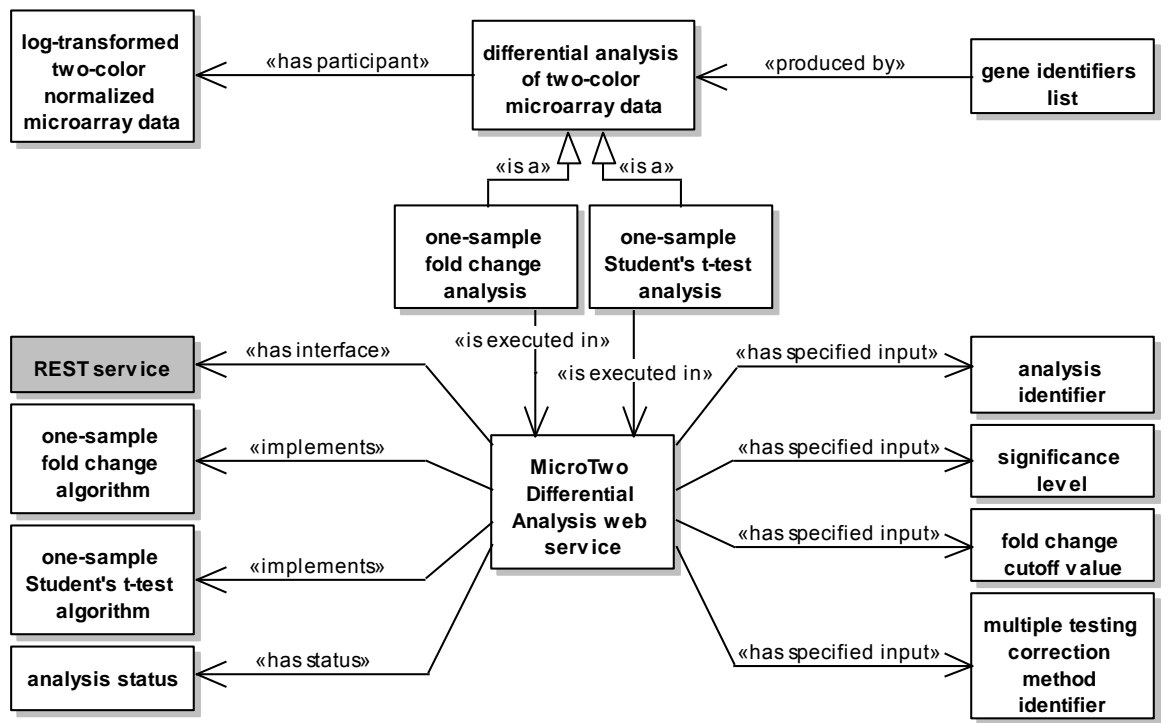

Figura 94: Análise diferencial de dados de microarray two-color no serviço MicroTwoDifferentialAnalysis.

A classe differential analysis of two-color microarray data representa o processo de identificação de genes diferencialmente expressos em dados de microarray two-color. Esta classe está associada à classe log-transformed two-color normalized microarray data por meio do relacionamento has participant. A classe log-transformed two-color normalized microarray data especializa a classe two-color normalized microarray data (relacionamento não apresentado na Figura 88). O relacionamento has participant indica que o processo de análise diferencial requer dados de microarray two-color normalizados e em escala logarítmica para sua execução. Além disto, a classe differential analysis of two-color microarray data está associada à classe gene identifiers list por meio do relacionamento produced by. A classe gene identifiers list especializa a classe gene expression data (relacionamento não apresentado na Figura 88). O relacionamento produced by indica que uma lista de identificadores de genes é produzida a partir da análise diferencial de dados de microarray. 
O processo de análise representado pela classe differential analysis of two-color microarray data é ainda especializado pelas classes one-sample fold change analysis e one-sample Student's t-test analysis. A classe one-sample fold change analysis representa o processo por meio do qual genes em uma amostra (associada a duas condições distintas) são identificados como diferencialmente expressos se os valores de expressão relativos dos genes forem maiores que um valor limiar de corte pré-determinado. A classe one-sample Student's t-test analysis representa o processo de análise estatístico teste t de Student, o qual pode ser utilizado para determinar se genes em uma amostra (associada a duas condições distintas) podem ser considerados diferencialmente expressos. Os processos representados pelas classes one-sample fold change analysis e one-sample Student's t-test analysis estão associados à classe MicroTwoDifferentialAnalysis web service por meio de relacionamentos is executed in, indicando que estes processos são executados no serviço MicroTwoDifferentialAnalysis.

A classe MicroTwoDifferentialAnalysis web service está associada à classe REST service por meio do relacionamento has interface, indicando que as funcionalidades do serviço MicroTwoDifferentialAnalysis podem ser acessadas por meio de uma interface REST. A classe MicroTwoDifferentialAnalysis web service também está associada às classes one-sample fold-change algorithm e one-sample Student's t-test algorithm por meio de relacionamentos implements, indicando que o serviço MicroTwoDifferentialAnalysis implementa algoritmos específicos para os testes fold change e t de Student em uma amostra, respectivamente. Além disto, a classe MicroTwoDifferentialAnalysis web service está associada à classe analysis status por meio do relacionamento has status, indicando que a execução do processo de análise diferencial no serviço possui um estado associado.

Finalmente, a classe MicroTwoDifferentialAnalysis web service está associada à classe analysis identifier por meio do relacionamento has specified input. Este relacionamento indica que o serviço MicroTwoDifferentialAnalysis requer como entrada um identificador de análise. De forma análoga, o relacionamento has specified input também foi definido entre a classe $M i$ croTwoDifferentialAnalysis web service e as classes significance level, fold change cutoff value e multiple testing correction method identifier, indicando que o serviço MicroTwoDifferentialAnalysis requer também como entradas um nível de significância, um valor limiar de corte e um identificador de método de correção de múltiplos testes. 
A Figura 95 apresenta uma visão geral do processo de agrupamento hierárquico de dados de microarray no serviço MicroHCluster.

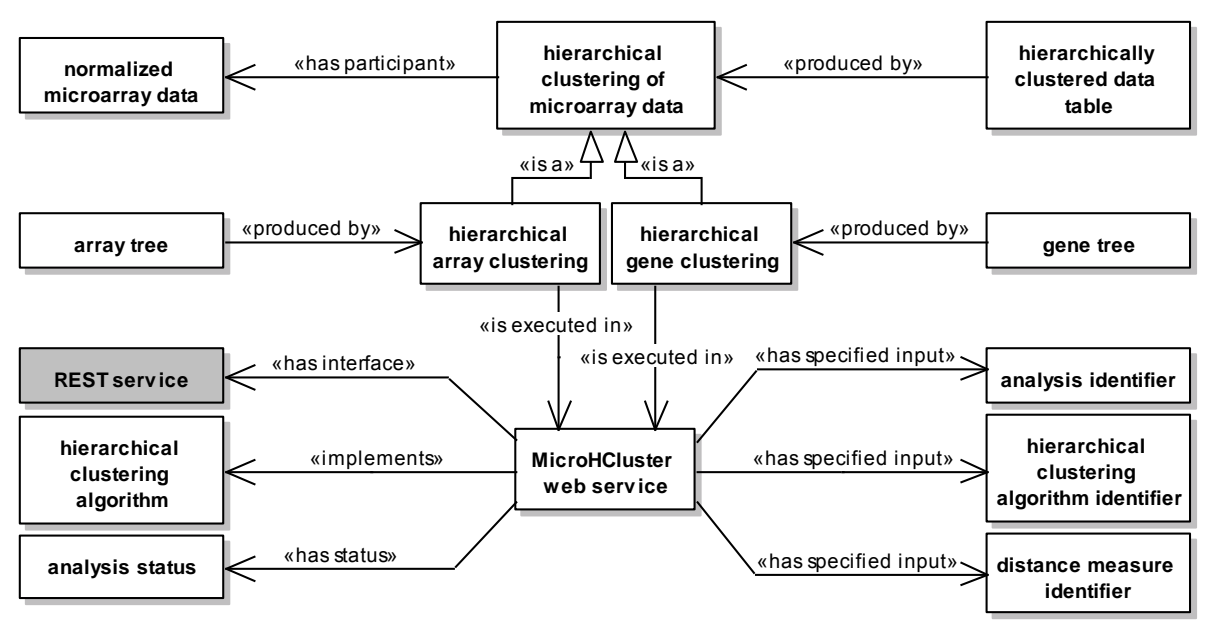

Figura 95: Agrupamento hierárquico de dados de microarray no serviço MicroHCluster.

A classe hierarchical clustering of microarray data representa o processo de agrupamento hierárquico de dados de microarray pelo qual perfis de expressão gênica similares são agrupados iterativamente até a formação de uma árvore hierárquica. Esta classe está associada à classe normalized microarray data por meio do relacionamento has participant. Este relacionamento indica que o processo de agrupamento hierárquico requer dados de microarray normalizados para sua execução. Além disto, a classe hierarchical clustering of microarray data está associada à classe hierarchically clustered data table por meio do relacionamento produced by. A classe hierarchically clustered data table especializa a classe hierarchically clustered microarray data (relacionamento não apresentado na Figura 88). O relacionamento produced by indica que uma tabela de dados agrupados é produzida a partir do agrupamento hierárquico de dados de microarray.

O processo de análise representado pela classe hierarchical clustering of microarray data é ainda especializado pelas classes hierarchical array clustering e hierarchical gene clustering. A classe hierarchical array clustering representa o processo de agrupamento hierárquico de arrays (condições experimentais). Esta classe está associada à classe array tree por meio do relacionamento produced by. A classe array tree especializa a classe hierarchically clustered microarray data (relacionamento não apresentado na Figura 88). O relacionamento produced by indica que uma árvore hierárquica de arrays é produzida a partir do agrupamento hierárquico de 
arrays. A classe hierarchical gene clustering representa o processo de agrupamento hierárquico de genes. Esta classe está associada à classe gene tree por meio do relacionamento produced by. A classe gene tree também especializa a classe hierarchically clustered microarray data (relacionamento não apresentado na Figura 88). O relacionamento produced by indica que uma árvore hierárquica de genes é produzida a partir do agrupamento hierárquico de genes. Os processos representados pelas classes hierarchical array clustering e hierarchical gene clustering estão associados à classe MicroHCluster web service por meio de relacionamentos is executed in, indicando que estes processos são executados no serviço MicroHCluster.

A classe MicroHCluster web service está associada à classe REST service por meio do relacionamento has interface, indicando que as funcionalidades do serviço MicroHCluster podem ser acessadas por meio de uma interface REST. A classe MicroHCluster web service também está associada à classe hierarchical clustering algorithm por meio do relacionamento implements, indicando que o serviço MicroHCluster implementa algoritmos específicos para o agrupamento hierárquico de dados. Estes algoritmos são representados pelas instâncias pairwise averagelinkage, pairwise centroid-linkage, pairwise single-linkage e pairwise complete-linkage (não apresentadas na figura) da classe hierarchical clustering algorithm. Além disto, a classe MicroHCluster web service está associada à classe analysis status por meio do relacionamento has status, indicando que a execução do processo de agrupamento hierárquico no serviço possui um estado associado.

Finalmente, a classe MicroHCluster web service está associada à classe analysis identifier por meio do relacionamento has specified input. Este relacionamento indica que o serviço MicroHCluster requer como entrada um identificador de análise. De forma análoga, o relacionamento has specified input também foi definido entre a classe MicroHCluster web service e as classes hierarchical clustering algorithm identifier e distance measure identifier, indicando que o serviço MicroHCluster requer também como entradas um identificador de algoritmo de agrupamento hierárquico e um identificador de métrica de similaridade.

A Figura 96 apresenta uma visão geral do processo de agrupamento k-means de dados de microarray no serviço MicroKCluster.

A classe k-means clustering of microarray data representa o processo de agrupamento não hierárquico de dados de microarray por meio do algoritmo k-means. Esta classe está associada à 


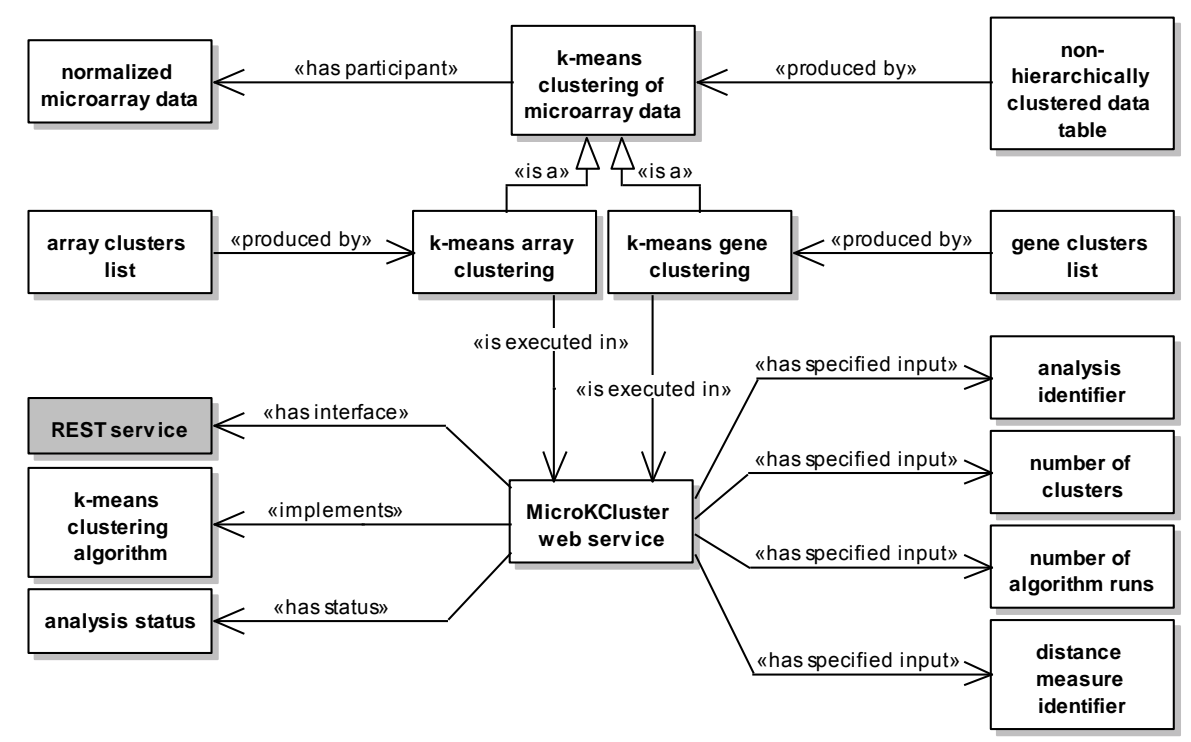

Figura 96: Agrupamento k-means de dados de microarray no serviço MicroKCluster.

classe normalized microarray data por meio do relacionamento has participant. Este relacionamento indica que o processo de agrupamento k-means requer dados de microarray normalizados para sua execução. Além disto, a classe k-means clustering of microarray data está associada à classe non-hierarchically clustered data table por meio do relacionamento produced by. A classe non-hierarchically clustered data table especializa a classe non-hierarchically clustered microarray data (relacionamento não apresentado na Figura 88). O relacionamento produced by indica que uma tabela de dados agrupados não hierarquicamente é produzida a partir do agrupamento k-means de dados de microarray.

O processo de análise representado pela classe $k$-means clustering of microarray data é ainda especializado pelas classes $k$-means array clustering e k-means gene clustering. A classe $k$ means array clustering representa o processo de agrupamento k-means de arrays (condições experimentais). Esta classe está associada à classe array clusters list por meio do relacionamento produced by. A classe array clusters list especializa a classe non-hierarchically clustered microarray data (relacionamento não apresentado na Figura 88). O relacionamento produced by indica que uma lista de grupos de arrays é produzida a partir do agrupamento k-means de arrays. A classe k-means gene clustering representa o processo de agrupamento k-means de genes. Esta classe está associada à classe gene clusters list por meio do relacionamento produced by. A classe gene clusters list especializa a classe non-hierarchically clustered microarray data 
(relacionamento não apresentado na Figura 88). O relacionamento produced by indica que uma lista de grupos de genes é produzida a partir do agrupamento k-means de genes. Os processos representados pelas classes $k$-means array clustering e $k$-means gene clustering estão associados à classe MicroKCluster web service por meio de relacionamentos is executed in, indicando que estes processos são executados no serviço MicroKCluster.

A classe MicroKCluster web service está associada à classe REST service por meio do relacionamento has interface, indicando que as funcionalidades do serviço MicroKCluster podem ser acessadas por meio de uma interface REST. A classe MicroKCluster web service também está associada à classe $k$-means clustering algorithm por meio do relacionamento implements, indicando que o serviço MicroKCluster implementa o algoritmo de agrupamento k-means. Além disto, a classe MicroKCluster web service está associada à classe analysis status por meio do relacionamento has status, indicando que a execução do processo de agrupamento k-means no serviço possui um estado associado.

Finalmente, a classe MicroKCluster web service está associada à classe analysis identifier por meio do relacionamento has specified input. Este relacionamento indica que o serviço MicroKCluster requer como entrada um identificador de análise. De forma análoga, o relacionamento has specified input também foi definido entre a classe MicroKCluster web service e as classes number of clusters, number of algorithm runs e distance measure identifier, indicando que o serviço MicroKCluster requer também como entradas um número pré-determinado de grupos, um número pré-determinado de execuções do algoritmo e um identificador de métrica de similaridade.

A Figura 97 apresenta uma visão geral do processo de geração de dendrogramas no serviço MicroHClusterViewer.

A classe dendrogram generation representa o processo de geração de dendrogramas. Esta classe está associada à classe hierarchically clustered data table por meio do relacionamento has participant. A classe hierarchically clustered data table especializa a classe hierarchically clustered microarray data (relacionamento não apresentado na Figura 88). O relacionamento has participant indica que o processo de geração de dendrogramas requer uma tabela de dados de microarray hierarquicamente agrupados para sua execução. 


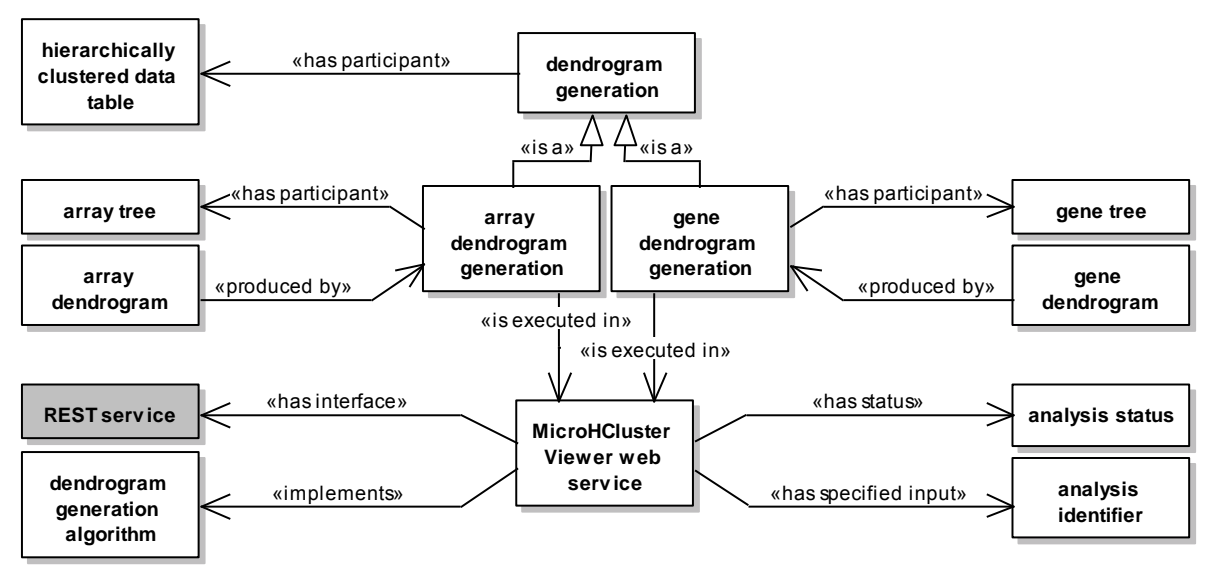

Figura 97: Geração de dendrogramas no serviço MicroHClusterViewer.

O processo de análise representado pela classe dendrogram generation é ainda especializado pelas classes array dendrogram generation e gene dendrogram generation. A classe array dendrogram generation representa o processo de geração de dendrogramas de arrays (condições experimentais). Esta classe está associada à classe array tree por meio do relacionamento has participant. A classe array tree especializa a classe hierarchically clustered microarray data (relacionamento não apresentado na Figura 88). O relacionamento has participant indica que o processo de geração de dendrogramas de arrays requer uma árvore hierárquica de arrays. Além disto, o processo representado pela classe array dendrogram generation está associada à classe array dendrogram por meio do relacionamento produced by. A classe array dendrogram especializa a classe microarray data (relacionamento não apresentado na Figura 88). O relacionamento produced by indica que um dendrograma de arrays é produzido a partir da execução do processo.

De forma análoga, a classe gene dendrogram generation representa o processo de geração de dendrogramas de genes. Esta classe está associada à classe gene tree por meio do relacionamento has participant. A classe gene tree especializa a classe hierarchically clustered microarray data (relacionamento não apresentado na Figura 88). O relacionamento has participant indica que o processo de geração de dendrogramas de genes requer uma árvore hierárquica de genes. Além disto, o processo representado pela classe gene dendrogram generation está associada à classe gene dendrogram por meio do relacionamento produced by. A classe gene dendrogram especializa a classe microarray data (relacionamento não apresentado na Figura 88). O relacionamento produced by indica que um dendrograma de genes é produzido a partir 
da execução do processo. Os processos representados pelas classes array dendrogram generation e gene dendrogram generation estão associados à classe MicroHClusterViewer web service por meio de relacionamentos is executed in, indicando que estes processos são executados no serviço MicroHClusterViewer.

A classe MicroHClusterViewer web service está associada à classe REST service por meio do relacionamento has interface, indicando que as funcionalidades do serviço MicroHClusterViewer podem ser acessadas por meio de uma interface REST. A classe MicroHClusterViewer web service também está associada à classe dendrogram generation algorithm por meio do relacionamento implements, indicando que o serviço MicroHClusterViewer implementa um algoritmo específico para a geração de dendrogramas. Além disto, a classe MicroHClusterViewer web service está associada à classe analysis status por meio do relacionamento has status, indicando que a execução do processo de geração de dendrogramas no serviço possui um estado associado. Finalmente, a classe MicroHClusterViewer web service está associada à classe analysis identifier por meio do relacionamento has specified input. Este relacionamento indica que o serviço MicroHClusterViewer requer como entrada um identificador de análise.

SERVIÇO PARA DADOS DE RNA-SEQ

Esta seção apresenta os conceitos e relacionamentos definidos na ontologia GEXPASO para a descrição dos aspectos estruturais e funcionais do serviço desenvolvido para a análise de dados de RNA-Seq.

A Figura 98 apresenta uma visão geral do processo de análise diferencial de dados de RNASeq no serviço RnaSeqDifferentialAnalysis.

A classe differential analysis of RNA-Seq data representa o processo de identificação de genes diferencialmente expressos em dados de RNA-Seq. Esta classe está associada à classe RNASeq count data table por meio do relacionamento has participant. Este relacionamento indica que o processo de análise diferencial requer uma tabela de dados de contagem de RNA-Seq para sua execução. Além disto, a classe differential analysis of RNA-Seq data está associada à classe gene identifiers list por meio do relacionamento produced by. A classe gene identifiers list especializa a classe gene expression data (relacionamento não apresentado na Figura 89). 


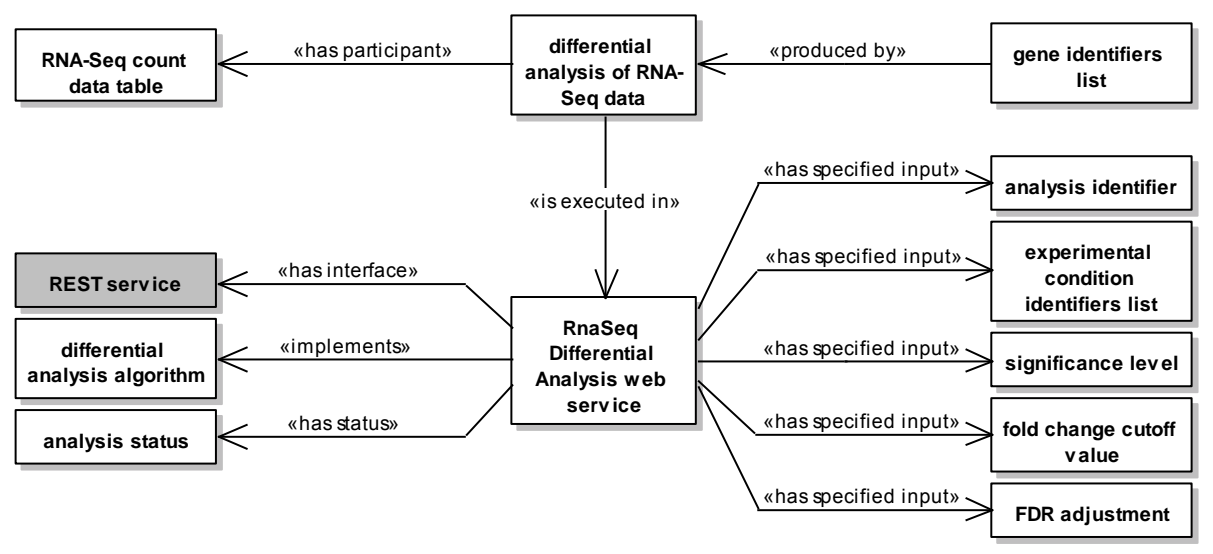

Figura 98: Análise diferencial de dados de RNA-Seq no serviço RnaSeqDifferentialAnalysis.

O relacionamento produced by indica que uma lista de identificadores de genes é produzida a partir da análise diferencial de dados de RNA-Seq. Adicionalmente, a classe differential analysis of RNA-Seq data está associada à classe RnaSeqDifferentialAnalysis web service por meio do relacionamento is executed in. Este relacionamento indica que o processo de análise diferencial de dados de RNA-Seq é executado no serviço RnaSeqDifferentialAnalysis.

A classe RnaSeqDifferentialAnalysis web service está associada à classe REST service por meio do relacionamento has interface, indicando que as funcionalidades do serviço RnaSeqDifferentialAnalysis podem ser acessadas por meio de uma interface REST. A classe RnaSeqDifferentialAnalysis web service também está associada à classe differential analysis algorithm por meio do relacionamento implements, indicando que o serviço RnaSeqDifferentialAnalysis implementa um algoritmo específico para a análise diferencial de dados de RNA-Seq. Além disto, a classe RnaSeqDifferentialAnalysis web service está associada à classe analysis status por meio do relacionamento has status, indicando que a execução do processo de análise diferencial no serviço possui um estado associado.

Finalmente, a classe RnaSeqDifferentialAnalysis web service está associada à classe analysis identifier por meio do relacionamento has specified input. Este relacionamento indica que o serviço RnaSeqDifferentialAnalysis requer como entrada um identificador de análise. De forma análoga, o relacionamento has specified input também foi definido entre a classe RnaSeqDifferentialAnalysis web service e as classes experimental condition identifiers list, significance level, fold change cutoff value e FDR adjustment, indicando que o serviço RnaSeqDifferenti- 
alAnalysis requer também como entradas uma lista de identificadores de amostras associadas a uma condição experimental, um nível de significância, um valor limiar de corte e um valor booleano indicando se o método de correção estatístico False Discovery Rate (FDR) deve ser aplicado.

SERVIÇOS PARA DADOS DE EXPRESSÃO GÊNICA

Esta seção apresenta os conceitos e relacionamentos definidos na ontologia GEXPASO para a descrição dos aspectos estruturais e funcionais dos serviços desenvolvidos para a análise de dados de expressão gênica.

A Figura 99 apresenta uma visão geral do processo de análise de enriquecimento simples de dados de expressão gênica no serviço EnrichmentAnalysis.

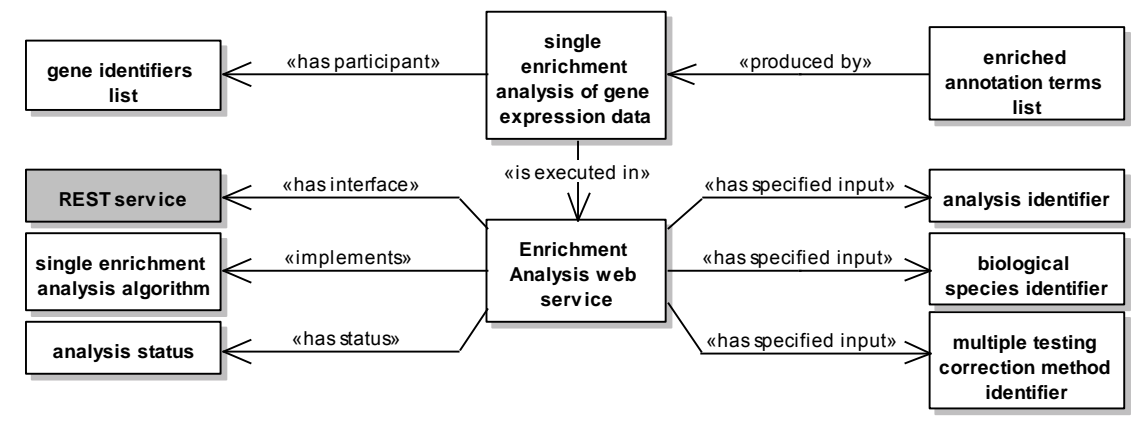

Figura 99: Análise de enriquecimento simples de dados de expressão gênica no serviço EnrichmentAnalysis.

A classe single enrichment analysis of gene expression data representa o processo de análise de enriquecimento simples de dados de expressão gênica, o qual permite a identificação estatística de genes associados a um determinado termo funcional. A classe single enrichment analysis of gene expression data está associada à classe gene identifiers list por meio do relacionamento has participant. A classe gene identifiers list especializa a classe gene expression data (relacionamento não apresentado na Figura 88). O relacionamento has participant indica que o processo de análise de enriquecimento simples requer uma lista de identificadores de genes para sua execução. Além disto, a classe single enrichment analysis of gene expression data está associada à classe enriched annotation terms list por meio do relacionamento produced by. A classe enriched annotation terms list especializa a classe gene expression data (relacionamento 
não apresentado na Figura 88). O relacionamento produced by indica que uma lista de termos biológicos de anotação enriquecidos é produzida a partir da análise de enriquecimento simples. Adicionalmente, a classe single enrichment analysis of gene expression data está associada à classe EnrichmentAnalysis web service por meio do relacionamento is executed in. Este relacionamento indica que o processo de análise de enriquecimento simples é executado no serviço EnrichmentAnalysis.

A classe EnrichmentAnalysis web service está associada à classe REST service por meio do relacionamento has interface, indicando que as funcionalidades do serviço EnrichmentAnalysis podem ser acessadas por meio de uma interface REST. A classe EnrichmentAnalysis web service também está associada à classe single enrichment analysis algorithm por meio do relacionamento implements, indicando que o serviço EnrichmentAnalysis implementa um algoritmo específico para a análise de enriquecimento simples de dados de expressão gênica. Este algoritmo é representado pela instância hypergeometric test (não apresentada na figura) da classe single enrichment analysis algorithm. Além disto, a classe EnrichmentAnalysis web service está associada à classe analysis status por meio do relacionamento has status, indicando que a execução do processo de análise de enriquecimento simples no serviço possui um estado associado.

Finalmente, a classe EnrichmentAnalysis web service está associada à classe analysis identifier por meio do relacionamento has specified input. Este relacionamento indica que o serviço EnrichmentAnalysis requer como entrada um identificador de análise. De forma análoga, o relacionamento has specified input também foi definido entre a classe EnrichmentAnalysis web service e as classes biological species identifier e multiple testing correction method identifier, indicando que o serviço EnrichmentAnalysis requer também como entradas um identificador de espécie biológica e um identificador de método de correção de múltiplos testes.

A Figura 100 apresenta uma visão geral do processo de análise de enriquecimento simples de dados de expressão gênica no serviço DAVID-REST.

A classe single enrichment analysis of gene expression data representa o processo de análise de enriquecimento simples de dados de expressão gênica, o qual permite a identificação estatística de genes associados a um determinado termo funcional. A classe single enrichment analysis of gene expression data está associada à classe gene identifiers list por meio do relacio- 


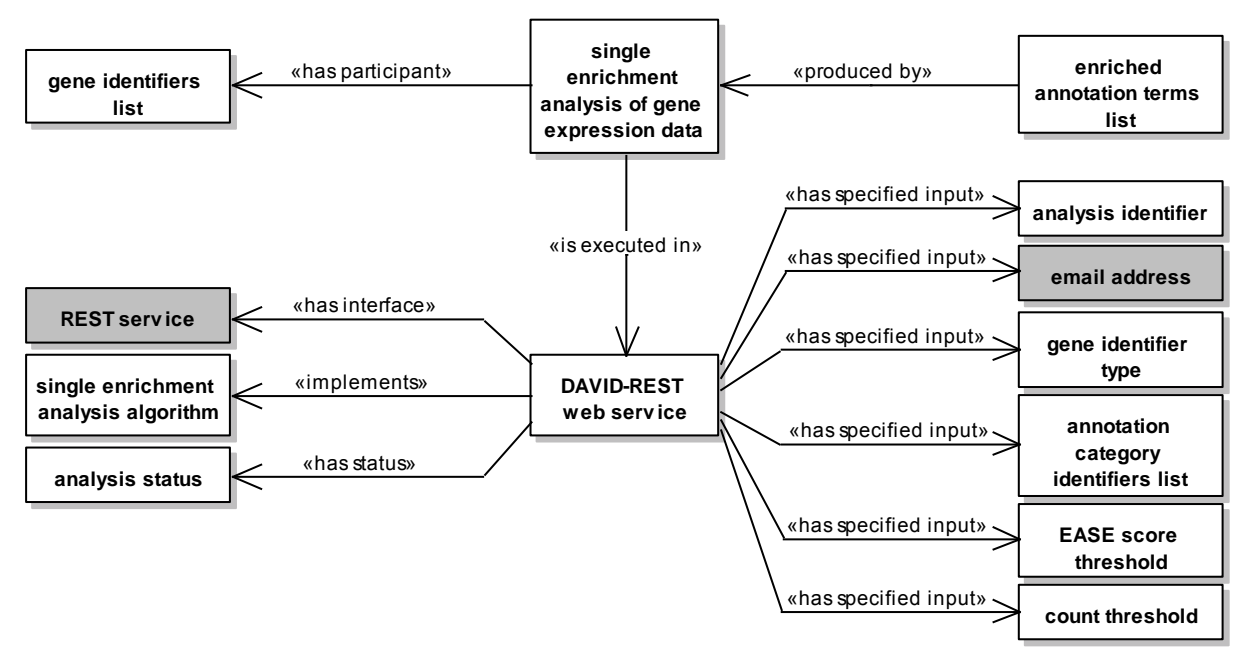

Figura 100: Análise de enriquecimento simples de dados de expressão gênica no serviço DAVID-REST.

namento has participant. A classe gene identifiers list especializa a classe gene expression data (relacionamento não apresentado na Figura 88). O relacionamento has participant indica que o processo de análise de enriquecimento simples requer uma lista de identificadores de genes para sua execução. Além disto, a classe single enrichment analysis of gene expression data está associada à classe enriched annotation terms list por meio do relacionamento produced by. A classe enriched annotation terms list especializa a classe gene expression data (relacionamento não apresentado na Figura 88). O relacionamento produced by indica que uma lista de termos biológicos de anotação enriquecidos é produzida a partir da análise de enriquecimento simples. Adicionalmente, a classe single enrichment analysis of gene expression data está associada à classe DAVID-REST web service por meio do relacionamento is executed in. Este relacionamento indica que o processo de análise de enriquecimento simples é executado no serviço DAVID-REST.

A classe DAVID-REST web service está associada à classe REST service por meio do relacionamento has interface, indicando que as funcionalidades do serviço DAVID-REST podem ser acessadas por meio de uma interface REST. A classe DAVID-REST web service também está associada à classe single enrichment analysis algorithm por meio do relacionamento implements, indicando que o serviço DAVID-REST implementa um algoritmo específico para a análise de enriquecimento simples de dados de expressão gênica. Este algoritmo é representado pela instância Fisher's exact test (não apresentada na figura) da classe single enrichment analy- 
sis algorithm. Além disto, a classe DAVID-REST web service está associada à classe analysis status por meio do relacionamento has status, indicando que a execução do processo de análise de enriquecimento simples no serviço possui um estado associado.

Finalmente, a classe DAVID-REST web service está associada à classe analysis identifier por meio do relacionamento has specified input. Este relacionamento indica que o serviço DAVID$R E S T$ requer como entrada um identificador de análise. De forma análoga, o relacionamento has specified input também foi definido entre a classe DAVID-REST web service e as classes email address, gene identifier type, annotation category identifiers list, EASE score threshold e count threshold, indicando que o serviço DAVID-REST requer também como entradas um endereço de email registrado, um tipo de identificador de gene, uma lista contendo identificadores de categorias de anotação, um valor limiar de corte de sobre-representação e um valor limiar de corte mínimo.

A Figura 101 apresenta uma visão geral do processo de análise de enriquecimento de grupos de genes em dados de expressão gênica no serviço GeneSetEnrichmentAnalysis.

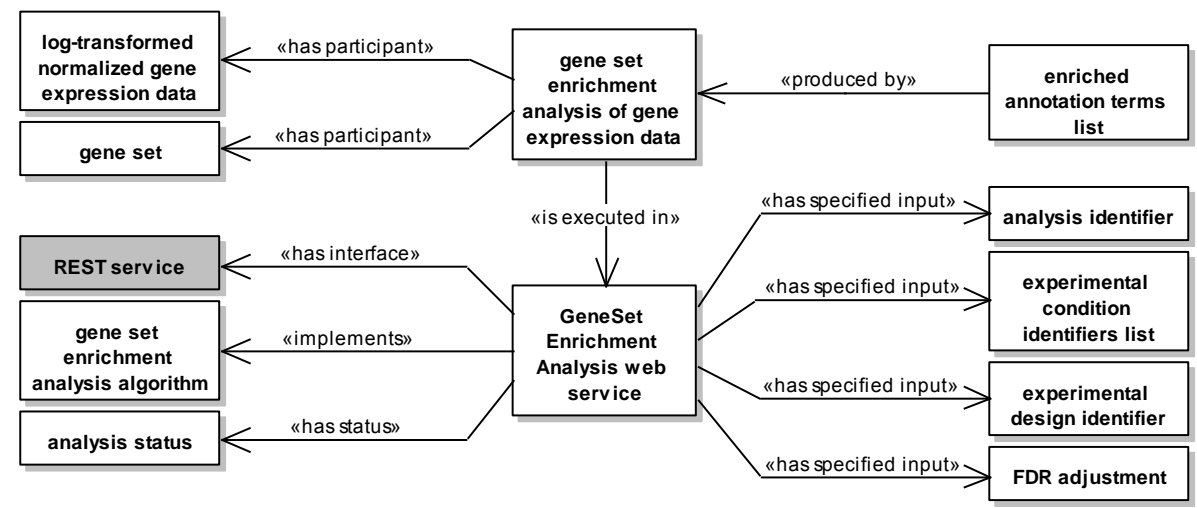

Figura 101: Análise de enriquecimento de grupos de genes no serviço GeneSetEnrichmentAnalysis.

A classe gene set enrichment analysis of gene expression data representa o processo de análise de enriquecimento de grupos de genes em de dados de expressão gênica, o qual permite a identificação estatística de grupos de genes diferencialmente expressos associados a um determinado termo funcional. A classe gene set enrichment analysis of gene expression data está associada à classe log-transformed normalized gene expression data por meio do relacionamento has participant. A classe log-transformed normalized gene expression data especializa a classe normalized gene expression data (relacionamento não apresentado na Figura 88). O relaciona- 
mento has participant indica que o processo de análise de enriquecimento de grupos de genes requer dados de expressão gênica normalizados e em escala logarítmica para sua execução. De forma análoga, o relacionamento has participant também foi definido entre a classe gene set enrichment analysis of gene expression data e a classe gene set, indicando que o processo requer também grupos de genes funcionalmente relacionados. A classe gene set especializa a classe gene expression data (relacionamento não apresentado na Figura 88). Além disto, a classe gene set enrichment analysis of gene expression data está associada à classe enriched annotation terms list por meio do relacionamento produced by. A classe enriched annotation terms list especializa a classe gene expression data (relacionamento não apresentado na Figura 88). O relacionamento produced by indica que uma lista de termos biológicos de anotação enriquecidos é produzida a partir da análise de enriquecimento de grupos de genes. Adicionalmente, a classe gene set enrichment analysis of gene expression data está associada à classe GeneSetEnrichmentAnalysis web service por meio do relacionamento is executed in. Este relacionamento indica que o processo de análise de enriquecimento de grupos de genes é executado no serviço GeneSetEnrichmentAnalysis.

A classe GeneSetEnrichmentAnalysis web service está associada à classe REST service por meio do relacionamento has interface, indicando que as funcionalidades do serviço GeneSetEnrichmentAnalysis podem ser acessadas por meio de uma interface REST. A classe GeneSetEnrichmentAnalysis web service também está associada à classe gene set enrichment analysis algorithm por meio do relacionamento implements, indicando que o serviço GeneSetEnrichmentAnalysis implementa um algoritmo específico para a análise de enriquecimento de grupos de genes. Este algoritmo é representado pela instância GAGE method (não apresentada na figura) da classe gene set enrichment analysis algorithm. Além disto, a classe GeneSetEnrichmentAnalysis web service está associada à classe analysis status por meio do relacionamento has status, indicando que a execução do processo de análise de enriquecimento de grupos de genes no serviço possui um estado associado.

Finalmente, a classe GeneSetEnrichmentAnalysis web service está associada à classe analysis identifier por meio do relacionamento has specified input. Este relacionamento indica que o serviço GeneSetEnrichmentAnalysis requer como entrada um identificador de análise. De forma análoga, o relacionamento has specified input também foi definido entre a classe GeneSe- 
tEnrichmentAnalysis web service e as classes experimental condition identifiers list, experimental design identifier e FDR adjustment, indicando que o serviço GeneSetEnrichmentAnalysis requer também como entradas uma lista de identificadores de amostras associadas a uma condição experimental, um identificador representando o design do experimento e um valor booleano indicando se o método de correção estatístico false discovery rate (FDR) deve ser aplicado.

A Figura 102 apresenta uma visão geral do processo de geração de grafos KEGG a partir de dados de expressão gênica no serviço KeggPathwayViewer.

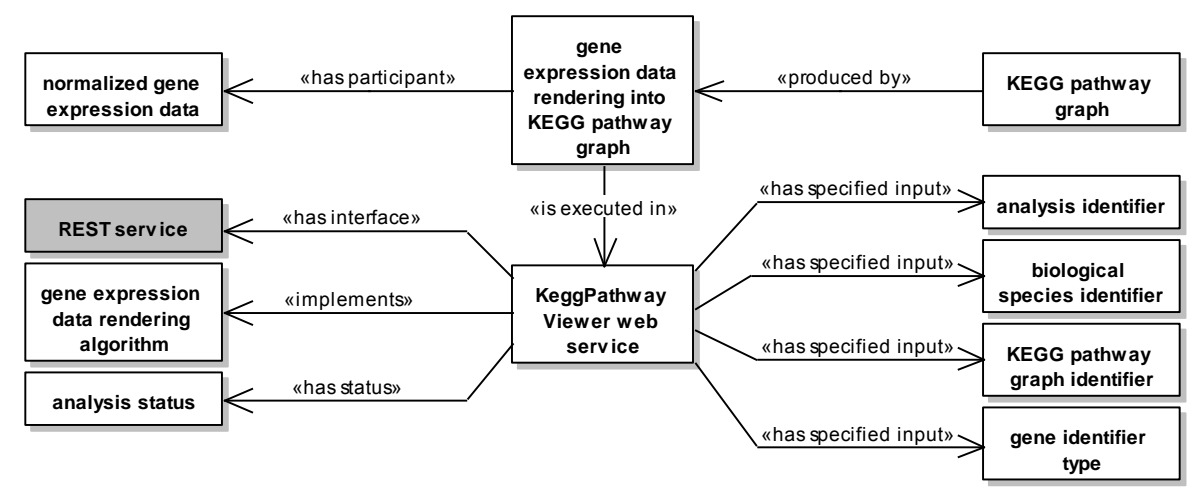

Figura 102: Geração de grafos KEGG no serviço KeggPathwayViewer.

A classe gene expression data rendering into KEGG pathway graph representa o processo de geração de grafos KEGG a partir de dados de expressão gênica. Esta classe está associada à classe normalized gene expression data por meio do relacionamento has participant. Este relacionamento indica que o processo de geração de grafos KEGG requer dados de expressão gênica normalizados para sua execução. Além disto, a classe gene expression data rendering into KEGG pathway graph está associada à classe KEGG pathway graph por meio do relacionamento produced by. A classe KEGG pathway graph especializa a classe gene expression data (relacionamento não apresentado na Figura 88). O relacionamento produced by indica que um grafo representando uma via ou processo biológico da base de dados KEGG é produzido pelo processo de geração de grafos KEGG. Adicionalmente, a classe gene expression data rendering into KEGG pathway graph está associada à classe KeggPathwayViewer web service por meio do relacionamento is executed in. Este relacionamento indica que o processo de geração de grafos KEGG é executado no serviço KeggPathwayViewer.

A classe KeggPathwayViewer web service está associada à classe REST service por meio do relacionamento has interface, indicando que as funcionalidades do serviço KeggPathway- 
Viewer podem ser acessadas por meio de uma interface REST. A classe KeggPathwayViewer web service também está associada à classe gene expression data rendering algorithm por meio do relacionamento implements, indicando que o serviço KeggPathwayViewer implementa um algoritmo específico para a geração de um grafo KEGG a partir de dados de expressão gênica. Além disto, a classe KeggPathwayViewer web service está associada à classe analysis status por meio do relacionamento has status, indicando que a execução do processo de geração de grafos KEGG no serviço possui um estado associado.

Finalmente, a classe KeggPathwayViewer web service está associada à classe analysis identifier por meio do relacionamento has specified input. Este relacionamento indica que o serviço KeggPathwayViewer requer como entrada um identificador de análise. De forma análoga, o relacionamento has specified input também foi definido entre a classe KeggPathwayViewer web service e as classes biological species identifier, KEGG pathway graph identifier e gene identifier type, indicando que o serviço KeggPathwayViewer requer também como entradas um identificador de espécie biológica, um identificador de grafo KEGG e um tipo de identificador de gene. 


\section{REFERENCIAS CRUZADAS ENTRE AS ONTOLOGIAS GEXPO E GEXPASO}

Após a definição das ontologias GEXPO e GEXPASO, algumas referências cruzadas foram estabelecidas entre estas ontologias. A Figura 103 apresenta os conceitos e relacionamentos pelos quais as ontologias GEXPO e GEXPASO são interligadas. Os conceitos apresentados em retângulos com preenchimento branco foram definidos como parte da ontologia GEXPASO. Os conceitos representados pelas classes data e microarray data são oriundos da ontologia Software Ontology. Os demais conceitos apresentados em retângulos com preenchimento cinza representam conceitos oriundos da ontologia GEXPO.

A classe data representa itens de dados. Esta classe é especializada pelas classes gene identifier, RNA-Seq data e microarray data. A classe gene identifier está associada à classe gene por meio do relacionamento represents, indicando que identificadores de genes são utilizados para representar genes.

A classe RNA-Seq data representa dados gerados a partir de experimentos de RNA-Seq. Esta classe é especializada pela classe raw RNA-Seq data. A classe raw RNA-Seq data representa dados brutos de RNA-Seq, ou seja, dados que não passaram por nenhum tipo de processamento computacional. Esta classe está associada à classe $c D N A$ read por meio do relacionamento has part, indicando que dados brutos de RNA-Seq possuem reads de cDNA sequenciadas.

A classe microarray data representa dados gerados a partir de experimentos de microarray. Esta classe é especializada pelas classes clustered microarray data, raw microarray data e nor- 


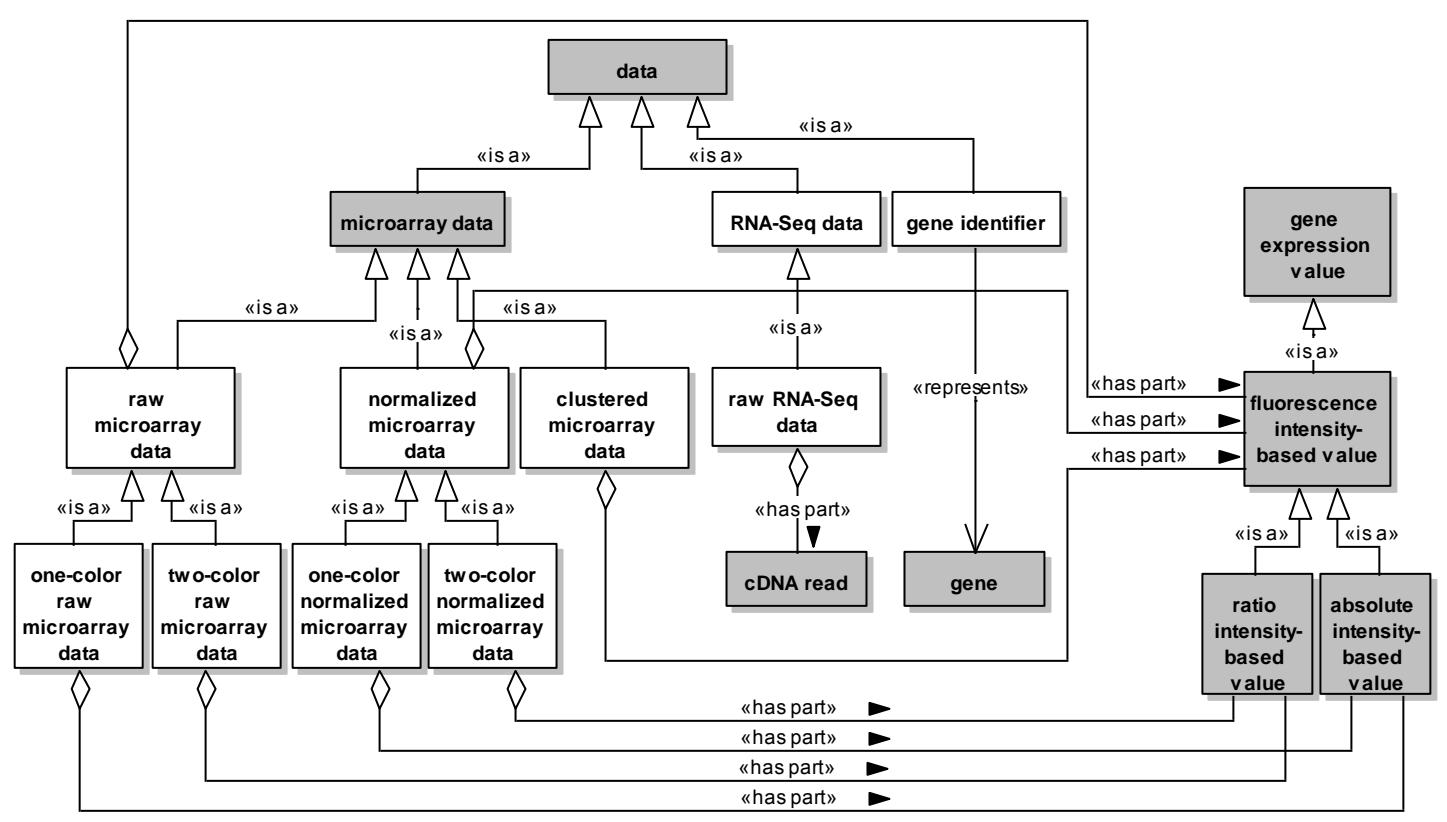

Figura 103: Referências cruzadas entre as ontologias GEXPO e GEXPASO.

malized microarray data. A classe clustered microarray data representa dados de microarray que passaram por um processo de agrupamento. Esta classe está associada à classe fluorescence intensity-based por meio do relacionamento has part, indicando que dados de microarray agrupados possuem valores de expressão baseados em intensidade de fluorescência.

A classe raw microarray data representa dados brutos de microarray, ou seja, dados que não passaram por nenhum tipo de processamento computacional. Esta classe está associada à classe fluorescence intensity-based value por meio do relacionamento has part, indicando que dados brutos de microarray possuem valores de expressão gênica baseados em intensidades de fluorescência. A classe raw microarray data é especializada pelas classes one-color raw microarray data e two-color raw microarray data, as quais representam dados brutos de microarray produzidos a partir de experimentos one-color e two-color, respectivamente. A classe one-color raw microarray data está associada à classe absolute intensity-based value por meio do relacionamento has part, indicando que dados brutos de microarray one-color são formados por valores de intensidade absolutos, os quais representam os níveis de expressão dos genes sob condições experimentais individuais. De forma análoga, a classe two-color raw microarray data está associada à classe ratio intensity-based value por meio do relacionamento has part, indicando que dados brutos de microarray two-color são formados por valores de intensidade relativos, os 
quais representam a razão entre os níveis de expressão dos genes sob condições experimentais distintas.

A classe normalized microarray data representa dados de microarray que passaram por um processo de normalização. Esta classe está associada à classe fluorescence intensity-based value por meio do relacionamento has part, indicando que dados de microarray normalizados possuem valores de expressão gênica baseados em intensidades de fluorescência. A classe normalized microarray data é especializada pelas classes one-color normalized microarray data e two-color normalized microarray data, as quais representam dados de microarray one-color e two-color normalizados, respectivamente. A classe one-color normalized microarray data está associada à classe absolut intensity-based value por meio do relacionamento has part, indicando que dados de microarray one-color normalizados possuem valores de intensidade absolutos. De forma análoga, a classe two-color normalized microarray data está associada à classe ratio intensity-based value por meio do relacionamento has part, indicando que dados de microarray two-color normalizados possuem valores de intensidade relativos. 


\section{ESTRUTURAS DE EXTENSÃO UDDI DO MÓDULO SERVICE REGISTRY}

Esta seção apresenta em detalhes as estruturas de extensão propostas ao modelo UDDI. Estas estruturas são utilizadas pelo módulo Service Registry para permitir o armazenamento de informações extraídas a partir de alguns elementos WSDL 2.0, anotações semânticas SAWSDL e elementos BPMN 2.0. Para cada estrutura de extensão, apresentamos uma breve descrição, a definição textual e XML da estrutura, os valores considerados válidos para o uso da estrutura e um exemplo de uso.

\section{E.1 BPMN ENTITY TYPE}

A estrutura de categorização BPMN Entity Type é utilizada para indicar que um elemento UDDI do tipo tModel representa um processo definido na linguagem Business Process Model and Notation version 2.0 (BPMN 2.0).

\section{Definição Textual}

Nome: uddi-extension:bpmn

Descrição: BPMN Process Type Category System 
Chave: uddi:extension:bpmn

Categorização: categorization

Verificação: unchecked

Definição XML

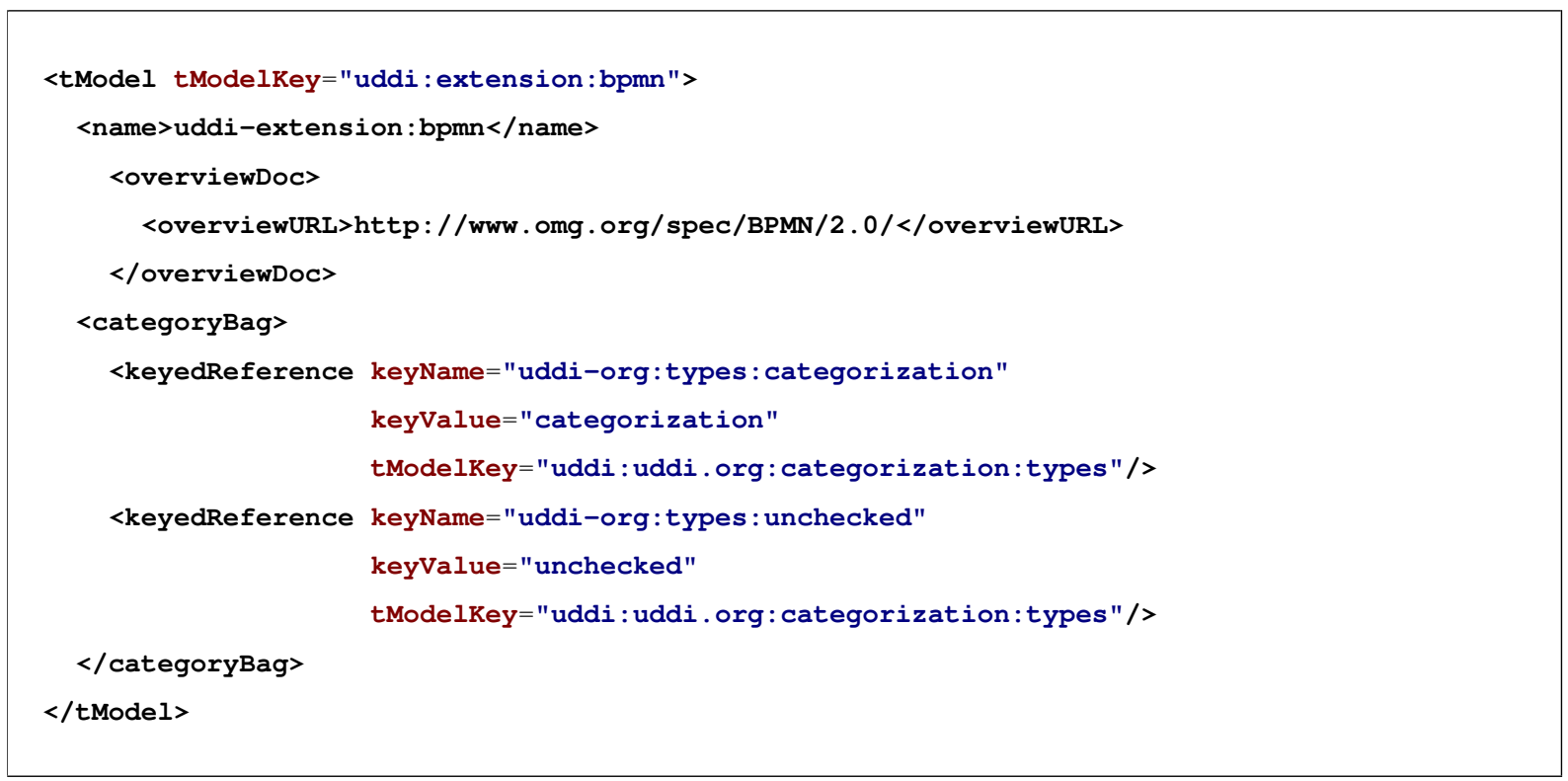

Valores Válidos

Apenas o valor "process" é considerado válido neste sistema de categorização. Desta forma, o valor do atributo keyValue neste sistema de categorização deve ser "process":

\begin{tabular}{|l|l|c|}
\hline keyValue & Descrição & Elemento UDDI \\
\hline process & $\begin{array}{l}\text { Representa um elemento UDDI catego- } \\
\text { rizado como bpmn:process }\end{array}$ & tModel \\
\hline
\end{tabular}

Exemplo de Uso

Um elemento UDDI do tipo tModel representando um processo BPMN 2.0 deve ter um elemento do tipo keyedReference utilizado para indicar o seu tipo: 


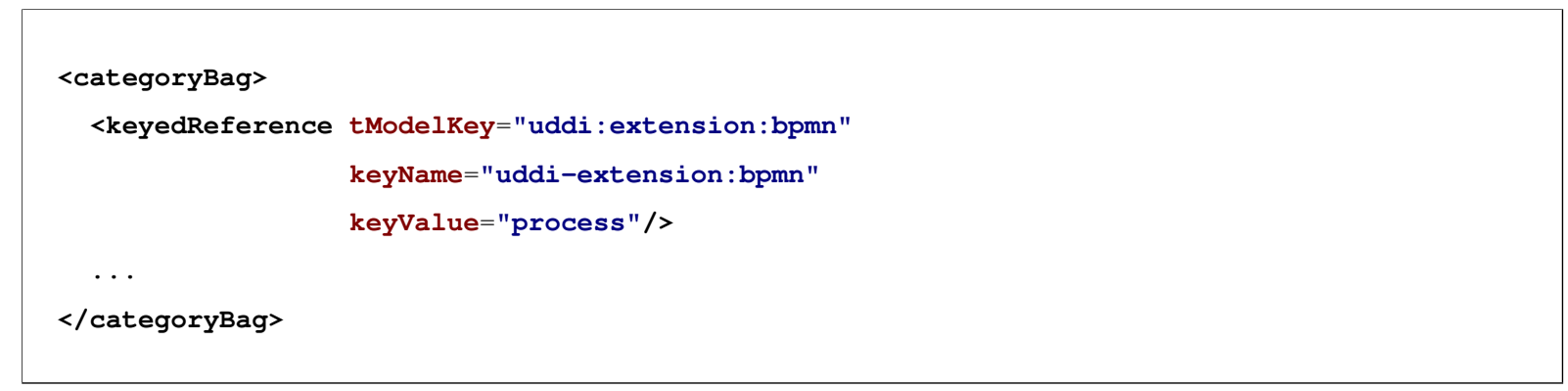

\section{E.2 WSDL INTERFACE REFERENCE}

No contexto deste trabalho, uma interface WSDL é referenciada por um binding WSDL e por um processo BPMN 2.0. Os relacionamentos definidos entre uma interface e um binding WSDL, bem como entre uma interface e um processo BPMN, devem ser mapeados para o módulo Service Registry. Este módulo representa um registro UDDI. No módulo Service Registry, os elementos interface e binding WSDL, bem como um processo BPMN são representados como elementos UDDI do tipo tModel. No entanto, a especificação UDDI não fornece um mecanismo intrínseco para a representação de relacionamentos entre dois elementos UDDI do tipo tModel. Assim, o sistema de categorização WSDL Interface Reference foi criado para fornecer um mecanismo que indica que um elemento UDDI do tipo $t$ Model tem um relacionamento com um elemento do tipo tModel representando uma interface WSDL. Este sistema de categorização pode ser utilizado para indicar o relacionamento entre um $t$ Model representando uma interface WSDL e um tModel representando um binding WSDL ou um processo BPMN 2.0.

\section{Definição Textual}

Nome: uddi-extension:wsdlinterfaceReference

Descrição: WSDL Interface Reference Type Category System

Chave: uddi:extension:wsdlinterfaceReference

Categorização: categorization

Verificação: unchecked 


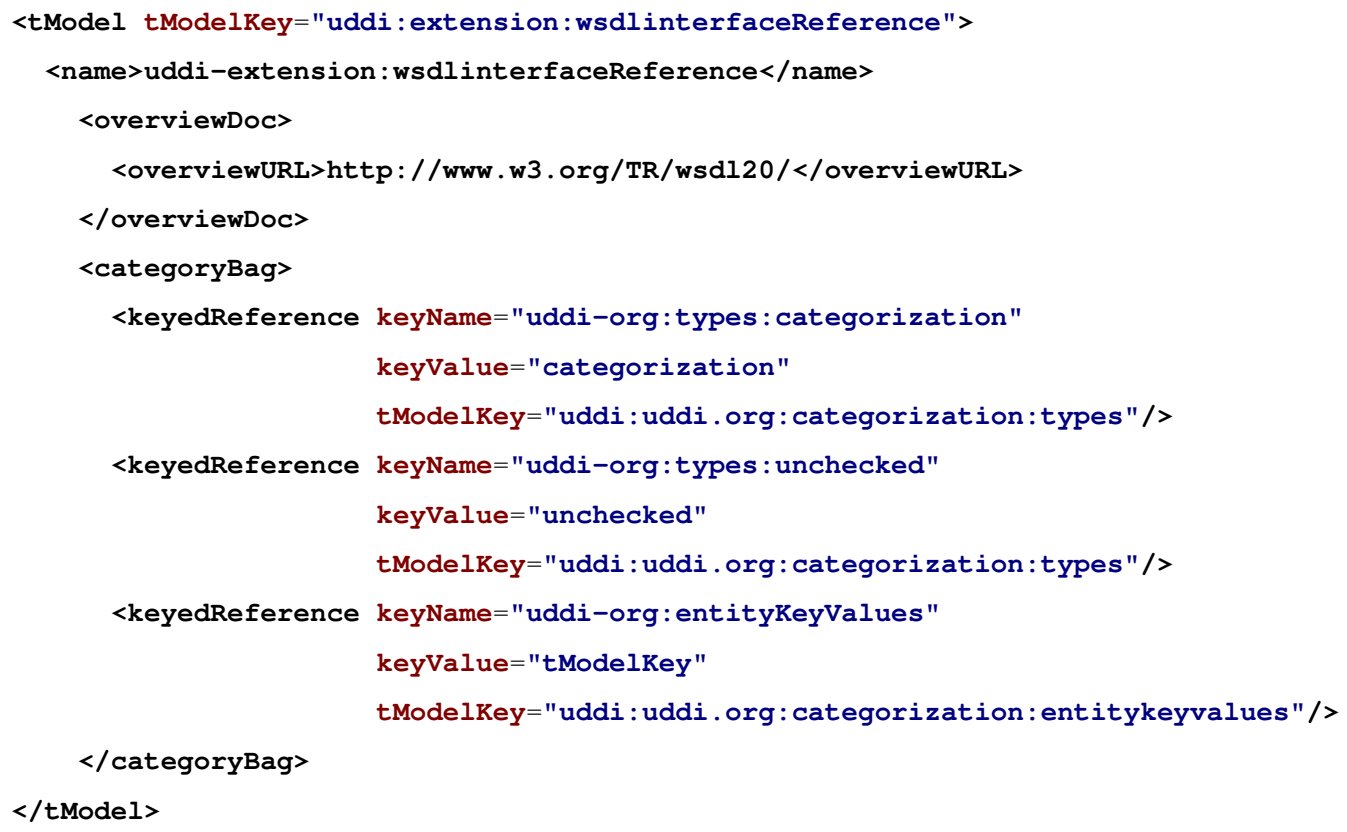

Valores Válidos

Os valores considerados válidos neste sistema de categorização são elementos UDDI do tipo tModelKey. O conteúdo do atributo keyValue neste sistema de categorização deve ser o valor do atributo tModelKey do elemento tModel que define a interface WSDL sendo referenciada:

\begin{tabular}{|l|l|c|}
\hline keyValue & Descrição & Elemento UDDI \\
\hline WSDL Interface tModel Key & $\begin{array}{l}\text { Representa um elemento UDDI catego- } \\
\text { rizado como wsdl:interfaceReference }\end{array}$ & tModel \\
\hline
\end{tabular}

\section{Exemplo de Uso}

Um elemento UDDI do tipo tModel representando um processo BPMN 2.0 ou um binding WSDL deve ter um elemento do tipo keyedReference indicando uma referência a um elemento do tipo tModel representando uma interface WSDL: 


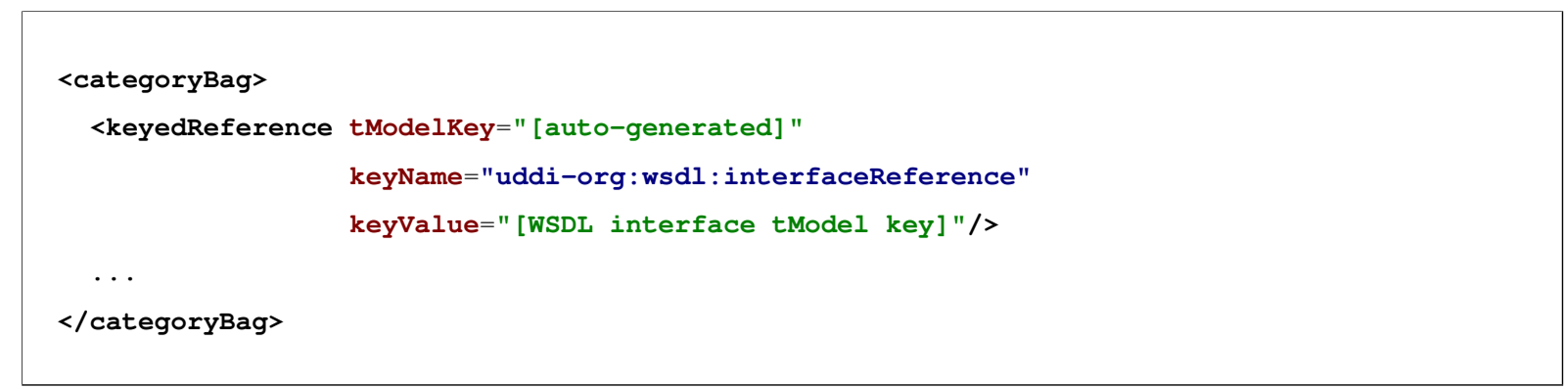

\section{E.3 FUNCTIONALITY REFERENCE}

Um processo BPMN 2.0 pode conter um conjunto de service tasks responsáveis por invocar diferentes operações de um serviço, de modo a fornecer diferentes funcionalidades. Estas funcionalidades podem ser semanticamente anotadas na descrição WSDL do serviço com o uso da abordagem SAWSDL. O sistema de categorização Functionality Reference fornece um mecanismo para indicar que um processo BPMN 2.0 representado em um elemento UDDI do tipo businessService tem um relacionamento (indireto) com um conceito de uma ontologia representando uma funcionalidade do serviço.

\section{Definição Textual}

Nome: uddi-extension:functionality

Descrição: Functionality Type Category System

Chave: uddi:extension:functionality

Categorização: categorization

Verificação: unchecked

\section{Definição XML}

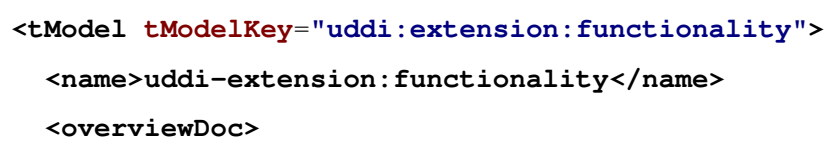




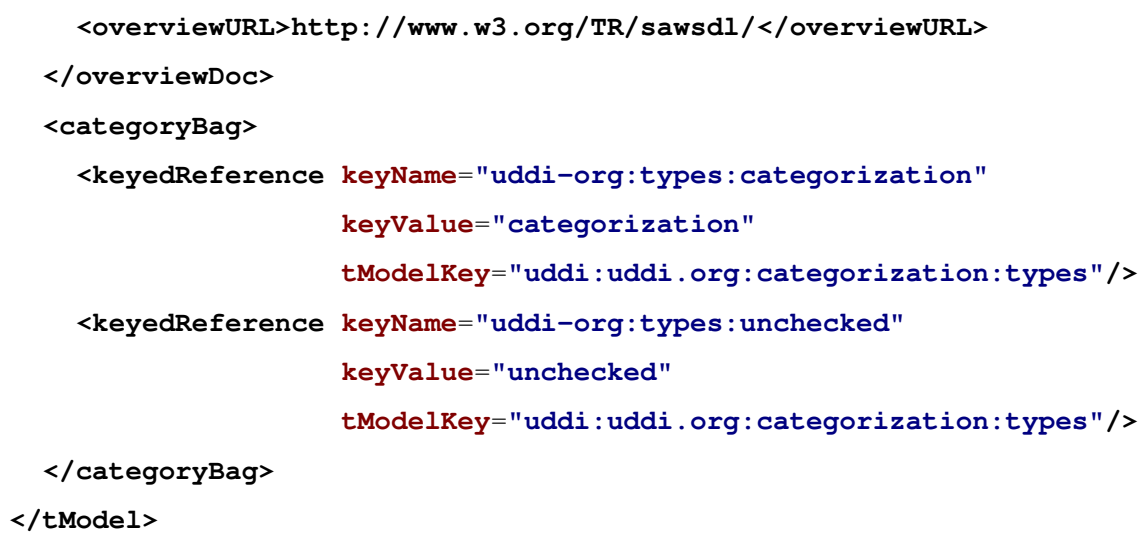

\section{Valores Válidos}

Os valores considerados válidos neste sistema de categorização são URIs. O conteúdo do atributo keyValue neste sistema de categorização deve ser um URI que referencia um conceito de uma ontologia representando uma funcionalidade:

\begin{tabular}{|l|l|c|}
\hline keyValue & Descrição & Elemento UDDI \\
\hline $\begin{array}{l}\text { URI de um conceito de uma onto- } \\
\text { logia representando uma funciona- } \\
\text { lidade }\end{array}$ & $\begin{array}{l}\text { Representa uma elemento UDDI cate- } \\
\text { gorizado como bpmn:functionality }\end{array}$ & tModel \\
\hline
\end{tabular}

\section{Exemplo de Uso}

Um elemento UDDI do tipo businessService representando um processo BPMN 2.0 pode ter um elemento UDDI do tipo keyedReference indicando um conceito de uma ontologia que representa uma funcionalidade:

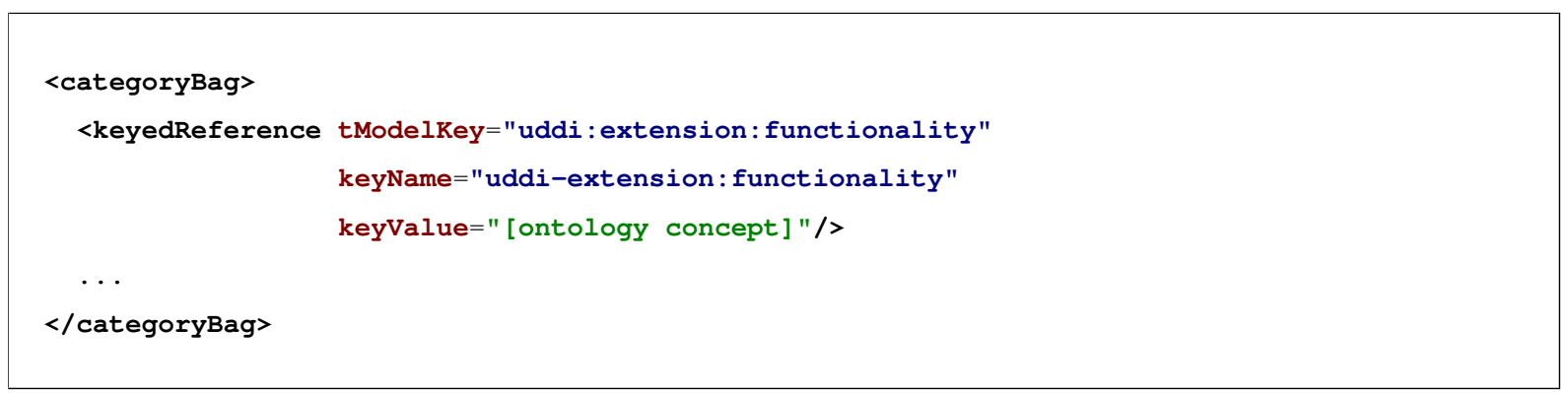




\section{E.4 INPUT REFERENCE}

Um processo BPMN 2.0 pode conter um conjunto de service tasks responsáveis por invocar diferentes operações de um serviço. Os dados de entrada exigidos por estas operações para que as mesmas sejam executadas podem ser semanticamente anotados na descrição WSDL do serviço com o uso da abordagem SAWSDL. O sistema de categorização Input Reference fornece um mecanismo para indicar que um processo BPMN 2.0 representado em um elemento UDDI do tipo businessService tem um relacionamento (indireto) com um conceito de uma ontologia representando o tipo dos dados de entrada de uma operação do serviço.

\section{Definição Textual}

Nome: uddi-extension:input

Descrição: Input Type Category System

Chave: uddi:extension:input

Categorização: categorization

Verificação: unchecked

\section{Definição XML}

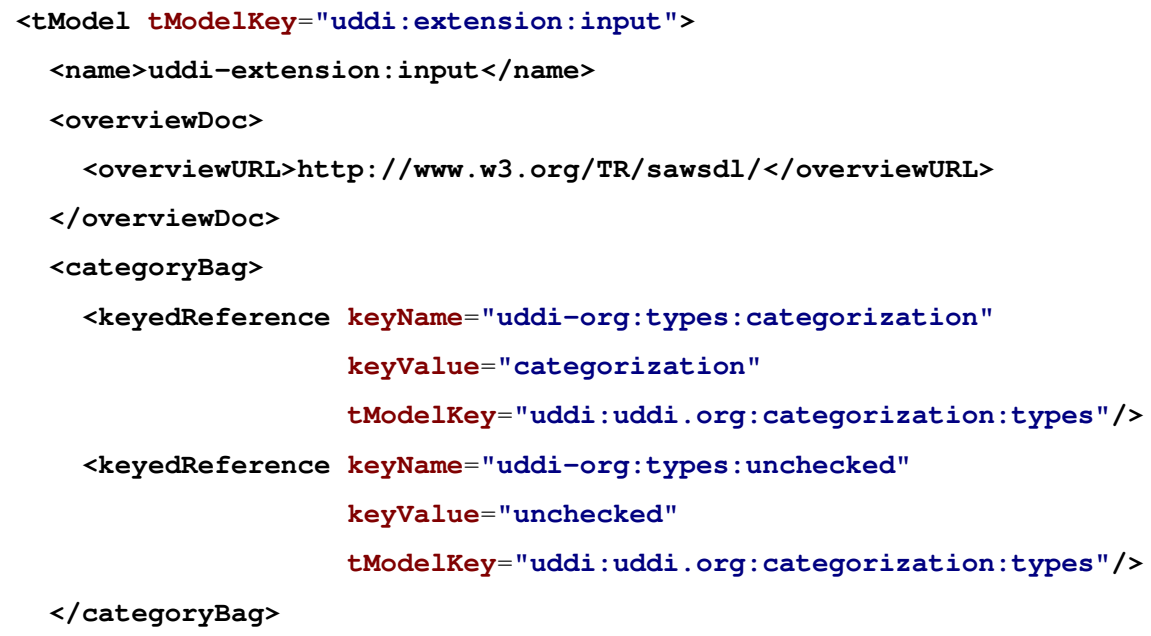




\section{Valores Válidos}

Os valores considerados válidos neste sistema de categorização são URIs. O conteúdo do atributo keyValue neste sistema de categorização deve ser um URI que referencia um conceito de uma ontologia representando um tipo de dado de entrada:

\begin{tabular}{|l|l|c|}
\hline keyValue & Descrição & Elemento UDDI \\
\hline $\begin{array}{l}\text { URI de um conceito de uma onto- } \\
\text { logia representando uma entrada }\end{array}$ & $\begin{array}{l}\text { Representa um elemento UDDI catego- } \\
\text { rizado como bpmn:input }\end{array}$ & tModel \\
\hline
\end{tabular}

\section{Exemplo de Uso}

Um elemento UDDI do tipo businessService representando um processo BPMN 2.0 pode ter um elemento UDDI do tipo keyedReference indicando um conceito de uma ontologia que representa um tipo de dado de entrada:

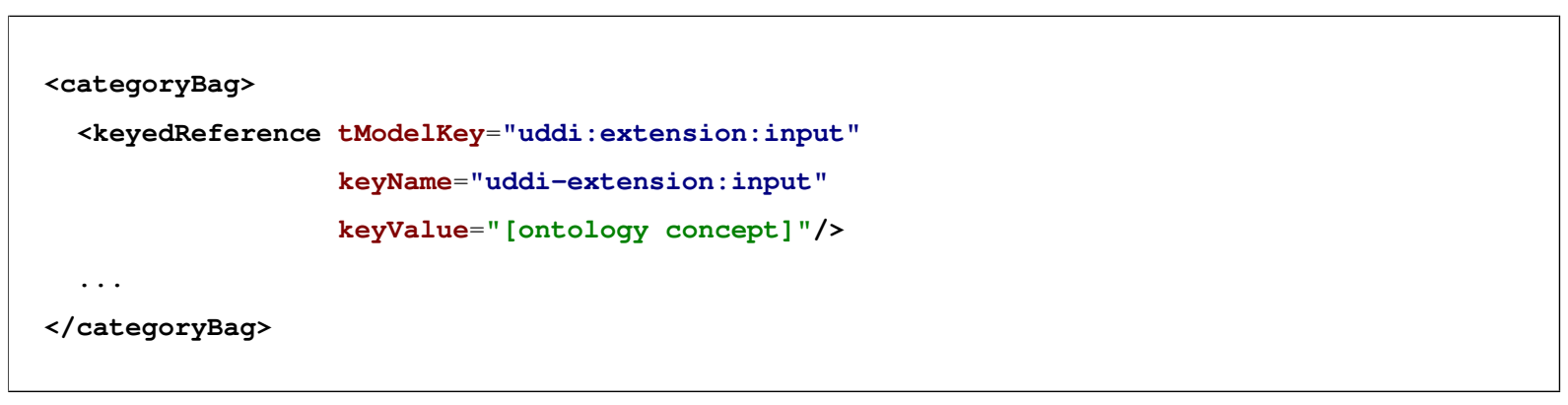

\section{E.5 OUTPUT REFERENCE}

Um processo BPMN 2.0 pode conter um conjunto de service tasks responsáveis por invocar diferentes operações de um serviço. Os dados produzidos por estas operações após sua execução podem ser semanticamente anotados na descrição WSDL do serviço com o uso da abordagem SAWSDL. O sistema de categorização Output Reference fornece um mecanismo para indicar 
que um processo BPMN 2.0 representado em um elemento UDDI do tipo businessService tem um relacionamento (indireto) com um conceito de uma ontologia representando o tipo dos dados produzidos por uma operação do serviço.

\section{Definição Textual}

Nome: uddi-extension:output

Descrição: Output Type Category System

Chave: uddi:extension:output

Categorização: categorization

Verificação: unchecked

Definição XML

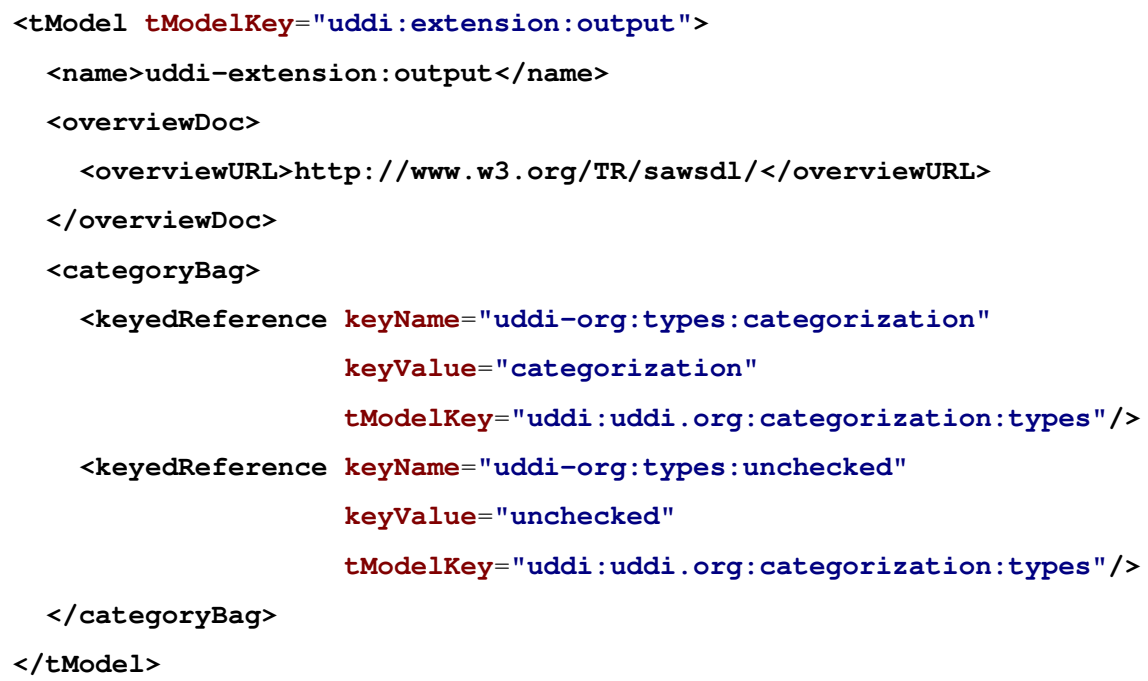




\section{Valores Válidos}

Os valores considerados válidos neste sistema de categorização são URIs. O conteúdo do atributo keyValue neste sistema de categorização deve ser um URI que referencia um conceito de uma ontologia representando um tipo de dado de saída:

\begin{tabular}{|l|l|c|}
\hline keyValue & Descrição & Elemento UDDI \\
\hline $\begin{array}{l}\text { URI de um conceito de uma onto- } \\
\text { logia representando uma saída }\end{array}$ & $\begin{array}{l}\text { Representa um elemento UDDI catego- } \\
\text { rizado como bpmn:output }\end{array}$ & tModel \\
\hline
\end{tabular}

\section{Exemplo de Uso}

Um elemento UDDI do tipo businessService representando um processo BPMN 2.0 pode ter um elemento UDDI do tipo keyedReference indicando um conceito de uma ontologia que representa um tipo de dado de saída:

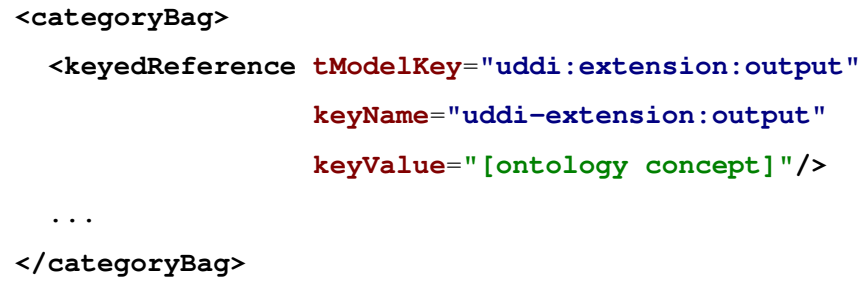




\section{PUBLICAÇÃO DE SERVIÇOS NO MÓDULO SERVICE REGISTRY}

De modo a publicar um serviço (processo) na plataforma SemanticSCo, um conjunto de informações extraídas a partir de elementos BPMN e WSDL devem ser mapeadas para o módulo Service Registry da plataforma. Inicialmente, o elemento WSDL Interface referenciado a partir do processo deve ser mapeado para o elemento UDDI Interface tModel. Em seguida, o elemento WSDL Binding que referencia o elemento WSDL Interface deve ser mapeado para o elemento UDDI Binding tModel. A seguir, o processo BPMN deve ser mapeado para o elemento UDDI Process tModel. Na sequência, o processo BPMN deve ser mapeado para o elemento UDDI Business Service. Finalmente, o elemento WSDL Endpoint que referencia o elemento WSDL Binding deve ser mapeado para o elemento UDDI Binding Template definido como parte do elemento UDDI Business Service. As seções a seguir detalham o mapeamento destes elementos para o módulo Service Registry.

\section{F.1 MAPEAMENTO DO ELEMENTO WSDL INTERFACE PARA O ELEMENTO UDDI INTERFACE TMODEL}

Os dados mapeados da interface WSDL para o elemento UDDI Interface tModel incluem o tipo, nome e namespace da interface, bem como a localização do documento WSDL que a define. A publicação do tipo da interface permite a realização de buscas no módulo Service Registry para recuperar elementos do tipo tModel representando interfaces de serviços. A publicação do 
nome, namespace e localização do documento WSDL permite identificar, de forma exclusiva, a interface de serviço no módulo Service Registry.

As informações da interface WSDL são armazenadas no elemento UDDI Interface tModel como descrito a seguir:

- O atributo name do elemento UDDI Interface tModel contém o valor do atributo name do elemento WSDL Interface.

- O elemento UDDI Interface tModel contém um elemento overviewDoc que, por sua vez, contém um elemento overviewURL. O elemento overviewURL contém a localização do documento WSDL que define a interface.

- O elemento UDDI Interface tModel contém um elemento categoryBag que, por sua vez, contém:

- um elemento keyedReference com um atributo tModelKey cujo valor é a chave do sistema de categorização "WSDL Entity Type" e um atributo keyValue cujo valor é "interface".

- um elemento keyedReference com um atributo tModelKey cujo valor é a chave do sistema de categorização "XML Namespace" e um atributo keyValue cujo valor é o target namespace do documento WSDL que define a interface.

As operações e falhas definidas na interface WSDL não precisam ser mapeadas para o módulo Service Registry.

Resumo do mapeamento wsdl:interface -> uddi:InterfaceTModel

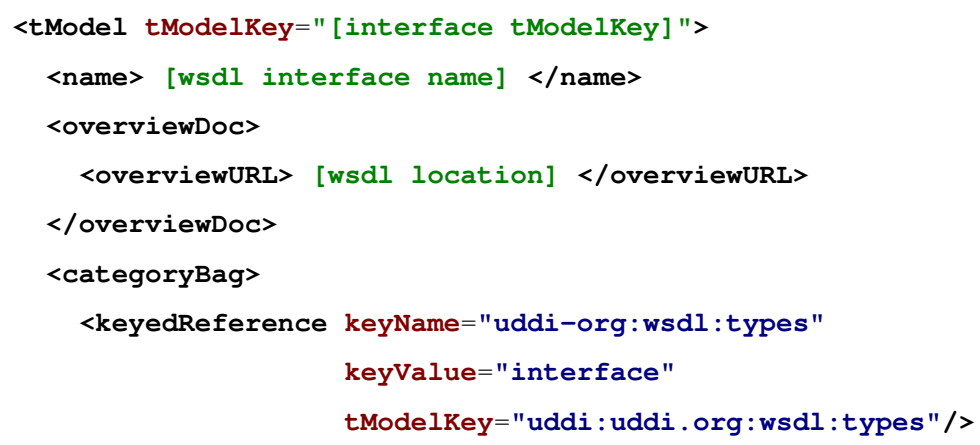




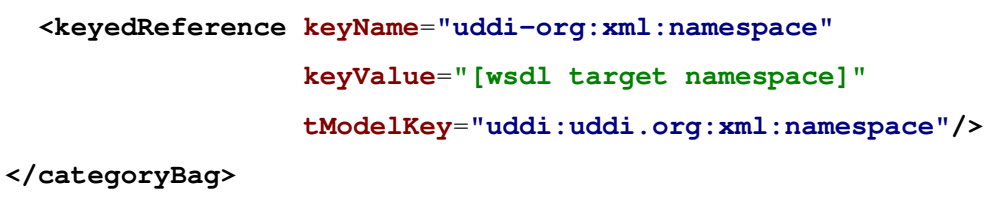

\section{F.2 MAPEAMENTO DO ELEMENTO WSDL Binding PARA O ELEMENTO UDdi Bin- DING TMODEL}

Os dados mapeados do binding WSDL para o elemento UDDI Binding tModel incluem o tipo, nome e namespace do binding, a localização do documento WSDL que o define, a interface implementada pelo binding e o protocolo de comunicação associado. A publicação do tipo do binding permite a realização de buscas no módulo Service Registry para recuperar elementos do tipo tModel representando bindings de serviços. A publicação do nome, namespace e localização do documento WSDL permite identificar, de forma exclusiva, o binding de serviço no módulo Service Registry. A publicação da interface implementada pelo binding permite a realização de buscas no módulo Service Registry para recuperar os bindings que implementam uma determinada interface. Finalmente, a publicação do protocolo de comunicação associado ao binding permite a realização de buscas no módulo Service Registry para recuperar os bindings que implementam um determinado protocolo.

As informações do binding WSDL são armazenadas no elemento UDDI Binding tModel como descrito a seguir:

- O atributo name do elemento UDDI Binding tModel contém o valor do atributo name do elemento WSDL Binding.

- O elemento UDDI Binding tModel contém um elemento overviewDoc que, por sua vez, contém um elemento overviewURL. O elemento overviewURL contém a localização do documento WSDL que define o binding.

- O elemento UDDI Binding tModel contém um elemento categoryBag que, por sua vez, contém: 
- um elemento keyedReference com um atributo tModelKey cujo valor é a chave do sistema de categorização "WSDL Entity Type" e um atributo keyValue cujo valor é "binding".

- um elemento keyedReference com um atributo tModelKey cujo valor é a chave do sistema de categorização "XML Namespace" e um atributo keyValue cujo valor é o target namespace do documento WSDL que define o binding.

- um elemento keyedReference com um atributo tModelKey cujo valor é a chave do sistema de categorização "WSDL Interface Reference" e um atributo keyValue cujo valor é a chave do elemento UDDI Interface tModel que define a interface WSDL implementada pelo binding.

- um elemento keyedReference com um atributo tModelKey cujo valor é a chave do sistema de categorização "Protocol Categorization" e um atributo keyValue cujo valor é a chave do tModel que define o protocolo indicado pelo atributo type do elemento WSDL binding:

* Se o valor do atributo type do elemento WSDL binding for "http://www.w3.org/ ns/wsdl/soap", o atributo version deste elemento também é verificado. Se o valor do atributo version for "1.1", então a chave do tModel "SOAP Protocol" é utilizada. Se o valor do atributo version for "1.2", então a chave do tModel "SOAP 12 Protocol" é utilizada.

* Se o valor do atributo type do elemento WSDL binding for "http://www.w3.org/ ns/wsdl/http", então a chave do tModel "REST Protocol" é utilizada.

As operações e falhas definidas no binding WSDL não precisam ser mapeadas para o módulo Service Registry.

Resumo do mapeamento wsdl:binding -> uddi:bindingTModel

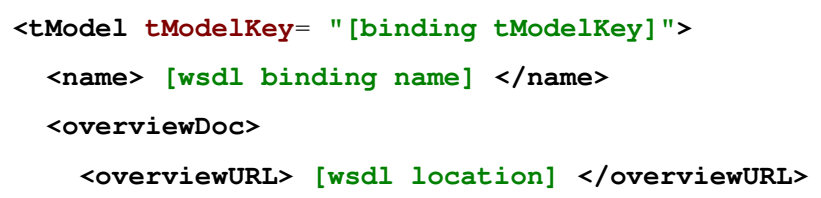




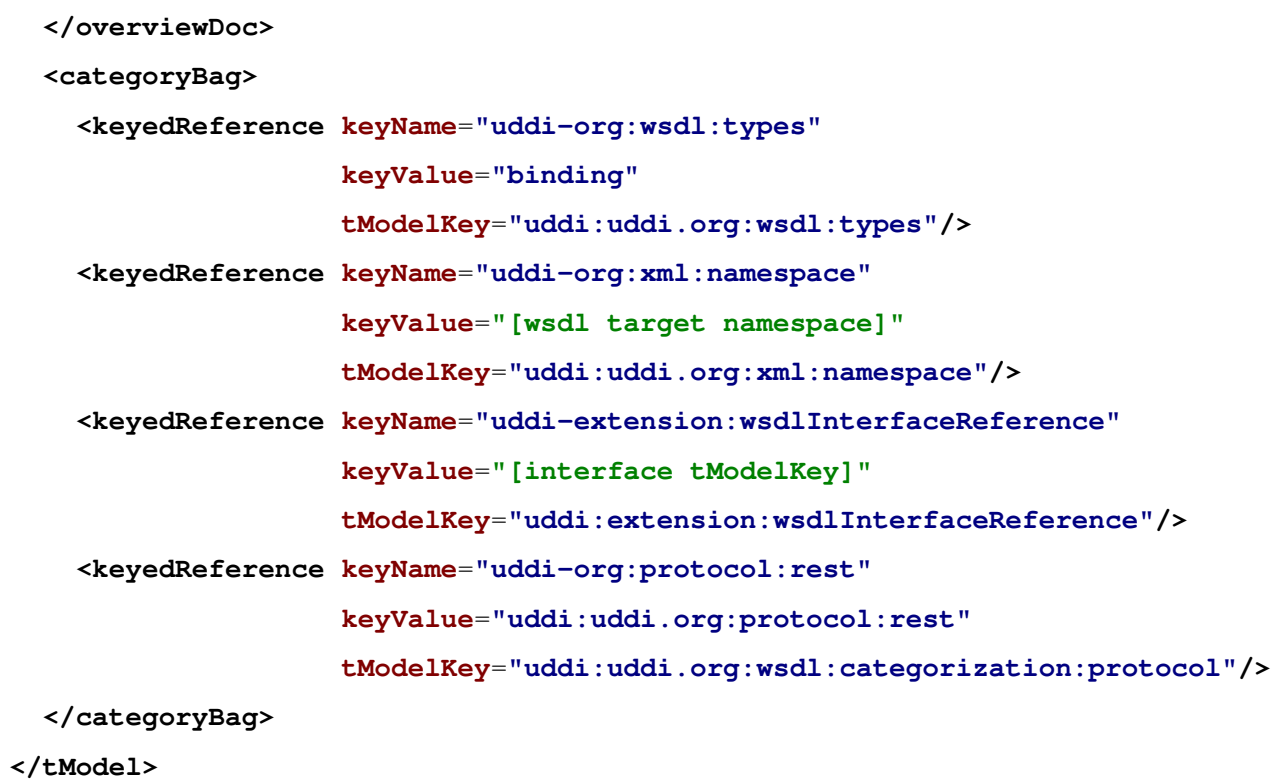

F.3 MAPEAMENTO DO PROCESSO BPMN PARA O ELEMENTO UDDI PROCESS TMODEL

Os dados mapeados do processo BPMN para o elemento UDDI Process tModel incluem o tipo, nome e namespace do processo, bem como a localização do documento BPMN que o define e a interface WSDL referenciada pelo processo. A publicação do tipo do processo permite a realização de buscas no módulo Service Registry para recuperar elementos do tipo tModel representando processos BPMN. A publicação do nome, namespace e localização do documento BPMN permite identificar, de forma exclusiva, o processo no módulo Service Registry. Finalmente, a publicação da interface de serviço referenciada pelo processo permite a realização de buscas no módulo Service Registry para recuperar os processos que referenciam uma determinada interface.

As informações do processo BPMN são armazenadas no elemento UDDI Process tModel como descrito a seguir:

- O atributo name do elemento UDDI Process tModel contém o valor do atributo name do processo BPMN. 
- O elemento UDDI Process tModel contém um elemento overviewDoc que, por sua vez, contém um elemento overviewURL. O elemento overviewURL contém a localização do documento BPMN que define o processo.

- O elemento UDDI Process tModel contém um elemento categoryBag que, por sua vez, contém:

- um elemento keyedReference com um atributo tModelKey cujo valor é a chave do sistema de categorização "BPMN Entity Type" e um atributo keyValue cujo valor é "process".

- um elemento keyedReference com um atributo tModelKey cujo valor é a chave do sistema de categorização "XML Namespace" e um atributo keyValue cujo valor é o target namespace do documento BPMN que define o processo.

- um elemento keyedReference com um atributo tModelKey cujo valor é a chave do sistema de categorização "WSDL Interface Reference" e um atributo keyValue cujo valor é a chave do elemento UDDI Interface tModel que define a interface WSDL referenciada pelo processo.

Resumo do mapeamento bpmn:process -> uddi:processTModel

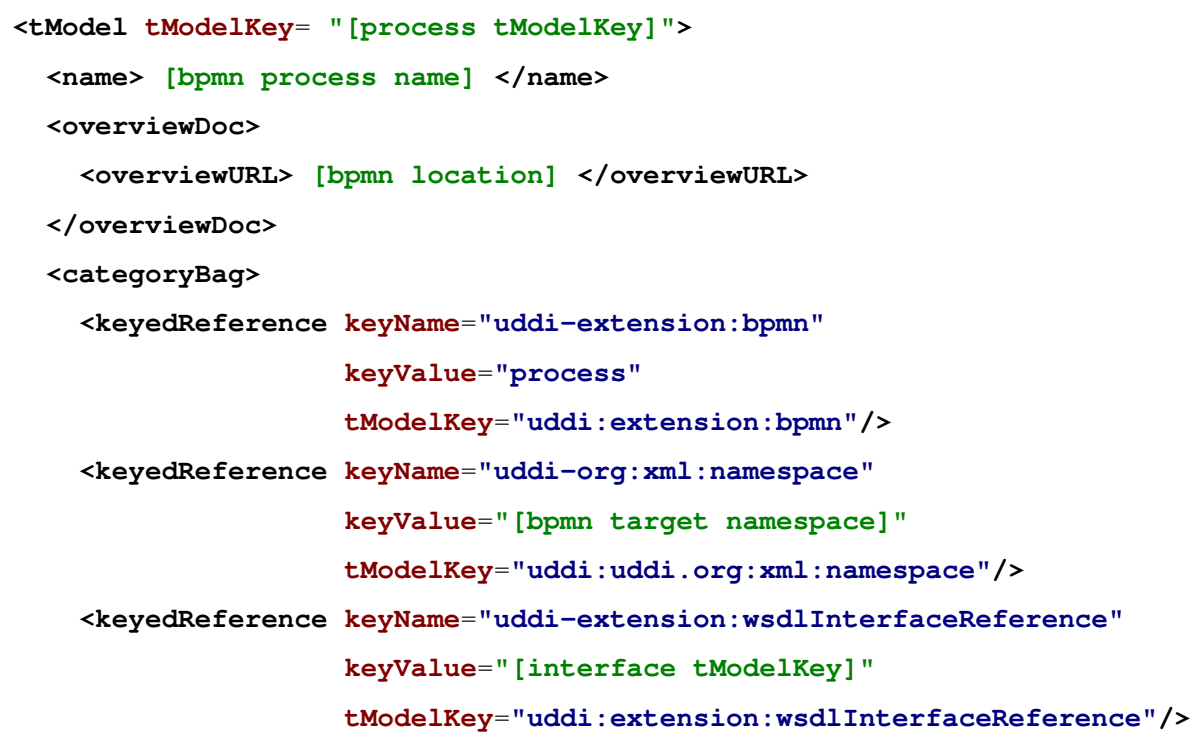




\section{F.4 MAPEAMENTO DO PROCESSO BPMN PARA O ELEMENTO UDDI BUSINESS SERVICE}

Os dados mapeados do processo BPMN para o elemento UDDI businessService incluem o tipo, nome e namespace do processo, bem como a lista de endpoints WSDL e as anotações semânticas associadas ao processo. A publicação do tipo do processo permite a realização de buscas no módulo Service Registry para recuperar elementos do tipo businessService representando processos BPMN. A publicação do nome e namespace do processo permite identificar, de forma exclusiva, o processo no módulo Service Registry. A publicação da lista de endpoints permite recuperar as informações necessárias para o acesso e execução do serviço referenciado pelo processo BPMN. Finalmente, a publicação das anotações semânticas associadas ao processo permite a realização de buscas no módulo Service Registry para recuperar processos BPMN que forneçam um determinado conjunto de funcionalidades e/ou que sejam capazes de processar ou produzir um determinado conjunto de tipos de dados.

As informações do processo BPMN são armazenadas no elemento UDDI businessService como descrito a seguir:

- O atributo name do elemento UDDI businessService contém o valor do atributo name do processo.

- O elemento UDDI businessService contém um elemento categoryBag que, por sua vez, contém:

- um elemento keyedReference com um atributo tModelKey cujo valor é a chave do sistema de categorização "BPMN Entity Type" e um atributo keyValue cujo valor é "process".

- um elemento keyedReference com um atributo tModelKey cujo valor é a chave do sistema de categorização "XML Local Name" e um atributo keyValue cujo valor é o nome do processo (valor do atributo BPMN name). 
- um elemento keyedReference com um atributo tModelKey cujo valor é a chave do sistema de categorização "XML Namespace" e um atributo keyValue cujo valor é o target namespace do documento BPMN que define o processo.

- para cada anotação semântica representando uma funcionalidade do processo, um elemento keyedReference com um atributo tModelKey cujo valor é a chave do sistema de categorização "BPMN Process Functionality" e um atributo keyValue cujo valor é o URI representando o conceito da ontologia.

- para cada anotação semântica representando uma entrada do processo, um elemento keyedReference com um atributo tModelKey cujo valor é a chave do sistema de categorização "BPMN Process Input" e um atributo keyValue cujo valor é o URI representando o conceito da ontologia.

- para cada anotação semântica representando uma saída do processo, um elemento keyedReference com um atributo tModelKey cujo valor é a chave do sistema de categorização "BPMN Process Output" e um atributo keyValue cujo valor é o URI representando o conceito da ontologia.

Adicionalmente, o elemento UDDI businessService contém um elemento bindingTemplates. O elemento bindingTemplates contém um ou mais elementos do tipo bindingTemplate representando os endpoints do serviço referenciado pelo processo BPMN. O mapeamento detalhado de um endpoint para uma estrutura UDDI bindingTemplate é apresentado na Seção F.5.

Resumo do mapeamento bpmn:process -> uddi:businessService

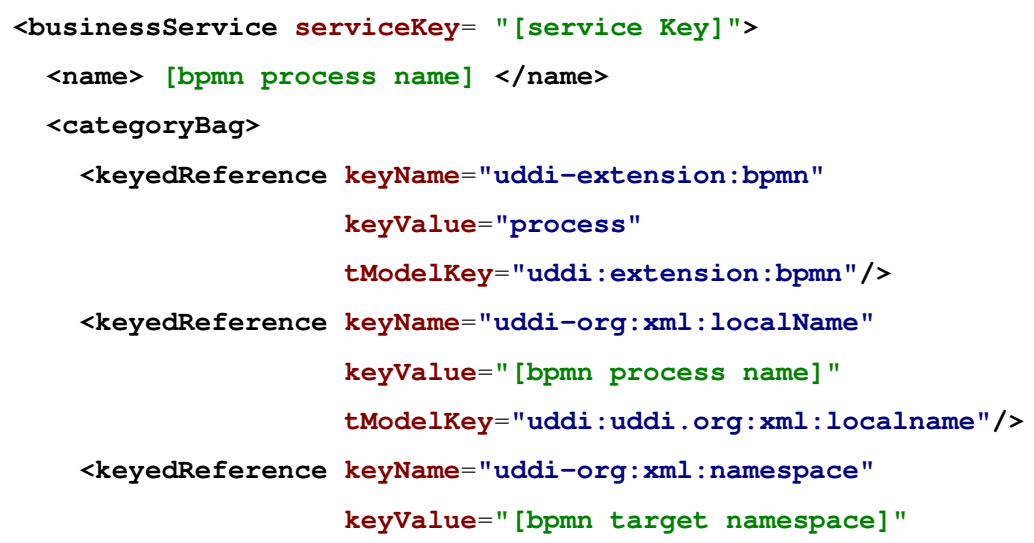




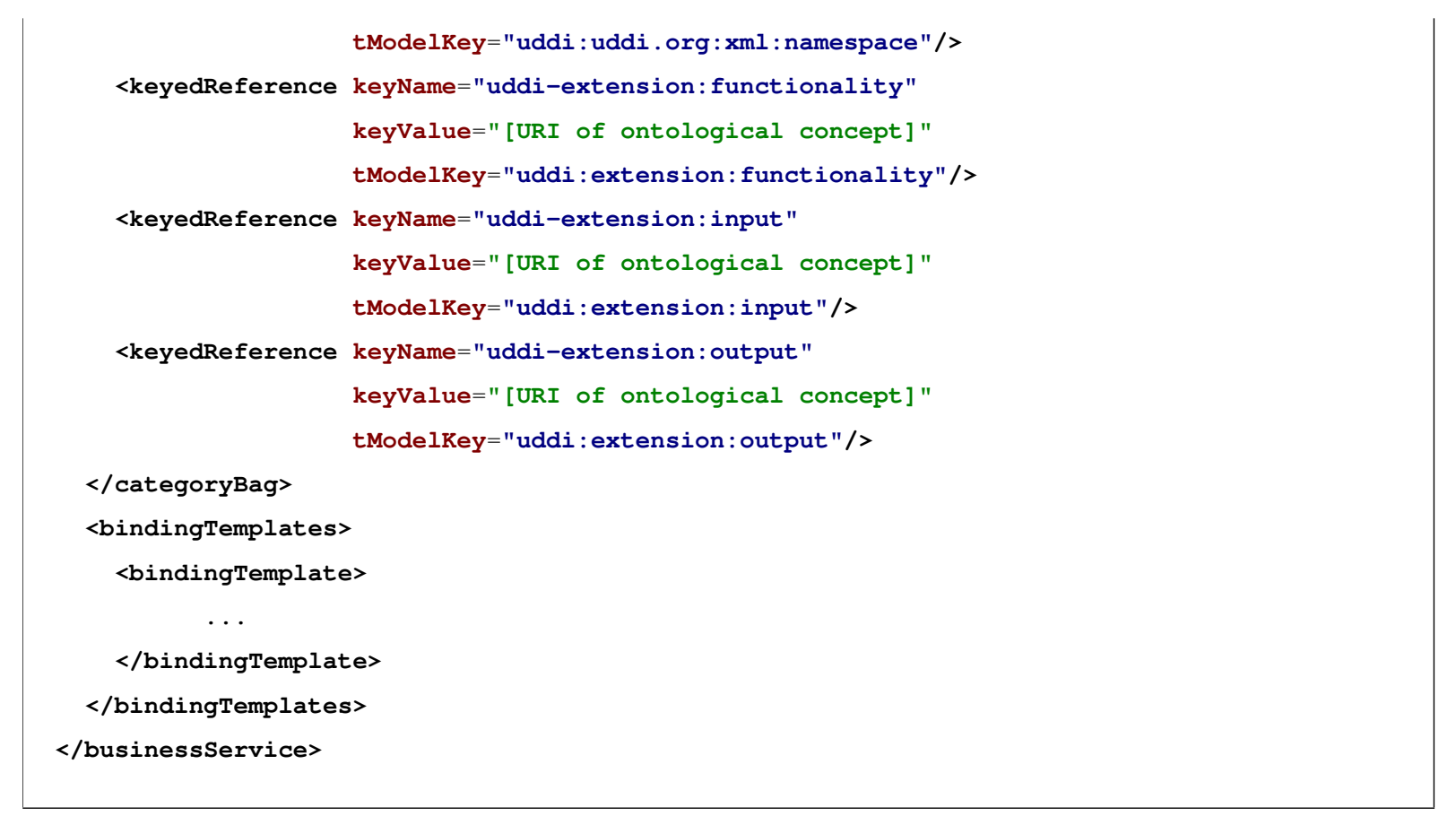

\section{F.5 MAPEAMENTO DO ELEMENTO WSDL ENDPOINT PARA O ELEMENTO UDDI} BINDING TEMPLATE

Os dados mapeados do endpoint WSDL para o elemento UDDI bindingTemplate incluem o nome do endpoint, o endereço de acesso ao serviço, a interface e o binding que o endpoint implementa, bem como o processo BPMN ao qual o endpoint está associado. A publicação do nome e do endereço do serviço permite a realização de buscas no módulo Service Registry para recuperar informações técnicas necessárias para a execução do serviço referenciado pelo processo BPMN. A publicação do binding associado ao endpoint permite a realização de buscas no módulo Service Registry para recuperar processos associados a um binding implementado por um determinado endpoint. A publicação da interface associada ao endpoint permite a realização de buscas no módulo Service Registry para recuperar processos que referenciam uma interface de serviço implementada por um determinado endpoint. Finalmente, a publicação do processo BPMN associado ao endpoint permite a realização de buscas no módulo Service Registry para recuperar processos que estejam associados a um determinado endpoint.

As informações do endpoint WSDL são armazenadas no elemento UDDI bindingTemplate como descrito a seguir: 
- O elemento UDDI bindingTemplate contém um elemento accessPoint cujo valor é o endereço de acesso ao serviço definido no atributo address do elemento WSDL endpoint. O valor do atributo useType do elemento accessPoint é "endPoint".

- O elemento UDDI bindingTemplate contém um elemento tModelInstanceDetails que, por sua vez, contém:

- um elemento tModelInstanceInfo com um atributo tModelKey cujo valor é a chave do elemento UDDI Binding tModel que define o binding WSDL implementado pelo endpoint. O elemento tModelInstanceInfo contém um elemento instanceParms cujo valor é o nome do endpoint WSDL.

- um elemento tModelInstanceInfo com um atributo tModelKey cujo valor é a chave do elemento UDDI Interface tModel que define a interface WSDL implementada pelo endpoint.

- um elemento tModelInstanceInfo com um atributo tModelKey cujo valor é a chave do elemento UDDI Process tModel que define o processo BPMN associado ao endpoint.

Resumo do mapeamento wsdl:endpoint -> uddi:bindingTemplate

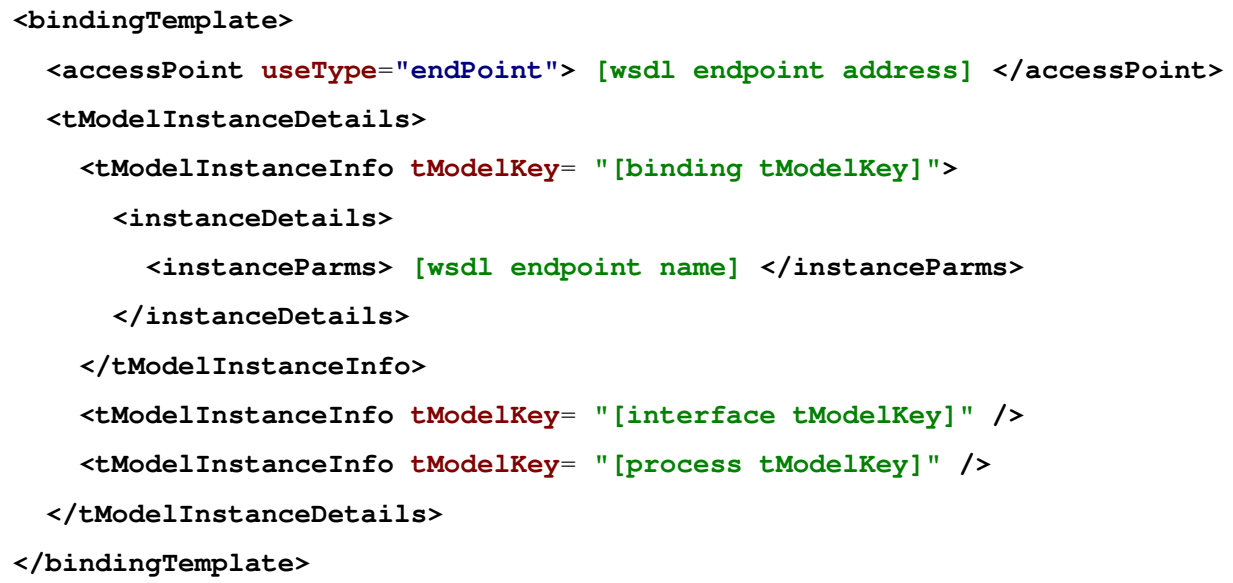




\section{COMANDOS PRIMITIVOS E ESTRATÉGIAS DE SUPORTE DA PLATAFORMA SEMANTICSCO}

Esta seção apresenta a definição XSD dos comandos primitivos utilizados na interação entre os módulos Composite Service Enactment e Coordinator para a realização de diferentes atividades associadas ao processo de composição de serviços. Além disto, as estratégias de suporte associadas a cada comando primitivo também são apresentadas. Cada estratégia de suporte determina os componentes básicos do módulo Service Composition que devem ser invocados pelo módulo Coordinator e a ordem de invocação destes componentes. Adicionalmente, cada estratégia de suporte determina o conjunto de informações que devem ser armazenadas pelo módulo Coordinator no módulo Composition and Execution Context.

\section{G.1 DISCOVER_INPUT_SEMANTICS}

O comando primitivo DISCOVER_INPUT_SEMANTICS permite que o módulo Composite Service Enactment solicite ao módulo Coordinator uma lista de conceitos de uma ontologia (URIs) que podem ser utilizados para especificar a semântica de um conjunto de dados de entrada. 


\section{Definição XSD}

A Figura 104 apresenta a definição XSD das mensagens de requisição e resposta especificadas pelo comando primitivo DISCOVER_INPUT_SEMANTICS.

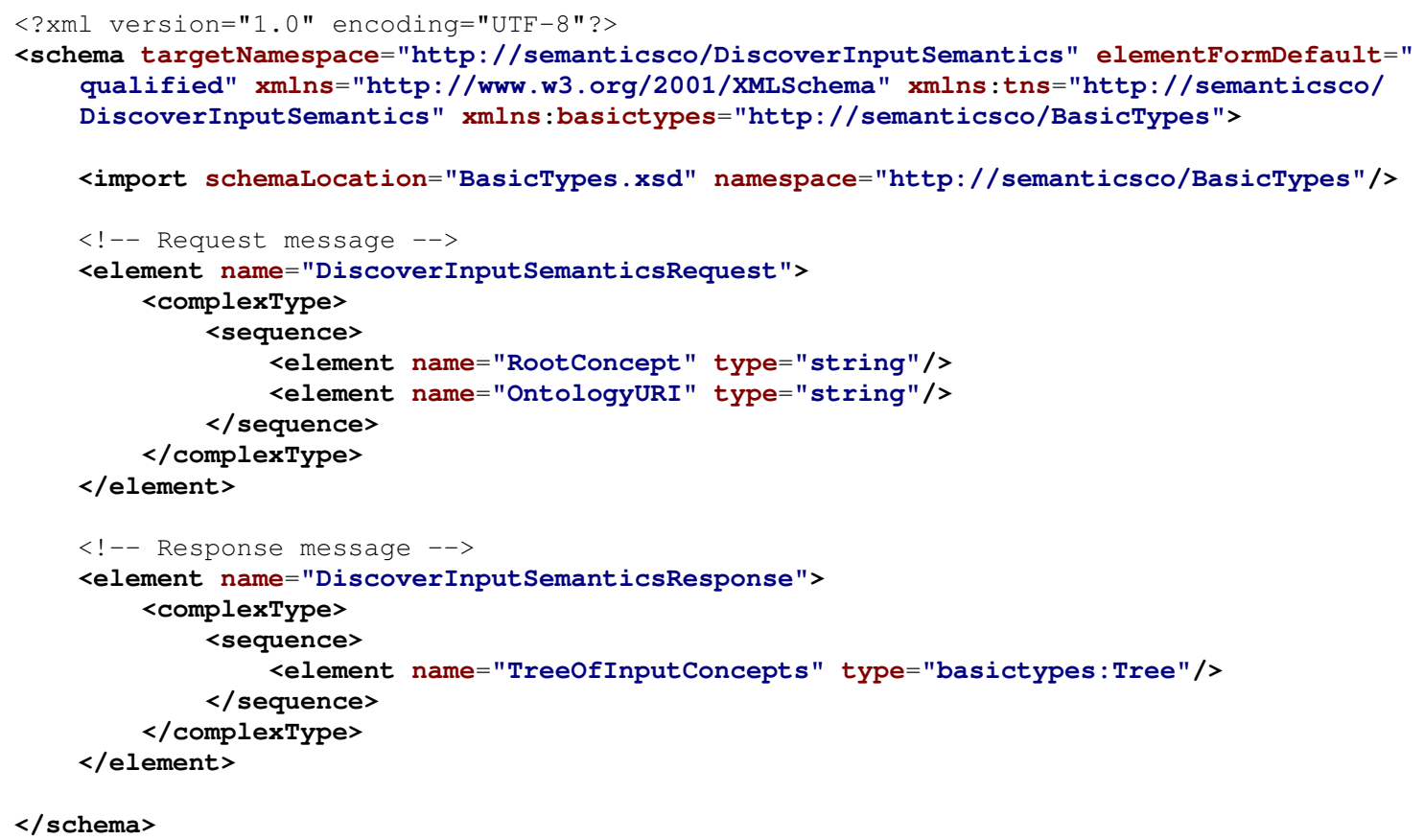

Figura 104: Definição XSD do comando DISCOVER_INPUT_SEMANTICS.

Estratégia de Suporte

A Figura 105 apresenta a estratégia de suporte associada ao comando primitivo DISCOVER_INPUT_SEMANTICS.

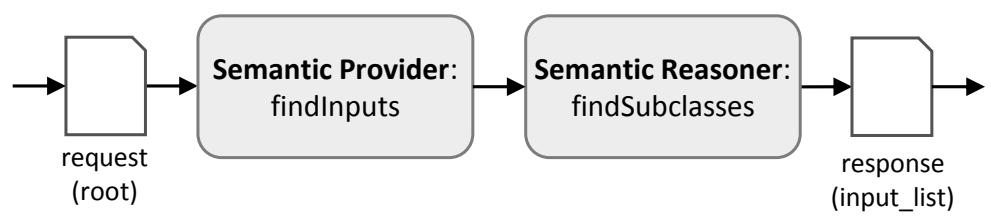

Figura 105: Estratégia de suporte ao comando DISCOVER_INPUT_SEMANTICS.

Quando o módulo Coordinator recebe uma mensagem de requisição do tipo DISCOVER_INPUT_SEMANTICS, o parâmetro root da mensagem é inicialmente extraído. Este parâmetro 
consiste no URI de uma classe (conceito) de ontologia que é superclasse de todas as classes representando tipos de dados na ontologia. Em seguida, o módulo Coordinator invoca o componente Semantic Provider para solicitar a descoberta de todas as classes da ontologia que podem ser utilizadas para especificar a semântica de um conjunto de dados de entrada. O componente Semantic Provider então invoca o componente auxiliar Semantic Reasoner para solicitar a descoberta de todas as subclasses da classe root na ontologia. Finalmente, uma mensagem de resposta contendo a lista de classes da ontologia (URIs) representando tipos de dados de entrada (input_list) é construída e enviada ao módulo Composite Service Enactment.

\section{G.2 DISCOVER_FUNCTION_SEMANTICS}

O comando primitivo DISCOVER_FUNCTION_SEMANTICS permite que o módulo Composite Service Enactment solicite ao módulo Coordinator uma lista de conceitos de uma ontologia (URIs) representando atividades de análise (funcionalidades) que podem ser realizadas em um tipo de dado especificado por um conceito de uma ontologia.

\section{Definição XSD}

A Figura 106 apresenta a definição XSD das mensagens de requisição e resposta especificadas pelo comando primitivo DISCOVER_FUNCTION_SEMANTICS.

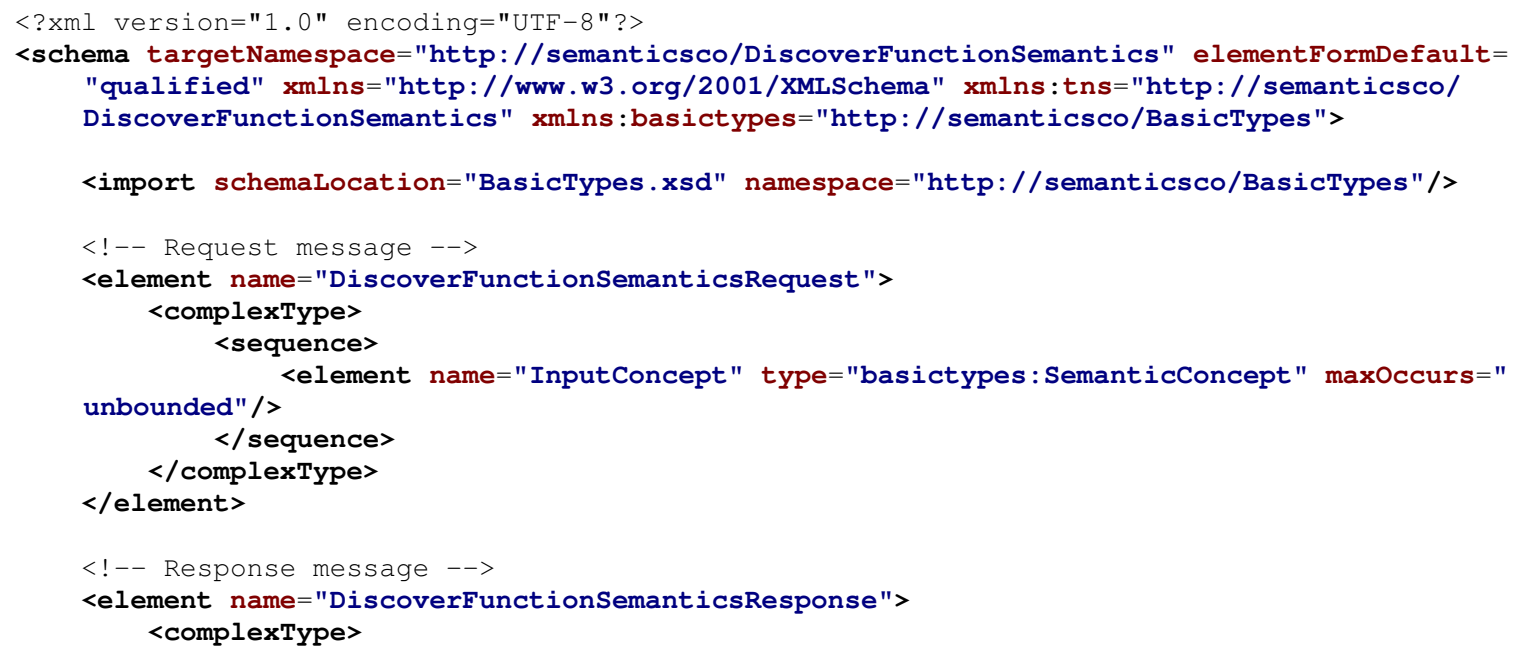




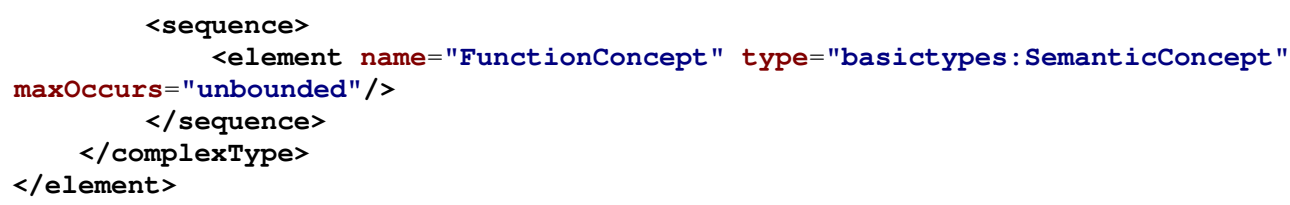

Figura 106: Definição XSD do comando DISCOVER_FUNCTION_SEMANTICS.

\section{Estratégia de Suporte}

A Figura 107 apresenta a estratégia de suporte associada ao comando primitivo DISCOVER_FUNCTION_SEMANTICS.

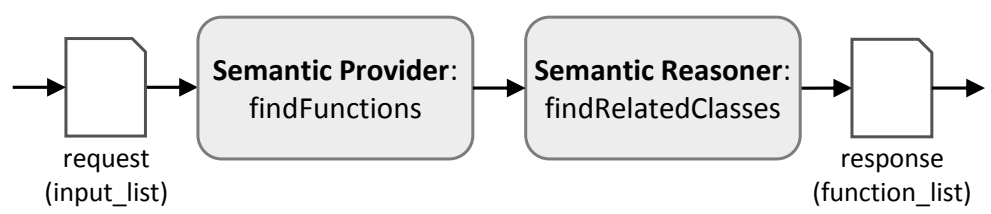

Figura 107: Estratégia de suporte ao comando DISCOVER_FUNCTION_SEMANTICS.

Quando o módulo Coordinator recebe uma mensagem de requisição do tipo DISCOVER_FUNCTION_SEMANTICS, o parâmetro input_list da mensagem é inicialmente extraído. Este parâmetro consiste em uma lista de URIs de classes (conceitos) de uma ontologia representando tipos de dados que um usuário deseja processar. Em seguida, o módulo Coordinator invoca o componente Semantic Provider para solicitar a descoberta de todas as funcionalidades (atividades de análise) que podem ser realizadas nos tipos de dados especificados. O componente Semantic Provider então invoca o componente auxiliar Semantic Reasoner para solicitar a descoberta de classes relacionadas na ontologia, ou seja, classes que representem funcionalidades e estejam associadas às classes representando os tipos de dados especificados. Finalmente, uma mensagem de resposta contendo uma lista de classes da ontologia (URIs) representando funcionalidades (function_list) é construída e enviada ao módulo Composite Service Enactment. 


\section{G.3 DISCOVER_SERVICES}

O comando primitivo DISCOVER_SERVICES permite que o módulo Composite Service Enactment solicite ao módulo Coordinator uma lista de serviços que forneçam um conjunto de funcionalidades e/ou que sejam capazes de processar um conjunto de tipos de dados especificados por meio de conceitos de uma ontologia (URIs).

\section{Definição XSD}

A Figura 108 apresenta a definição XSD das mensagens de requisição e resposta especificadas pelo comando primitivo DISCOVER_SERVICES.

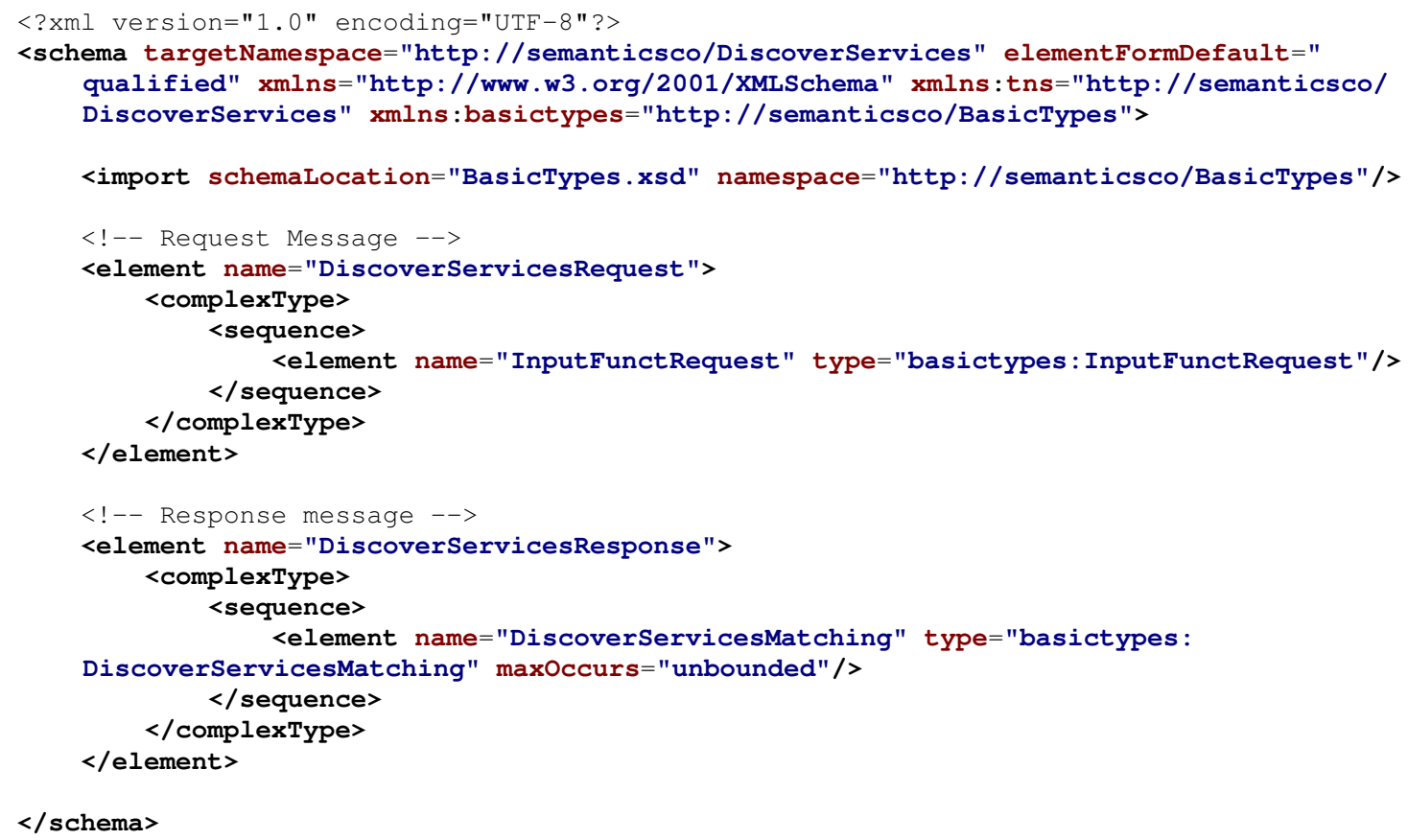

Figura 108: Definição XSD do comando DISCOVER_SERVICES. 


\section{Estratégia de Suporte}

A Figura 109 apresenta a estratégia de suporte associada ao comando primitivo DISCOVER_SERVICES

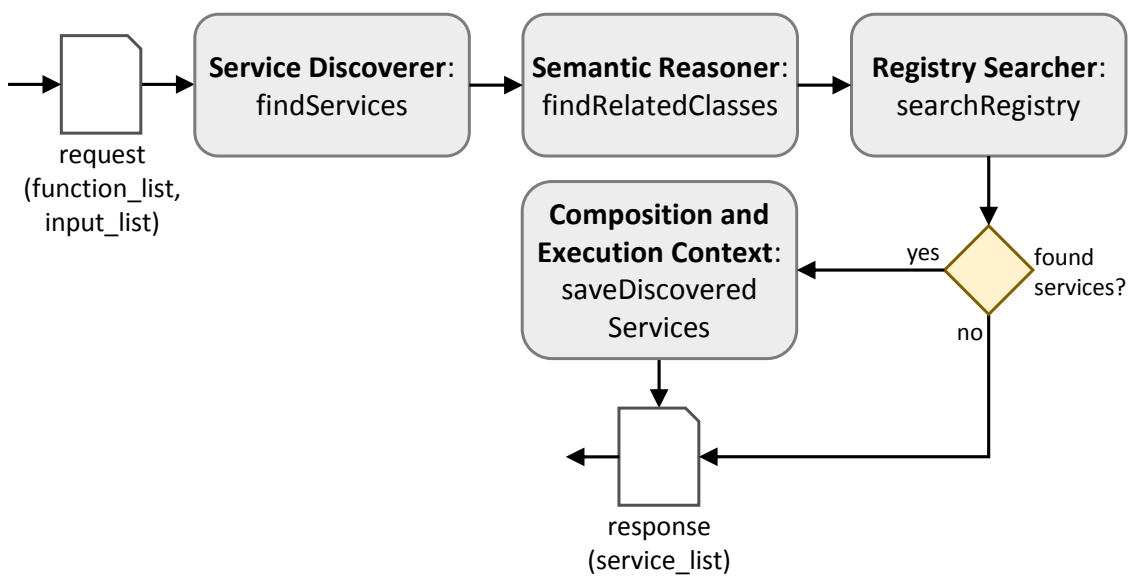

Figura 109: Estratégia de suporte ao comando DISCOVER_SERVICES.

Quando o módulo Coordinator recebe uma mensagem de requisição do tipo DISCOVER_SERVICES, os parâmetros function_list e input_list da mensagem são inicialmente extraídos. O parâmetro function_list consiste em uma lista de URIs de classes (conceitos) de uma ontologia representando atividades de análise (funcionalidades) que um usuário deseja realizar. O parâmetro input_list consiste em uma lista de URIs de classes (conceitos) de uma ontologia representando tipos de dados que um usuário deseja processar. Em seguida, o módulo Coordinator invoca o componente Service Discoverer para solicitar a descoberta semântica de serviços que forneçam as funcionalidades especificadas ou que sejam capazes de processar os tipos de dados especificados. O componente Service Discoverer então invoca o componente auxiliar Semantic Reasoner para solicitar a descoberta de classes equivalentes, subclasses e superclasses das classes da ontologia especificadas na mensagem de requisição. A seguir, o componente Service Discoverer invoca o componente auxiliar Registry Searcher para solicitar a descoberta de serviços de interesse no registro de serviços (módulo Service Registry). Este processo de descoberta baseia-se na realização de comparações entre as classes previamente obtidas pelo componente Semantic Reasoner e as anotações semânticas dos serviços. Caso uma lista de serviços de interesse seja encontrada, o módulo Coordinator invoca o módulo Composition and Execution 
Context para solicitar o armazenamento desta lista. Uma mensagem de requisição contendo a lista de serviços (service_list) é então construída e enviada ao módulo Composite Service Enactment. Caso nenhum serviço de interesse seja encontrado, uma mensagem de resposta contendo uma lista vazia é construída e enviada ao módulo Composite Service Enactment.

\section{G.4 INCLUDE_SERVICES}

O comando primitivo INCLUDE_SERVICES permite que o módulo Composite Service Enactment solicite ao módulo Coordinator a inclusão de um conjunto de serviços especificados na composição de serviços sendo criada.

\section{Definição XSD}

A Figura 110 apresenta a definição XSD das mensagens de requisição e resposta especificadas pelo comando primitivo INCLUDE_SERVICES.

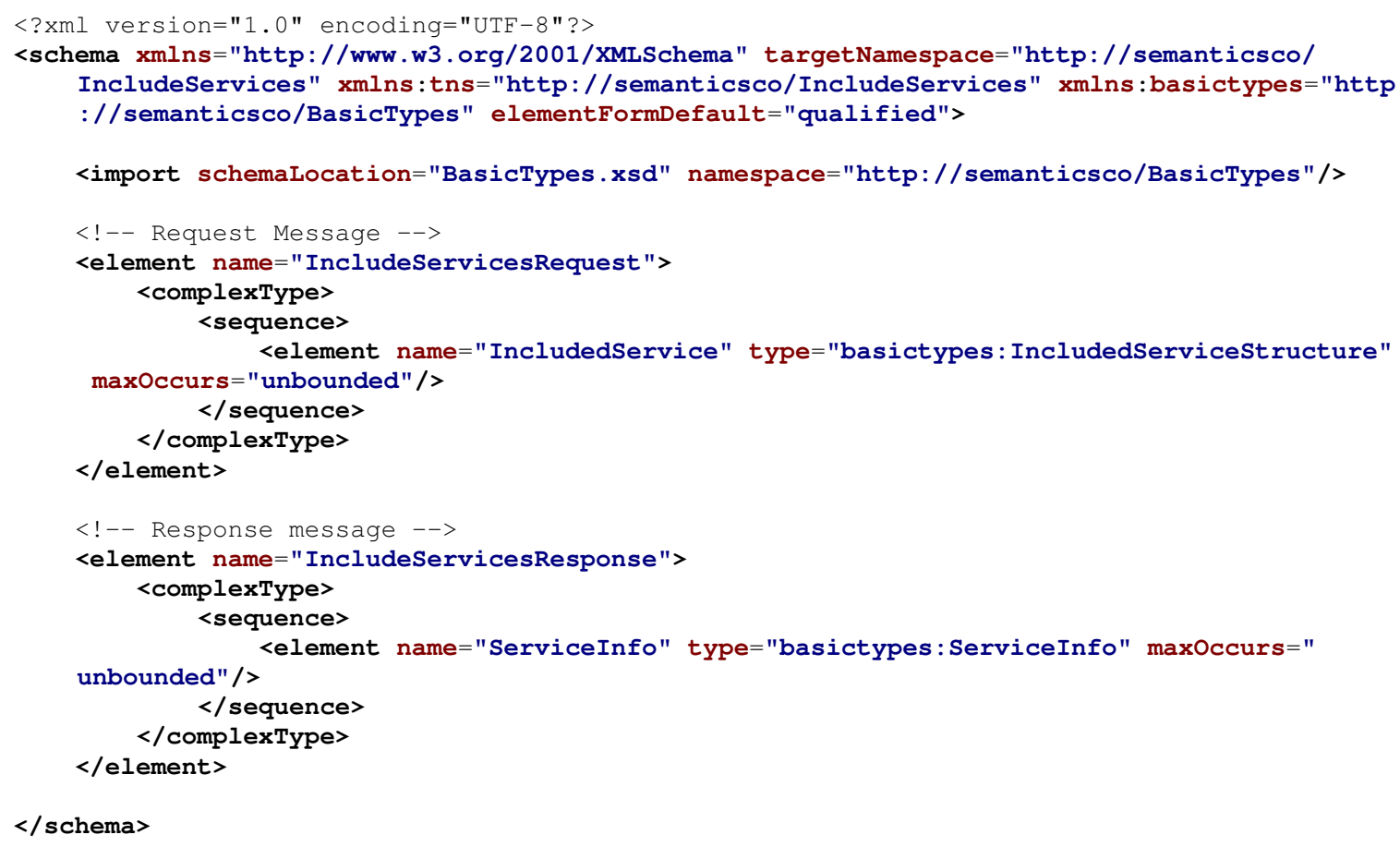

Figura 110: Definição XSD do comando INCLUDE_SERVICES. 
A Figura 111 apresenta a estratégia de suporte associada ao comando primitivo INCLUDE_SERVICES.

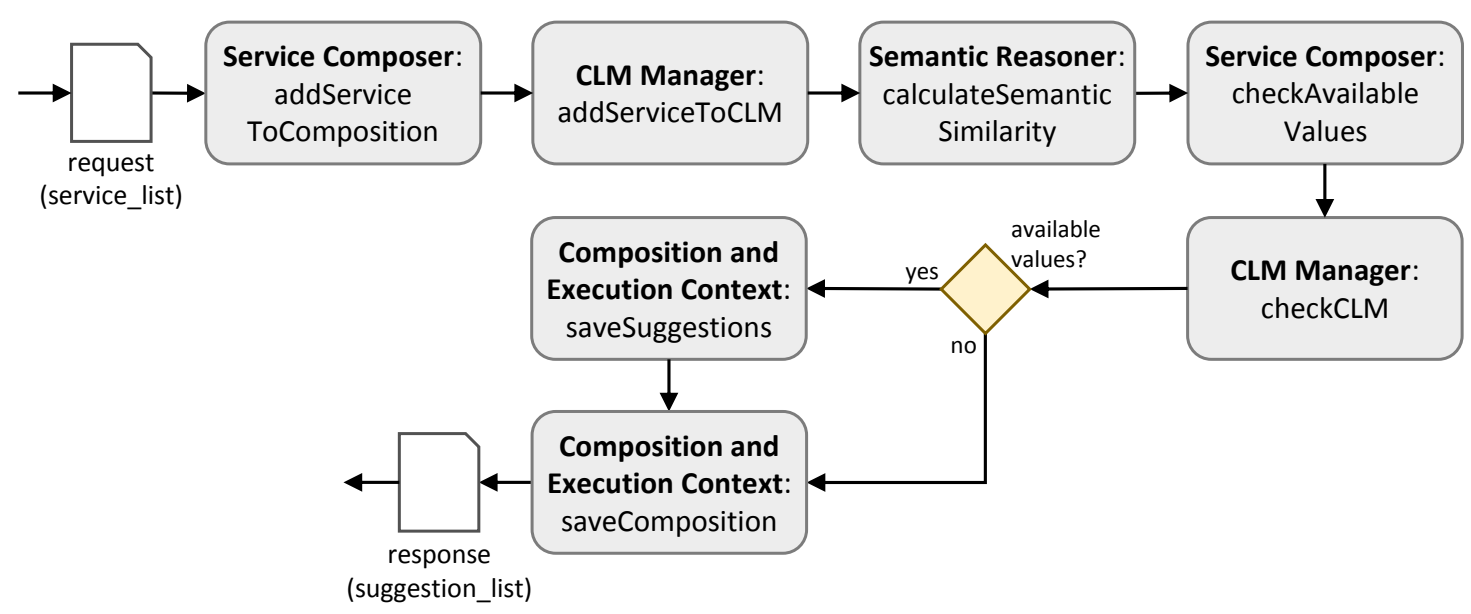

Figura 111: Estratégia de suporte ao comando INCLUDE_SERVICES.

Quando o módulo Coordinator recebe uma mensagem de requisição do tipo INCLUDE_SERVICES, o parâmetro service_list da mensagem é inicialmente extraído. Este parâmetro consiste em uma lista de identificadores de serviços a serem incluídos na composição de serviços sendo criada. Em seguida, o módulo Coordinator invoca o componente Service Composer para solicitar a inclusão dos serviços no grafo de composição. O componente Service Composer então invoca o componente auxiliar CLM Manager para solicitar a inclusão dos serviços na matriz CLM. Por sua vez, o componente CLM Manager invoca o componente auxiliar Semantic Reasoner para solicitar o cálculo de similaridade semântica entre os conceitos utilizados para representar os tipos de dados produzidos e consumidos pelos serviços definidos na matriz CLM.

Após a inclusão dos serviços na matriz CLM e no grafo de composição, o módulo Coordinator invoca o componente Service Composer para verificar se há conjuntos de dados disponíveis que possam ser utilizados para validar os dados de entrada dos serviços selecionados. Estes conjuntos de dados podem ter sido previamente fornecidos pelo usuário ou serem produzidos por um outro serviço previamente inserido na composição. De modo a realizar esta verificação, o componente Service Composer invoca o componente auxiliar CLM Manager para solicitar os valores de similaridade semântica definidos entre os tipos de dados disponíveis e os tipos de da- 
dos de entrada dos serviços selecionados. Caso haja conjuntos de dados disponíveis, o módulo Coordinator invoca o módulo Composition and Execution Context para solicitar o armazenamento de referências a estes conjuntos de dados como sugestões para a validação dos dados de entrada dos serviços selecionados. Caso contrário, o módulo Coordinator invoca diretamente o módulo Composition and Execution Context para solicitar o armazenamento do grafo de composição e da matriz CLM atualizados. Finalmente, uma mensagem de resposta contendo a lista de sugestões de dados disponíveis para a validação das entradas dos serviços (suggestion_list) é construída e enviada ao módulo Composite Service Enactment.

\section{G.5 RESOLVE_SERVICES}

O comando primitivo RESOLVE_SERVICES permite que o módulo Composite Service Enactment solicite ao módulo Coordinator uma lista de serviços que sejam capazes de produzir um conjunto de tipos de dados exigidos como entrada para um conjunto de serviços especificados. Os tipos de dados são especificados por meio de conceitos de uma ontologia (URIs).

\section{Definição XSD}

A Figura 112 apresenta a definição XSD das mensagens de requisição e resposta especificadas pelo comando primitivo RESOLVE_SERVICES.

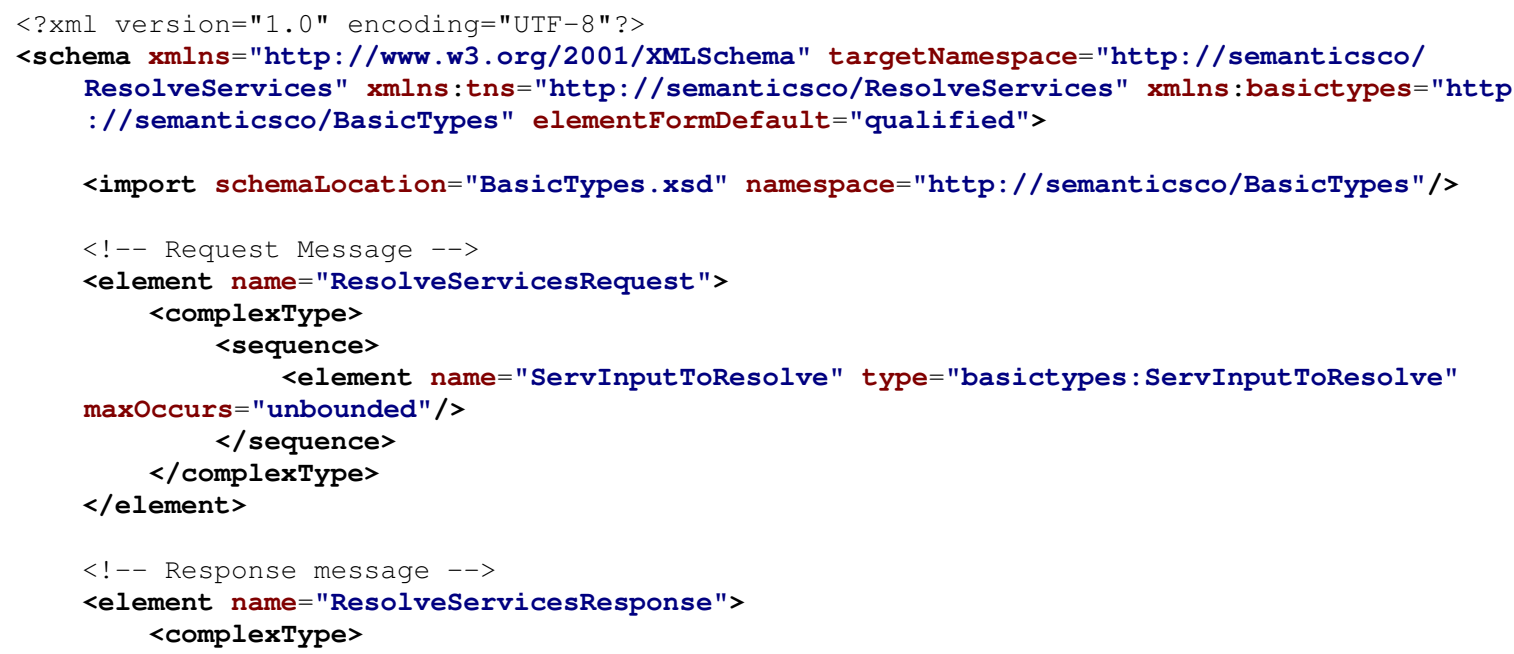




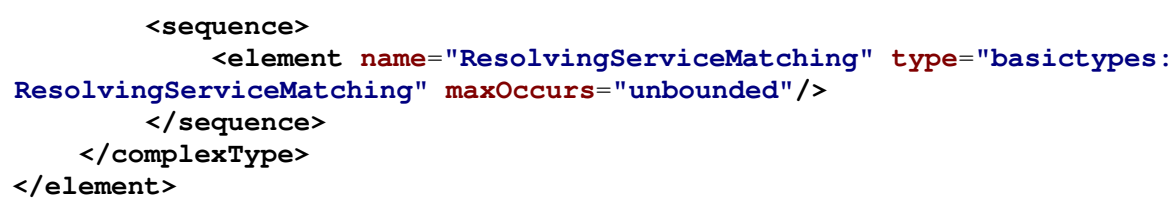

Figura 112: Definição XSD do comando RESOLVE_SERVICES.

Estratégia de Suporte

A Figura 113 apresenta a estratégia de suporte associada ao comando primitivo RESOLVE_SERVICES.

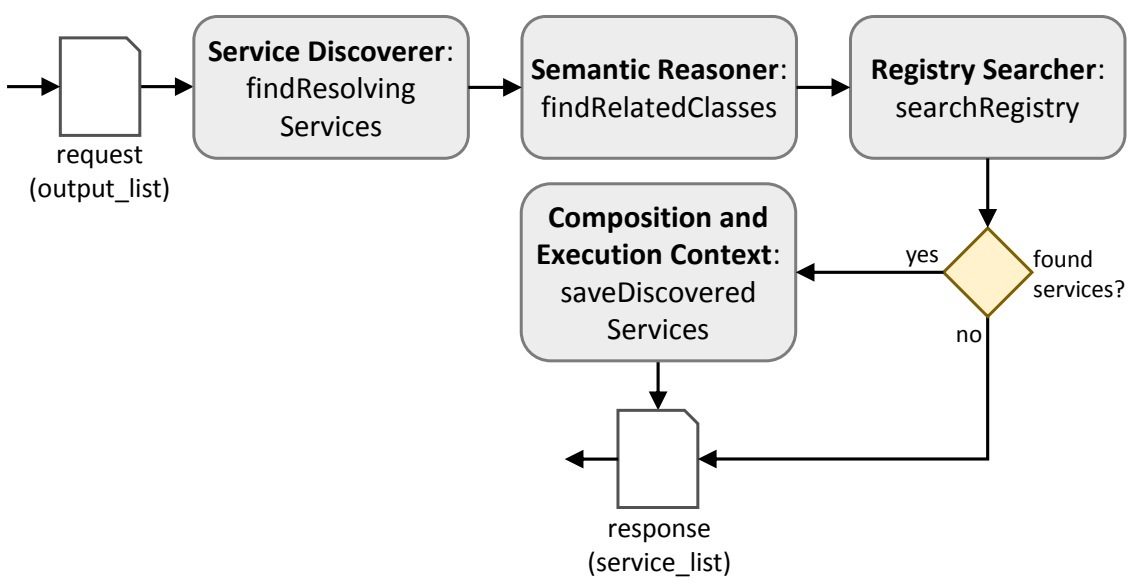

Figura 113: Estratégia de suporte ao comando RESOLVE_SERVICES.

Quando o módulo Coordinator recebe uma mensagem de requisição do tipo RESOLVE_SERVICES, o parâmetro output_list da mensagem é inicialmente extraído. Este parâmetro consiste em uma lista de URIs de classes (conceitos) de uma ontologia representando tipos de dados exigidos como entrada para um conjunto de serviços. Em seguida, o módulo Coordinator invoca o componente Service Discoverer para solicitar a descoberta semântica de serviços que sejam capazes de produzir os tipos de dados especificados. O componente Service Discoverer então invoca o componente auxiliar Semantic Reasoner para solicitar a descoberta de classes equivalentes, subclasses e superclasses das classes da ontologia especificadas na mensagem de requisição. A seguir, o componente Service Discoverer invoca o componente auxiliar Registry Searcher para solicitar a descoberta de serviços de interesse no registro de serviços (módulo 
Service Registry). Este processo de descoberta baseia-se na realização de comparações entre as classes previamente obtidas pelo componente Semantic Reasoner e as anotações semânticas dos serviços. Caso uma lista de serviços de interesse seja encontrada, o módulo Coordinator invoca o módulo Composition and Execution Context para solicitar o armazenamento desta lista. Uma mensagem de requisição contendo a lista de serviços (service_list) é então construída e enviada ao módulo Composite Service Enactment. Caso nenhum serviço de interesse seja encontrado, uma mensagem de resposta contendo uma lista vazia é construída e enviada ao módulo Composite Service Enactment.

\section{G.6 VALIDATE_INPUTS}

O comando primitivo VALIDATE_INPUTS permite que o módulo Composite Service Enactment solicite ao módulo Coordinator a validação do conjunto de dados de entrada de um serviço especificado com um conjunto de dados fornecido pelo usuário.

\section{Definição XSD}

A Figura 114 apresenta a definição XSD das mensagens de requisição e resposta especificadas pelo comando primitivo VALIDATE_INPUTS.

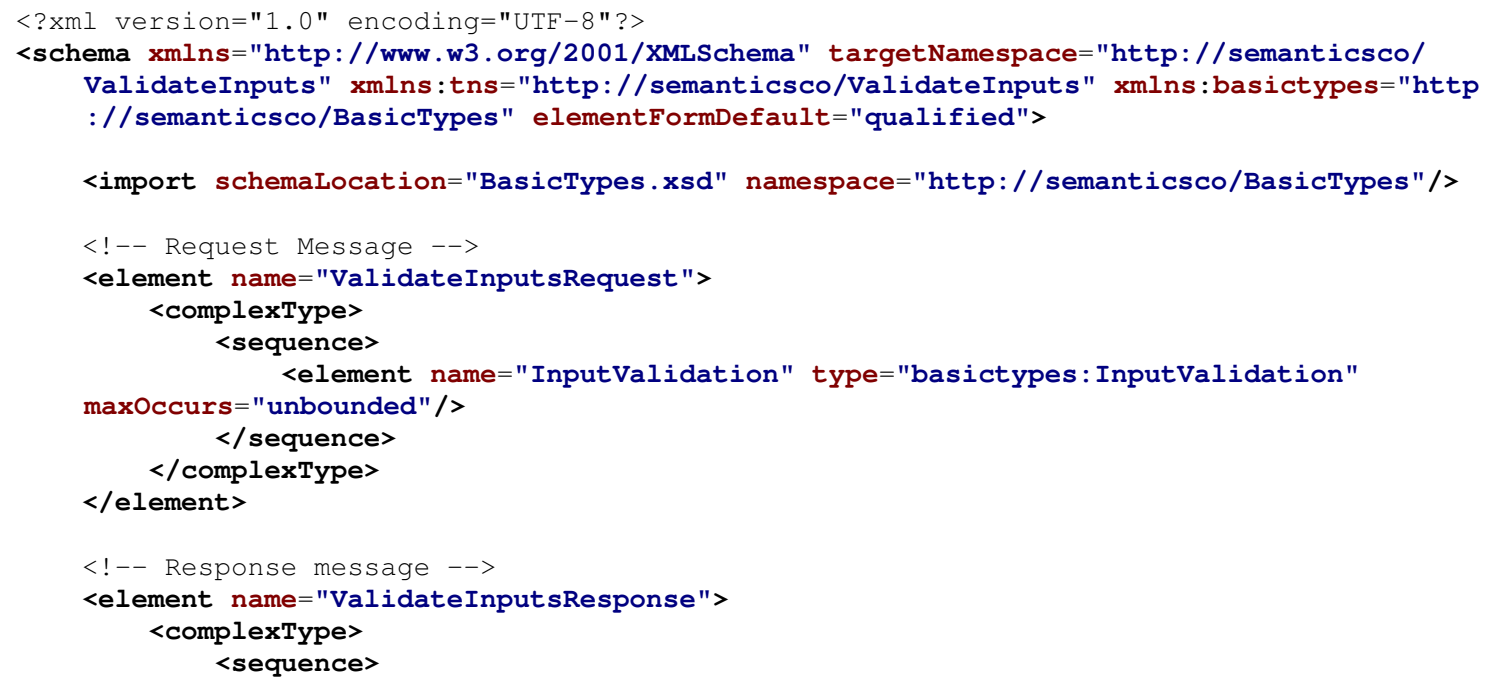


Figura 114: Definição XSD do comando VALIDATE_INPUTS.

\section{Estratégia de Suporte}

A Figura 115 apresenta a estratégia de suporte associada ao comando primitivo VALIDATE_INPUTS.

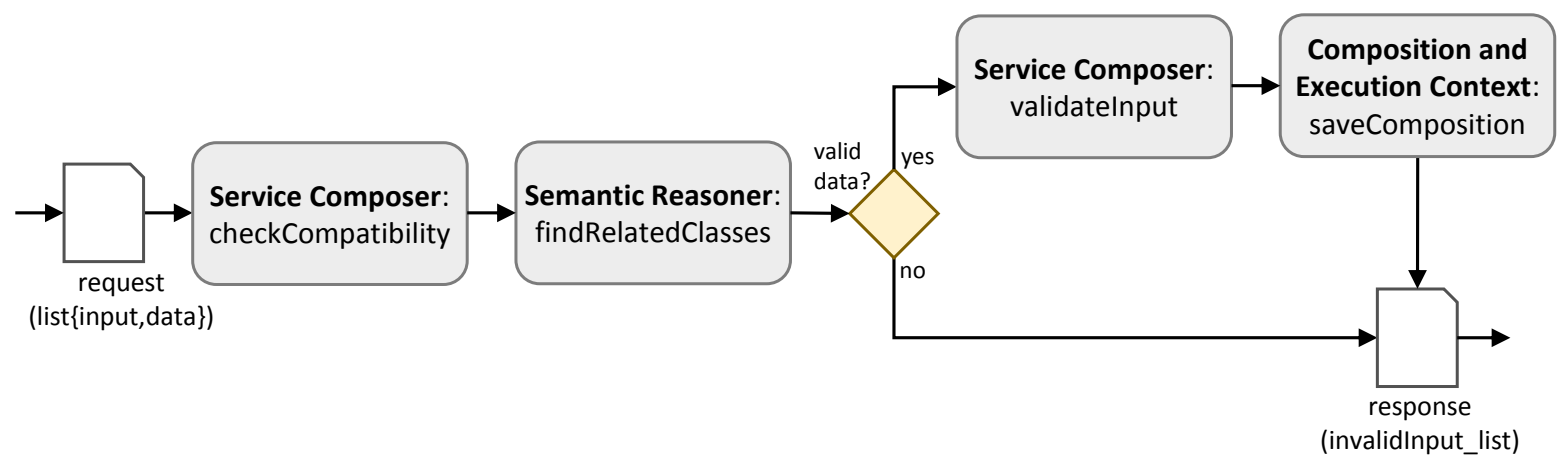

Figura 115: Estratégia de suporte ao comando VALIDATE_INPUTS.

Quando o módulo Coordinator recebe uma mensagem de requisição do tipo VALIDATE_INPUTS, o parâmetro list\{input,data\} da mensagem é inicialmente extraído. Este parâmetro consiste em uma lista de tuplas \{input,data\}, de modo que input consiste nos dados de entrada de um serviço que um usuário deseja validar e data consiste na localização dos dados fornecidos para validar a entrada do serviço. Para cada tupla \{input,data\}, o módulo Coordinator invoca o componente Service Composer para verificar se os dados fornecidos são compatíveis com a entrada do serviço. De modo a realizar esta verificação, o componente Service Composer invoca o componente auxiliar Semantic Reasoner para solicitar a descoberta de classes equivalentes, subclasses e superclasses da classe de uma ontologia utilizada para especificar a semântica dos dados de entrada do serviço. Caso os dados fornecidos sejam compatíveis com a entrada do serviço, o módulo Coordinator invoca o componente Service Composer para solicitar a validação dos dados de entrada do serviço, ou seja, a associação dos dados fornecidos à entrada 
do serviço no grafo de composição. Após o processamento de todas as tuplas $\{$ input,data\}, o módulo Coordinator então invoca o módulo Composition and Execution Context para solicitar o armazenamento do grafo de composição atualizado. Finalmente, caso algum conjunto de dados fornecido seja inválido, uma mensagem de resposta contendo os identificadores dos dados de entrada inválidos (invalidInput_list) é construída e enviada ao módulo Composite Service Enactment. Caso contrário, uma mensagem de resposta contendo uma lista vazia é construída e enviada ao módulo Composite Service Enactment.

\section{G.7 COMPOSE_SERVICES}

O comando primitivo COMPOSE_SERVICES permite que o módulo Composite Service Enactment solicite ao módulo Coordinator a composição (forward ou backward) de dois serviços especificados, de modo que o conjunto de dados produzido por um dos serviços seja associado à entrada do outro serviço.

Definição XSD

A Figura 116 apresenta a definição XSD das mensagens de requisição e resposta especificadas pelo comando primitivo COMPOSE_SERVICES.

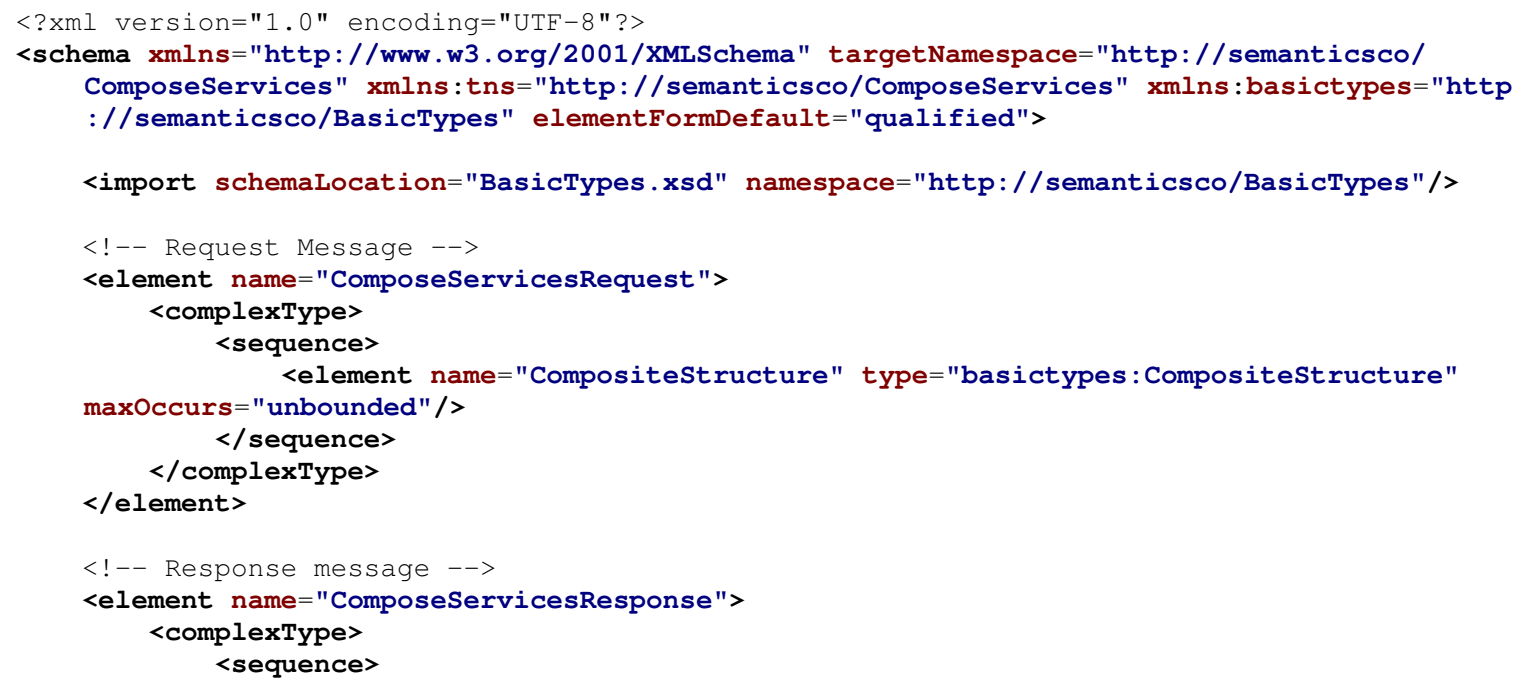




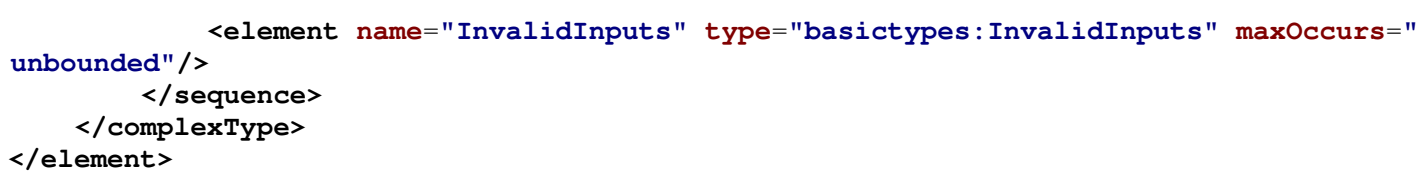

Figura 116: Definição XSD do comando COMPOSE_SERVICES.

\section{Estratégia de Suporte}

A Figura 117 apresenta a estratégia de suporte associada ao comando primitivo COMPOSE_SERVICES.

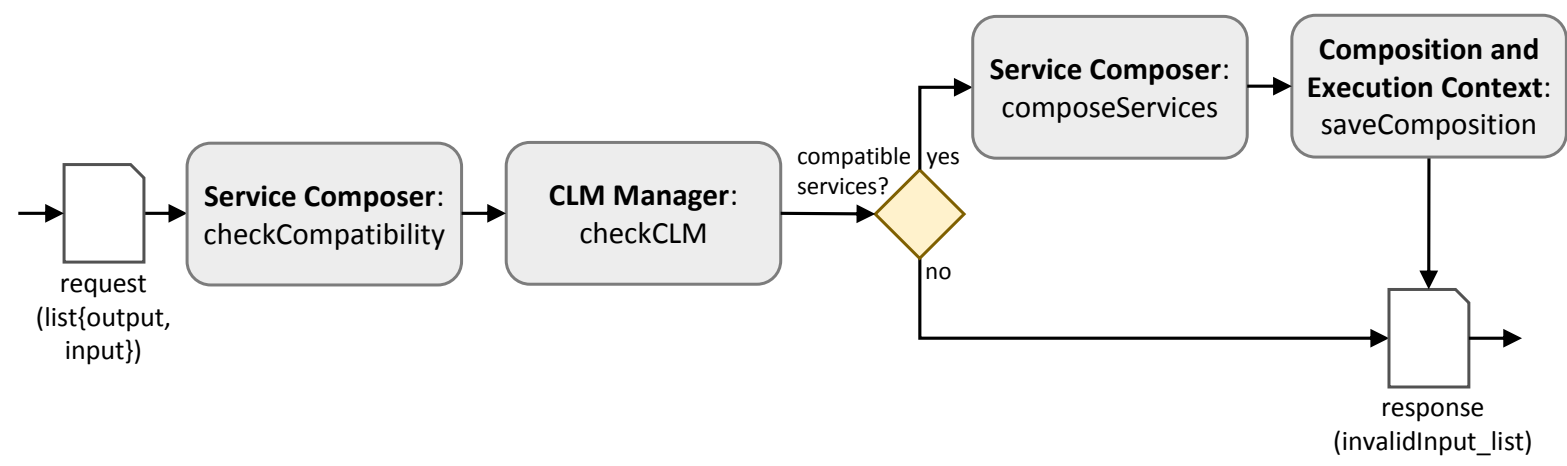

Figura 117: Estratégia de suporte ao comando COMPOSE_SERVICES.

Quando o módulo Coordinator recebe uma mensagem de requisição do tipo COMPOSE_SERVICES, o parâmetro list\{output,input\} da mensagem é inicialmente extraído. Este parâmetro consiste em uma lista de tuplas \{output,input\}, de modo que output consiste nos dados de saída de um serviço que devem ser associados aos dados de entrada de outro serviço (input). Para cada tupla \{output,input\}, o módulo Coordinator invoca o componente Service Composer para verificar se a saída do serviço é compatível com a entrada do outro serviço e se a composição dos serviços não gera uma situação de deadlock. De modo a realizar esta verificação, o componente Service Composer invoca o componente auxiliar CLM Manager para solicitar a verificação dos valores de similaridade semântica definidos entre os serviços na matriz CLM. Caso os serviços sejam compatíveis, o módulo Coordinator invoca o componente Service Composer para solicitar a composição dos serviços, ou seja, a associação dos dados de saída de um serviço aos 
dados de entrada do outro serviço no grafo de composição. O módulo Coordinator então invoca o módulo Composition and Execution Context para solicitar o armazenamento do grafo de composição atualizado. Após o processamento de todas as tuplas \{output,input\}, caso alguma tupla seja incompatível, uma mensagem de resposta contendo os identificadores dos dados de entrada inválidos (invalidInput_list) é construída e enviada ao módulo Composite Service Enactment. Caso contrário, uma mensagem de resposta contendo uma lista vazia é construída e enviada ao módulo Composite Service Enactment.

\section{G.8 GET_EXECUTABLE_SERVICES}

O comando primitivo GET_EXECUTABLE_SERVICES permite que o módulo Composite Service Enactment solicite ao módulo Coordinator uma lista de serviços que estejam prontos para serem executados.

\section{Definição XSD}

A Figura 118 apresenta a definição XSD das mensagens de requisição e resposta especificadas pelo comando primitivo GET_EXECUTABLE_SERVICES.

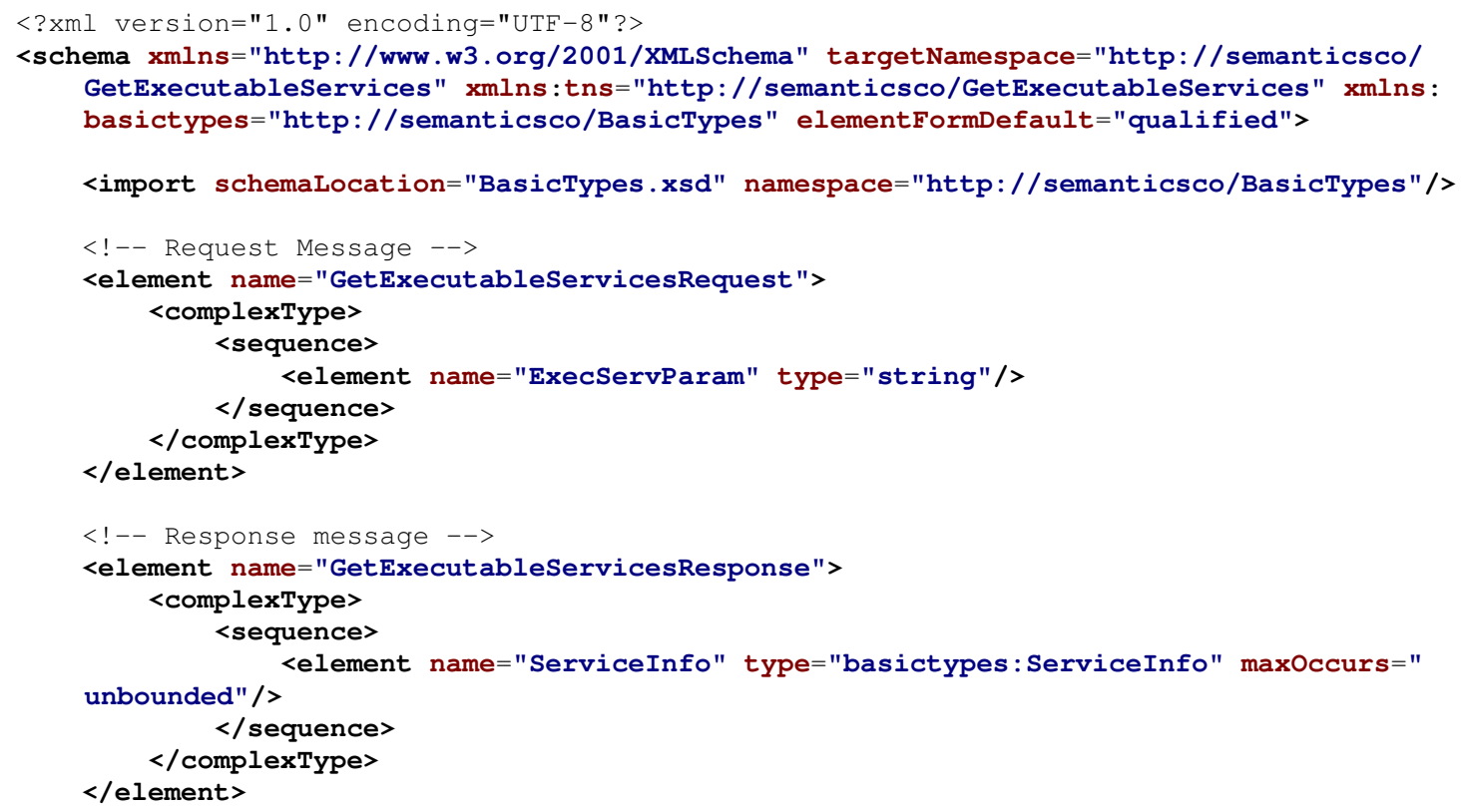


Figura 118: Definição XSD do comando GET_EXECUTABLE_SERVICES.

\section{Estratégia de Suporte}

A Figura 119 apresenta a estratégia de suporte associada ao comando primitivo GET_EXECUTABLE_SERVICES.

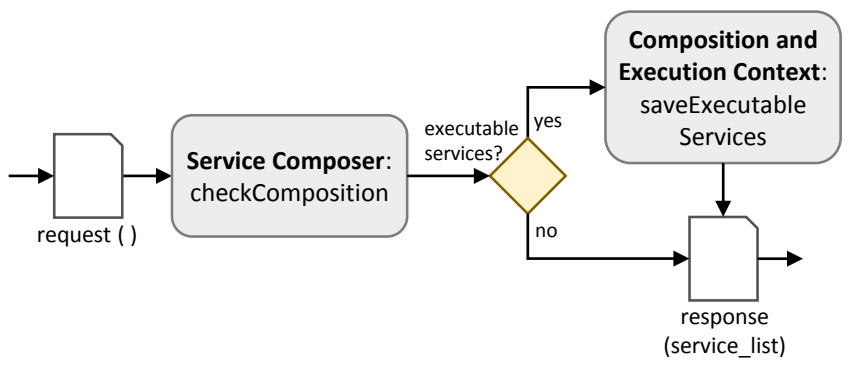

Figura 119: Estratégia de suporte ao comando GET_EXECUTABLE_SERVICES.

Quando o módulo Coordinator recebe uma mensagem de requisição do tipo GET_EXECUTABLE_SERVICES, o mesmo invoca o componente Service Composer para solicitar a verificação do grafo de composição. Para cada serviço definido no grafo de composição, o componente Service Composer verifica se todos os seus dados de entrada estão disponíveis, ou seja, se o serviço está pronto para execução. Caso existam serviços prontos para execução, o módulo Coordinator invoca o módulo Composition and Execution Context para solicitar o armazenamento destes serviços e uma mensagem de resposta contendo estes serviços (service_list) é construída e enviada ao módulo Composite Service Enactment. Caso não haja serviços prontos para execução, uma mensagem de resposta contendo uma lista vazia é construída e enviada ao módulo Composite Service Enactment. 


\section{G.9 ADD_TO_CONTEXT}

O comando primitivo ADD_TO_CONTEXT permite que o módulo Composite Service Enactment solicite ao módulo Coordinator o armazenamento de informações sobre os dados produzidos por um conjunto de serviços.

Definição XSD

A Figura 120 apresenta a definição XSD das mensagens de requisição e resposta especificadas pelo comando primitivo ADD_TO_CONTEXT.

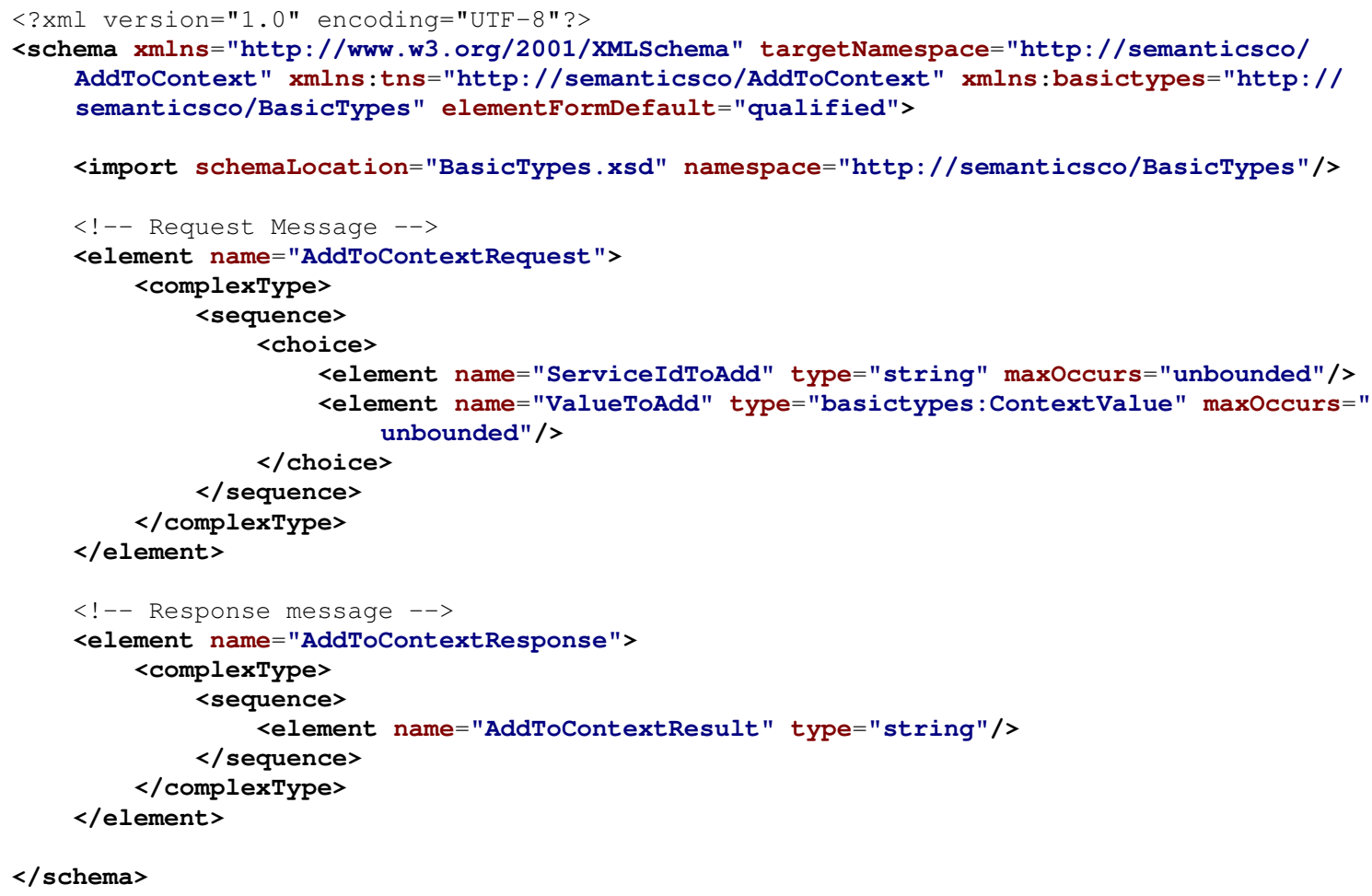

Figura 120: Definição XSD do comando ADD_TO_CONTEXT. 
A Figura 121 apresenta a estratégia de suporte associada ao comando primitivo $A D D \_T O \_C O N$ TEXT.

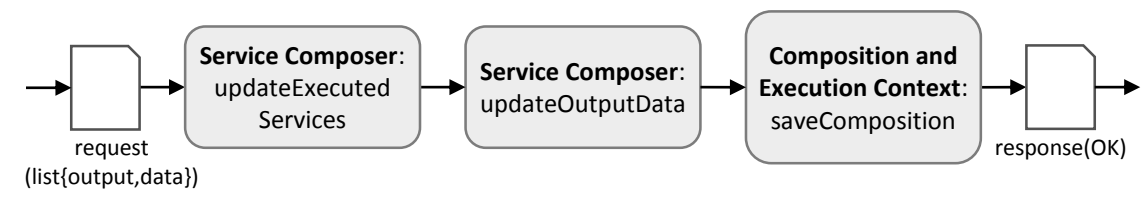

Figura 121: Estratégia de suporte ao comando $A D D \_T O \_C O N T E X T$.

Quando o módulo Coordinator recebe uma mensagem de requisição do tipo $A D D \_T O \_C O N$ TEXT, o parâmetro list\{output,data\} da mensagem é inicialmente extraído. Este parâmetro consiste em uma lista de tuplas \{output,data\}, de modo que output consiste no identificador da saída de um serviço que deve ser associada aos dados produzidos pelo serviço (data). O parâmetro data consiste na localização dos dados produzidos pelo serviço. Em seguida, o módulo Coordinator invoca o componente Service Composer para solicitar o armazenamento dos serviços em uma lista de serviços executados. Para cada tupla \{output,data\}, o módulo Coordinator então invoca o componente Service Composer para solicitar a associação dos dados produzidos pelo serviço à sua saída no grafo de composição. Finalmente, uma mensagem de resposta é construída e enviada ao módulo Composite Service Enactment. 
Diferentes serviços de adaptação foram desenvolvidos para facilitar a realização dos estudos de expressão gênica na plataforma SemanticSCo. Estes serviços também estão publicamente disponíveis no repositório GEAS. As seções a seguir apresentam, em detalhes, os serviços de adaptação desenvolvidos.

\section{H.1 SERVIÇO DE ADAPTAÇÃO AS 1}

Dados de expressão gênica normalizados frequentemente incluem, em um mesmo conjunto de dados, os valores de expressão de um conjunto de genes/transcritos em múltiplas amostras de mRNA (réplicas) associadas a diferentes condições experimentais. No entanto, em algumas situações, o particionamento dos dados de acordo com diferentes condições experimentais pode ser necessário. Neste contexto, o serviço de adaptação ASl tem como objetivo permitir o particionamento de um conjunto de dados de expressão gênica normalizados em dois conjuntos de dados independentes, cada um associado a uma única condição experimental. A Figura 122 ilustra o processamento de um conjunto de dados pelo serviço de adaptação ASl.

O serviço AS1 requer como entrada um conjunto de dados de expressão gênica normalizados, representando duas ou mais amostras associadas a diferentes condições experimentais. Os dados normalizados devem ser disponibilizados em um único arquivo texto tabular. Cada linha do arquivo deve conter um identificador de gene/transcrito (primeira coluna) e os seus valo- 


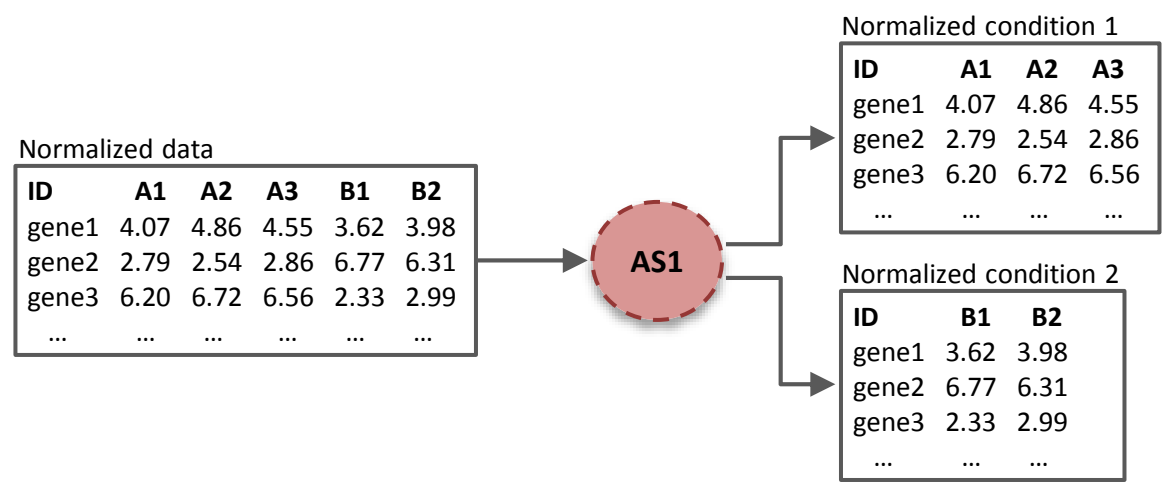

Figura 122: Processamento de dados pelo serviço de adaptação AS1.

res de expressão normalizados em cada amostra (demais colunas). Adicionalmente, o serviço AS1 requer como entrada dois parâmetros especificando o conjunto de amostras (colunas) de interesse.

O serviço ASl é responsável por particionar os dados de expressão gênica normalizados em dois conjuntos de dados independentes, de modo que cada conjunto contenha apenas os valores de expressão normalizados referentes às amostras especificadas para cada condição experimental. Como resultado, este serviço produz dois arquivos multi-colunas contendo os dados de expressão gênica normalizados, particionados de acordo com as duas condições experimentais.

\section{H.2 SERVIÇO DE ADAPTAÇÃO AS 2}

Em geral, dados de expressão diferencial incluem simultaneamente informações sobre genes/transcritos induzidos e reprimidos em um experimento. No entanto, em algumas situações, o particionamento dos dados em dois conjuntos independentes (genes reprimidos e induzidos) pode ser necessário. Neste contexto, o serviço de adaptação $A S 2$ tem como objetivo permitir o particionamento de um conjunto de dados de expressão diferencial em dois conjuntos de dados independentes, compreendendo os genes reprimidos e induzidos, respectivamente. Adicionalmente, este serviço permite o mapeamento entre diferentes tipos de identificadores de genes. A Figura 123 ilustra o processamento de um conjunto de dados pelo serviço de adaptação $A S 2$.

O serviço de adaptação $A S 2$ requer como entrada um conjunto de dados de expressão gênica diferencial. Estes dados devem ser disponibilizados em um arquivo texto tabular. Cada linha 


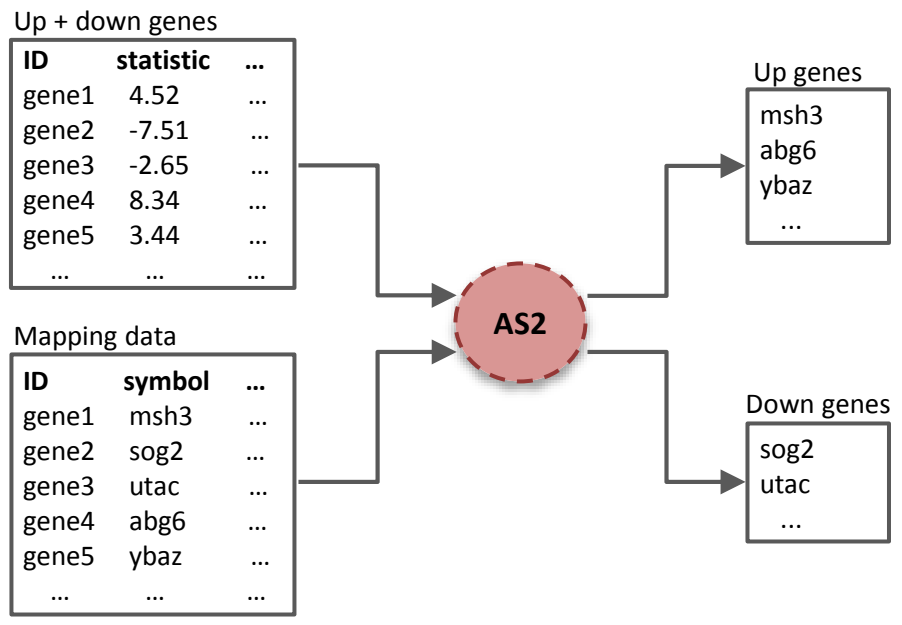

Figura 123: Processamento de dados pelo serviço de adaptação AS2.

do arquivo deve conter um identificador de gene (primeira coluna) e um valor de estatística de teste correspondente (segunda coluna). Adicionalmente, o serviço AS2 requer como entrada um conjunto de dados de mapeamento entre diferentes tipos de identificadores de genes. Estes dados também devem ser disponibilizados em um arquivo texto tabular, de modo que cada coluna do arquivo represente um tipo de identificador de gene.

Inicialmente, o serviço AS2 é responsável por converter os identificadores de genes armazenados nos dados de expressão diferencial para outro tipo de identificador especificado no arquivo de mapeamento fornecido como entrada. Para este propósito, o serviço também requer como entrada dois parâmetros especificando as colunas (origem e destino) do arquivo de mapeamento a serem consideradas para a conversão dos identificadores de genes diferencialmente expressos. Uma vez que os identificadores de genes são convertidos, o serviço AS2 é responsável por particionar os dados de expressão diferencial em dois conjuntos de dados distintos, cada um representando genes induzidos e reprimidos, respectivamente. O particionamento dos dados de expressão diferencial é realizado pelo serviço com base nos valores de estatística correspondentes aos genes. Como resultado, o serviço $A S 2$ produz dois arquivos contendo os conjuntos de dados dos genes induzidos e reprimidos, respectivamente. 


\section{H.3 SERVIÇO DE ADAPTAÇÃO AS 3}

Dados de expressão gênica normalizados frequentemente incluem, em um mesmo conjunto de dados, os valores de expressão de um conjunto de genes/transcritos em múltiplas amostras de mRNA (réplicas). Em algumas situações, a filtragem de apenas um subconjunto dos genes pode ser necessária. Neste contexto, o serviço de adaptação $A S 3$ tem como objetivo permitir a filtragem de dados de expressão gênica normalizados com base em conjuntos de genes funcionalmente enriquecidos. Adicionalmente, este serviço permite o mapeamento entre diferentes tipos de identificadores de genes. A Figura 124 ilustra o processamento de um conjunto de dados pelo serviço de adaptação $A S 3$.

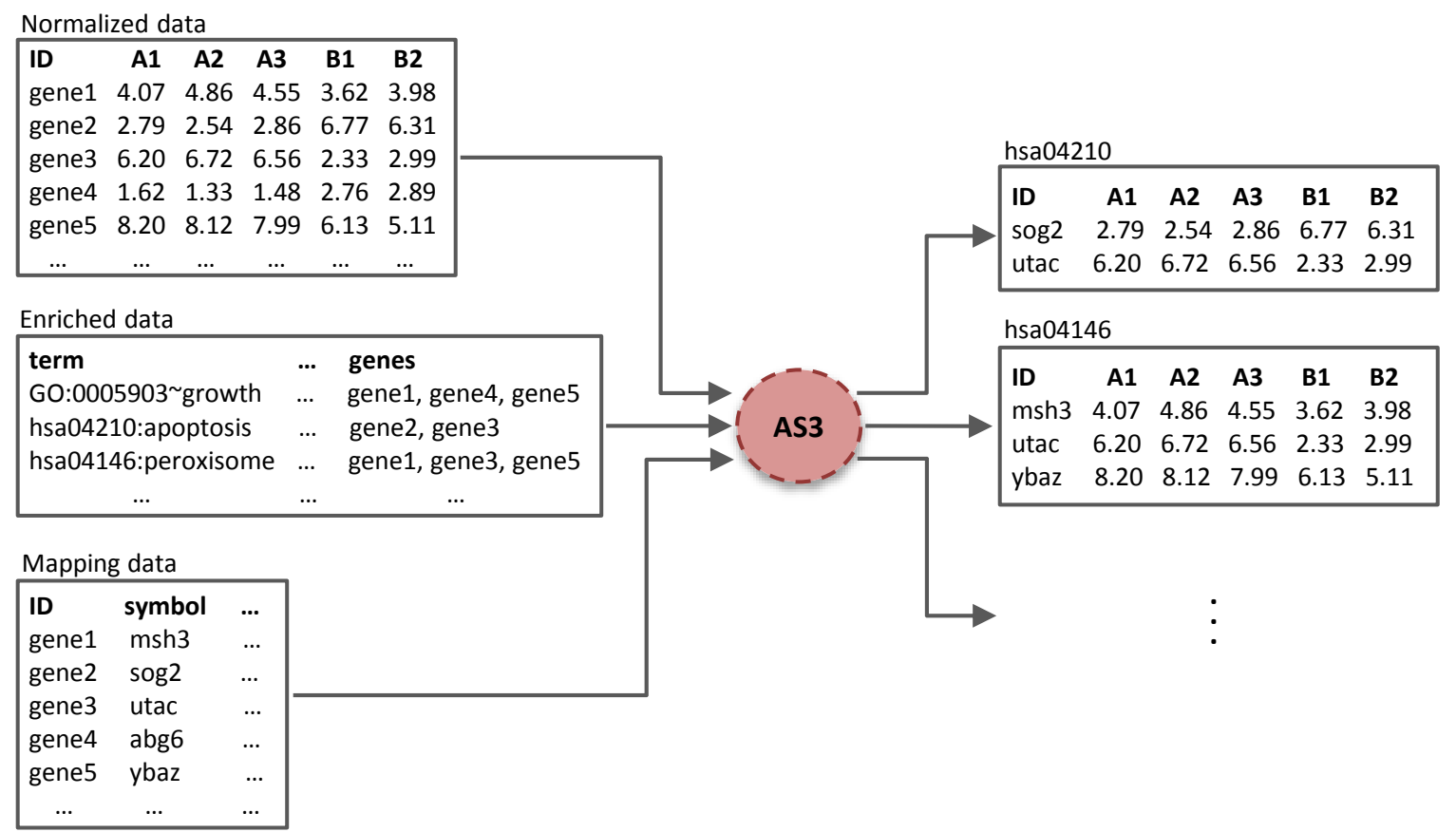

Figura 124: Processamento de dados pelo serviço de adaptação AS3.

O serviço de adaptação $A S 3$ requer como entrada um conjunto de dados de expressão gênica normalizados. Estes dados podem representar uma ou mais amostras de mRNA (réplicas) associadas a diferentes condições experimentais. Os dados normalizados devem ser disponibilizados em um arquivo texto tabular. Cada linha do arquivo deve conter um identificador de gene/transcrito (primeira coluna) e os seus valores de expressão normalizados em cada amostra (demais colunas). Além disto, o serviço AS3 requer como entrada uma lista de termos bio- 
lógicos enriquecidos, também disponibilizada em um arquivo texto tabular. Cada linha deste arquivo deve conter um termo biológico e uma lista de identificadores de genes associados ao termo. Finalmente, o serviço $A S 3$ requer como entrada um conjunto de dados de mapeamento entre diferentes tipos de identificadores de genes. Estes dados também devem ser disponibilizados em um arquivo texto tabular, de modo que cada coluna do arquivo represente um tipo de identificador de gene.

Inicialmente, o serviço AS3 é responsável por selecionar apenas as vias biológicas da base de dados KEGG [169] e os genes associados a cada via na lista de termos biológicos enriquecidos. Para cada via biológica KEGG selecionada, o serviço filtra os dados normalizados, selecionando apenas os valores de expressão dos genes associados àquela via biológica e armazenando estes valores em um arquivo multi-colunas (uma coluna para cada amostra). Finalmente, o serviço é responsável por converter os identificadores de genes armazenados no arquivo multi-colunas para outro tipo de identificador especificado no arquivo de mapeamento fornecido como entrada. Para este propósito, o serviço também requer como entrada dois parâmetros especificando as colunas (origem e destino) do arquivo de mapeamento a serem consideradas para a conversão dos identificadores armazenados no arquivo multi-colunas. Como resultado, o serviço AS3 produz um arquivo multi-colunas para cada via biológica KEGG selecionada. Cada arquivo contém apenas os valores de expressão normalizados dos genes associados àquela via biológica.

\section{H.4 SERVIÇO DE ADAPTAÇÃO AS4}

Dados de expressão gênica normalizados frequentemente incluem, em um mesmo conjunto de dados, os valores de expressão de um conjunto de genes/transcritos em múltiplas amostras de mRNA (réplicas). Em algumas situações, a filtragem de apenas um subconjunto dos genes pode ser necessária. Neste contexto, o serviço de adaptação $A S 4$ tem como objetivo permitir a filtragem de dados de expressão gênica normalizados com base em um conjunto de genes diferencialmente expressos. Adicionalmente, este serviço permite o mapeamento entre diferentes tipos de identificadores de genes. A Figura 125 ilustra o processamento de um conjunto de dados pelo serviço de adaptação $A S 4$. 


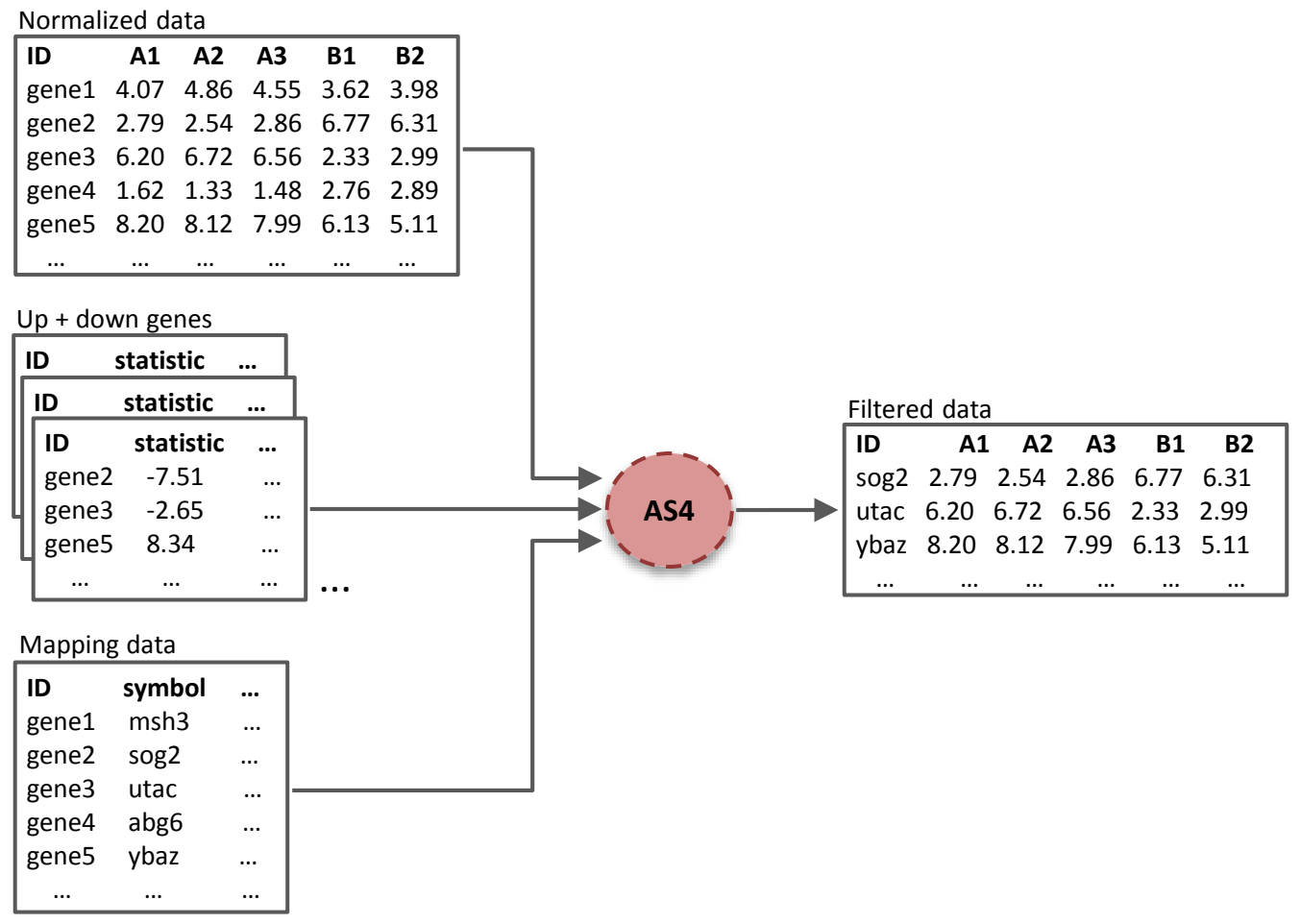

Figura 125: Processamento de dados pelo serviço de adaptação AS4.

O serviço de adaptação $A S 4$ requer como entrada um conjunto de dados de expressão gênica normalizados. Estes dados podem representar uma ou mais amostras de mRNA (réplicas) associadas a diferentes condições experimentais. Os dados normalizados devem ser disponibilizados em um arquivo texto tabular. Cada linha do arquivo deve conter um identificador de gene/transcrito (primeira coluna) e os seus valores de expressão normalizados em cada amostra (demais colunas). Além disto, o serviço AS4 requer como entrada um ou mais conjuntos de dados de expressão gênica diferencial. Estes conjuntos de dados devem ser separadamente disponibilizados em arquivos texto tabulares. Cada linha destes arquivos deve conter um identificador de gene (primeira coluna) e um valor de estatística de teste correspondente (segunda coluna). Finalmente, o serviço AS4 requer como entrada um conjunto de dados de mapeamento entre diferentes tipos de identificadores de genes. Estes dados também devem ser disponibilizados em um arquivo texto tabular, de modo que cada coluna do arquivo represente um tipo de identificador de gene.

Inicialmente, o serviço AS4 é responsável por filtrar os dados normalizados, selecionando apenas os valores de expressão dos genes/transcritos armazenados nos dados de expressão dife- 
rencial. O serviço armazena estes valores em um arquivo multi-colunas (uma coluna para cada amostra). Finalmente, o serviço é responsável por converter os identificadores de genes armazenados no arquivo multi-colunas para outro tipo de identificador especificado no arquivo de mapeamento fornecido como entrada. Para este propósito, o serviço também requer como entrada dois parâmetros especificando as colunas (origem e destino) do arquivo de mapeamento a serem consideradas para a conversão dos identificadores armazenados no arquivo multi-colunas. Como resultado, este serviço produz um arquivo multi-colunas contendo apenas os valores de expressão normalizados dos genes diferencialmente expressos.

\section{H.5 SERVIÇO DE ADAPTAÇÃO AS 5}

Dados de expressão gênica normalizados frequentemente incluem, em um mesmo conjunto de dados, os valores de expressão de um conjunto de genes/transcritos em múltiplas amostras de mRNA (réplicas). No entanto, em algumas situações, a filtragem dos dados de expressão referentes a apenas algumas amostras pode ser necessário. Neste contexto, o serviço de adaptação AS5 tem como objetivo permitir a filtragem de um conjunto de dados de expressão gênica normalizados com base em um conjunto de amostras de interesse. Adicionalmente, este serviço permite o mapeamento entre diferentes tipos de identificadores de genes. A Figura 126 ilustra o processamento de um conjunto de dados pelo serviço de adaptação AS5.

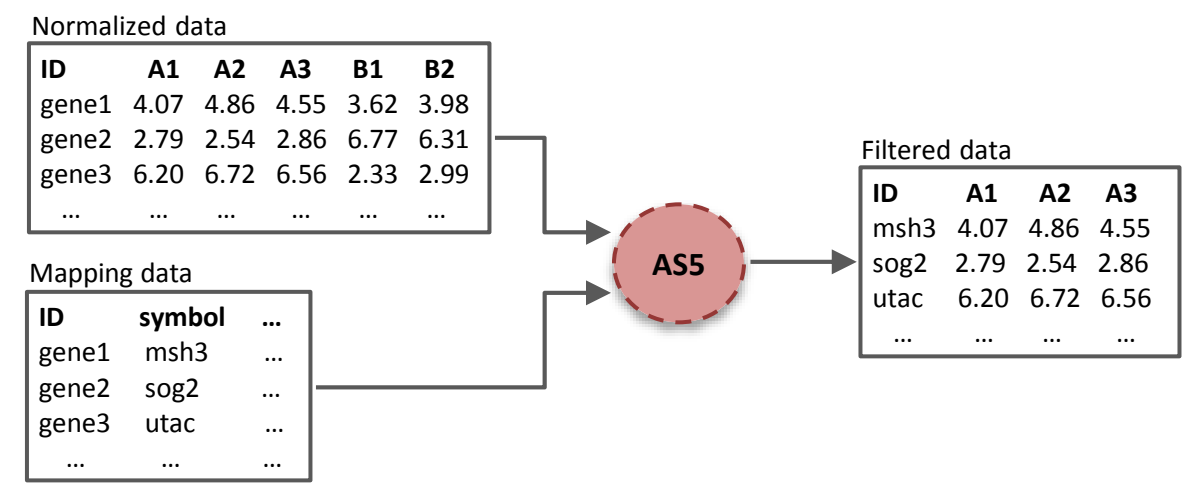

Figura 126: Processamento de dados pelo serviço de adaptação AS5.

O serviço de adaptação AS5 requer como entrada um conjunto de dados de expressão gênica normalizados. Estes dados podem representar uma ou mais amostras de mRNA (réplicas) 
associadas a diferentes condições experimentais. Os dados normalizados devem ser disponibilizados em um arquivo texto tabular. Cada linha do arquivo deve conter um identificador de gene/transcrito (primeira coluna) e os seus valores de expressão normalizados em cada amostra (demais colunas). Além disto, o serviço AS5 requer como entrada um conjunto de dados de mapeamento entre diferentes tipos de identificadores de genes. Estes dados também devem ser disponibilizados em um arquivo texto tabular, de modo que cada coluna do arquivo represente um tipo de identificador de gene. Finalmente, o serviço $A S 5$ requer como entrada um parâmetro especificando o conjunto de amostras (colunas) que devem ser filtradas nos dados.

Inicialmente, o serviço AS5 é responsável por filtrar os dados normalizados, selecionando apenas os valores de expressão dos genes/transcritos referentes às amostras especificadas. $\mathrm{O}$ serviço armazena estes valores em um arquivo multi-colunas (uma coluna para cada amostra). Finalmente, o serviço é responsável por converter os identificadores de genes armazenados no arquivo multi-colunas para outro tipo de identificador especificado no arquivo de mapeamento fornecido como entrada. Para este propósito, o serviço também requer como entrada dois parâmetros especificando as colunas (origem e destino) do arquivo de mapeamento a serem consideradas para a conversão dos identificadores armazenados no arquivo multi-colunas. Como resultado, este serviço produz um arquivo multi-colunas contendo apenas os valores de expressão normalizados dos genes referentes às amostras de interesse.

\section{H.6 SERVIÇO DE ADAPTAÇÃO AS6}

Dados de expressão diferencial apresentam um conjunto de genes/transcritos induzidos e reprimidos identificados em um estudo. Em algumas situações, os genes induzidos e reprimidos obtidos em comum em dois estudos distintos precisam ser identificados. Neste contexto, o serviço de adaptação $A S 6$ tem como objetivo permitir a extração dos genes reprimidos e induzidos em comum em dois conjuntos distintos de dados de expressão diferencial para dois conjuntos de dados independentes. A Figura 127 ilustra o processamento de um conjunto de dados pelo serviço de adaptação AS6.

O serviço de adaptação AS6 requer como entrada dois conjuntos de dados de expressão gênica diferencial. Estes conjuntos de dados devem ser separadamente disponibilizados em arquivos 


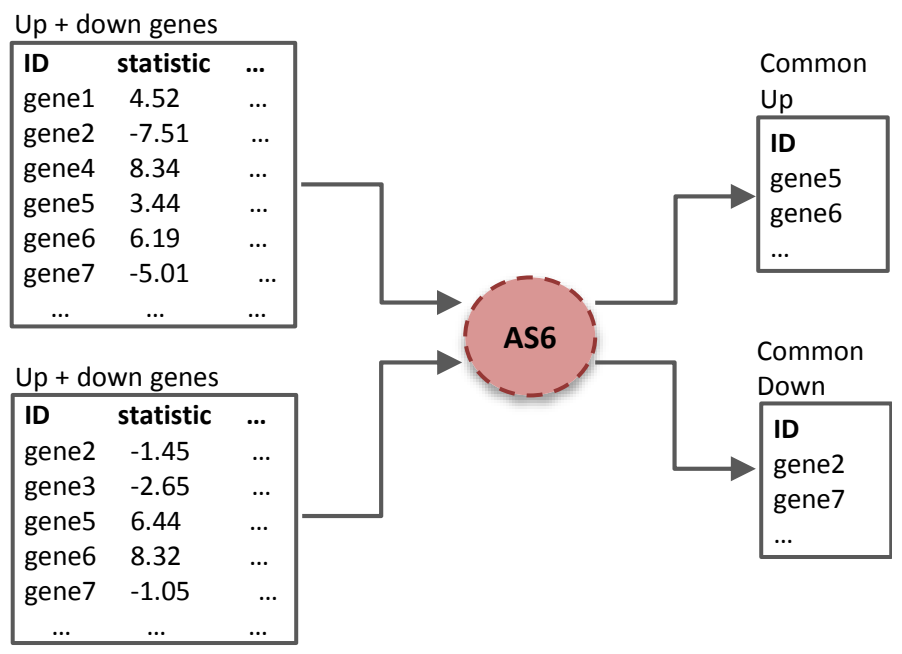

Figura 127: Processamento de dados pelo serviço de adaptação AS6.

texto tabulares. Cada linha destes arquivos deve conter um identificador de gene (primeira coluna) e um valor de estatística de teste correspondente (segunda coluna).

O serviço AS6 é responsável por extrair os genes reprimidos e induzidos em comum nos dois conjuntos de dados para dois conjuntos de dados independentes. Como resultado, este serviço produz dois arquivos, cada um contendo o conjunto de genes induzidos e reprimidos em comum, respectivamente. 